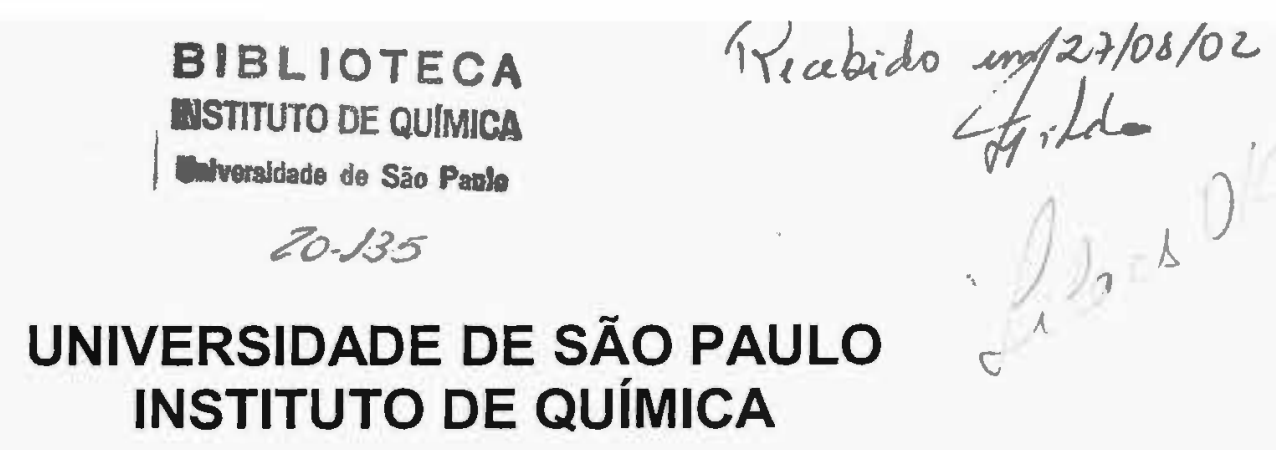

\title{
MODELO DE ANÁLISE DO PAPEL DAS AULAS PRÁTICAS NO ENSINO DE BIOQUÍMICA \\ Vol. 1
}

Marina André de Alvarez

Tese de Doutorado

Orientador: Prof. Dr. Bayardo Baptista Torres 


\section{DEDALUS - Acervo - CQ uninitumin \\ 30100004854}

Ficha Catalográfica

Elaborada pela Divisão de Biblioteca e

Documentação do Conjunto das Quimicas da USP.

\section{Alvarez, Marina André de \\ A473 m Modelo de análise do papel das aulas práticas no ensino de bioquímica / Marina André de Alvarez. -- São Paulo,} 2002.

$2 \mathrm{v}$.

Tese (doutorado) - Instituto de Química da Universidade de São Paulo. Departamento de Bioquímica.

Orientador: Torres, Bayardo Baptista

1. Bioquímica : Ensino 3. Metodologia científica Baptista, orientador.
2. Bioquímica: Laboratório

I. T. II. Torres, Bayardo 


\section{"MODELO DE ANÁlise do PAPEL DAS AULAS PRÁTICAS NO ENSINO DE BIOQUIMICA"}

\section{MARINA ANDRÉ DE ALVAREZ}

Tese de Doutorado submetida ao Instituto de Química da Universidade de São Paulo como parte dos requisitos necessários à obtenção do grau de Doutor em Ciências - Área: Bioquímica.

Aprovado por:

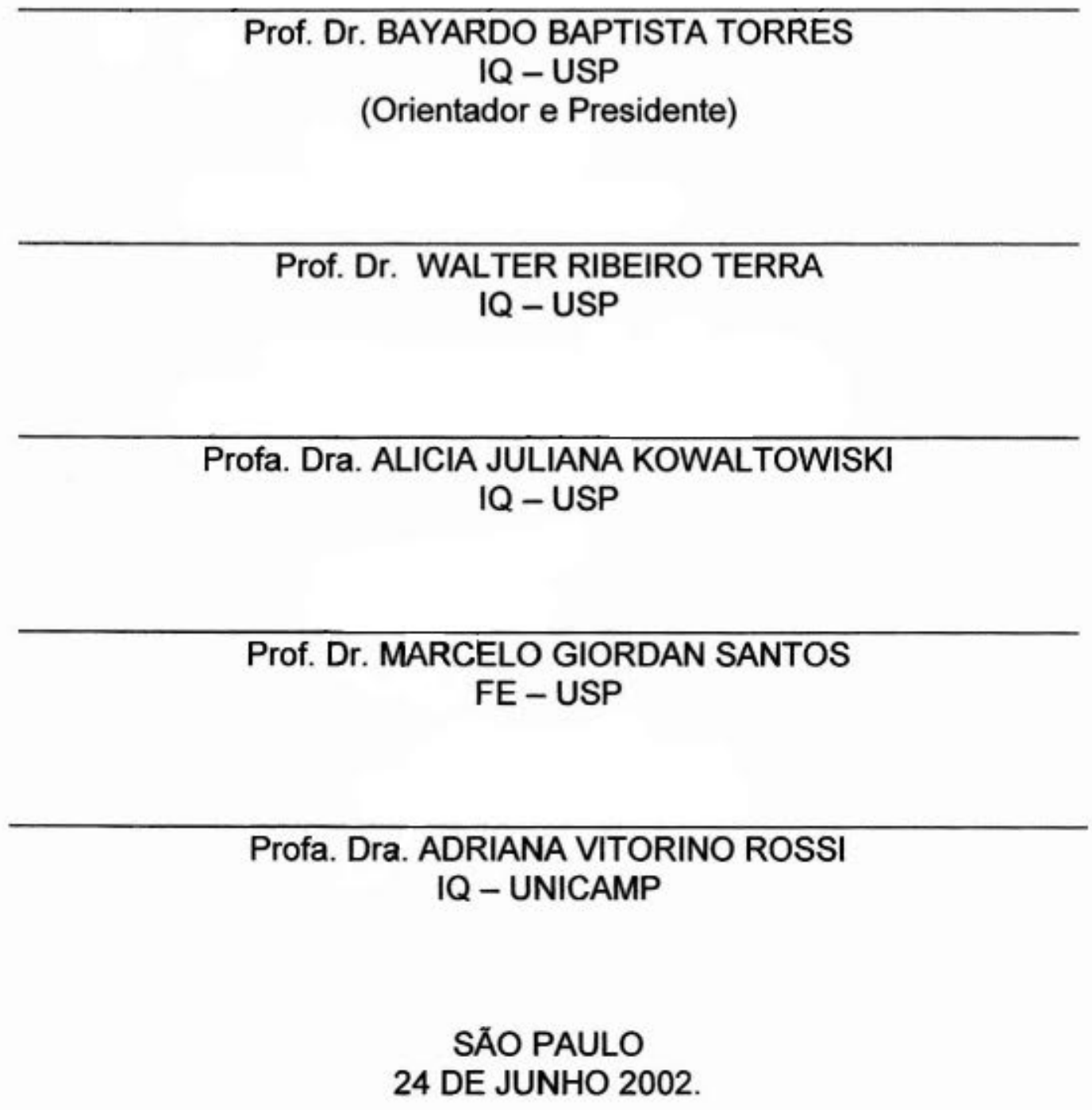


Dedico este trabalho a meus pais, Octacílio e Maria Aparecida, incentivadores de meu gosto pelo estudo. 


\section{AGRADECIMENTOS}

Meu reconhecimento vai especialmente para o amigo Prof. Dr. Bayardo Baptista Torres, orientador deste trabalho, que colocou toda sua presteza, eficiência e simplicidade a meu favor: indicou-me atalhos para encurtar caminhos na fase de desenvolvimento da pesquisa, e, ao criticar com competência minhas idéias e conclusões, tornou melhor o que produzi.

Às instituições e aos professores cujas aulas práticas analisei, citados no corpo do trabalho e nos apêndices, agradeço a confiança e a solicitude que me dispensaram, dando a meu trabalho uma contribuição decisiva. Também sou grata aos professores que participaram da pesquisa exploratória, cujos nomes mantenho no anonimato.

Agradeço ao Departamento de Bioquímica do Instituto de Química da USP, nas pessoas dos membros da Comissão de Pós-Graduação, pelo crédito dado a meu projeto de pesquisa, e da Banca Examinadora do Exame de Qualificação, pelo interesse e questionamento; à Universidade de São Paulo, berço de minha graduação e mestrado, pelo uso de suas instalações durante o curso de doutorado. Quero ainda destacar as contribuições dadas pelo Conselho Nacional de Desenvolvimento Científico e Tecnológico (CNPq) que me concedeu bolsa nos últimos seis meses de trabalho e pela Comissão de PósGraduação que destinou-me verba para a impressão dos exemplares da tese.

Sou grata aos colegas do grupo de trabalho de "Ensino de Bioquímica" pela agradável convivência, aos funcionários da Secretaria de Pós-Graduação, pela simpatia e eficácia no atendimento, à Profa. Czarda Maria de Mendonça André, pela correção gramatical dos originais da tese e à Profa. Dra. Fernanda Bacellar, pela correção do "Summary".

Ao Jacob, meu agradecimento pessoal pelo amor que acompanha todas minhas iniciativas, ao filho Ivan, agrônomo e pesquisador, pela presença constante, afeto, incentivo e leitura crítica da redação final, à nora Inessa, pela leitura do texto, ao filho Alexandre e à neta Bruna, por alegrarem minha existência, enriquecendo tudo que faço. 


\section{ÍNDICE}

\section{Vol. 1 - CORPO DO TRABALHO}

\section{Conteúdo}

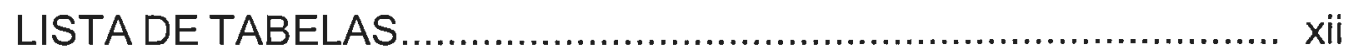

RESUMO …...................................................................... xii

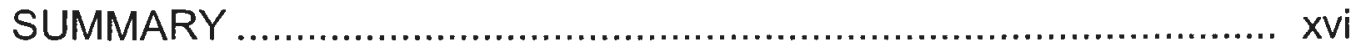

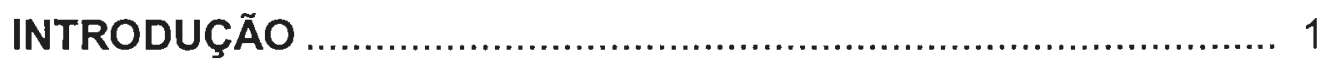

METODOLOGIA ............................................................... 17

EMBASAMENTO TEÓRICO DO MODELO DE ANÁLISE DO PAPEL DE AULAS PRÁTICAS NO ENSINO DE BIOQUÍMICA ..................................... 17

Dimensão ideológica ................................................... 17

Objeto de estudo ............................................. 17

A análise das aulas práticas ................................ 18

O processo ensino-aprendizagem ........................... 19

A Visão Holística e o Olhar das Ciências Humanas ..... 21

Pesquisa qualitativa $X$ pesquisa quantitativa ............. 23

Elaboração do Modelo de Análise do Papel das Aulas Práticas no Ensino de Bioquímica ......................... 24

Dimensão técnica ............................................................ 25

Criação e elaboração dos instrumentos de coleta de dados ............................................................. 25

Objetivos …................................................ 25

Técnicas utilizadas .................................. 25

Teste do Modelo de Análise do Papel das Aulas Práticas no

Ensino de Bioquímica ............................................... 26

UNIVERSO DA PESQUISA E AMOSTRAGEM ............................... 26

Universo da pesquisa ................................................... 26 


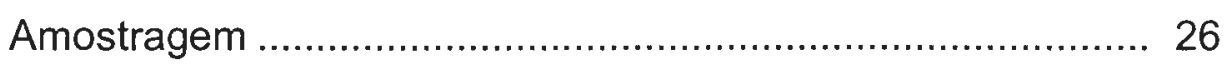

Características da amostragem ................................. 26

Instituições e cursos escolhidos ................................. 27

Instituições ..................................................... 27

Cursos ........................................................... 27

Contextos escolhidos para a aplicação dos instrumentos de coleta de dados ................................................. 28

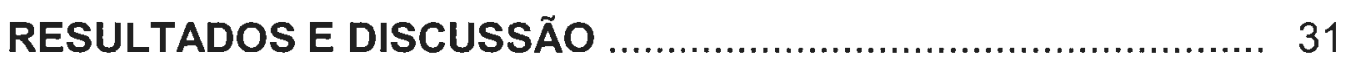

I. INSTRUMENTOS DE COLETA DE DADOS ................................................ 31

I. A. Construção dos Instrumentos de Coleta de Dados ................... 31

I. A. 1. Resultados da pesquisa de campo exploratória ......... 32

I. A. 2. Dados coletados na literatura para a definição dos itens dos instrumentos de coleta de dados ......................... 36

I. A. 2a. O contexto das aulas práticas …………......... 36

Laboratório, instituição, curso, disciplina .......... 36

Professor .................................................... 36

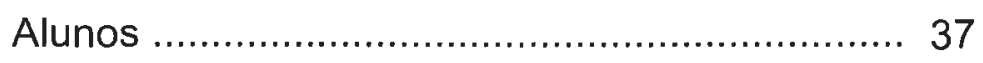

Comunidade, país ......................................... 38

Ensino superior, pesquisa .............................. 39

Graduação, pós-graduação, extensão, publicações científicas .................................................... 40

Currículo ..................................................... 41

Sociedade ..................................................... 41

Contexto ......................................................... 42

I. A. 2b. Aula prática e o processo ensinoaprendizagem ........................................... 42

Planejamento das aulas práticas ..................... 42 
1. número, assunto, ordem na programação, relações com outras atividades, dinâmica . 42

2. conhecimento prévio dos alunos 43

3. recursos materiais, suporte técnicodidático, funcionamento do laboratório .. 44

4. preparo e teste dos experimentos 44

5. normas de segurança e manipulação de material biológico .............................. 44

6. objetivos, conteúdo 45

7. substituição de aulas práticas por outras atividades de ensino 46

8. problemas a serem resolvidos em aulas práticas ................................. 46

9. protocolo 46

Trabalho no laboratório 47

1. estratégia de ensino 47

2. utilização do protocolo 47

3. bibliografia 47

4. execução dos experimentos 48

5. grupos de trabalho 48

6. precisão, sensibilidade, higiene 48

7. habilidades técnicas e mentais, atitudes pessoais 48

8. orientação, assistência 49

9. registro dos resultados, processamento dos dados 50

10. duração da aula 50

11. comportamento dos participantes 50

12. encerramento da aula 51 
Atividades posteriores à obtenção dos dados ... 51

1. discussão ..................................... 51

2. relatório ........................................ 51

3. atividades decorrentes do trabalho prático .............................................. 52

4. avaliação do aprendizado em aula prática

I. A. 2c. Funções das aulas práticas .......................... 52

Funções do conteúdo ................................... 52

Funções da metodologia ................................ 53

Funções do treinamento técnico ...................... 53

Funções das interações entre participantes ...... 53

I. A. 2d. Papel das aulas práticas .............................. 54

I. A. 3. Uso dos instrumentos de coleta de dados ................... 54

I. A. 3a. Uso para planejamento ............................... 54

1. A. 3b. Uso para avaliação ................................... 55

I. B. Os Instrumentos de Coleta de Dados elaborados .................. 56

I. B. 1. Caracterização do contexto ................................... 56

I. B. 1a. Instituição ................................................. 56

Dados gerais ............................................ 56

Natureza / Classificação ................................ 57

Cursos ........................................................ 57

Atividades de Pós-Graduação ....................... 57

Atividades de pesquisa ............................... 57

Prestação de serviços à comunidade ( atividades de extensão ) ............................................ 57

Publicações científicas ................................... 57

Regime de trabalho dos professores de Bioquímica ................................................ 58 
Apoios técnico e didático ao professor 58

I. B. 1b. Curso analisado e disciplina de Bioquímica.... 59

Faculdade 59

Curso 59

Disciplina com conteúdo de Bioquímica 60

I. B. 1c. Laboratório 61

Natureza 61

Condições físicas 61

Condições de trabalho dos alunos 63

I. B. 1d. Entrevistas 64

Questionário endereçado aos alunos . 64

Questionário endereçado aos professores 65

I. B. 2. Aula prática 69

I. B. 2a. Dados gerais 69

I. B. 2b. Características gerais ............................ 69

I. B. 2c. Materiais .................................................. 70

I. B. 2d. Preparo e teste ........................................ 71

I. B. 2e. Normas de segurança, de manipulação de material biológico e de descarte de materiais/questões éticas. 71

I. B. 2f. Conteúdo da aula ....................................... 71

I. B. 2g. Roteiro / Protocolo ..................................... 72

I. B. 2h. Etapas da aula / Estratégia de ensino ........... 74

I. B. 2i. Discussão dos resultados obtidos ................. 77

I. B. 2j. Relatório das aulas práticas ........................ 77

I. B. 2l. Atividades suscitadas pelas aulas práticas ..... 78

I. B. $2 \mathrm{~m}$. Avaliação do aprendizado em aulas práticas . 78

I. B. 2 n. Ocorrências não previstas durante a aula prática observada ..................................... 78

I. B. 3. Funções e Papéis das aulas práticas ...................... 79 
I. B. 3a. Funções ............................................. 79

Funções do conteúdo .................................... 79

Funções da metodologia de ensino ................. 79

Funções do treinamento de habilidades técnicas experimentais 80

Funções das interações entre os participantes . 80

I. B. 3b. Papéis 80

II. MODELO DE ANÁLISE DO PAPEL DAS AULAS PRÁTICAS NO ENSINO DE BIOQUIMICA

II. A. Roteiro de uso dos instrumentos de coleta de dados

II. A. 1. Caracterização do contexto das aulas práticas de Bioquímica

II. A. 2. Planejamento e implantação de laboratório didático de Bioquímica 82

II. A. 3. Planejamento de aulas práticas de Bioquímica 82

II. A. 4. Avaliação das aulas práticas da disciplina de Bioquímica .. 84

II. A. 4a. Análise da metodologia ............................. 84

II. A. 4b. Análise dos conteúdos .............................. 84

II. A. 4c. Análise das condições de trabalho dos alunos no laboratório

II. A. 4d. Análise da adequação das aulas práticas da disciplina de Bioquimica ao curso de graduação em questão e às condições presentes na instituição .... 86

II. A. 4e. Análise da contribuição das aulas práticas da disciplina de Bioquímica para a vida acadêmica e profissional do estudante e para sua atuação como cidadão

II. B. Uso dos instrumentos de coleta de dados para a determinação das funções e do papel das aulas práticas no ensino de Bioquímica ... 
II. B. 1. Conceito de Função e de Papel das aulas práticas ... 88

II. B. 1a. Função .............................................. 88

II. B. 1b. Papel .................................................... 90

II. B. 2. Funções das aulas práticas ................................... 90

II. B. 2a. Funções do conteúdo ................................ 90

Funções de ilustração, aprofundamento e/ou ampliação e aplicação do conteúdo de aulas teóricas................................................. 90

Função de compreensão de conceito ............... 93

Função de construção de conceito ................... 96

Função de divulgação do conhecimento científico .. 100

II. B. 2b. Funções da metodologia de ensino .............. 102

Função de ensinar como seguir instruções escritas, registrar e processar resultados experimentais ..... 103

Função de ensinar como discutir resultados experimentais .......................................... 105

Função de comunicação dos resultados

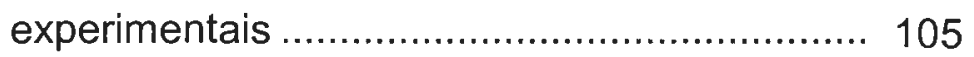

Função de desenvolver autonomia na execução de experimentos ...................................... 106

Função de ensinar como utilizar o método científico ............................................... 108

II. B. 2C. Função do treinamento de habilidades técnicas experimentais ......................................... 113

II. B. 2d. Função das interações entre os participantes ... 115

II. B. 3. Papéis das aulas práticas no ensino de Bioquímica .. 119

II. B. 3a. Papel de reprodução de conhecimento ......... 119

II. B. 3b. Papel de construção de conhecimento ......... 120

II. B. 3c. Papel de crítica a conhecimento ................. 120 
III. UM EXEMPLO DE APLICAÇÃO DO MODELO DE ANÁLISE DO PAPEL DAS AULAS PRÁTICAS NO ENSINO DE BIOQUIMMICA

III. A. Resultados da aplicação dos instrumentos de coleta de dados em seis contextos diferentes

III. A. 1. Caracterização dos contextos 124

III. A. 2. Análise das aulas práticas observadas 124

III. B. Análise comparativa dos seis contextos observados 162

III. B. 1. Comparação entre as características gerais das instituições analisadas

III. B. 2. Comparação entre cursos semelhantes, ministrados em instituições privadas e públicas

III. B. 3. Adequação das programações das disciplinas com conteúdo de Bioquímica analisadas, em relação ao enfoque dos cursos em que estão inseridas .

III. B. 4. Comparação entre os laboratórios didáticos das instituições analisadas

III. B. 5. Análise das opiniões e do comportamento dos atores do processo ensino-aprendizagem nos contextos analisados . 175 III. C. Funções e papéis das aulas práticas nos seis contextos analisados 195 


\section{LISTA DE TABELAS}

\section{Conteúdo}

Tabela I - Características dos contextos em que foi feito o pré-teste dos instrumentos de coleta de dados 30

Quadro do questionário endereçado aos professores - Consecução de expectativas do professor e dos objetivos das aulas práticas ... 67

Tabela II - Características das instituições analisadas 125

Tabela III - Características dos cursos analisados

Tabela IV - Características das disciplinas com conteúdo de Bioquímica analisadas

Tabela V - Características dos laboratórios didáticos observados .

Tabela VI - Respostas das perguntas do questionário endereçado a alunos das disciplinas analisadas

Tabela VII - Respostas das perguntas do questionário endereçado a professores de Bioquímica dos cursos analisados

Tabela VIII -Respostas das perguntas do questionário endereçado a professores de Bioquímica: Opiniões quanto à consecução dos objetivos de suas aulas práticas

Tabela IX - Dados gerais e características das aulas práticas observadas

Tabela $X$ - Características e conteúdo dos protocolos das aulas práticas observadas

Tabela XI - Etapas e estratégias de ensino das aulas práticas observadas

Tabela XII - Características dos relatórios das aulas práticas observadas

Tabela XIII - Grades curriculares dos cursos de Ciências Biológicas analisados

Tabela XIV - Grades curriculares dos cursos de Nutrição analisados 166

Tabela XV - Resumo comparativo das programações das disciplinas com conteúdo de Bioquímica analisadas. 


\section{MODELO DE ANÁLISE DO PAPEL DAS AULAS PRÁTICAS NO ENSINO DE BIOQUÍMICA}

Autora: MARINA ANDRÉ DE ALVAREZ

Orientador: BAYARDO BAPTISTA TORRES

\section{RESUMO}

Aulas práticas, nesta pesquisa, são aquelas que ocorrem no recinto do laboratório, utilizando vidraria, reagentes, equipamentos e aparelhos especializados. O problema foi como analisá-las de forma a entender suas funções, isto é, o quê elas ensinam, e descobrir seu papel no ensino da disciplina, quer dizer, para que elas ensinam.

O objetivo geral deste trabalho foi propor um modelo de análise do papel de aulas práticas no ensino de Bioquímica que desse subsídios ao professor para estabelecer critérios de inclusão e utilização dessas aulas em sua disciplina, considerando-se o contexto em que se inserem.

A metodologia teve como base a pesquisa qualitativa, complementada por pesquisa quantitativa, com a visão das Ciências Humanas.

A abordagem holística adotada expressou-se na tese defendida no trabalho, que incluiu a idéia de que o contexto das aulas práticas é constituído pela instituição, pelo curso, pela disciplina, pelas condições materiais e de funcionamento do laboratório, pelos professores e pelos alunos, e que os instrumentos de coleta de dados a serem utilizados para a análise de aulas práticas precisam ser abrangentes, precisos, profundos, válidos e confiáveis.

Foi produzido um conjunto de documentos intitulado Instrumentos de Coleta de Dados, úteis para levantar informações e fazer observações, tanto para caracterizar o contexto, como para analisar as aulas práticas em si. O uso de parte dos referidos instrumentos também se mostrou adequado para que o corpo técnico das instituições de ensino superior tivesse base para implantar, implementar, manter e gerenciar laboratório de aulas práticas, avaliar planejamentos e trabalho docente. 
Para complementar, ajustar e julgar a validade dos instrumentos de coleta de dados construídos, eles foram aplicados em seis contextos diferentes, a saber: (1) disciplina de Bioquímica do curso de Ciências Biológicas das Faculdades Integradas Hebraico-Brasileiras Renascença; (2) disciplina de Bioquímica Aplicada do curso de Engenharia Química das Faculdades Oswaldo Cruz; (3) disciplina de Bioquímica do curso de Nutrição do Centro Universitário São Camilo; (4) disciplina de Bioquímica do curso de Nutrição da Faculdade de Saúde Pública; (5) disciplina de Bioquímica Experimental do curso de Farmácia e Bioquímica da Faculdade de Ciências Farmacêuticas; (6) disciplina de Bioquímica do curso de Ciências Biológicas do Instituto de Biociências, os três últimos cursos pertencentes à Universidade de São Paulo. Os seis contextos analisados diferiram pelo tipo de entidade mantenedora e pela classificação das Instituições de Ensino Superior, características previstas pela Lei de Diretrizes e Bases da Educação Nacional em vigor, e por tudo que decorre dessas características. Outras diferenças foram: o enfoque do currículo dos cursos e a posição da disciplina com conteúdo de Bioquímica na grade curricular.

Discutiu-se uma forma de estudar aulas práticas, denominada Modelo de Análise do Papel das Aulas Práticas no Ensino de Bioquímica, que permite descobrir quais as funções e definir os papéis destas aulas dentro do contexto em que ocorrem. Servindo-se desse conhecimento, o professor pode estabelecer seus critérios de adoção e utilização do trabalho laboratorial, fundamentar seu planejamento e avaliar o desempenho do ensino prático.

De acordo com o modelo de análise proposto, foi realizada uma análise das aulas práticas observadas no seis contextos acima citados, após o levantamento de informações por meio dos instrumentos de coleta de dados, com a forma originalmente concebida, antes das modificações necessárias. Esse estudo serviu de exemplo de como usar o modelo para fazer comparações quanto às características gerais das instituições, com relação a cursos semelhantes, ministrados em instituições pública e privada, e no que se refere aos laboratórios didáticos e ainda para entender o significado das opiniões e do comportamento dos atores do processo ensino-aprendizagem. 
A análise feita também exemplificou como a definição de funções e de papéis de aulas práticas permite avaliar a adequação das programações das disciplinas com conteúdo de Bioquímica aos cursos em que estão inseridas.

As principais conclusões do trabalho foram:

- Os Instrumentos de Coleta de Dados criados têm as necessárias abrangência, precisão, profundidade, validez e confiabilidade.

- Os referidos instrumentos e o Modelo de Análise do Papel das Aulas Práticas no Ensino de Bioquímica podem ser usados por professores de Bioquímica, por aqueles de outras disciplinas que têm aulas práticas em laboratório e pelo corpo técnico de instituições superiores de ensino, com diferentes fins. 


\title{
A MODEL OF ANALYSIS OF LABORATORY CLASSES ROLE IN BIOCHEMICAL EDUCATION
}

\author{
Author: MARINA ANDRÉ DE ALVAREZ \\ Adviser: BAYARDO BAPTISTA TORRES
}

\section{SUMMARY}

Laboratory classes are those that occur in the laboratory, using specialised glassworks, reagents, equipment and apparatus. The problem is how to analyse those classes in order to understand their functions, that is, what they are teaching, and find their role in the discipline, i. e., for what they are being taught.

The general objective of the present work was to propose a model of analysis of laboratory classes role in biochemical education that could offer teachers the basis to establish rules to include and use those classes in their discipline, considering the context where they happen.

The methodology applied was founded on qualitative research, complemented with quantitative research, as used in Human Sciences.

The thesis defended by the present work had, as a basis, a holistic approach. It was expressed by two assertions: (1) the laboratory classes context is composed of institution, course and discipline characteristics, material conditions and operation of didactic laboratory, teachers and students as persons; (2) the data gathering check lists and questionaires, 
specially designed to be used for laboratory classes analysis, had to be inclusive, precise, profound, valid and reliable.

A set of data gathering documents was specially created to get information and to make observations that are useful to characterise the context and to study the practical work itself. The university institution staffs can apply part of those documents to establish, implement, support and control the didactic laboratory and evaluate teaching planning and work.

To complement, adapt and judge the validity of the developed data gathering documents, they were applied at six different contexts, namely: (1) Chemistry of Biomolecules discipline - Biological Sciences course - "Faculdades Integradas Hebraico-Brasileiras Renascença"; (2) Biochemistry discipline Nutrition course - "Centro Universitário São Camilo"; (3) Applied Biochemistry discipline - Chemical Engineering course - "Faculdades Oswaldo Cruz"; (4) Biochemistry discipline - Nutrition Course - "Faculdade de Saúde Púclica USP"; (5) Experimental Biochemistry discipline - Pharmaceutical Sciences course - "Faculdade de Ciências Farmacêuticas - USP"; (6) Biochemistry discipline Biological Sciences course - "Instituto de Biociências - USP". The six contexts analysed differed with regard to maintainer corporation type and position in the university institution classification, in accordance with the "Lei de Diretrizes e Bases da Educação Nacional" ( National Education Guidelines and Basis Law ) in force. Other differences were: curriculum focus and the order of discipline with biochemistry contents in discipline roll of the course.

A laboratory class kind of study was discussed. It was called "A model of analysis of laboratory classes role in biochemical education". This model allows to disclose the functions and to define the roles of laboratory classes in the context where they happen. Using it, the teachers can establish their criteria of adoption and utilisation of laboratory work, they can base their planning and evaluate their performance in practical teaching.

In accordance with the proposed model, an analysis of the observed laboratory classes in the six contexts cited before was carried out. It was 
applied to obtain information, the original data gathering documents, as they were prior conceived. The developed study helped to exemplify how to use this model to compare general characteristics of university institutions, analogous courses of public and private colleges, material and operation conditions of didactic laboratories. It also helped to understand the opinions and behaviours of the instruction-apprenticeship process actors, i. e., teachers and pupils. This analysis can also be used as an example of how the definition of laboratory classes functions and roles permits to evaluate the adequacy of Biochemistry discipline programs to the courses in where they are inserted.

The main conclusions of this work were:

- The elaborated data gathering documents have the necessary richness, profoundness, validity and trustworthiness.

- The documents and the model of analysis of laboratory classes role in biochemical education can be used by Biochemistry teachers, by teachers of other disciplines that have laboratory classes and by other members of university institution staff, to several purposes. 


\section{INTRODUÇÃO}

Aulas práticas têm sido apontadas por professores e alunos como necessárias e mesmo essenciais para o aprendizado de disciplinas cujos acervos de conhecimentos foram obtidos principalmente por pesquisa experimental (Hodson, 1992; Smith et al., 1995; Austin, 1997; Bennett, 2000). Entretanto, aulas práticas são caras, difíceis de planejar, montar e executar, exigem treinamento técnico e mobilizam grande número de pessoas (Bennett, 2000). É importante que sejam eficientes, isto é, que ensinem o que se pretende ao realizá-las. Nem sempre é o que se observa: aulas práticas muitas vezes são alvo de inúmeras críticas e motivo de insatisfação e frustrações (Johnstone e Letton, 1990; Byrne, 1990).

Até que ponto a idéia de que para aprender ciência é necessário trilhar, pelo menos em parte, o caminho seguido para construir ciência (Hodson, 1992; Gil et al., 1999) é um dogma, ou mesmo um mito? É sempre necessário seguir o ritual de dar aulas práticas ao ensinar conteúdo de ciências naturais em cursos de graduação, sem refletir sobre as exigências dessas aulas, de quanto despendem esforço, tempo e dinheiro? Como dar-se ao luxo de desperdiçá-las ou usá-las com capacidade inferior às suas possibilidades (Wood, 1996)? Não seria mais eficiente substituí-las por simulação em computador ou por resolução de problemas (Pamula, Wigmore e Wheldrake, 1996; Pich-Otero et al., 1998 ; Bennett, 2000)?

Todas as escolhas que se referem a aulas práticas, assim como qualquer outra tarefa inerente ao processo ensino-aprendizagem é, em última instância, atribuição do professor. Resta saber se as instituições permitem e se ele tem cabedal para decidir por adotar ou não aulas práticas e de que forma as utilizar em seu trabalho.

Há que se refletir, por ocasião do planejamento da disciplina, sobre que parcela da responsabilidade de ensinar deve ser atribuída a aulas práticas, dentro do amplo cenário em que elas se desenvolvem e em confronto com outras práticas docentes (Wood, 1996). O que se aprende e 
para que serve o aprendizado obtido só são conhecidos após definição das funções e do papel do ensino no laboratório, em cada situação particular. O professor precisa dispor de dados que the permitam tirar conclusões com embasamento teórico claro e definido, considerar suas necessidades, possibilidades e potencial de realização e ter em conta todos os elementos do contexto que possam influir sobre o processo ensino-aprendizagem.

A Bioquímica inclui-se no rol das disciplinas que utilizam aulas práticas que, no escopo da pesquisa realizada e aqui apresentada, são aquelas que ocorrem no recinto do laboratório, utilizando vidraria, reagentes, equipamentos e aparelhos especializados.

Em geral, o discurso dos professores que ministram aulas práticas inclui afirmações, tais como: "aulas práticas treinam pesquisa laboratorial" (Hodson, 1992; Austin, 1997); "servem para ensinar o aluno a resolver problemas por meio de experimentos" (Byrne, 1990; Kirschner et al., 1993; Wood, 1996); "são mais dinâmicas que as aulas teóricas" (opinião de alunos aplicação dos instrumentos de coleta de dados - ver capítulo de "Resultados e Discussão" - item III. A.), "mais descontraídas e motivadoras" (Hodson, 1994; Giordan, 1999) e "permitem maior integração professor-aluno" (Wood, 1996); "mostram como a teoria foi construída, traduzem os fatos presentes nos livros didáticos" (Wood, 1990); "incitam o raciocínio crítico" (Walter Colli pesquisa exploratória, comunicação pessoal, 1999); "permitem aprender sobre a natureza da Ciência e desenvolvem atitudes científicas" (Hodson, 1994).

O número de limitações das aulas práticas parecem superar suas vantagens em relação às aulas teóricas, pois, embora os professores reconheçam a importância das primeiras, em geral, dão mais ênfase às últimas (Norato e Silva, 1996).

O problema a ser resolvido é como detectar a contribuição que as aulas práticas podem dar ao ensino de Bioquímica, no que se refere a compreensão de conteúdos, a assimilação de conceitos, a treinamento técnico, a preparo profissional, a desenvolvimento de habilidades mentais 
necessárias ao aprendizado de ciência e como o trabalho laboratorial promove a participação social do aluno.

Dados da literatura sobre aulas práticas - A literatura científica, de 1990 a esta parte, aborda o assunto "aulas práticas" sob vários aspectos, todos particularizados para contextos específicos, como um curso em especial (Smith et al., 1995; Wood, 1996; Pich-Otero et al., 1998), como uma instituição ou país (Mckenzie, 1996; Austin, 1997), como uma determinada maneira de desenvolver as aulas (Mckenzie, 1996; Austin, 1997; Pich-Otero et al., 1998). Nas publicações lidas, não foi explicitada a fundamentação das opções feitas pelos professores, com relação a aulas práticas, nas circunstâncias analisadas, e suas escolhas foram apenas relatadas como resultado da avaliação de uma situação isolada.

Quanto aos objetivos das aulas práticas, os autores apontam:

- dar ênfase à ilustração de conceitos teóricos importantes, desenvolvidos em aulas teóricas (Smith et al., 1995; Mckenzie, 1996; Wood, 1996; Austin, 1997; Pich-Otero et al., 1998);

- ilustrar fenômenos e uso de equipamentos (Silverman, 1996; Wood, 1996);

- ilustrar fatos presentes em livros didáticos (Wood, 1990);

- verificar princípios (Smith et al., 1995; Wood, 1990 e 1996);

- melhorar as habilidades laboratoriais dos estudantes (Smith et al., 1995; Wood, 1990 e 1996; Mckenzie, 1996; Austin, 1997; Pich-Otero et al., 1998) e a capacidade de uso de equipamentos e aparelhos (Wood, 1990 e 1996; Silverman, 1996);

- permitir aos estudantes a manipulação de materiais biológicos (Wood, 1996);

- ensinar técnicas padrões ou históricas (Wood, 1996), métodos experimentais relevantes num assunto ou área (Mckenzie, 1996; Austin, 1997); 
- ensinar a seguir com controle e segurança instruções escritas no protocolo (Wood, 1996; Austin, 1997);

- ensinar como observar e registrar acuradamente (Wood, 1996);

- ensinar como processar dados, usar métodos estatísticos (Wood, 1996; Austin, 1997; Pich-Otero et al., 1998);

- ensinar a procurar bibliografia (Pich-Otero et al., 1998);

- ensinar como apresentar dados, resultados, tirar conclusões (Wood, 1996; Austin, 1997; Pich-Otero et al., 1998);

- ensinar como expressar idéias, organizar informações (Pich-Otero et al., 1998);

- permitir aos alunos conviverem com as limitações do método experimental, dar-lhes intensa experiência pessoal com os profissionais e a operacionalidade da Ciência (Wood, 1990) e mostrar-lhes como realmente é o ambiente de laboratório (Austin, 1997).

- permitir aos estudantes perceberem a importância da Bioquímica em vários ramos de conhecimento e atividades profissionais (Wood, 1996; Pich-Otero et al., 1998);

- dar aos alunos uma idéia do que seja pesquisa científica (Silverman, 1996);

- em aulas práticas com tarefas avançadas, em projetos e cursos concentrados, levar os alunos a:

- aprender a planejar experimentos, validar ensaios, escrever protocolos, criticar dados; comunicar resultados de forma oral e escrita (Wood, 1996; Pich-Otero et al., 1998);

- aprender a ler literatura, encontrar dados na literatura, pensar em novos experimentos para responder questões interessantes e relevantes; propor e testar hipóteses, raciocinando logicamente (Wood, 1996);

- encorajar entusiasmo em fazer ciência (caráter motivacional); estabelecer relações interpessoais, participar de uma equipe de pesquisa; estabelecer interação com o supervisor (orientador); aprender a cooperar, trabalhando em grupo; adquirir independência, responsabilidade, confiabilidade (Wood, 1996); 
- adquirir capacidade de se auto-avaliar (Wood, 1990; Pich-Otero et al., 1998).

As instruções dadas aos alunos para a realização do trabalho de laboratório variam grandemente. As maneiras como elas são redigidas e utilizadas podem definir as estratégias e a dinâmica da aula e esclarecer as reais intenções do professor, conscientes ou inconscientes, determinando, em parte, que funções essas aulas irão exercer no ensino. Domin (1999) fez uma classificação dos tipos de instruções (protocolos) de laboratório, de acordo com a predeterminação ou não dos resultados, com a abordagem dedutiva ou indutiva e com a forma de escolher os procedimentos técnicos, pelo professor ou pelo aluno. Assim, o autor definiu quatro tipos de instruções de trabalho de laboratório: expositivas, inquisitivas, de descoberta e baseadas em problema.

Para vários tipos de trabalho prático, os autores descrevem e analisam posições das aulas práticas na programação, estratégias de ensino, dinâmicas de aula.

Referindo-se à seqüência em que as aulas são colocadas na disciplina de Bioquímica, em cursos tradicionais, os autores relatam que, comumente, o trabalho no laboratório aparece intercalado com aulas teóricas e seminários, em pacotes que cobrem unidades individuais de uma dada programação (Pich-Otero et al., 1998), com tempo equivalente a aulas teóricas ou tutoriais (Mckenzie, 1996; Bennett, 2000). Muitas vezes, há uma divisão clara entre aulas práticas, de um lado, e outros tipos de atividades docentes, de outro. Assim, o curso prático pode aparecer na metade final do curso, com os alunos planejando e executando um projeto de laboratório, depois que na primeira metade do curso houve aprendizado baseado em problemas ou outras atividades referentes a conceitos teóricos (Pich-Otero et al., 1998).

Há referência à programação de aulas práticas desenvolvida na forma de um projeto intensivo para cursos à distância, em que não se segue a 
seqüência teórica (Mckenzie, 1996) e como miniprojetos, concentrados em algumas aulas, em cursos normais (Mckenzie, 1996).

Mckenzie (1996), discutindo a adequação de aulas práticas semanais intercaladas com aulas teóricas, considera que elas são eficientes se forem usados experimentos curtos, mais simples, que ilustrem aulas teóricas e quando se apresentarem limitações, como classes numerosas, presença de estudantes de cursos diversos e/ou com poucas habilidades laboratoriais e, ainda, escassez de tempo e espaço por razões administrativas.

O mesmo autor considera que pacotes com pequenos cursos intensivos somente são adequados, se ficar claro qual o objetivo do uso de laboratório no assunto em questão e, se o tipo de experimento a ser realizado atender a esse objetivo. Minicursos funcionam quando os estudantes têm de antemão desenvolvidas as habilidades necessárias. Suas limitações são as restrições administrativas em relação ao tempo. Projetos maiores só são viáveis em caso de classes em final de curso, classes menores e homogêneas e com estudantes mais treinados em habilidades laboratoriais. Nessas situações, os projetos permitem experimentos mais longos e sofisticados.

São descritas várias funções das aulas de laboratório, a partir de avaliações feitas por alunos e de conclusões obtidas pelos pesquisadores.

Os alunos do grupo de Pich-Otero et al. (1998) atribuíram, em ordem decrescente de valor, as seguintes funções para as aulas práticas: treinar habilidade manual de trabalhar em laboratório e habilidade de analisar dados experimentais; dar entendimento da Bioquímica como um todo; ensinar a capacidade de planejar experimentos e desenvolver a capacidade de se auto-avaliar. Por sua vez, os relatórios de aulas práticas, de acordo com esses alunos, ensinam a processar e comunicar dados experimentais, ordenar e expressar idéias, organizar informação e procurar bibliografia.

Austin (1997) concluiu que projetos práticos permitem aos alunos, além de realizarem tarefas ensinadas em aulas práticas comuns, a chance de demonstrarem suas qualidades e seu potencial como cientistas inovadores, o que é essencial para estudantes que têm aspirações de 
continuar na pesquisa ou em outras carreiras baseadas em laboratório. Esses projetos práticos permitem ao professor perceber o esforço, as habilidades e a motivação de cada aluno.

Discorrendo sobre expectativas dos alunos com relação a trabalhos práticos e suas consecuções, em cursos de Biologia e Química à distância, Kirschner et al. (1993) colocaram as seguintes funções do laboratório como atendendo às expectativas dos alunos, em ordem decrescente de valor: usar habilidade laboratorial em experimentos simples, interpretar resultados experimentais, descrever claramente experimentos, planejar experimentos simples para testar hipóteses e resolver problemas, usar conhecimentos e habilidades adquiridas no laboratório, em situação desconhecida.

Na literatura pesquisada, pouca discussão foi encontrada a respeito do papel das aulas práticas no ensino, isto é, como estas aulas podem ser usadas para reproduzir ou construir conhecimento, discutir teorias, criticar algum dogma, entre outras finalidades.

Desvantagens das aulas práticas e limitações de várias ordens são assinaladas pelos pesquisadores:

Ao intercalar aulas práticas com teoria e seminários, utilizando aquelas apenas para ilustrar conceitos teóricos, o grupo que trabalhou com PichOtero (1998) considerou que o aluno fica sem visão integrada dos assuntos, tornando-se a manipulação de equipamentos mais importante que os objetivos específicos do trabalho laboratorial, a saber, as explicações racionais dos resultados. Esses pesquisadores salientaram que o tempo restrito das sessões práticas impede que os estudantes se tornem familiarizados com a maioria das técnicas e abordagens. Lembraram, ainda, que o planejamento do trabalho e a avaliação da reprodutividade dos métodos não são considerados e a elaboração e a comunicação dos resultados não são encorajadas. Bennett (2000) mostrou que os estudantes de Química, devido à alta carga de trabalhos laboratoriais, têm pouco tempo para a reflexão, a investigação, a exploração, o aprendizado independente e para as leituras paralelas aos assuntos dados em aulas teóricas. 
Na literatura, encontram-se pareceres evidenciando que pode haver reducionismo na aprendizagem de Bioquímica no campo experimental, por ocasião de realização de projetos experimentais sobre um único assunto, o que limitaria o entendimento de outros (Pich-Otero et al., 1998). Mesmo que tais projetos sejam pertinentes, faltam tempo ao professor, bem como dinheiro e espaço nos laboratórios de pesquisa para desenvolvê-los (Wood, 1996; Austin, 1997) e os alunos precisariam ter pré-requisitos do ensino médio, como conhecimentos de Química, Biologia, Física e Matemática, que nem sempre estão presentes. Além do mais, os estudantes têm pouca familiaridade com a linguagem da Bioquímica, mesmo que superficial, apresentam pouca habilidade experimental e seu conhecimento do método científico é pequeno (Wood, 1996).

No que concerne à natureza dos experimentos, Mckenzie (1996) diz que, às vezes, uma dada técnica toma muito tempo e, embora relevante, não pode ser escolhida e que, sem dúvida, além do mais, parte do tempo deve ser gasto com cálculos e discussão.

Escrevendo sobre objetivos das aulas práticas, Wood (1996) comentou que existe uma certa acomodação ao defini-los. Pensa-se em dar, nessas aulas, uma visão de tudo que o estudante deve experenciar no laboratório, antes de se tornar um bioquímico "qualificado". Isso implica que o trabalho em aulas práticas deva ser infalivel, precise ser completado em tempo determinado e outras exigências. Entretanto, o que é importante para se qualificar como bioquímico muda constantemente e muitos objetivos que continuam a ser colocados foram pensados por professores de outros tempos, observação também feita por Bennett (2000). Com relação ao trabalho no laboratório, o primeiro autor afirmou que há sempre uma dose de tradição e hábito no número de aulas, disposição na programação etc; os objetivos nem sempre são claros, pretendendo-se atingir muito e muitas coisas ao mesmo tempo. Por exemplo, espera-se que os estudantes obtenham dados precisos com aparelhagem com a qual não estão familiarizados e que processem os dados de pouca qualidade que reuniram para chegar a conclusões previamente estabelecidas. É melhor separar as duas funções: primeiro treiná-los para obter dados precisos e depois ensiná-los a processar 
dados. Schwartz (1999), como os dois últimos autores citados, comenta o tradicionalismo do ensino de Química, em que ele também inclui assuntos de Bioquímica, em cursos universitários dos Estados Unidos, mais voltados para a preparação do químico, sem levar em consideração a pessoa do profissional.

Referindo-se aos fatores psicológicos envolvidos, Johnstone e Letton (1990) opinaram que a ineficiência é fruto principalmente de fatores psicológicos causados no estudante pelos manuais de laboratório, nos quais as instruções são inadequadas e suscitam dúvidas. Esses autores dizem que as aulas práticas são apontadas pelos alunos como pouco agradáveis, difíceis e desinteressantes, com muita falta de organização e tempo insuficiente. Nessa situação, enfrentam problemas com reagentes e materiais, perdem tempo e não aprendem nada.

Segundo Bennett (2000), os alunos em geral não gostam das aulas práticas, porque dão pequeno retorno para tanto gasto de tempo, relacionam-se pouco com as aulas teóricas e seminários, são restritas a determinados tópicos, usando, às vezes, exaustivamente uma técnica, em detrimento de outras que continuam desconhecidas.

Quanto ao uso ou não de aulas práticas, nem todos os autores são favoráveis à utilização de trabalho laboratorial em qualquer situação: Austin (1997) viu a possibilidade de trocar aulas de laboratório por projetos bibliográficos, quando houver problemas com espaço para dar aulas práticas, falta de tempo do professor para orientar trabalho laboratorial e falta de recursos. Há autores que consideram que o processamento de dados e sua avaliação são melhor obtidos com dados precisos, em situações não-laboratoriais (Pamula et al., 1996; Pich-Otero et al., 1998). Bennett (2000) mostrou que as fases pré e pós aulas práticas são importantes. Na primeira, os alunos aprendem a discutir um problema e, na última, avaliam e validam seus trabalhos, discutem aspectos positivos e negativos do processo investigativo, analisam criticamente seus resultados e planejam experimentos subseqüentes, consolidam sua equipe de trabalho, escrevem apresentações orais e escritas. Nessas fases que antecedem e 
sucedem os trabalhos de laboratório, 0 autor considera que podem ser usadas simulações em computador.

Os autores pesquisados relatam etapas, formas de contornar limitações e sugestões para que haja consecução dos objetivos propostos com relação a várias formas de ministrar aulas práticas.

É de : interesse assinalar que, na África do Sul, projetos com abordagem holística foram usados para preparar estudantes negros com defasagem para iniciar o curso universitário (Grayson, 1997). Em tais projetos, os conteúdos foram desenvolvidos integrando vários aspectos do processo ensino-aprendizagem, inclusive a aquisição de habilidades práticas.

Para projetos, Pich-Otero et al. (1998) propõem as seguintes etapas:

- identificar e equacionar o problema;

- selecionar a técnica própria para desenvolver o projeto;

- avaliar os recursos materiais e humanos;

- executar o projeto através de seu desenvolvimento tecnológico;

- avaliar o processo global e seus resultados.

As limitações de espaço, de tempo do professor para orientar e de falta de recursos, segundo Austin (1997), podem ser contornadas realizando projetos mais curtos, utilizando conteúdo mais simples e com escopo mais limitado, trabalhando em grupos e não individualmente.

A garantia de que um miniprojeto dê certo, na opinião de Lewis (1999), é obtida se for assegurado que os conteúdos e objetivos não sejam ambíguos, se for reconhecido que a natureza de um miniprojeto acarreta dificuldade ao aluno. O autor mostra a necessidade de dar tempo suficiente, apoio e orientação para permitir aos estudantes desenvolverem as tarefas requeridas e entendê-las.

Em cursos à distância, Mckenzie (1996) considera adequadas as seguintes etapas:

- o conteúdo é distribuído aos alunos em textos, de acordo com seu próprio ritmo; 
- no meio do semestre, geralmente, é realizado um curso intensivo de laboratório, de quatro dias, em que a assistência do professor tem que ser constante, e que apresenta as seguintes características:

- um experimento é completado em um período de um dia e não em meio-período;

- os quatro dias preenchem todas as habilidades experimentais em um único assunto;

- os cálculos de resultados e relatório são muito comprimidos.

Várias sugestões foram dadas por Byrne (1990) para que o trabalho de laboratório, em geral, seja mais eficiente, como colocar claramente as partes do experimento, salientando o que é essencial e o que é secundário, como assegurar que o experimento não tenha pontos obscuros ou irrelevantes e que as habilidades necessárias tenham sido adquiridas previamente. O mesmo autor recomendou o uso de linguagem simples e precisa nas orientações orais e escritas, o seqüenciamento dos procedimentos experimentais em passos numerados, usando diagramas, escrevendo instruções de forma que se permita uma abordagem de solução de problema.

Silverman (1996) propõe que as atividades de laboratório, no caso dele, ligadas à Física e à Astronomia, possam ser realizadas pelo método do aprendizado auto-dirigido. Essa também foi a opinião de um dos professores de Bioquímica que participou da pesquisa aqui relatada, na fase de aplicação e teste dos instrumentos de coleta de dados (apêndice $6-p$. 253).

Watts e Alsop (2000) chamaram a atenção dos pesquisadores, em geral, para que levem em conta, em suas pesquisas, o domínio afetivo do processo ensino-aprendizagem, apoiando as idéias dos modelos construtivistas.

Chin-Chung Tsai (1999), da Universidade Chiao Tung de Taiwan, trabalhando com adolescentes, mostrou que no laboratório podem estabelecer-se vários tipos de negociações entre os atores (professores, auxiliares e alunos), benéficas para o ensino, como negociação de status 
(quem comanda em cada situação), de ação (quem age em determinada ordem), de significação (troca de explicações e conhecimentos), de materiais (compartilhamento de aparelhos, vidraria e reagentes), além de relações interpessoais. Essas considerações são válidas também para adultos de cursos universitários, na concepção adotada no trabalho aqui relatado.

Tsai (1999) utilizou questionários para obter a opinião dos alunos sobre a necessidade de uso do laboratório na aprendizagem da Ciência, sobre se essa atividade ensina, sobre como deve ser um laboratório ideal, sobre que papel o aluno gostaria de exercer em aulas práticas e qual efetivamente exerce.

Esse olhar sobre pesquisas realizadas na última década mostra que há grande interesse em analisar aulas práticas, para entender que tipo de ensino elas podem propiciar, mas não a que servirá este ensino. Segundo Bennett (2000), professores secundários, apesar de formados em cursos universitários nos quais vivenciaram trabalho laboratorial, continuam a perguntar-se: "Por que fazer trabalho prático?" "Há muitas limitações em tal trabalho?". Os pesquisadores perscrutam as virtudes e defeitos do ensino em laboratório, mensuram seus resultados, discutem os fatores que interferem sobre a consecução dos objetivos propostos para a disciplina e para as aulas práticas em si. Entretanto, cada conclusão encerra-se em si mesma, serve a uma situação restrita, explica um caso específico.

Há poucas generalizações a fazer com dados do tipo descrito acima. Cada professor, ao ler a literatura sobre aulas práticas no recinto do laboratório, talvez continue em dúvida, perguntando-se: "Será que em meu caso isto funcionará?", "Que informações eu devo recolher para estabelecer critérios de escolha em relação às minhas aulas práticas?"

Em face dessas constatações, é importante dar meios ao professor de Bioquímica para que ele possa obter todo tipo de informação que the propicie formar um quadro completo das circunstâncias em que o ensino da prática laboratorial pode ocorrer, em seu caso. Um modelo de como analisar, interpretar e compreender dados mostrará ao professor quais os fatores que 
influem sobre o ensino em laboratório, no contexto que vivencia, e o orientará na descoberta de quais são as funções e o papel que suas aulas práticas potencialmente podem exercer, num determinado momento, clareando os caminhos mais curtos e mais seguros que o conduzirão de suas expectativas às suas realizações.

Objetivo geral do trabalho - O objetivo deste trabalho é propor um modelo de análise do papel de aulas práticas no ensino de Bioquímica que dê subsídios ao professor para estabelecer critérios de inclusão e utilização dessas aulas em sua disciplina, levando em consideração o contexto em que elas se inserem.

O modelo desenvolvido neste trabalho utiliza um conjunto de instrumentos de coleta de dados constituído de questionários e de roteiros para observação, análise e pesquisa documental, material especificamente construído para esses fins, e constitui-se de uma discussão de como tais documentos podem ser utilizados, em sua totalidade ou em partes, pelo professor e pelo corpo técnico das instituições de ensino superior, para fazer escolhas em relação a aulas práticas ou para avaliar o desempenho do professor ao utilizá-las. Tal modelo permite generalizações que tornam possível sua aplicação em contextos variados e até em outras disciplinas com características semelhantes à Bioquímica no que se refere a aulas práticas.

Tese - A tese a ser defendida é expressa nas seguintes afirmações: (1) aspectos inerentes à instituição, ao curso, à disciplina, às condições materiais e de funcionamento do laboratório, aos professores e alunos são parâmetros (variáveis) que devem ser levados em consideração para caracterizar o contexto em que as aulas práticas ocorrem; (2) instrumentos de coleta de dados para a análise do papel de aulas práticas precisam ser abrangentes, precisos, profundos, válidos e confiáveis, o que vincula suas criação e elaboração a uma visão holística do processo ensino-aprendizagem, pela qual nenhum fenômeno pode isolar-se, no tempo e no espaço, do contexto em que ocorre. 
Metodologia - Neste trabalho, justifica-se uma abordagem holística, considerando-se que o processo ensino-aprendizagem é muito complexo e a holística vê processo como um todo, cujas várias manifestações (sinergias) estão estreitamente ligadas entre $\mathrm{si}$, em interações constantes e paradoxais (Weil, 1990). A visão holística incita-nos a estudar qualquer forma de ensino, mesmo o de matérias de cunho experimental como a Bioquímica, com o olhar das Ciências Humanas, em que qualidade e quantidade interpenetram-se, fornecendo-nos conhecimento mais significante que mesmo a mais complexa análise estatística, sozinha, não poderia nos proporcionar.

A precisão dos roteiros e questionários formulados neste trabalho está expressa na exatidão com que os mesmos permitem observar e analisar, nos mínimos detalhes, cada aspecto do ensino em aulas práticas; sua abrangência refere-se à intenção de cobrir o maior número possivel de situações em que aulas práticas podem ocorrer; eles são profundos, na medida em que vão além das aparências, buscam sentimentos, reações verbais e não-verbais dos atores do processo ensino-aprendizagem, procurando descobrir o âmago das questões em foco; são válidos, porque medem aquilo que se propõem a medir e confióveis (fidedignos), porque dão os mesmos resultados, levam a conclusões semelhantes e a generalizações equivalentes para situações idênticas, quando usados por pesquisadores diferentes (Gressler, 1989; Richardson, 1989).

A pesquisa desenvolvida neste trabalho, visando a criar e montar os instrumentos de coleta de dados teve um enfoque qualitativo (Lüdke e André, 1986; Gressler, 1989; Lythcott e Duschl, 1990; Minayo, 1994) e foi complementada por pesquisa quantitativa (Niaz, 1997; Santos Filho e Gamboa, 1997).

Resultados - Foi feito uma estudo bibliográfico sobre Educação e uma pesquisa documental sobre legislação educacional no Brasil para definir os itens que deveriam constar dos instrumentos de coleta de dados. 
Os instrumentos produzidos levantam informações que tornam possiveis:

(1) caracterização do contexto - (a) roteiros de pesquisa documental sobre a instituição de ensino superior, o curso de graduação, a disciplina com conteúdo de Bioquímica e os professores que a ministram, (b) roteiro de observação sobre o espaço físico do laboratório e análise de suas condições de funcionamento e (c) questionários dirigidos a professores e alunos sobre suas opiniões, expectativas e desempenho em aulas práticas;

(2) análise das aulas práticas - roteiro para (a) coleta de informações sobre objetivos, conteúdo, preparo de experimentos, elaboração de protocolos, (b) observação sobre execução, forma de registro dos dados obtidos e comportamento dos participantes, (c) análise da discussão e do relato dos resultados experimentais e (d) avaliação dos conhecimentos adquiridos;

(3) roteiro para definição das funções e determinação do papel das aulas práticas no contexto analisado.

Os instrumentos de coleta de dados construídos foram aplicados em seis contextos que se distinguiam pelo tipo de instituição de ensino superior, quanto à entidade mantenedora (pública ou privada) e à classificação (faculdade, instituto ou escola superior; centro universitário; universidade), pelo enfoque do curso das áreas de Ciências Biológicas ou da Saúde escolhido (ciência pura, aplicada ou tecnologia), pela posição da disciplina na grade curricular. Essa aplicação visou ao pré-teste dos instrumentos e serviu de base para a montagem do modelo de análise do papel de aulas práticas.

O Modelo de Análise do Papel das Aulas Práticas no Ensino de Bioquímica criado é uma forma de analisar aulas práticas e o contexto em que elas ocorrem, para definir as funções e os papéis que o ensino no laboratório exerce dentro da disciplina.

Os resultados da aplicação do Modelo de Análise do Papel das Aulas Práticas no Ensino de Bioquímica nos seis contextos escolhidos são apresentados 
no capítulo de "Resultados e Discussão", exemplificando como esse modelo pode ser usado para determinar funções e papéis das aulas práticas de Bioquímica e para comparar formas de ensino dessa disciplina em contextos diferentes.

O presente trabalho discute, ainda, como o professor e/ou o corpo técnico da instituição, adotando o modelo de análise proposto para avaliar o trabalho em aulas práticas e/ou para fazer seus planejamentos do curso e da disciplina de Bioquímica, podem estabelecer critérios que definam:

(1) inclusão ou não de aulas práticas na programação;

(2) substituição de aulas práticas por outras estratégias de ensino ou sua integração com outros tipos de atividades docentes;

(3) caso haja inclusão de aulas práticas na programação, utilizá-las com um ou mais dos seguintes objetivos:

- ilustrar e aprofundar conteúdo de aulas teóricas;

- desenvolver habilidades técnicas;

- desenvolver habilidades mentais;

- ensinar a resolver problemas por meio de experimentação;

- fazer treinamento para pesquisa laboratorial;

- ensinar utilização de literatura científica;

- treinar redação científica;

- fazer integração com outras disciplinas do currículo e/ou com atividades de pesquisa e de extensão da instituição;

- motivar aluno e melhorar relações aluno-aluno e/ou professoraluno;

- mostrar a importância da Bioquímica;

- desenvolver o espírito científico e o interesse pela Ciência;

- preparar o aluno para a vida profissional;

- integrar o aluno à vida acadêmica e/ou contribuir para a vida cotidiana do aluno como cidadão;

- outros, que podem ser aventados, atendendo a necessidades e particularidades não descritas no presente trabalho. 


\title{
METODOLOGIA
}

\section{EMBASAMENTO TEÓRICO DO MODELO DE ANÁLISE DO PAPEL DAS AULAS PRÁTICAS NO ENSINO DE BIOQUÍMICA}

\author{
SUMÁRIO \\ EMBASAMENTO TEÓRICO DO MODELO DE ANÁLISE DO PAPEL DAS AULAS PRÁTICAS NO ENSINO DE \\ BIOQUIMICA \\ Dimensão ideológica \\ Objeto de estudo \\ A análise das aulas práticas \\ O processo ensino-aprendizagem \\ A Visão Holística e o Olhar das Ciências Humanas \\ Pesquisa qualitativa $X$ pesquisa quantitativa \\ Elaboração do Modelo de Análise do Papel das Aulas Práticas no Ensino de Bioquímica \\ Dimensão técnica \\ Criação e elaboração dos instrumentos de coleta de dados \\ Objetivos \\ Técnicas utilizadas \\ Teste do Modelo de Análise do Papel das Aulas Práticas no Ensino de Bioquimica \\ UNIVERSO DA PESQUISA E AMOSTRAGEM \\ Universo da pesquisa \\ Amostragem \\ Características da amostragem \\ Instituições e cursos escolhidos \\ Instituiçöes \\ Cursos \\ Contextos escolhidos para a aplicação dos instrumentos de coleta de dados
}

\section{Dimensão ideológica}

\section{Objeto de estudo}

O objeto de estudo do presente trabalho, o papel das aulas práticas no ensino de Bioquímica, como qualquer aspecto do estudo do processo ensino-aprendizagem, foi abordado sob a luz de uma orientação teórica previamente estabelecida e explicitada com clareza, de modo a obter harmonia entre as formas de levantamento de dados e suas interpretação e compreensão.

A intenção não foi discutir conceitos teóricos, mas mostrar que o professor de Bioquímica, ao utilizar os instrumentos de coleta de dados construídos e ao seguir o modelo de análise proposto, estará baseando suas escolhas e decisões, com relação a aulas práticas, em determinado corpo de 
conhecimentos já legitimados. Essa idéia foi desenvolvida por Abreu e Masetto no livro "O professor universitário em aula" (Abreu e Masetto, 1990). Dos mesmos autores também foi encampada a afirmação que, em sala de aula, o enfoque do trabalho do professor pende ora para a pessoa do professor, aquele que ensina, ora para a do aluno, aquele que aprende, embora ensino e aprendizagem sejam processos indissociáveis. Considerando que toda instituição de ensino só existe em função do aprendiz (pessoa, futuro profissional e membro de uma sociedade) e do contexto social em que ele se insere, optou-se aqui por direcionar as reflexões para a aprendizagem do aluno; o ensino ministrado pelo professor apareceu em função de mostrar como ele cria e organiza o conhecimento que o aluno pode obter. Assim, negase a pedagogia centrada no professor, que valoriza as relações hierárquicas, a transmissão de conhecimentos do Neo-behaviorismo, mas também não se pende para o extremo oposto, de adotar a pedagogia centrada no aluno, defendida pela Escola Nova e pela Psicologia da Gestalt, que pressupõe, no adulto, capacidade de abstração, volume de informações organizadas, domínio sistematizado de conhecimentos de determinada área, o que nem sempre ele apresenta (Becker, 1999).

\section{A análise das aulas práticas}

A forma de analisar aulas práticas apresentada neste trabalho visou a desvendar as relações entre a aprendizagem obtida no recinto do laboratório e o tipo de ensino aí praticado pelo professor; apoiou a pedagogia centrada na relação aluno-professor, defendida por Piaget e Vygotsky (Howe, 1996; La Taille, Kohl e Dantas, 1992), em que nada pode ser definido previamente sem os dados do local e da hora. Nesse enfoque, valorizou-se a importância do conteúdo sistematizado pela Ciência, o acervo cultural da humanidade e a autoridade do saber do professor, ao mesmo tempo que levou-se em conta a experiência de vida do aluno, o conjunto de conhecimentos construídos até o momento da aprendizagem em questão, a capacidade que ele tem de construir o novo conhecimento que será ativado em sala de aula (Masetto, 1998a e 1998b; Becker, 1999). 


\section{O processo ensino-aprendizagem}

O estudo efetuado iniciou-se com "o que àprender em aulas práticas", seguiu pesquisando "o que pode ser aprendido nas circunstâncias em que elas ocorrem" e "para que aprender", para chegar a "o que fazer para obter o aprendizado pretendido e possível".

Entre os aspectos do processo ensino-aprendizagem focalizados está o aspecto cognitivo que é tudo que se refere à captação e processamento de informações, à organização de dados, à apreensão e/ou criação de conceitos, ao relacionamento entre conceitos, à percepção e resolução de problemas, à aquisição de habilidades, ao desenvolvimento de pensamento e raciocínio (Mager, 1962 e 1972). A aprendizagem, nesse aspecto, diz respeito tanto ao conhecimento já integrante da Ciência, como à resolução de problemas pouco ou nada conhecidos.

A razão do destaque dado à cognição prende-se ao fato de o aluno, normalmente, procurar um curso superior para adquirir, em menos tempo possível, o maior número de informações que o habilitem a exercer uma profissão (Vella, 1989). Isso significa responder à solicitação do mercado de trabalho que exige competência, especialização, nível técnico avançado, além das capacidades de rápida adaptação a novas circunstâncias e de manter relações de fina sintonia com seus pares, superiores e subalternos (Toffler, 1980). Entretanto, a mesma sociedade que constrói e mantém estruturas que mecanizam o homem vê-se na premência de valorizá-lo como ser humano, para que ele produza mais e melhor. Um ensino nesta e para esta sociedade não pode, então, ater-se apenas ao cognitivo, deixando de lado elementos do mundo afetivo do educando e de sua vida em comunidade (Watts e Alsop, 2000). Entendeu-se que, por isso, e coerentemente com uma visão holística (Crema, 1989; Weil, 1990; Brandão e Crema, 1991; Tavares, 1998), adotada e discutida em outra parte deste capítulo, deve-se levar em consideração que há reciprocidade entre processo ensino-aprendizagem e seu entorno. Mantendo essa postura e não perdendo de vista que o 
presente estudo enfoca as pessoas do aluno e do professor e as relações entre eles, os roteiros de coleta de informações, observação e análise e os questionários criados coletam também dados sobre os aspectos emocionais e sociais da aprendizagem. É possivel, por meio deles, pesquisar sentimentos do professor e dos alunos, que se expressam por comportamentos, opiniões e expectativas. Os dados obtidos por esses documentos evidenciam as motivações do aluno ao escolher seu curso e as do professor ao ministrar sua disciplina, deixam claras as relações interpessoais no laboratório, mostram que possibilidades de participar da construção de seu conhecimento o professor dá ao aluno, ao fazer o levantamento do tipo de atuação do estudante em discussões, de como é seu envolvimento em projetos inter e multidisciplinares, em atividades de pesquisa laboratorial e de extensão da instituição; aqueles dados também expõem qual a interação do aprendiz com a sociedade.

O modelo de análise de aulas práticas proposto pouco explorou o aspecto do aluno como cidadão, como pessoa capaz de decidir e de se envolver por opção própria, comprometendo-se social e politicamente (Minayo, 1994; Santos e Schnetzler, 1996; Schwartz, 1999), embora neste trabalho defenda-se que qualquer conhecimento, inclusive o de Bioquímica, não tem um fim em si mesmo, mas se presta a "desenvolver as habilidades básicas que caracterizam um cidadão: participação e julgamento" (Santos e Schnetzler, 1996). Sob essa perspectiva, alguns itens dos instrumentos de coleta de dados evidenciam parcialmente o espaço que é dado ao aluno em aulas práticas, para que possa adquirir autonomia de pensamento e de ação.

O foco das atenções foi a aprendizagem significativa (Abreu e Masetto, 1990), quer dizer, aquela em que o aprendiz é capaz de reter e repetir a informação ou a habilidade ensinada, relacionando-a com o que já sabe, capacitando-se a aplicar o que foi aprendido em situações semelhantes. Esse tipo de aprendizagem cresce exponencialmente: quanto mais se aprende, mais fácil é aprender e mais duradouro é o conhecimento aprendido. Isso só ocorrerá se o que se aprende fizer sentido para o 
estudante, relacionando-se com seu universo de conhecimento e com seu viver cotidiano, se torná-lo capaz de formular problemas ou questões, se fizer com que se sinta responsável pela própria aprendizagem, pois esta é pessoal: ninguém aprende pelo outro ou pensa com a cabeça alheia.

A meta, ao montar os roteiros e questionários aqui expostos, foi a de que o professor de Bioquímica, antes de executar seu planejamento, utilize esses instrumentos para obter informações e possa usar as conclusões que aflorem da análise feita de acordo com o modelo proposto, para definir seus critérios de escolha com relação a aulas práticas, imbuído do conhecimento de qual potencial o contexto em que trabalha tem de propiciar aprendizagem significativa, de modo que ele tenha condições de estabelecer objetivos realísticos para seu ensino. Um professor que reavalia constantemente seu planejamento e suas ações está dentro dos padrões de formação continuada preconizado para uma sociedade de informação, caracterizada por estudiosos atuais (Behrens, 1998).

\section{A Visão Holística e o Olhar das Ciências Humanas}

A montagem do modelo de análise do papel das aulas práticas empregou uma abordagem holística da realidade (Crema, 1989; Weil, 1990; Brandão e Crema, 1991; Tavares, 1998), uma vez que tratou o processo ensinoaprendizagem como um todo constituído de múltiplas sinergias estreitamente ligadas entre si, em interações constantes. As relações estabelecidas entre as partes e o todo são paradoxais, por conter contradições, sob o ponto de vista da lógica tradicional, mas estas são aparentes, considerando-se que mesmo a Ciência, como corpo de conhecimentos, vem derrubando a idéia de dualidades geradoras de conflitos (Bachelard, 1974). Assim, não se estabeleceram, neste trabalho, fronteiras nítidas entre sujeito e objeto, espaço interno e espaço externo, pessoal e transpessoal, sentimento e razão.

O ensino de Bioquímica, ciência construída por experimentação, foi estudado sob a óptica das Ciências Humanas e/ou Sociais, mantendo um aspecto comum às Ciências Naturais, qual seja, a construção de 
conhecimentos por conceitos ou cientificidade (Richardson, 1989; Minayo, 1994), mas não parando por aí. Das Ciências Humanas e Sociais, o valor da subjetividade foi acrescentado à objetividade típica das Ciências Naturais, pois, concretamente, o ensino trata de uma realidade em que nós próprios, seres humanos, somos agentes e observadores. Isso mostra que não é possível o pesquisador fazer uma observação totalmente neutra, isenta de ânimo.

As características básicas das Ciências Sociais, a saber, a provisoriedade, o dinamismo e a especificidade dos processos (Minayo, 1994) foram apropriadas por esta pesquisa. Assumiu-se, ainda, que a Ciência é sempre comprometida com uma ideologia (Severino, 1986; Demo, 1987).

A pesquisa feita considerou a compreensão e não apenas a interpretação como a essência da investigação (Minayo, 1994), o que se opõe claramente à visão cartesiana adotada ao longo do tempo pelas Ciências Naturais, na qual só os termos matemáticos, obtidos por pesquisa quantitativa e analisados a partir de tratamento estatístico, traduzem com clareza a realidade. O estudo feito nega o enfoque da pesquisa quantitativa que se alicerça notadamente na observação sensorial e que interpreta os dados subjetivos sobretudo à luz dos dados objetivos (Minayo, 1994; Chizzotti, 1995); levou-se em conta, neste trabalho, que também os dados subjetivos, como valores e crenças, têm significado em si mesmos.

O estudo realizado percorreu o caminho do meio, entre "todo universo pode ser expresso matematicamente", do Positivismo, e o "tudo é relativo", da Dialética, embora esta última concorde com a pedagogia centrada na relação aluno-professor aqui adotada. Consideramos as "quantidades" como um caso particular das "qualidades" (Kenneth, 1992; Santos Filho e Gamboa, 1997).

Fica assim consignado que, no escopo deste trabalho, homem e natureza são aspectos de uma mesma manifestação - o existir - não 
havendo, nesse sentido, uma separação entre ensinar uma ciência humana, social ou natural.

\section{Pesquisa qualitativa $X$ pesquisa quantitativa}

A abordagem qualitativa mostrou-se adequada para a construção dos instrumentos de coleta de dados que permitiram a elaboração de um modelo de análise das aulas práticas, porque a metodologia empregada utilizou 0 ambiente natural em que tais aulas ocorrem (Bogdan e Biklen, 1982), o laboratório, como fonte direta de dados e a pesquisadora, autora desta obra, como principal instrumento de coleta de dados (Lüdcke e André, 1986).

Para uma análise mais precisa e completa, os dados descritivos, típicos da pesquisa qualitativa, são mais ricos que os quantitativos, porque, além de descreverem comportamentos verbais e não-verbais, situações, acontecimentos, dão importância ao significado que as pessoas atribuem às coisas e mostram aspectos psicológicos, como motivações, expectativas, crenças e valores, vivência e experiências do professor e dos alunos (Minayo, 1994). Os dados obtidos pelo uso dos instrumentos produzidos não são coisas isoladas, acontecimentos fixos, captados em um instante, como uma fotografia de um recorte da realidade, mas são fenômenos que, mais que percebidos pelos sentidos, pretende-se que sejam entendidos em sua essência. Todos os fatos apreendidos sobre os aspectos estudados do processo ensinoaprendizagem foram considerados igualmente importantes: a constância e a ocasionalidade das manifestações, a fala e o silêncio. As contribuições das pessoas que atuam em aulas práticas, professores, alunos e auxiliares, têm o mesmo valor, mas são únicas, por serem todas relevantes.

A ênfase na qualidade possibilita estudar o funcionamento e a dinâmica de um fenômeno, ela não conflita com a visão holística que se pretendeu dar ao processo ensino-aprendizagem, uma vez que contém a idéia de que ele interage com o contexto em que está inserido, num fluxo contínuo de influências mútuas. 
Na pesquisa qualitativa, as conclusões não são determinadas pelos dados, pois elas são obtidas por "defesa" e não por "prova", pelo uso do desencadear de boas razões a favor de certos argumentos; não há uma justificativa absoluta do conhecimento só pela experiência, nem só pela razão (Lythcott e Duschl, 1990).

A opção pela pesquisa qualitativa e a negação do "reducionismo matemático" não excluiu o levantamento de alguns dados quantitativos, cujo tratamento não foi além de percentagens e proporções, usadas apenas como indicadores que foram interpretados sob a égide dos elementos qualitativos e subjetivos apurados (Kenneth, 1992; Santos Filho e Gamboa, 1997). De fato, pendeu-se, ora para a qualidade, ora para a quantidade, dependendo da necessidade de compreensão dos eventos observados e analisados (Richardson, 1989; Minayo, 1994; Niaz, 1997).

A ordenação da coleta de dados nos questionários e roteiros produzidos seguiu um processo indutivo, em que não há preocupação em buscar evidências para comprovar hipóteses definidas previamente (Bogdan e Biklen, 1982). Partiu-se das particularidades para o geral, das conclusões parciais para as generalizações. Por outro lado, o professor de Bioquímica, ao aplicar o modelo de análise das aulas práticas assim construído, para entender sua situação específica, estará seguindo o caminho dedutivo, uma vez que uma concepção geral estará sendo aplicada a um contexto particular.

Elaboração do Modelo de Análise do Papel das aulas Práticas no Ensino de Bioquímica

A montagem de um modelo de análise das aulas práticas, isto é, uma proposta de como fazer essa análise, iniciou-se com o tratamento das informações coletadas por roteiros e questionários, para descobrir quais as funções que as aulas práticas de Bioquímica exercem no ensino desta disciplina, em um dado contexto, isto é, o quê elas ensinam. Isso feito, concluiu-se que papel têm as aulas práticas, em outras palavras, para que serve o aprendizado obtido em laboratório, em certas circunstâncias, o 
que resulta na definição de até que ponto o ensino possível pode ser efetivamente praticado.

A análise proposta decodifica o que está escrito nos documentos preenchidos, apreendendo o conteúdo explícito e/ou implícito que as comunicações orais, visuais, escritas e gestuais originais continham. Isso significa que há uma passagem dos elementos descritivos para os interpretativos e destes para a compreensão do fenômeno de aprendizagem em aulas práticas como um todo (Lythcott e Duschl, 1990; Thiollent, 1986).

\section{Dimensão técnica}

\section{Criação e elaboração dos instrumentos de coleta de dados}

Os objetivos e as técnicas da pesquisa exploratória feita para a criação e a elaboração dos instrumentos de coleta de dados foram:

\section{Objetivos}

- delimitar o problema;

- definir e mostrar a evolução do objeto de estudo;

- definir os objetivos do trabalho de pesquisa;

- construir o marco teórico;

- explorar o campo de pesquisa;

- levantar os itens para a elaboração dos instrumentos de coleta de dados.

\section{Técnicas utilizadas}

- pesquisa bibliográfica sobre:

- ensino-aprendizagem;

- currículo;

- aula prática;

- estratégias de ensino;

- pesquisa documental sobre leis e normas que regem o ensino superior no Brasil. 
- pesquisa de campo - questionário aplicado a professores que ministravam aulas práticas em disciplinas de cursos com conteúdo de Ciências Biológicas e da Saúde (Apêndice 8). Não houve um critério específico de escolha dos professores e/ou cursos, tendo sido feita apenas uma solicitação informal a vários professores para que respondessem algumas questões e, entre eles, alguns prontificaram-se a colaborar.

\section{Teste do Modelo de Análise do Papel das aulas Práticas no Ensino de}

\section{Bioquímica}

O pré-teste dos instrumentos de coleta de dados foi realizado em seis contextos diferentes. A partir da análise dos resultados obtidos, correções, adaptações, aprofundamento e acréscimos foram feitos, quando necessários, nos instrumentos de coleta de dados e na proposta de montagem do modelo de análise das aulas práticas de Bioquímica, de acordo com a fundamentação teórica e a metodologia empregadas.

\section{UNIVERSO DA PESQUISA E AMOSTRAGEM}

\section{Universo da pesquisa}

Aulas práticas de disciplinas com conteúdo de Bioquímica de cursos superiores de graduação das áreas de Ciências Biológicas e da Saúde.

\section{Amostragem}

\section{Características da amostragem}

Para a elaboração da amostragem das instituições universitárias em que os instrumentos de coleta de dados seriam aplicados para seu pré-teste, 
seguiu-se a proposta de Minayo (1992), que considera como amostragem boa aquela que possibilita abranger a totalidade do problema investigado em suas múltiplas dimensões.

A seleção das aulas práticas a serem observadas procurou garantir a possibilidade de serem verificados diferentes desenvolvimentos de habilidades e utilização de variadas técnicas laboratoriais.

\section{Instituições e cursos escolhidos}

Os instrumentos de coleta de dados elaborados foram aplicados em instituições e cursos designados a seguir:

Instituições

Natureza

Quanto à natureza da mantenedora das instituições observadas, as empresas eram:

- públicas;

- privadas.

\section{Classificação}

As instituições pesquisadas classificavam-se, de acordo com a Lei de Diretrizes e Bases da Educação Nacional (Brasil - Lei 9394/96 e Brasil Decreto Lei 3860/01) em:

- Faculdade ou Instituto ou Escola Superior;

- Centro Universitário;

- Universidade.

\section{Cursos}

- Ciências Biológicas;

- Nutrição;

- Ciências Farmacêuticas;

- Engenharia Química (foi observada a modalidade "Alimentos").

As áreas envolvidas e os enfoques dos cursos analisados foram:

- Ciências Biológicas - enfoque em ciência pura e aplicada e em docência - curso de Ciências Biológicas;

- Saúde 
- enfoque em ciência aplicada e em tecnologia - cursos de Nutrição e Ciências Farmacêuticas;

- enfoque em tecnologia - curso de Engenharia Química.

\section{Contextos escolhidos para a aplicação dos instrumentos de coleta de} dados

Com os critérios de escolha da amostragem descritos anteriormente, o modelo de análise do papel das aulas práticas no ensino de Bioquímica proposto neste trabalho foi aplicado em seis contextos diferentes, enumerados a seguir e resumidos e comparados na Tabela l:

- Contexto no1: Faculdades Integradas Hebraico-Brasileiras Renascença (FIHBR) - Campus Bom Retiro - R. Prates, 790 - Bom Retiro; Campus Higienópolis - R. São Vicente de Paulo, 659 Higienópolis - São Paulo - SP.

- instituição privada;

- faculdades integradas;

- Curso de Ciências Biológicas (ênfase em meio ambiente) - 8 semestres: enfoque de ciência pura, aplicada e docência bacharelado e licenciatura - período noturno;

- Disciplina de Química de Biomoléculas: lecionada no $1^{0}$ semestre do curso $-80 \mathrm{~h}$.

- Contexto no2: Centro Universitário São Camilo (CUSC) - Av. Nazaré, 1501 - Ipiranga - São Paulo - SP.

- instituição privada;

- centro universitário;

- Curso de Nutrição - 8 semestres: enfoque em ciência aplicada e tecnologia - bacharelado - período matutino;

- Disciplina de Bioquímica: lecionada no $2^{\circ}$ semestre do curso - $80 \mathrm{~h}$.

- Contexto no3: Faculdades Oswaldo Cruz (FOC) - R. Brigadeiro Galvão, 540 - Barra Funda - São Paulo - SP.

- instituição privada;

- faculdades e escolas superiores; 
- Curso de Engenharia Química - 6 anos: enfoque em tecnologia bacharelado - período noturno;

- Disciplina de Bioquímica Aplicada (Bioquímica Industrial - alimentos): lecionada na $6^{a}$ série do curso - 140 h (observação do $2^{\circ}$ semestre)

- Contexto no4: Faculdade de Saúde Pública (FSP) - USP - Av. Dr. Arnaldo, 715 - São Paulo - SP.

- instituição pública;

- universidade;

- Curso de Nutrição - 8 semestres: enfoque em ciência aplicada e tecnologia - bacharelado - período diurno;

- Disciplina de Bioquímica: lecionada no $2^{0}$ semestre do curso $120 \mathrm{~h}$.

- Contexto n05: Faculdade de Ciências Farmacêuticas (FCF) - USP - Av. Prof. Lineu Prestes, 580 - Cidade Universitária - São Paulo - SP.

- instituição pública;

- universidade;

- Curso de Farmácia e Bioquímica - 10 semestres: enfoque em ciência pura e aplicada e tecnologia - bacharelado - período diurno;

- Disciplina de Bioquímica Experimental (turma A): lecionada no $4^{ }$ semestre do curso - $120 \mathrm{~h}$.

- Contexto no6: Instituto de Biociências (IB) - USP - R. do Matão trav. 14, 321 - Cidade Universitária - São Paulo - SP.

- instituição pública;

- universidade;

- Curso de Ciências Biológicas - 8 semestres: enfoque em ciência pura e aplicada e docência - bacharelado e licenciatura período diurno;

- Disciplina de Bioquímica: lecionada no $2^{\circ}$ semestre do curso $180 \mathrm{~h}$. 
Tabela I - Características dos contextos em que foi feito o pré-teste dos instrumentos de coleta de dados

\begin{tabular}{|c|c|c|c|c|c|c|c|}
\hline \multirow[b]{2}{*}{ Instituição } & \multicolumn{7}{|c|}{ Características } \\
\hline & $\begin{array}{c}\text { Nature- } \\
\text { za }\end{array}$ & $\begin{array}{l}\text { Classifica- } \\
\text { ção }\end{array}$ & $\begin{array}{l}\text { Curso I } \\
\text { Ênfase I } \\
\text { Enfoque }\end{array}$ & Habilitação & Disciplina & $\begin{array}{l}\text { Posição } \\
\text { na grade } \\
\text { curricular }\end{array}$ & $\begin{array}{c}\text { Perio- } \\
\text { do / } \\
\text { № total } \\
\text { de } \\
\text { horas }\end{array}$ \\
\hline FIHBR & Privada & $\begin{array}{l}\text { Faculdades } \\
\text { Integradas }\end{array}$ & $\begin{array}{l}\text { Ciências } \\
\text { Biológicas / } \\
\text { Meio } \\
\text { ambiente / } \\
\text { Ciência pura, } \\
\text { aplicada e } \\
\text { docência } \\
\end{array}$ & $\begin{array}{c}\text { Bacharelado } \\
\text { e } \\
\text { Licenciatura }\end{array}$ & $\begin{array}{l}\text { Química de } \\
\text { Biomoléculas }\end{array}$ & $\begin{array}{l}1^{0} \\
\text { semestre }\end{array}$ & $\begin{array}{l}\text { Noturno } \\
\text { / } 80 \mathrm{~h}\end{array}$ \\
\hline cusc & Privada & $\begin{array}{l}\text { Centro } \\
\text { Universitário }\end{array}$ & $\begin{array}{l}\text { Nutrição / - / } \\
\text { Ciência } \\
\text { aplicada e } \\
\text { tecnologia } \\
\end{array}$ & Bacharelado & Bioquímica & $\begin{array}{l}2^{9} \\
\text { semestre }\end{array}$ & $\begin{array}{l}\text { Diurno / } \\
\text { 80h }\end{array}$ \\
\hline FOC & Privada & $\begin{array}{l}\text { Faculdades } \\
\text { e Escolas } \\
\text { Superiores }\end{array}$ & $\begin{array}{l}\text { Engenharia } \\
\text { Química / - / } \\
\text { Tecnologia }\end{array}$ & Bacharelado & $\begin{array}{l}\text { Bioquímica } \\
\text { Aplicada - } \\
\text { Bioquímica } \\
\text { Industrial } \\
\text { (alimentos) }\end{array}$ & $\begin{array}{l}2^{\circ} \\
\text { semestre } \\
\text { da } 6^{\mathrm{a}} \\
\text { série }\end{array}$ & $\begin{array}{l}\text { Noturno } \\
/ 140 \mathrm{~h} \\
(70 \mathrm{~h} \text { no } \\
2^{\circ} \text { sem) } \\
\end{array}$ \\
\hline FSP-USP & Pública & Universidade & $\begin{array}{l}\text { Nutrição / - / } \\
\text { Ciência } \\
\text { aplicada e } \\
\text { tecnologia }\end{array}$ & Bacharelado & Bioquímica & $\begin{array}{l}2^{\circ} \\
\text { semestre }\end{array}$ & $\begin{array}{l}\text { Diurno / } \\
120 \mathrm{~h}\end{array}$ \\
\hline FCF-USP & Pública & Universidade & $\begin{array}{l}\text { Farmácia e } \\
\text { Bioquimica / - } \\
\text { / Ciência } \\
\text { pura, } \\
\text { aplicada e } \\
\text { tecnologia } \\
\end{array}$ & Bacharelado & $\begin{array}{l}\text { Bioquimica } \\
\text { Experimental }\end{array}$ & $\begin{array}{l}4^{\circ} \\
\text { semestre }\end{array}$ & $\begin{array}{l}\text { Diurno / } \\
120 \mathrm{~h}\end{array}$ \\
\hline IB-USP & Pública & Universidade & $\begin{array}{l}\text { Ciências } \\
\text { Biológicas / - } \\
\text { / Ciência } \\
\text { pura, } \\
\text { aplicada e } \\
\text { docência }\end{array}$ & $\begin{array}{c}\text { Bacharelado } \\
e \\
\text { Licenciatura }\end{array}$ & Bioquímica & $\begin{array}{l}2^{\circ} \\
\text { semestre }\end{array}$ & $\begin{array}{l}\text { Diurno / } \\
180 \mathrm{~h}\end{array}$ \\
\hline
\end{tabular}




\section{RESULTADOS E DISCUSSÃO}

\section{INSTRUMENTOS DE COLETA DE DADOS}

\section{A. Construção dos Instrumentos de Coleta de Dados}

\section{SUMÁRIO}

I. A. 1. Resultados da pesquisa de campo exploratória

I. A. 2. Dados coletados na literatura para a definição dos itens dos instrumentos de coleta de dados

I. A. 2a. O contexto das aulas práticas

Laboratório, instituição, curso, disciplina
Professor
Alunos
Comunidade, país
Ensino superior, pesquisa
Graduação, pós-graduação, extensão, publicações científicas
Currículo
Sociedade
Contexto

I. A. 2b. Aula prática e o processo ensino-aprendizagem

Planejamento de aulas práticas

1. número, assunto, ordem na programação, relaçães com outras atividades, dinâmica

2. conhecimento prévio dos alunos

3. recursos materiais, suporte técnico-didático, funcionamento do laboratório

4. preparo e teste dos experimentos

5. normas de segurança e de manipulação de material biológico

6. objetivos, conteúdo

7. substituição de aulas práticas por outras atividades de ensino

8. problemas a serem resolvidos em aulas práticas

9. protocolo

Trabalho no laboratório

1. estratégia de ensino

2. utilização do protocolo

3. bibliografia

4. execução dos experimentos

5. grupos de trabalho

6. precisão, sensibilidade, higiene

7. habilidades técnicas e mentais, atitudes pessoais

8. orientação, assistência

9. registro dos resultados, processamento dos dados

10. duração da aula

11. comportamento dos participantes

12. encerramento da aula

Atividades posteriores à obtençăo dos dados

1. discussão

2. relatório

3. atividades decorrentes do trabalho prático

4. avaliação do aprendizado em aula prática

I. A. 2c. Funções das aulas práticas

Funções do conteúdo

Funções da metodologia

Funções do treinamento técnico

Funções das interações entre os participantes

I. A. 2d. Papel das aulas práticas

I. A. 3. Uso dos instrumentos de coleta de dados

I. A. 3a. Uso para planejamento

I. A. 3b. Uso para avaliação 
Para a construção dos instrumentos de coleta de dados, foram considerados os resultados de pesquisa de campo, de pesquisa bibliográfica sobre processo ensino-aprendizagem e currículos e de pesquisa documental sobre leis e normas que regem o ensino superior de graduação, feitas para dar subsídios à construção dos instrumentos de coleta de dados.

\section{A. 1. Resultados da pesquisa de campo exploratória: a importância que os professores dão a aulas práticas}

A pesquisa exploratória, realizada por meio de questionários endereçados a professores de Bioquímica (Apêndice 8), obteve resposta de treze deles, distribuídos entre os seguintes cursos: Agronomia da ESALQ - USP Piracicaba; Ciências Biológicas - IB - USP - São Paulo; Farmácia e Bioquímica - Faculdade de Ciências Farmacêuticas - USP - São Paulo; Farmácia e Bioquímica - Universidade Camilo Castelo Branco - São Paulo; Farmácia Universidade Paulista - Bauru, SP; Medicina - Faculdade de Medicina do ABC - Santo André, SP; Medicina - Faculdade de Medicina - USP - São Paulo; Medicina Veterinária - Faculdade de Medicina Veterinária - USP São Paulo; Nutrição - Universidade Anhembi-Morumbi - São Paulo; Nutrição Universidade Católica Dom Bosco - Campo Grande, MS.

Onze dos professores consultados deram aulas práticas nos cursos que estavam desenvolvendo, no momento da pesquisa ou no último curso que ministraram, os outros dois declararam não ter incluído aulas práticas em suas disciplinas, porque havia escassez de tempo. Um professor escreveu que sete, das quinze aulas práticas constantes da programação, foram utilizadas como aulas teóricas.

As respostas à pergunta "Por que ter aulas práticas?" incluíram razões que se referiram tanto à apreensão de conhecimentos, como à aquisição de habilidades. Dois professores disseram que as aulas práticas complementam as aulas teóricas e sete, que os alunos exercitam e/ou ilustram os conhecimentos teóricos, usando afirmações como: os alunos "verificam in vitro as reações que ocorrem in vivo" e "visualizam o que aprendem na teoria"; as aulas práticas "oferecem argumentos experimentais para as teorias apresentadas 
em classe", "dão credibilidade à teoria", "mostram o processo de construção da teoria".

Dois professores consideraram que, em aulas de laboratório, os alunos entendem os conceitos, isto é, essas aulas "tornam a Bioquímica mais fácil de ser compreendida" e outro respondeu que elas "incitam o raciocínio crítico". "Aulas práticas estruturam" e "constroem os conhecimentos, verificando-os e validando-os" foram outras opiniões emitidas, respectivamente, por dois professores diferentes dos já citados.

Algumas respostas salientaram que aulas práticas servem para a aprendizagem de pesquisa laboratorial; entre elas, estão as de quatro professores que declararam que elas ensinam técnicas laboratoriais básicas. Outro disse que elas "desenvolvem as capacidades de observação e interpretação de resultados, de se expressar, de escrever e de apresentar dados experimentais, usando termos adequados, por meio de pesquisa na literatura, ao fazer relatório".

Um professor mostrou o caráter motivacional das aulas práticas, explicando que a colocação deste tipo de aulas em seu curso foi por solicitação dos alunos.

Houve uma resposta em que o professor afirma que se deve fazer relação entre aulas práticas e aulas teóricas, ao dizer que: "Existe uma dissociação entre teoria e prática, para a maioria dos alunos. Quer se dê a teoria ou a prática antes, é difícil para eles juntarem os conhecimentos dos dois tipos de atividades, mas, pelo menos em alguns experimentos, isso deve ser tentado".

Vê-se que, pelas respostas obtidas, mesmo tendo em vista que dois professores não deram aulas práticas nos cursos considerados, todos atribuem algum tipo de importância às aulas práticas, o que é enfaticamente expresso nas palavras de dois deles, respectivamente: "Em toda minha experiência como professor, as aulas práticas tiveram forte impacto na formação do aluno"; "Aulas práticas são essenciais em qualquer curso de Ciências Físicas e Biológicas". Um professor, porém, ponderou que, em certas 
circunstâncias, as aulas práticas devem ser substituídas por exercícios com consulta em livros.

Com relação à questão "Como você acha que devem ser as aulas práticas?", as respostas foram das seguintes ordens: preocupação com conteúdo e/ou estratégias de ensino, com habilidades técnicas, com relações com outras atividades e com posição das aulas práticas na programação.

Entre as recomendações para que as aulas práticas tenham aproveitamento, dois professores escreveram que os experimentos devem ser simples, diretos, sem muita elaboração e fáceis de executar; um deles mostrou a importância da ligação do conteúdo com assuntos da carreira profissional escolhida pelos alunos.

Um professor salientou que, mesmo que as aulas não sejam em grande número, nelas deve ser dada ênfase à discussão dos dados, quando estiver envolvido ensino de conceitos; dois outros também reconheceram a importância de se ter tempo para a discussão dos resultados experimentais e outro sugeriu que, em condições adversas para realização de aulas práticas, pelo menos sejam dados resultados experimentais para os alunos discutirem.

No que se refere às habilidades técnicas que devam ser aprendidas, dois professores responderam que as aulas práticas precisam desenvolver o máximo de procedimentos experimentais, com uso do maior número possível de equipamentos e abranger todo o conteúdo do curso.

Um professor deu grande importância à experimentação para ensinar Bioquímica: opinou que, em condições ideais, enquanto o professor desse aulas teóricas, um técnico ou um monitor deveria ir demonstrando alguns experimentos, à medida que os conceitos fossem sendo dados, e, depois, realizar-se-iam as aulas de laboratório sobre o assunto. Um professor propôs, como uma boa forma de desenvolver aulas práticas, fornecer um problema e deixar os alunos buscarem um caminho experimental para resolvê-lo.

Em todos os casos, os professores relacionaram aulas práticas com aulas teóricas. 
No que se refere à posição das aulas práticas na programação, dois professores são de opinião que as primeiras devam ser dadas sempre após o término de um capítulo teórico, outro acredita que pequenos projetos com aulas de laboratório em seqüência, sem grandes intervalos entre elas, é melhor. Um professor lembrou que o tipo de aula prática a ser dado "depende dos objetivos do curso, variando desde o oferecimento de um protocolo de técnicas para demonstrar um fenômeno, até o desenvolvimento de um pequeno projeto científico".

A pergunta "As suas aulas práticas estão de acordo com as opiniões que expressou? Justifique" foi respondida de forma variada. Sete professores disseram que sim, dos quais dois ponderaram que houve limitações e impedimentos, dando a entender que o trabalho poderia ter sido melhor. Os demais disseram que não, apontando uma ou mais razões para a não consecução de seus objetivos, tais como: faltaram apoio técnico qualificado (um dos entrevistados), materiais (três deles) e conhecimentos aos alunos (um deles); não havia laboratório especializado em Bioquímica em sua instituição (um deles); foi necessário dar conta de uma vasta programação (dois deles); era pequena a carga horária das aulas (dois deles); havia pouco tempo do professor para planejar e preparar as aulas (um deles); havia grande número de alunos no laboratório (um deles).

Os resultados da pesquisa de campo realizada mostraram que seria importante levar em consideração que professores de Bioquímica vêem as aulas práticas como momento de ensino de conceitos e de linguagem científica, não só de treinamento técnico, mas sem unanimidade em suas visões sobre o assunto. Eles apontaram barreiras de vários tipos para realizar trabalho de laboratório com os alunos, de acordo com seus interesses, expectativas, necessidades e possibilidades. Isso mostrou que vale a pena investir esforços na análise das funções e na compreensão do papel das aulas práticas em situações variadas. 


\section{A. 2. Dados coletados na literatura para a definição dos itens dos instrumentos de coleta de dados}

Uma vez definidos quais são os elementos do contexto em que as aulas práticas de Bioquímica ocorrem e os aspectos importantes para sua análise acurada, coletaram-se dados na literatura, especialmente aqueles sobre assuntos legais e de educação. Foram selecionadas as informações que se harmonizavam com a visão filosófico-metodológica adotada, para a determinação de todos os itens e sub-itens que deveriam constar dos roteiros e para a elaboração das questões que seriam feitas nos questionários.

\section{A. 2 a. $O$ contexto das aulas práticas}

\section{Laboratório, instituição, curso, disciplina}

O laboratório é o local onde ocorre a experimentação, o cerne das aulas práticas de Bioquímica. Para o professor, elas começam antes, no planejamento e no preparo. Os alunos, principais protagonistas dessas aulas, iniciam seu trabalho ao entrar em contato com o protocolo de exercícios práticos, são acompanhados pelo professor durante a execução dos experimentos e em todas as fases posteriores que se seguem às aulas práticas em si: tratamento e discussão dos dados, relato e avaliação.

O aproveitamento das aulas práticas é parcialmente determinado pela qualidade do laboratório, o que depende de vontade politica, dos propósitos e das condições econômicas da instituição, do curso em questão - objetivos e currículo - e da disciplina com conteúdo de Bioquímica - posição na grade curricular, carga horária, objetivos e programação.

O conteúdo de Bioquímica ensinado nos cursos universitários é um corpo de conhecimentos definido por autores de livros, somados a um conjunto de habilidades laboratoriais e uma atividade humana para explicar, entender e manipular um segmento de nosso ambiente e de nós mesmos (Vella, 1989).

\section{Professor}

O planejamento e pelo menos uma parcela do preparo de aulas práticas são executados pelo professor e dependem de seu treinamento técnico e de seu conhecimento de Bioquímica; as atividades do trabalho laboratorial, 
em geral, são também influenciadas por seu preparo didático e pedagógico. A pedagogia refere-se às suas idéias sobre educação e a didática determina suas ações durante o ensino (Minayo, 1994). A prática pedagógica de cada professor expressa suas concepções de ensino, de aprendizagem e de conhecimento. Portanto, não basta a ele ser treinado como bioquímico, adquirindo domínio sobre conteúdos e habilidades laboratoriais, ele precisa conhecer metodologia de ensino (Vella, 1989).

Em cursos de licenciatura, existe uma preocupação com a formação do futuro professor, em função de sua qualificação para atuar no ensino médio. Essa clareza de intenções nem sempre ocorre em relação à formação do professor para cursos universitários. As disciplinas voltadas para a prática docente são mais comuns nos cursos de pós-graduação lato-sensu e especialização e vêm crescendo em participação nos cursos de mestrado e doutorado. No ensino de Ciências Naturais, "o que o aluno precisa aprender" é, ainda, mais importante do que "o como ensinar" e "para que ensinar". Em Bioquímica, a necessidade de discutir-se "de que forma obter aprendizado significante" torna-se aguda, porque é voz corrente, entre os estudantes, que esta disciplina é "muito difícil" e a atração de seus professores pela pesquisa laboratorial é uma vocação irresistível que, de certa forma, os distancia da busca por uma formação pedagógica adequada. Essa constatação estendese para professores universitários em geral e, embora sugerida pelos resultados de avaliações e discutida por pedagogos (Abreu e Masetto, 1990; Silva, 1990; Catani, 1998; Fazenda, 1998; Masetto, 1998a e 1998b) não é claramente sentida e/ou expressa pelos docentes.

A atuação do professor é também determinada, facilitada ou limitada pelas condições materiais, disponibilidade de tempo e apoio técnico-didático que the são facultados.

\section{Alunos}

As características próprias dos alunos, como bagagem de informações, estruturas mentais, habilidades, atitudes e comportamentos, adquiridas em suas vidas escolar e social pregressas, devem ser definidas e levadas em consideração, quando se pensa em ensinar por meio da prática. 
O aluno universitário é um indivíduo em final de adolescência ou na idade adulta. Por isso, geralmente se desconsidera que, terminado o crescimento biológico, não termina o crescimento psicológico e intelectual. $\mathrm{A}$ Andragogia, que se refere ao ensino do adulto, é baseada nos seguintes princípios: (1) aluno adulto vê-se como auto-diretivo e responsável; (2) possui experiência acumulada que é uma fonte potencial para seu próprio conhecimento e aquele de seus pares; (3) é motivado a aprender, principalmente, se percebe a aplicabilidade imediata em sua vida cotidiana; (4) focaliza seu interesse em resolver problemas, mais do que em teoria ou conteúdo abstrato, independentemente da idade, estado civil, tipo de avaliação, tamanho da classe, graduação ou pós-graduação; (5) ao obter informações, o adulto as usa para resolver problemas, adquire novas habilidades pela repetição e pela prática (Vella, 1989).

O aprendiz não é solitário na construção do conhecimento, mas o que aprende é resultado de sua interação com o professor, colegas e outras pessoas, relações que são mediadas pela linguagem, expressas verbalmente, por escrito, por gestos, por reações físicas e expressões (Alvarez, 1999 e 2000). As interações estabelecidas no processo ensino-aprendizagem, entre professores e alunos, não são previamente construídas; a aquisição de conhecimento é sempre contextualizada, porque, para cada ambiente, há uma interação, de acordo com o ponto de vista construtivista de Vygotsky (Howe, 1996), idéia esta que o presente trabalho endossa.

Alunos e professores, porém, não são robôs programados para executar tarefas com determinados fins. Certas atitudes que manifestam têm a ver com afetividade - valores, crenças, sentimentos, com compromissos políticos e sociais, são de cunho ideológico, mesmo que eles não tenham a intenção de explicitar seus desejos íntimos, suas verdadeiras intenções e motivações.

\section{Comunidade, país}

As circunstâncias que envolvem aulas práticas como forma de ensinar Ciência extrapolam os limites da educação. Há que serem considerados os aspectos políticos, econômicos, sociais e até religiosos das comunidades intra e extramuros com que a instituição trabalha. Além disso, deve ser 
lembrado que, em primeira instância, o ensino em geral é regulado pelas leis do país, atuando sob os princípios que as fundamentam.

\section{Ensino superior, pesquisa}

A Lei de Diretrizes e Bases da Educação Nacional (Brasil - Lei 9394/96), em seu Título $V$ (Dos Níveis e Modalidades de Educação e Ensino), Capítulo IV (Da Educação Superior), Art. 45 e o Decreto Lei 3860/01, Capítulo I, Art. 1ํㅜ dizem que as instituições de ensino superior podem ser classificadas como públicas ou privadas, com diferentes graus de abrangência e especialização, o que na prática traduz-se pela possibilidade de existirem várias organizações acadêmicas: faculdades, faculdades integradas, institutos ou escolas superiores, centros universitários e universidades, estas nos moldes tradicionais ou "especializadas por campo do saber" (Brasil - Lei 9394/96, Art. 52, Parágrafo único; Brasil - Decreto Lei 3860/01, Capítulo III, Art. $7^{0}$ ). O Art. 43 da Lei de Diretrizes e Bases define as finalidades do Ensino Superior, entre elas, "Incentivar o trabalho de pesquisa e investigação científica, visando ao desenvolvimento da Ciência e da Tecnologia..." (Inciso III). Este objetivo concretiza-se, em parte, ensinando-se como fazer pesquisa, discutindo-se sua importância e pesando-se o valor da investigação científica e da própria Ciência. Aulas práticas são, sem dúvida, um momento em que esses processos podem acontecer. Portanto, sempre que possível e pertinente, elas devem existir nos cursos de graduação.

O ensino da prática laboratorial é mais proveitoso, quando atrelado a atividades de pesquisa da instituição ou de fora dela (Hodson, 1992). Vários autores têm salientado que o professor-pesquisador é o docente ideal, tanto sob o ponto de vista de que aulas são um laboratório de pesquisa educacional, quer sejam teóricas ou práticas, como no sentido estrito do termo pesquisa (Silva, 1990; Kyle Jr et al., 1991; Schnetzler e Aragão, 1995; Kenski, 1998).

Para viabilizar a existência do professor-pesquisador, a Lei 9394/96, em seus Art. 52, Incisos II e III, determina que, pelo menos, um terço dos docentes da instituição deva ter titulação acadêmica de mestrado e doutorado e que, no mínimo, um terço deva trabalhar em regime de tempo integral. Quanto à 
titulação, normalmente a lei é posta em prática: as instituições de ensino superior exigem e valorizam professores titulados, algumas patrocinam a pós-graduação de seus docentes. Com relação ao regime de trabalho dos professores, porém, muitas faculdades isoladas ainda adotam o regime horista, com a carga horária do professor destinada exclusivamente à docência em sala de aula ou outros locais. Ora, além do tempo necessário para ministrar as aulas em si, inclusive práticas, o professor precisa ter momentos para planejamento e pesquisa dentro da instituição. Como isso pode ocorrer nesse tipo de regime horista?

Às vezes, o professor faz pesquisa em outras instituições, mas, neste caso, existe uma desvinculação e até uma competição entre suas duas atividades profissionais, a docência e a pesquisa. A concorrência é geralmente desleal: perde quase sempre a primeira, porque as instituições de pesquisa exigem muita dedicação (Chaimovich, 1995) e o professor, mesmo que a investigação científica não seja seu maior interesse, vê-se pressionado a dedicarse mais a ela, pois precisa aumentar sua especialização, alavancar sua titulação e manter-se atualizado. Mesmo presente esse conflito, a pesquisa na vida do professor sempre acrescenta (Masetto, 1998b).

Graduação, pós-graduação, extensão, publicą̧ões científicas

Ainda no âmbito legal, o Art. 44 da Lei 9394/96 determina que a educação superior abranja cursos de graduação, pós-graduação e extensão. $O$ ideal é que estes três níveis coexistam e integrem-se em termos de conteúdos e propósitos. Dessa forma, os projetos de pesquisa desenvolvidos na pós-graduação e nas atividades de extensão podem ter ligação com a graduação e interação com aulas práticas desse nível de ensino, como ocorre em algumas instituições (Exemplo: aulas prática de Bioquímica do curso de Nutrição da Universidade Católica Dom Bosco, em Campo Grande, MS, visitada por esta pesquisadora; experiências do grupo de pesquisa "Memória, Ensino e Novas Tecnologias (MENT)" da UNICAMP - KENSKI, 1998.)

As atividades de extensão têm atuação enraizada em algumas das finalidades do ensino superior, como "promover a divulgação de conhecimentos culturais, científicos e técnicos que constituem o patrimônio da humanidade e comunicar o saber através do ensino, de publicações e outras formas de comunicação" (Brasil - Lei 9394/96, Art. 43, Inciso IV). Aqui entra outro produto da extensão, que contribui com o ensino propriamente dito: as publicações de 
cunho científico da própria instituição e a participação de seus membros como colaboradores de publicações de outras entidades ligadas a Ciência e Tecnologia, nacionais e internacionais.

\section{Curriculo}

A Lei $9394 / 96$ e o Decreto Lei 3860/01 incluem, no que se refere ao ensino superior, aspectos que se coadunam com as premissas do currículo crítico, em contraposição às do currículo tecnicista (Silva, 1990), concordando com a abordagem holística e a visão das Ciências Humanas presente na metodologia desta pesquisa. Assim, a lei:

- admite a diversidade, permitindo a implantação de universidades especializadas (Brasil - Lei 9394/96, Art. 52, Parágrafo único; Brasil - Decreto Lei 3860/01, Capítulo III, Art. $7^{\circ}$, §º);

- valoriza o processo de ensino e não só seu resultado, aceitando outros critérios para ingresso na Universidade e não exclusivamente o exame vestibular (Brasil - Lei 9394/96, Art. 44, Inciso II, Art. 50 e 51);

- tem como princípios diretores (Brasil - Lei 9394/96, Título II, Art. $3^{\circ}$ ) a liberdade de aprender, ensinar, pesquisar e divulgar a cultura, o pensamento, a arte e o saber (Inciso II) e o pluralismo de idéias e de concepções pedagógicas (Inciso III);

- determina a avaliação contínua do ensino, através do processo nacional de avaliação (Brasil - Lei 9394/96, Art. 46).

\section{Sociedade}

O papel social dos cursos superiores explicita-se na Lei de Diretrizes e Bases da Educação Nacional vigente, na forma das seguintes finalidades (Art. 43):

- Inciso VI - "estimular o conhecimento dos problemas do mundo presente, em particular os nacionais e regionais, prestar serviços especializados à comunidade e estabelecer com esta uma relação de reciprocidade";

- Inciso VII - "promover a extensão, aberta à participação da população, visando à difusão das conquistas e benefícios resultantes da criação cultural e da pesquisa científica e tecnológica gerada na instituição". 


\section{Contexto}

Neste trabalho, apóia-se a idéia de que o contexto determina o conhecimento (Morin, 1998; Ryder e Leach, 1999). Tudo que, direta ou indiretamente e por qualquer via, influi sobre aulas práticas, enfim, deve ser considerado para que a análise delas torne-se completa e suas interpretação e compreensão sejam maximizadas.

Dessa forma, inicialmente, foi caracterizado, no presente trabalho, o contexto em que as aulas práticas ocorrem, o qual abrange: (1) o país, como entidade política; (2) a comunidade, como representante do caráter social da educação; (3) a instituição, com suas características estruturais e de funcionamento, como palco das ações; (4) os profissionais, professores, auxiliares e técnicos de laboratório, responsáveis pelo ensino; (5) os estudantes, como protagonistas do processo de aprendizagem e (6), como seres humanos, todos os que integram esse quadro, com seus valores, sua bagagem de conhecimentos e sua carga de emoção.

Para caracterizar esse cenário tão amplo, o contexto do trabalho desenvolvido em laboratório, e com a intenção de considerar todos os fatores que possam influir sobre o papel das aulas práticas no ensino de Bioquímica, foram elaborados roteiros para reunir informações sobre a instituição, o curso analisado e a disciplina enfocada, roteiros para descrever a estrutura física e o funcionamento do laboratório didático observado e questionários para apurar sentimentos dos professores e dos alunos envolvidos.

\section{A. 2b. Aula prática e o processo ensino-aprendizagem}

O roteiro de coleta de informações, observação e análise de aulas práticas foi montado de forma a cobrir todas as etapas compreendidas por esta atividade didática: planejamento, experimentação, discussão dos resultados, relatório e avaliação.

Planejamento de aulas práticas

1. número, assunto, ordem na programação, relações com outras atividades, dinâmica

O professor de Bioquímica que decidir usar aulas práticas como momento de ensino precisa planejar quantas serão estas aulas, quais seus assuntos, 
em que ordem elas devem ser colocadas na programação. Em seguida, delineará outras características gerais do trabalho prático, tais como sua ligação com atividades docentes e de pesquisa não pertinentes exclusivamente à disciplina, exploração concomitante de literatura científica sobre o tema desenvolvido, ordenação de aulas teóricas e práticas do mesmo assunto. Também será necessário estabelecer a dinâmica das aulas no laboratório, determinada pela distribuição de tempo entre planejamento e/ou explicações iniciais, execução dos experimentos, análise elou discussão dos resultados e sua apresentação.

\section{2. conhecimento prévio dos alunos}

Os aspectos das aulas práticas listados acima completam-se com o diagnóstico que o professor faz sobre qual é o estado do saber dos alunos ou, no mínimo, a expectativa de qual ele deva ser. Para ensinar Ciência, é necessário ter em conta a base epistemológica dos alunos e o que eles pensam (Ryder e Leach, 1999). É importante conhecer a capacidade de compreensão dos educandos para trabalhar as novas informações que thes serão fornecidas em aulas práticas, de modo que possam evoluir em seus conhecimentos. O termo "compreensão", aqui, não significa o produto de uma aprendizagem, mas uma habilidade mental que se manifesta durante esse processo e "evoluir" é usado no sentido de mudar, reorganizar, desenvolver o quadro conceitual dos alunos (Schnetzler e Aragão, 1995). Não se pode perder a dimensão do professor como educador. Sua função não é só a de conservar o que é bom, mas também a de melhorar sempre: ensinar não tem fim, começa sempre onde parou o conhecimento já adquirido.

Cada curso ou disciplina exige pré-requisitos mínimos para ser cursado a contento, mas o professor freqüentemente se depara com maturidades intelectuais, valores, experiências de vida, expectativas e comportamentos dos educandos bastante heterogêneos. Em seu relacionamento com os alunos, o principal desafio do professor é enfrentar a ansiedade de muitos de deixar para trás "todo aquele conhecimento inútil a que tiveram de se submeter" no ensino médio e que costuma reaparecer nas disciplinas ditas básicas, como Bioquímica, para, finalmente, "estudar aquele conteúdo 
necessário à profissão que escolheram". Manter a motivação e o interesse dos alunos é trabalhoso, porque a linguagem da Bioquímica é altamente especializada e, por mais que tenha aplicação, está inserida numa "disciplina de serviço".

Algumas instituições traçam o perfil dos alunos e muitos professores procuram, de alguma forma, conhecê-los melhor antes de iniciar os trabalhos. As duas medidas são benéficas para orientar o planejamento das aulas práticas.

3. recursos materiais, suporte técnico-didático, funcionamento do laboratório

Após a primeira fase do planejamento, a viabilização do que foi teoricamente arquitetado depende dos recursos materiais, do suporte técnico e da maneira como é feito o gerenciamento do laboratório. O professor faz agora o levantamento da vidraria, dos aparelhos e equipamentos, das drogas e materiais biológicos, dos dispositivos de segurança a sua disposição e certifica-se sobre a existência de técnicos e/ou monitores com que possa contar para o preparo, o teste dos experimentos, a distribuição dos materiais durante os trabalhos e auxílio na orientação e assistência aos alunos durante as aulas práticas.

A previsão do horário de uso do recinto do laboratório é necessária quando ele é partilhado com professores da mesma ou de outras disciplinas.

\section{4. preparo e teste dos experimentos}

O preparo das aulas práticas é planejado pelo professor e convém que seja orientado por ele, pois nem sempre o treinamento e os conhecimentos de técnicos e monitores são adequados ou suficientes, assim como deve ser dada atenção ao teste dos experimentos, participando de perto desse processo, se possivel.

\section{5. normas de segurança e de manipulação de material biológico}

Em algum ponto do planejamento, devem ser definidas as normas de segurança do trabalho experimental e levantadas as questões éticas e de saúde pertinentes ao uso de animais vivos ou mortos, de órgãos e tecidos. 0 professor deve decidir como as normas serão apresentadas aos alunos: no protocolo ou em separado, por escrito ou oralmente. Com certeza, é no mínimo perigoso relegar a segundo plano ou ao esquecimento a tarefa de 
estabelecer normas de segurança e manuseio de material biológico; a obrigação de passá-las aos alunos, assim como a de treiná-los tecnicamente para garantir sua execução, é de responsabilidade do professor.

6. objetivos, conteúdo

O próximo passo do planejamento é explicitar os objetivos das aulas práticas e, em função destes, determinar quais serão os conteúdos delas, isto é, os assuntos, os experimentos e as técnicas laboratoriais que serão ensinados e cujo aprendizado leve à consecução dos objetivos propostos. Neste aspecto, é costume o professor ficar ansioso por cobrir todas as habilidades necessárias ao trabalho experimental. Isso não é possível, mas sem dúvida, a prática não é dispensável no ensino de Bioquímica: nada como "pôr a mão na massa" (Bennett, 2000). O grande problema a enfrentar não é só uma questão de variedade, mas a rapidez com que as técnicas laboratoriais desenvolvem-se e a impossibilidade de abrangê-las nas aulas de laboratório, quer pela sofisticação, quer pelo tempo que demandam, quer pelo custo que acarretam, por mais que sejam importantes.

Cabe aqui abrir parênteses para explicar que este momento do planejamento, de escolha de experimentos e técnicas, pode ser feito junto com os alunos ou apenas por eles, dependendo da metodologia adotada pelo professor.

Os conteúdos das aulas práticas, normalmente, não têm um fim em si mesmos. Em geral, relacionam-se com o que foi ou será desenvolvido em aulas teóricas, integram-se, às vezes, com a programação de outras disciplinas ou vinculam-se com pesquisa ou projetos de extensão da instituição ou de fora dela, podem ou não refletir as especialidades profissionais do curso; é possivel que ecoem na vida cotidiana do aluno, como estudante universitário e como cidadão.

Ao se escolherem os conteúdos, segundo Abreu e Masetto (1990), é necessário ter em mente que eles não devem ditar o curso, dentro do planejamento, mas serem escolhidos de acordo com os objetivos; portanto, não são intocáveis: podem ser revistos, atualizados, adaptados a novas situações. Ao selecionar conteúdos, por outro lado, há casos em que se 
percebe a necessidade de rever objetivos, mas, de qualquer forma, os objetivos devem preceder os conteúdos.

7. substituição de aulas práticas por outras atividades de ensino

Quando há muitas barreiras a superar para realizar aulas práticas, há interesse que, por meio do roteiro de análise dessas aulas, possam ser obtidas informações que contribuam para uma reflexão sobre a possibilidade de substituir a prática laboratorial por outras estratégias de ensino, com 0 mesmo ou maior proveito e com menos dificuldades.

8. problemas a serem resolvidos em aulas práticas

Dependendo dos objetivos do curso e da disciplina, assim como das intenções do professor, o conteúdo das aulas práticas pode apresentar uma situação problemática a ser resolvida no transcorrer ou após serem realizados os experimentos. Os problemas aparecem como: (1) uma questão levantada no início da aula, como um estopim para os trabalhos; (2) perguntas cujas respostas são descobertas a partir do processamento dos dados obtidos na aula; (3) perguntas que orientam a discussão dos resultados, podendo ser respondidas com o uso de informações bibliográficas e/ou da interpretação dos dados.

9. protocolo

Nesse momento, o professor já tem condições de elaborar os protocolos das aulas práticas, escolher uma ou mais das várias formas de construí-lo e explorá-lo, tarefa que deve ser coerente com todas as questões teóricas e práticas referentes ao processo ensino-aprendizagem que o nortearam até então.

Domin (1999) classifica os protocolos em quatro tipos:

- expositivo: resultado predeterminado dos experimentos, abordagem dedutiva, procedimentos experimentais definidos;

- inquisitivo: resultado indeterminado, abordagem indutiva, procedimentos experimentais gerados pelos alunos;

- de descoberta: resultado predeterminado dos experimentos, abordagem indutiva, procedimentos experimentais definidos; 
- baseado em problema: resultado predeterminado dos experimentos, abordagem dedutiva, procedimentos experimentais gerados pelos alunos.

Para a divulgação dos protocolos, o professor pode optar por imprimilos, fornecê-los oralmente ou disponibilizá-los na internet.

\section{Trabalho no laboratório}

1. estratégia de ensino

A estratégia de ensino adotada na aula realizada no laboratório, definida de uma forma abrangente, inclui tudo que tem sido posto como metodologia de sala de aula, técnica de ensino, técnica pedagógica, técnica de métodos didáticos, expressões que têm diferentes significados, mas que são ligeiramente iguais em seu conteúdo. Estratégia é toda organização dentro de sala de aula que visa a facilitar a aprendizagem do aluno, tais como arrumação dos móveis, os materiais a serem utilizados, as perguntas, os comentários, as instruções, os recursos audio-visuais, os trabalhos, enfim, todas as atividades solicitadas aos alunos e as do professor, praticadas durante a aula ou fora, porém relacionadas a ela. As estratégias de ensino incluem processos de avaliação e relações professor-aluno (Abreu e Masetto, 1990).

2. utilização do protocolo

O protocolo apresentado aos alunos ou confeccionado por eles, sozinhos ou junto com o professor, pode ser utilizado de várias formas durante a aula: com leitura individual silenciosa ou em voz alta, para toda a classe ou no pequeno grupo, sem leitura prévia e com leitura e execução à medida que a aula avança e/ou com explicações orais e anotações na lousa, feitas pelo professor etc. Dependendo da metodologia adotada, os dados a serem obtidos são definidos previamente, até mesmo no próprio protocolo, ou ficam ao sabor do que foi realizado e obtido.

\section{3. bibliografia}

Uma bibliografia sobre o assunto ou técnicas da aula aparece no protocolo ou é fornecida separadamente, a cada aula ou na primeira, por escrito ou oralmente e, muitas vezes, nem é fornecida aos alunos. 


\section{4. execução dos experimentos}

Quanto aos experimentos, incluindo a montagem deles e o uso dos aparelhos e equipamentos, as opções são entre demonstração feita pelo professor, execução somente pelo aluno ou um misto, com participação de ambos. Nesse aspecto, a atuação do professor confunde-se com a de auxiliares, técnicos e monitores. Convém chamar a atenção, neste ponto, que o professor deve orientar e treinar seus auxiliares com antecedência, discutindo opiniões e trocando idéias, para que não haja conflitos entre eles na atuação com os alunos, pondo em risco a efetivação das propostas da aula.

\section{5. grupos de trabalho}

Nas turmas de graduação, normalmente, os trabalhos no laboratório são conduzidos por grupos em que o número de participantes varia com o tamanho da turma, com a proporção entre orientadores e alunos, com os recursos materiais existentes e a complexidade das técnicas utilizadas.

O trabalho em grupo durante a experimentação pode mascarar o que é, de fato, uma demonstração, no caso em que apenas um ou poucos alunos trabalham, geralmente aqueles que já sabem manipular bem os materiais, por terem aprendido em outro lugar ou situação, enquanto os outros apenas assistem. A dinâmica do trabalho em grupo, portanto, fica sujeita ao tamanho do grupo e ao seu grau de homogeneidade quanto às habilidades dos participantes.

\section{6. precisão, sensibilidade, higiene}

A obtenção de resultados coerentes, com o menor erro experimental possivel, depende da precisão com que se obtém os dados, da sensibilidade dos métodos e técnicas empregados. A preocupação com essas questões e também com a higiene, em certos casos, podem aparecer no protocolo ou serem comentadas na fase inicial de apresentação da aula.

\section{7. habilidades técnicas e mentais, atitudes pessoais}

O aproveitamento das aulas práticas também é conseqüência da presença, nos alunos, de habilidades técnicas para a realização dos experimentos e de atributos intelectuais que lhes permitam entender as instruções orais e escritas, fazer o relato, a análise, a interpretação dos resultados e a comunicação deles oralmente ou por escrito. 
Segundo Vella (1989), o aluno, para continuar sua "auto-educação", no sentido construtivista, para aprender efetiva e eficientemente a partir de fontes impressas - livros, literatura científica etc - e de fontes orais - aulas teóricas, seminários e discussões - e, acrescente-se aqui, também, a partir de atividades práticas, ele deve ter as habilidades do pensamento crítico e as que se relacionam com o trabalho científico produtivo: planejamento, cooperação, imaginação criativa, definição e resolução de problemas, discernimento de oportunidades, exploração de alternativas e escolha, geração e avaliação de hipóteses e modelos. São necessárias também habilidades de comunicação oral, escrita e eletrônica, habilidades de computação, técnicas, manuais e instrumentais, familiaridade com o método científico. Isso inclui suficiente autoconfiança, para assegurar que novas tarefas laboratoriais possam ser aprendidas no futuro. As atitudes pessoais necessárias são honestidade e diligência.

Com relação à profissão, Torres (1998), também vê a importância de se desenvolverem nos alunos habilidades que lhes dêem a capacidade de claramente identificar um problema e de discernir que informação essencial é necessária para que se chegue a soluções, o que, no caso desta pesquisa, acredita-se que possa ser feito pelo trabalho prático.

Ao mesmo tempo que indispensáveis ao educando para obter o conhecimento ensinado na aula, as habilidades apresentadas acima podem ser introduzidas ou melhoradas pelo ensino no laboratório, ao seguir instruções orais e escritas e nas etapas de experimentação, de relato e de discussão.

\section{8. orientação, assistência}

A orientação dos estudantes e a assistência aos trabalhos práticos pautam-se pela estratégia de ensino adotada, prendem-se ao grau de autonomia que o professor pensa dar aos alunos, mas também estão subordinadas ao apoio didático que ele possui. Complicadores, nesta fase, são classes grandes, heterogeneidade dos grupos, espaço reduzido e dificuldade de circulação no laboratório. O professor precisa ficar atento à ação dos monitores, cujo conhecimento pedagógico e treinamento didático 
podem ser insuficientes para pôr em prática a metodologia e a estratégia pretendida, como dito acima. Porém, a vantagem deles sobre o professor é que geralmente suas formas de comunicação e linguagem são aquelas dos alunos, por causa da proximidade de idade.

\section{9. registro dos resultados, processamento dos dados}

O registro dos resultados obtidos é feito de acordo como os tipos de protocolo e de estratégia de ensino. O processamento dos dados pode ser definido no protocolo, ser parte da orientação inicial da aula ou ser de iniciativa exclusiva dos alunos, na tarefa de interpretar os resultados. Uma opção é tratar cada experimento como único, de forma que o grupo trabalhe só com seus próprios resultados; outra possibilidade é a de que os resultados sejam compartilhados pelos grupos, funcionando o experimento de cada grupo como uma de várias repetições, simulando o que ocorre na pesquisa científica. Quando são cobrados determinados resultados e por algum motivo eles não são obtidos, os alunos podem repetir os experimentos na própria aula ou em outra ocasião, sozinhos ou com orientação, mas isso geralmente não ocorre. Também é possível que os dados diferentes do esperado sejam discutidos, o professor e/ou os alunos elaborando hipóteses para explicar o insucesso, ou esses dados serem simplesmente desprezados ou substituídos pelos "certos", obtidos na literatura ou em outros grupos.

10. duração da aula

A duração da aula depende de sua dinâmica e do surgimento de imprevistos, como quebra de aparelhos, reagentes mal preparados, atrasos dos participantes etc, que são comuns acontecerem, embora não devessem. É importante que o tempo previsto pelo professor para realização das aulas práticas harmonize-se com a carga horária delas e inclua a possibilidade de ocorrerem imprevistos.

11. comportamento dos participantes

É importante que seja observado o comportamento dos participantes da aula, quanto ao seu envolvimento, interesse, comprometimento, animação etc, como meio de perceber as intenções não explicitadas, as reações não verbalizadas, os impedimentos para a consecução dos objetivos que não foram previamente diagnosticados e outros aspectos do afetivo e do 
emocional das pessoas que participam do processo ensino-aprendizagem ou que possam nele interferir.

12. encerramento da aula

O que ocorre no final da etapa de experimentação é decisivo para completar as informações necessárias para o entendimento das funções e do papel que a aula prática exerceu no ensino. É aí que aparece o sucesso que os alunos tiveram na obtenção de dados previamente definidos, a capacidade do professor e dos alunos de trabalhar dados inesperados ou que não eram conhecidos de antemão. O encerramento da aula é um espelho de tudo que se pretendeu realizar no seu decorrer. Ela pode ir acabando, à medida que cada grupo obtém seus dados, guardando-os para si ou colocando-os também na lousa; então, os alunos retiram-se do laboratório. Em outros tipos de dinâmica, a aula prática termina com a discussão dos dados, podendo também ter ainda o tempo final reservado para a confecção dos relatórios.

\section{Atividades posteriores à obtenção dos dados}

1. discussão

A discussão dos resultados das aulas práticas pelos alunos pode ser realizada no final da aula, no laboratório, ou posteriormente, com ou sem a presença do professor, individualmente ou em grupo. Ela depende da organização dos dados, de seu processamento por meio de cálculos, de sua apresentação na forma de descrições, tabelas e gráficos e compreende a análise posterior dos dados assim transformados, sua interpretação e compreensão.

Discussão proveitosa é aquela em que os alunos são encorajados a questionar, depois de observar, experimentar, tudo dentro de seu ritmo de trabalho, não sendo penalizados pelas conclusões que fizerem, mesmo que não sejam as esperadas (Silverman, 1996).

\section{2. relatório}

O relatório, confeccionado a seguir, contém, no mínimo, a descrição dos resultados, mas normalmente vai além disso, apresentando a discussão realizada e as conclusões obtidas; em muitos casos, ele tem a estrutura de uma publicação cientifica, incluindo também informações teóricas e bibliografia. A 
contribuição desta forma de relato cientifico para o ensino abrange habilidades mentais de ordenação, classificação, análise, síntese, generalização, crítica, julgamento, expressões oral e escrita.

O relatório assume os mais variados formatos, dependendo do proveito que o professor quer fazer dele, sua redação pode servir para o aluno aprender a escrever um artigo científico, para ensiná-lo a consultar a literatura científica, a entender e usar a linguagem técnica de conteúdo bibliográfico e poder aplicar o conhecimento obtido a uma situação particular nova.

\section{3. atividades decorrentes do trabalho prático}

Em algumas circunstâncias, o conteúdo das aulas práticas e seu treinamento técnico servem como uma iniciação científica para projetos de pesquisa posteriores, como ponto de partida para trabalhos de aplicação do conhecimento aprendido em situações novas. Isto pode ocorrer quando os alunos fazem cursos de extensão, quando montam trabalhos de encerramento de curso, por exemplo.

4. avaliação do aprendizado em aula prática

A avaliação do aprendizado em aula prática, em certos casos, limita- se à análise do relatório. Às vezes, são apresentadas questões sobre prática laboratorial em prova que abarca todos os assuntos tratados pela disciplina em um dado período de tempo ou, em alguns casos, são feitas provas só sobre as aulas práticas. As questões variam em quantidade e na proporção que aparecem em relação às perguntas sobre os assuntos abordados, por meio de outras técnicas de ensino. O conteúdo da avaliação pode apenas cobrar o que foi visto e aprovado como adequado ou propor problemas cuja solução dependa do conhecimento obtido em aula prática. $O$ teor das questões pode ser de natureza técnica ou conceitual.

\section{A. 2c. Funções das aulas práticas}

\section{Funções do conteúdo}

Cada aspecto da aula prática exerce uma função. O conteúdo pode servir como ilustração, compreensão, aprofundamento ou aplicação do que foi desenvolvido em aula teórica, mas pode servir também para construção de novos conceitos ou ainda para mostrar a importância da Bioquímica, divulgar descobertas recentes da Ciência, discutir questões científicas polêmicas e o papel social da Ciência etc. 


\section{Funções da metodologia}

As funções da metodologia de ensino vão desde aprender atividades inerentes a qualquer trabalho prático, como processar, interpretar, apresentar dados e consultar literatura científica, até atividades de pesquisa laboratorial autônoma, como propor hipóteses, montar experimentos, validar ensaios, criticar dados, montar protocolos e experimentos. Com relação ao uso de aulas práticas para desenvolver projetos, é importante levar em consideração as pesquisas didáticas descritas por Hodson (1992). Ele concluiu que, tanto no campo das prè-concepções, como no dos trabalhos práticos e da resolução de problemas, estudantes desenvolvem melhor sua compreensão conceitual e aprendem mais acerca da natureza da Ciência quando participam genuinamente de investigação científica.

As funções das aulas práticas inserem-se, além do mais, no campo das habilidades do pensamento, como ensinar a resolver problemas e pensar acurada e criticamente (funções da pesquisa, Gressler, 1989); isto demanda incitar a curiosidade e desenvolver a criatividade (Watts e Alsop, 2000).

O uso da aula prática para formar no aluno uma imagem da Ciência e para apreender a linguagem científica engloba a apreensão da natureza do conhecimento científico, a definição dos propósitos da Ciência e da atuação do processo social sobre a atividade científica (Ryder e Leach, 1999). Isto quer dizer, em outras palavras, que para atuar sobre a imagem que os alunos têm de Ciência é preciso dar importância ao contexto e ao que os alunos pensam.

\section{Funções do treinamento técnico}

As aulas práticas, no mínimo, treinam habilidades técnicas experimentais, como manipulação de materiais, uso de equipamentos e aparelhos, mas isto não pode ser considerado experimentação. Segundo Bennett (2000), experimentar significa testar, não é só seguir uma série de instruções.

\section{Funções das interações entre os participantes}

À parte e paralelamente às funções instrucionais, as aulas práticas exercem funções decorrentes das interações que se estabelecem entre os participantes: professores, auxiliares e alunos. Estas funções incluem 
desenvolver autoconfiança no aluno, contribuir para sua vida acadêmica como um todo e para a escolha de sua especialidade dentro da profissão, formar um profissional-cidadão (Santos e Schnetzler, 1996), capaz de gerenciar sua própria evolução e sua atualização permanente, contribuir para a construção de um homem feliz, realizado e partícipe de sua sociedade.

\section{A. 2d. Papel das aulas práticas}

O papel que as aulas práticas cumprem no ensino de Bioquímica está diretamente relacionado às funções que elas desempenham. A natureza desse papel pode ser no nivel de transmissão de informações, como no caso de aplicação de leis e princípios, de reprodução do conhecimento científico estabelecido e legitimado, ou no nível conceitual, como ocorre com a compreensão ou a construção de conceitos. Esse papel pode referir-se também à criação de novas idéias, à crítica de teorias, ao desenvolvimento da liberdade intelectual e do pensamento independente.

\section{A. 3. Uso dos instrumentos de coleta de dados}

Os instrumentos de coleta de dados elaborados podem ser utilizados, em seu total ou em partes, para criar ou avaliar processos educacionais.

\section{A. 3a. Uso para planejamento}

Um planejamento de aulas práticas completo e adequado a cada situação é importante para delinear projetos futuros da disciplina, do curso e da instituição. Ele pode ser feito a partir de coleta sistematizada de informações por meio dos instrumentos aqui apresentados.

O planejamento relaciona-se com a vida diária do homem, é uma forma de relação de mão dupla entre pensar e fazer, vislumbra um ideal, um objetivo a atingir, e enfoca a prática das ações a executar (Cardoso, 1999). Não pode ser conduzido como uma atividade neutra, como se tivesse um fim em si mesmo, sem importar a quem se endereça e em que cenário suas prescrições serão postas em prática; não é um modo de definir aplicações técnicas para obter resultados. O planejamento é uma decisão política, está estreitamente ligado aos interesses de uma coletividade, é ideologicamente comprometido, submete-se ao direito público no que se refere à educação. 
Sob o aspecto prático de sua viabilização, ele deve levar em conta a capacidade de quem executa as ações que ele prescreve, o professor, os auxiliares e os alunos.

A primeira fase do planejamento, segundo Cardoso (1999), é a de levantar opiniões e sugestões, fazer um confronto entre realidade $e$ concepção filosófico-pedagógica. A realidade configura-se em seus três aspectos: sócio-político, pedagógico e administrativo. A concepção filosóficopedagógica engloba o aspecto político - visão ideal de homem, sociedade, educação e escola , o aspecto pedagógico - proposta teórico-metodológica da ação educativa e o aspecto administrativo - proposta teórico-metodológica da ação da administração. Acrescente-se, aqui, ainda, como importante, a explicitação das condições materiais disponíveis.

Todos os aspectos desta primeira etapa do planejamento são contemplados nos roteiros de caracterização do contexto e apresentados neste trabalho. Esses roteiros não incluem os estatutos da instituição, com quadro hierárquico, com definições de papéis e funções, ou outras normas particulares que regem os cursos. Porém, considera-se também importante que o professor tenha esclarecimento sobre as relações de poder dentro da instituição, o que ele pode deduzir a partir de sua vivência, adquirida na participação em reuniões e eventos, e da análise de currículos ou outros documentos que cheguem às suas mãos.

\section{A. 3b. Uso para avaliação}

O professor pode usar os roteiros de observação e análise para medir a eficiência da aula prática dada, de uma forma aberta e divulgada ou particularmente, uma vez que muitas vezes ele tem receio de que os alunos ou a instituição o julguem. 


\title{
I. B. Os instrumentos de coleta de dados elaborados
}

I. B. 1. Caracterização do contexto

\author{
SUMÁRIO
}

I. B. 1a. Instituição

Dados gerais

Natureza / Classificação

Cursos

Atividades de pós-graduação

Atividades de pesquisa

Prestação de serviços à comunidade (atividades de extensão)

Publicações científicas

Regime de trabalho dos professores de Bioquímica

Apoios técnico e didático ao professor

I. B. 1b. Curso analisado e disciplina de Bioquímica

Faculdade

Curso

Disciplina de Bioquímica

I. B. 1c. Laboratório

Natureza

Condições físicas

Condições de trabalho dos alunos

I. B. 1d. Entrevistas

Questionário endereçado aos alunos

Questionário endereçado aos professores

I. B. 2. Aula Prática
I. B. 2a. Dados Gerais
I. B. 2 b. Caracteristicas gerais
I. B. 2c. Materiais
I. B. 2d. Preparo e teste
I. B. 2f. Conteúdo da aula
I. B. 2g. Roteiro / Protocolo
I. B. 2 h. Etapas da aula / Estratégias de ensino
I. B. 2i. Discussão dos resultados obtidos
I. B. 2j. Relatório das aulas práticas
I. B. 21. Atividades suscitadas pelas aulas práticas
I. B. $2 m$. Avaliação do aprendizado em aulas práticas
I. B. 2 n. Ocorrezncias não previstas durante a aula prática observada

l. B. 2e. Normas de segurança, de manipulação de material biológico e de descarte de materiais / questões éticas

1. B. 3. Funções e Papéis das aulas práticas

I. B. 3a. Funções

Funções do conteúdo

Funções da metodologia de ensino

Funções do treinamento de habilidades técnicas experimentais

I. B. 3b. Papéis

Funções das interações entre os participantes

\section{B. 1. Caracterização do contexto}

\section{B. 1a. Instituição}

\section{Dados gerais}

nome -

endereço -

CEP - C.P. -

telefones e-mail - 


\section{Natureza / Classificação}

- pública ( ) privada ( )

- universidade ( ) centro universitário ( ) faculdades integradas / reunidas ( ) instituto ou escolas superiores ( ) faculdades ( )

\section{Cursos}

\section{Atividades de pós-graduação}

- possui centro de pós-graduação ou equivalente ( ):

* lato sensu -

* stricto sensu:

- mestrado -

- doutorado -

* participação de alunos de graduação em programas de pósgraduação ( )

- não possui centro de pós-graduação ou equivalente ( )

Atividades de pesquisa

- $\operatorname{sim}()$ :

- área(s) -

- participação de alunos de graduação em projetos de pesquisa ( )

- a instituição promove congressos, encontros ou similares em suas dependências ( )

- a instituição mantém estrutura para professores e/ou alunos participarem de congressos, cursos, palestras ou similares fora da instituição ( )

- não ( )

Prestação de serviços à comunidade (atividades de extensão)

- $\operatorname{sim}($ ) -

- participação de alunos de graduação em projetos de extensão ( ) -

- não( )

Publicações científicas

- $\operatorname{sim}()-$ ISSN -

- participação de professores ( ) e alunos de graduação ( ) em publicação científica da instituição 
- a instituição mantém estrutura para professores ( ) e alunos de graduação

( ) participarem de publicações de outras instituições

- não ( )

Regime de trabalho dos professores de Bioquímica

- integral ( ) número de horas -

- parcial ( ) número de horas -

- horista ( ) número de horas -

- faz pesquisa na instituição:

- $\operatorname{sim}($ ) número de horas -

- tema da pesquisa -

- participação de alunos:

* $\operatorname{sim}($ ) número de alunos séries -

* não ( )

- remuneração do professor para:

* horário de planejamento / preparo de aula prática - sim ( ) não ( )

* atendimento de alunos fora das aulas - $\operatorname{sim}($ ) Local -

* não ( )

- faz pesquisa fora da instituição:

* $\operatorname{sim}()$ Local -

* não ( )

- exerce outra atividade profissional que não a de professor e/ou pesquisador - $\operatorname{sim}($ )

* atividade -

* local -

- não ( )

Apoios técnico e didático ao professor

- $\mathrm{n}^{\mathrm{o}}$ de técnico(s) de laboratório:

- nivel superior -

- nível médio ( auxiliar técnico ) -

- pessoal para datilografar material produzido pelo professor, a ser utilizado em aulas práticas ( )

- fotocópia: 
- usada gratuitamente pelo professor, para reproduzir material a ser utilizado em aulas práticas ( )

- paga pelos alunos, para reproduzir material a ser utilizado em aulas práticas ( )

- $\mathrm{n}^{\circ}$ de sala(s) de projeção -

- recursos audio-visuais:

- projetor de diapositivos ( ) projetor de transparências ( )

- vídeo ( ) DVD( ) projetor multimídia( )

- os seguintes aparelhos podem ser transportados para o laboratório -

- laboratório de informática para uso do curso de Bioquímica ( ), utilizado para:

- demonstrações do professor ( )

- uso dos alunos ( )

- biblioteca:

- $\operatorname{sim}($ ) com livros ( ) e periódicos ( ) sobre Bioquímica

- com acesso a redes de informações (internet e outras )( )

I. B. 1b. Curso analisado e disciplina de Bioquímica

Faculdade

Curso

- ênfase (especialidade dentro da área geral) -

- enfoque (ciência pura, ciência aplicada, tecnologia) -

- habilitação:

- bacharelado ( ) licenciatura ( )

- atividades profissionais para as quais habilita -

- período de funcionamento:

- diurno parcial ( ) -

* manhã ( ) tarde ( )

- diurno integral ( )

- noturno( )

- duração / regime - 
- currículo - séries e disciplinas, objetivos do curso (Anexo $\mathrm{n}^{0}$ - )

- convênios da instituição com empresas ou outras instituições para treinamento profissional dos alunos ( )

\section{Disciplina com conteúdo de Bioquímica}

- nome da disciplina -

- carga horária aulas ( ou horas ) semanais / total de $\mathrm{h}$

- posição na grade curricular - disciplina lecionada no o semestre (ou série) do curso

- objetivos e programa da disciplina - Anexo no

- porcentagem de assuntos da programação que é desenvolvida em aulas práticas $\%$

- $n^{\circ}$ de assuntos de aulas práticas que não acompanham a programação de aulas teóricas -

- divisão / proporção entre tipos de aulas -

* $\mathrm{n}^{\circ}$ de aulas práticas -

* $\mathrm{n}^{\circ}$ de aulas teóricas -

* $\mathrm{n}^{\circ}$ de outras atividades diferentes de aulas teóricas e práticas -

- $\mathrm{n}^{\circ}$ de períodos de discussão -

- $\mathrm{n}^{\circ}$ de aulas de exercícios -

- no de seminários -

- no de avaliações -

- outras: $\mathrm{n}^{\mathrm{0}-}$

* proporção aulas práticas : atividades diferentes de aulas teóricas e práticas -1 :

* proporção aulas práticas : aulas teóricas -1 :

- integração com outra(s) disciplina(s):

- $\operatorname{sim}($ ) - disciplina(s) :

- não( )

- relações de pré-requisitos com outra(s) disciplina(s):

- $\operatorname{sim}($ ) - disciplina(s) -

- não( )

- titulação do professor da Bioquímica e instituição onde a obteve: 
- só graduação , obtida em

- especialização em , obtida em

- mestrado em ,obtido em

- doutorado em obtido em

- outro título , obtido em

- outra(s) atividade(s) do professor de Bioquímica fora da instituição / instituição(ões) onde realiza

- atividade(s) docente(s) do professor na disciplina de Bioquímica

- dá só aulas práticas ( ) dá aulas teóricas e práticas ( )

- dá só aulas teóricas ( ) outras -

- resumo do perfil dos alunos ingressantes na disciplina ( se a instituição o possuir ) -

\section{B. 1c. Laboratório}

Natureza

- didática ( ) didática e de pesquisa ( )

\section{Condições fisicas}

- dimensões da sala:

- largura m comprimento m área $m^{2}$

- bancadas e/ou mesas:

- número tipo -

- tipo de tampo das bancadas e/ou mesas -

- número de locais para trabalho por bancada e/ou mesa -

- instalações de água:

- pias ou similares ( $n^{\circ}$, tipo, localização ) -

- água destilada ( tipo de armazenamento, localização ) -

- instalações de gás ( $n^{\circ}$, tipo, localização ) I

- instalações elétricas ( $\mathrm{n}^{\circ}$, localização):

- tomadas de 110V -

- tomadas de 220V -

- iluminação artificial ( $n^{\circ}$, localização ):

- lâmpadas incandescentes -

- lâmpadas fluorescentes I I 
- iluminação natural / ventilação:

- janela(s) ( $n^{\circ}$, tipo, localização ) -

- ventilador(es) ( $n^{\circ}$, localização ) -

- aparelho(s) de ar condicionado ( $\mathrm{n}^{\circ}$, localização ) -

- sistema de exaustão de ar e vapores:

- capela para uso dos alunos ( $n^{\circ}$, localização ) -

- capela para uso do(s) técnico(s), professor(es) ou auxiliar(es) ( $\mathrm{n}^{\circ}$, localização ) -

- outra forma de exaustão de vapores e/ou renovação de $\operatorname{ar}\left(\mathrm{n}^{\circ}\right.$, localização ) -

- $\operatorname{lousas~(~nำ/~posição~)~-~}$ I

- quadro de aviso e/ou outros afixados nas paredes ( $n^{\circ}$ / posição / finalidade ) -

- instalações para uso dos alunos:

- tipo de assento dos alunos -

* cadeira ( ) banco baixo ( ) banco alto ( )

- número de assentos -

* suficiente para todos os alunos ( ) insuficiente ( )

- local para colocação de material pessoal do aluno -

* própria bancada ( ) outro local -

- local para o aluno fazer o registro de dados -

- instalações para uso do(s) professor(es) elou auxiliar(es):

- professor(es) -

* assento diferenciado para o(s) professor(es) ( )

- monitor(es) ou equivalente(s) -

- técnico(s) -

- pessoal da limpeza -

- sistema de segurança:

- avisos / regras escritas afixadas no recinto do laboratório ( )

- uso de avental -

* $\operatorname{professor(es)(~)~auxiliar(es)(~)~alunos(~)~}$

- óculos protetores - 
* usados por-alunos ( ) professor(es) ( ) técnico(s) e/ou auxiliar(es) ( ) * os óculos eram - de propriedade particular ( ) distribuídos pela instituição ( )

- pipeta automática e/ou pêra -

- chuveiros e lava-olhos ( $\mathrm{n}^{\circ}$, localização ) -

- extintores de incêndio ( $\mathrm{n}^{\circ}$, localização ) -

- tipo de piso -

- falhas de segurança -

- formas de descarte de materiais -

- higiene:

- condições de higiene ( boas, médias, ruins ) -

- limpeza da vidraria ( local, periodicidade, quem faz ) -

- latões de lixo ( $n^{\circ}$ - localização ) -

- local de estoque e colocação de materiais:

- vidraria -

- drogas -

- aparelhos e equipamentos -

\section{Condições de trabalho dos alunos}

- distribuição dos alunos no recinto do laboratório:

- $\quad \mathrm{n}$ - total de alunos -

- densidade populacional nas aulas práticas alunos $/ \mathrm{m}^{2}$

- no de alunos por bancada e/ou mesa -

- $n^{\circ}$ de alunos por grupo -

- adequação do local às necessidades dos experimento -

- acesso a:

- água -

- gás -

- eletricidade -

- materiais dos experimentos -

- aparelhos -

- equipamentos -

- lixo - 
- condições de:

- iluminação -

- ventilação -

- distribuição do material:

- colocado antes sobre a bancada ( ) pelo(a)

- distribuído na hora pelo(s) orientador(es)( )

- separado na hora pelos alunos ( )

- possibilidades de visualizar e ouvir:

- o professor - ___ a lousa ou recursos audio-visuais -

- facilidade de circulação pelo laboratório, durante as aulas / justificativa -

\section{B. 1d. Entrevistas}

\section{Questionário endereçado aos alunos}

Este questionário visa ao levantamento de dados para a pesquisa "Papel das Aulas Práticas no Ensino de Bioquímica" que é parte dos requisitos para a elaboração da Tese de Doutoramento de Marina André de Alvarez, sob a orientação do Prof. Dr. Bayardo Baptista Torres, do Departamento de Bioquímica do Instituto de Química da Universidade de São Paulo.

Os dados levantados são destinados exclusivamente à pesquisa, sem fins lucrativos, sigilosos, e não serão usados para avaliação de alunos, professores, metodologia, conteúdos, cursos ou instituições. Não é necessário identificar-se.

Agradecemos sua colaboração. *

Faculdade -

Curso -

Disciplina -

1. O que você esperava das aulas práticas de Bioquímica antes de iniciálas?

2. Dê sua opinião sobre as aulas práticas que você realizou na disciplina de Bioquímica, respondendo as questões a seguir:

* Esta apresentação deve ser adaptada para cada caso em que os instrumentos de coleta de dados forem utilizados 
a. Qual(is) foi(ram) a(s) aula(s) prática(s) mais interessante(s)? Por quê?

b. Qual(is) foi(ram) a(s) aula(s) prática(s) mais proveitosa(s)? Por quê?

c. Qual(is) o(s) defeito(s) de aulas práticas, em geral?

d. Há alguma(s) limitação(ões) para seu desempenho em aulas práticas? Qual(is)?

e. Qual(is) a(s) diferença(s) entre aulas teóricas e práticas, em geral?

3. Faça comentários sobre os relatórios de aulas práticas que você realizou:

4. Você acredita que alguma aula que você assistiu poderia ser substituída por outro tipo de atividade? . Qual(is) aula(s)?

Que atividade(s)?

Seria $(m)$ equivalente(s) em aprendizado ou teria(m) vantagem(ns)?

Que vantagem(ns)?

5. Descreva seu relacionamento, em aulas práticas:

- com colegas -

- com professores -

- com auxiliares -

OBS - Atitudes dos alunos frente à tarefa de responder o questionário:

\section{Questionário endereçado aos professores}

Este questionário visa ao levantamento de dados para a pesquisa "Papel das Aulas Práticas no Ensino de Bioquímica" que é parte dos requisitos para a elaboração da Tese de Doutoramento de Marina André de Alvarez, sob a orientação do Prof. Dr. Bayardo Baptista Torres, do Departamento de Bioquímica do Instituto de Química da Universidade de São Paulo.

Os dados levantados são destinados exclusivamente à pesquisa, sem fins lucrativos, sigilosos, e não serão usados para avaliação de alunos, professores, metodologia, conteúdos, cursos ou instituições. Não é necessário identificar-se. 
Agradecemos sua colaboração. *

Faculdade -

Curso -

Disciplina -

Professor -

- cargo na instituição -

- titulação -

- curso de graduação / instituição -

- curso(s) de pós-graduação / instituição(ões) -

- realiza pesquisa ( ):

- na instituição ( )

- em outro local ( ) -

- linha de pesquisa -

1. Qual a importância das aulas práticas para o ensino de Bioquímica?

2. Qual(is) foi(ram) o(s) critério(s) de escolha de número, posição e assunto das aulas práticas na disciplina com conteúdo de Bioquímica que leciona?

3. Em que medida suas expectativas para o curso ministrado coincidiram com suas realizações? Explique:

4. Quais as limitações das aulas práticas? (Responda as que forem o seu caso.)

- de ordem pessoal -

- de ordens ética e/ou moral -

- impostas pela estrutura institucional e/ou legal -

- de número de alunos -

- de formação dos alunos -

- de preparação da aula -

- de materiais -

* Esta apresentação deve ser adaptada para cada caso em que os instrumentos de coleta de dados forem utilizados 
- de espaço -

- de tempo -

5. Por meio de que instrumentos de avaliação ( provas, auto-avaliação, relatórios ) você avalia o aprendizado obtido em aulas práticas?

6. Você faz provas só sobre conteúdo de aulas práticas?

7. Quando coloca questões sobre conteúdo de aulas práticas em provas gerais, qual a proporção em relação ao conteúdo de outras atividades didáticas desenvolvidas ( aulas teóricas, seminários etc )?

8. As questões sobre aulas práticas avaliam:

- conteúdo ( )

- conhecimento das técnicas ( ) e/ou métodos ( )

- habilidades técnicas ( ) e/ou mentais ( )

- capacidade de discutir dados semelhantes aos obtidos em aulas práticas ( )

- capacidade de resolver problemas novos utilizando aprendizado obtido em aulas práticas ( )

9. Você gostaria de acrescentar algo sobre aulas práticas que não constou deste questionário?

10. Levantamento da consecução de expectativas e objetivos

Preencha o quadro a seguir, assinalando com um $\underline{x}$ os espaços em branco:

Consecução de expectativas do professor e dos objetivos das aulas práticas

\begin{tabular}{|l|l|l|l|}
\hline Funções das aulas práticas & $\begin{array}{l}\text { Acredita que } \\
\text { deveria ter } / \\
\text { gostaria que } \\
\text { tivesse }\end{array}$ & $\begin{array}{l}\text { Colocou } \\
\text { como objetivo } \\
\text { no presente } \\
\text { curso }\end{array}$ & $\begin{array}{l}\text { Realmente } \\
\text { tiveram no } \\
\text { presente } \\
\text { curso }\end{array}$ \\
\hline a. conteúdo & & & \\
\hline 1. ilustrar fatos e/ou fenômenos & & & \\
\hline $\begin{array}{l}\text { 2. aprofundar e/ou ampliar conteúdo de } \\
\text { aula teórica }\end{array}$ & & & \\
\hline 3. aplicar teoria, lei, princípio & & & \\
\hline 4. ensinar a compreender conceitos & & & \\
\hline
\end{tabular}




\begin{tabular}{|c|c|c|c|}
\hline $\begin{array}{l}\text { Funções das aulas práticas - } \\
\text { continuação }\end{array}$ & $\begin{array}{l}\text { Acredita que } \\
\text { deveria ter I } \\
\text { gostaria que } \\
\text { tivesse }\end{array}$ & $\begin{array}{l}\text { Colocou } \\
\text { como objetivo } \\
\text { no presente } \\
\text { curso }\end{array}$ & $\begin{array}{l}\text { Realmente } \\
\text { tiveram no } \\
\text { presente } \\
\text { curso }\end{array}$ \\
\hline \multicolumn{4}{|l|}{ a. conteúdo - continuação } \\
\hline \multicolumn{4}{|l|}{ 5. ensinar a construir conceitos } \\
\hline \multicolumn{4}{|l|}{$\begin{array}{l}\text { 6. mostrar a importância da Bioquímica } \\
\text { em campos específicos do conhecimento }\end{array}$} \\
\hline \multicolumn{4}{|l|}{$\begin{array}{l}\text { 7. divulgar descobertas recentes da } \\
\text { Ciência }\end{array}$} \\
\hline \multicolumn{4}{|l|}{ b. metodologia de ensino } \\
\hline \multicolumn{4}{|l|}{ 1. ensinar como seguir protocolo } \\
\hline \multicolumn{4}{|l|}{ 2. ensinar como registrar dados } \\
\hline \multicolumn{4}{|l|}{ 3. ensinar como processar dados } \\
\hline \multicolumn{4}{|l|}{ 4. ensinar como organizar informações } \\
\hline \multicolumn{4}{|l|}{ 5. ensinar como ordenar e expressar idéias } \\
\hline \multicolumn{4}{|l|}{$\begin{array}{l}\text { 6. ensinar como discutir resultados } \\
\text { experimentais }\end{array}$} \\
\hline \multicolumn{4}{|l|}{ 7. ensinar como fazer conclusões } \\
\hline \multicolumn{4}{|l|}{$\begin{array}{l}\text { 8. ensinar como apresentar dados, } \\
\text { resultados e conclusões por escrito } \\
\text { ( fazer relatório ) }\end{array}$} \\
\hline \multicolumn{4}{|l|}{$\begin{array}{l}\text { 9. ensinar como comunicar resultados } \\
\text { oralmente }\end{array}$} \\
\hline \multicolumn{4}{|l|}{$\begin{array}{l}\text { 10. ensinar como consultar literatura } \\
\text { científica }\end{array}$} \\
\hline \multicolumn{4}{|l|}{ 11. ensinar como fazer redação científica } \\
\hline \multicolumn{4}{|l|}{$\begin{array}{l}\text { 12. desenvolver autonomia na execução } \\
\text { de experimentos }\end{array}$} \\
\hline \multicolumn{4}{|l|}{ 13. ensinar como propor hipóteses } \\
\hline \multicolumn{4}{|l|}{ 14. ensinar como testar hipóteses } \\
\hline \multicolumn{4}{|l|}{ 15. ensinar como montar experimentos } \\
\hline \multicolumn{4}{|l|}{ 16. ensinar como validar ensaios } \\
\hline \multicolumn{4}{|l|}{ 17. ensinar como criticar dados } \\
\hline \multicolumn{4}{|l|}{ 18. ensinar como escrever protocolos } \\
\hline 19. ensinar a pensar novos experimentos & & & \\
\hline
\end{tabular}




\begin{tabular}{|l|l|l|l|}
\hline $\begin{array}{l}\text { Funções das aulas práticas - } \\
\text { continuação }\end{array}$ & $\begin{array}{l}\text { Acredita que } \\
\text { deveria ter I } \\
\text { gostaria que } \\
\text { tivesse }\end{array}$ & $\begin{array}{l}\text { Colocou } \\
\text { como objetivo } \\
\text { no presente } \\
\text { curso }\end{array}$ & $\begin{array}{l}\text { Realmente } \\
\text { tiveram no } \\
\text { presente } \\
\text { curso }\end{array}$ \\
\hline $\begin{array}{l}\text { c. treinamento de habilidades } \\
\text { técnicas experimentais }\end{array}$ & & & \\
\hline $\begin{array}{l}\text { 1. ensinar como observar } \\
\text { l. treinar manuseio de material de } \\
\text { laboratório e de reagentes }\end{array}$ & & & \\
\hline $\begin{array}{l}\text { 3. treinar uso de equipamentos e } \\
\text { aparelhos }\end{array}$ & & & \\
\hline $\begin{array}{l}\text { 4. treinar manipulação de material biológico } \\
\text { 5. treinar procedimentos de segurança no }\end{array}$ & & & \\
laboratório & & & \\
\hline $\begin{array}{l}\text { 6. treinar técnicas de pesquisa } \\
\text { laboratorial }\end{array}$ & & & \\
\hline d. interações entre participantes & & & \\
\hline 1. motivar o aluno & & & \\
\hline $\begin{array}{l}\text { 2. melhorar relações entre professor e } \\
\text { alunos }\end{array}$ & & & \\
\hline 3. melhorar relações entre alunos & & & \\
\hline 4. encorajar entusiasmo pela Ciência & & & \\
\hline
\end{tabular}

\section{B. 2. Aula Prática}

\section{B. 2a. Dados gerais}

- $\mathrm{n}^{0}$ de aulas observadas datas -

- período ( manhã / tarde / noite ) -

- curso -

- nome do(s) professor(es) -

- nome do(s) auxiliar(es) / tipo de participação na aula -

\section{B. 2b. Características gerais}

- assunto -

- unidade da programação - 
- ordem dentro da programação - ___ _ a aula

- ligação com atividade(s) desenvolvida(s) fora do âmbito específico da Disciplina de Bioquímica:

$-\operatorname{sim}()-$

- não( )

- acompanhada de artigo científico correlato:

- $\operatorname{sim}()-$

- não( )

- posição em relação à aula teórica do mesmo assunto:

- antes ( ) entre aulas teóricas ( ) depois ( )

- outra situação -

- dinâmica da aula:

- duração $h$

- divisão de tempo da aula -

* planejamento / explicações iniciais $\%$

* execução $\%$

* análise de resultados / discussão $\%$

- condições de orientação dos alunos:

- $\mathrm{n}^{\circ}$ de professores -

- $n^{\circ}$ de auxiliares que participam da orientação -

- $n^{\circ}$ de alunos -

- proporção orientador : aluno -

- condições dos alunos quanto a conhecimentos necessários para a compreensão da aula -

- possibilidade de uso do laboratório pelos alunos, fora do horário de aula ( ) Horário -

- possibilidade do professor orientar os alunos fora do horário de aula ( ) Horário Local -

- local para os alunos trabalharem em grupo fora da aula Horário -

I. B. 2c. Materiais

- vidraria - 
- aparelhos -

- equipamentos -

- drogas -

- material biológico -

- quem distribui o material / quando I

- custo do material de consumo -

I. B. 2d. Preparo e teste

- preparo:

- pelo professor ( ) pela técnica com planejamento e supervisão do professor ( )

- teste:

- todas são testadas ( )

- só algumas são testadas ( ) -

* teste é feito (por e quando ) I

- não são testadas ( )

I. B. 2e. Normas de segurança, de manipulação de material biológico e de descarte de materiais / questões éticas

- normas de segurança:

- orais ( ) por escrito ( ) com compromisso escrito e assinado ( )

- sem normas ( )

- normas de manipulação de material biológico:

- orais ( ) por escrito ( ) com compromisso escrito e assinado ( )

- sem normas ( )

- treinamento sobre segurança no laboratório ( ) ou sobre manipulação de tecidos, órgãos ou animais vivos( ) ou mortos ( ) ou sobre descarte de materiais ( ) (quando / como / onde ) I I

- discussão de questões éticas (o quê / quando) -

I. B. 2f. Conteúdo da aula

- relações:

- com o resto da programação -

* acompanha o conteúdo das aulas teóricas ( )

* programação separada das aulas teóricas ( ) 
- com outra(s) disciplina(s)( )-

- com pesquisa da instituição ( ) ou fora dela ( ) -

- com projeto(s) de extensão da instituição ( ) -

- com a vida profissional futura dos alunos ( ) -

- com a vida universitária dos alunos ( ) -

- com a vida cotidiana dos alunos fora da universidade ( ) -

- com o contexto social geral dos alunos como cidadãos ( ) -

- equivalência / pode ser substituída por ( de acordo com a opinião do professor ):

- exercício(s) de fixação ( ) -

- resolução de problema(s) ( ) -

- análise de caso(s) ( ) ou discussão de artigo(s) científico(s) ( ) -

- simulação(ções) em computador ( ) -

- outros -

- presença de problema(s) a ser(em) resolvido(s) pela aula:

- questão(ões) colocada(s) antes de iniciar a aula, para ser(em) resolvida(s) por meio dos experimentos que deverão ser planejados para tal:

* $\operatorname{sim}()$ -

- explicitada(s) no protocolo ( ) -

- dada(s) oralmente ( ) -

* não ( )

- pergunta(s) para ser(em) resolvida(s) com os resultados dos experimentos $* \operatorname{sim}()$

- explicitada(s) no protocolo ( )

- dada(s) oralmente ( ) -

* não ( )

- pergunta(s) como orientação para a discussão dos resultados no relatório ( ):

* constante(s) no protocolo ( ) -

* fornecida(s) oralmente ( ) - 


\section{B. 2g. Roteiro/ Protocolo}

- quem produz:

- o professor ( )

- outra(s) pessoa(s) -

- tipo:

- impresso -

* um para cada aluno ( ) um para cada grupo ( )

* comprado pelo aluno ( ) fornecido pela instituição ( )

- outro tipo -

- obtenção:

- na hora da aula ( ) com antecedência ( )

- conteúdo - são especificados:

- objetivo(s) da aula ( ) ou dos experimentos ( )

* explicitados no roteiro - Objetivo(s):

* não estão explicitados no roteiro -

- foram fornecidos oralmente ( ) - Objetivo(s):

- por escrito, na lousa ( ), no início da aula - Objetivo(s):

* não foram explicitados ( )

- lista de materiais ( )

- diretrizes para a execução dos experimentos ( ) -

* todas ( )

* parte delas ( )

* com orientações específicas de como e o quê observar ( )

- observações sobre o tipo de diretriz dada -

- normas de segurança ( ) e de manipulação de material biológico ( ) tipo: ; fornecidas ( por, quando ):

- regras de higiene ( ) -

- instruções sobre como registrar os dados ( ) -

- instruções sobre o relatório ( ) -

- questão(ões) e/ou problema(s) a serem resolvidos no relatório, usando os dados obtidos ( ) -

- orientações para a discussão dos dados ( ) - 
- bibliografia específica sobre a técnica e/ou assunto da aula prática -

$* \operatorname{sim}()$

* não ( )

I. B. 2h. Etapas da aula / Estratégias de ensino

- utilização do protocolo ( roteiro da aula ):

- protocolo fornecido pelo professor ( ) -

* o protocolo é lido pelo professor ou aluno, em voz alta, no início da aula ( )

* os alunos lêem o protocolo antes de iniciar os trabalhos,

- nos grupos ( )

- individualmente ( )

* não há leitura prévia do protocolo, ele vai sendo executado à medida que os trabalhos acontecem ( )

* os alunos tiram dúvidas sobre o protocolo com o professor ( )

- montagem de um roteiro a partir de um problema -

* pelos alunos, só orientados pelo professor ( )

* pelos alunos e o professor, em conjunto ( )

* parte de um projeto de pesquisa mais amplo -

- tipo de dado -

* conjunto de dados a ser obtido é definido previamente ( )

* sem meta final prevista ( )

- fornecimento de bibliografia específica sobre a técnica e/ou assunto da aula prática, separadamente do protocolo:

$-\operatorname{sim}()$

- não( )

- tipo de execução:

- demonstração pelo professor ( )

- execução de um roteiro pronto pelos alunos ( ) Roteiro - Anexo noㅡ

- manipulação dos aparelhos pelo professor( )

- manipulação de aparelhos pelos alunos -

* sozinhos ( )

* com o auxílio e supervisão do professor e/ou auxiliar ( ) 
- quem executa os experimentos no grupo -

* todos os alunos, há divisão eqüitativa de tarefas ( )

* principalmente um ou poucos alunos ( )

* cada aluno especializa-se numa tarefa ( )

* há rodízio dos alunos na execução das várias tarefas ( )

- precisão / sensibilidade / higiene:

- preocupação com a precisão na obtenção dos dados -

* $\operatorname{sim}()$ não ( )

- preocupação com as sensibilidades dos métodos e das técnicas -

* $\operatorname{sim}($ ) não ( )

- preocupação com higiene, quando necessária e pertinente -

* $\operatorname{sim}($ ) não ( )

- habilidades:

- técnicas -

* exigidas pela aula -

- os alunos não tinham as seguintes habilidades -

* treinadas durante a aula -

- mentais -

* exigidas pela aula -

- os alunos não tinham as seguintes habilidades -

* treinadas durante a aula -

- forma de orientação dos alunos pela equipe:

- antes, fora da aula ( ) no início da aula ( ) durante a aula ( )

- quem orienta -

* professor ( )

* outro membro da equipe -

- observações sobre as explicações iniciais -

- forma de registro dos resultados -

- com orientação ( ) -

* escrita ( ) oral ( )

- sem orientação específica ( )

- processamento dos dados obtidos: 
- registro de dados -

* no caderno ( )

* em impresso fornecido pelo professor ( )

* forma de registro -

- cada experimento é tratado como único; cada grupo trabalha com seus próprios dados ( )

- os dados dos vários grupos são tratados como repetições do mesmo experimento ( )

- há cobrança de resultados previamente esperados ( ) -

* os experimentos deram os resultados esperados ( )

* os experimentos não deram os resultados esperados ( )

- os experimentos não puderam ser concluídos, porque -

- quando não se obtiveram os resultados esperados ou não deu tempo -

* o aluno não repete ou completa o experimento ( ),

- o professor ( ) elou os alunos ( ) faz(em) hipóteses para explicar o ocorrido ( )

- o professor explica o possível motivo ( )

- não se utilizam os dados obtidos, nem outros dados; discute-se teoricamente o experimento ( )

* o aluno repete ou completa o experimento,

- na própria aula ou em aula subseqüente ( )

- em outro momento,

- sozinho( )

- assessorado pelo professor ( ) ou auxiliar ( )

- tempo disponível para a execução proposta no início da aula:

- insuficiente ( ) suficiente ( ) excessivo( )

- comportamento dos participantes:

- alunos -

* interessados ( ) envolvidos ( ) comprometidos ( ) animados ( )

* observações -

- professor(es) -

* comprometido(s) ( ) com intencionalidade ( ) 
* observações -

- encerramento das aulas - as aulas encerram-se:

- após a obtenção dos dados pelos grupos ( )

- colocando os resultados dos grupos na lousa ( )

- com o professor discutindo os dados com os alunos ( )

- com a confecção dos relatórios ( ) -

* após discussão com o professor ( )

* sem discussão com o professor ( )

I. B. 2i. Discussão dos resultados obtidos

- com o professor:

- no fim da aula ( )

- outro momento ( )

- sem o professor ( ) momento -

- observações sobre a discussão -

I. B. $2 \mathrm{j}$. Relatório das aulas práticas

- não exigido ( ) optativo ( ) obrigatório( )

- realizado na própria aula ( ) em outro momento ( )-

- prazo de entrega:

- no fim da aula ( ) depois da aula ( )

- tipo:

- por escrito ( ) oral ( )

- emgrupo( ) individual ()

- sem diretrizes sobre sua estrutura( )

- com diretrizes específicas sobre sua estrutura, dadas pelo professor -

* tradicional (Introdução, Materiais, Métodos e Técnicas, Resultados, Discussão, Conclusões e Referências Bibliográficas ou alguma de suas variações ) ( )

* outro tipo -

- o que ensina:

- apresentar dados ( )

- fazer tratamento dos dados ( )

- discutir resultados - 
* analisar dados ( )

* relacionar dados ( )

- ordenar e expressar idéias ( )

- organizar informações ( )

- processar bibliografia ( )

- aprender como apresentar dados, resultados e conclusões ( )

- aprender como fazer redação científica ( )

- faz parte da avaliação ( ),

- valor em relação às outras atividades didáticas $\%$

I. B. 21. Atividades suscitadas pelas aulas práticas

- a aula prática teve como decorrência a seguinte atividade, diferente do relatório em si -

- a aula encerrou-se em si mesma, não suscitou trabalhos posteriores ( )

I. B. $2 \mathrm{~m}$. Avaliação do aprendizado em aulas práticas

- a avaliação é feita por:

- relatório somente ( )

- prova exclusivamente sobre aulas práticas ( )

- questões sobre aulas práticas em prova geral ( ) -

* proporção de questões com conteúdo de aulas práticas em relação a conteúdo de outras atividades

- auto-avaliação ( )

- natureza das questões sobre aulas práticas - as questões avaliam:

- conteúdo de Bioquímica das aulas práticas ( )

- conhecimento dos métodos e das técnicas desenvolvidas nas aulas práticas ( )

- capacidade de discutir dados semelhantes aos obtidos em aulas práticas ( )

- capacidade de resolver problemas novos utilizando aprendizado obtido em aulas práticas ( )

I. B. 2n. Ocorrências não previstas durante a aula prática observada 


\section{B. 3. Funções e Papéis das aulas práticas}

I. B. 3a. Funções

\section{Funções do conteúdo}

- ilustrar fatos ( )

- ilustrar fenômenos ( )

- aprofundar conteúdo de aula teórica ( )

- ampliar conteúdo de aula teórica ( )

- aplicar teoria, lei, princípio ( )

- ensinar a compreender conceito ( )

- ensinar a construir conceito ( )

- mostrar a importância da Bioquímica em campos específicos do conhecimento ( )

- divulgar descobertas recentes da Ciência ( )

- outras -

Funções da metodologia de ensino

- ensinar como seguir protocolo ( )

- ensinar como registrar dados ( )

- ensinar como processar dados ( )

- ensinar como organizar informações ( )

- ensinar como ordenar e expressar idéias ( )

- ensinar como analisar, interpretar e sintetizar ( discutir) resultados experimentais ( )

- ensinar como fazer conclusões ( )

- ensinar como apresentar dados, resultados e conclusões:

- ensinar como fazer relatório escrito ( )

- ensinar como comunicar resultados oralmente ( )

- ensinar como fazer redação científica ( )

- ensinar como consultar literatura ( )

- desenvolver autonomia na execução de experimentos ( )

- ensinar como propor hipóteses ( )

- ensinar como testar hipóteses ( ) 
- ensinar como propor novos experimentos ( )

- ensinar como montar experimentos ( )

- ensinar como validar ensaios ( )

- ensinar como criticar dados ( )

- ensinar como escrever protocolos ( )

- ensinar como pensar novos experimentos ( )

- outras -

Funções do treinamento de habilidades técnicas experimentais

- ensinar como observar ( )

- treinar manuseio de material de laboratório e de reagentes ( )

- treinar uso de equipamentos e aparelhos ( )

- treinar manipulação de material biológico ( )

- treinar procedimentos de segurança no laboratório ( )

- treinar técnicas de pesquisa laboratorial ( )

- outras -

\section{Funções das interações entre os participantes}

- motivar os alunos ( )

- melhorar relações:

- entre professor e alunos ( )

- entre alunos ( )

- encorajar entusiasmo pela Ciência ( )

- outras -

I. B. 3b. Papéis

- reprodução de conhecimento ( )

- construção de conhecimento ( )

- crítica a alguma teoria / técnica / metodologia ou outra estrutura estabelecida -

- outro(s) 


\section{MODELO DE ANÁlise DO PAPEL DAS AULAS PRÁticas NO ENSINO DE BIOQUÍMICA}

\section{SUMÁRIO}

II. A. Roteiro de uso dos instrumentos de coleta de dados

II. A. 1. Caracterização do contexto das aulas práticas de Bioquímica

II. A. 2. Planejamento e implantação de laboratório didático de Bioquímica

II. A. 3. Planejamento de aulas práticas de Bioquímica

II. A. 4. Avaliação das aulas práticas da disciplina de Bioquímica

II. A. 4a. Análise da metodologia

II. A. 4b. Análise dos conteúdos

II. A. 4c. Análise das condições de trabaiho dos alunos no laboratório

II. A. 4d. Análise da adequação das aulas práticas da disciplina de Bioquimica ao curso de graduação em questão e às condiçöes presentes na instituição

II. A. 4e. Análise da contribuição das aulas práticas da disciplina de Bioquímica para a vida acadêmica e profissional do estudante e para sua atuação como cidadão

II. B. Uso dos instrumentos de coleta de dados para a determinação das funções e do papel das aulas práticas no ensino de Bioquímica

II. B. 1. Conceito de Função e de Papel das aulas práticas

II. B. 1a. Função

II. B. 1b. Papel

II. B. 2. Funções das aulas práticas

II. B. 2a. Funções do conteúdo

Funções de ilustração, aprofundamento e/ou ampliação e aplicação do conteúdo de aulas teóricas

Função de compreensão de conceito

Função de construção de conceito

Função de divulgação do conhecimento científico

II. B. 2b. Funções da metodologia de ensino

Funções de ensinar como seguir instruções escritas, registrar e processar resultados experimentais

Função de ensinar como discutir resultados experimentais

Função de comunicação dos resultados experimentais

Função de desenvolver autonomia na execução de experimentos

Função de ensinar como utilizar o método científico

II. B. 2c. Função do treinamento de habilidades técnicas experimentais

II. B. 2d. Função das interações entre os participantes

II. B. 3. Papéis das aulas práticas no ensino de Bioquímica

II. B. 3a. Papel de reprodução de conhecimento

II. B. 3b. Papel de construção de conhecimento

II. B. 3c. Papel de critica a conhecimento

\section{A. Roteiro de uso dos instrumentos de coleta de dados}

Os instrumentos de coleta de dados podem ser usados por

professores ou pelo corpo técnico da instituição (coordenação, chefia de

departamentos, direção, presidência) para variados fins. Alguns deles são descritos a seguir. 


\section{A. 1. Caracterização do contexto das aulas práticas de Bioquímica}

Para a caracterização do contexto em que as aulas práticas ocorrem, devem ser usadas as informações contidas nos seguintes instrumentos de coleta de dados:

- roteiro sobre a instituição;

- roteiro sobre o curso analisado e a disciplina de Bioquímica;

- roteiro sobre o laboratório;

- questionários enviados a alunos e professores.

\section{A. 2. Planejamento e implantação de laboratório didático de Bioquímica}

Para a montagem do laboratório didático, o corpo técnico da instituição deve utilizar os instrumentos de coleta de dados da seguinte forma:

- roteiros sobre a instituição, o curso analisado e a disciplina de Bioquímica;

- utilização do roteiro sobre o laboratório, usando seus itens como diretriz para preencher as necessidades da disciplina e de acordo com os recursos materiais disponíveis.

\section{A. 3. Planejamento de aulas práticas de Bioquímica}

O professor, para fazer o planejamento das aulas práticas da disciplina de Bioquímica, deverá coletar dados específicos por meio de algumas partes ou do total dos instrumentos de coleta de dados, além de outros dados que não se encontram neles, como se segue:

- roteiro sobre a instituição: atividades de pós-graduação, atividades de pesquisa, publicações científicas, atividades de extensão, condições de trabalho do professor (regime de trabalho, atividades de pesquisa dentro e fora da instituição, remuneração para planejamento e preparo de aula prática, outras atividades profissionais que possam interferir positiva ou negativamente em seu trabalho na instituição), apoios técnico e didático;

- roteiro sobre o curso analisado e a disciplina de Bioquímica:

- curso: todos os itens;

- disciplina: carga horária semanal e total, posição na grade curricular, objetivos (ementa), integração com outras disciplinas, relações de prérequisitos com outras disciplinas;

- perfil dos alunos ingressantes na disciplina, se a instituição o possuir; 
- roteiro sobre o laboratório;

- auto-avaliação: clarificação de suas expectativas, de seu embasamento teórico, da metodologia a ser adotada, de sua postura pessoal frente ao processo ensino-aprendizagem, das limitações de ordem pessoal ou de outro gênero;

- levantamento de opiniões dos colegas da disciplina e dos auxiliares (monitores e técnicos);

- discussão com colegas da disciplina e com auxiliares e técnicos sobre formas de preparo e teste de aulas práticas, orientação e assistência aos alunos;

- treinamento técnico de todos os auxiliares, treinamento didático e metodológico dos monitores;

- levantamento de bibliografia sobre técnicas laboratoriais e experimentos;

- análise da programação e diagnóstico de que parte dela pode ser desenvolvida em aulas práticas;

- número de aulas da disciplina no total do curso e decisão de quantas aulas práticas poderão ser dadas;

- confrontação do número de aulas práticas possíveis com o número de assuntos que poderão ser desenvolvidos em aulas práticas, de acordo com a metodologia adotada e as condições materiais e de funcionamento do laboratório;

- usar os itens do roteiro de aulas práticas para refletir e tomar decisões sobre: dinâmica da aula, condições de orientação dos alunos, condições dos alunos quanto aos conhecimentos necessários para a compreensão das aulas, materiais de laboratório, preparo e teste das aulas, normas de segurança, de manipulação de material biológico e de higiene do trabalho no laboratório, relações das aulas práticas com outras atividades da disciplina e fora dela, presença de problemas a serem resolvidos pela aula, protocolo, etapas da aula / estratégia de ensino (exceto comportamento dos participantes e tempo disponível para a execução da proposta no início da aula), discussão dos dados, relatório, atividades suscitadas pela aula, avaliação. 


\section{A. 4. Avaliação das aulas práticas da disciplina de Bioquímica}

As aulas práticas da disciplina de Bioquímica podem ser analisadas por meio do uso dos instrumentos de coleta de dados e por levantamento de alguns outros dados, normalmente de fácil acesso. Tal procedimento pode ser feito sob vários pontos de vista e com variados objetivos, entre eles:

\section{A. 4a. Análise da metodologia}

A análise da metodologia pode ser feita empregando, da seguinte forma, partes dos roteiros de coleta de dados:

- roteiro sobre a instituição: participação de alunos de graduação em projetos de pós-graduação, de pesquisa, de extensão, em congressos e similares, na instituição e fora dela, e em publicações da instituição; regime de trabalho dos professores (disponibilidade de tempo para atender alunos fora da aula); apoios técnico e didático ao professor;

- roteiro sobre o curso analisado e a disciplina de Bioquímica:

- curso: presença de convênio da instituição com empresas e outras instituições para treinamento profissional dos alunos;

- disciplina: integração e relações de pré-requisitos com outras disciplinas;

- todo o questionário endereçado ao professor;

- roteiro de aula prática: uso de artigo científico correlato, posição em relação à aula teórica do mesmo assunto, dinâmica da aula, condições de orientação dos alunos, normas de segurança, de manipulação de material biológico e de higiene, conteúdo da aula, protocolo, etapas da aula / estratégias de ensino (menos comportamento dos participantes), discussão dos resultados, relatório, atividades suscitadas pela aula, avaliação.

\section{A. 4b. Análise dos conteúdos}

Os conteúdos das aulas práticas da disciplina de Bioquímica estão expressos em seus objetivos, em sua programação e nas relações que esta estabelece com outras atividades didáticas, inclusive com a literatura científica, e com a programação de outras disciplinas. Esses conteúdos também ficam claros no desenvolvimento do protocolo, na forma de registro e relato dos resultados e explicitam-se por meio das habilidades mentais e técnicas dos alunos, exigidas e treinadas durante a aula. Assim, o uso dos instrumentos 
de coleta de dados para analisar o conteúdo das aulas práticas deve ser feito como se segue:

- roteiro sobre o curso analisado e a disciplina de Bioquímica:

- disciplina: objetivos e programa, integração com outras disciplinas, relações de pré-requisitos com outras disciplinas;

- roteiro sobre aula prática: características gerais (assunto, presença de artigos científicos correlatos), conteúdo (relações, equivalência com relação a outras atividades didáticas, presença de problemas a serem resolvidos pela aula), protocolo, habilidades exigidas e treinadas, forma de registro dos resultados, relatório, atividades suscitadas pela aula.

É importante lembrar que, na escolha das aulas práticas a serem ministradas, o professor deve refletir se as técnicas laboratoriais e os experimentos escolhidos realmente ensinam conteúdos diferentes a cada nova aula, se não são apenas uma repetição, com outros nomes, dos mesmos procedimentos técnicos, do treinamento das mesmas habilidades, da discussão das mesmas questões etc. Por exemplo, ao fazer dosagem de glicose, de uréia, de proteínas por meio da técnica de espectrofotometria, a simples mudança de reagentes propicia conhecimento novo?

\section{A. 4c. Análise das condições de trabalho dos alunos no laboratório}

As condições de trabalho prático oferecidas aos estudantes é conseqüência das condições físicas do laboratório, das formas de gerenciamento e funcionamento deste, da assistência e da orientação que é dada aos alunos durante atividades de investigação experimental e da supervisão geral do trabalho no laboratório. Os instrumentos de coleta de dados que permitem a análise das condições de os alunos realizarem trabalhos práticos na disciplina de Bioquímica são:

- roteiro sobre a instituição: participação de alunos de graduação em projetos de pós-graduação, pesquisa, extensão, em congressos e similares, na instituição e fora dela, e em publicações científicas da instituição; regime de trabalho do professor (disponibilidade para atendimento dos alunos fora das aulas); apoios técnico e didático ao professor;

- roteiro sobre o curso analisado e a disciplina de Bioquímica: 
- curso: convênio da instituição com empresas ou outras instituições para treinamento profissional dos alunos;

- todo o roteiro sobre o laboratório;

- roteiro sobre aula prática: características gerais (condições de orientação dos alunos), materiais, normas de segurança, de manipulação de material biológico e de higiene.

II. A. 4d. Análise da adequação das aulas práticas da disciplina de Bioquímica ao curso de graduação em questão e às condições presentes na instituição

Os cursos das áreas de Ciências Biológicas e da Saúde que possuem Bioquímica em seus currículos têm características específicas que fazem com que as aulas práticas sejam planejadas dentro dessas particularidades, para que sejam eficientes. Em face disso, aulas práticas de Bioquímica podem ter características comuns, mas não são universais e seguramente não são intemporais. Para julgar se as aulas práticas de Bioquímica de um determinado curso são adequadas a ele, podem-se usar os instrumentos de coletas de dados do seguinte modo:

- todo o roteiro sobre a instituição;

- roteiro sobre o curso analisado e a disciplina de Bioquímica:

- curso: todos os itens;

- disciplina: carga horária, posição na grade curricular, objetivos, programa, integração e relações de pré-requisitos com outras disciplinas, perfil dos alunos ingressantes na disciplina;

- todo o roteiro sobre o laboratório;

- todo o questionário endereçado a alunos (adaptar, se necessário);

- roteiro de aula prática: condições de orientação dos alunos, protocolo (conteúdo - objetivos da aula), etapas da aula / estratégias de ensino (tipo de execução dos experimentos).

II. A. 4e. Análise da contribuição das aulas práticas da disciplina de Bioquímica para a vida acadêmica e profissional do estudante e para sua atuação como cidadão 
O ensino de qualquer disciplina transcende seu próprio conteúdo, mesmo fazendo parte de um currículo tecnicista instrumental com fragmentação do universo de saber. Esse ensino invade outras esferas de conhecimento e atuação, podendo, no caso dos estudantes, contribuir para outros aspectos de sua vida, como o preparo para atividades profissionais, como o envolvimento em projetos da instituição ou na vida universitária do país, como a participação política e social, exercendo sua cidadania. Toda ação educativa tem efeito também sobre a vida afetiva do educando.

Para a análise da contribuição das aulas práticas de Bioquímica sobre vários aspectos da vida dos estudantes, podem-se coletar dados como a seguir:

- roteiro sobre a instituição: participação dos alunos em atividades de pósgraduação, pesquisa, extensão, em congressos e similares, na instituição e fora dela, e em publicações cientificas relacionadas com Bioquímica; existência de biblioteca com livros e periódicos especializados em Bioquímica e acesso a redes eletrônicas de informações e dados;

- existência de centros de treinamento ou centros de atendimento à comunidade dos quais a disciplina de Bioquímica faz parte ou com quem se relaciona e que pode servir para o treinamento profissional do estudante, na área de Bioquímica;

- roteiro sobre o curso analisado e a disciplina de Bioquímica:

- curso: convênio com empresas ou outras instituições para treinamento profissional dos alunos na área de Bioquímica;

- disciplina: integração com disciplinas profissionalizantes do curso, quando a disciplina de Bioquímica for de caráter básico;

- oferecimento de projetos de iniciação científica para alunos de graduação, pela disciplina de Bioquímica;

- roteiro sobre aula prática: condições de orientação dos alunos (possibilidade de uso do laboratório fora do horário de aula para desenvolver projetos profissionalizantes); conteúdo da aula (relações com pesquisa da instituição ou fora dela, com projeto de extensão da instituição na área de Bioquímica, com a vida profissional futura dos alunos, com a vida universitária dos 
alunos, com a vida cotidiana dos alunos fora da universidade, com o contexto social geral dos alunos como cidadãos); presença de problemas a serem resolvidos pela aula, relativos à profissão para a qual o aluno se habilita ou que enfocam sua participação na sociedade; etapas da aula / estratégia de ensino (treinamento de habilidades técnicas diretamente ligadas à futura profissão do aluno); atividades suscitadas pela aula, relacionadas com a profissão futura dos alunos.

Além das possibilidades descritas acima, a instituição ou o professor de Bioquímica, em particular, podem usar os instrumentos de coleta de dados para outros fins que não tenham sido aventados aqui.

\section{B. Uso dos instrumentos de coleta de dados para a determinação das funções e do papel das aulas práticas no ensino de Bioquímica}

\section{B. 1. Conceito de Função e de Papel das aulas práticas}

\section{B. 1a. Função}

A função que a aula prática exerceu é o que ela realmente ensinou ao seu término. $O$ fato de o que se pretendia ensinar estar declarado nos objetivos da aula não quer dizer que isso realmente aconteceu. Cada aula prática tem uma ou mais funções e estas podem ou não corresponder às metas propostas. A consecução dos objetivos, nesse caso, depende do grau de realismo com que eles foram elaborados e da presença das condições que se supunha existir para o desenvolvimento da aula, quando eles foram pensados.

Fazer planejamento é uma suposição e não um ato de adivinhação. Para fazer uma previsão, deve-se procurar o maior número possível de informações sobre a realidade que será vivida, para atingir o grau máximo de certeza, o que, porém, não impede a ocorrência de acidentes e incidentes, a existência de fatos desconhecidos, camuflados, deturpados intencionalmente ou inventados e a possibilidade de ter havido uma interpretação incorreta dos dados disponíveis. 
O quê, como e para que o professor ensina pode ser discutível, mas é inegável que ele quer que o aluno aprenda, adquira conhecimentos. Sua preocupação é "preparar" a aula prática, isto é, conhecer o assunto e determinar como fazer para que os alunos passem também a dominá-lo e sejam capazes de aplicá-lo. O professor trabalha bastante para isso, o que tem em mente antes de iniciar seu ensino é fruto de vivência e reflexão. Ele não quer, de modo algum, ver seus planos irem por água abaixo. Muitas vezes, pressentindo que isso vai ocorrer ou percebendo que de fato aconteceu, o professor prefere não clarificar esta constatação por meio de uma avaliação formal de seu processo de ensino, furta-se a julgar-se ou a ser julgado: escolhe continuar falando sobre como é importante o ensino no laboratório e reproduzindo aulas práticas ineficientes.

Gressler (1989) constatou, com suas investigações e com as de outros pesquisadores, que o professor tem receio de pesquisa educacional. Mesmo assim, neste trabalho defende-se que é melhor o professor "perder" mais tempo em fazer seu planejamento do que costumeiramente o faz, para evitar o malogro, assistindo suas intenções não se traduzirem nos resultados desejados. Colocar em prática essa recomendação é mais eficaz na consecução dos objetivos que seguir os usos e costumes vigentes até então ou reverenciar a idéia de que "serviu para eu aprender, logo, servirá para ensinar os outros". A certeza da validade do que foi afirmado fundamentou a estruturação deste modelo de análise de aulas práticas, formalizado em um documento que utiliza dados obtidos por meio de roteiros e questionários construidos especificamente para esse fim.

A coleta minuciosa de informações pode parecer, a princípio e numa visão mais simplista ou comodista, excessiva, desnecessária, dispensável, exagerada ou de preciosismo inócuo. Porém, o grau de detalhamento pode abrir espaço para dados normalmente esquecidos ou desprezados por não serem considerados relevantes, também aparecem aqueles que são propositalmente escamoteados por gerarem conflitos ou que não são pesquisados, porque há medo de se encontrar uma realidade totalmente 
diferente daquela imaginada ou percebida. A descoberta gera necessidades, estranheza, desconforto, pede novas ações, há que se vencer a inércia; dá trabalho, exige coragem, mas vale a pena. A vida do educador é feita de desafios: a cada ano, todo curso, mais uma vez, os alunos "não sabem nada" e ele tem que ensinar "tudo de novo".

II. B. 1b. Papel

O papel da aula prática é o que ela representa no quadro geral do ensino, isto é, para que serve o aprendizado nela obtido.

\section{B. 2. Funções das aulas práticas}

A utilização dos instrumentos de coleta de dados aqui apresentados permite definir, para as aulas práticas de Bioquímica, as funções descritas a seguir, entre outras.

\section{B. 2a. Funções do conteúdo}

Funções de ilustração, aprofundamento e/ou ampliação e aplicação do conteúdo de aulas teóricas

As funções de ilustrar, aprofundar, ampliar e aplicar conteúdo, englobam:

- ilustrar fatos e fenômenos;

- aprofundar o conteúdo de aulas teóricas;

- ampliar o conteúdo de aulas teóricas;

- aplicar teoria, lei, princípio ensinados em aulas teóricas.

As aulas práticas têm somente as funções descritas acima quando apresentam o conjunto de características abaixo enumeradas ou, pelo menos, parte delas:

(1) o conteúdo da aula prática é o mesmo de parte, de uma ou de mais de uma aula teórica;

(2) a aula prática está colocada na programação entre outras atividades, como aulas teóricas, seminários, aulas de exercícios, avaliações, sempre após a aula teórica do mesmo assunto, imediatamente a seguir ou não;

(3) as aulas práticas são testadas previamente; 
(4) a fase antes da execução dos experimentos é dedicada a instruções e explicações sobre o trabalho a realizar e não ao seu planejamento com os alunos;

(5) o protocolo contém os dados a serem obtidos;

(6) o protocolo ou as explicações iniciais dizem como processar os dados: que cálculos fazer, como apresentar os dados;

(7) questões relativas à precisão na obtenção dos dados, à sensibilidade dos métodos e técnicas fazem parte das instruções iniciais elou do protocolo e não de planejamento inicial ou só da discussão dos resultados;

(8) análise, interpretação e raciocínio são as necessárias habilidades mentais dos alunos para a explicação e aplicação dos dados. A análise refere-se à decomposição do objeto (objeto material ou idéia) em suas partes constitutivas (Minayo, 1994). A análise permite $\circ$ estabelecimento de relações de causa e efeito, entre produtor e produto, entre a variável independente e a dependente. Por meio dela, chega-se a respostas para indagações, ao teste de hipóteses. A interpretação vai além dos resultados da análise, é uma atividade infelectual que procura dar um significado mais amplo às respostas obtidas, ligando-as a outros conhecimentos (Lakatos, 1990). Raciocínio é o processo de pensamento pelo qual conhecimentos são logicamente encadeados, de maneira a produzirem novos conhecimentos (Severino, 1996). Ele permite a interpretação dos resultados produzidos em aulas práticas e a aplicação dos conhecimentos obtidos em aulas teóricas.

(9) quando, sendo obtidos resultados inesperados, o professor detecta o motivo ou faz hipóteses e explica as possiveis causas do insucesso; (10) o conteúdo das aulas práticas pode ser substituido, com igual proveito, por exercícios de fixação ou aplicação dos conhecimentos obtidos em aulas teóricas, como análise de casos, ou por recursos audio-visuais e programas de computador que mostram fatos e descrevem fenômenos; 
(11) as ações e o comportamento do professor revelam intencionalidade na forma como ele conduz sua orientação para um fim previsto;

(12) quando, no comportamento dos alunos, há a clara preocupação de saber se o que obtiveram como resultado é "o certo", se o que presenciaram e interpretaram confere com o conteúdo dos livros didáticos e com suas anotações de aulas teóricas;

(13) o relatório das aulas práticas prioriza a apresentação dos resultados obtidos e sua interpretação;

(14) a avaliação do aprendizado em aulas práticas é feita somente pelo relatório ou por perguntas sobre como interpretar os resultados da prática dada ou de experimentos equivalentes, quando se trata de ilustração, ampliação e aprofundamento de conteúdo de aulas teóricas; a prova contém questões que avaliam a capacidade de resolver problemas novos, utilizando aprendizado obtido em aulas práticas, quando se trata da função de aplicação de conhecimentos de aulas teóricas;

(15) os conhecimentos obtidos em aulas práticas não suscitam nenhuma atividade posterior, encerrando-se em si mesmos;

(16) convém levar em consideração, embora não seja condição sine qua non, que, quando o professor de aulas práticas é o mesmo das aulas teóricas, ele tende a relacioná-las estreitamente, quanto ao conteúdo.

Em resumo, pode-se dizer que:

* quando o conteúdo da aula prática mostra fatos, acompanha o desenvolvimento de fenômenos ensinados em aulas teóricas e a interpretação dos dados segue um processo indutivo (do particular para o geral), trata-se da função de ilustração do conhecimento. A indução não é um processo que tem apenas a participação da inteligência, mas também da experiência concreta dos sentidos, passa-se de um fato para fatos semelhantes, num desencadear lógico de conseqüências, até se obter generalizaçōes, resultando em 
uma explicação, uma regra, uma lei, um princípio universal, chegando a um novo conhecimento (Severino, 1996);

* quando o conteúdo da aula prática fornece informações adicionais àquelas dadas em aulas teóricas do mesmo assunto, no protocolo ou por meio de consulta à literatura, trata-se da função de aprofundamento e/ou ampliação do conhecimento anteriormente obtido;

* quando, em aula prática, há uma hipótese a ser testada, uma teoria a ser aplicada, uma lei ou princípio a ser demonstrado e a interpretação dos dados segue um processo dedutivo, trata-se da função de aplicação do conhecimento. $O$ raciocínio dedutivo é aquele cujo antecedente é constituído de affrmaçōes previamente aceitas e delas decorre, de maneira lógica, a afirmaçāo conseqüente ou conclusāo (Severino, 1996). O uso da aula prática para responder problemas também é uma forma de aplicação do conteúdo das aulas teóricas.

Função de compreensão de conceito

A compreensão é a habilidade mental de percepção das características, das propriedades e das qualidades do objeto (material ou do pensamento). Ela permite a apreensão global de uma dada visão do objeto ou do fenômeno, enquanto a explicação faz apenas uma demonstração de relaçōes causais de fatos. De acordo com Husserl (Chizzotti, 1995), na concepção holística, há, com a compreensão, uma captação das coisas em si mesmas, ultrapassando sua aparência imediata para se aproximar de sua essência (Crema, 1989; Weil, 1990; Brandão e Crema, 1991; Tavares, 1998).

A função de compreensão aparece em aulas práticas, quando há uso de conceitos desenvolvidos ou apresentados em outras atividades didáticas e a experimentação serve à completa assimilação desses conceitos, para posterior aplicação.

O conceito é uma imagem mental por meio da qual se representa um objeto. O conhecimento humano começa com a formação de conceitos (Severino, 1996). Eles servem para ordenar os objetos e processos e fixar melhor o recorte da realidade que deve ou não ser examinado e construído 
durante o processo ensino-aprendizagem. A função cognitiva do conceito expressa-se por "o quê" vai ser estudado e que enfoque vai ser dado a esse estudo; a função pragmática do conceito é como ele vai ser usado; sua função comunicativa é conter uma explicação clara, específica e abrangente de um aspecto da realidade, de maneira que ela possa ser incorporada igualmente por todos em sua área de interesse. Os conceitos sempre se inserem em uma ou mais correntes teóricas de pensamento, não existe um conceito absoluto para cada coisa ou situação, daí ser toda aprendizagem vinculada a uma ideologia (Minayo, 1994). A escolha de qual conceito será ensinado já expressa para que ele será ensinado, ou seja, seu papel no ensino.

As aulas práticas com o fim de compreender, e não de construir novos conceitos, apresentam algumas ou todas as seguintes situações em seu planejamento e desenvolvimento:

(1) cursos com currículos tecnicistas, com uma ordenação de disciplinas que reflete a idéia de "disciplinas básicas" e "disciplinas profissionalizantes", que evolui do teórico para o prático, da compreensão do conceito para sua aplicação, sem passar por sua construção;

(2) a disciplina de Bioquímica é lecionada nos primeiros semestres do curso;

(3) há uso de literatura científica para explanar conceitos em substituição ou ao lado das aulas teóricas sobre o conceito a ser compreendido em aula prática. É pertinente lembrar que explicações iniciais de aulas práticas que oferecem explanação de conceitos são também consideradas como aulas teóricas, embora ocorram no laboratório;

(4) as aulas práticas são colocadas na programação após as aulas teóricas do mesmo assunto;

(5) a porcentagem da programação que é desenvolvida em aulas práticas é a mesma ou menor que a de aulas teóricas, de modo que as funções das aulas práticas têm pouco tempo para avançar em relação ao treinamento técnico e ilustração do conteúdo de aulas teóricas; pelo mesmo motivo, a proporção entre aulas práticas e outras atividades é pequena, pelo menos, menor que 1:1; 
(6) há integração e/ou relações de pré-requisito da Bioquímica com outras disciplinas que usam conceitos em comum;

(7) as aulas práticas são testadas previamente;

(8) há uma dinâmica com ênfase na discussão dos resultados em detrimento do planejamento ou explicações iniciais e execução dos experimentos;

(9) os alunos devem conhecer os princípios que norteiam as técnicas empregadas na aula;

(10) são necessárias as habilidades mentais de análise e interpretação para o desenvolvimento da aula prática e a habilidade de síntese, se não exigida, é treinada durante a aula. As habilidades de análise e interpretação foram explicadas na característica (8) do item II. B. 2a - p. 91. Síntese é a recomposiçāo de um objeto decomposto pela análise, reconstituindose sua totalidade, dando à uniāo das partes um único sentido. É a consciência do todo sem perder a consciência das partes (Severino, 1996);

(11) as aulas práticas não partem de problemas que desencadeiam os trabalhos, nem os resultados obtidos servem para responder a questões formuladas previamente. Eventualmente, há perguntas ou problemas a serem resolvidos na aula, se ela exercer outras funções, que não somente a de compreensão;

(12) as diretrizes para a execução dos experimentos são fornecidas no protocolo ou oralmente;

(13) os dados a serem obtidos são definidos previamente;

(14) o professor explica as falhas, quando ocorrem, ou a causa é procurada na literatura;

(15) há, no protocolo, orientação para a discussão dos resultados, sob forma de perguntas ou de outro recurso, ou ela é dada oralmente, no início da aula;

(16) a discussão é conduzida preferencialmente pelo professor e há intencionalidade deste com relação ao fim a ser atingido. Não é só o professor que ensina, nem só o aluno que aprende, segundo Vygotsky, o professor guia a aprendizagem do aluno (Howe, 1996); 
(17) o relatório contém alguma forma de apresentar a discussão e chega até as conclusões, não se detendo apenas em apresentação, análise e interpretação de resultados;

(18) a avaliação da aula é feita pelo relatório, quando este chega até as conclusões, ou por questões que demandam a aplicação de conceitos, o que, supõe-se, só pode ser realizado por alunos que compreenderam os conceitos.

Função de construção de conceito

A construção do conhecimento depende da maturação física e das relações do aprendiz com $\circ$ contexto. Piaget deu ênfase aos estágios do desenvolvimento para a aprendizagem, isto é, disse que a instrução deve esperar pelo desenvolvimento, enquanto Vygotsky mostrou a importância das relações com o professor, com os colegas, com as estruturas sociais e com o universo da cultura, quer dizer, considerou que instrução e desenvolvimento estão interligados. Ambos, entretanto partilharam a idéia construtivista da aquisição de conceitos, em que cada indivíduo constrói seu próprio conhecimento e entendimento e o pensamento do indivíduo só se completa a partir da adolescência, quando terminam de se estruturar as funções intelectuais superiores, incluindo a consciência de operações mentais (Howe, 1996).

De acordo com Vygotsky (Howe, 1996; La Taille, Kohl e Dantas, 1992), os conceitos podem ser classificados como científicos e do cotidiano. Os últimos preponderam na infância e têm grande influência sobre os primeiros, mas, em cursos universitários, ocorre o inverso: os conceitos científicos, desenvolvidos pela educação formal, é que têm papel relevante sobre os conceitos usados na vida diária. Os conceitos científicos estabelecem-se da mesma forma, quer se trate de Ciências Humanas, Linguagem, Matemática ou Ciências Naturais.

A construção de conceitos é mediada pela linguagem, o aprendiz vai progredindo da linguagem coloquial para a científica, sem abandonar a primeira. Ele usa objetos para construir conceitos científicos, mas o conhecimento não é obtido só por pensamento lógico, baseado na observação e manipulação, mas pela interação, pela discussão ocasionada 
pela atividade proposta pelo professor. A linguagem é usada para fazer o aluno refletir e explicar, para entender com suas vivências e para que seus conhecimentos, ligados ao contexto, insiram-se em um sistema mais amplo.

Pessoas adultas, com estágio máximo de desenvolvimento, quando operam no sentido de construir conhecimento, chegam a resultados de aprendizado diferentes, com o mesmo ensino, isto é, com conteúdo e estrutura de tarefas iguais. Isso ocorre, porque o contexto pessoal é único.

A construção de conceitos não se processa em ambiente no qual o universo do saber apresenta-se fragmentado ao aluno. Por isso, cursos com currículos interdisciplinares são facilitadores do ensino nos moldes construtivistas.

Currículos interdisciplinares e transdisciplinares são aqueles que pressupõem uma visão holística de organização dos conteúdos das áreas abrangidas pelo curso, que derrubam as fronteiras entre os vários tipos de conhecimento, em contraste com currículos multidisciplinares ou polidisciplinares (Severino, 1998).

Nos currículos multidisciplinares, aparece, no máximo, uma integração vertical entre as disciplinas distintas, com relações de prérequisitos entre elas. Entretanto, a interdisciplinaridade demanda uma integração verdadeira, com uma fusão de linguagens, com a utilização de técnicas de várias disciplinas, com a união de conceitos específicos de cada área de conhecimento em teorias mais amplas. A interdisciplinaridade utiliza fluidez de conhecimento ou o conhecimento em movimento, já previsto por Blaise Pascal, que utiliza um circuito pedagógico que vai da parte ao todo e do todo às partes (Morin, 1998). Isto significa que o conhecimento fornecido por uma disciplina é o estopim para a construção do conhecimento dentro do domínio de outra disciplina; os novos conhecimentos podem ampliar os anteriormente adquiridos ou modificá-los, e assim sucessivamente.

De acordo com Severino (1998), na interdisciplinaridade, o agir e o saber não são compartimentados, tanto em situações de ensino como nas de pesquisa. A interdisciplinaridade, na esfera pedagógico-educacional, 
refere-se à formação científica e profissional do homem e dele como agente social, em sentido mais amplo. A interdisciplinaridade caracteriza-se por:

* articular o todo com as partes;

* articular os meios com o fim;

* existir em função da prática, do agir;

* conduzir-se com intencionalidade;

* pressupor que aprender é pesquisar para construir, constrói-se pesquisando;

* depender da existência de um projeto educacional.

Devido à complexidade das ações do homem, há múltiplos enfoques do conhecimento, mediados pelas abordagens dos vários ramos da Ciência, mas o existir não pode ser apenas a justaposição de múltiplos saberes, é preciso chegar-se à unidade na qual o todo se reconstitui como uma síntese, maior que a soma das partes entendidas por meio da análise. A prática do existir precisa ser transdisciplinar. Ela é uma fusão tanto de elementos cognitivos, como de elementos valorativos de uma realidade, como explicita o paradigma holístico. (Crema, 1989)

As aulas práticas exercem a função de construção de conceitos, quando há as seguintes características do contexto e apresentam-se os seguintes elementos nas aulas práticas:

(1) o currículo do curso é interdisciplinar ou transdisciplinar;

(2) a programação das aulas práticas acompanha a das aulas teóricas e a aula prática é colocada antes da aula teórica ou outra atividade do mesmo assunto, que utilizam os conceitos construídos naquela aula prática;

(3) os alunos dominam as habilidades de análise, interpretação e síntese;

(4) o assunto mantém relações de conteúdo com outras disciplinas, com a atividade cotidiana do aluno e com seu contexto social, para que as premissas do construtivismo e da visão holística estejam presentes;

(5) a aula prática em questão pode ser substituída por atividades em que são fornecidas informações ou são feitas observações ou se utilizam dados obtidos por análise de um fato ou fenômeno e, a partir daí, constrói-se uma unidade por meio de síntese; 
(6) a aula prática não apresenta problemas a serem resolvidos, como uma forma de aplicar conhecimento, uma vez que a resolução de problemas, nesse caso, implica em encadeamento lógico de conceitos já assimilados;

(7) o protocolo contém os objetivos da aula explicitados e as diretrizes da execução dos experimentos; nele não há orientação para a discussão dos dados, deixando a cargo do professor dirigir a discussão;

(8) o protocolo é analisado e interpretado antes de iniciar-se a experimentação;

(9) os dados a serem obtidos são previamente estabelecidos;

(10) não é fornecida bibliografia com informações teóricas sobre o assunto da aula;

(11) há preocupação com precisão na obtenção dos dados, com a sensibilidade dos métodos e técnicas, com higiene, quando necessária e pertinente;

(12) os alunos têm as habilidades técnicas necessárias para realizar os experimentos com precisão;

(13) as orientações do professor são conduzidas com intencionalidade;

(14) para o processamento dos dados, os alunos são orientados quanto à forma de registro e apresentação dos dados e os experimentos dos vários grupos são tratados como repetições do mesmo experimento, simulando, o mais possivel, os procedimentos de uma pesquisa laboratorial;

(15) as falhas são detectadas e corrigidas, sendo os experimentos repetidos, se necessário;

(16) há disponibilidade de tempo, local para a repetição dos experimentos e possibilidade de orientação pela equipe de ensino;

(17) o relatório pode ser apenas a apresentação dos dados processados;

(18) a discussão é conduzida pelo professor, utilizando os dados já tratados e convenientemente apresentados, o aluno chega a uma síntese que expressa o conceito que se pretende construir, este pode transcender aquele apresentado na literatura, tendo caráter interdisciplinar ou transdisciplinar;

(19) a avaliação contém uma aplicação do conceito para perceber até que ponto ele foi construído. Ela pode ser feita por meio de provas convencionais ou por um trabalho suscitado pelo conteúdo da aula prática, de preferência interdisciplinar ou transdisciplinar. 


\section{Função de divulgação do conhecimento científico}

No ensino de Bioquímica, a aprendizagem de como divulgar o produto da Ciência, por meio da prática laboratorial, aparece toda vez que as aulas práticas exercerem as funções que se seguem:

- mostrar a importância da Bioquímica em campos específicos do conhecimento;

- divulgar descobertas recentes da Ciência.

O existir é o fazer do dia-a-dia e o conhecimento que o permeia tem a ver com teoria e pensamento. Entretanto, qualquer conhecimento só é expresso pelo agir. "É na prática e pela prática que as coisas humanas efetivamente acontecem, que a história se faz" (Severino, 1998). A prática, por um lado, refere-se à produção ou trabalho, que garante a existência material do homem, ela não é individual, mas coletiva. Nas sociedades humanas, os sujeitos não se sobrepõem em igualdade, mas há uma hierarquia e estabelecem-se estruturas de poder, em que uns dominam os outros: a sociedade é política. A prática política é intencionalizada, ela é orientada por uma simbolização que faz com que o homem aja além de suas necessidades imediatas de sobrevivência. Ela ultrapassa a percepção dos órgãos do sentido e da razão, é social, expressa-se num universo de saber que é a cultura, o conjunto de padrões de comportamento, crenças e valores, instituições de uma sociedade. Isto é válido para cada indivíduo e para a humanidade como um todo. Assim, a Ciência, como uma das formas de equacionar o conhecimento, também ela expressa estas três dimensões que compõem o saber: o trabalho, a sociedade e a cultura. $O$ que a pesquisa busca e produz depende destes três aspectos de nosso universo de conhecimentos. Ela, portanto, é produzida com intencionalidade e, sendo um bem coletivo, só tem sentido se divulgada.

A divulgação da Ciência é uma das funções do ensino das disciplinas técnico-científicas, como a Bioquímica.

Uma aula prática que faz divulgação científica tem as seguintes características ou parte delas:

(1) a instituição tem atividade de pesquisa e há possibilidade de participação de alunos de graduação nessas atividades; 
(2) a instituição tem publicações científicas em que os alunos de graduação podem divulgar seus trabalhos ou os pesquisadores da instituição incluem a participação destes alunos em suas publicações ou abrem espaço para eles em publicações de outras instituições;

(3) a instituição promove congressos, encontros ou similares em suas dependências, nos quais há a participação de alunos de graduação;

(4) a instituição mantém estrutura que permite aos alunos de graduação participarem de congressos, encontros e similares fora da instituição;

(5) o conteúdo das aulas práticas é vinculado a atividades de congressos, encontros, cursos e similares, realizadas na instituição e fora dela, patrocinadas pela instituição;

(6) o professor tem disponibilidade de tempo e recebe remuneração para orientar e acompanhar alunos de graduação em atividades que se referem à divulgação científica: workshops, congressos, aprendizagem de redação científica etc;

(7) o professor dispõe de bons apoios técnico e didático para atividades fora da sala de aula, com alunos de graduação, inclusive a presença de uma biblioteca bem equipada;

(8) o professor utiliza audio-visual como coadjuvante e como extensão de aula prática, mostrando técnicas laboratoriais refinadas e avançadas sobre $o$ assunto de divulgação científica em foco, procedimentos cuja complexidade e custo impedem sua reprodução em laboratório didático;

(9) o curso tem um currículo e grade horária que prevêem horário para trabalho extraclasse;

(10) a programação tem uma alta porcentagem de assuntos desenvolvidos em aulas práticas; a proporção entre estas aulas e outras atividades é grande, isto é, maior que 1:1. Isto contrasta com o que normalmente ocorre, situações em que as aulas práticas são prioritariamente usadas para treinamento técnico e outras atividades relacionadas a aprendizagem de Bioquímica, quando pouco tempo resta, no ambiente do laboratório, para a atividade de divulgação dos progressos desta ciência. 
(11) não importa a ordem em que a aula prática com assunto de divulgação cientifica é colocada na programação, sendo esta ordem aleatória ou ditada pelas relações que a aula prática em questão possa ter com outras atividades do graduando, na disciplina ou fora dela;

(12) a dinâmica da aula e as condições de orientação variam de acordo com a estratégia escolhida pelo professor;

(13) o conteúdo da aula prática liga-se à vida profissional dos alunos e/ou à sua vida cotidiana e/ou ao seu contexto social geral;

(14) a aula prática com assunto de divulgação científica pode ser substituída por sessão de audio-visual, por visitas monitoradas, por assistência a palestras;

(15) o protocolo, quando presente, é prescritivo; a experimentação é feita por demonstração, de preferência;

(16) há fornecimento de bibliografia específica sobre a técnica e/ou assunto da aula prática;

(17) os resultados são definidos previamente;

(18) os alunos devem conhecer os princípios que norteiam as técnicas empregadas na aula;

(19) as habilidades necessárias são de compreensão da mensagem escrita oral e visual;

(20) há intencionalidade na orientação do professor;

(21) a discussão está em segundo plano em relação à execução dos experimentos, ao registro, ao tratamento dos dados e à apresentação dos resultados;

(22) a discussão enfoca a interpretação e o arquivamento de informações;

(23) as aulas práticas encerram-se em si mesmas, não suscitando trabalhos posteriores.

II. B. 2b. Funções da metodologia de ensino

Metodologia é a senda do pensamento; consiste de um programa teórico que regula uma série de passos com previsōes que permitem evitar erros no caminho para atingir um determinado resultado. $O$ fim a que se pretende chegar é uma abordagem prática da realidade. 
A metodologia faz uma articulação entre conteúdos, pensamentos e ações, incluindo: concepções teóricas de abordagem, técnicas que possibilitam a construção da realidade e potencial criativo do investigador (Minayo, 1994).

As funções da metodologia de ensino aplicada a aulas práticas são:

- desenvolver o entendimento de instrução escrita;

- ensinar a registrar dados;

- ensinar a processar dados, dando-Ihes nova feição;

- ensinar como discutir resultados experimentais;

- ensinar como organizar os dados para apresentá-los de forma coerente e lógica;

- ensinar como transmitir por escrito e oralmente os dados, sua análise e interpretação e as conclusões a que eles levaram;

- ensinar a executar experimentos de forma autônoma;

- ensinar o método científico e como utilizá-lo em experimentação.

Funções de ensinar como seguir instruções escritas, registrar e processar resultados experimentais

Em trabalho laboratorial, para realizar-se a coleta de dados, é necessário dominar determinadas habilidades técnicas e possuir a capacidade de observar acuradamente. O primeiro passo para que os alunos executem os experimentos com precisão é que eles sejam capazes de traduzir corretamente as instruções contidas no protocolo. A próxima etapa é observar os fatos e fenômenos ocorridos durante o experimento e anotar o resultado dessas observações, sem o que muitas das informações podem perder-se.

Feito o registro, segue-se o tratamento dos dados brutos, o que implica em processá-los, por meio de cálculos, fazer sua triagem, sua ordenação, sua classificação, mudanças de linguagem, quando necessárias (por exemplo, da linguagem discursiva para a linguagem matemática ou viceversa) etc. Só então é possivel proceder à interpretação dos resultados, que é fruto da análise dos dados e sua explicação. Esse processo de elaboração de pensamentos leva à compreensão e à assimilação. 
As funções de ensinar como seguir instruções escritas, registrar e processar resultados experimentais incluem:

- ensinar como seguir protocolo;

- ensinar como registrar dados;

- ensinar como processar dados;

- ensinar como organizar informações.

As funções acima são alcançadas quando:

(1) a dinâmica da aula prevê tempos necessários e suficientes para explicações e instruções no início da aula e para análise e interpretação dos resultados;

(2) cada aluno dispõe de um protocolo impresso;

(3) o protocolo contém:

* objetivos da aula explicitados;

* lista de materiais;

* diretrizes para a execução dos experimentos;

* orientação de como e o quê observar;

* normas de segurança específica para os experimentos e/ou regras de higiene, quando pertinentes;

* orientação para o registro dos dados;

* bibliografia específica sobre técnica e/ou assunto da aula prática;

(4) a utilização do protocolo é feita da seguinte forma:

* leitura prévia em voz alta, com toda a classe ou no grupo, ou silenciosamente, dando tempo para que todos os alunos concluam a leitura;

* análise e interpretação dos itens do protocolo feitas pelos alunos, sob a orientação do professor;

* esclarecimento das dúvidas dos alunos pelo professor, à medida que o protocolo vai sendo colocado em prática;

(5) os alunos são instruídos sobre como construir tabelas e gráficos;

(6) os alunos conhecem os princípios que norteiam as técnicas empregadas na aula;

(7) os alunos têm habilidades de interpretação de textos e capacidade de observação; 
(8) os resultados são registrados por todos os alunos, não só por um dos elementos do grupo;

(9) os dados são organizados em tabelas, gráficos, esquemas, individualmente e partilhados com o grupo.

\section{Função de ensinar como discutir resultados experimentais}

A função de ensinar como discutir resultados experimentais inclui:

- ensinar como ordenar e expressar idéias;

- ensinar como analisar, interpretar e sintetizar (discutir) dados experimentais;

- ensinar como fazer conclusões.

Para que a função acima seja exercida pela aula prática, esta apresenta as seguintes situações:

(1) os alunos são capazes de expressar-se de forma clara, oralmente;

(2) a dinâmica da aula prevê tempos necessários e suficientes para o tratamento dos dados e para a discussão dos resultados;

(3) é fornecida bibliografia específica sobre o assunto e os métodos e técnicas da aula;

(4) o protocolo contém instrução sobre como discutir os resultados;

(5) os alunos têm as habilidades de análise, interpretação e argumentação e são treinados na habilidade de síntese. Argumentação é apresentar provas ou razões que estāo a favor de uma afirmação (tese) e concluir pela sua validade ou não. Ela se fundamenta na evidência racional e na evidência dos fatos (Severino, 1996);

(6) os alunos apresentam oralmente os resultados já elaborados convenientemente, assim como sua interpretação e argumentação; a discussão dos dados é feita por todos os alunos, com a orientação do professor; (7) em prova, há questões que avaliam a capacidade de discutir dados semelhantes aos obtidos em aulas práticas.

Função de comunicação dos resultados experimentais

A aula prática que tem a função de comunicação de resultados experimentais, ensina a:

- apresentar dados, resultados e conclusões;

- fazer relatório escrito; 
- comunicar resultados oralmente;

- fazer redação científica.

Para ensinar as habilidades descritas acima em aulas práticas, ela apresenta os seguintes elementos:

(1) os alunos conhecem a linguagem cientifica;

(2) a dinâmica da aula prevê tempos para o relato dos resultados, da discussão e das conclusões;

(3) o protocolo contém instrução de como apresentar a discussão dos dados no relatório e sobre o conteúdo e a linguagem de cada item do relatório;

(4) é fornecida bibliografia específica sobre o assunto e os métodos e técnicas da aula;

(5) os alunos possuem a habilidade de expressar-se por escrito;

(6) há local adequado para os alunos redigirem o relatório, quando em grupo;

(7) há disponibilidade de tempo do professor para orientar a elaboração e a redação dos relatórios;

(8) a entrega dos relatórios é obrigatória;

(9) os alunos apresentam oralmente os resultados já elaborados convenientemente, assim como sua interpretação e argumentação;

(10) o relatório é parte integrante da avaliação da disciplina e deve ter todos os itens de um artigo científico convencional;

(11) em provas, pode haver questões que avaliam a capacidade de fazer redação científica.

Função de desenvolver autonomia na execução de experimentos

Autonomia significa, no caso do trabalho do laboratório, fer liberdade de pensamento e de ação.

Os alunos podem desenvolver a autonomia na execução de experimentos quando se apresentam, no contexto e no desenvolvimento das aulas práticas, as seguintes situações:

(1) a instituição tem um técnico de laboratório qualificado que prepara adequadamente os experimentos; 
(2) o curso em questão habilita em profissões que dependem de trabalho de laboratório;

(3) o laboratório didático apresenta, no mínimo, as seguintes características:

- tamanho adequado para que a densidade populacional seja baixa e haja boas condições de circulação;

- condições de trabalho dos alunos totalmente adequadas aos experimentos, quanto a:

* assentos e bancadas suficientes e adaptadas às condições exigidas pelos experimentos; local adequado para guardar material pessoal dos alunos;

* condições de preparo e de teste de aulas adequadas e distribuição eficiente de vidrarias e reagentes;

* local acessível para estoque de vidraria e de reagentes, de acordo com regras de segurança e precisão;

* disponibilidade de materiais e de reagentes;

* fácil acesso e número adequado de aparelhos e equipamentos;

* equipamentos e aparelhos atualizados e em perfeito estado de funcionamento;

* fácil acesso a instalações de água, de gás, de eletricidade e a lixo;

* condições de ventilação, de iluminação e de exaustão de vapores boas;

* condições adequadas de segurança; cuidado com descarte de materiais e higiene; piso seguro;

* boas condições de visão da lousa e dos recursos audio-visuais e de audição das explicações do professor;

* instalações adequadas para professores e auxiliares;

(4) as aulas são testadas previamente;

(5) a dinâmica da aula dá ênfase à etapa de execução dos experimentos;

(6) a proporção orientador : aluno é alta;

(7) os alunos conhecem os princípios que norteiam as técnicas empregadas na aula;

(8) a aula não pode ser substituída por outro tipo de atividade didática para atingir o mesmo fim; 
(9) o protocolo é interpretado antes da execução dos experimentos, pelos alunos, sob a orientação do professor;

(10) o protocolo contém as diretrizes para a execução dos experimentos;

(11) há fornecimento de bibliografia sobre as técnicas experimentais;

(12) os alunos executam os experimentos por sua própria conta, sob a supervisão do professor;

(13) há preocupação com precisão e sensibilidade;

(14) as habilidades técnicas exigidas pelo experimento são de domínio dos alunos;

(15) os grupos de trabalho não ultrapassam cinco pessoas e a distribuição de tarefas é eqüitativa;

(16) a estratégia de ensino é prevista para garantir envolvimento e comprometimento dos alunos;

(17) a discussão dos dados contém a crítica à precisão na obtenção dos dados, às validez e confiabilidade deles;

Função de ensinar como utilizar o método científico

A Bioquímica é uma ciência obtida em laboratório e, como tal, aplica o método científico experimental em suas pesquisas.

Existem muitas abordagens deste método, mas todas partem da premissa de que uma investigação se dá para resolver um problema, observado ou sentido, e que deve ser claramente delimitado. Esta delimitação implica levantamento de hipóteses que guiarão as ações no sentido de resolver o problema. O levantamento de hipóteses é precedido de observações e coleta de dados e fundamenta-se em conhecimento científico pré-estabelecido.

A hipótese oferece uma explicação provisória para as observações e seu teste, em Bioquímica, é feito pela experimentação, razão pela qual esta modalidade de método científico é também dita experimental. Uma hipótese que, por meio da experimentação é reconhecida como verdadeira, gera conclusões que resolvem total ou parcialmente o problema, levanta outros problemas ou serve de base para um processo indutivo que chega a uma lei 
ou a um princípio. O conhecimento obtido por esse método experimental, quando inserido em um contexto mais amplo, pode gerar teorias.

O método científico experimental utiliza os processos mentais de análise e síntese, dedução e indução, que são comuns ao método científico racional, mas distingue-se deste último, porque tem como objeto de estudo fatos e fenômenos, enquanto o método racional utiliza a interpretação da realidade, empregando unicamente o universo do pensamento (Cervo e Bervian, 1996).

No âmbito do presente trabalho, são feitas referências às etapas do método científico experimental, pelo qual as hipótese podem ser testadas e comprovadas em laboratório.

Para que a aula prática ensine a utilizar o método científico experimental, ela deve:

- ensinar como consultar literatura;

- ensinar como propor hipóteses;

- ensinar como testar hipóteses;

- ensinar como montar experimentos;

- ensinar como validar ensaios;

- ensinar como criticar dados;

- ensinar como escrever protocolos;

- ensinar como pensar novos experimentos.

Aulas práticas que ensinam as etapas do método científico experimental têm as características que se incluem entre as descritas a seguir:

(1) a instituição possui atividades de pesquisa e extensão, das quais participam alunos de graduação;

(2) a instituição promove congressos, encontros ou similares em suas dependências, com a participação de alunos de graduação;

(3) a instituição mantém estrutura para professores e/ou alunos de graduação participarem de congressos, cursos, palestras ou similares fora da instituição;

(4) os professores de Bioquímica fazem pesquisa nesta área, na instituição ou fora dela; 
(5) os professores de Bioquímica têm tempo remunerado para atendimento de alunos de graduação, fora do horário das aulas;

(6) o professor conta com apoio de técnico de laboratório;

(7) a biblioteca possui bom acervo de livros e periódicos na área de Bioquímica, mantém relações com outras bibliotecas e disponibiliza acesso a redes de informações, como a internet;

(8) o curso em questão inclui habilitação em especialidades profissionais em que se realiza pesquisa laboratorial;

(9) a utilização do método científico experimental é melhor ensinada em cursos com currículos interdisciplinares ou que, pelo menos, tenham integração vertical entre as disciplinas;

(10) a instituição mantém convênio com empresas ou outras entidades nas quais seus alunos de graduação participam de pesquisa laboratorial como aprendizes, no nível de iniciação científica ou como estagiário;

(11) a disciplina de Bioquímica em questão é lecionada do meio para o fim do curso, quando os alunos já passaram por treinamento técnico laboratorial em várias disciplinas da área de Química;

(12) a porcentagem de programação que é desenvolvida em aulas práticas é grande;

(13) o laboratório didático é bem equipado, adequado ao fim a que aqui se propõe, como descrito no item (3) da página 106, e há possibilidade de seu uso também fora do horário de aulas práticas;

(14) as aulas práticas são reunidas em uma seqüência, de forma a propiciar o desenvolvimento de pequenos projetos de pesquisa;

(15) a dinâmica das aulas dá grande ênfase à fase de planejamento;

(16) a fase de planejamento tem as seguintes características:

* o tema e os assuntos a serem desenvolvidos em aulas práticas são definidos pelos alunos, sob a orientação e supervisão do professor;

* os alunos e o professor delimitam o problema a ser resolvido, estabelecendo hipóteses; 
* o tema da aula pode ser parte ou estar relacionado com projetos de pós-graduação, com pesquisa, com extensão, com projetos de conclusão de cursos e outros, dentro e fora da instituição;

* o conteúdo relaciona-se com a vida profissional futura dos alunos;

* a elaboração de hipóteses utiliza os conhecimentos de Bioquímica obtidos anteriormente pelos alunos e são complementados por pesquisa bibliográfica, na medida do necessário; as hipóteses elaboradas têm uma fundamentação teórica clara;

* os alunos, sob a orientação do professor, escolhem os experimentos e as técnicas para testar as hipóteses;

* os alunos, sob a orientação do professor, elaboram o protocolo que contém: objetivos, materiais, embasamento teórico, informações sobre as técnicas, roteiro de execução dos experimentos, definição sobre as forma de observação e registro dos resultados e bibliografia;

* os alunos montam os experimentos, com assessoria do professor e/ou técnicos e/ou auxiliares;

(17) a proporção orientador : aluno é grande;

(18) os alunos têm bom treinamento técnico e conhecem as principais técnicas de pesquisa laboratorial de Bioquímica;

(19) os alunos dominam as habilidades mentais de análise, interpretação, síntese, compreensão, capacidade de expressar-se por escrito e oralmente; (20) há técnicos e auxiliares para preparo e teste dos experimentos, disponíveis durante o projeto;

(21) todas as fases de aprendizagem da utilização do método científico, com exceção da experimentação, podem ser substituídas, no lugar de aulas práticas, por exercícios feitos a partir de problemas colocados pelo professor; a fase de experimentação pode, em parte, ser substituída por simulação em computador;

(22) os alunos utilizam os equipamentos e aparelhos sozinhos, apenas com supervisão do professor, auxiliar ou técnico;

(23) há preocupação com precisão e sensibilidade; 
(24) há preocupação com descarte de materiais, consciência ecológica e impacto da experimentação sobre a saúde dos participantes e sobre o meio ambiente;

(25) há preocupação com custo/benefício da aula e sua utilidade para a profissionalização e autogerenciamento da atualização e da especialização dos alunos;

(26) os grupos não são grandes em relação às necessidades dos experimentos, de forma que há divisão de tarefas de forma eqüitativa para todos os alunos;

(27) todos os alunos participam de todas as atividades manuais e intelectuais;

(28) o processamento dos dados é feita pelos alunos, sob a supervisão do professor;

(29) cada fase do processo é interrompida quando surgem impedimentos, novas atividades de discussão, consulta à literatura, observação, coleta de dados e planejamento são feitas, para depois retornar ao programa inicialmente proposto;

(30) os horários devem ser flexíveis, com disponibilidade tanto dos alunos como dos professores, dentro de uma certa carga horária;

(31) a estratégia de ensino garante que os alunos mantenham-se interessados, envolvidos, comprometidos e, se possivel, animados;

(32) o professor é comprometido e sua intencionalidade é dirigida para alcançar a autonomia dos alunos;

(33) a discussão inclui:

* apresentação escrita, visual e oral dos dados de todos os grupos, em conjunto;

* análise e crítica da confiabilidade e da validez dos resultados, do grau de previsão e do índice de erros dos valores obtidos;

* interpretação dos resultados;

* estabelecimento de conclusões e de generalizações;

* inserção dos dados obtidos num contexto mais amplo; 
* visão das perspectivas de aplicação do produto do trabalho realizado, proposição de novos experimentos e levantamento de novos problemas;

(34) relato dos trabalhos na forma de um artigo científico e sua possivel publicação.

\section{B. 2c. Função do treinamento de habilidades técnicas experimentais}

Habilidades técnicas são aquelas que se referem ao uso dos sentidos e das mãos, incluindo:

- ensinar como observar;

- treinar manuseio de material de laboratório e de reagentes;

- treinar uso de equipamentos e aparelhos;

- treinar manipulação de material biológico;

- treinar técnicas de pesquisa laboratorial.

A aula prática que tem como função treinar habilidades técnicas laboratoriais apresenta as seguintes características:

(1) o laboratório didático tem as condições descritas no item (3) da página 106;

(2) a dinâmica da aula tem maior tempo dedicado à execução dos experimentos, em detrimento de planejamento inicial e de discussão que, eventualmente, podem ser feitos em outro momento e local;

(3) a proporção orientador : aluno é grande;

(4) os alunos conhecem os princípios que fundamentam as técnicas que serão utilizadas na aula;

(5) o preparo e o teste das aulas práticas são acurados e são feitos com participação, orientação e/ou supervisão do professor;

(6) as normas básicas de segurança são treinadas e distribuídas por escrito aos alunos, em algum momento do curso que precede as aulas práticas aqui em questão;

(7) as técnicas de aula escolhidas são relevantes para a futura profissão do aluno;

(8) os assuntos escolhidos e os experimentos são simples, para que o aluno possa concentrar-se no desenvolvimento das habilidades técnicas; 
(9) a aula não pode ser substituída por outra atividade didática com os mesmos objetivos;

(10) o protocolo é impresso e cada aluno tem o seu; apresenta claramente o objetivo de treinamento técnico, lista de materiais e reagentes, detalhamento da experimentação, reforço das regras de segurança e higiene pertinentes à aula e bibliografia específica sobre as técnicas utilizadas;

(11) o protocolo deve ser lido e interpretado por todos os alunos, sob a orientação do professor;

(12) os dados a serem obtidos são conhecidos previamente;

(13) os alunos dominam técnicas básicas de trabalho laboratorial de Química, que são treinadas no ensino médio ou em aulas introdutórias de cursos que têm disciplinas com conteúdo de Química (Ex: usar vidraria volumétrica, balança, banho-maria, bico de Bunsen etc); as habilidades mentais necessárias são as de interpretação da linguagem escrita e capacidade de seguir instruções escritas e orais;

(14) os alunos montam e executam os experimentos seguindo o roteiro e manipulando pessoalmente os aparelhos e equipamentos, com a orientação e supervisão do professor, técnico e auxiliares;

(15) todos os alunos do grupo executam todas as tarefas, fazendo rodízio entre si;

(16) os grupos não são pequenos demais, o que dificultaria a distribuição de tarefas que devem ser executadas simultaneamente, nem grandes demais, $\mathrm{o}$ que impediria que todos participassem igualmente;

(17) há preocupação com precisão e sensibilidade;

(18) a orientação dos alunos pela equipe é constante; alunos que não apresentam os pré-requisitos técnicos exigidos pela aula recebem atenção especial e são treinados no momento da aula;

(19) há cobrança dos resultados previamente esperados;

(20) a discussão contém análise da precisão e do nível de erro dos dados obtidos e diagnóstico das falhas ocorridas;

(21) o relatório contém detalhamento das técnicas e críticas relativas ao aspecto técnico feitas na discussão; 
(22) a aula pode suscitar trabalhos em que os alunos propõem novos experimentos com as mesmas técnicas ou propõem modificações na técnica padrão, para fins diversos;

(23) a avaliação é feita por prova prática.

\section{B. 2d. Função das interações entre os participantes}

Os motivos que levam os seres humanos a agirem são naturais e sociais. Os primeiros são condicionados por fatores internos ou hereditários e os últimos, por fatores externos ou ambientais, tais como família, ambiente cultural, escola, profissão etc. Em Pedagogia, o ponto de vista do indivíduo é que deve importar. Os dados individuais, pessoais, serão aqueles do educando, pois a educação serve-se das potencialidades presentes no aprendiz. Entre aquelas importantes para aprender, estão os motivos da ação e dos comportamentos ou formas interiores de conduta.

Para detectar as motivações dos alunos, é necessário observar seu comportamento. Entretanto, motivos análogos podem resultar em comportamentos diferentes e vice-versa. As motivações também podem ser detectadas pelas declarações do aluno, mas, como todo discurso, elas podem falsear a verdade ou os motivos não serem explicitados por serem inconscientes (Deldime e Demoulin, 1977).

De acordo com Abreu e Masetto (1990), as aulas são encontros entre professor e alunos em que se estabelece uma situação de ensino com tempo determinado (50 minutos a 4 ou 5 horas), com uma certa freqüência, geralmente semanal, por um certo período de tempo, semestral ou anual; nelas, seres humanos defrontam-se, comunicam-se e influenciam-se mutuamente. A razão central desse encontro é a aprendizagem do aluno, lidando com o conteúdo da disciplina, utilizando recursos que são a estratégia de ensino, avaliação e clima sócio-emocional estabelecido pelas relações professor-aluno e aluno-aluno.

Conforme os autores por último citados, o cerne da aprendizagem, mesmo estando esta limitada pelas condições do contexto, é a interação professor-aluno. Dependendo do rumo que essa relação toma, a aprendizagem pode ser mais ou menos facilitada e orientada para uma ou outra direção. Ao 
professor cabe dar o tom desse relacionamento, o que pode depender da compreensão do desenvolvimento do aluno, da inserção da escola na vida, nos problemas, na realidade da sociedade, na cultura. De qualquer forma, o ensino é sempre uma relação de autoridade-subordinação, no sentido de que o professor é o agente controlador e a educação é sistemática.

$\mathrm{Na}$ visão interdisciplinar e holística que este trabalho defende, a aula universitária e, em particular, a aula prática de Bioquímica, confinada ao laboratório, pressupõe que o professor "está com" o aluno, é parceiro de troca, age por meio de uma ação conjunta do grupo. A aula prática motivadora aqui é vista como um trabalho em equipe que se explicita na aprendizagem do conteúdo experimental da disciplina de Bioquímica, encaixando-se nele a vida, o concreto, o real, as expectativas, os interesses e os problemas dos aprendizes, dentro das especificidades da disciplina. As estratégias têm embutidas a formação do cidadão, do profissional, do pesquisador, favorecendo a iniciativa, a criatividade e a participação no processo. A avaliação visa a todos esses objetivos educacionais e não só aos objetivos cognitivos. Esta concepção acima explanada foi adaptada de publicações de vários autores que abordaram as relações interpessoais em aula, entre eles: Marcos Masetto (1998a e 1998b), Imídio Nérici (1992), Maria Célia Abreu (Abreu e Masetto, 1990), E. J. Wood (1996), Fernando Becker (1999).

As funções das aulas práticas relacionadas com a promoção das relações interpessoais entre os participantes são:

- motivar os alunos;

- melhorar relações entre professor e alunos;

- melhorar relações entre alunos;

- encorajar entusiasmo pela Ciência.

As funções acima apresentam-se no ensino, se houver atendimento aos interesses e expectativas dos alunos, se apresentarem-se oportunidades de contato pessoal do professor com cada aluno, se o que o aluno pensa, faz e diz tem espaço para expressar-se durante a aula, se o aluno puder participar de todas as atividades exercidas dentro da instituição, na área de 
Bioquímica. Tais funções são exercidas pelas aulas práticas de Bioquímica ou facilitadas quando aparecem, no contexto e no ensino, parte ou todos os seguintes elementos:

(1) a instituição possui centro de pós-graduação onde alunos de graduação podem participar de projetos de iniciação científica na área de Bioquímica;

(2) a instituição possui atividades de extensão em que alunos de graduação podem participar de projetos profissionalizantes, na área de Bioquímica;

(3) a instituição possui convênio com empresas ou outras instituições onde alunos de graduação podem fazer estágios na área de Bioquímica;

(4) a instituição possui publicações científicas em que alunos de graduação podem publicar trabalhos de iniciação científica;

(5) a instituição promove congressos, encontros ou similares em que alunos de graduação podem participar na área de Bioquímica;

(6) a instituição possui estrutura que permite aos professores e alunos de graduação a participação em congressos, encontros ou similares, na área de Bioquímica, fora da instituição;

(7) o regime de trabalho dos professores permite atendimento de alunos fora dos horários de aula;

(8) o professor exerce outra atividade profissional na área de Bioquímica, além daquela de ensino, contribuindo, em suas aulas, com experiência nessa atividade;

(9) o(s) professor(es) de aulas práticas é(são) o(s) mesmo(s) que de outras atividades;

(10) professor conta com bons apoios técnico e didático que permitem que as aulas práticas não tenham limitações de ordens material, organizacional e de funcionamento;

(11) a ênfase e as atividades profissionais para as quais o curso em questão habilita são de natureza bioquímica ou estão estreitamente ligadas a ela;

(12) a porcentagem da programação desenvolvida em aula prática é grande, pelo menos próxima de $50 \%$; a proporção entre aulas práticas e outras atividades é maior ou igual 1:1; 
(13) a disciplina tem o perfil dos alunos ingressantes ou faz diagnóstico das expectativas e interesses deles com relação à disciplina de Bioquímica; (14) o laboratório é bem equipado e tem, pelo menos, as condições de trabalho descritas no item (3) da página 106;

(15) os assuntos desenvolvidos em aulas práticas relacionam-se com os interesses dos alunos, especialmente na área profissional, são integrados com outras disciplinas;

(16) a dinâmica das aulas reserva tempo para planejamento inicial e discussão;

(17) a proporção orientador: aluno é grande;

(18) cada aluno tem condição de participar de todas as etapas da aula, mesmo trabalhando em grupo;

(19) a aula prática é integrada com outras atividades do mesmo assunto, como aulas teóricas, exercícios de fixação, simulação de computador, consulta à literatura científica;

(20) a aula parte de um problema ou há perguntas para serem resolvidas com os resultados experimentais obtidos;

(21) o protocolo é montado a partir do planejamento conjunto entre professores e alunos;

(22) os alunos têm autonomia na execução dos experimentos, como descrito no item II. B. 2b (Função de desenvolver autonomia na execução de experimentos, p. 106);

(23) os alunos têm conhecimento dos princípios e conceitos utilizados pela aula e as habilidades técnicas necessárias para desenvolvê-las;

(24) os alunos dominam as capacidades de observação e registro dos resultados ou são treinados para tal;

(25) a discussão inicia-se com os resultados de todos os grupos; o tratamento e a interpretação dos dados e a elaboração de conclusões são feitos em conjunto, com toda a classe, sob a orientação dos professor;

(26) há possibilidade de fazer novos experimentos ou repetir experimentos, se necessário; 
(27) o professor deve ser comprometido e ter intencionalidade de promover relações interpessoais em sua aula;

(28) a aula prática não se encerra em si mesma, tem continuidade em outras atividades.

\section{B. 3. Papéis das aulas práticas no ensino de Bioquímica}

As aulas práticas podem exercer, basicamente, os seguintes papéis no ensino de qualquer disciplina:

- reproduzir conhecimento;

- construir conhecimento;

- fazer crítica a conhecimentos novos ou estabelecidos e aceitos.

II. B. 3a. Papel de reprodução de conhecimento

As aulas práticas exercem o papel de reprodução de conhecimento quando elas têm uma ou mais das seguintes funções:

(1) ilustrar fatos e fenômenos;

(2) ampliar o conteúdo de aulas teóricas;

(3) aplicar teoria, lei, princípio ensinados em aulas teóricas;

(4) compreender conceitos;

(5) divulgar conhecimento cientifico;

(6) ensinar como seguir protocolo;

(7) ensinar como registrar dados;

(8) ensinar como processar dados;

(9) ensinar como organizar informações;

(10) ensinar como ordenar e expressar idéias;

(11) ensinar como apresentar dados, resultados e conclusões;

(12) ensinar como fazer relatório escrito;

(13) ensinar como comunicar resultados oralmente;

(14) ensinar como fazer redação científica;

(15) ensinar como consultar literatura;

(16) ensinar como observar;

(17) treinar manuseio de material de laboratório e reagentes;

(18) treinar uso de equipamentos e aparelhos; 
(19) treinar manipulação de material biológico;

(20) treinar técnicas de pesquisa laboratorial.

II. B. 3b. Papel de construção de conhecimento

As funções das aulas práticas que permitem a construção de conhecimento englobam aquelas que desenvolvem habilidades de observação, análise, interpretação e discussão de dados obtidos por meio de experimentação, de sintese e de generalização. Essas funções são:

(1) construir conceitos;

(2) ensinar como observar;

(3) ensinar como analisar, interpretar e sintetizar dados experimentais;

(4) ensinar como fazer conclusões;

(5) desenvolver autonomia na execução de experimentos;

(6) ensinar como propor hipóteses;

(7) ensinar como testar hipóteses;

(8) ensinar como montar experimentos;

(9) ensinar como validar ensaios;

(10) ensinar como escrever protocolos;

(11) ensinar como pensar novos experimentos.

\section{B. 3c. Papel de crítica a conhecimento}

Para que aulas práticas exerçam o papel de crítica a conhecimento estabelecido, quer ele se expresse por meio de uma metodologia, quer por meio de um conceito, elas precisam utilizar habilidades de crítica e capacidade de expressão oral e escrita, além de permitirem liberdade intelectual, expressa pelo pensamento independente, e autonomia na realização de trabalho laboratorial.

Crítica é a faculdade de examinar e/ou julgar, dar um valor. Para exercê-la, é necessário ter discernimento e estabelecer critérios de valoração; isto implica uma tomada de decisão (Severino, 1996). A crítica aparece toda vez que um conhecimento é legitimado pela sua aplicação, com resultados que obtêm aprovação da maioria.

Todo homem, durante sua existência, absorve um acervo de informações mais ou menos organizadas pela sua vivência e experiência 
pessoal, apropria-se de conceitos, de soluções, de normas práticas de conduta, ditadas pela sociedade, pela cultura, pela educação e pela religião. Porém, por mais consenso que haja entre seus pares, ele questiona, julga a validade de suas ações e de seus pensamentos e aqueles de seus semelhantes. Essa busca séria da verdade é o espírito crítico, que inclui a ponderação de razões, a busca de motivos (Ruiz, 1986).

Para a Ciência, a crítica não leva a nada, se não for acompanhada de criação de novo conhecimento para completar, ampliar ou substituir aquele que foi julgado parcial ou totalmente inadequado, no sentido de cumprir seu papel no mundo físico e mental. Portanto, aulas práticas que exercem o papel de crítica a conhecimento fatalmente resultam em aulas que promovem a construção de conhecimento novo. 


\title{
III. UM EXEMPLO DE APLICAÇÃO DO MODELO DE ANÁLISE DO PAPEL DAS AULAS PRÁTICAS NO ENSINO DE BIOQUÍMICA
}

\author{
SUMÁRIO
}

III. A. Resultados da aplicação dos instrumentos de coleta de dados em seis contextos diferentes

III. A. 1. Caracterização dos contextos

Tabela II - Características das instituiçōes analisadas

Tabela III - Características dos cursos analisados

Tabela IV - Características das disciplinas com conteúdo de Bioquímica analisadas

Tabela V - Características dos laboratórios didáticos observados

Tabela VI - Respostas das perguntas do questionánio endereçado a alunos das disciplinas analisadas

Tabela VII - Respostas das perguntas do questionánio endereçado a professores de Bioquímica dos cursos analisados

Tabela VIII - Respostas das perguntas do questionário endereçado a professores: Opinióes quanto à consecução dos objetivos de suas aulas práticas

III. A. 2. Análise das aulas práticas observadas

Tabela IX - Dados gerais e características das aulas práticas observadas

Tabela X - Características e conteúdo dos protocolos das aulas práticas observadas

Tabela XI - Etapas e estratégias de ensino das aulas práticas observadas

Tabela XII - Características dos relatórios das aulas práticas observadas

III. B. Análise comparativa dos seis contextos observados

III. B. 1. Comparação entre as características gerais das instituições analisadas

III. B. 2. Comparação entre cursos semelhantes, ministrados em instituições privadas e públicas

Tabela XIII - Grades curriculares dos cursos de Ciências Biológicas analisados

Tabela XIV - Grades curriculares dos cursos de Nutrição analisados

III. B. 3. Adequação das programações das disciplinas com conteúdo de Bioquímica analisadas, em relação ao enfoque dos cursos em que estão inseridas

Tabela XV - Resumo comparativo das programações das disciplinas com conteúdo de Bioquímica analisadas

III. B. 4. Comparação entre os laboratórios didáticos das instituições analisadas

III. B. 5. Análise das opiniões e do comportamento dos atores do processo ensino-aprendizagem nos contextos analisados

III. C. Funçőes e papéis das aulas práticas nos seis contextos analisados

Para o pré-teste dos instrumentos de coleta de dados, eles foram aplicados em seis contextos diferentes, cujas características estão descritas no capítulo de "Metodologia" (Tabela I, p. 30).

A partir dos resultados apresentados abaixo, os instrumentos de coleta de dados foram ampliados ou modificados, de acordo com as necessidades constatadas na prática de sua aplicação. Por essa razão, nem todas as partes dos instrumentos, apresentados no item I.B (p. 56-80) do presente capítulo, foram observados nesses contextos. Por outro lado, uma vez que esta pesquisa não visa a avaliar o ensino dos professores ou das instituições que se propuseram a colaborar, também houve algumas omissões de informação propositais, por iniciativa da autora ou a pedido dos participantes, devido a 
questões éticas ou pelo fato de que certos dados, de alguma forma, poderiam comprometer a pessoa ou a posição profissional dos informantes e dos observados ou ferir as imagens das instituições.

Os questionários endereçados a alunos foram distribuidos aleatoriamente para 10 alunos, desde que eles estivessem concordes. Em alguns casos, todos os alunos que se propuseram a responder devolveram o questionário, em outros, alguns não devolveram os questionários e não foram interrogados sobre isso, deixando-os à vontade. Houve casos em que alunos pediram para responder o questionário, mesmo não sendo solicitados, o que fez 0 número de entrevistados ser maior que 10 . $\boldsymbol{A}$ amostragem foi pequena $e$ não teve significância como pesquisa quantitativa, servindo apenas para coletar opiniões e sentimentos variados. As respostas foram agrupadas em categorias, sem detalhes de seus conteúdos, os quais, se houver interesse ou necessidade, podem ser obtidos nos Apêndices de 1 a 7 .

Todos os professores que ministravam as aulas práticas observadas responderam o questionário. Nesse caso, foram aqui relatadas só as respostas dadas, não sendo comentadas as faltas de resposta e somente assinalados os casos em que as perguntas ainda não haviam sido colocadas no questionário, por ocasião da pesquisa.

III. A. Resultados da aplicação dos instrumentos de coleta de dados em seis contextos diferentes

Os resultados da pesquisa de campo realizada em seis contextos diferentes são o produto da utilização dos instrumentos de coleta de dados elaborados para a construção do Modelo de Análise do Papel de Aulas Práticas no.Ensino de Bioquímica. Para facilitar o entendimento da análise comparativa entre os contextos observados, os resultados foram organizados em tabelas apresentadas a seguir e seu detalhamento foi feito em apêndices e anexos. 


\section{A. 1. Caracterização dos contextos}

As Tabelas II, III e IV apresentam, respectivamente, as caracteristicas das instituições, dos cursos e das disciplinas analisados.

A Tabela $V$ apresenta as características dos laboratórios didáticos onde as aulas práticas observadas se realizaram.

As respostas do questionário endereçado aos alunos estão resumidas na Tabela VI e as do endereçado aos professores, nas Tabelas VII e VIII.

\section{A. 2. Análise das aulas práticas observadas}

Os dados gerais e as características das aulas práticas observadas são mostrados na Tabela IX.

A Tabela X contém características do protocolo (roteiros) das aulas práticas analisadas.

As etapas e as estratégias de ensino adotadas nas aulas práticas pesquisadas são apresentadas na Tabela XI.

A Tabela XII contém as características dos relatórios das aulas práticas observadas. 


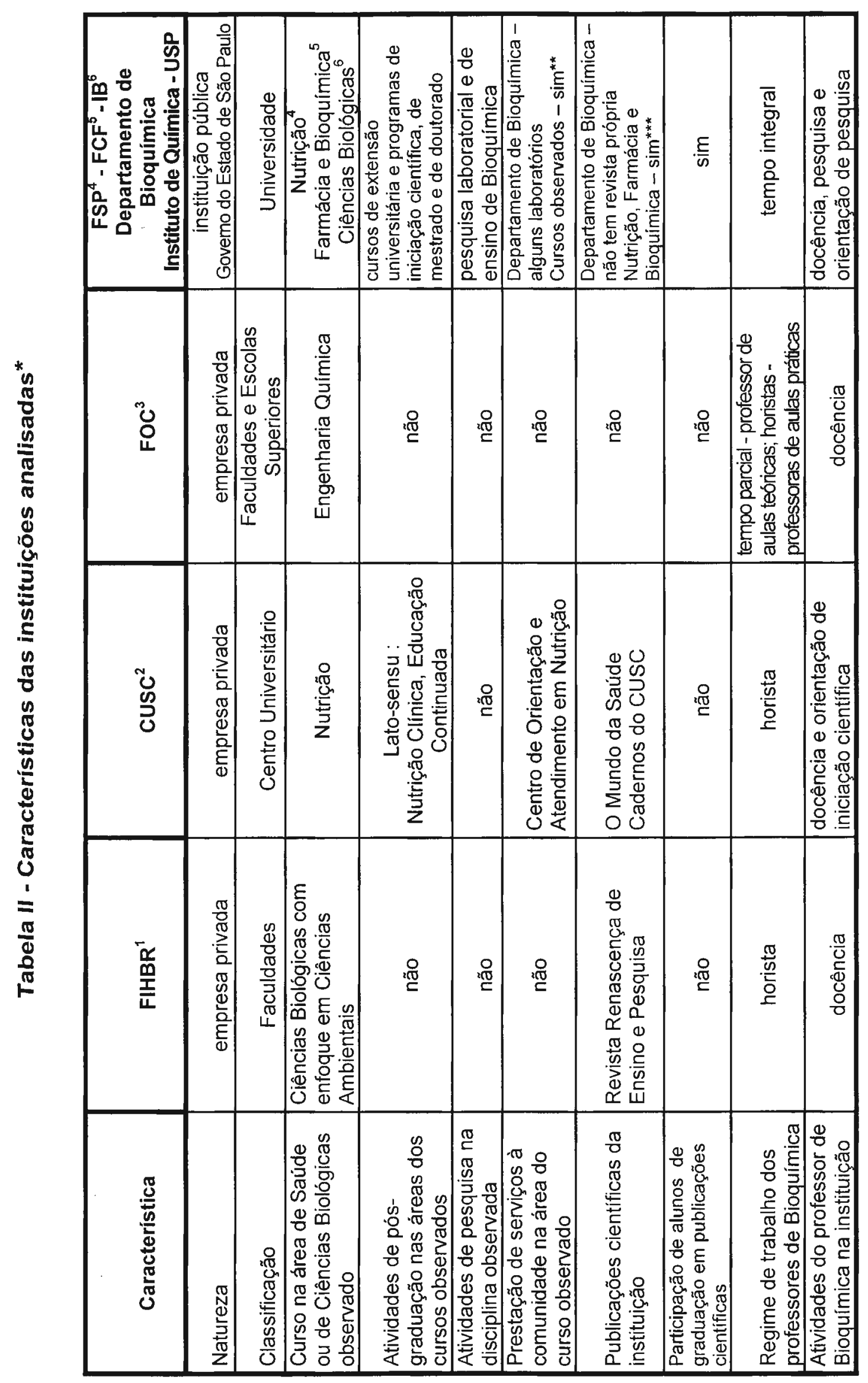



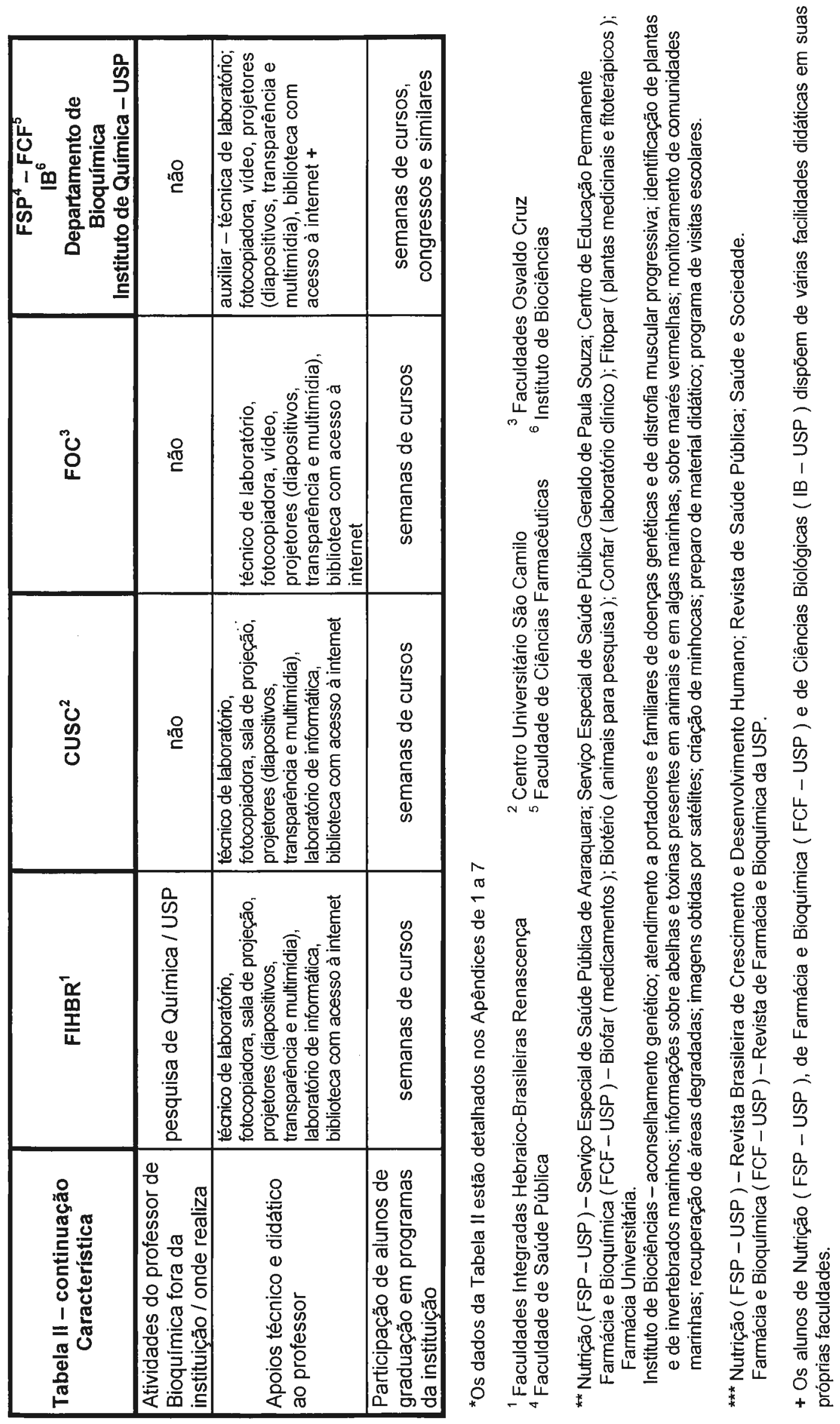


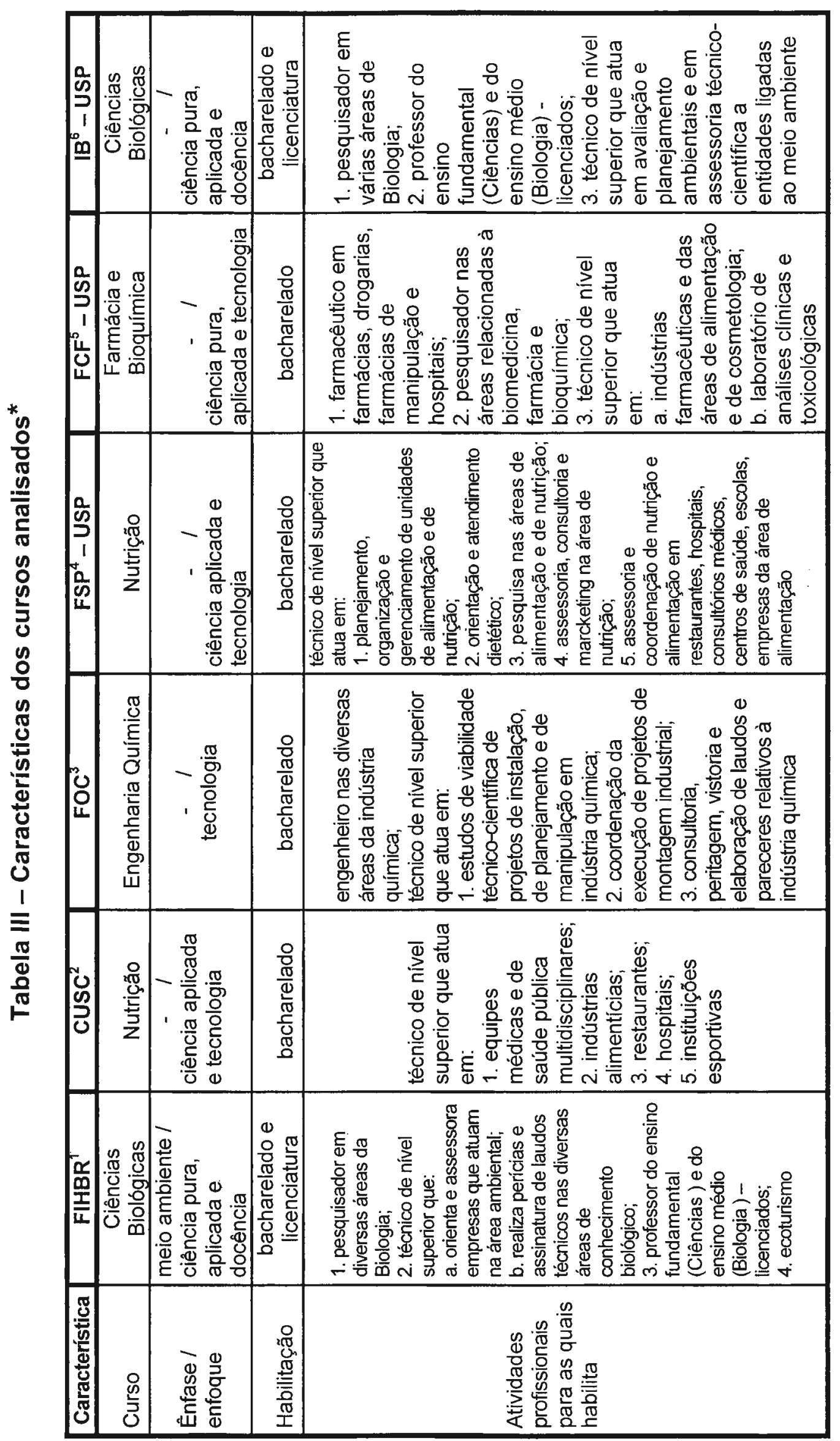



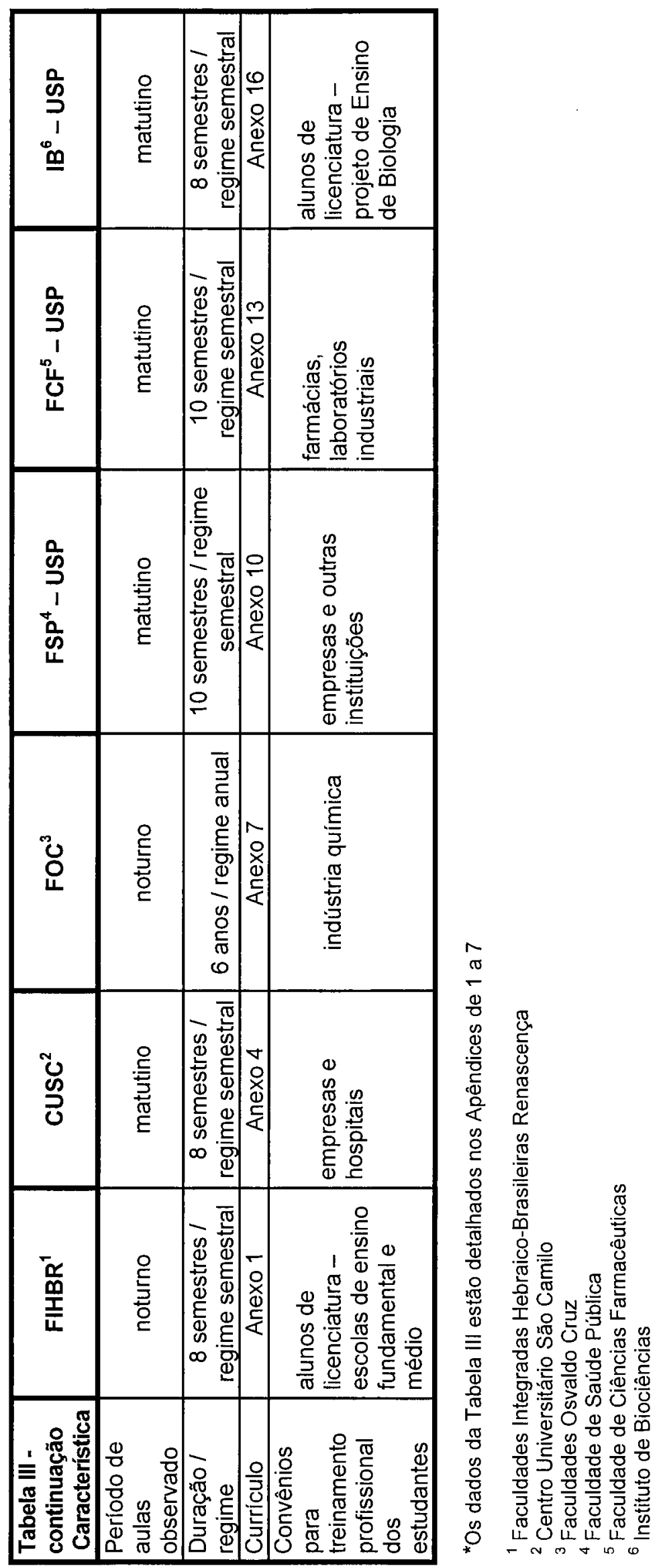


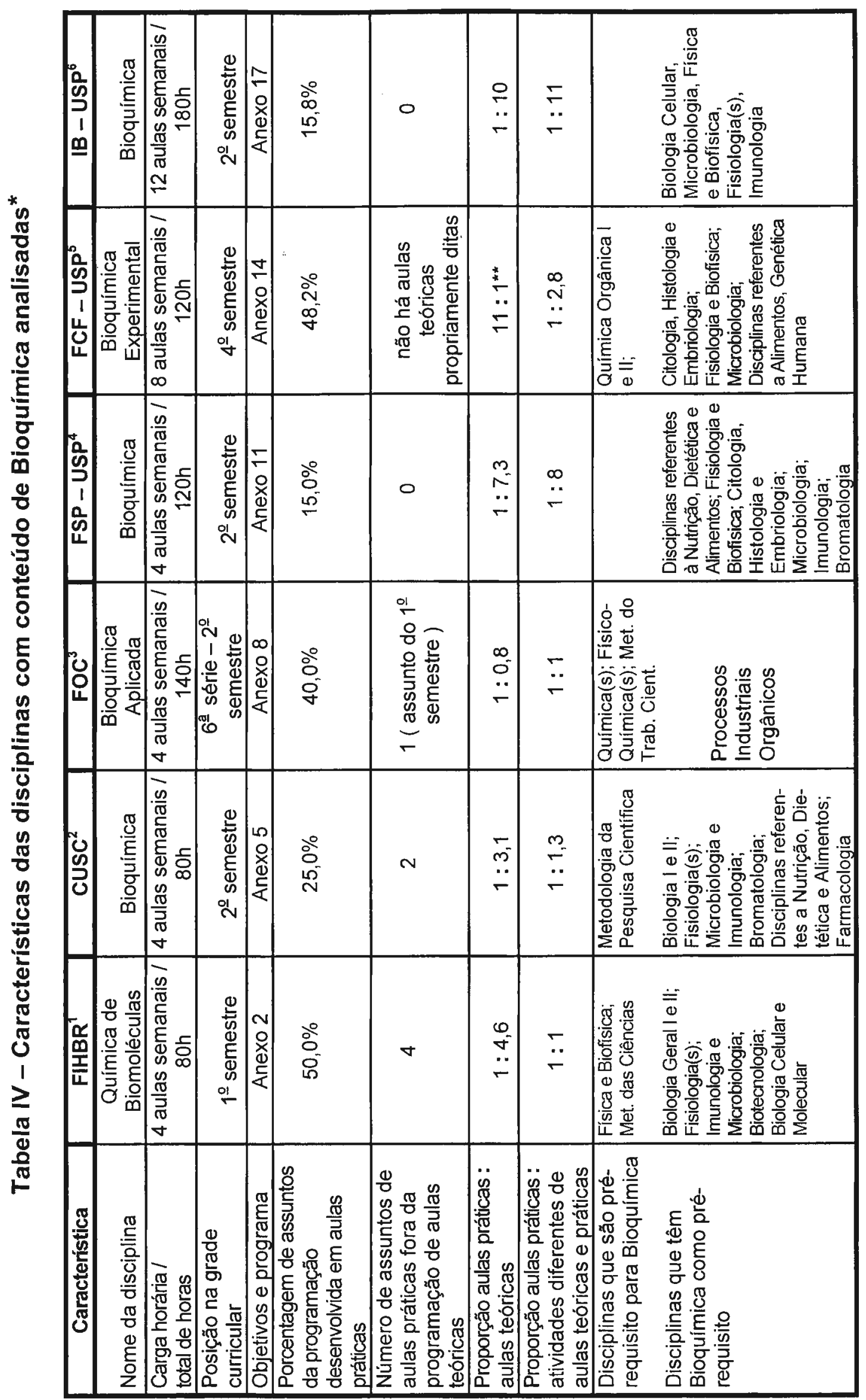




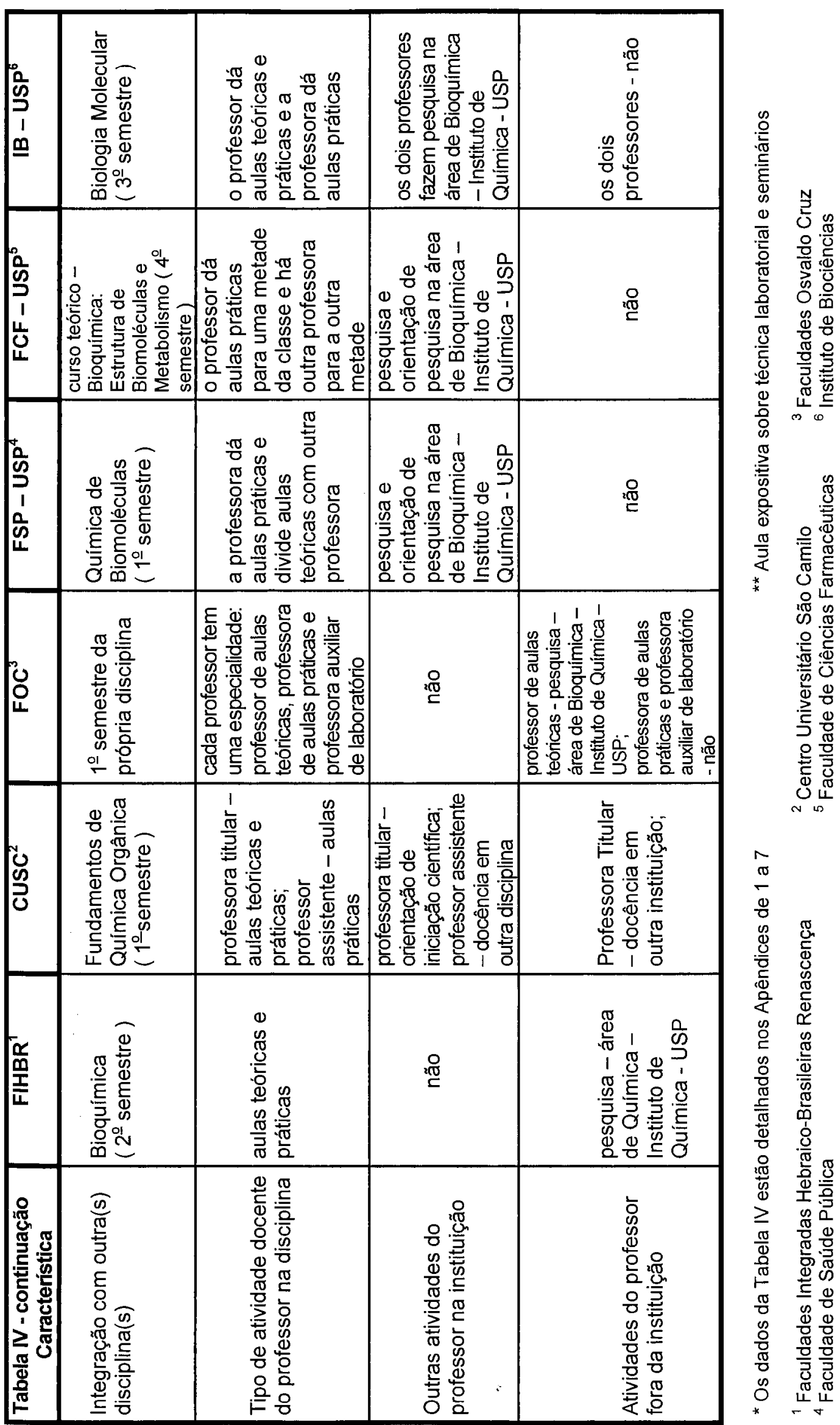




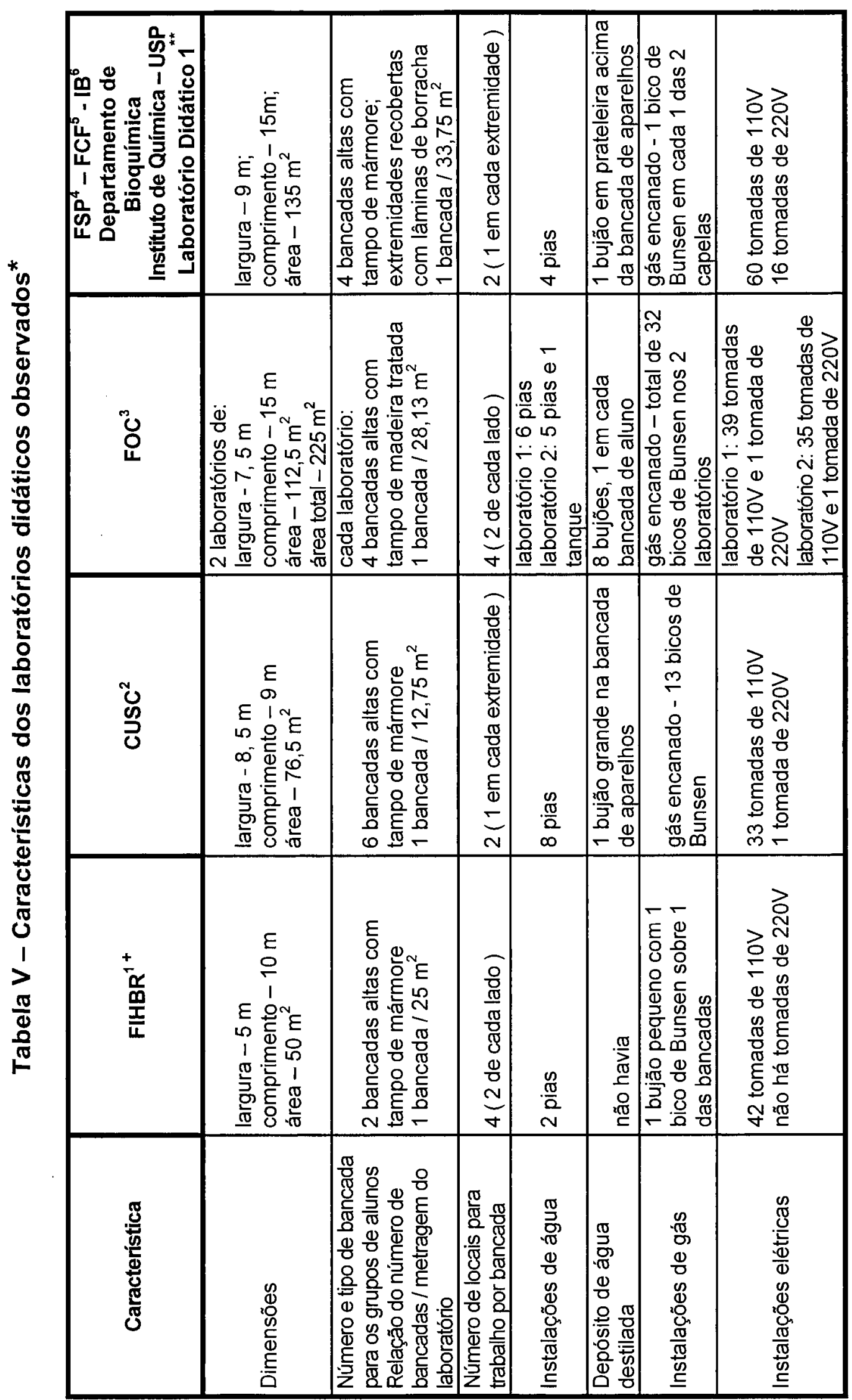




\begin{tabular}{|c|c|c|c|c|c|c|c|c|}
\hline 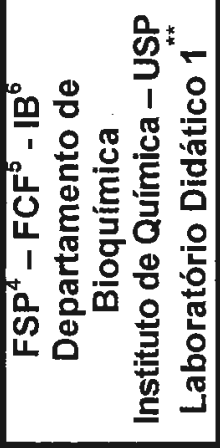 & 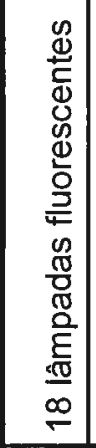 & 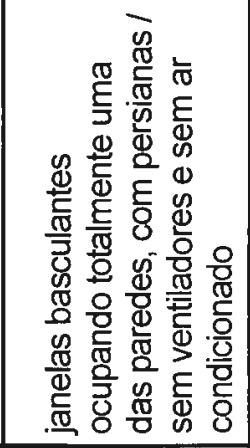 & 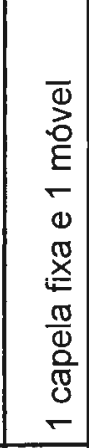 & 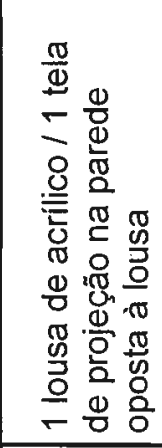 & 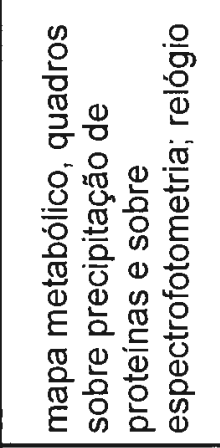 & 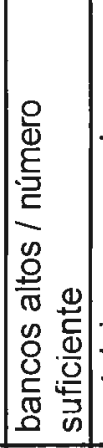 & 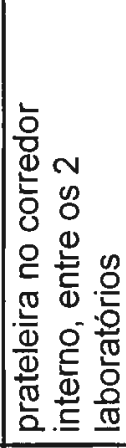 & 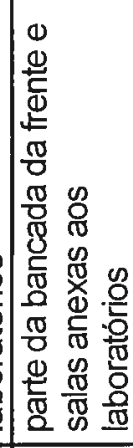 \\
\hline ”인 & 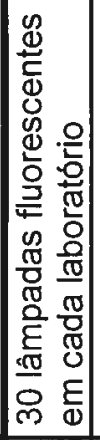 & 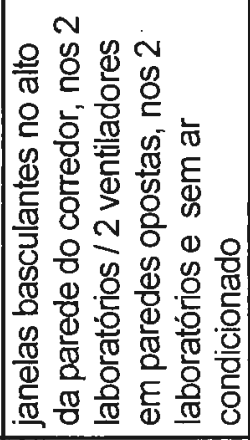 & 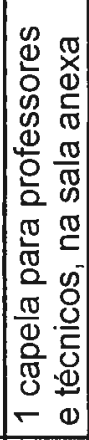 & 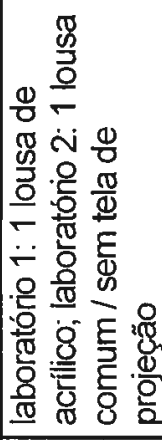 & 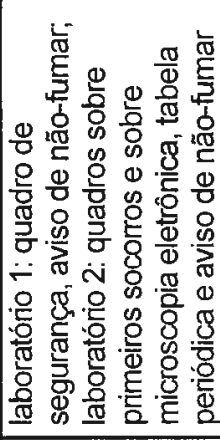 & 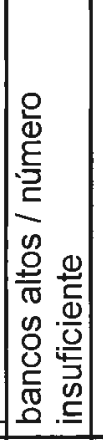 & 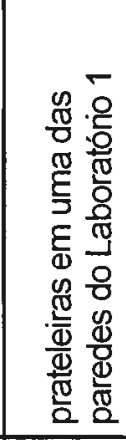 & 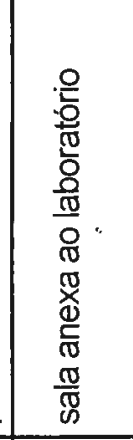 \\
\hline 导 & 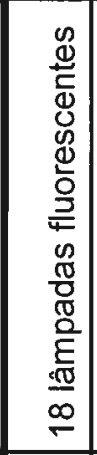 & 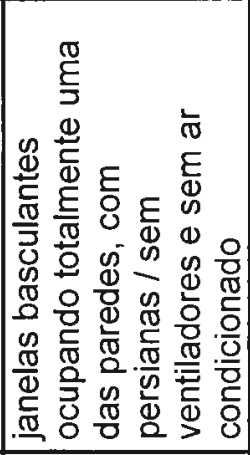 & 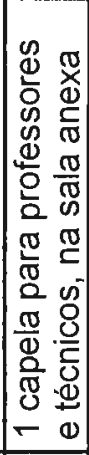 & 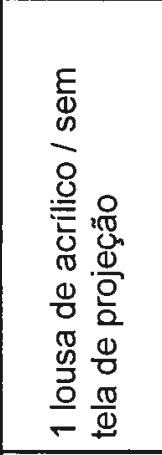 & 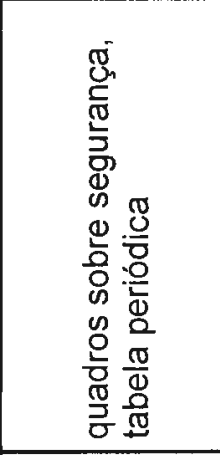 & 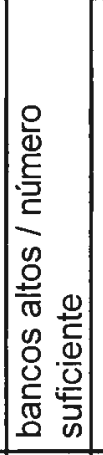 & 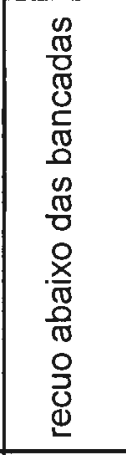 & 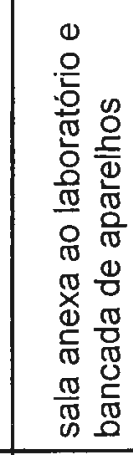 \\
\hline $\begin{array}{l}+ \\
\bar{\alpha} \\
\underline{\underline{\alpha}} \\
\underline{\bar{x}}\end{array}$ & 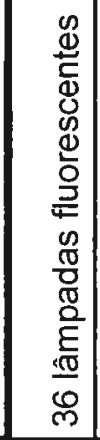 & 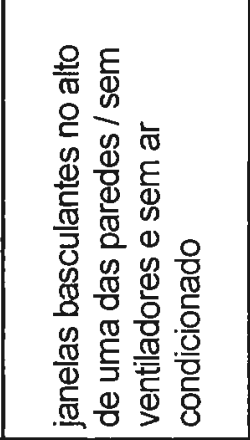 & 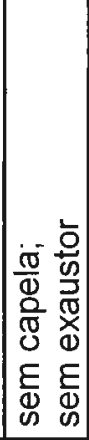 & 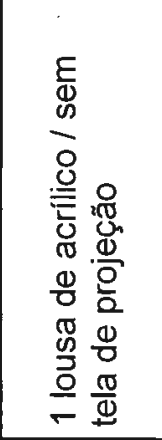 & 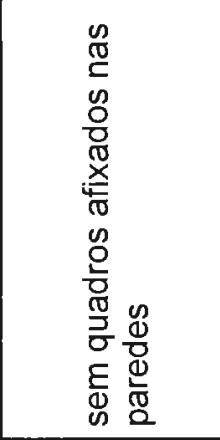 & 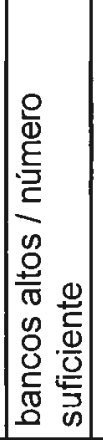 & 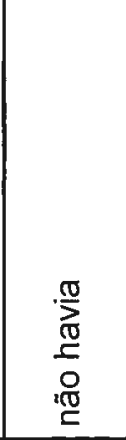 & 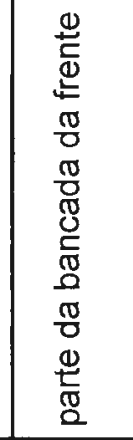 \\
\hline 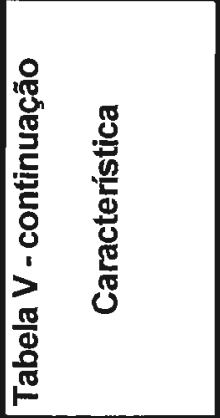 & 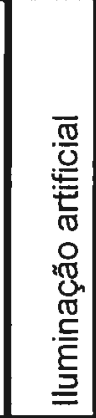 & 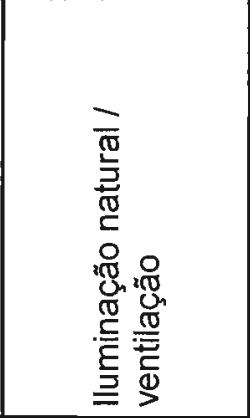 & 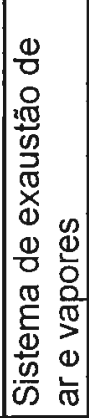 & 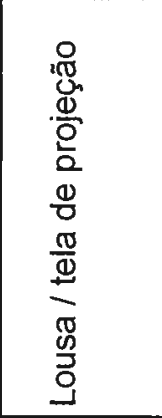 & 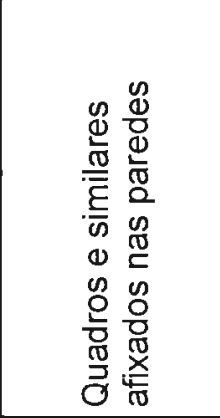 & 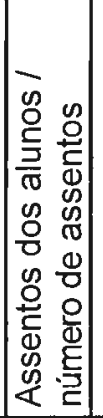 & 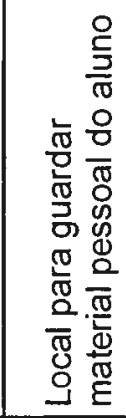 & 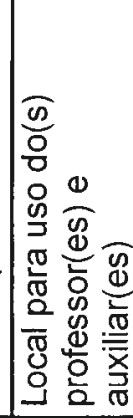 \\
\hline
\end{tabular}




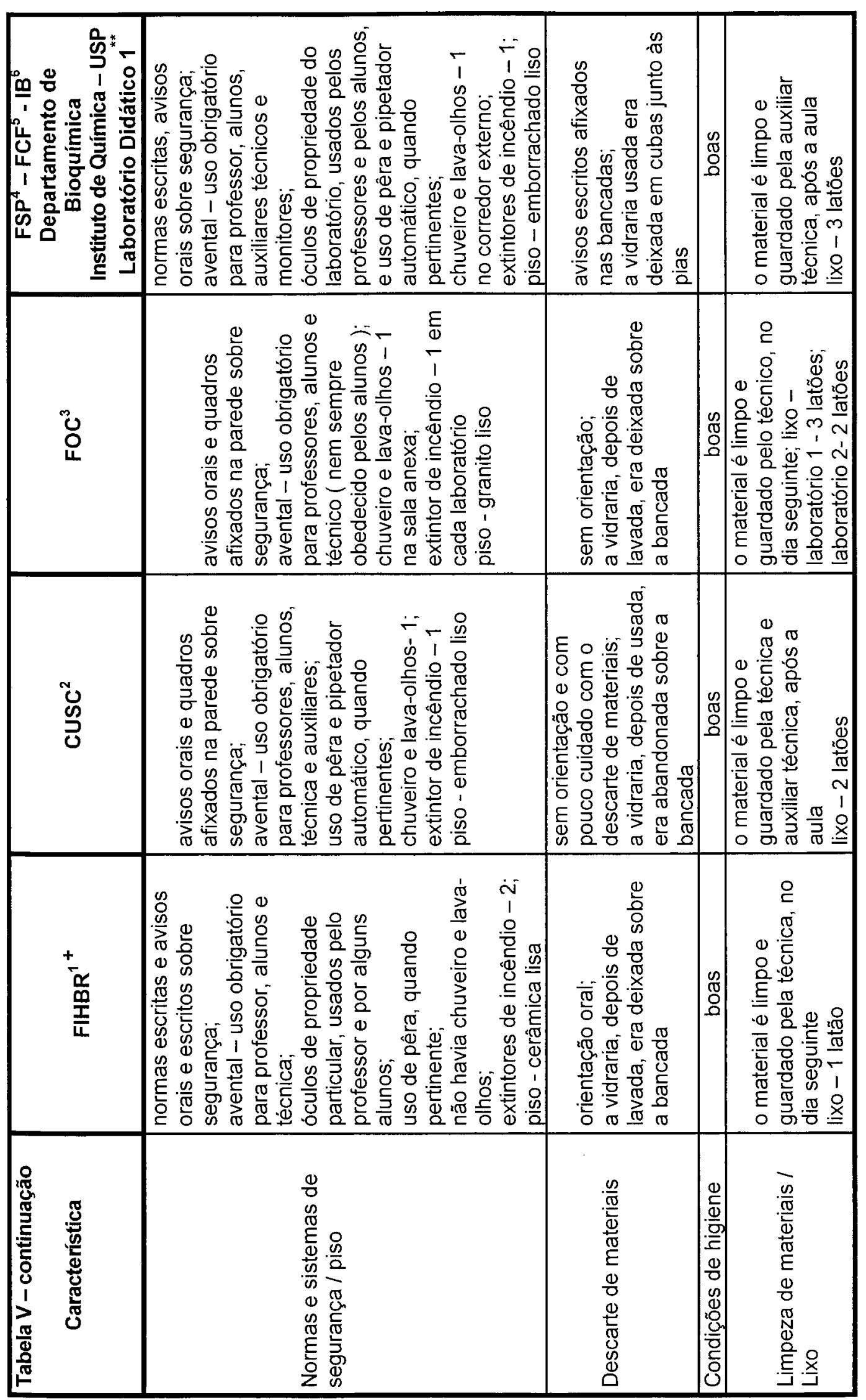




\begin{tabular}{|c|c|c|c|c|c|c|c|}
\hline 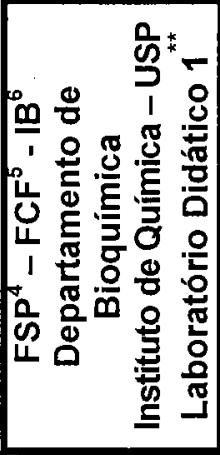 & 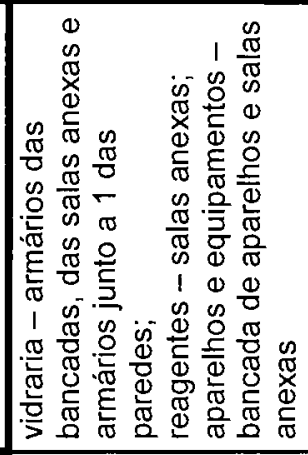 & 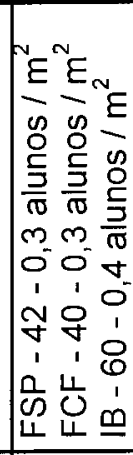 & 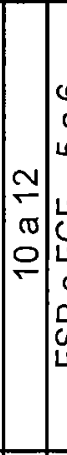 & $\begin{array}{ll}0 & 0 \\
0 & \\
0 & 0 \\
1 & 0 \\
1 & 0 \\
0 & 8 \\
0 & 1 \\
1 & 1 \\
0 & 0 \\
0 & \\
0 & \end{array}$ & 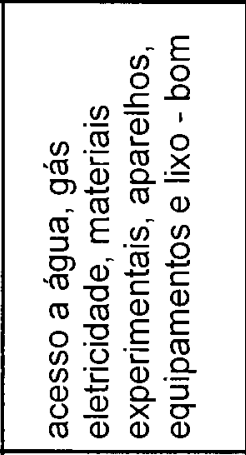 & $\begin{array}{l}\mathscr{0} \\
\mathbb{0} \\
8 \\
8\end{array}$ & 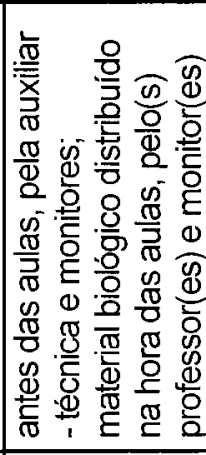 \\
\hline 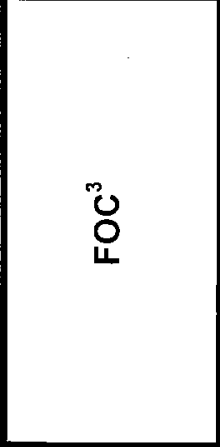 & 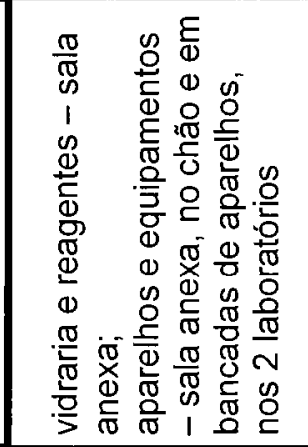 & 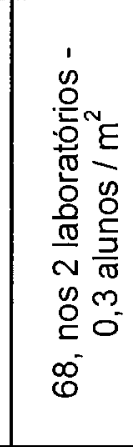 & $\left|\begin{array}{l}\approx \\
\hdashline \\
0 \\
0\end{array}\right|$ & $\begin{array}{l}0 \\
\sigma \\
m\end{array}$ & 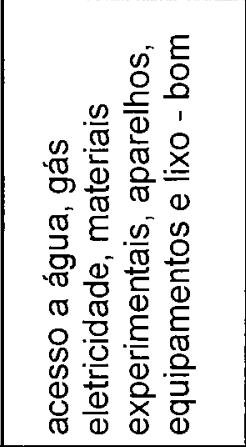 & 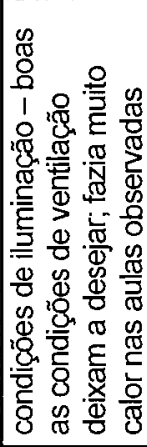 & 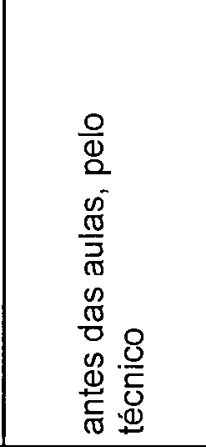 \\
\hline 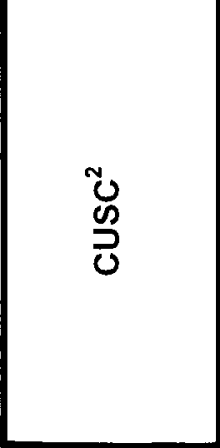 & 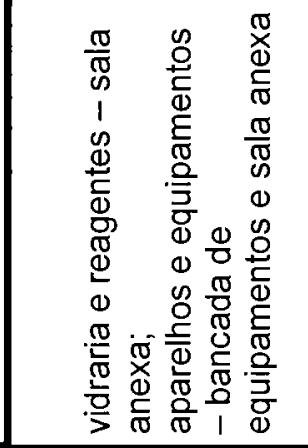 & $\begin{array}{l}\frac{N}{E} \\
0 \\
\frac{5}{5} \\
\frac{D}{\sigma} \\
0 \\
5- \\
1 \\
0 \\
0\end{array}$ & $\left|\begin{array}{l}y \\
\tilde{x} \\
0 \\
0\end{array}\right|$ & $\begin{array}{l}0 \\
\pi \\
0 \\
0\end{array}$ & 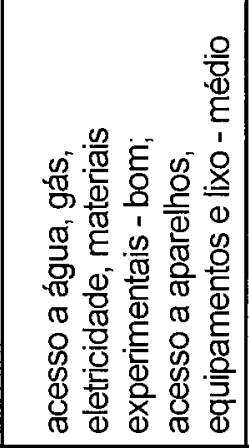 & $\begin{array}{l}\text { 足 } \\
\stackrel{0}{8} \\
8\end{array}$ & 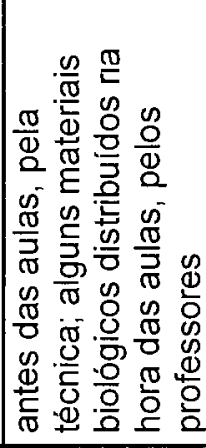 \\
\hline 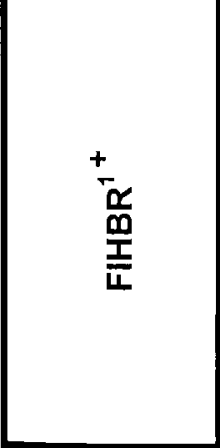 & 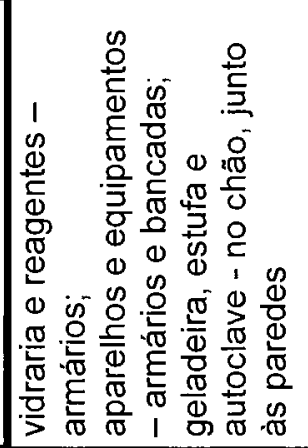 & 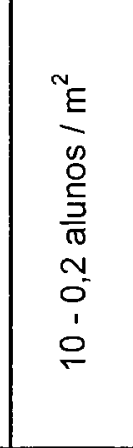 & $\left|\begin{array}{l}0 \\
\pi \\
\nabla\end{array}\right|$ & $\begin{array}{l}m \\
\sigma \\
\sim\end{array}$ & 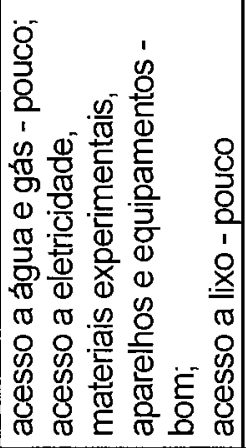 & $\begin{array}{l}\mathscr{0} \\
\mathbb{8} \\
8\end{array}$ & 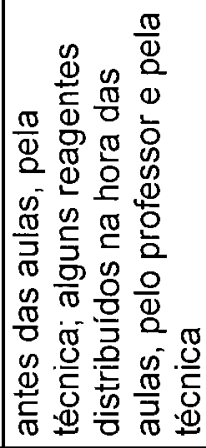 \\
\hline 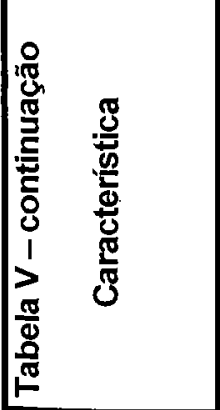 & 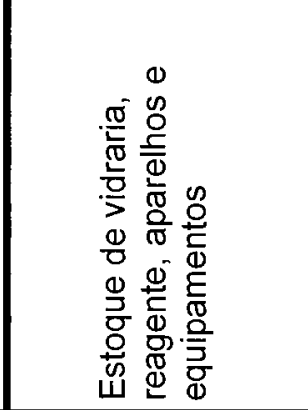 & 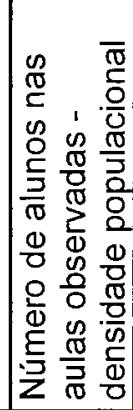 & & 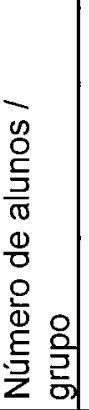 & 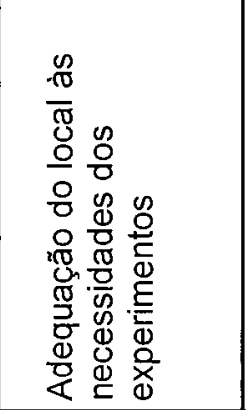 & 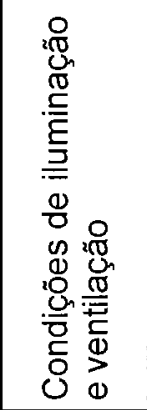 & 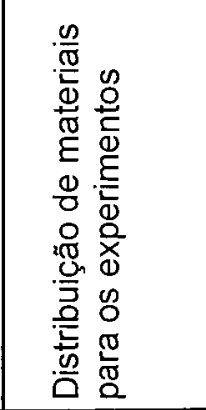 \\
\hline
\end{tabular}




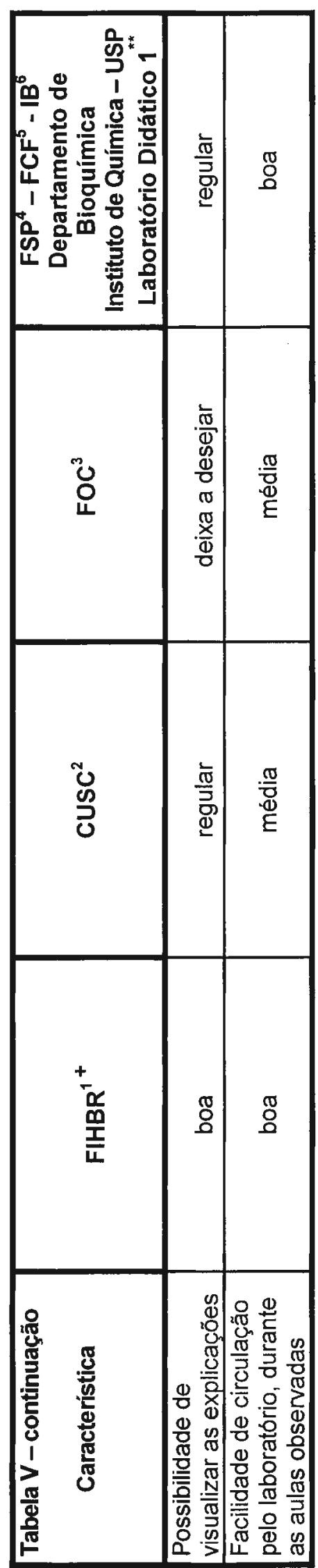

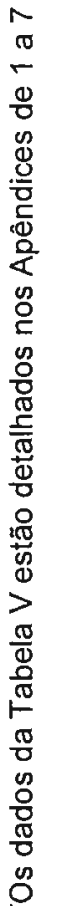
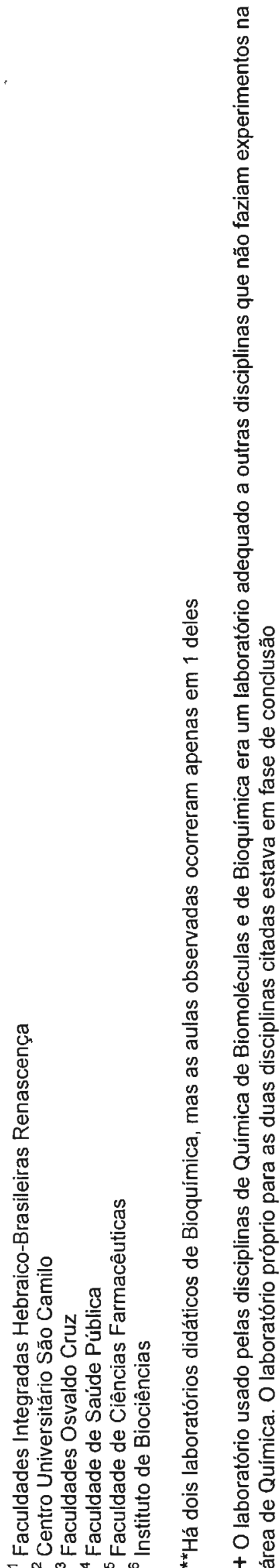


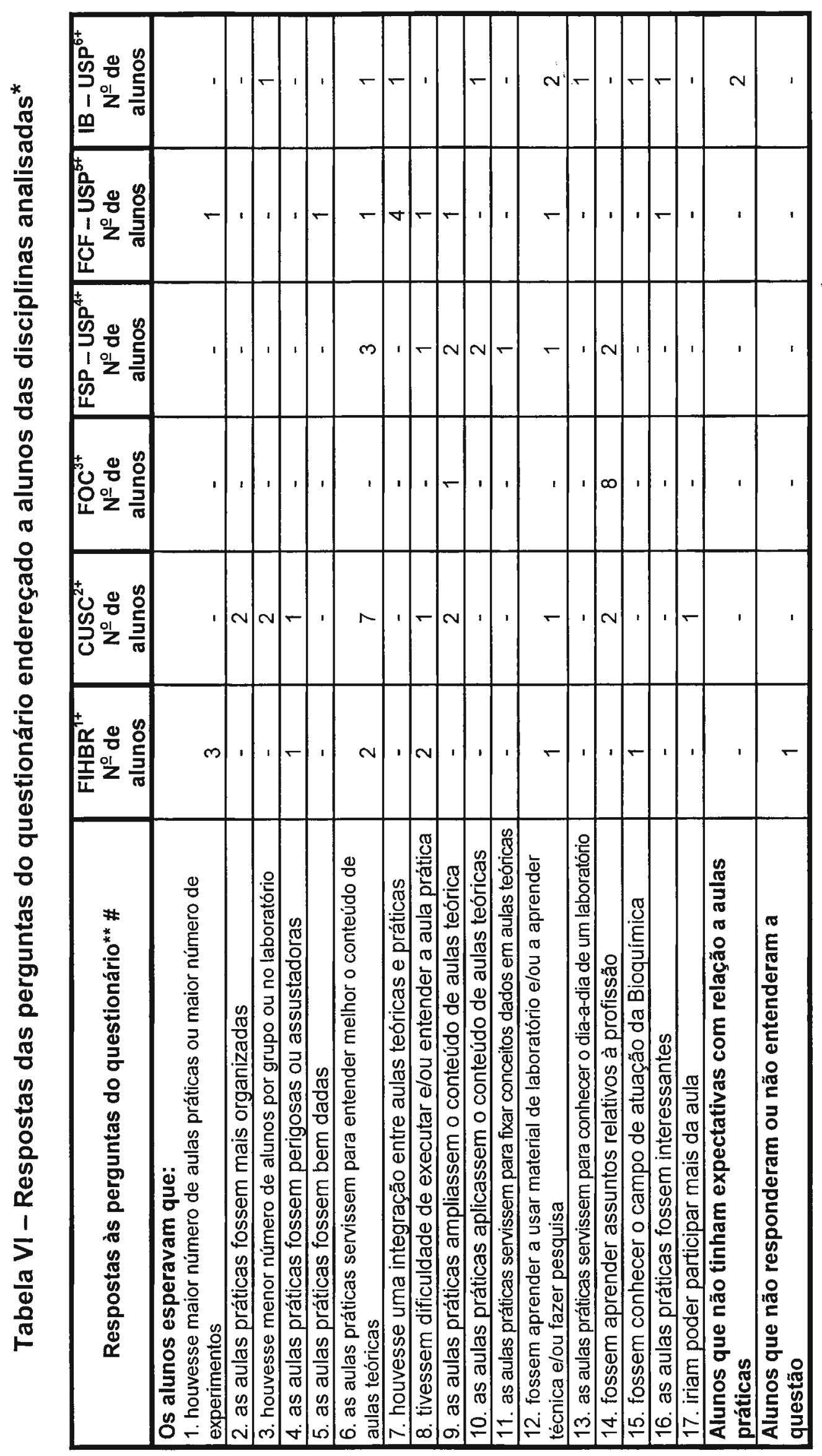




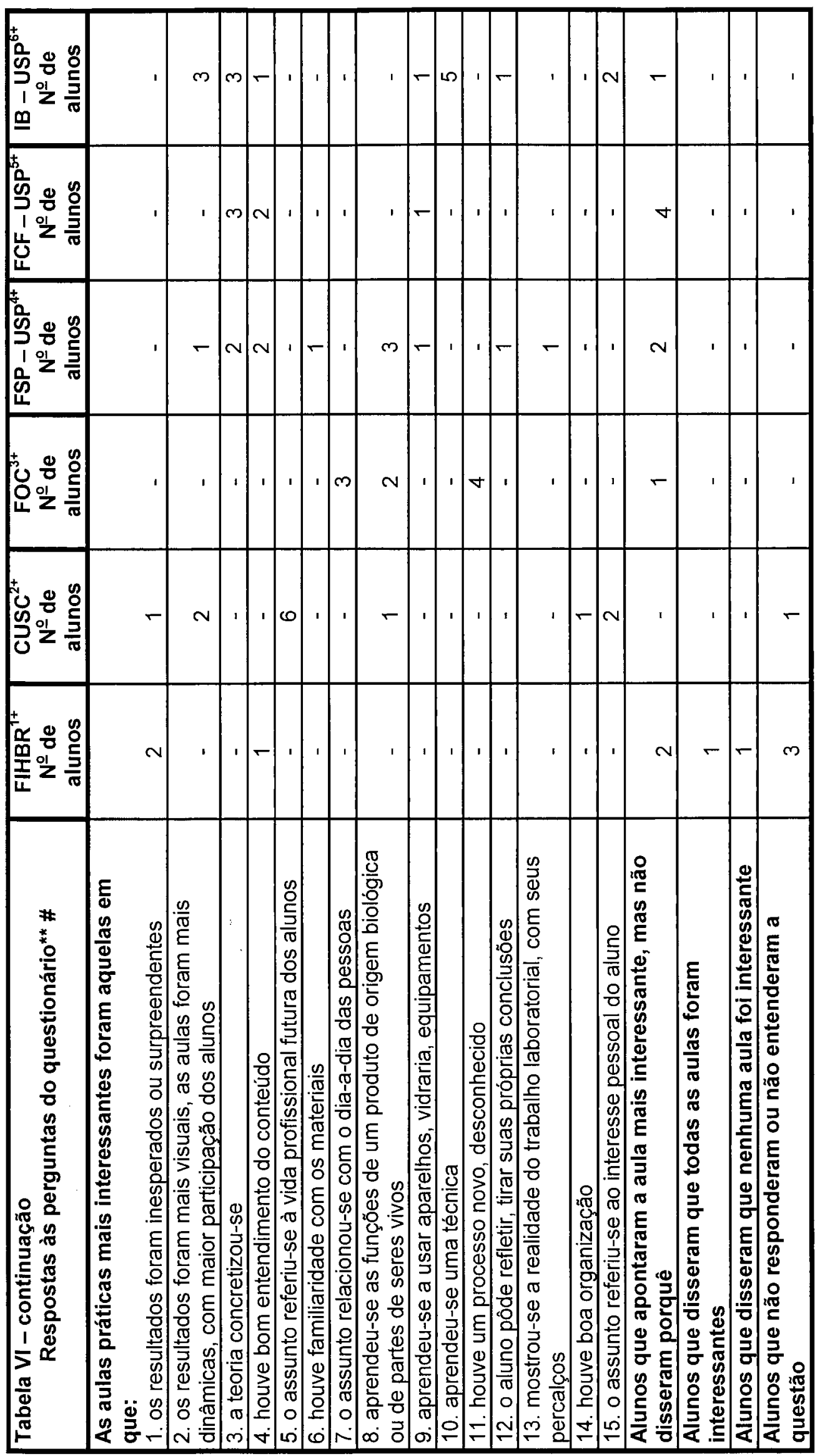




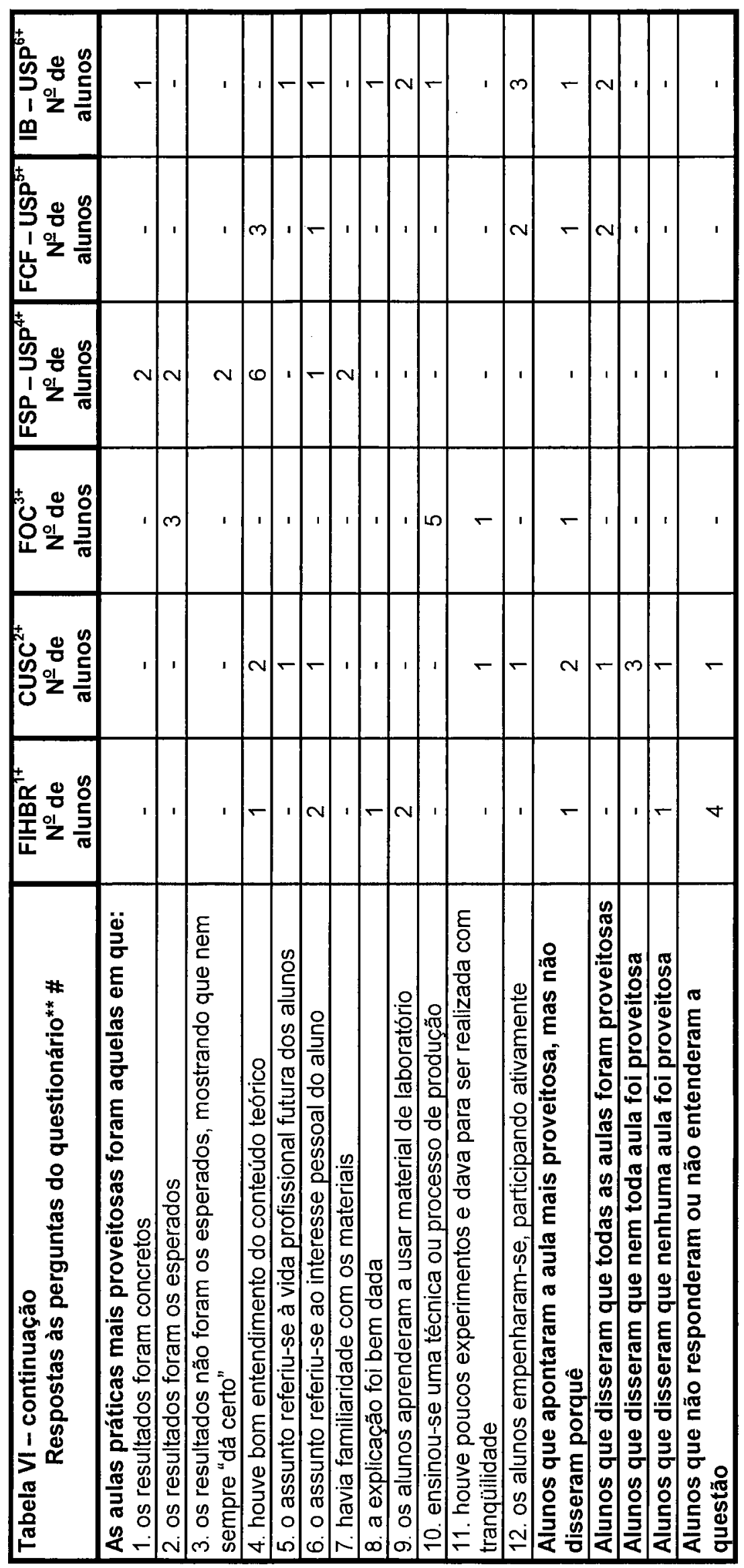




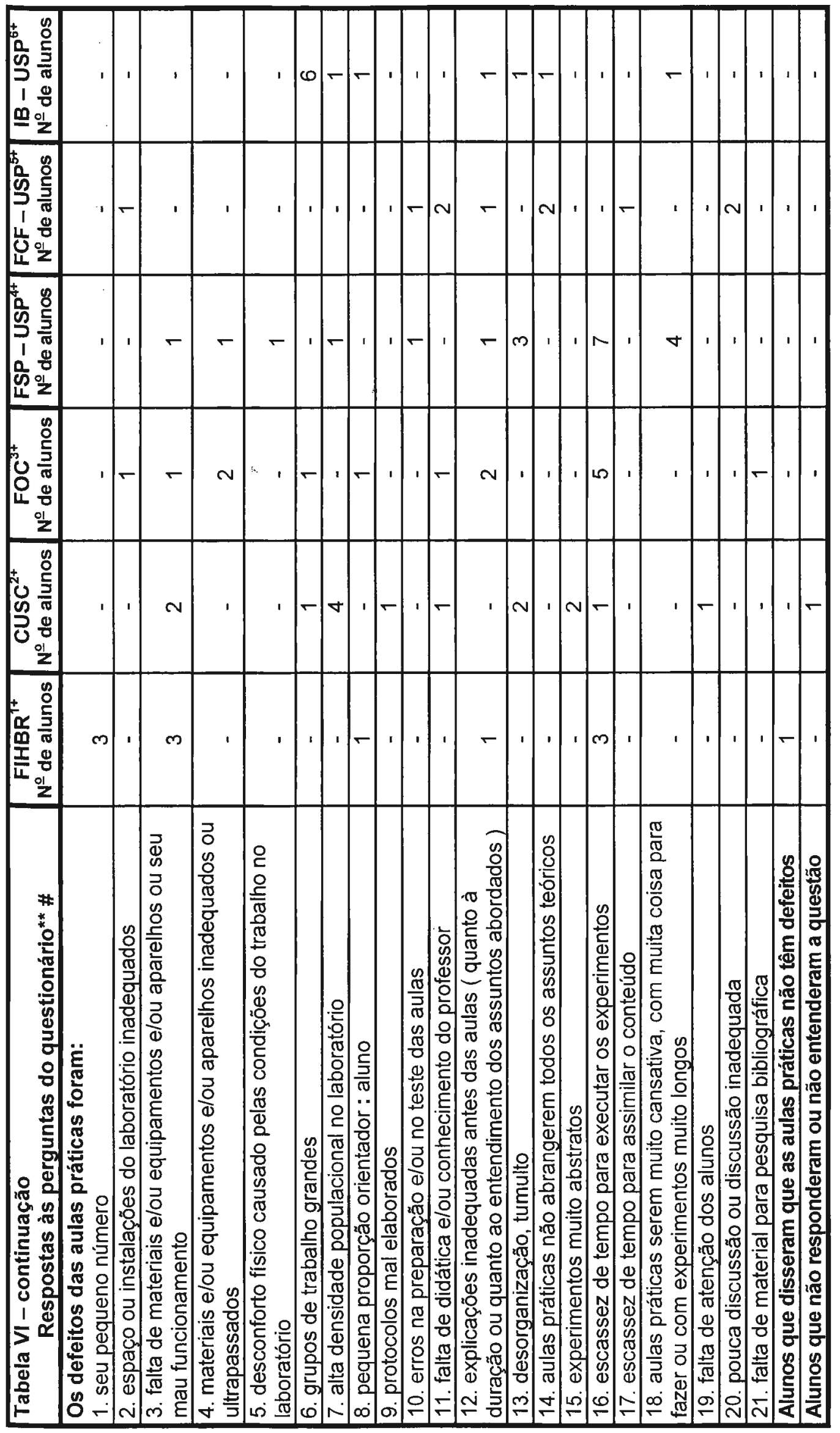

BIBLIOTECA

WSTITUTO DE QUIMLO

Culversldade de São Paulc 


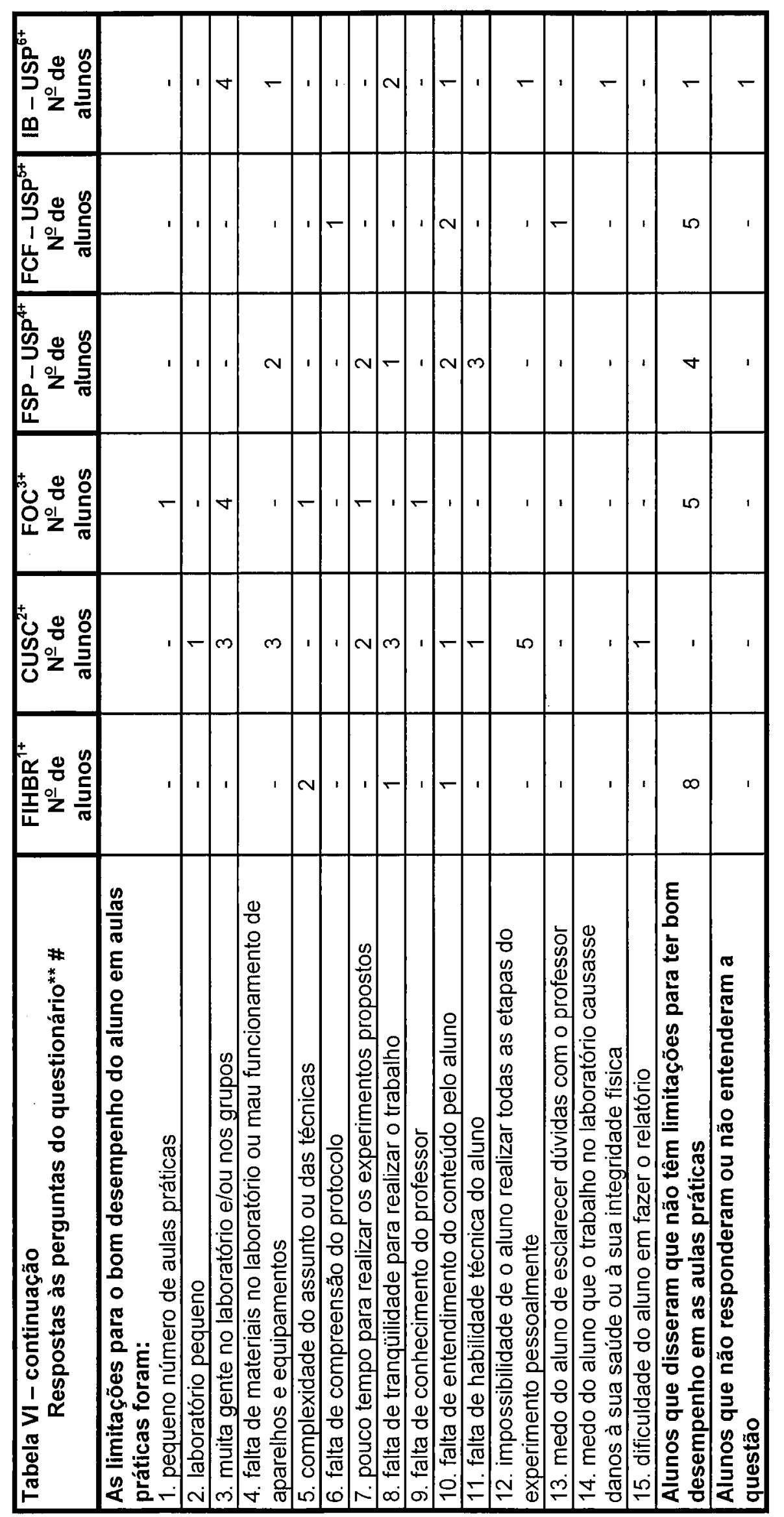




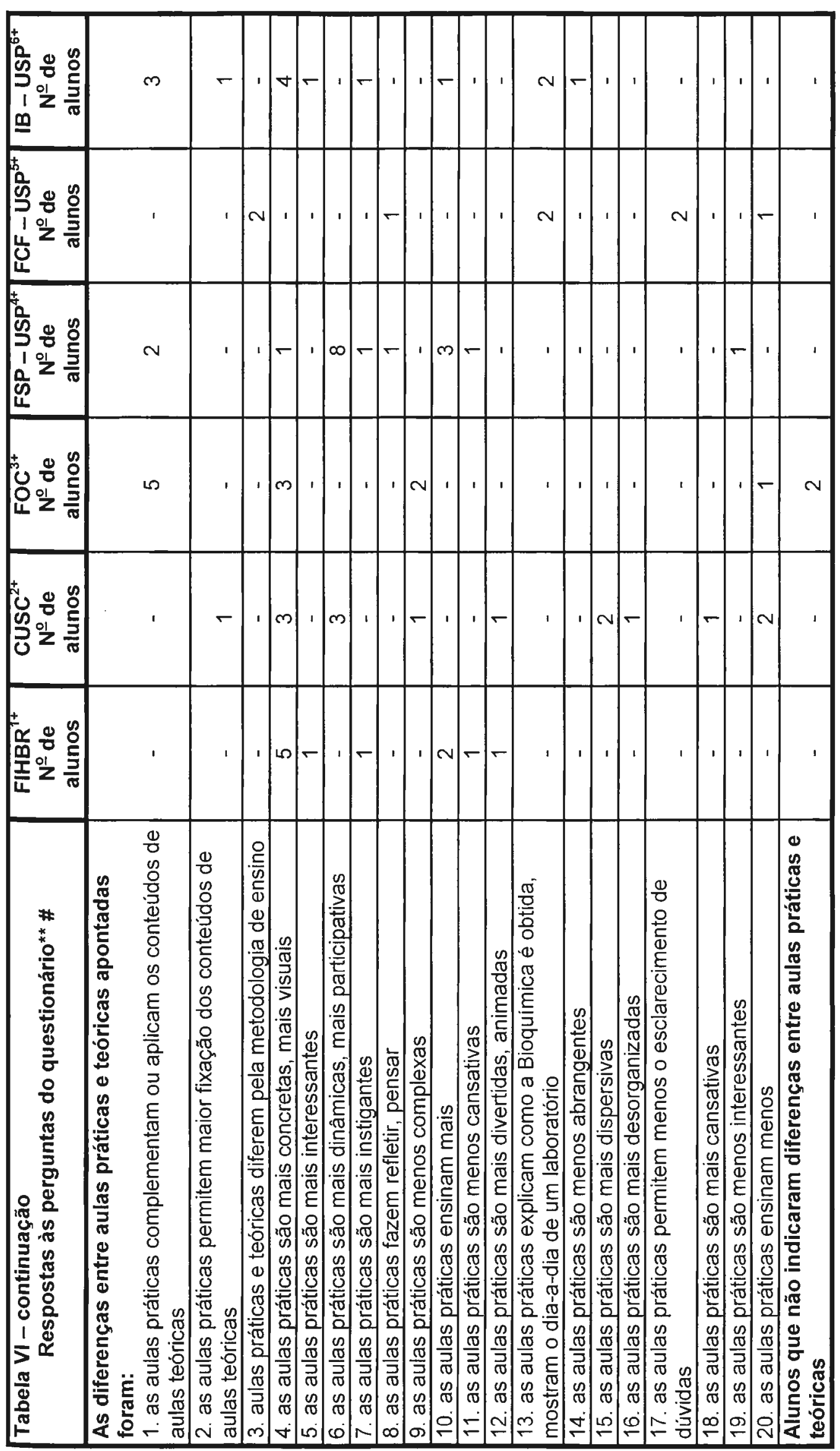




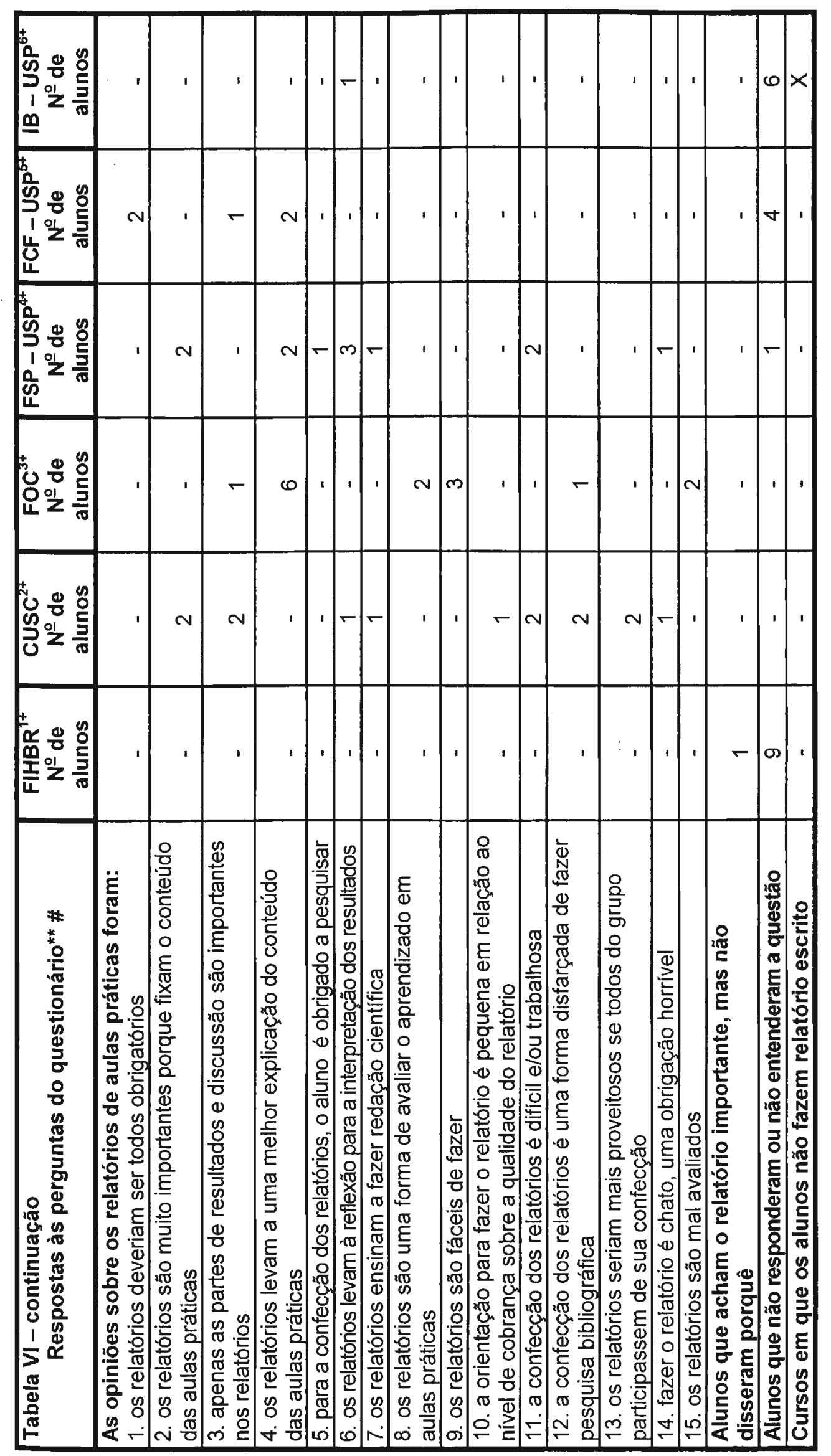



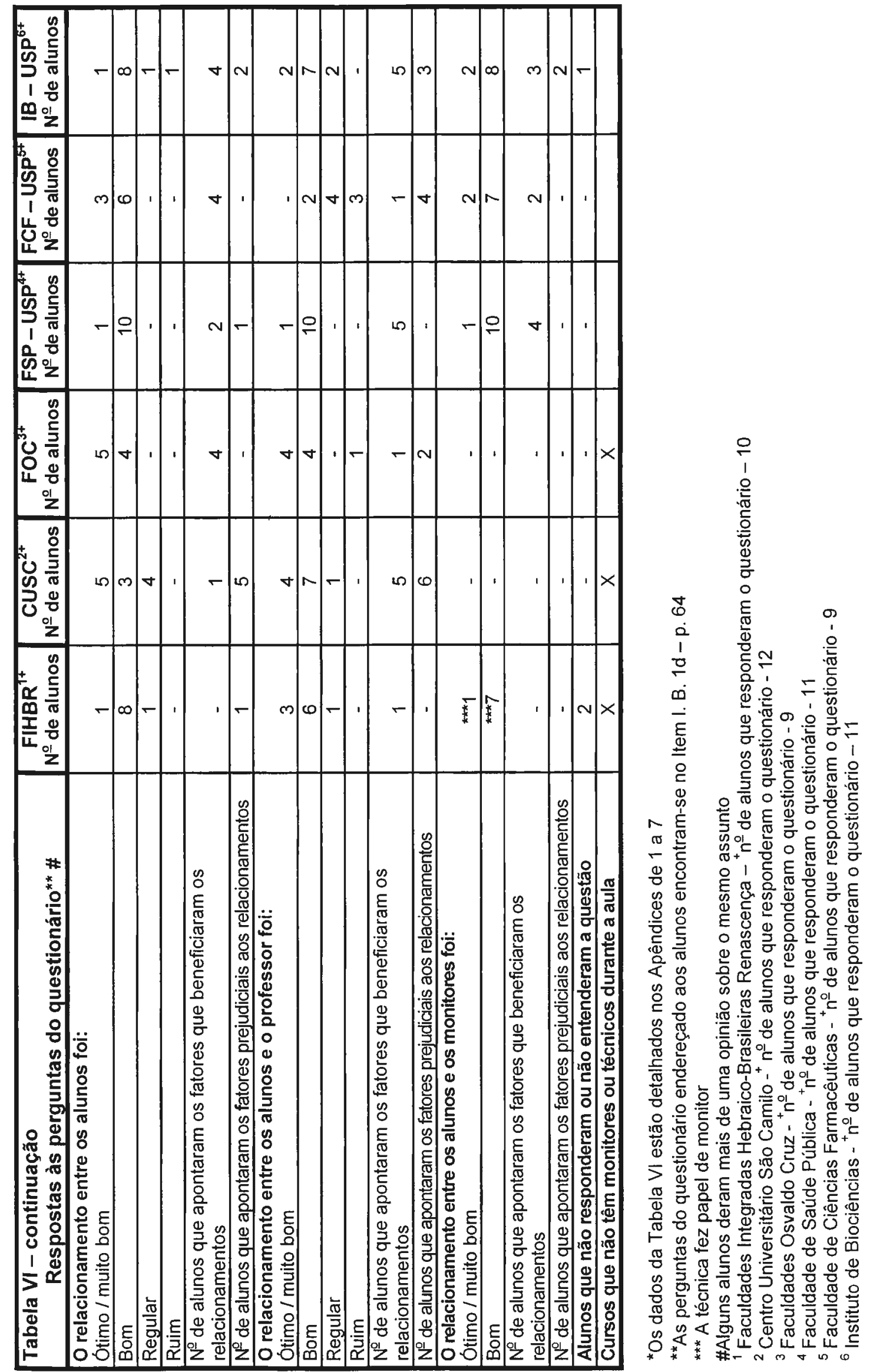


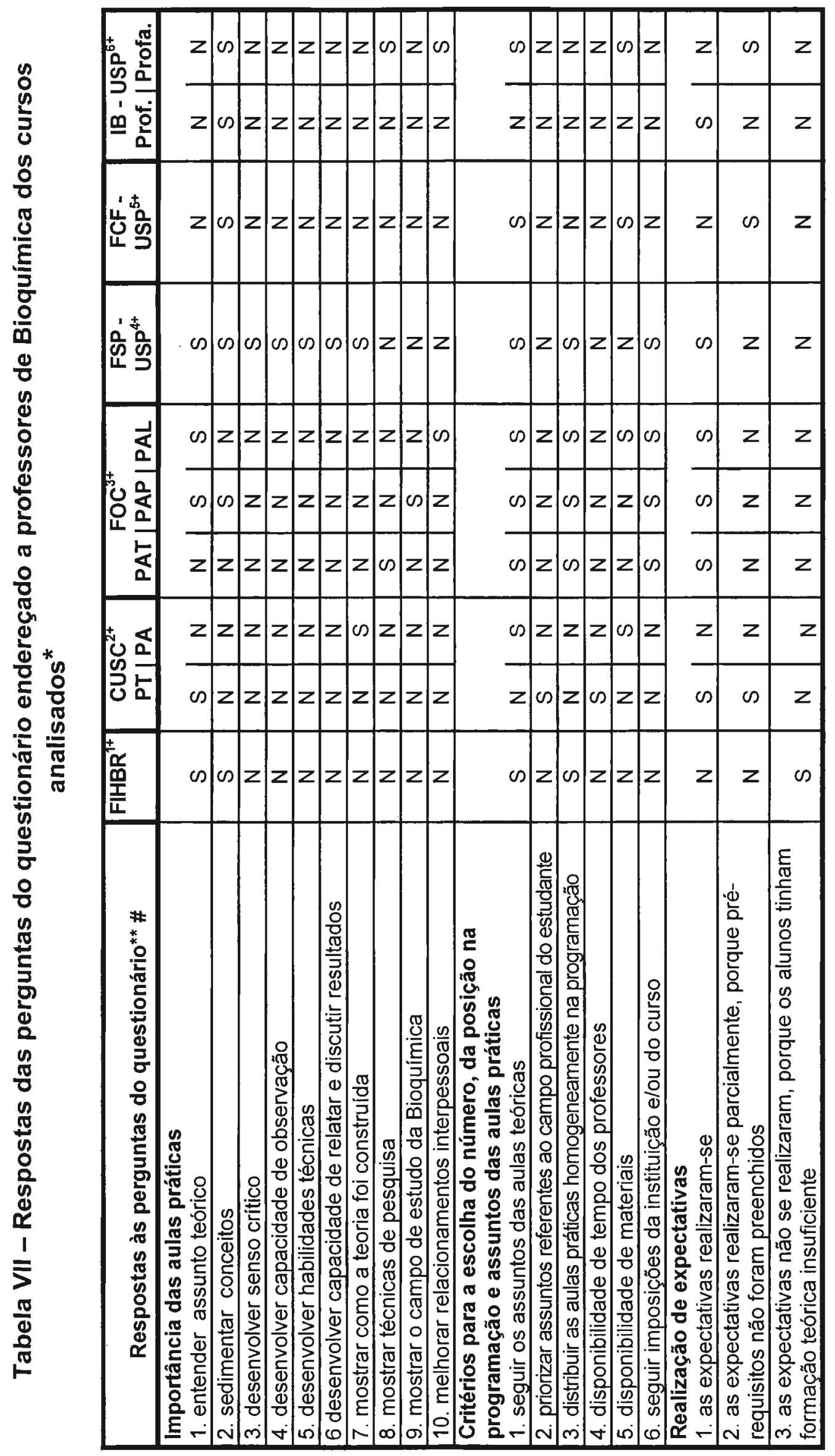




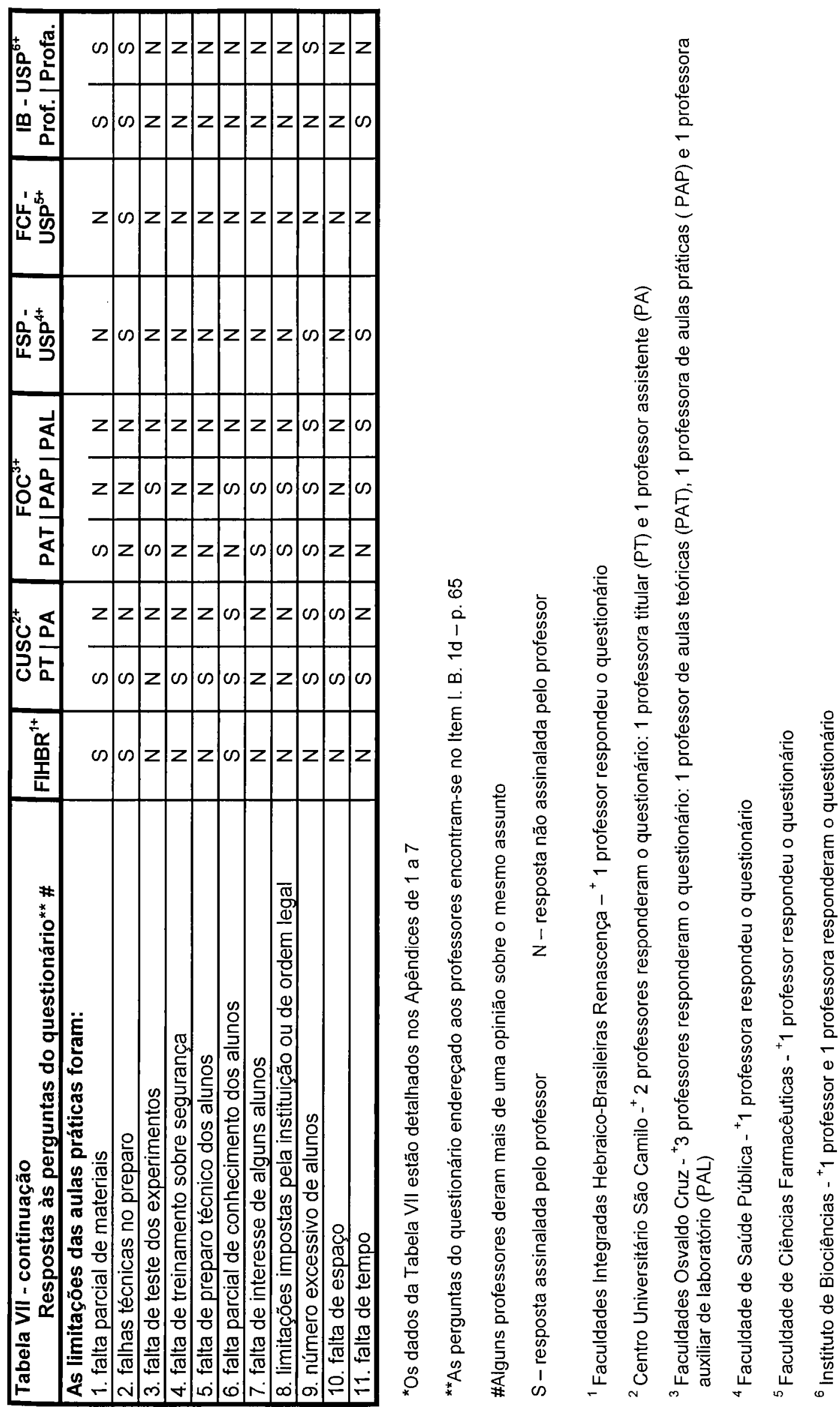




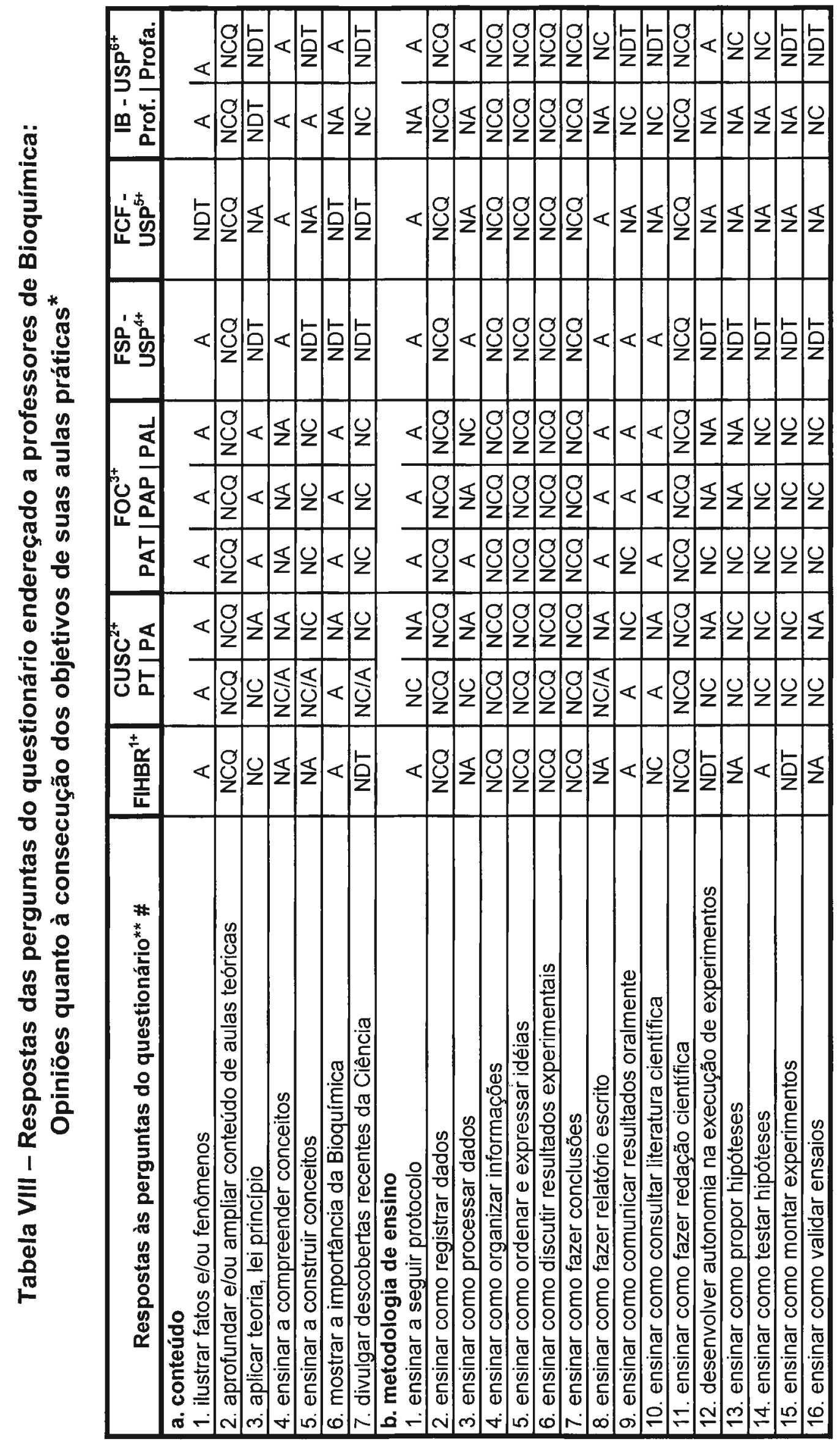



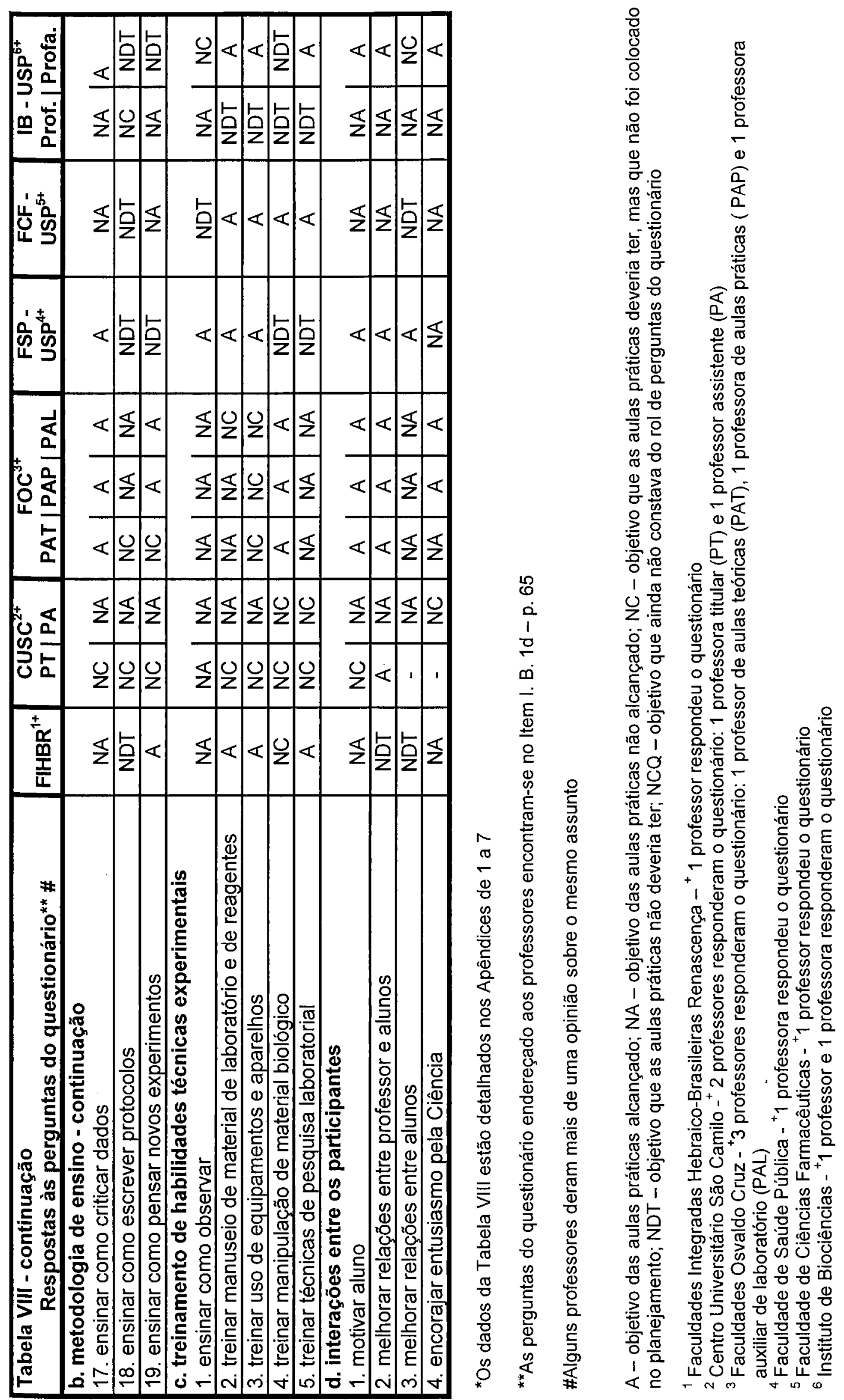


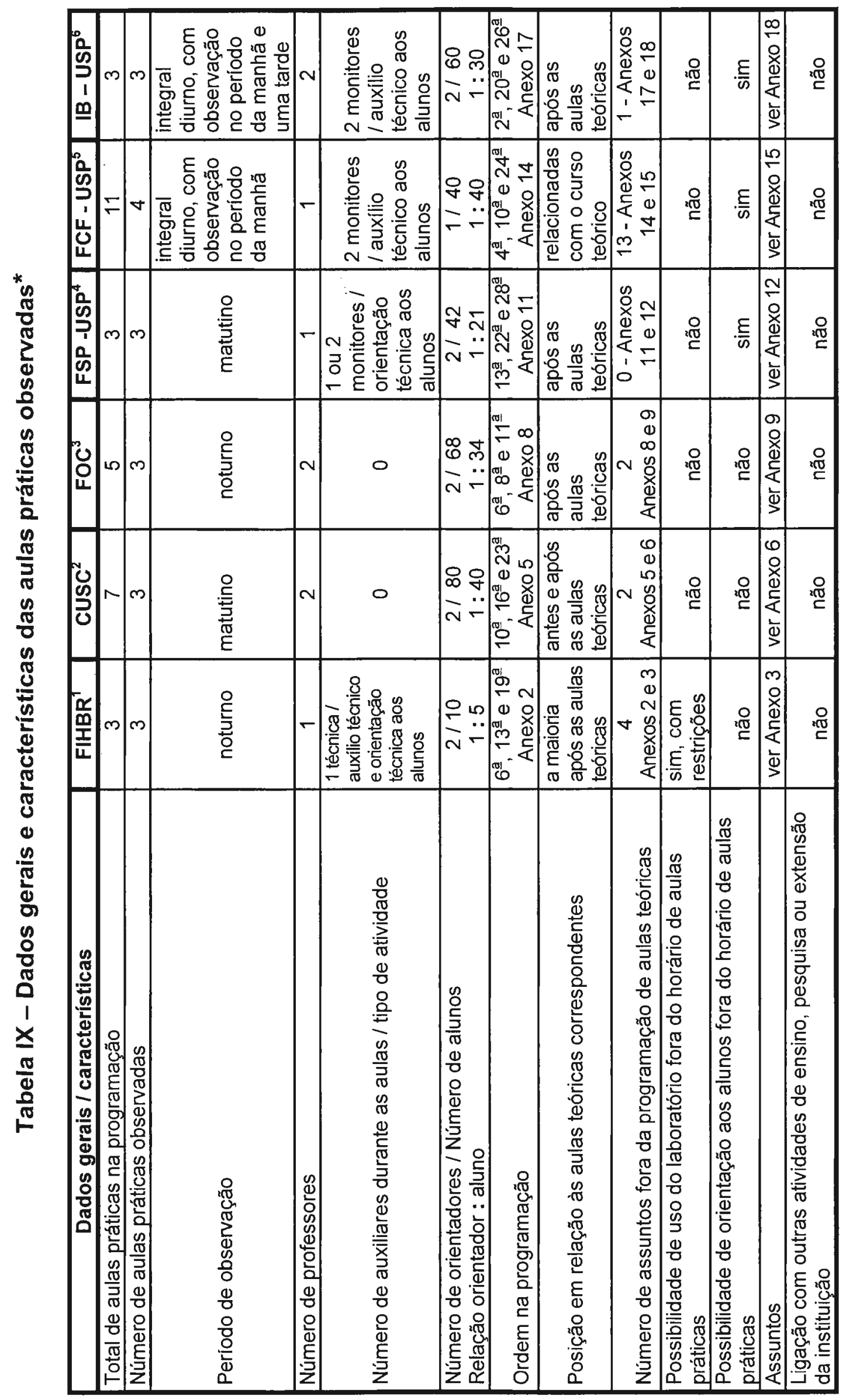




\begin{tabular}{|c|c|c|c|c|c|c|c|c|c|}
\hline $\begin{array}{l}\stackrel{0}{0} \\
\stackrel{0}{2} \\
1 \\
\underline{m}\end{array}$ & 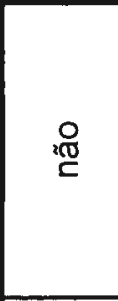 & 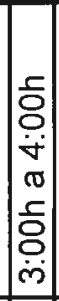 & 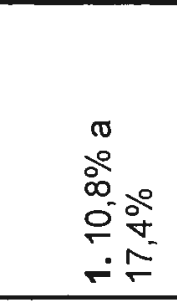 & 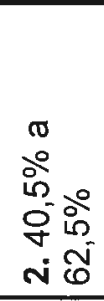 & 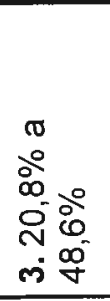 & & 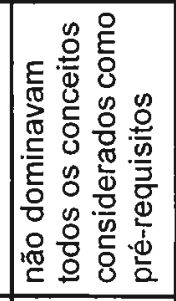 & 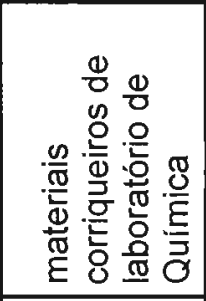 & 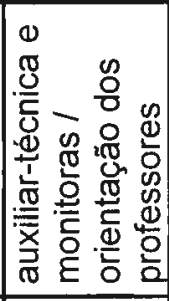 \\
\hline 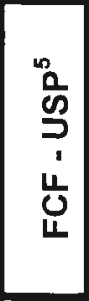 & 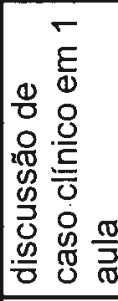 & 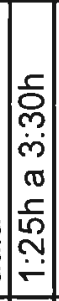 & 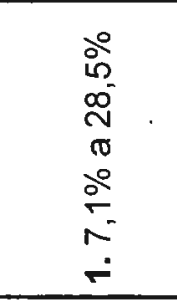 & 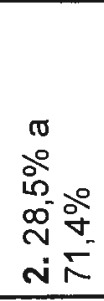 & $\begin{array}{l}\circ 0 \\
\circ \\
0 \\
0 \\
0 \\
\circ \\
\circ \\
0 \\
\text { m. }\end{array}$ & & 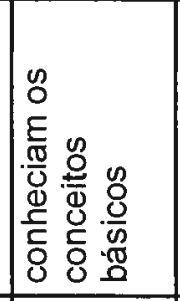 & 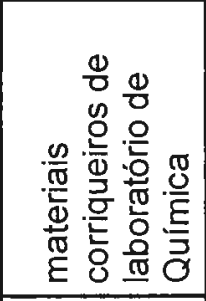 & 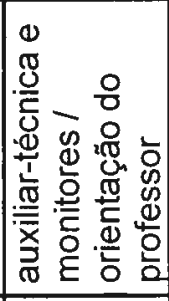 \\
\hline $\begin{array}{l}0 \\
0 \\
5 \\
1 \\
0 \\
5 \\
4\end{array}$ & 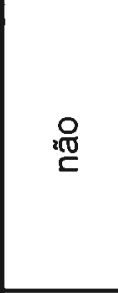 & 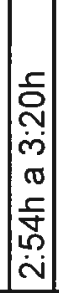 & 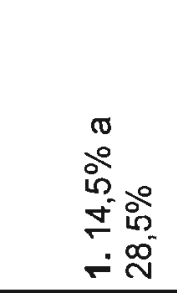 & 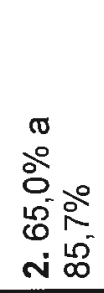 & $\begin{array}{l}\circ \\
\circ \\
\frac{0}{0} \\
\sigma \\
\circ \\
\circ \\
\circ \\
\text { m. } \\
\text { m. }\end{array}$ & & 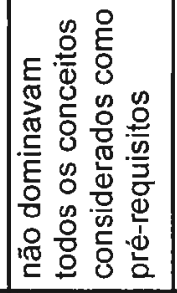 & 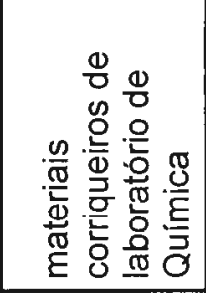 & 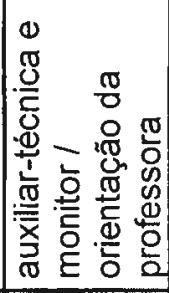 \\
\hline $\begin{array}{l}\text { "U } \\
\text { 인 }\end{array}$ & 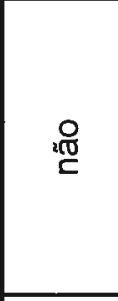 & 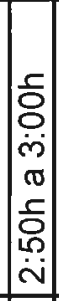 & 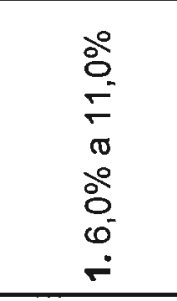 & 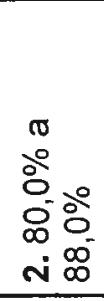 & $\begin{array}{l}80 \\
\circ \\
\circ \\
0 \\
\circ \\
\circ \\
0 \\
0 \\
\text { m. }\end{array}$ & & 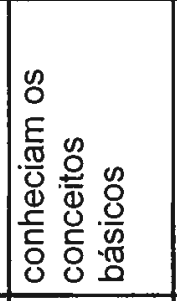 & 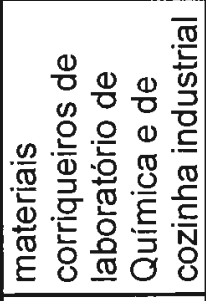 & 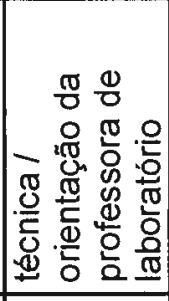 \\
\hline $\begin{array}{l}\text { U } \\
\mathscr{~} \\
\mathcal{0}\end{array}$ & 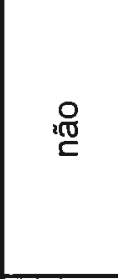 & 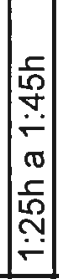 & 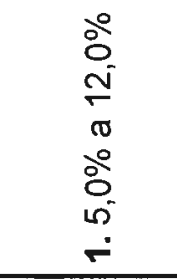 & 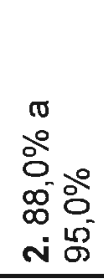 & $\begin{array}{l}80 \\
0 \\
0 \\
\text { m. }\end{array}$ & & 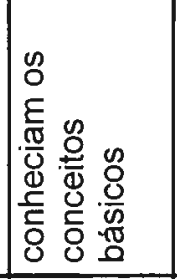 & 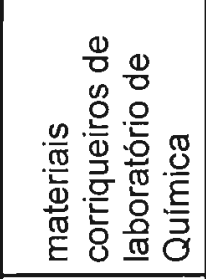 & 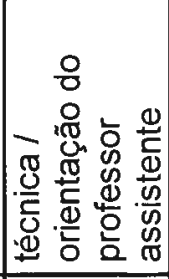 \\
\hline $\begin{array}{l}\frac{\mathbf{x}}{\mathbf{0}} \\
\mathbf{M} \\
\underline{\overline{\mathbf{u}}}\end{array}$ & 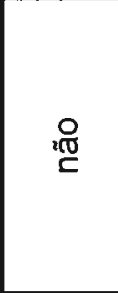 & 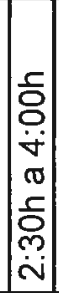 & 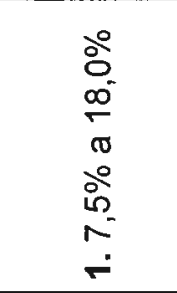 & 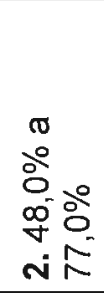 & 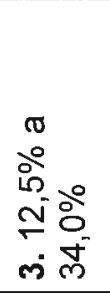 & & 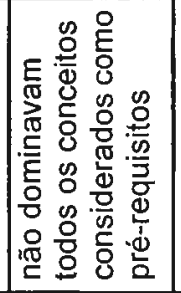 & 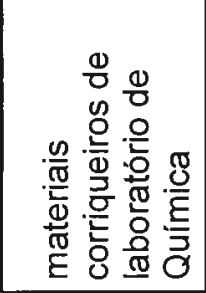 & 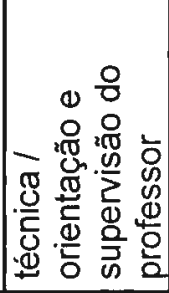 \\
\hline 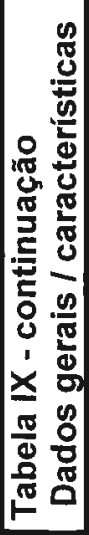 & 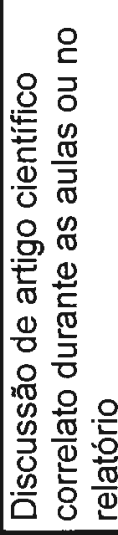 & 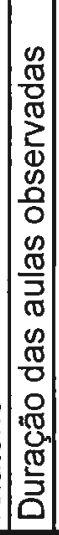 & 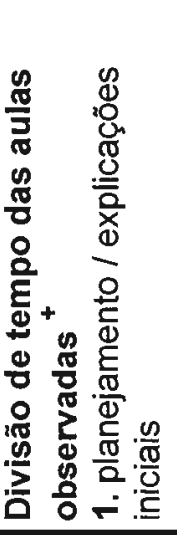 & 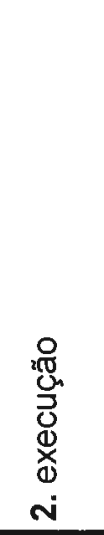 & 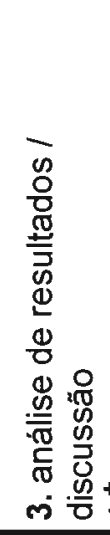 & 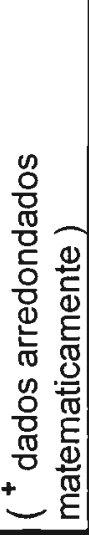 & 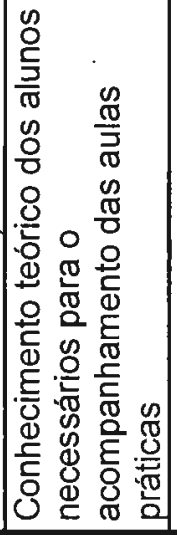 & 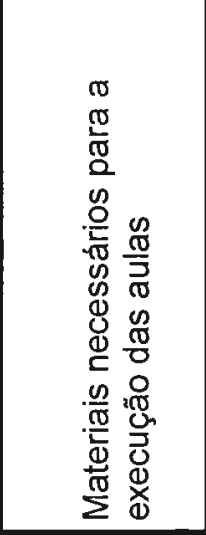 & 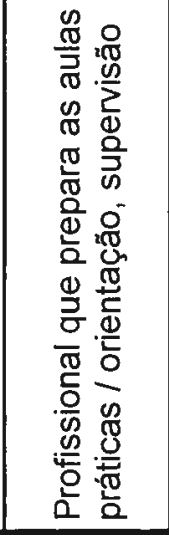 \\
\hline
\end{tabular}




\begin{tabular}{|c|c|c|c|c|c|c|c|c|c|}
\hline $\begin{array}{l}0 \\
0 \\
\mathscr{D} \\
د \\
1 \\
\underline{\underline{D}}\end{array}$ & 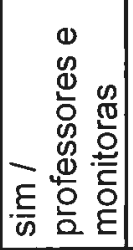 & 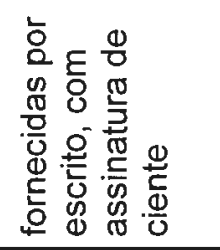 & 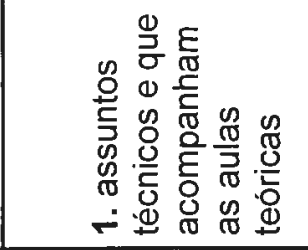 & 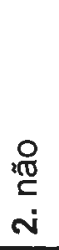 & $\begin{array}{l}\stackrel{8}{\pi} \\
\dot{i n} \\
\dot{\pi}\end{array}$ & $\begin{array}{l}\stackrel{8}{20} \\
\stackrel{20}{C} \\
\dot{+}\end{array}$ & 'id & $\begin{array}{l}\stackrel{8}{\mathrm{~d}} \\
\mathrm{c} \\
\dot{0}\end{array}$ & 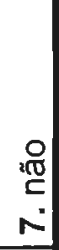 \\
\hline $\begin{array}{l}0 \\
0 \\
0 \\
1 \\
u \\
u \\
4\end{array}$ & 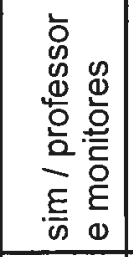 & 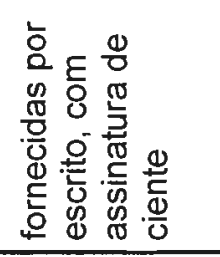 & 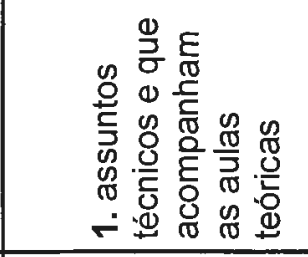 & $\begin{array}{l}\stackrel{8}{ \pm} \\
\text { N } \\
\end{array}$ & 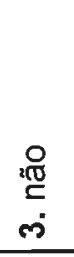 & $\begin{array}{l}\frac{E}{\omega} \\
\dot{+}\end{array}$ & $\begin{array}{l}\frac{E}{\omega} \\
\infty \\
\end{array}$ & $\begin{array}{l}\stackrel{8}{20} \\
\dot{0} \\
0\end{array}$ & 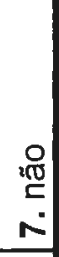 \\
\hline 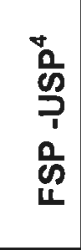 & 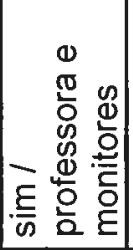 & 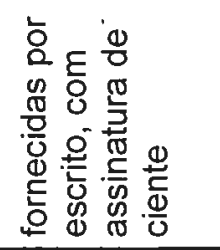 & 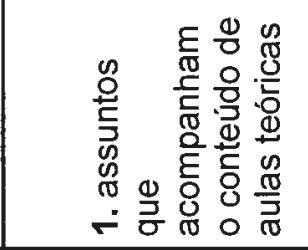 & 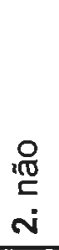 & 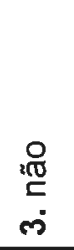 & $\begin{array}{l}\stackrel{0}{20} \\
\stackrel{20}{+} \\
\dot{\forall}\end{array}$ & 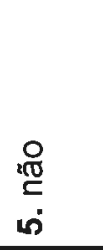 & 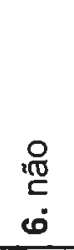 & 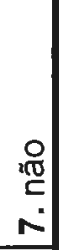 \\
\hline $\begin{array}{l}0 \\
0\end{array}$ & 읻 & 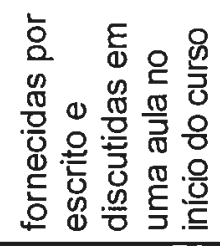 & 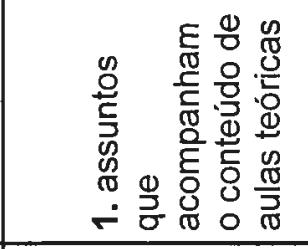 & 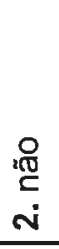 & 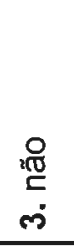 & $\begin{array}{l}\frac{E}{\omega} \\
\dot{\nabla}\end{array}$ & $\begin{array}{l}\frac{E}{\omega} \\
\omega \\
\end{array}$ & $\begin{array}{l}\stackrel{8}{c} \\
\dot{0} \\
0\end{array}$ & $\begin{array}{l}\stackrel{0}{n} \\
\stackrel{n}{c} \\
\end{array}$ \\
\hline $\begin{array}{l}\text { U్ } \\
\text { J }\end{array}$ & 品 & 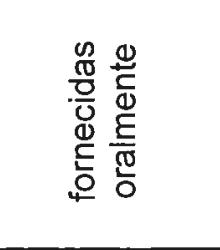 & 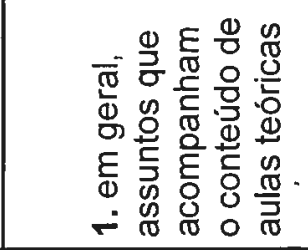 & 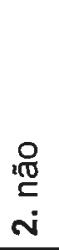 & 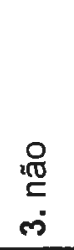 & 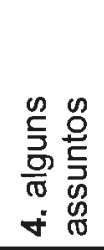 & 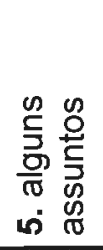 & $\begin{array}{l}\stackrel{\circ}{c} \\
\stackrel{20}{c}\end{array}$ & 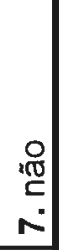 \\
\hline 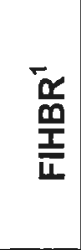 & 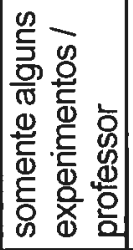 & 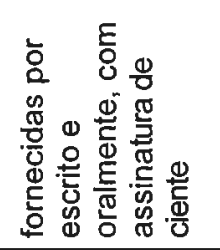 & 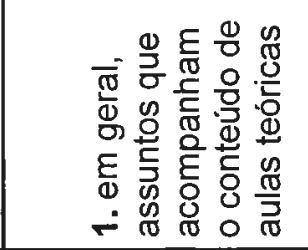 & $\begin{array}{l}\stackrel{0}{\infty} \\
\text { N } \\
\text { N }\end{array}$ & 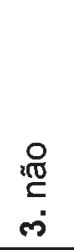 & 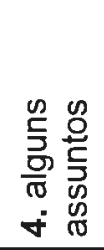 & 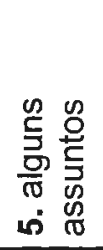 & $\begin{array}{l}\stackrel{\circ}{20} \\
\stackrel{2}{c} \\
0\end{array}$ & 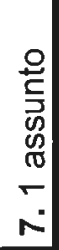 \\
\hline 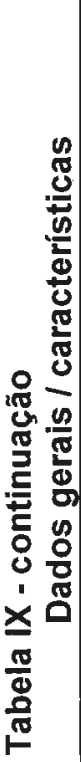 & 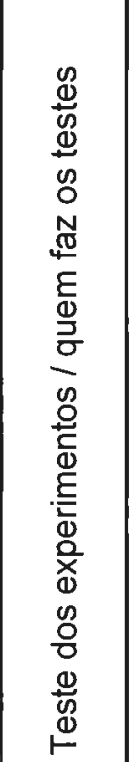 & 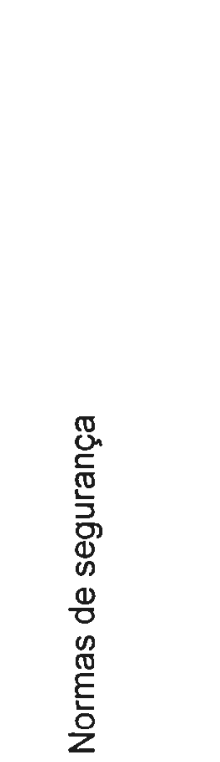 & 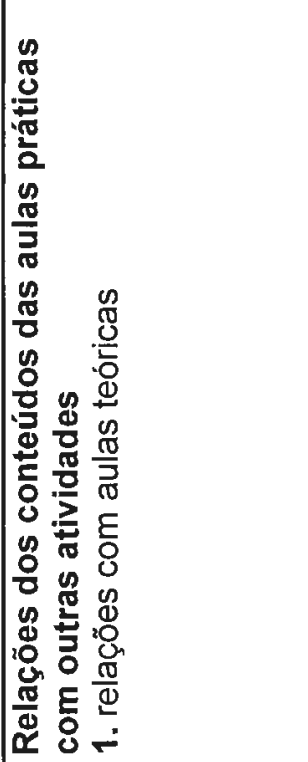 & 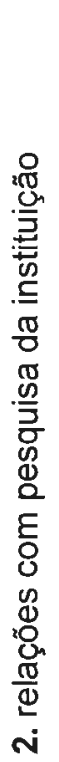 & 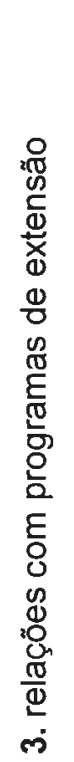 & 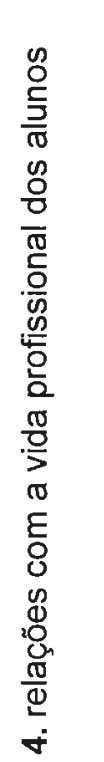 & 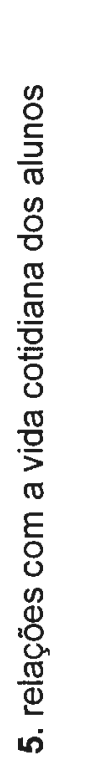 & 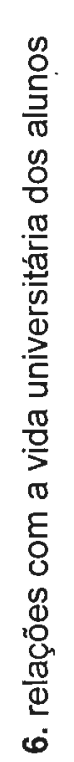 & 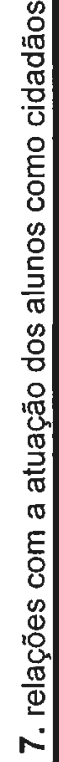 \\
\hline
\end{tabular}




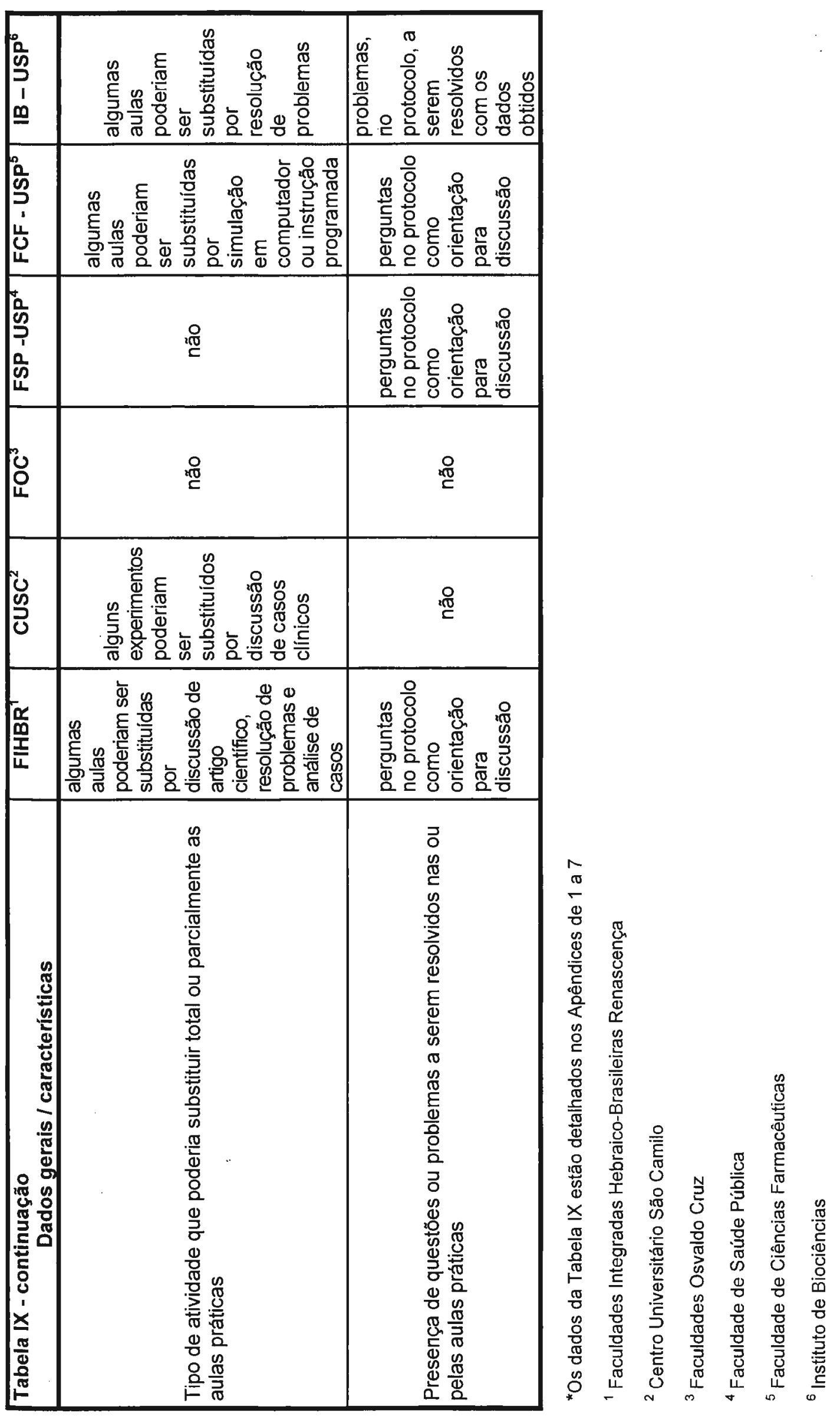




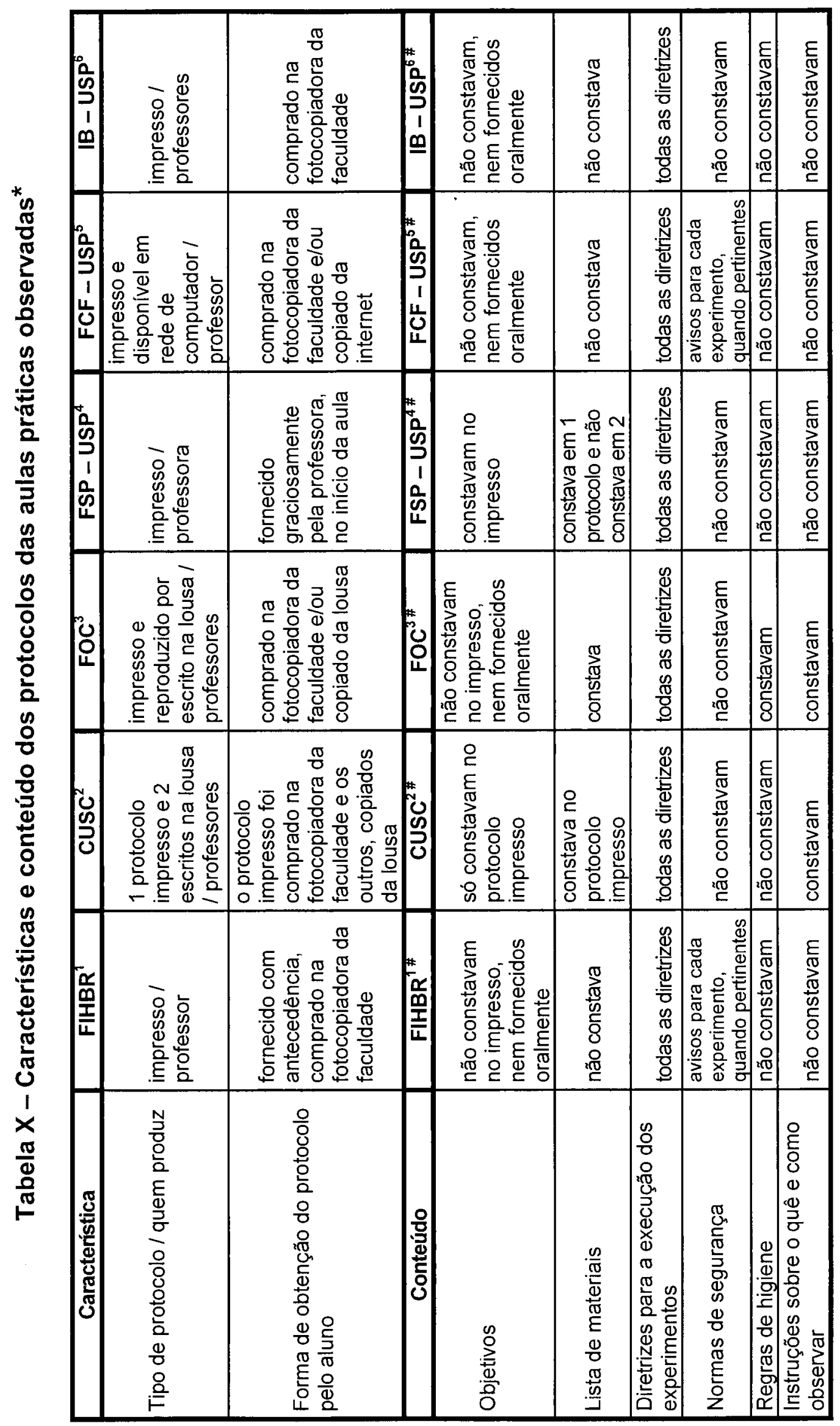



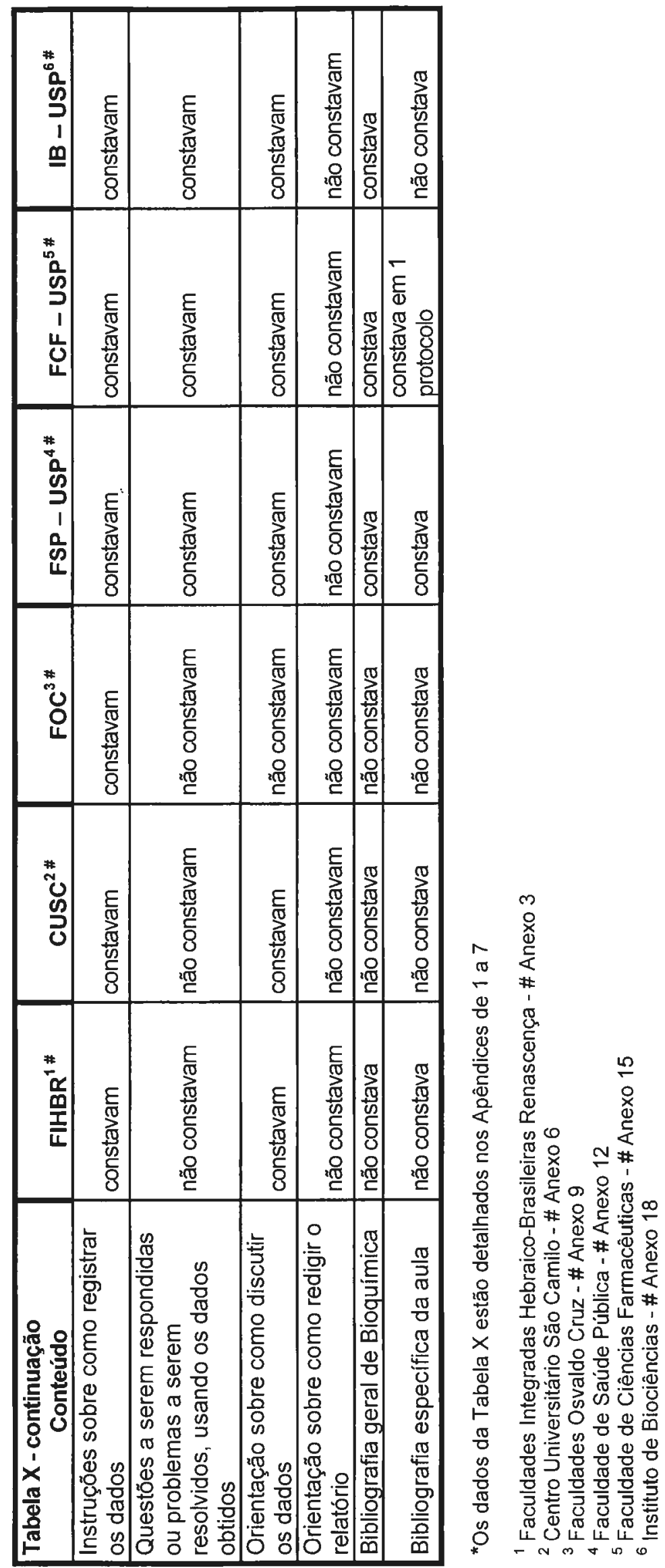


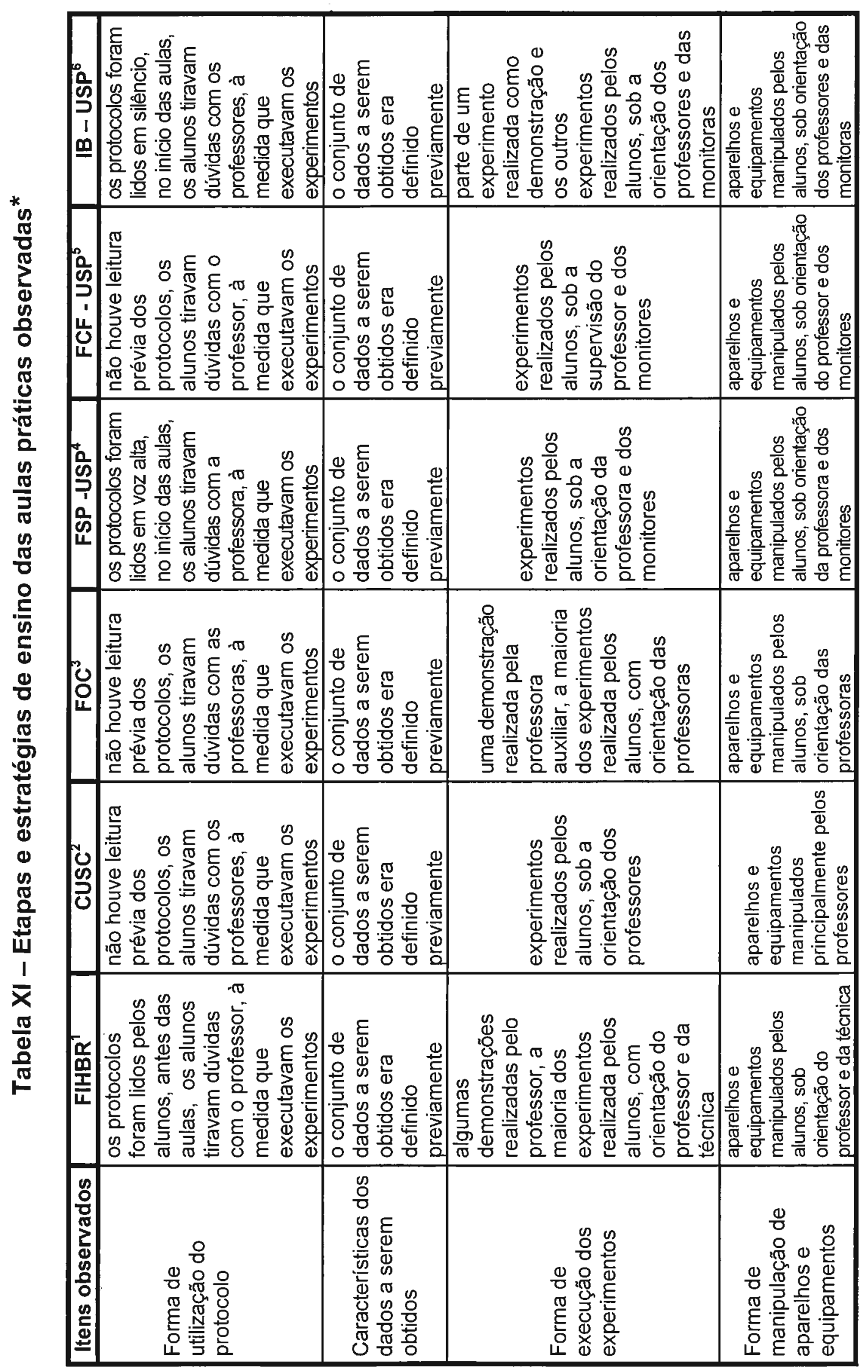




\begin{tabular}{|c|c|c|c|}
\hline & 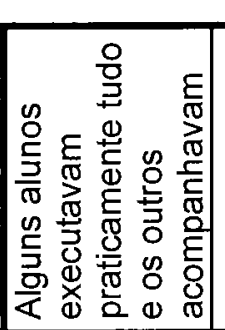 & 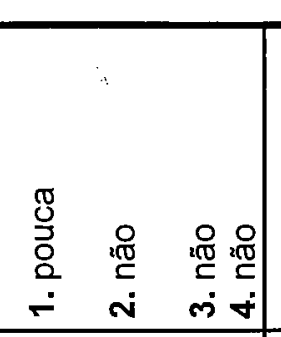 & 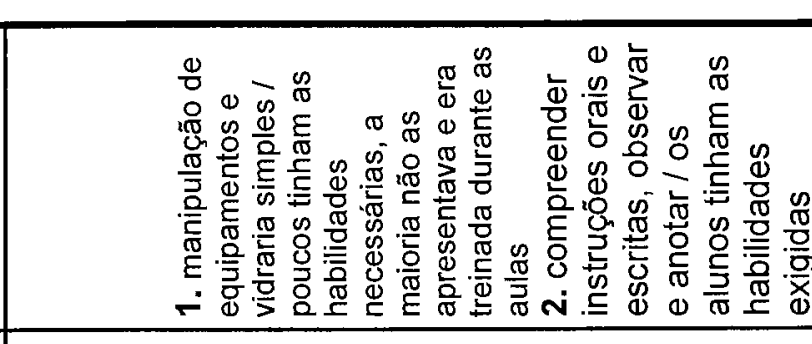 \\
\hline & 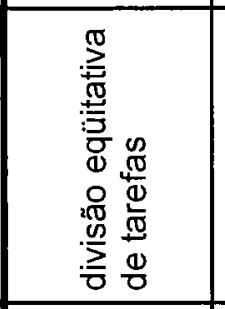 & 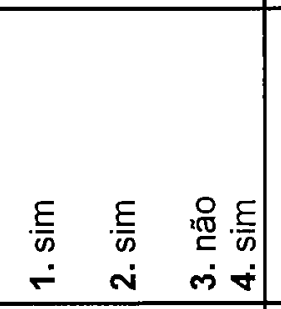 & 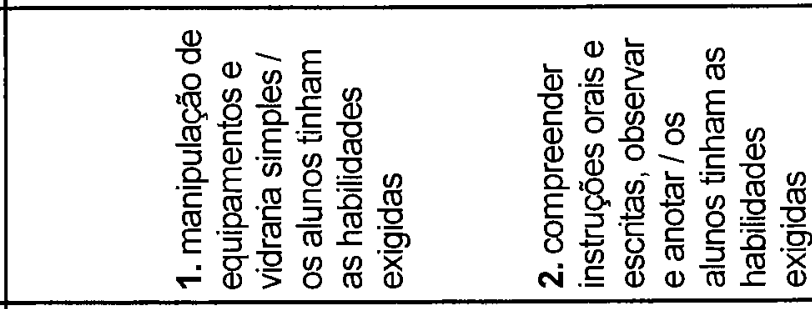 \\
\hline & 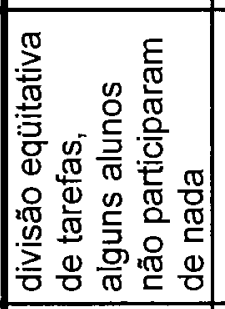 & 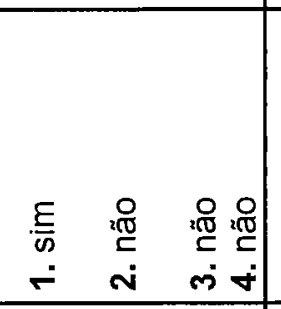 & 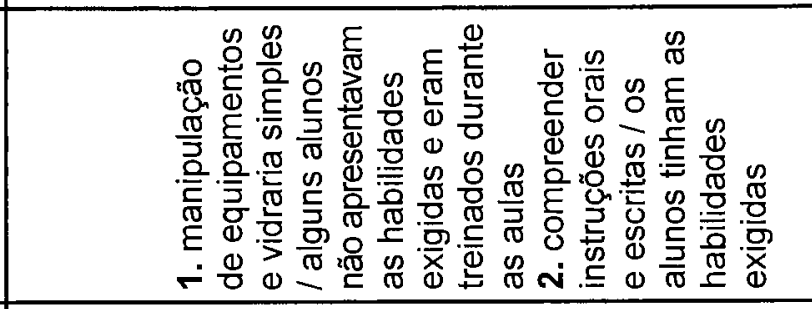 \\
\hline & 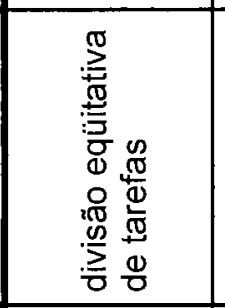 & 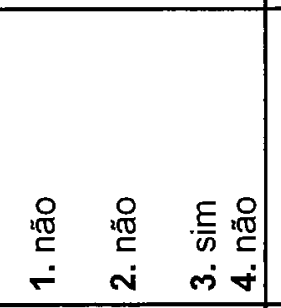 & 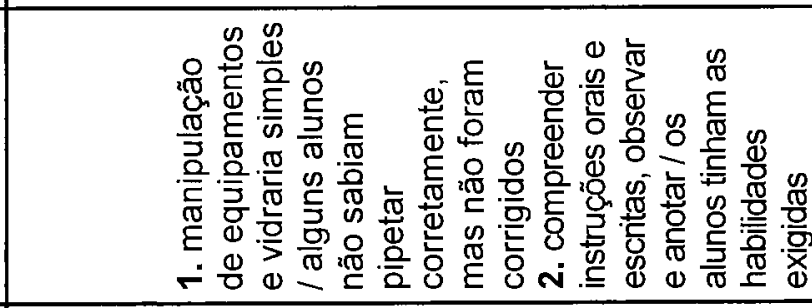 \\
\hline & 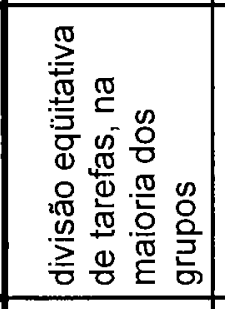 & 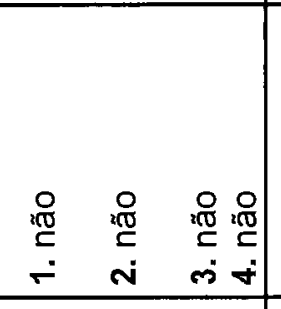 & 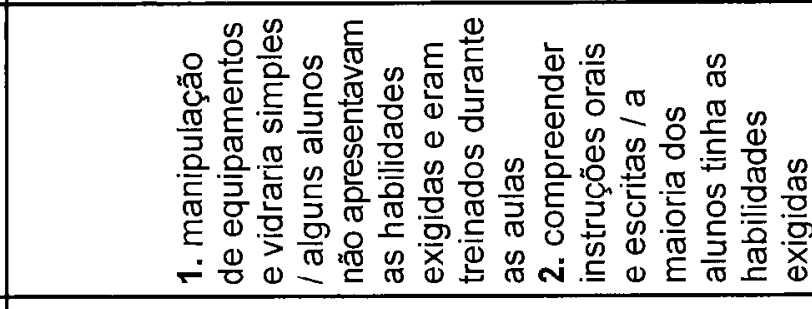 \\
\hline & 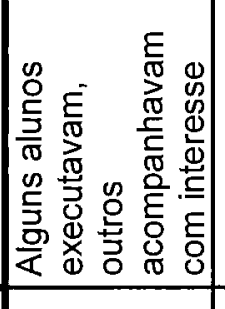 & 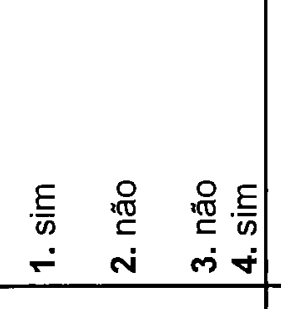 & 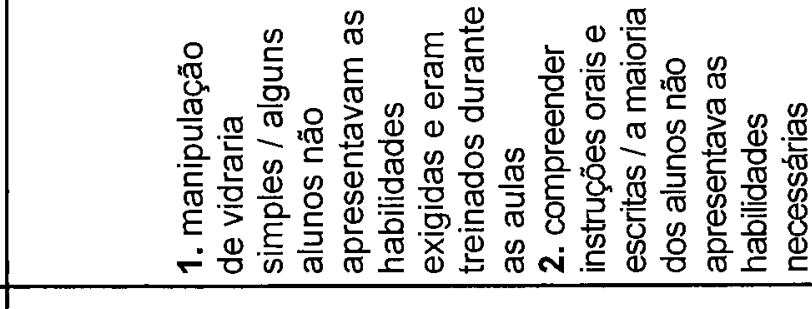 \\
\hline & 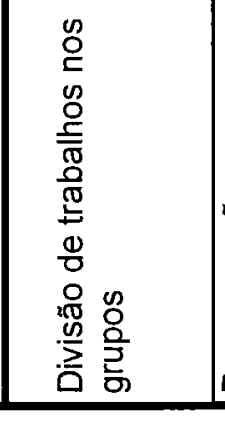 & 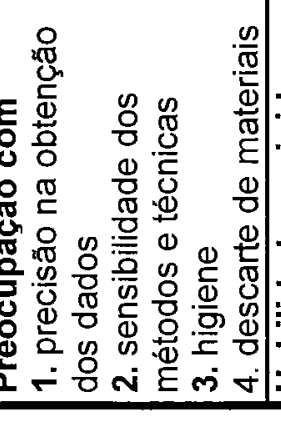 & 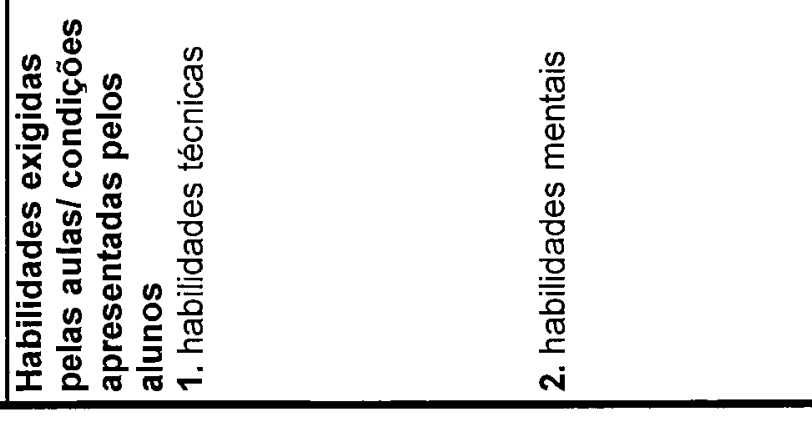 \\
\hline
\end{tabular}




\begin{tabular}{|c|c|c|c|c|}
\hline $\begin{array}{l}\text { : } \\
\text { s } \\
3 \\
1 \\
1 \\
\underline{9}\end{array}$ & 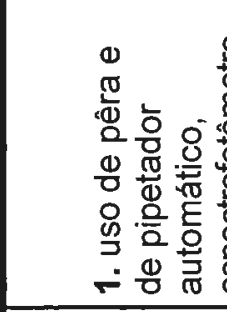 & 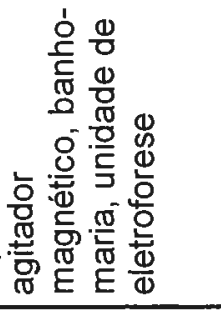 & 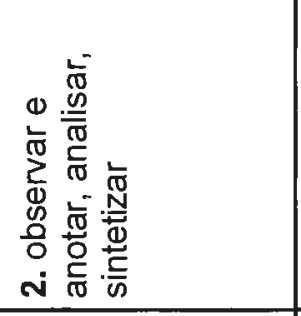 & 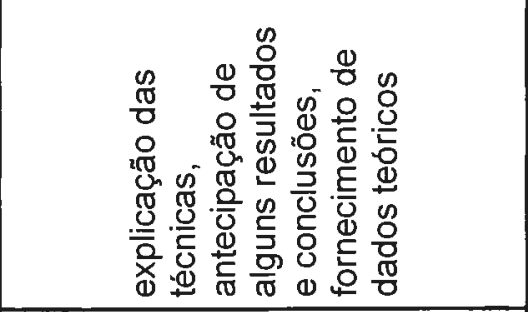 \\
\hline 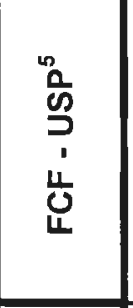 & \multicolumn{3}{|c|}{ 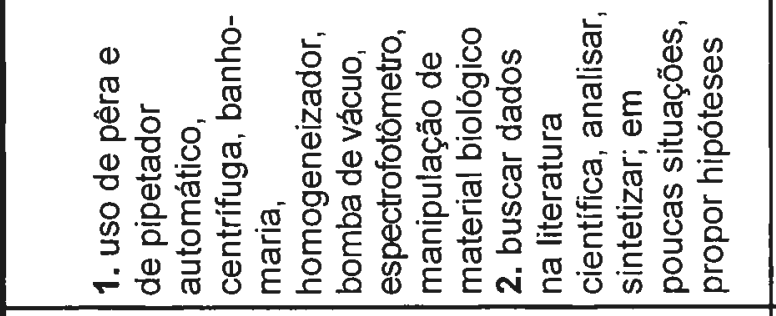 } & 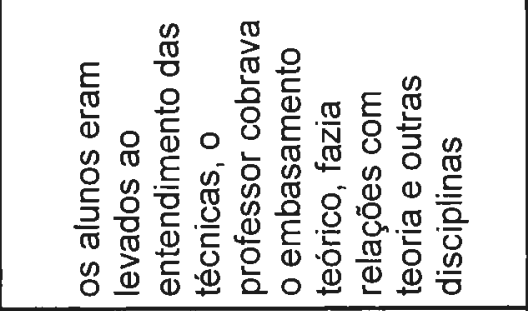 \\
\hline 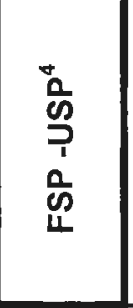 & 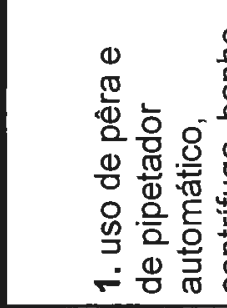 & 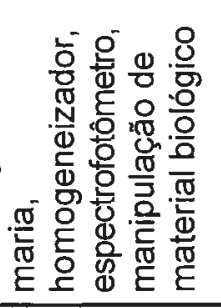 & 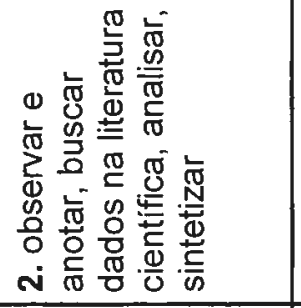 & 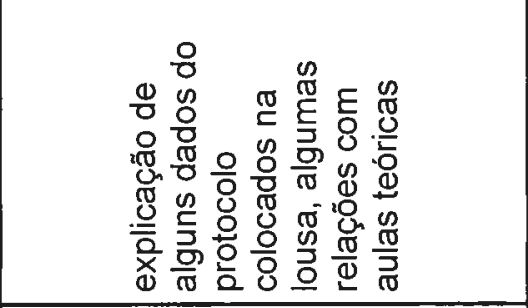 \\
\hline "' & 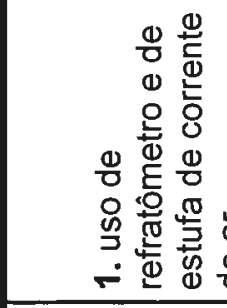 & & 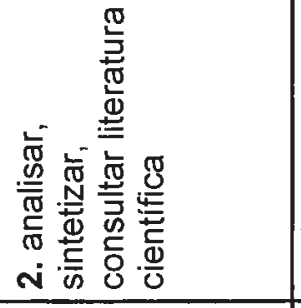 & 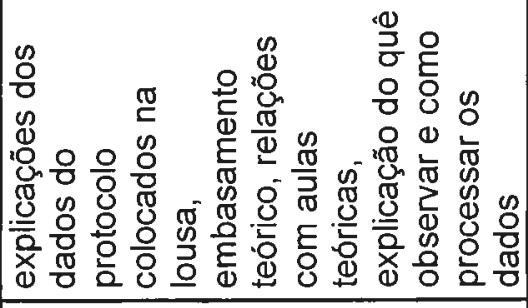 \\
\hline 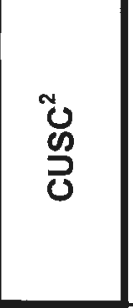 & 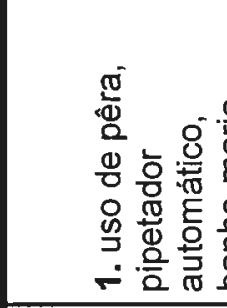 & 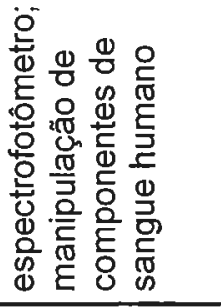 & 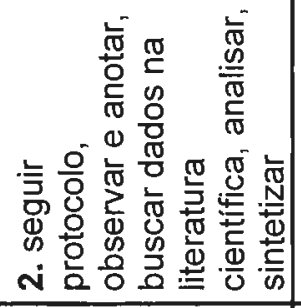 & 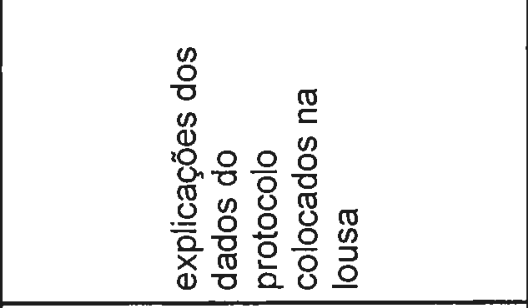 \\
\hline & 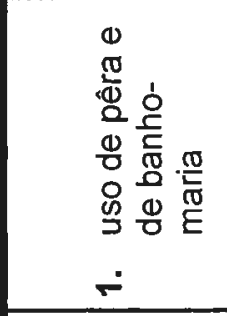 & & 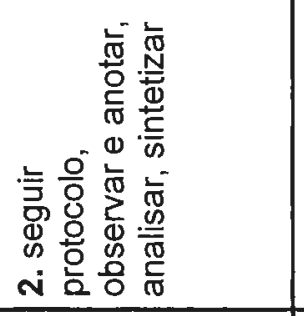 & 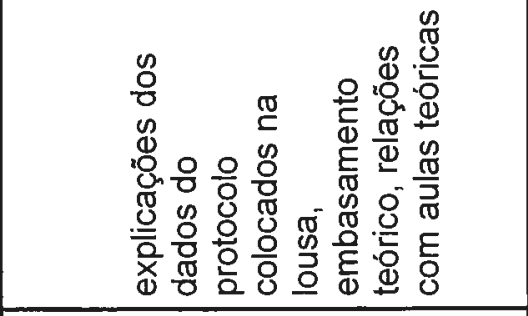 \\
\hline 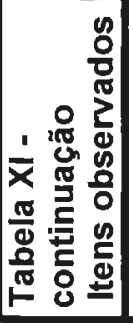 & 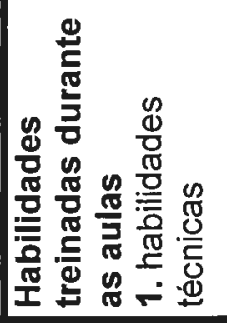 & & 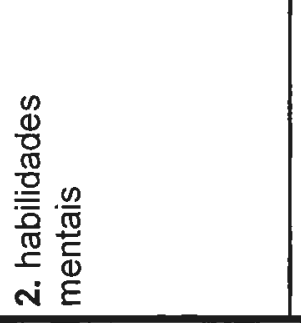 & 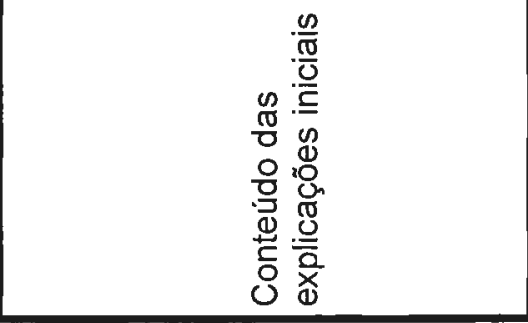 \\
\hline
\end{tabular}




\begin{tabular}{|c|c|c|c|c|}
\hline $\begin{array}{l}0 \\
0 \\
s \\
1 \\
\underline{m} \\
\underline{m}\end{array}$ & 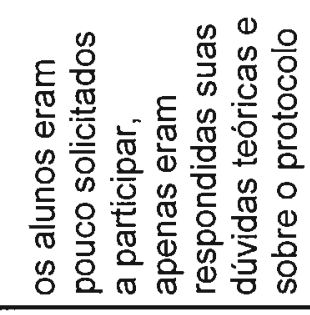 & 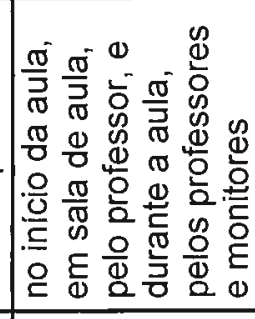 & 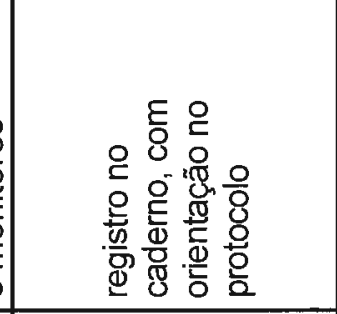 & 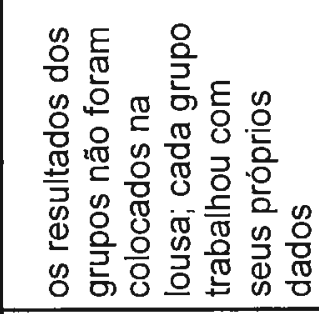 \\
\hline 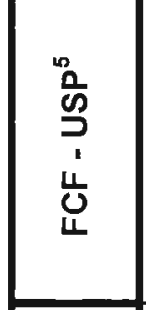 & 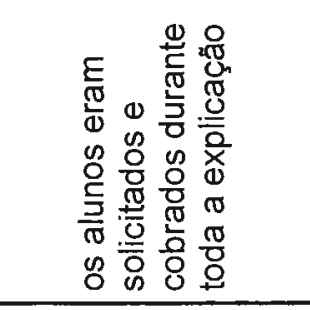 & 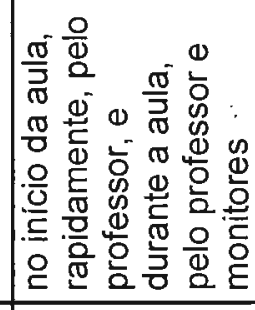 & 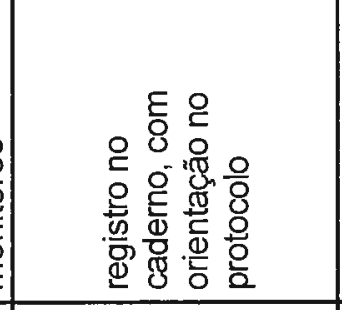 & 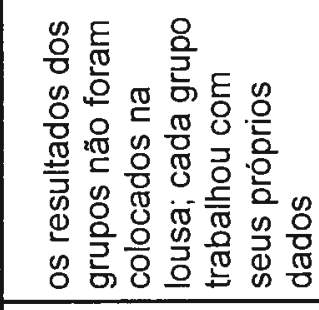 \\
\hline 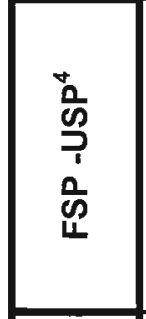 & 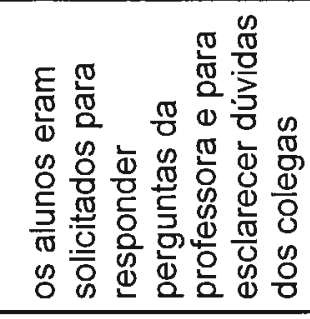 & 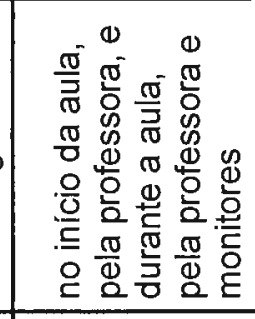 & 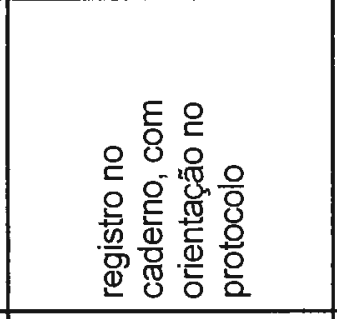 & 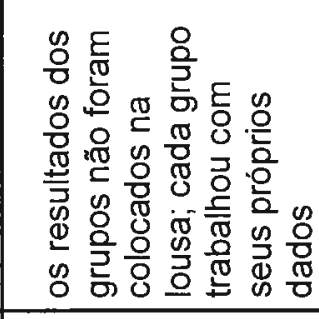 \\
\hline $\begin{array}{l}0 \\
\end{array}$ & 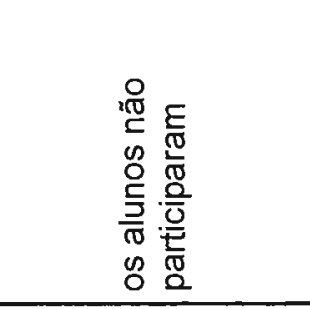 & 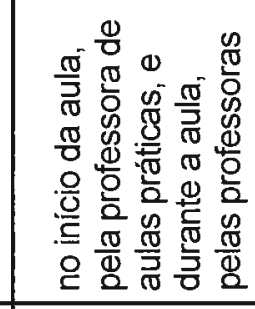 & 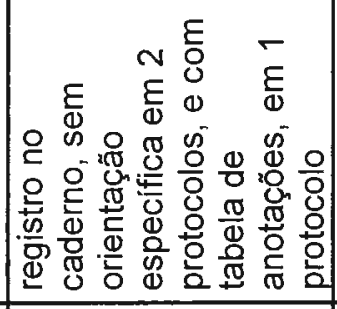 & 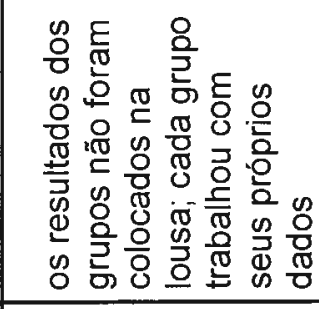 \\
\hline $\begin{array}{l}\tilde{W} \\
\text { ב్ }\end{array}$ & 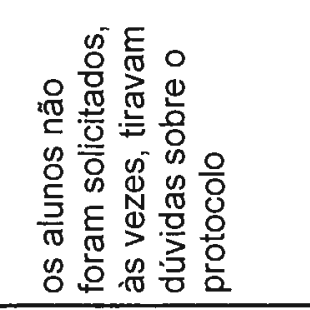 & 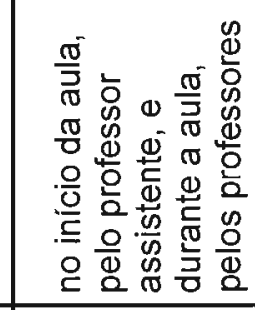 & 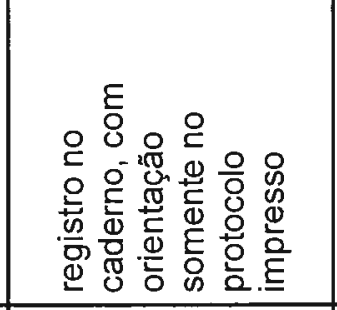 & 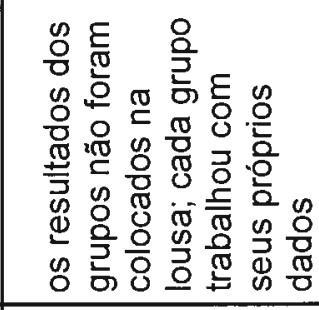 \\
\hline & 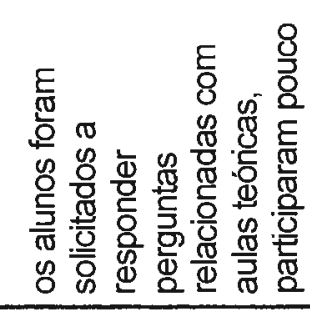 & 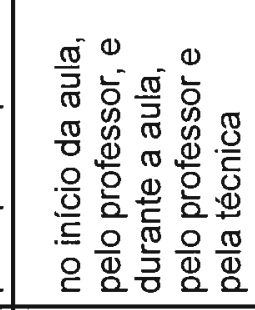 & 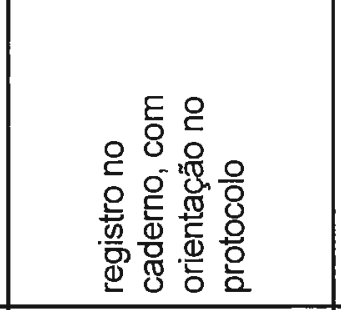 & 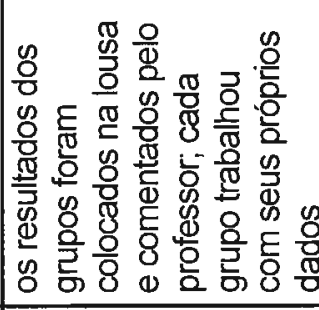 \\
\hline 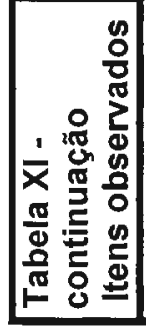 & 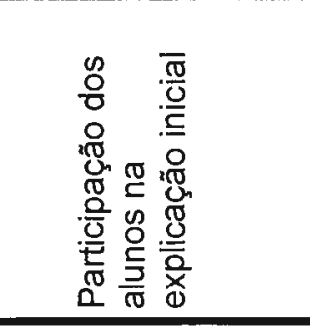 & 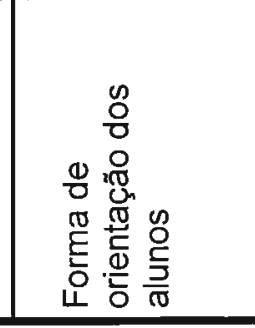 & 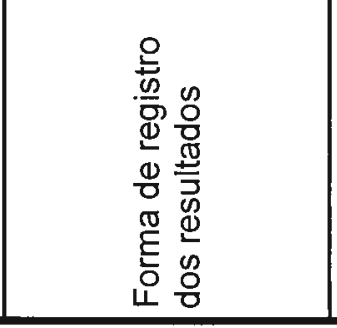 & 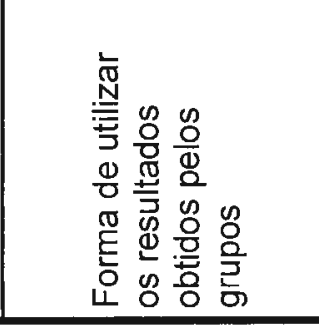 \\
\hline
\end{tabular}




\begin{tabular}{|c|c|c|c|c|}
\hline $\begin{array}{l}\stackrel{0}{0} \\
\stackrel{0}{د} \\
1 \\
\underline{m}\end{array}$ & $\frac{E}{\omega}$ & 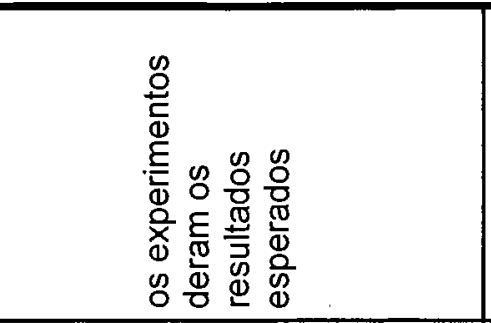 & 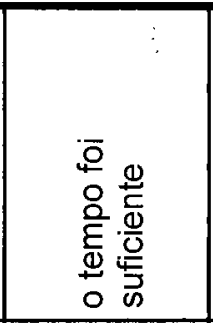 & 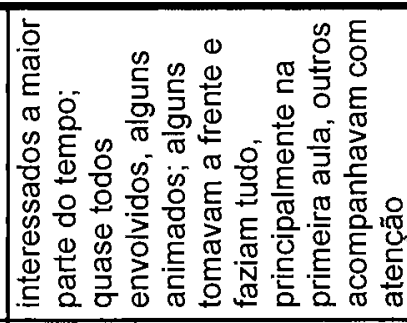 \\
\hline 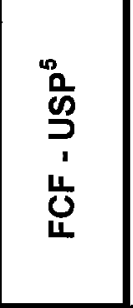 & $\frac{E}{\omega}$ & 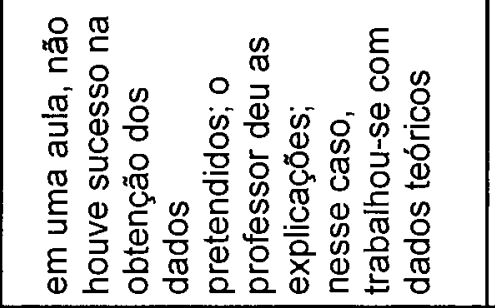 & 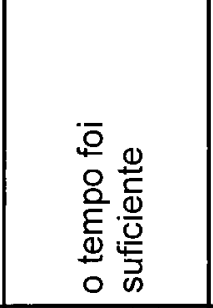 & 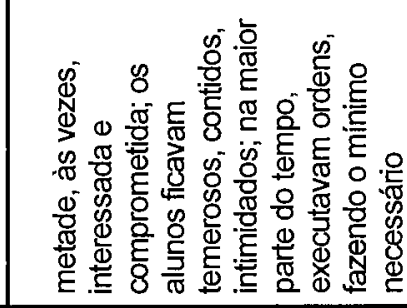 \\
\hline 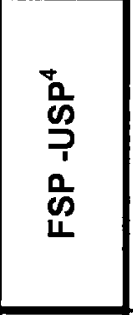 & $\frac{\varepsilon}{\omega}$ & 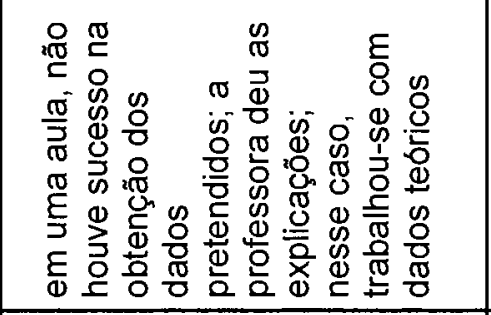 & 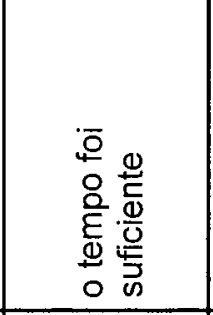 & 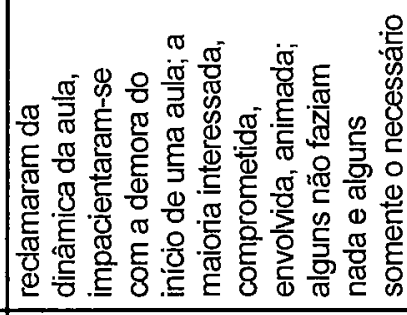 \\
\hline ”욤 & $\frac{E}{\omega}$ & 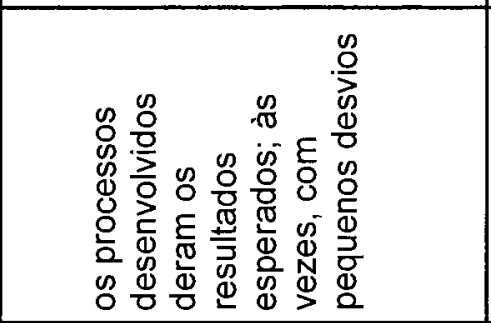 & 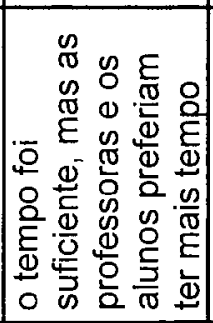 & 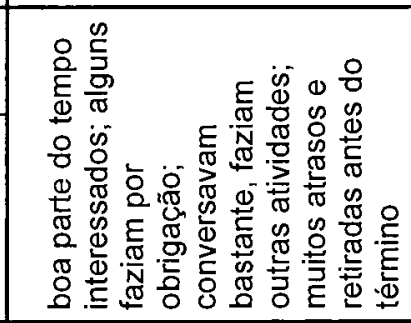 \\
\hline $\begin{array}{l}\text { U్ } \\
\text { త్ }\end{array}$ & $\frac{E}{\omega}$ & 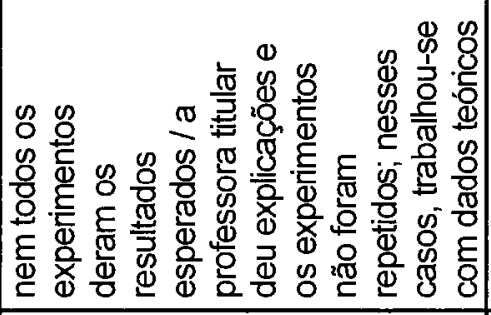 & 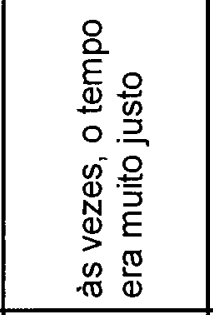 & 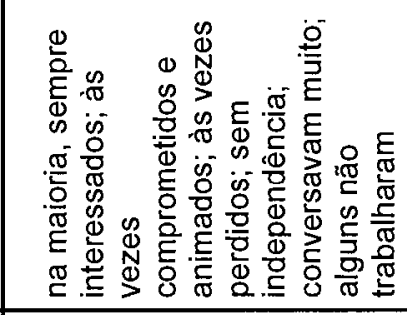 \\
\hline 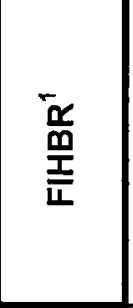 & $\frac{E}{\omega}$ & 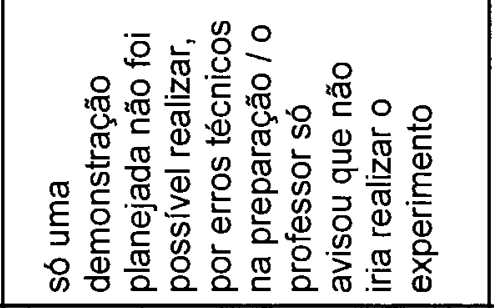 & 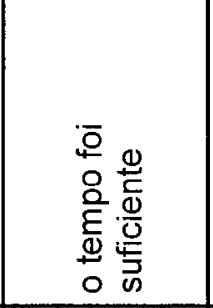 & 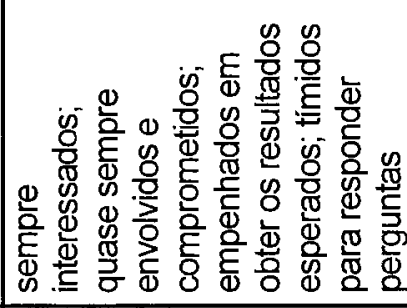 \\
\hline 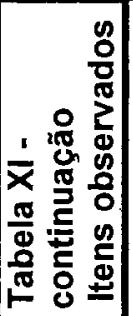 & 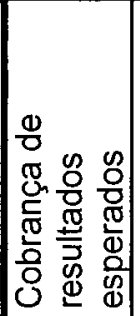 & 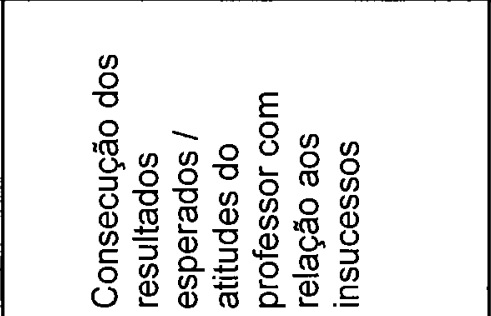 & 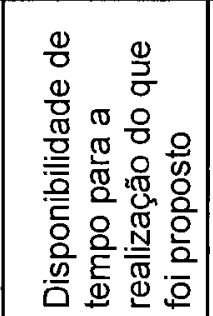 & 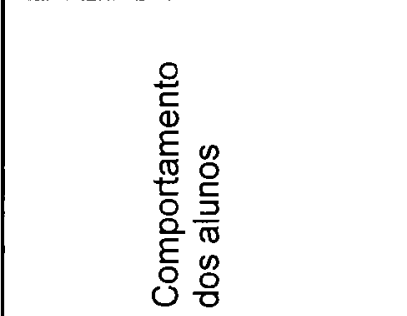 \\
\hline
\end{tabular}




\begin{tabular}{|c|c|c|c|c|}
\hline $\begin{array}{l}\frac{0}{0} \\
\stackrel{0}{\rho} \\
1 \\
\underline{m} \\
\underline{m}\end{array}$ & 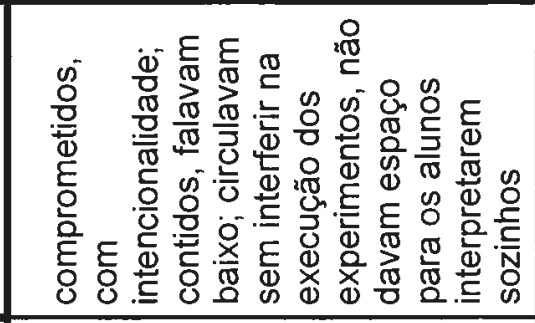 & 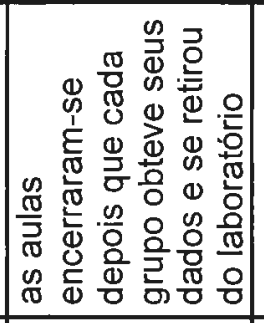 & 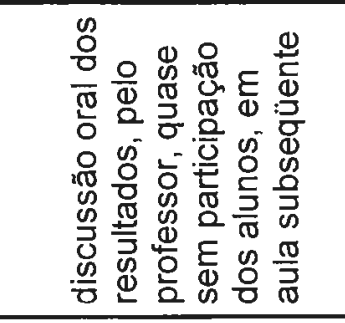 & 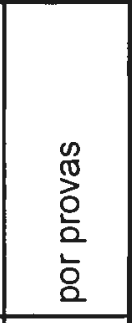 \\
\hline 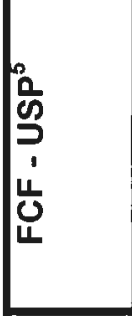 & 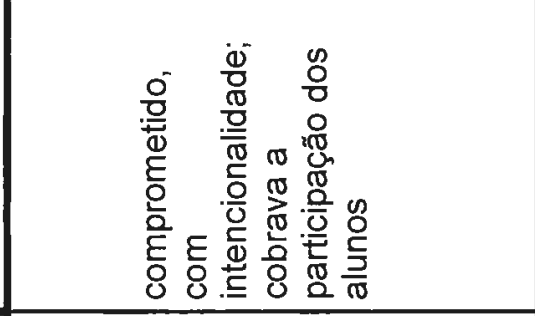 & 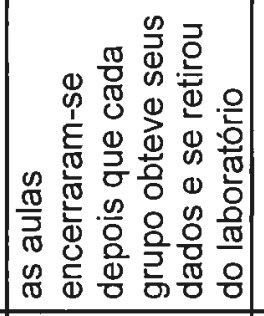 & 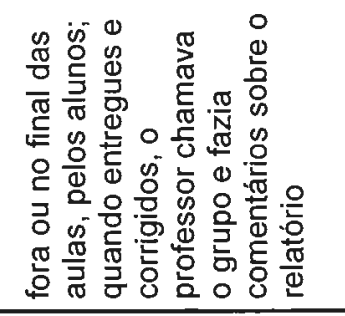 & 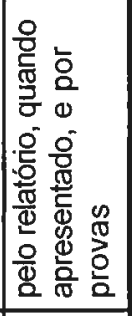 \\
\hline 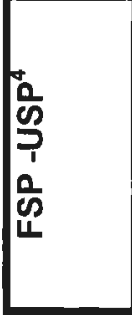 & 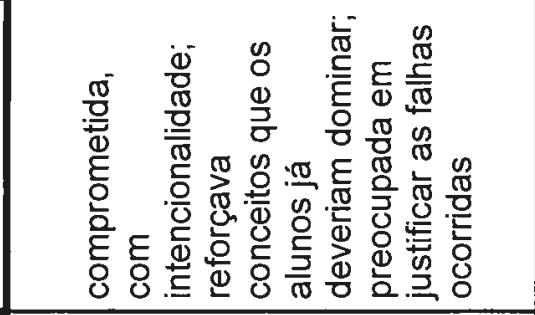 & 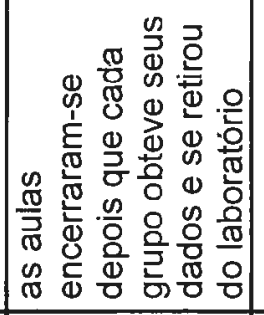 & 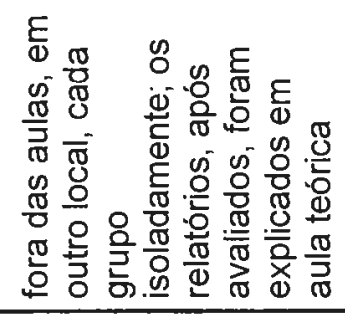 & 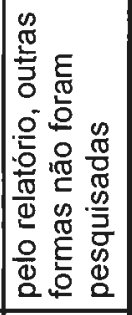 \\
\hline "0 & 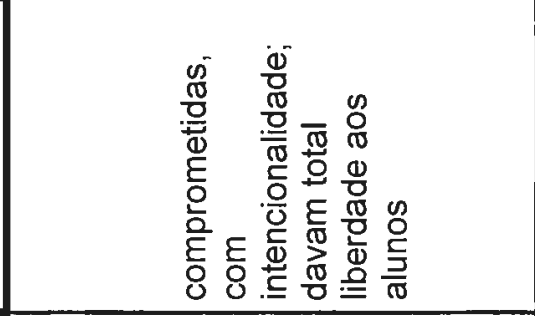 & 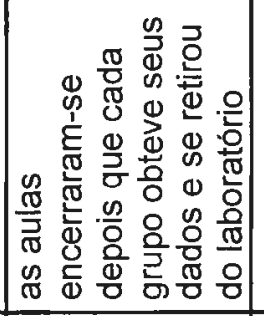 & 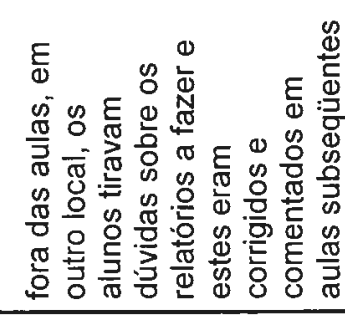 & 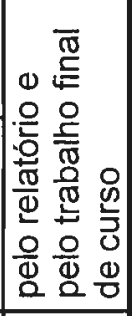 \\
\hline 苂 & 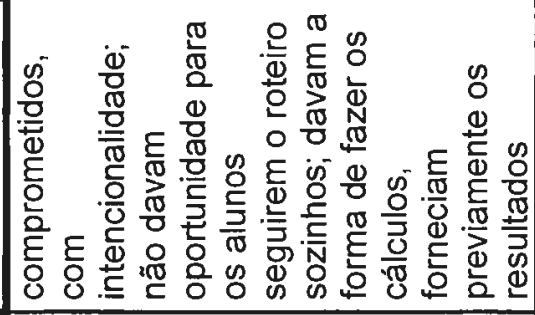 & 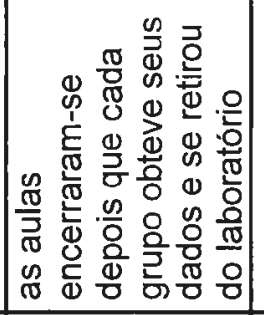 & 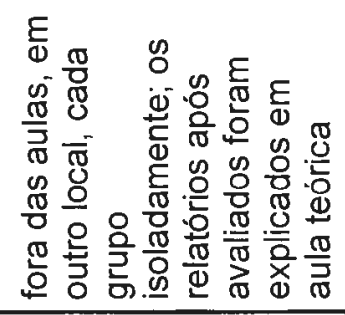 & 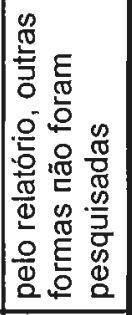 \\
\hline & 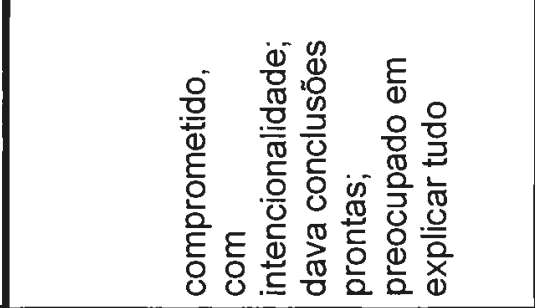 & 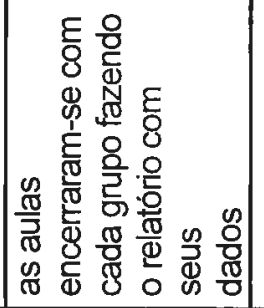 & 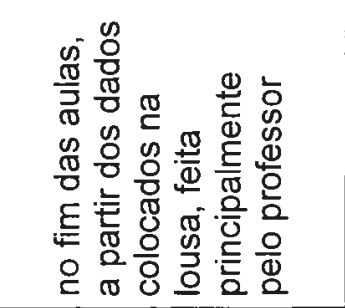 & 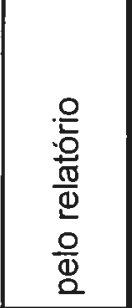 \\
\hline 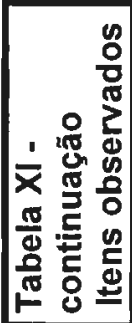 & 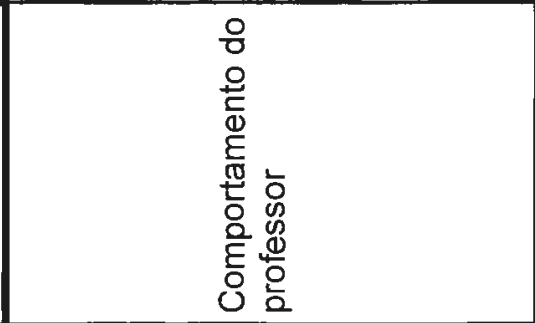 & 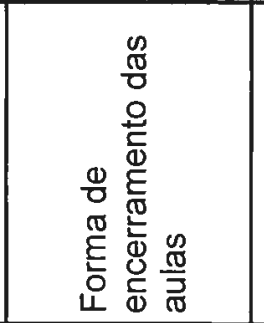 & 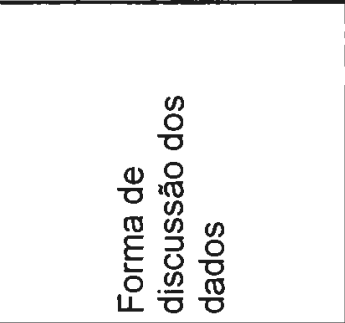 & 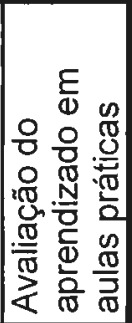 \\
\hline
\end{tabular}




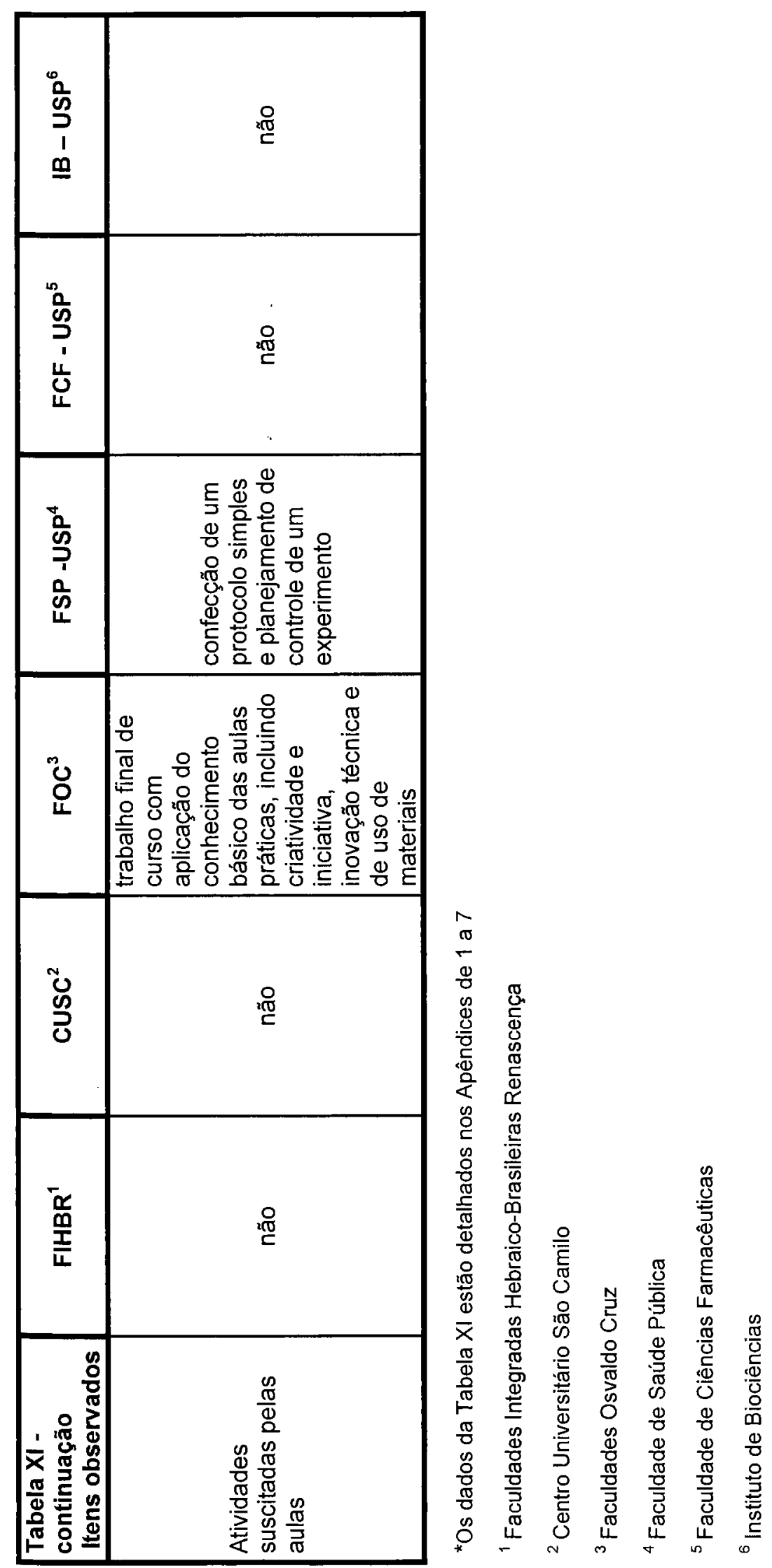




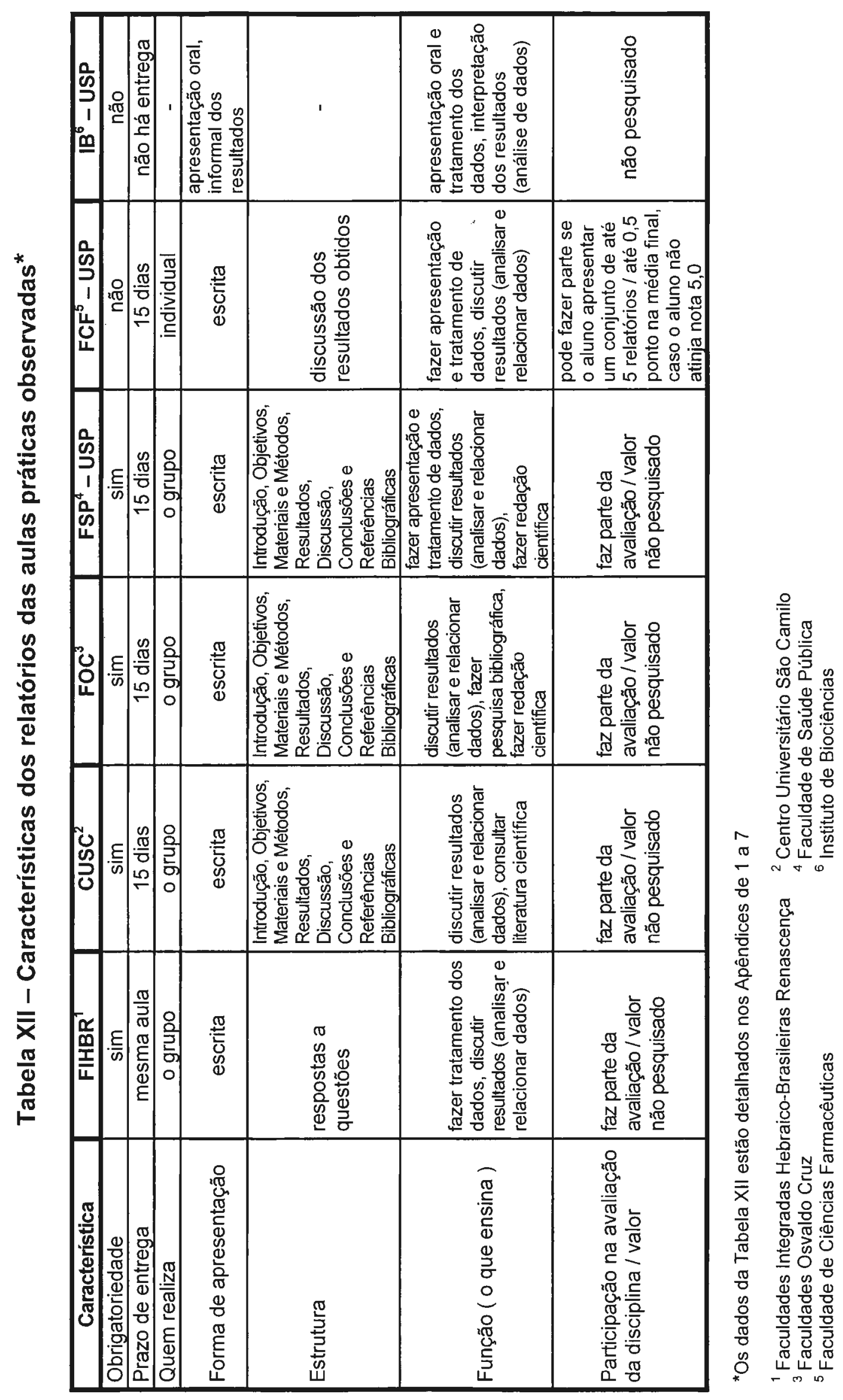




\section{B. Análise comparativa dos seis contextos observados}

\section{B. 1. Comparação entre as características gerais das instituições analisadas}

As seis instituições analisadas eram divididas em: três mantidas pela iniciativa privada e três mantidas pelo Governo do Estado de São Paulo. Verificou-se que há um cumprimento das exigências mínimas da Lei de Diretrizes e Bases da Educação Nacional (Brasil-Lei 9394/96) com relação à existência de cursos de pós-graduação, de atividades de extensão e de pesquisa, em cada nivel da classificação das instituições (Ver Item I. A. 2a - p. 39 - 41 e Apêndices de 1 a 7). Assim, as Faculdades Integradas HebraicoBrasileiras Renascença (FIHBR) e as Faculdades Oswaldo Cruz (FOC), classificadas como "Faculdades e/ou Escolas Superiores", não desenvolviam pesquisa laboratorial, nem atividades de extensão, e sim cursos de pósgraduação lato sensu / especialização; as publicações científicas não eram de artigos originais. Os "Centros Universitários" foram aqui representados pelo Centro Universitário São Camilo (CUSC) que também apresentava pósgraduação em nivel de lato sensu / especialização, com cursos que excediam em horas ao que é estabelecido por lei, não desenvolvia pesquisa laboratorial, nem suas publicações científicas eram de artigos originais. Das três instituições privadas analisadas, só o Centro Universitário São Camilo desenvolvia atividades de extensão que prestavam serviço à comunidade extramuros e sediavam parte do treinamento profissional dos estudantes.

As três unidades da Universidade de São Paulo observadas (FSP Faculdade de Saúde Pública; FCF - Faculdade de Ciências Farmacêuticas; IB Instituto de Biociências) desenvolviam pesquisa laboratorial, atividades de atendimento à comunidade (atividades de extensão). A Faculdade de Saúde Pública e a Faculdade de Ciências Farmacêuticas publicavam periódicos de divulgação científica e de artigos originais.

Os professores de Bioquímica que ministravam aulas práticas eram horistas, exerciam apenas docência nas instituições privadas e tinham outras atividades profissionais fora delas, enquanto que aqueles da instituição pública 
(USP) eram docentes, pesquisadores e orientadores de pesquisa, trabalhando em tempo integral e em regime de dedicação exclusiva.

As instituições privadas e a pública (ora representada pelo Departamento de Bioquímica do Instituto de Química da USP), analisadas nesta pesquisa, praticamente equivaliam-se nos apoios técnico e didático dados aos professores, com ligeira superioridade das empresas particulares de ensino. As instalações para atendimento e uso de alunos, fora de sala de aula teórica e laboratório (excluindo-se as bibliotecas), são melhores nas FOC e CUSC que no Departamento de Bioquímica e nas FIHBR.

O suporte econômico, muito maior na instituição pública, refletia-se no número de cursos oferecidos nas áreas de Ciências Biológicas e da Saúde em questão no presente estudo e no tamanho das instalações físicas ocupadas pelos cursos citados, muito maiores na USP que nas demais instituições observadas. Também a titulação dos professores era maior na USP, mas era adequada à legislação nas instituições particulares.

Aos alunos de graduação, em todas as instituições analisadas, eram oferecidas semanas científicas e/ou culturais específicas de cada curso, quando eram apresentadas palestras e outras atividades de divulgação de conhecimento, ministrados cursos e havia espaço e tempo para divulgação de trabalhos de alunos. Estes, contudo, não apresentavam trabalhos de iniciação científica em congressos oficiais das áreas estudadas, nas instituições particulares, porém houve casos dessas participações no Departamento de Bioquímica da USP.

\section{B. 2. Comparação entre cursos semelhantes, ministrados em} instituicões privadas e públicas

O curso de Ciências Biológicas foi observado nas Faculdades Integradas Hebraico-Brasileiras Renascença e no Instituto de Biociências da Universidade de São Paulo - Campus da Capital.

A Tabela XIII resume, de forma comparativa, os currículos dos dois cursos. 


\section{Tabela XIII - Grades curriculares dos cursos de Ciências Biológicas analisados*}

\begin{tabular}{|c|c|c|c|}
\hline \multicolumn{2}{|c|}{$\begin{array}{c}\text { FACULDADE INTEGRADAS HEBRAICO- } \\
\text { BRASILEIRAS RENASCENÇA }\end{array}$} & \multicolumn{2}{|c|}{$\begin{array}{l}\text { INSTITUTO DE BIOCIÊNCIAS - } \\
\text { UNIVERSIDADE DE SÃO PAULO }\end{array}$} \\
\hline Bacharelado - disciplinas & $\begin{array}{l}\text { No- de } \\
\text { horas }\end{array}$ & Bacharelado - disciplinas & $\begin{array}{l}N^{\circ} \text { de } \\
\text { horas }\end{array}$ \\
\hline $\begin{array}{l}\text { Biologia Geral I/ } \\
\text { Biologia Celular e Molecular }\end{array}$ & $\begin{array}{c}80 / \\
80\end{array}$ & $\begin{array}{l}\text { Biologia Celular / } \\
\text { Biologia Tecidual / } \\
\text { Biologia Molecular }\end{array}$ & $\begin{array}{l}120 / \\
60 / \\
120 \\
\end{array}$ \\
\hline $\begin{array}{l}\text { Química de Biomoléculas / } \\
\text { Bioquímica }\end{array}$ & $\begin{array}{l}801 \\
80 \\
\end{array}$ & $\begin{array}{l}\text { Química de Biomoléculas }{ }^{+} \\
\text {Bioquímica }^{+}\end{array}$ & $\begin{array}{l}60 / \\
120 \\
\end{array}$ \\
\hline $\begin{array}{l}\text { Princípios de Sistemática e } \\
\text { Biogeografia }\end{array}$ & 60 & $\begin{array}{l}\text { Princípios de Sistemática e } \\
\text { Biogeografia }\end{array}$ & 60 \\
\hline Estatistica & 80 & $\begin{array}{l}\text { Matemática / } \\
\text { Noções de Estatística }\end{array}$ & $\begin{array}{l}301 \\
60\end{array}$ \\
\hline Metodologia das Ciências & 60 & História e Filosofia das Ciências & 60 \\
\hline Educação Física (I a VIII) & 320 & Prática Esportiva & 30 \\
\hline Biologia Geral II & 80 & Genética & 120 \\
\hline Zoologia I & 80 & $\begin{array}{l}\text { Invertebrados I/ } \\
\text { Invertebrados II }\end{array}$ & $\begin{array}{l}120 l \\
120 \\
\end{array}$ \\
\hline Botânica I & 80 & $\begin{array}{l}\text { Morfologia e Taxonomia de } \\
\text { Criptógamas }\end{array}$ & 120 \\
\hline Fisica e Biofísica & 80 & Física e Biofísica & 120 \\
\hline Zoologia II & 80 & Vertebrados & 120 \\
\hline $\begin{array}{l}\text { Botânica II / } \\
\text { Botânica III }\end{array}$ & $\begin{array}{c}80 / \\
80 \\
\end{array}$ & $\begin{array}{l}\text { Morfologia e Anatomia de Plantas } \\
\text { Vasculares / } \\
\text { Taxonomia de Fanerógamas }\end{array}$ & $\begin{array}{c}120 / \\
60 \\
\end{array}$ \\
\hline Ecologia Geral & 80 & Ecologia & 60 \\
\hline Fisiologia Humana e Comparativa I & 80 & Fisiologia Humana e Comparativa I & 120 \\
\hline Geologia e Paleontologia & 80 & $\begin{array}{l}\text { Geologia Geral / } \\
\text { Paleontologia Geral }\end{array}$ & $\begin{array}{c}60 / \\
60 \\
\end{array}$ \\
\hline Fisiologia Humana e Comparativa II & 80 & $\begin{array}{l}\text { Fisiologia Humana e Comparativa II / } \\
\text { Fisiologia Humana e Comparativa III }\end{array}$ & $\begin{array}{l}120 \prime \\
120 \\
\end{array}$ \\
\hline Imunologia e Microbiologia & 40 & $\begin{array}{l}\text { Imunologia / } \\
\text { Microbiologia }\end{array}$ & $\begin{array}{l}601 \\
60 \\
\end{array}$ \\
\hline Ecossistemas & 80 & Fauna, Flora e Ambiente & 60 \\
\hline Ecologia Vegetal & 80 & $\begin{array}{l}\text { Ecologia Vegetal / } \\
\text { Fisiologia Vegetal }\end{array}$ & $\begin{array}{c}240 / \\
120 \\
\end{array}$ \\
\hline Ecologia Animal & 80 & Ecologia Animal & 60 \\
\hline Processos Evolutivos & 60 & Processos Evolutivos & 60 \\
\hline Ecologia Humana & 80 & Ecologia Humana & 60 \\
\hline Recursos Naturais & 60 & Recursos Econômicos Vegetais & 60 \\
\hline & & Saúde Coletiva & 60 \\
\hline $\begin{array}{l}\text { História do Povo e da Cultura dos } \\
\text { Judeus I / } \\
\text { História do Povo e da Cultura dos } \\
\text { Judeus II }\end{array}$ & $\begin{array}{l}40 / \\
40 \\
\end{array}$ & & \\
\hline Conservação da Natureza & 60 & & \\
\hline Biotecnologia & 80 & & \\
\hline Total de horas do bacharelado & 2420 & Total de horas do bacharelado & 3060 \\
\hline
\end{tabular}




\begin{tabular}{|c|c|c|c|}
\hline \multicolumn{2}{|c|}{$\begin{array}{l}\text { Tabela XIII - continuação } \\
\text { FACULDADE INTEGRADAS HEBRAICO- } \\
\text { BRASILEIRAS RENASCENÇA }\end{array}$} & \multicolumn{2}{|c|}{$\begin{array}{l}\text { INSTITUTO DE BIOCIÊNCIAS - } \\
\text { UNIVERSIDADE DE SÃO PAULO }\end{array}$} \\
\hline Licenciatura - disciplinas & $\begin{array}{l}\mathrm{N} \text { - de } \\
\text { horas }\end{array}$ & Licenciatura - disciplinas & $\begin{array}{l}N^{\circ}-\text { de } \\
\text { horas }\end{array}$ \\
\hline & & $\begin{array}{l}\text { Introdução aos Estudos da } \\
\text { Educação }\end{array}$ & 60 \\
\hline Didática & 80 & Didática & 60 \\
\hline Prática de Ensino & 80 & $\begin{array}{l}\text { Metodologia de Ensino em } \\
\text { Ciências Biológicas I/ } \\
\text { Metodologia de Ensino em } \\
\text { Ciências Biológicas II }\end{array}$ & $\begin{array}{l}60 l \\
60\end{array}$ \\
\hline $\begin{array}{l}\text { Estrutura e Funcionamento do } \\
\text { Ensino Fundamental / E. F. E. Médio }\end{array}$ & $\begin{array}{l}80 / \\
80\end{array}$ & $\begin{array}{l}\text { Política e Organização da } \\
\text { Educação Básica no Brasil I e II }\end{array}$ & $\begin{array}{l}60 / \\
20 \\
\end{array}$ \\
\hline Psicologia da Educação & 80 & Psicologia da Educação & 60 \\
\hline \multirow[t]{3}{*}{ Educação e Legislação Ambiental } & 60 & Ensino de Educaçăo Ambiental & 60 \\
\hline & & $\begin{array}{l}\text { Instrumentação para o Ensino de } \\
\text { Ciências }\end{array}$ & 60 \\
\hline & & $\begin{array}{l}\text { Coleta e Manutenção de Material } \\
\text { Biológico }\end{array}$ & 60 \\
\hline $\begin{array}{l}\text { Estágio Supervisionado I/ } \\
\text { Estágio Supervisionado II }\end{array}$ & $\begin{array}{l}150 / \\
150\end{array}$ & Projeto de Ensino de Biologia & 60 \\
\hline Total de horas da licenciatura & 760 & Total de horas da licenciatura & 620 \\
\hline $\begin{array}{l}\text { Total de horas de bacharelado + } \\
\text { licenciatura }\end{array}$ & 3180 & $\begin{array}{l}\text { Total de horas de bacharelado + } \\
\text { licenciatura }\end{array}$ & 3680 \\
\hline
\end{tabular}

*Os dados da Tabela XIII estão detalhados nos Anexos 1 e 16

Fazendo a análise da Tabela XIII, verifica-se que o número de horas de disciplinas equivalentes, nos dois cursos, é quase sempre maior no curso de Ciências Biológicas do Instituto de Biociências da USP do que naquele das Faculdades Integradas Hebraico-Brasileiras Renascença, com exceção de "Práticas Desportivas" e "Educação Física", respectivamente de cada curso, em que a última disciplina, das FIHBR, tem carga horária bem maior, sendo desenvolvida aos sábados, em todos os semestres, pois trata-se de um curso noturno.

As diferenças entre os conjuntos de disciplinas dos cursos das duas instituições são pequenas. Sendo as FIHBR uma empresa de iniciativa da comunidade judaica, apresenta, nos currículos de todos os cursos, a disciplina "História do Povo e da Cultura dos Judeus". Nessa instituição, as disciplinas "Conservação da Natureza" e "Biotecnologia" refletem o fato de o curso ser de criação recente e já espelhar as tendências mais atuais da Biologia. "Saúde Coletiva", de Ciências Biológicas do IB - USP, fica, de certa forma, à parte da tendência geral de seu currículo. 
O curso de Ciências Biológicas das FIHBR tem 2420 horas no Bacharelado e 760 horas na Licenciatura, enquanto que o do IB - USP tem, respectivamente, 3060 horas e 720 horas. De forma geral, tendo o IB - USP grande desenvolvimento em pesquisa laboratorial e esta atividade sendo ausente nas FIHBR, pode-se afirmar que os currículos dos cursos de Ciências Biológicas das duas instituições pendem, ligeiramente, o primeiro para o preparo de pesquisadores (Bacharelado) e o último, para o preparo de docentes (Licenciatura), se compararmos a proporção entre o número de horas de bacharelado e o de licenciatura de cada instituição.

Dois outros cursos semelhantes foram observados na presente pesquisa, em instituições privada e pública: Nutrição do Centro Universitário São Camilo e Nutrição da Faculdade de Saúde Pública da Universidade de São Paulo. A Tabela XIV mostra, a seguir, o resumo comparativo dos currículos destes dois cursos.

Tabela XIV - Grades curriculares dos cursos de Nutrição analisados*

\begin{tabular}{|c|c|c|c|}
\hline \multicolumn{2}{|c|}{ CENTRO UNIVERSITÁRIO SÃO CAMILO } & \multicolumn{2}{|c|}{$\begin{array}{l}\text { FACULDADE DE SAÚDE PÚBLICA } \\
\text { UNIVERSIDADE DE SÃO PAULO }\end{array}$} \\
\hline Ciclo Básico - disciplina & $\begin{array}{l}N^{\circ} \text { de } \\
\text { horas }\end{array}$ & Ciclo Básico - disciplina & $\begin{array}{l}N^{\circ} \text { de } \\
\text { horas }\end{array}$ \\
\hline Biologia / / Biologia II & $80 / 40$ & Citologia, Histologia e Embriologia & 75 \\
\hline Anatomia Humana & 80 & Anatomia Humana & 105 \\
\hline $\begin{array}{l}\text { Metodologia da Pesquisa } \\
\text { Científica / } \\
\text { Comunicação Oral e Gráfica }\end{array}$ & $\begin{array}{l}40 / \\
40\end{array}$ & $\begin{array}{l}\text { Orientação Bibliográfica / } \\
\text { Informática }\end{array}$ & $\begin{array}{l}30 / \\
15\end{array}$ \\
\hline $\begin{array}{l}\text { Fundamentos de Química } \\
\text { Orgânica }\end{array}$ & 40 & Química de Biomoléculas & 60 \\
\hline Bioquímica & 80 & Bioquímica & 120 \\
\hline $\begin{array}{l}\text { Morfologia Humana / } \\
\text { Fisiologia Humana I/ } \\
\text { Fisiologia Humana II }\end{array}$ & $\begin{array}{l}40 / \\
60 / \\
60 \\
\end{array}$ & Fisiologia e Biofísica & 135 \\
\hline Bioestatística & 40 & $\begin{array}{l}\text { Bioestatística Aplicada à Saúde } \\
\text { Pública }\end{array}$ & 75 \\
\hline Microbiologia e Imunologia & 80 & $\begin{array}{l}\text { Microbiologia / } \\
\text { Microbiologia de Alimentos / } \\
\text { Imunologia Aplicada à Nutrição }\end{array}$ & $\begin{array}{l}60 / \\
60 / \\
60\end{array}$ \\
\hline $\begin{array}{l}\text { Introdução à Ciência da Nutrição / } \\
\text { Nutrição Normal }\end{array}$ & $\begin{array}{l}80 / \\
80 \\
\end{array}$ & Nutrição Normal & 90 \\
\hline Bromatologia & 80 & Bromatologia Básica & 90 \\
\hline Epidemiologia e Saneamento & 60 & $\begin{array}{l}\text { Epidemiologia / } \\
\text { Fundamentos de Saneamento do } \\
\text { Meio }\end{array}$ & $\begin{array}{l}45 / \\
30\end{array}$ \\
\hline Higiene e Qualidade dos Alimentos & 60 & Higiene e Controle de Alimentos & 75 \\
\hline
\end{tabular}




\begin{tabular}{|c|c|c|c|}
\hline \multicolumn{2}{|c|}{$\begin{array}{l}\text { Tabela XIV - continuação } \\
\text { CENTRO UNIVERSITÁRIO SÃO CAMILO }\end{array}$} & \multicolumn{2}{|c|}{$\begin{array}{l}\text { FACULDADE DE SAÚDE PÚBLICA } \\
\text { UNIVERSIDADE DE SÃO PAULO }\end{array}$} \\
\hline $\begin{array}{l}\text { Ciclo Básico - disciplina } \\
\text { continuação }\end{array}$ & $\begin{array}{l}N^{\circ} \text { de } \\
\text { horas }\end{array}$ & $\begin{array}{l}\text { Ciclo Básico - disciplina } \\
\text { continuação }\end{array}$ & $\begin{array}{l}N^{0} \text { de } \\
\text { horas }\end{array}$ \\
\hline Sociologia & 40 & Sociologia Aplicada à Nutrição & 30 \\
\hline Parasitologia & 40 & Parasitologia Aplicada à Nutrição & 60 \\
\hline Patologia Aplicada à Nutrição & 60 & $\begin{array}{l}\text { Patologia Geral / } \\
\text { Fisiopatologia da Nutrição }\end{array}$ & $\begin{array}{l}30 / \\
120\end{array}$ \\
\hline Dietética & 80 & $\begin{array}{l}\text { Dietética / Fundamentos } \\
\text { Bromatológicos da Dietética }\end{array}$ & $\begin{array}{l}1051 \\
75 \\
\end{array}$ \\
\hline $\begin{array}{l}\text { Técnicas Dietéticas I/ } \\
\text { Técnicas Dietéticas II }\end{array}$ & $\begin{array}{l}100 / \\
100 \\
\end{array}$ & Técnica Dietética & 105 \\
\hline Composição dos Alimentos & 40 & Estudo Experimental de Alimentos & 105 \\
\hline Tecnologia dos Alimentos & 60 & Tecnologia dos Alimentos & 60 \\
\hline Farmacologia & 60 & $\begin{array}{l}\text { Farmacologia / } \\
\text { Substâncias Tóxicas em Alimentos }\end{array}$ & $\begin{array}{l}45 \prime \\
30\end{array}$ \\
\hline $\begin{array}{l}\text { Estudo da Comunidade / } \\
\text { Desenvolvimento da Comunidade }\end{array}$ & $\begin{array}{l}401 \\
40 \\
\end{array}$ & Desenvolvimento de Comunidade & 45 \\
\hline $\begin{array}{l}\text { Dietoterapia / } \\
\text { Terapia Nutricional }\end{array}$ & $\begin{array}{l}100 / \\
100\end{array}$ & Dietoterapia & 120 \\
\hline $\begin{array}{l}\text { Avaliação Nutricional I/ } \\
\text { Avaliação Nutricional II }\end{array}$ & $\begin{array}{l}601 \\
60 \\
\end{array}$ & Avaliação do Consumo Alimentar & 75 \\
\hline Educação Nutricional & 60 & Educação Nutricional & 105 \\
\hline Nutrição em Saúde Pública & 60 & Nutrição em Saúde Pública & 60 \\
\hline \multirow[t]{3}{*}{$\begin{array}{l}\text { Nutrição e Desenvolvimento } \\
\text { Humano }\end{array}$} & 80 & & \\
\hline & & Antropologia Social & 30 \\
\hline & & $\begin{array}{l}\text { Saúde Materna, da Criança e do } \\
\text { Adolescente }\end{array}$ & 75 \\
\hline Tópicos Especiais em Nutrição & 60 & & \\
\hline Introdução à Administração & 60 & & \\
\hline $\begin{array}{l}\text { Administração de Unidades de } \\
\text { Alimentação e Nutrição (UAN) }\end{array}$ & 60 & $\begin{array}{l}\text { Administração de Unidades de } \\
\text { Alimentação e Nutrição (UAN) }\end{array}$ & 90 \\
\hline Gestão Organizacional & 60 & Gerenciamento Institucional & 120 \\
\hline Economia & 60 & & \\
\hline $\begin{array}{l}\text { Administração das Organizações } \\
\text { da Saúde }\end{array}$ & 40 & & \\
\hline Gestão de Qualidade em UAN & 60 & & \\
\hline $\begin{array}{l}\text { Etica, Bioética e Legislação } \\
\text { Profissional }\end{array}$ & 40 & & \\
\hline $\begin{array}{l}\text { Psicologia e Desenvolvimento das } \\
\text { Relaçōes }\end{array}$ & 60 & & \\
\hline $\begin{array}{l}\text { Comunicação e Educação } \\
\text { Alimentar }\end{array}$ & 60 & & \\
\hline $\begin{array}{l}\text { Ciclo Profissionalizante } \\
\text { Estágios Supervisionados }\end{array}$ & $\begin{array}{l}N^{\circ} \text { de } \\
\text { horas }\end{array}$ & $\begin{array}{l}\text { Ciclo Profissionalizante } \\
\text { Estágios Supervisionados }\end{array}$ & $\begin{array}{l}\text { No de } \\
\text { horas }\end{array}$ \\
\hline Saúde Pública & 300 & & \\
\hline Alimentação Institucional & 300 & & \\
\hline Instituições Diferenciadas & 300 & & \\
\hline \multirow[t]{3}{*}{ Nutriçăo Clínica } & 300 & Nutrição Clínica & 255 \\
\hline & & Administração de UAN & 255 \\
\hline & & Nutrição de Grupos Populacionais & 255 \\
\hline
\end{tabular}




\begin{tabular}{|c|c|c|c|}
\hline \multicolumn{2}{|c|}{$\begin{array}{l}\text { Tabela XIV - continuação } \\
\text { CENTRO UNIVERSITÃRIO SÃO CAMILO }\end{array}$} & \multicolumn{2}{|c|}{$\begin{array}{l}\text { FACULDADE DE SAÚDE PÚBLICA } \\
\text { UNIVERSIDADE DE SÃO PAULO }\end{array}$} \\
\hline $\begin{array}{l}\text { Ciclo Profissionalizante } \\
\text { Estágios Supervisionados } \\
\text { continuação }\end{array}$ & $\begin{array}{l}N^{\circ} \text { de } \\
\text { horas }\end{array}$ & $\begin{array}{l}\text { Ciclo Profissionalizante } \\
\text { Estágios Supervisionados } \\
\text { continuação }\end{array}$ & $\begin{array}{l}N^{\circ} \text { de } \\
\text { horas }\end{array}$ \\
\hline & & $\begin{array}{l}\text { Experimentação com Alimentos e } \\
\text { Marketing" }\end{array}$ & 255 \\
\hline Total de horas do ciclo básico & 2780 & Total de horas do ciclo básico & 2610 \\
\hline $\begin{array}{l}\text { Total de horas do ciclo } \\
\text { profissionalizante }\end{array}$ & 1200 & $\begin{array}{l}\text { Total de horas do ciclo } \\
\text { profissionalizante }\end{array}$ & 1020 \\
\hline Total de horas do curso & 3980 & Total de horas do curso & 3630 \\
\hline
\end{tabular}

*Os dados da Tabela XIV estão detalhados nos Anexos 4 e 10

O curso de Nutrição do CUSC excede em número de horas-aulas e de estágios supervisionados àquele da FSP - USP.

Verifica-se, pelo rol de disciplinas dos dois cursos, que, no curso de Nutrição do CUSC, há uma preocupação com as relações "nutricionista $X$ assistidos", representada pelas disciplinas de "Ética, Bioética e Legislação Profissional", "Psicologia e Desenvolvimento das Relações" e "Comunicação e Educação Alimentar", num total de $160 \mathrm{~h}$, que não aparece no da FSP USP.

O curso de Nutrição da FSP - USP desenvolve o assunto "experimentação com alimentos", tanto no ciclo básico ("Estudo Experimental de Alimentos"), como no ciclo profissionalizante ("Experimentação com Alimentos e Marketing"), concordando com a já citada tradição de pesquisa laboratorial da USP, e trata de marketing, tópico extremamente importante na atualidade, pois influi sobre a escolha de alimentos pela população e, portanto, indiretamente, sobre sua saúde. Estes dois últimos enfoques citados não aparecem no curso de Nutrição do CUSC.

Disciplinas sobre saúde pública do curso de nutrição da FSP - USP estão presentes, tanto no ciclo básico ("Nutrição em Saúde Pública", "Saúde Materna, da Criança e do Adolescente", somando 135 horas), como no ciclo profissionalizante ("Nutrição de Grupos Populacionais", com 255 horas), totalizando 390 horas; também no CUSC, as disciplinas dessa área aparecem no ciclo básico, "Nutrição em Saúde Pública", com 60 horas, e no ciclo profissionalizante, "Saúde Pública", com 300 horas, num total de 360 horas. Há, portanto, uma equivalência, nesse aspecto, entre os dois cursos. 
No CUSC, percebe-se uma ligeira tendência a valorizar os aspectos gerais da profissão, ao contrário do que ocorre na FSP - USP, cujo currículo pende mais para os aspectos específicos ("Bioestatística" $X$ "Bioestatística Aplicada à Saúde Pública"; "Microbiologia e Imunologia" X "Microbiologia", "Microbiologia de Alimentos" e "Imunologia Aplicada à Nutrição"; "Sociologia" $X$ "Sociologia Aplicada à Nutrição" e "Antropologia Social"; "Parasitologia" X "Parasitologia Aplicada à Nutrição"; "Patologia Aplicada à Nutrição" X "Patologia Geral" e "Fisiopatologia da Nutrição"; "Bromatologia" X "Bromatologia Básica" e "Fundamentos Bromatológicos da Dietética"; "Farmacologia" X "Farmacologia" e "Substâncias Tóxicas em Alimentos").

O curso de Nutrição do CUSC dá especial atenção ao ensino sobre as instituições de saúde que trabalham com nutrição e alimentação (ciclo básico "Introdução à Administração", "Administração de Unidades de Alimentação e Nutrição (UAN)", "Gestão Organizacional", "Economia", "Administração das Organizações da Saúde", "Gestão de Qualidade em UAN"; ciclo profissionalizante - "Alimentação Institucional", "Instituições Diferenciadas"), perfazendo 940h, enquanto que o curso de Nutrição da FSP - USP, dedica a esse assunto 210 horas no ciclo básico ("Administração de UAN", "Gerenciamento Institucional") e 255 horas no ciclo profissionalizante ("Administração de UAN"), somando 465 horas, metade do tempo do CUSC. Isso justifica a presença de disciplinas que tratam de relações humanas, citadas anteriormente, presentes no currículo de Nutrição desta última instituição, que é mantida pelos padres camilianos, e que pode ter origem no fato de eles serem administradores de grande número de hospitais em São Paulo e em todo país.

\section{B. 3. Adequação das programações das disciplinas com conteúdo} de Bioquímica observadas, em relação ao enfoque dos cursos em que estão inseridas

A Tabela XV mostra um resumo que permite a comparação entre as disciplinas com conteúdo de Bioquímica dos cursos analisados. 


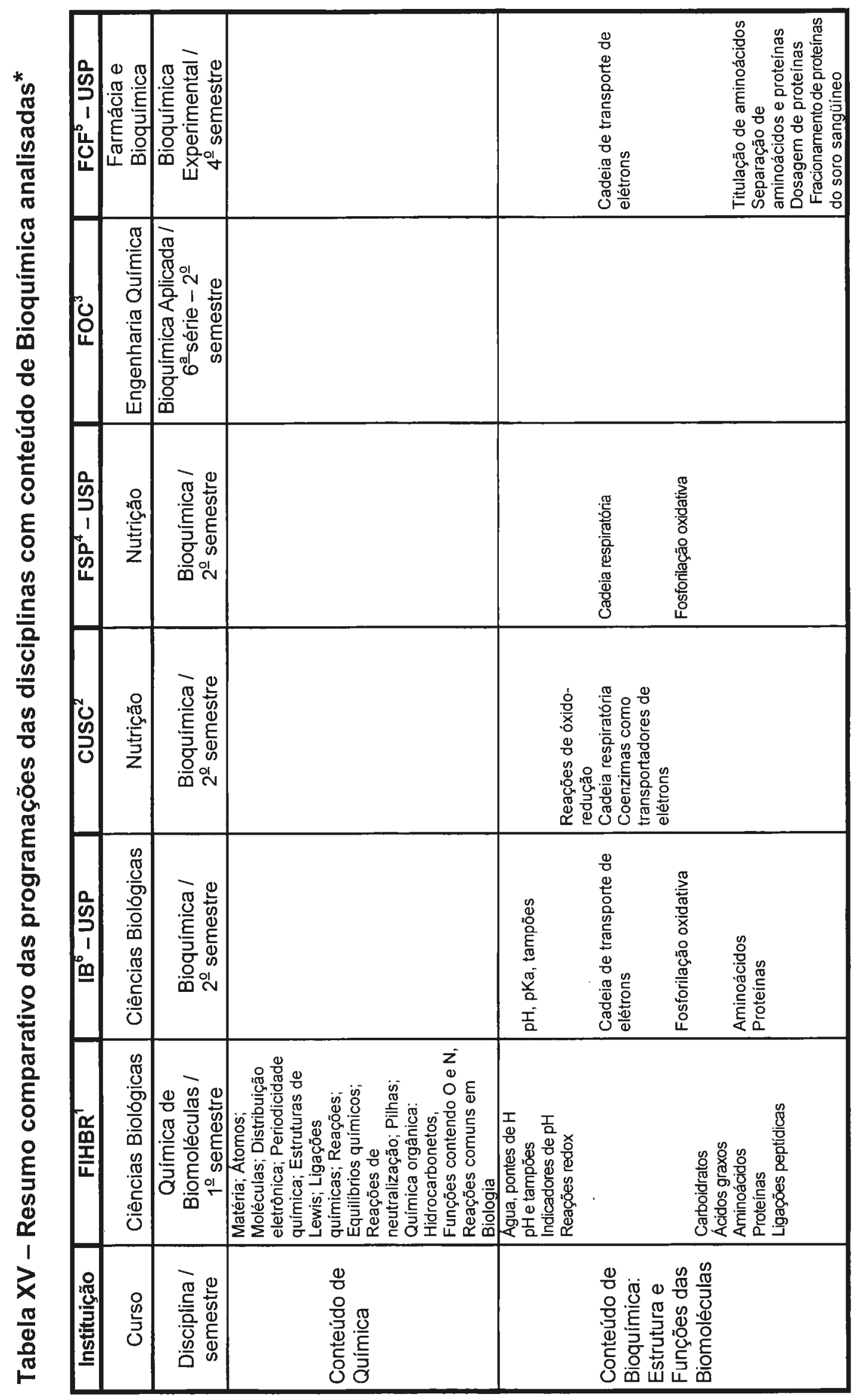




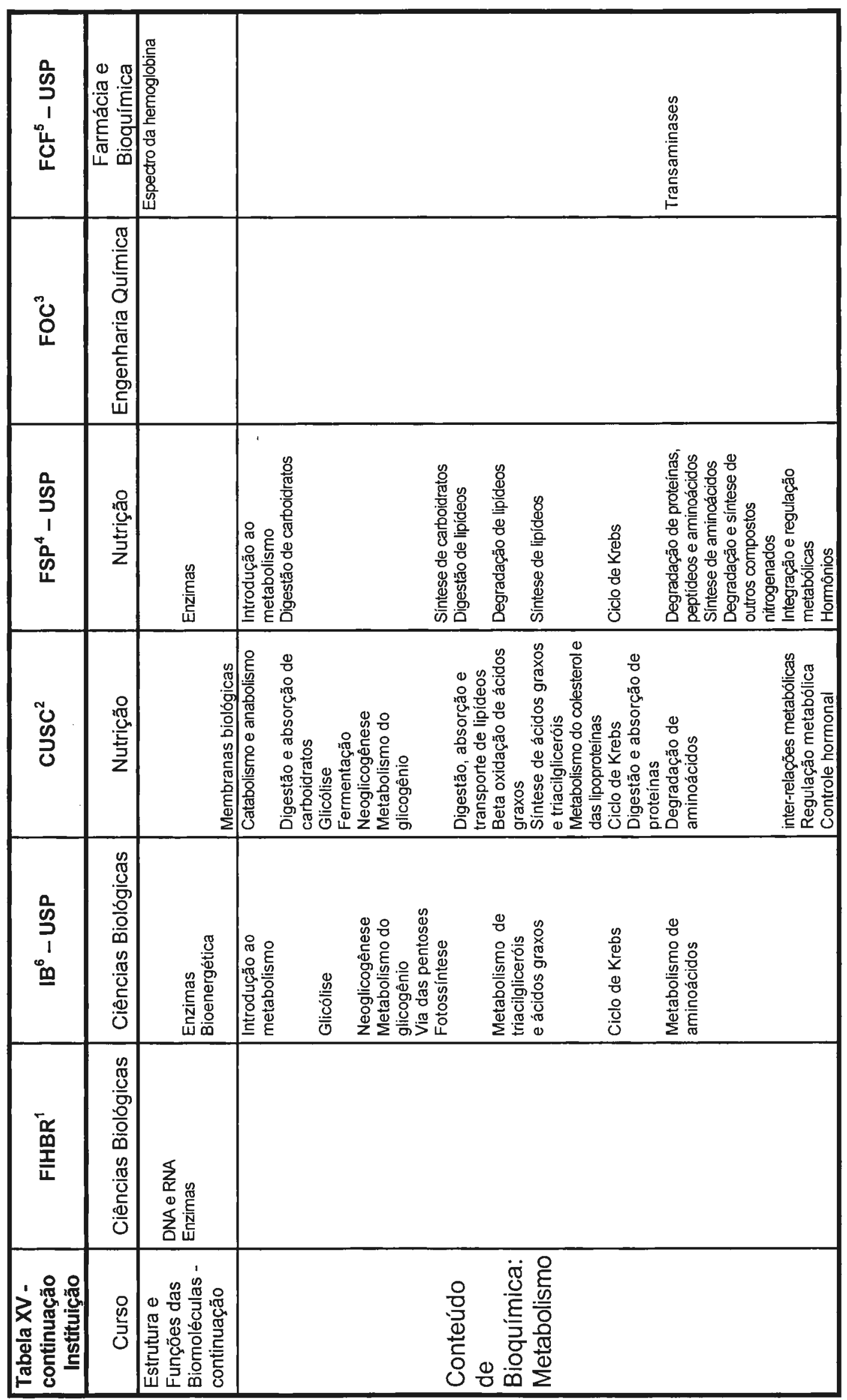




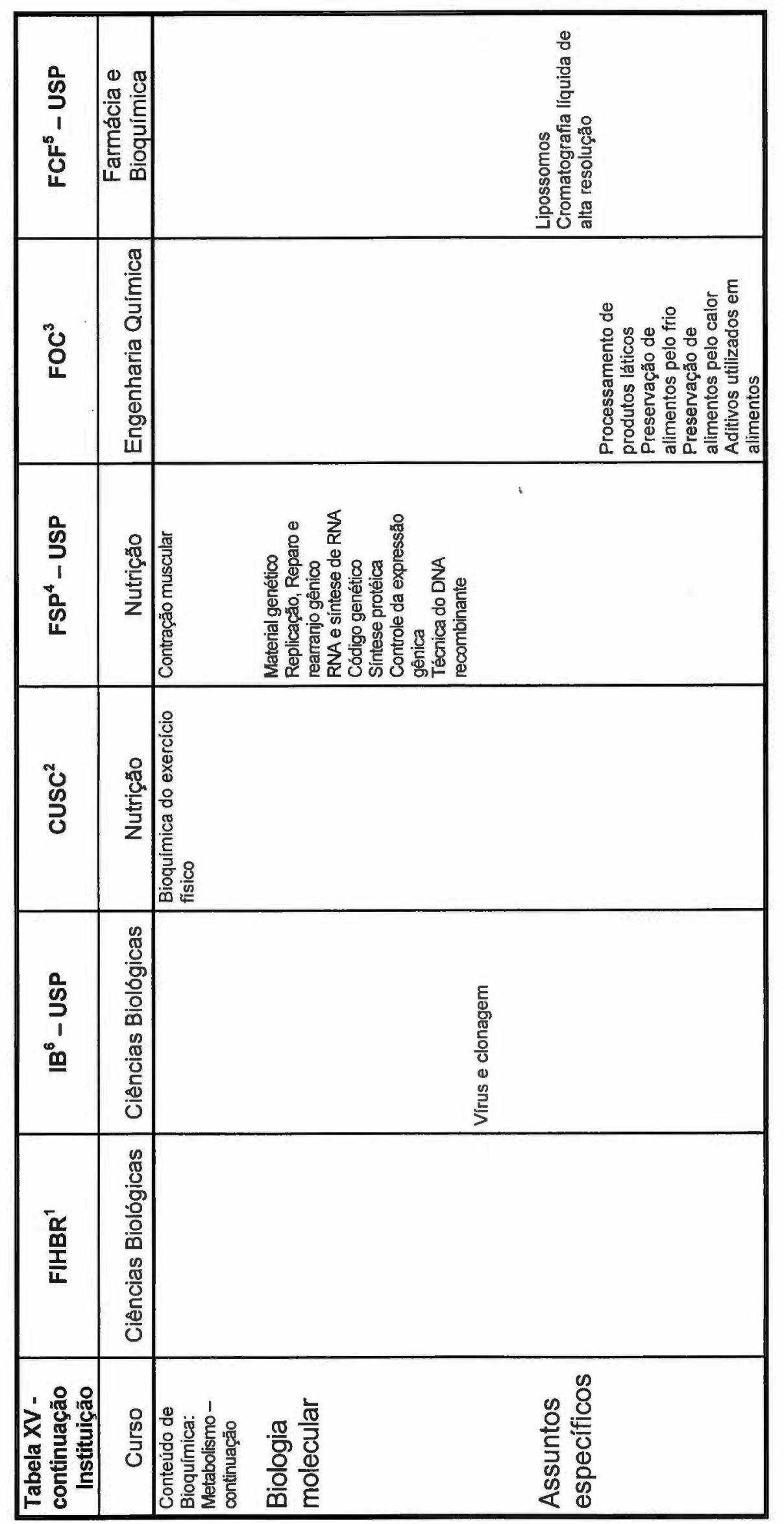

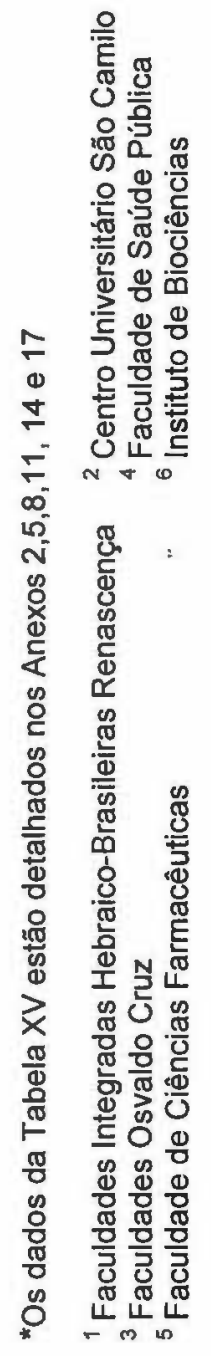

BIBLIOTECA USTITUTO DE QUIMICA 
A Tabela XV revela que disciplina lecionada no primeiro semestre do curso (Química de Biomoléculas - FIHBR) contém conteúdo de Química Geral e de Química Orgânica, além de conteúdo de Bioquímica, que disciplinas ministradas no segundo semestre, antecedidas por outras com conteúdo de Bioquímica (Nutrição do CUSC e da FSP - USP), focalizam mais assuntos de metabolismo.

O conteúdo de Bioquímica Experimental acompanha alguns tópicos dos curso teórico correspondente e acrescenta conteúdo de técnicas de laboratório. A disciplina Bioquímica Aplicada é de cunho profissionalizante e tem tópicos específicos do curso de Engenharia Química. Vê-se que, enquanto que em curso de Nutrição o enfoque é na bioquímica animal (humana), em cursos de Ciências Biológicas, a disciplina de Bioquímica apresenta tópicos que interessam à Ecologia e à Fisiologia Vegetal também.

O restante dos conteúdos de Bioquímica que não estava presente nas disciplinas analisadas, em cada curso estudado, é lecionado, respectivamente, nas seguintes disciplinas: "Bioquimica" - Ciências Biológicas das FIHBR (Anexo 1); "Fundamentos de Química Orgânica" - Nutrição do CUSC (Anexo 4); "Química de Biomoléculas" - Nutrição da FSP - USP (Anexo 10); "Bioquímica: Estrutura de Biomoléculas e Metabolismo", "Bioquímica e Biologia Molecular do Gene" - Farmácia e Bioquímica da FCF - USP (Anexo 13); "Química Orgânica I e II", "Processos Industriais Orgânicos", "Bioquímica Aplicada - 1ํs semestre" Engenharia Química das FOC (Anexo 7).

Em resumo, disciplinas lecionadas no primeiro e segundo semestres do curso, como em Ciências Biológicas e Nutrição, são de caráter básico e as lecionadas do meio para o fim do curso, como Bioquímica Experimental e Bioquímica Aplicada, têm caráter profissionalizante, mostrando a tendência tecnicista dos currículos analisados, como comentado anteriormente.

Pela discussão feita, pode-se concluir que as disciplinas em questão, quanto ao conteúdo, estão adequadas ao enfoque e à ênfase pertinentes aos cursos dos quais elas fazem parte. 


\section{B. 4. Comparação entre os laboratórios didáticos das instituições analisadas}

Os dados da Tabela $V$ (p. 131) e os apêndices de 1 a 7 permitem uma comparação entre os laboratórios didáticos observados, quanto à qualidade e adequação em relação às aulas práticas das disciplinas analisadas.

O maior espaço físico observado foi o dos laboratórios das Faculdades Oswaldo Cruz, mas, neles, não havia grande facilidade de circulação, nem os alunos tinham possibilidade de visualizar bem a lousa e acompanhar as explicações do professor, por causa das prateleiras sobre as bancadas e aparelhos de grande porte que ocupavam muito espaço. Por outro lado, o menor dos laboratórios observados foi o das Faculdades Integradas Hebraico-Brasileiras Renascença onde, devido ao pequeno número de alunos e à ausência de equipamentos e aparelhos espalhados pelo chão, como em outros, havia boa circulação, a visibilidade da lousa e a possibilidade de ouvir as explicações do professor eram adequadas. No Centro Universitário São Camilo, o que se observou foi que o laboratório era pequeno em relação ao número de bancadas e que a densidade populacional era alta, o que prejudicava o bom andamento das aulas práticas. O laboratório didático do Departamento de Bioquímica da USP permitia boa circulação, mas a grande distância das últimas bancadas em relação à lousa causava um certo desconforto aos alunos e, dentro das estratégias de ensino adotadas pelos professores, nas aulas práticas observadas, havia, por isso, menor participação daqueles que se encontravam mais distantes, limitação que foi contornada pelo professor de Ciências Biológicas do IB - USP, dando as explicações iniciais e fazendo a discussão dos dados no anfiteatro de aulas teóricas.

Com relação às condições materiais oferecidas pelos laboratórios, o mais precário era o das FIHBR, por não ter reservatório de água destilada, pela ausência de gás encanado e de sistemas de exaustão de vapores, por falhas de segurança, por não ter local apropriado para guardar material pessoal dos alunos. Nos demais, todos esses itens foram satisfatórios, com exceção das condições de ventilação dos laboratórios das FOC, que 
deixaram a desejar nas aulas observadas, porque o número de bicos de gás acesos e a temperatura externa alta provocavam grande calor, que os ventiladores não conseguiam amenizar. Quanto a instalações para professores e auxiliares, nenhum laboratório tinha locais apropriados. Em todos os laboratórios, reagentes, equipamentos e aparelhos eram guardados de forma a preservar suas segurança e qualidade. A distribuição de materiais e a lavagem de vidraria mostrou-se adequada em todos os laboratórios observados.

Em ordem crescente das densidades populacionais, constatamos os seguintes valores: (1) 0,2 alunos $/ \mathrm{m}^{2}$ nas FIHBR; (2) 0,3 alunos $/ \mathrm{m}^{2}$ nas FOC, na FSP e na FCF - USP; (3) 0,4 alunos / $\mathrm{m}^{2}$ no IB - USP e (4) 1,0 aluno $/ \mathrm{m}^{2}$ no CUSC. A densidade populacional, aliada à proporção orientador : aluno, interfere sobre as condições de atendimento aos alunos durante as aulas práticas. De fato, com relação a esse aspecto, foram os alunos do CUSC, cujo laboratório apresentava alta densidade populacional e pequena proporção professor : aluno (a menor, 1:40, junto com a da FCF - USP), que mais apontaram expectativas frustradas (esperavam "que as aulas práticas fossem mais organizadas"; "que houvesse menor número de alunos por grupo ou no laboratório"). Também foram os alunos do CUSC que indicaram defeito ("alta densidade populacional no laboratório") e limitações para o bom desempenho em aulas práticas ("muita gente no laboratório e/ou nos grupos"; "falta de tranqüilidade para realizar o trabalho"; "impossibilidade de o aluno realizar todas as etapas do experimento pessoalmente"), no que se refere à questão da relação entre número de alunos e área útil do laboratório (Tabela VI, p. 136, e Tabela IX, p. 148).

\section{B. 5. Análise das opiniões e do comportamento dos atores do processo ensino-aprendizagem nos contextos analisados}

Os atores principais do processo ensino-aprendizagem são os professores e os alunos, mas, na pesquisa em questão, também importantes foram os técnicos, os auxiliares-técnicos de laboratório e os monitores de aulas práticas.

Quanto às expectativas dos alunos em relação às aulas práticas (Tabela VI, p.136), vemos que eles referem-se ao número de aulas, à sua organização e 
funcionamento, à densidade populacional no laboratório, a questões de segurança, à didática do professor, ao conteúdo teórico, ao treinamento técnico, à profissionalização e à possibilidade de participação na execução dos experimentos. Os números mais expressivos a destacar são: um terço dos alunos que responderam o questionário nas FIHBR desejavam mais aulas práticas, mais da metade dos alunos do CUSC esperavam entender melhor o conteúdo de aulas teóricas em aulas práticas, quase a metade dos alunos da FCF - USP desejavam uma integração entre o curso teórico e o prático, todos os alunos do curso de Engenharia Química das FOC esperavam aprender assuntos relativos à profissão.

Com relação a quais aulas práticas foram mais interessantes, as opiniões, em geral, foram muito variadas, chamando apenas a atenção o fato de metade dos alunos do CUSC que responderam o questionário terem indicado as aulas que tinham assuntos ligados à Nutrição e de quase a metade dos alunos das FOC entrevistados terem interesse em aulas que apresentassem processos novos ou ainda desconhecidos para eles. As opiniões sobre o proveito das aulas práticas também foram muito variadas, mas houve maior incidência de respostas que se referiam às aulas em que houve entendimento do conteúdo teórico e que se relacionavam com o interesse pessoal do aluno (Tabela VI, p. 136).

Um terço dos alunos das FIHBR confirmaram seu apreço às aulas práticas, dizendo que um de seus defeitos era seu pequeno número. Outros resultados que chamaram a atenção no quesito, "defeitos de aulas práticas", foram: um terço dos alunos do CUSC apontaram a alta densidade populacional, mais da metade dos alunos do IB - USP consideraram o número de alunos por grupo grande; "falta de materiais e/ou equipamentos e/ou aparelhos ou seu mau funcionamento" apareceu com maior incidência nas FIHBR. Nas disciplinas observadas, com exceção daquelas da FCF e do IB USP, os alunos apontaram escassez de tempo para executar os experimentos, com alta incidência nas FIHBR, nas FOC e, principalmente, na FSP - USP.

As limitações para o bom desempenho em aulas práticas mais apontadas pelos alunos foram: um terço dos alunos das FOC e do CUSC disseram que 
havia muita gente no laboratório e/ou nos grupos e metade dos do CUSC acrescentaram que isso impossibilitava os alunos de realizarem todas a etapas dos experimentos pessoalmente. A maioria dos alunos das FIHBR, mais da metade dos alunos das FOC e da FCF - USP, quase a metade dos alunos da FSP - USP não apontaram limitações para um bom desempenho em aulas práticas; nenhum aluno do CUSC e apenas um, entre onze do IB USP, consideraram que não havia limitações para um bom desempenho.

$\mathrm{Na}$ comparação entre aulas teóricas e práticas, os alunos das FOC foram aqueles que mais responderam que as duas se complementavam; os das FIHBR, os que mais apontaram o fato de as aulas práticas serem mais concretas e visuais e os da FSP - USP, os que mais salientaram serem as aulas práticas mais dinâmicas e participativas que as teóricas.

Para os alunos de Bioquímica Experimental (FCF - USP), os relatórios eram optativos, mas eles pareciam valorizar a elaboração de relatórios apesar disso, uma vez que boa parte deles preferiria que esta atividade fosse obrigatória. Opiniões positivas, com relação a relatórios de aulas práticas, também apareceram entre os alunos de Bioquímica Aplicada (FOC), com dois terços opinando que relatórios levam a uma melhor explicação do conteúdo das aulas práticas. Vê-se, portanto, que nos cursos com enfoque técnico e/ou tecnológico, o relatório de aulas práticas são considerados um importante instrumento de ensino. Dados sobre o quesito "relatórios", no caso de Química de Biomoléculas (FIHBR), não puderam ser obtidos, porque os alunos não entenderam a questão do questionário; também em Bioquímica do IB - USP, em que os alunos não faziam relatórios escritos, mais da metade não se pronunciou sobre $o$ assunto.

A maioria de todos os alunos entrevistados considerou bom, muito bom ou ótimo seu relacionamento com os colegas, apontando tanto fatores facilitadores para os relacionamentos, como fatores prejudiciais. Os alunos também consideraram, em sua maioria, ótimo, muito bom ou bom seu relacionamento com o(s) professor(es). As interações dos alunos com auxiliares (técnica, no caso das FIHBR, e monitores, no caso dos cursos da USP) foram consideradas, pela maioria dos alunos, como boas, sendo que 
foram apontados mais fatores positivos que negativos para o estabelecimento dos relacionamentos, nesse caso.

Os dez professores que participaram desta pesquisa consideraram as aulas práticas importantes, apontando a sedimentação de conceitos, seguida de entendimento do assunto teórico como sua principal importância.

O critério de escolha do número, posição na programação e conteúdo das aulas práticas mais indicado foi o de "correspondência com aulas teóricas", seguido de "distribuição homogênea ao longo da programação" e "disponibilidade de materiais". "Exigências da instituição ou referentes ao curso" foram apontadas pelos professores das FOC (onde 50\% das aulas deveriam ser práticas) e da FSP - USP, em que o número de aulas da disciplina foi diminuido no ano em que foi feita a pesquisa, limitando a possibilidade de planejar aulas práticas, segundo a professora consultada.

Quanto à realização das expectativas para as aulas práticas, a maioria considerou que elas se realizaram e dois professores disseram que elas não se realizaram total ou parcialmente: o professor das FIHBR considerou que suas expectativas frustaram-se, porque os alunos não tinham formação teórica e habilidades adequadas para acompanhar as aulas práticas propostas, enquanto que a professora titular do CUSC explicou que a realização parcial de suas expectativas deveu-se à falta de preparo técnico dos alunos e a ausência de treinamento deles quanto à segurança do trabalho em laboratório.

As limitações para o desenvolvimento de aulas práticas indicadas foram, em ordem decrescente de citações: "falhas técnicas no preparo" e "número excessivo de alunos" (6 indicações); "falta parcial de materiais" e "escassez de tempo" (5 indicações); "faltà parcial de conhecimento dos alunos" (4 indicações); "falta de teste dos experimentos", "falta de preparo técnico dos alunos", "falta de interesse dos alunos", "imposições feitas pela instituição" e "falta de espaço" (2 indicações). Note-se que as imposições da instituição limitaram o sucesso das aulas práticas somente no curso de Engenharia 
Química das FOC (opinião das duas professoras que ministraram aulas práticas), inclusive com relação à possibilidade de testar os experimentos (Apêndice 3). A falta de espaço foi apontada somente pelos professores do CUSC (Apêndice 2); as falhas técnicas no preparo foram citadas, entre outros, pelos professores da USP, onde o laboratório é o mais bem equipado entre os observados.

As opiniões dos professores do CUSC a respeito de limitações das aulas práticas, falta de preparo técnico suficiente dos alunos e falta de treinamento deles sobre segurança causam certa estranheza, porque 0 curso que serve de pré-requisito para a disciplina de Bioquímica, "Fundamentos de Química Orgânica", foi ministrado por eles próprios, no semestre que antecedeu àquele observado.

Fatores como "falta de materiais", "número excessivo de alunos", "falta de espaço", são ligados à estrutura da organização, mas fatores outros apontados pelos professores são de sua exclusiva competência e poderiam ser evitados ou, pelo menos, minimizados com um planejamento adequado às condições oferecidas à disciplina. De grande ajuda seria ter em mãos, durante o planejamento, um perfil dos alunos ingressantes na disciplina.

Digno de nota é também o fato de haver uma certa discordância nas opiniões de professores da mesma disciplina, notadamente entre a professora titular e o professor assistente do CUSC, em menor escala entre os professores de Ciências Biológicas da USP. Há uma maior concordância entre os professores das FOC. No dois primeiros casos, do CUSC e do IB - USP, o fato pode ter ocorrido, porque não teria sido feito um planejamento conjunto ou uma avaliação conjunta do planejamento, o que não foi pesquisado. No último caso, das FOC, os professores responderam juntos o questionário, inclusive com a participação do professor de aulas teóricas, responsável pela disciplina e cujas aulas não foram objeto desta pesquisa, podendo ter havido, nessa ocasião, um aplainamento das discordâncias, significando que as respostas traduziam a "opinião da maioria" ou a "opinião de consenso" ou que realmente houve um planejamento coerente, feito, executado e avaliado em conjunto. 
As disparidades e semelhanças de opiniões de professores de mesma disciplina ficam mais evidentes no julgamento sobre a consecução dos objetivos, quando aparecem as já citadas divergências entre os professores do CUSC e de Ciências Biológicas - USP e se confirma a concordância entre os professores das FOC.

Entre os objetivos mais alcançados, com relação às aulas práticas, aparecem os de "ilustrar fatos elou fenômenos", de "ensinar a seguir protocolo" e de "melhorar relações entre professor e alunos". O objetivo que menor número de professores alcançou, entre os que foram colocados no planejamento, foi "ensinar como observar".

Dos objetivos relacionados no questionário, o que menos os professores colocaram em seus planejamentos foi "ensinar como testar hipóteses". Os objetivos que a maioria dos professores não considerou como pertinente para as aulas práticas de graduação, nas disciplinas observadas, foram: "divulgar as descobertas recentes da Ciência" e "ensinar como escrever protocolos".

Comparando opiniões de professores de cursos de Ciências Biológicas, vemos que eles concordam que as aulas práticas devam ter como objetivos "ilustrar fatos e fenômenos", "ensinar a compreender conceitos", "mostrar a importância da Bioquímica", "ensinar como criticar dados", "motivar aluno", "encorajar entusiasmo pela Ciência", ainda que nem todos esses objetivos tenham sido alcançados.

Os professores de cursos de Nutrição concordam que as aulas práticas devam ter os seguintes objetivos: "ilustrar fatos e fenômenos", "ensinar a compreender conceitos", "melhorar relações entre professor e alunos", "melhorar relações entre alunos", também sem terem, em todos os casos, esses objetivos sido atingidos.

Interessante notar que os professores de Ciências Biológicas, um curso com enfoque mais teórico, de ciência pura e docência, apontaram objetivos como "mostrar a importância da Bioquímica", "encorajar entusiasmo pela Ciência", que são típicos da função de divulgação científica, própria do pesquisador e do professor. Por outro lado, professores de Nutrição, curso 
com enfoque de ciência aplicada e tecnologia, assinalaram objetivos relacionados com interações pessoais ("melhorar relações entre professor e alunos", "melhorar relações entre alunos"), importantes para as relações entre o profissional e os assistidos.

Nos cursos com forte tendência técnica ou tecnológica, como os de Farmácia e Bioquímica e Engenharia Química, apareceram em comum a indicação dos seguintes objetivos de aulas práticas como importantes: "aplicar teoria, lei, princípio", "ensinar a compreender conceito", "ensinar como seguir protocolo", "ensinar como fazer relatório escrito", "ensinar como consultar literatura científica", "ensinar como criticar dados", "treinar manuseio de material de laboratório e de reagentes", "treinar manipulação de material biológico", "treinar técnicas de pesquisa laboratorial", "motivar aluno", "melhorar relações entre professor e alunos" e "encorajar entusiasmo pela Ciência". No caso destes últimos cursos, de acordo com as opiniões dos professores consultados, a aula prática é um meio de treinar técnicas de pesquisa laboratorial, de valorizar a Ciência e de incentivar relacionamentos interpessoais, objetivos que concordam com a atuação dos graduados em suas futuras profissões.

A seguir, serão resumidos alguns pontos tratados anteriormente e acrescentados outros, ainda não apontados, para deixar claras as funções que as aulas práticas observadas exerceram no ensino de Bioquímica, nos contextos estudados.

As instituições analisadas não envolviam alunos de graduação dos cursos observados em projetos de pesquisa, nem as aulas práticas de Bioquímica relacionavam-se com qualquer outra atividade da instituição, nem se integravam com outras disciplinas, mesmo na USP, com tradição em pesquisa laboratorial em Bioquímica (Tabela II, p.125; Tabela III, p. 127; Tabela IV, p. 129 e Tabela IX, p.148). Apesar de existirem locais para treinamento profissional no centro universitário e na universidade em que a pesquisa foi realizada, as aulas de Bioquímica não se integravam às atividades deles.

O apoio técnico-didático ao professor e ao aluno equivalem-se, de forma geral, nas instituições estudadas, com relação à presença de técnico 
de laboratório, recursos audio-visuais e acesso à internet. A Biblioteca do Departamento de Bioquímica da USP excede muito, em acervo e qualidade de atendimento, à qualquer das outras observadas. Entre as instituições particulares, o CUSC e as FOC são semelhantes, quanto à qualidade da biblioteca, focalizando-se mais em livros didáticos que em periódicos; a biblioteca das FIHBR praticamente não tinha acervo na área de Bioquímica. Entretanto, em qualquer dessas instituições, as aulas práticas utilizavam a pesquisa bibliográfica apenas para complementação dos dados fornecidos pelo professor, oralmente em aulas teóricas e práticas, ou nos protocolos, para a elaboração dos relatórios, nunca para planejamento ou solução de problemas referentes às aulas práticas (Tabela IX, p. 148 e Tabela XI, p.154). Também não foram discutidos artigos científicos de assuntos correlatos aos desenvolvidos em aulas práticas (Tabela IX), apenas com uma exceção, em uma das aulas da FCF - USP.

Por ocasião desta pesquisa, só as Faculdades Oswaldo Cruz faziam um perfil sócio-econômico dos alunos que ingressavam na instituição, mas mesmo esse perfil não foi de utilidade para os professores de Bioquímica Aplicada, porque seus alunos tinham sido caracterizados há, pelo menos, cinco anos. O ideal é que as instituições façam o perfil dos alunos que ingressam no primeiro semestre, por meio de questionários distribuídos por ocasião da matrícula, para uso dos professores de disciplinas de $1^{0}$ semestre, e ao final de cada semestre, para os demais.

Todos os laboratórios didáticos observados (Tabela V, p.131) ofereciam condições para a realização das aulas, com algumas limitações, listadas a seguir. Nas FIHBR, o curso de Ciências Biológicas acabava de ser instalado e o laboratório utilizado era de microscopia e de disseç̧ão, o que fez com que houvesse necessidade de certas improvisações, que não comprometeram o desenvolvimento das aulas. As deficiências foram compensadas pelo grande esforço do professor e da técnica, em garantir a segurança e a precisão e pela boa vontade dos alunos. No CUSC, as aulas foram tumultuadas, porque o laboratório, embora com instalações bem cuidadas, apresentava escassez de equipamentos e aparelhos, a proporção orientador : aluno era 
pequena, o espaço, reduzido e o número de alunos, grande. Esses fatores contribuíram para que a densidade populacional fosse alta e a circulação no laboratório dificultosa (Tabela V, p. 131, Tabela VI, p.136 e Tabela VII, p.144). Nas FOC, o laboratório era bem equipado, mas as instalações e os aparelhos eram velhos, muitos estavam colocados no chão e sobre as bancadas de experimentos, dificultando a visão e a circulação; o sistema de ventilação não era eficaz e o calor era grande durante as aulas, provocando, além do desconforto, a desobediência às regras de segurança e higiene, representadas pelo uso de aventais pelos alunos (Apêndice 3). Embora o laboratório da USP tenha sido considerado o melhor em todos os quesitos (Apêndice 4), a ausência da técnica no período observado comprometeu o preparo e teste das aulas, causando vários problemas de precisão na obtenção dos dados. As limitações apresentadas pelos laboratórios didáticos eram conhecidas de antemão e foram ou poderiam ter sido contornadas por meio de um planejamento de aulas práticas mais eficaz.

Os currículos dos cursos analisados não apresentavam integração entre disciplinas, nem interdisciplinaridade verdadeiras, apenas deles constavam "semanas de cursos", nas quais os alunos de graduação assistiam palestras, faziam minicursos e apresentavam trabalhos, como uma forma de iniciação científica. Tais semanas eram planejadas pelos professores, tendo tido os alunos um papel de execução de tarefas (Tabela II, p. 125 e Anexos 1, 4, 7, 10, $13,16)$.

Os cursos aqui estudados, que possuiam publicações científicas, não propiciaram aos alunos de graduação com os quais se teve contato, nesta pesquisa, a oportunidade de participar dessas publicações, mesmo que cursando séries e/ou semestres mais avançados, como os da FCF - USP e os das FOC (Tabela II, p. 125).

A disciplina em que houve maior número de encontros no laboratório foi a de Bioquímica Experimental da FCF - USP, seguida da disciplina de Bioquímica da Nutrição - CUSC. Das aulas em laboratório observadas, as mais longas foram as do curso de Ciências 
Biológicas do IB - USP, que duraram de três a quatro horas, e as mais curtas foram as do CUSC, de uma hora e vinte e cinco minutos a uma hora e quarenta e cinco minutos.

A maior relação orientador : aluno foi observada nas FIHBR (1:5), as demais variaram de 1:21 a 1:40 (Tabela IX, p.148). As FIHBR foi a única instituição que permitia a presença dos alunos no laboratório, fora do horário de aulas, com supervisão e orientação da técnica. A possibilidade de os professores atenderem os alunos fora dos horários de aula só ocorreu na USP, onde o regime de trabalho é de tempo integral e os professores têm salas próprias.

As atividades de laboratório cobriram, no máximo, $50 \%$ da programação nas FIHBR e na FCF - USP, enfocando apenas $15 \%$ dela na FSP - USP e no IB - USP (Tabela IV, p. 129). Os assuntos foram relacionados, prioritariamente, com aulas teóricas, até nos casos em que as aulas práticas antecediam as teóricas e mesmo no curso de Bioquímica Experimental da FCF - USP, no qual não há aulas teóricas, mas sim um curso teórico dado paralelamente (Anexos $2,5,8,11,14,17)$.

Quanto ao número de aulas práticas presentes na programação, a maior proporção entre aulas práticas e aulas teóricas foi a de 1:0,8 nas FOC e, entre aulas práticas e outras atividades, a de 1:1 nas FIHBR e nas FOC. Em outros casos, sempre havia menos aulas práticas que qualquer outra atividade de ensino-aprendizagem (Tabela IV, p. 129). Quase sempre, portanto, a programação das disciplinas de Bioquímica colocaram aulas práticas em segundo plano. Nas FOC, havia uma obrigatoriedade de que $50 \%$ das aulas fossem práticas, mas os professores consideraram isso uma limitação para seu trabalho (Apêndice 3). Mesmo no curso de Bioquímica Experimental, a programação era linear, não por projetos, e havia mais atividades fora do laboratório que realização de atividades em torno de experimentos (Tabela IV, p. 129, Anexo 14 e Apêndice 6).

Os professores de Bioquímica que participaram desta pesquisa, embora uns fizessem pesquisa laboratorial e outros não (Tabela II, p. 125), todos apontaram razões para que as aulas práticas fossem incluídas na programação (Tabela VII, p. 144). De fato, elas aconteceram em todos os cursos 
analisados. Como docentes, esses professores fizeram escolhas e atuaram de formas semelhantes, como será demonstrado posteriormente, sem que aqueles que atuavam também como pesquisadores introduzissem qualquer inovação ou modificação na maneira "tradicional" de desenvolver aulas práticas de Bioquímica. Em nenhum caso houve o desenvolvimento de projetos de pesquisa, embora a literatura (por exemplo, Mckenzie, 1996) e a opinião de alguns professores consultados (pesquisa exploratória - Item A. 1, p. 32) os considerassem ideais para certas situações. Todas as aulas foram isoladas, encerrando-se em si mesmas, não suscitando nem se integrando com nenhuma outra atividade (Tabela XI, p. 154). A única exceção foi o trabalho de final de ano da disciplina Bioquímica Aplicada do curso de Engenharia Química (FOC), que exigia aplicação do conhecimento técnico obtido em aulas práticas (Apêndice 3).

Nas aulas observadas, as que ocuparam maior tempo para as explicações iniciais foram as de Bioquímica do curso de Nutrição - USP, seguida das de Ciências Biológicas da USP. É interessante relatar que o período inicial da aula foi utilizado pelo professor da Bioquímica Experimental, principalmente para interpretar os dados da aula anterior e pouco para explicar a aula em andamento (Apêndice 6). No curso de Ciências Biológicas da USP, o professor passava conceitos teóricos ao lado da explicação dos protocolos de aulas práticas (Apêndice 7), nos demais cursos, os primeiros momentos da aula foram usados para explicação dos protocolos (Apêndices $1,2,3,5)$. Todas as aulas observadas tiveram seu enfoque na execução dos experimentos constantes dos protocolos. Nos períodos de aula observados (Tabela IX, p. 148), as aulas de Ciências Biológicas - USP foram as que mais deixaram espaço para o tratamento dos dados pelos grupos de alunos, embora tenha sido a discussão dos dados da disciplina de Química de Biomoléculas (FIHBR) a única feita pelos alunos, na própria aula, com exigência de entrega do relatório no fim da aula pratica.

Os preparos das aulas observadas sempre foram feitos por técnicos, sob orientação e/ou supervisão dos professores, e o teste dos experimentos 
coube a professores e monitores, quando era feito, o que não ocorreu no CUSC e nas FOC.

A preocupação com segurança foi maior nas FIHBR e na USP (Apêndices 1 e 4) e menor no CUSC, como comentou a professora titular desta instituição (Apêndice 2).

Apesar de todos os professores terem considerado as aulas práticas importantes, só as professoras das FOC e da FSP disseram que as aulas práticas dadas não poderiam ser substituídas por outros tipos de atividades didáticas, com os mesmos objetivos (Tabela IX, p. 148). As considerações sobre usar outras técnicas de ensino para substituir aulas práticas parecem não ter sido produto de uma reflexão apurada, porque as opiniões dos professores variaram muito quanto à colocação de objetivos que se referiam à aquisição de habilidades técnicas experimentais em seu planejamento (Tabela VII, p. 144). Houve professores, até da mesma disciplina, que diferiram em suas declarações, aparecendo tanto aqueles que não colocaram certos objetivos relativos a habilidades técnicas, mas consideraram as aulas práticas insubstituíveis, como aqueles que colocaram vários objetivos nessa área, embora tenham afirmado que poderiam trocar aulas práticas por outras atividades. De fato, as contradições que aparecem nas respostas dadas às perguntas do questionário endereçado a professores, referentes a objetivos, e as disparidades de opiniões coletadas durante a observação no laboratório, sobre a possibilidade de suprimir aulas práticas, pode significar, entre outras coisas, que, por ocasião do planejamento, os professores não fizeram relações entre objetivos, metodologia, técnicas de ensino e conteúdo das aulas, como deve ser feito, para que as aulas tenham as funções e o papel que se pretende.

Quanto às estratégias de ensino empregadas pelos professores, vemos que elas têm mais semelhanças do que diferenças. O que se refere ao conteúdo dos protocolos (Tabela X, p. 152) é apresentado a seguir:

- nos protocolos, não foram lançados aos alunos problemas que desencadeassem a realização de aulas práticas;

- a maioria dos protocolos são impressos (exceção de dois protocolos do CUSC que foram escritos na lousa); 
- a maioria dos protocolos são adquiridos pelos alunos, apenas a disciplina de Bioquímica da Nutrição - USP distribuiu-os gratuitamente;

- os protocolos priorizavam a execução dos experimentos, constando seus objetivos somente em um protocolo do CUSC e em um da FSP - USP;

- regras de higiene só foram enfatizadas nos protocolos de Bioquímica Aplicada do curso de Engenharia Química das FOC, em que havia processamento de alimentos;

- normas de segurança foram reforçadas por escrito somente nos protocolos das FIHBR e da FCF - USP;

- em nenhum protocolo constavam instruções sobre o quê e como observar, porém, todos apresentavam algumas instruções de como registrar os dados;

- questões a serem respondidas ou problemas a serem resolvidos, usando os dados obtidos, constavam somente no protocolo das disciplinas dos cursos da USP;

- nos protocolos de todas as disciplinas observadas constavam orientações de como discutir os dados, menos nos das FOC;

- não havia orientação de como redigir os relatórios, nos protocolos analisados;

- uma bibliografia geral de Bioquímica apareceu apenas nos protocolos de Nutrição e de Ciências Biológicas da USP; bibliografia específica sobre métodos e técnicas constou somente em um protocolo da FCF - USP;

- em todas as aulas práticas observadas, o conjunto de dados foi definido previamente e constava do protocolo.

Quanto ao desenvolvimento da aulas (Tabela IX, p. 148 e Tabela XI, p. 154), observou-se que:

- a utilização do protocolo durante a aula foi feita da seguinte forma: em Ciências Biológicas das FIHBR, a leitura individual deveria ter precedido a aula, conforme instruções do professor; na Nutrição da USP, houve leitura do protocolo por um aluno, em voz alta, antes do início das explicações; em Ciências Biológicas da USP, houve leitura silenciosa antes de 
iniciarem-se as explicações e não houve leitura dos protocolos, em conjunto, nos três outros casos, em que os alunos liam e tiravam dúvidas sobre os protocolos, à medida que iam executando os experimentos;

- a parte inicial da aula foi reservada para explicações sobre a execução dos experimentos, com pequena participação dos alunos, exceção feita à disciplina de Bioquímica Experimental, em que os alunos eram mais cobrados com relação à aplicação de conteúdos básicos de Bioquímica e de outras disciplinas, relativos ao assunto em discussão;

- praticamente todos os experimentos eram realizados pelos alunos, assim como o manuseio de aparelhos e equipamentos, com a orientação dos professores e auxiliares; a maior autonomia, nesse sentido, foi dada pelo professor de Bioquímica Experimental (FCF - USP), também o uso de equipamentos e aparelhos foi feita com bastante liberdade pelos alunos de Bioquímica Aplicada (FOC);

- em poucas situações em que aparelhos ou equipamentos mais sofisticados e/ou caros e/ou escassos eram usados, como foi o caso, em nossa pesquisa, do uso de refratômetro (FOC) e de unidade de eletroforese (IB - USP), por exemplo, os professores optaram por fazer demonstrações;

- a preocupação com a precisão na obtenção dos dados apareceu em todas as disciplinas observadas, menos na do CUSC e na das FOC;

- a relevância de discutir a sensibilidade dos métodos e das técnicas foi salientada apenas na disciplina de Bioquímica Experimental (FCF - USP) e a importância de fazer o descarte de materiais de forma correta, em Química de Biomoléculas das FIHBR;

- as habilidades técnicas exigidas para a execução dos experimentos eram simples, mas, em todos as disciplinas estudadas, havia alunos que não as dominavam totalmente, mesmo no caso de Bioquímica Aplicada, em que os alunos estavam terminando o curso;

- as habilidades técnicas treinadas durante as aulas observadas eram simples, restringindo-se a uso de instrumentos de medição volumétrica que permitem maior segurança e precisão (pêra e pipetador automático), de 
equipamentos, como banho-maria, estufa, bomba de vácuo, homogeneizador e de aparelhos (principalmente espectrofotômetro);

- os alunos que menos preencheram as expectativas do professor, quanto às habilidades consideradas como pré-requisitos para o entendimento $e$ desenvolvimento de aula prática, foram os de Ciências Biológicas das FIHBR;

- na dinâmica dos grupos, a divisão de trabalho era eqüitativa, com algumas exceções nos dois cursos de Ciências Biológicas, nos quais se encontrava maior número de alunos sem prévio treinamento técnico, com alguns alunos realizando os experimentos e outros apenas acompanhando;

- em nenhum caso, os dados obtidos pelos vários grupos foram tratados como repetições do mesmo experimento ou uma discussão dos resultados foi feita com toda a turma; cada grupo processava, interpretava e discutia seus próprios dados e recorria à literatura para completá-los;

- o tempo previsto para a execução dos experimentos foi suficiente em todos os casos, segundo observou-se, mas houve opiniões, tanto de alunos, como de professores (Tabela VI, p. 136 e Tabela VII, p. 144), de que seria melhor se dispusessem de mais tempo, principalmente nas disciplinas de Bioquímica do CUSC e Bioquímica Aplicada das FOC;

- os alunos dos dois cursos noturnos observados (Ciências Biológicas das FIHBR e Engenharia Química das FOC) tinham em comum o fato de apresentarem mais dificuldade de cumprir os horários de aulas, porque a maioria trabalhava durante o dia;

- os alunos de Ciências Biológicas, quer das FIHBR, quer da USP, eram, em geral, interessados, envolvidos e até desejariam que houvesse mais aulas práticas (FIHBR); mesmo que mais tímidos e inexperientes no uso de materiais de laboratório, sempre estavam comprometidos com o trabalho.

- os alunos de Nutrição do CUSC e de Engenharia Química das FOC foram os que mais se mostraram preocupados com aprender assuntos ligados à profissão (Tabela VI, p. 136); 
- os alunos de Bioquímica Experimental (FCF - USP) e os de Bioquímica Aplicada (FOC) foram os mais eficientes no trabalho laboratorial; porém, boa parte dos primeiros executava o que era necessário e suficiente e os últimos eram os que mais conversavam, não seguiam as regras de segurança, desobedeciam aos horários de entrada e saída e faziam atividades não pertinentes à aula;

- as aulas em que maior número de alunos alheava-se ao trabalho que estava transcorrendo eram as de Bioquímica dos cursos de Nutrição do CUSC e da FSP - USP;

- todos os professores mostraram-se comprometidos, com intencionalidade, atentos ao trabalho dos alunos, diferenciando-se entre si quase que exclusivamente por traços de personalidade, como timidez, agressividade, solicitude etc;

- entre os professores, as que deram mais liberdade aos alunos foram as das FOC e o que mais cobrou a participação dos alunos em todas as etapas foi o da FCF - USP, os mais preocupados em explicar, fazer o aluno entender, relacionar assuntos de aulas práticas com os de aulas teóricas foram o das FIHBR e a da FSP - USP;

- professores que eram também pesquisadores (FIHBR; FSP, FCF, IB USP) mostraram preocupação com a precisão na obtenção dos dados, enquanto que aqueles que exerciam somente a docência, por ocasião da pesquisa (CUSC e FOC), não o fizeram;

- de forma geral, as aulas práticas encerraram-se com a obtenção de dados pelos grupos que, a partir daí, trabalhavam independentemente e com seus próprios recursos;

- em nenhuma aula observada, os alunos foram instruídos oralmente sobre como redigir o relatório; segundo alguns professores, essa orientação havia sido dada em aulas anteriores;

- os relatórios de aulas práticas (Tabela XII, p. 161) no CUSC, nas FOC e na FSP - USP serviam para que os alunos aprendessem a fazer pesquisa bibliográfica, a discutir os dados "esperados" e não os "obtidos" e a fazer 
redação científica, ainda que alguns alunos considerassem apenas como importantes os itens "Resultados" e "Discussão" (Tabela VI, p. 136);

- "ensinar a fazer redação científica" não apareceu como finalidade dos relatórios das FIHBR, da FCF - USP e do IB - USP, em que era dada ênfase apenas na interpretação dos dados, o relatório resumindo-se, no primeiro caso citado, em responder a questões, no segundo, em interpretar livremente os resultados, sem obrigatoriedade de entrega por escrito, e, no último caso, na interpretação oral dos resultados obtidos pelos alunos, sem confecção de relatório escrito.

- a forma de avaliação do aprendizado em laboratório foi pouco pesquisada, porque não constava, inicialmente, dos instrumentos de observação de aulas práticas; conseqüentemente, não foi possivel fazer uma análise desse aspecto do processo ensino-aprendizagem nos contextos observados;

Analisando o conteúdo de aulas práticas (Anexos 2 e 3, 5 e 6, 8 e 9, 11 e 12,14 e 15, 17 e 18), vê-se que:

- em Química de Biomoléculas (FIHBR) e em Bioquímica Experimental (FCF USP), os conteúdos das aulas práticas eram variados, contemplando um bom número de procedimentos básicos de laboratório de Química / Bioquímica, assim como nas FOC, em que havia diferentes processos de conservação e processamento de alimentos; por outro lado, na Nutrição do CUSC, as três aulas observadas utilizavam a mesma técnica: dosagem por espectrofotometria;

- as técnicas escolhidas para as aulas práticas de Nutrição da FSP - USP eram elaboradas e o assunto complexo, tornando as aulas longas e complicadas, além de não envolverem conteúdo relacionado à nutrição, alimentação ou saúde pública, próprios do curso;

- as aulas práticas do curso de Ciências Biológicas do IB-USP foram tão poucas, frente a outras atividades das disciplinas em foco, e tão pouco específicas, com relação ao curso, que apenas serviram como amostra de como se processa o trabalho de laboratório na área de Bioquímica e como 
demonstração de determinadas técnicas bastante empregadas, uma vez que o protocolo fornecia a maioria das informações necessárias para o entendimento dos resultados e do princípio básico das técnicas utilizadas.

Houve falhas no planejamento das aulas práticas, evidenciadas pelos seguintes fatos, entre outros já citados:

- nas FIHBR (Apêndice 1), o professor foi surpreendido com a pouca capacidade dos alunos de seguir instruções orais e escritas, a ponto de ver frustradas suas expectativas com relação às aulas práticas;

- no CUSC, os professores expuseram problemas no preparo das aulas e falta de base de Química dos alunos (Apêndice 2), quando foram eles que ministraram a disciplina que introduz o conteúdo de Bioquímica e também reclamaram da falta de espaço e do grande número de alunos, dificuldades com as quais convivem de longa data; além do mais, mesmo exigindo precisão na obtenção dos resultados, não elaboraram todos os protocolos, nem os disponibilizaram a tempo para os alunos e improvisaram dois roteiros, dos três analisados;

- nas FOC (Apêndice 3), as professoras criticaram a limitação, imposta pela instituição, de que $50 \%$ das aulas devessem ser práticas, o que, de antemão, já sabiam; ou seja, não tiveram em mente que o planejamento deveria ser concorde com essa realidade;

- embora os professores da USP tivessem tempo integral e auxílio de monitores, a ausência da técnica e sua substituição por profissional de menor experiência acarretaram dificuldades no preparo e teste das aulas, 0 que evidenciou a pequena flexibilidade de seus planejamentos;

- em todos os cursos, os protocolos eram incompletos, às vezes pouco claros, ou, em certos casos, traziam as conclusões que deveriam ser obtidas.

As aulas práticas observadas concordaram com as premissas dos currículos tecnicistas (Silva, 1990), principalmente porque valorizaram os resultados e não o processo, não dando liberdade aos alunos para aprenderem com os erros, não divulgando a cultura, o pensamento 
científico, o pluralismo de idéias e não avaliando o aprendizado de forma continuada.

Nas aulas práticas observadas, quase não se levou em conta que os estudantes são pessoas que, como todos, fazem exercício de sua cidadania, além de haver, nessas aulas, pouco relacionamento com a profissão inerente ao curso e de não aparecerem ligações de seus assuntos com a vida na comunidade universitária da qual fazem parte professores e alunos.

Podemos afirmar, a respeito do que foi observado em aulas práticas, nos seis contextos analisados, que:

- não é o tamanho do laboratório, em si, que importa para o planejamento das estratégias de ensino de aulas práticas, mas também a densidade populacional, a proporção orientador : aluno e a facilidade de circulação;

- não é o luxo, mas a praticabilidade, as boas condições de segurança, de iluminação e de ventilação, que contam para a tranqüilidade dos alunos durante as aulas práticas;

- distribuição gratuita de protocolos no início das aulas e leitura conjunta ou individual deles facilita o bom desenvolvimento das atividades, evitando que alguns alunos não tenham em mão esses roteiros ou que os professores sejam consultados sobre o conteúdo dos mesmos, a todo momento, durante a aula;

- há maior autonomia, durante aulas práticas, de alunos com maior experiência no uso de materiais de laboratório, como era de se esperar: um treinamento prévio nesse campo é desejável;

- as aulas práticas, da forma como são desenvolvidas, não dão bom treinamento técnico a todos os alunos, quer porque não há obrigação de que eles participem igualmente das atividades, que são sempre em grupo, quer porque não há condições materiais, de espaço e de orientação, para que cada um possa executar todos os passos das técnicas desenvolvidas, quer pelo pequeno número de vezes que o aluno vai ao 
laboratório, comparado com o número de atividades em outros locais de ensino;

- experimentos cujos resultados são previstos, quando preparados inadequadamente ou realizados sem precisão, podem provocar insucessos que levam os alunos a falsear seus dados e a procurar 0 que deles se exigia na literatura, tornando a aula prática apenas uma motivação para uma pesquisa bibliográfica e o relatório, transcrição do que já é encontrado nos livros didáticos, não servindo nem para treinamento de redação científica, quanto mais para atingir os objetivos próprios de aulas no laboratório;

- aulas longas e complexas para alunos iniciantes e com pouco treinamento em trabalho laboratorial tendem a ser aflitivas, tumultuadas, cansativas, imprecisas e dão pequena autonomia aos alunos; há pouco tempo para discutir os dados e assimilar o grande número de informações e conceitos, demandando muitas explicações do professor;

- dinâmicas de aula que priorizam a execução de experimentos, em detrimento de seu planejamento e discussão, destinam pouco tempo à reflexão, ao ensino individualizado, à investigação, à exploração e às leituras paralelas;

- aulas cujos conteúdos repetem as mesmas técnicas experimentais funcionam, com relação à aprendizagem, como se fossem uma única aula, em termos de desenvolvimento de habilidades técnicas e mentais, acrescentando, cada uma, apenas informações que poderiam ser transmitidas de forma mais rápida e talvez mais eficiente, em outras situações que não aula de laboratório;

e ainda:

- uma das formas de entenderem-se as funções das aulas práticas e seu papel no ensino, de avaliarem-se a eficiência de seu planejamento e de sua execução é pesquisar o que se exige que os alunos conheçam após realizá-las; em função disso, itens sobre avaliação do 
ensino em laboratório, que inicialmente não constavam nos roteiros de observação de aulas práticas, foram posteriormente incluídos nos instrumentos de coleta de dados;

- os instrumentos de coleta de dados, fora o item "avaliação de aulas práticas", mostraram-se adequados e completos da maneira como foram elaborados de início, preenchendo as necessárias abrangência, precisão, profundidade, validade e confiabilidade; houve pouca necessidade de complementações, cortes e modificações;

Podemos dizer, finalmente, que as aulas práticas de Bioquímica observadas, apesar de os seis contextos analisados terem diferenças quanto à estrutura, organização, funcionamento e dotação orçamentária, apresentaram, entre si, muito mais semelhanças que diferenças.

\section{C. Funções e papéis das aulas práticas nos seis contextos analisados}

De acordo com a análise apresentada no item III. B. imediatamente anterior (p. 162 a p. 195) e utilizando o Modelo de Análise do Papel das Aulas Práticas no Ensino de Bioquímica, descrito no item II deste capítulo ( $p$. 81 a p. 121), as funções que todas as aulas práticas observadas exerceram nos seis contextos pesquisados foram:

- ilustrar fatos e fenômenos;

- ampliar o conteúdo de aulas teóricas;

- compreender conceitos;

- desenvolver o entendimento de instruções orais e/ou escritas;

- ensinar como processar dados, dando-lhes nova feição;

- treinar manuseio de materiais de laboratório e de reagentes;

- treinar uso de equipamentos e aparelhos;

- treinar manuseio de material biológico (nos casos pertinentes). 
Em todas as disciplinas com conteúdo de Bioquímica observadas, o papel das aulas práticas foi o de reprodução do conhecimento científico estabelecido. 


\section{CONSIDERAÇÕES FINAIS}

A pesquisa aqui apresentada teve, como objetivo principal, instrumentar o professor de Bioquímica e o corpo técnico de instituições de ensino superior para que possam planejar e avaliar atividades que se relacionam com o ensino no recinto do laboratório. A intenção foi ampliar a visão desses profissionais e fornecer-lhes uma forma rápida e bastante completa de abordar todos os fatores que interferem sobre aulas práticas, economizando tempo e fôlego, melhor empregados na reflexão de como agir em seu caso particular: é mais fácil criar a partir da negação ou da adaptação de algo já estabelecido.

O trabalho resultou na produção de um conjunto de instrumentos de coleta de dados e na elaboração de um Modelo de Análise do Papel das Aulas Práticas no Ensino de Bioquímica que, inspirando-se em metodologias próprias das Ciências Sociais e seguindo tendências holísticas, não pretendeu ser um preceito de "como dar aulas práticas de Bioquímica", nem defendeu qualquer teoria de ensino-aprendizagem, mas procurou conter uma coerência interna, quanto às idéias que utilizou e expôs. A literatura foi consultada apenas para suscitar idéias e para resguardar autorias, pois o trabalho propôs-se a repetir e complementar o que tem sido considerado como bom e válido, a modificar e adaptar o que deixa a desejar, a inovar, preenchendo lacunas e criticando o que tem sido defendido como fato consumado, como tradição, como puro ritual e rejeitando o que é implantado por modismo ou como meio de propaganda e "marketing". Não houve, porém, a presunção de que, como isso, haverá uma revolução no ensino de Bioquímica.

A utilização dos instrumentos de coleta de dados e o uso do modelo de análise aqui apresentados permitem determinar as funções e o papel das aulas práticas no ensino de Bioquímica, em uma determinada disciplina de um dado curso, mostrando que contribuição essas aulas dão para a compreensão de conteúdos, para a assimilação de conceitos, para o 
treinamento técnico, para o preparo profissional, para o desenvolvimento de habilidades mentais necessárias ao aprendizado de ciência e respondendo a questão de como o trabalho laboratorial pode promover a participação social do aluno. Esses conhecimentos resolvem o problema que desencadeou a presente pesquisa.

No decorrer do processo de montagem dos instrumentos e de construção do modelo de análise, deu-se importância a tudo que pudesse, direta ou indiretamente, influir sobre aulas práticas. Isso mostrou-se bastante pertinente, porque muito do que foi estudado extravasou os limites do recinto do laboratório e extrapolou os domínios da disciplina de Bioquímica, o que constitui-se num apoio à parte da tese, defendida neste trabalho, de que o contexto que envolve as aulas práticas não é representado somente pelo espaço físico do laboratório, mas também por aspectos inerentes à instituição, ao curso, à disciplina, aos professores e alunos. Assim:

As condições oferecidas para o desenvolvimento de aulas práticas relacionam-se com as finalidades da instituição, com o tipo de currículo do curso, com os objetivos da disciplina, com os recursos destinados à implantação, à implementação e ao gerenciamento do laboratório. Da mesma forma e por iguais razões, o regime de trabalho do professor pode interferir sobre a possibilidade de ele fazer pesquisa na instituição, reciclarse e manter-se atualizado, integrar-se com outros professores para planejar sua disciplina e avaliar seu desempenho. Esses aspectos determinam se ele tem tempo, recursos e apoio para criar, adaptar, preparar e testar experimentos, para atender alunos fora do horário de aulas, para participar de congressos e similares, para orientar projetos com participação de alunos, para atuar junto à comunidade, para conviver com outros membros da instituição, atuando como professor-cidadão. As convicções, aspirações, emoções, aspectos de personalidade de professores e alunos, acontecimentos sociais e políticos, tendências culturais e inúmeros outros aspectos fazem parte do contexto do processo ensino-aprendizagem.

A metodologia adotada pelo professor precisa ser coerente com os fatores que determinam sua atuação como docente, citados acima. Os 
objetivos de suas aulas práticas devem refletir a metodologia que adotou; a dinâmica, as estratégias de ensino e o conteúdo das aulas práticas decorrem desses objetivos. Tais premissas, somadas à adequação às condições oferecidas e/ou impostas pelas circunstâncias do momento, às características da clientela, estabelecidas pelo perfil dos alunos, ao atendimento das expectativas da sociedade, das necessidades das comunidades, próxima e mais abrangente, das tendências de evolução do mercado de trabalho, é que fazem um planejamento ser bom e ter chance de ser executado com sucesso.

Ao analisarmos aulas práticas, geralmente descobrimos que elas exercem funções que, em termos de conteúdo, de treinamento técnico e no campo conceitual, não vão muito além daquelas das aulas teóricas. Por isso, às vezes, da forma como aulas práticas são desenvolvidas, talvez seria melhor substituí-las por resolução de problemas, simulações em computador, programas de instrução programada, aulas com recursos audio-visuais, excursões, debates ou qualquer outra técnica de ensino menos dispendiosa e trabalhosa. Nem a questão de que elas sejam motivadoras sustenta-se, porque vê-se que aulas mal organizadas são tumultuadas, cheias de reclamações dos alunos que provocam ressentimentos no professor, ele que se esforçou para que tudo "saísse direitinho". A causa de tamanha frustração pode ser o fato de o professor não dar o devido valor ao entorno das aulas práticas ou não se conscientizar de que tudo que se refere ao contexto em que as aulas se desenrolam é importante. É por isso que os instrumentos de coleta de dados precisam ser abrangentes, precisos, profundos, válidos e confiáveis, constatação que defende parte da tese deste trabalho.

Pela aplicação dos instrumentos de coleta de dados em contextos diferentes, foi possivel determinar alguns critérios que o professor pode utilizar para optar por incluir ou não aulas práticas em sua programação e, se o fizer, definir seu número, posição na programação e conteúdo, no sentido de obter determinadas funções para suas aulas, esclarecendo o papel delas no ensino de Bioquímica, em sua disciplina.

Para que o professor possa ter como critério utilizar aulas práticas em sua programação: 
- é preciso que haja um laboratório minimamente equipado para aulas de Bioquímica, na instituição;

- é bom que haja técnico de laboratório e/ou que o professor seja remunerado especificamente para preparo de aulas práticas;

- não é condição sine qua non, mas é fator facilitador que o professor seja pesquisador ou mesmo pós-graduado em Bioquímica;

- é um estímulo a presença de pesquisa na instituição e atividades de extensão integradas a cursos de graduação;

- há que se enfrentar o fato de haver menor interesse e até resistência dos alunos por aulas práticas, em cursos de graduação que formam profissionais que não utilizam o laboratório;

- é necessário conscientizar-se de que uma programação obrigatória longa dificulta o desenvolvimento de aulas práticas.

Ao adotar o critério de utilização de aulas práticas como forma de ensinar Bioquímica, o professor deve saber que essas aulas terão apenas a função de ilustrar fatos e fenômenos, se a realidade apresentar as seguintes situações:

- a disciplina de Bioquímica é lecionada nos primeiros semestres do curso, servindo de pré-requisitos para outras disciplinas, não tendo cunho profissionalizante;

- há poucas aulas para desenvolver aulas práticas, por imposições inerentes à programação da disciplina;

- o professor acumula as atribuições de dar aulas teóricas e práticas e seu tempo para preparo e teste de aulas práticas é pequeno ou inexistente ou o contato com o técnico é improvisado e informal;

- há um ou mais tipos de limitação, como precariedade de materiais, espaço reduzido no laboratório, grande número de alunos, pouca assistência técnico-didática, biblioteca sem acervo adequado;

- o treinamento de técnicas laboratoriais dos alunos é inexistente ou pequeno, impedindo o uso de aulas elaboradas;

- as habilidades mentais dos alunos, referentes à compreensão e/ou construção de conceitos, assim como as exigidas por outras funções mais 
complexas exercidas por aulas práticas, ainda não estão presentes ou apresentam-se pouco desenvolvidas;

- o domínio dos alunos sobre os assuntos a serem estudados em aulas práticas é nulo ou precário.

Se o professor pretende que suas aulas tenham a função de ampliar e/ou aprofundar conteúdo de aulas teóricas, as seguintes condições precisam ser preenchidas, para que ele estabeleça esse critério de utilização de aulas práticas:

- os alunos têm a oportunidade de assimilar, em aulas teóricas precedentes, os conhecimentos básicos sobre o conteúdo das aulas práticas;

- os alunos têm capacidades mínimas de entender a linguagem científica utilizada em aulas práticas e de seguir instruções orais e escritas;

- os alunos são capazes de interpretar, compreender e assimilar dados obtidos na literatura científica e aplicar seu conteúdo;

- há possibilidade de fornecer artigos científicos aos alunos ou protocolos com um certo número de informações e/ou os alunos têm tempo livre e acesso à biblioteca com acervo de livros e periódicos e à internet, para consulta sobre conteúdo das aulas práticas, com vistas a complementar o conhecimento adquirido em aulas teóricas e para elaborar o relatório;

- há oportunidade de os alunos processarem, interpretarem e discutirem os dados obtidos com orientação do professor.

Quando o critério adotado é o que aulas práticas devem exercer a função de aplicar teoria, lei, princípio, os seguintes fatos precisam ocorrer:

- há todas as condições, listadas acima, para que as aulas práticas exerçam a função de ampliar e aprofundar conteúdo de aulas teóricas;

- os alunos têm conhecimento sobre as etapas do método científico experimental e a capacidade de desenvolvê-las em laboratório;

- os alunos são capazes de transferir conhecimento adquirido em uma situação, para analisar e explicar situação análoga.

Os critérios propostos acima são um exemplo de como esta pesquisadora poderia ter utilizado os instrumentos de coleta de dados para 
estabelecer alguns de seus próprios critérios de inclusão e utilização de aulas práticas de Bioquímica. Com eles, essas aulas teriam, se planejadas de acordo com o que foi amplamente discutido, no mínimo as funções que normalmente são as mais encontradas nas disciplinas de Bioquímica de cursos das áreas de Ciências Biológicas e da Saúde. Claro que o estabelecimento desses critérios, da forma como foi feito, é passivel de crítica por parte de outros professores, que devem servir-se dos instrumentos de coleta de dados e do modelo de análise de aulas práticas à sua maneira e, com base em seu próprio julgamento, definir suas escolhas.

Os documentos elaborados para análise de aulas práticas podem ser utilizados, no todo ou em partes e com adaptações, se necessário, por disciplinas de cursos variados, que desenvolvam aulas práticas dentro de um recinto fechado. Esse uso pode limitar-se a uma análise que propicie a interpretação dos dados coletados e a compreensão de seus significados para as mais variadas finalidades. A extensão desse estudo permite chegar a generalizações importantes para o ensino de Bioquímica e ainda ultrapassar os limites do laboratório e de qualquer disciplina, atingindo um campo maior, o da Educação, ou transcender para um saber holístico, sem as amarrar da fragmentação, da classificação e dos "ismos" reducionistas. A que nivel se pode chegar - análise, interpretação, compreensão, interrelação, extrapolação, crítica, generalização, síntese -, tudo depende de quem usa o produto do trabalho aqui apresentado, como o faz e com que fim emprega o conhecimento obtido.

Enfim, os instrumentos de coleta de dados elaborados e o modelo de análise de aulas práticas proposto podem ser úteis dentro das premissas de qualquer paradigma que tenha sido adotado até esta data, inclusive o paradigma holístico que muitos defendem e que vem paulatinamente substituindo os demais. 
As conclusões finais que se pôde obter por meio desta pesquisa foram:

- Os instrumentos de coleta de dados criados têm a necessária abrangência, precisão, profundidade, validez e confiabilidade.

- O Modelo de Análise do Papel das Aulas Práticas no Ensino de Bioquímica complementa, descarta erros e inova a respeito de aulas práticas e de uso de laboratório didático. Seu emprego permite definição de critérios de inclusão na programação e utilização de aulas práticas, planejamento e avaliação dessas aulas, assim como estabelecimento de plano de montagem e gerenciamento de laboratório de Bioquímica. 


\section{REFERÊNCIAS BIBLIOGRÁFICAS*}

ABREU, M. C.; MASETTO, M. T. O professor universitário em aula: prática e princípios teóricos. 8. ed. São Paulo: MG Ed. Associados, 1990. 130 p.

ALVAREZ, M. A. Aspectos neurológicos da linguagem: um assunto que interessa a professores de línguas e comunicadores em geral. Revista AEI de Ensino e Pesquisa - Revista da Associação de Ensino de Itapetininga, Itapetininga, SP, v. 2, p .83-89, 1999.

. Aprendendo com todo o corpo. Revista Renascença de Ensino e

Pesquisa - Revista das Faculdades Integradas Hebraico-Brasileiras Renascença, São Paulo, v. 2, p. 55-64, 2000.

AUSTIN, C. A. A survey of final-year undergraduate laboratory projects in Biochemistry and related degrees in Great Britain. Biochemical Education, v. 25, n. 1, p. 12-14, 1997.

* AZANHA, J. M. P. Experimentação educacional: uma contribuição para sua análise. São Paulo: EDART, 1974. 78 p.

BACHELARD, G. O novo espirito científico. Tradução J. J. M. Ramos; R. F. Kuhnen; A. C. Leal; L. V. S. Leal. São Paulo: Abril, 1974. p. 247-337 (Coleção Os Pensadores, 38). Trabalho original publicado em 1934.

BARROWS, H. S.; TAMBLING, R. M. Problem-based learning: an approach to Medical Education. New York: Springer, 1980. Apud: Smith, C. A. Problembased learning. Biochemical Education, v .26, n. 4, p. 292-293, 1998.

BECKER, F. A. Epistemologia do professor: o cotidiano da escola. 7. ed. Petrópolis, RJ: Vozes, 1999.

BEHRENS, M. A. Formação pedagógica e os desafios do mundo moderno. In: MASETTO, M. (Org.). Docência na universidade. Campinas, SP: Papirus, 1998, cap. 4, p. 57-68. (Coleção Práxis).

BENNETT, S. W. University practical work: why do we do it? Education in Chemistry, v. 37, n. 2, p. 49-50, 2000.

BLADSOE, J. C. A comparative study of values and critical skills of a group of educational workers. Journal of Education Psychology, v. 46, p. 408-417, 1955.

BLOOM, B. S. (Ed.) Taxionomia dos objetivos educacionais. v. 1 - Domínio cognitivo. Tradução: F. M. Sant'Anna. Porto Alegre: Globo, 1973. 180 p. 
BLOOM, B. S.; KRATHWOHL, D. R.; MASIA, B. B. Taxionomia dos objetivos educacionais. v. 2 - Domínio afetivo. Tradução: J. A. Cunha. 7. ed. Porto Alegre: Globo, 1979. 204 p.

BOGDAN, R.; BIKLEN, S. K. Qualitative Research for Education. Boston: Allyn and Bacon, 1982. Apud: Lüdcke, M., André, M. E. D. A. Pesquisa em Educação: abordagens qualitativas. São Paulo: EPU, 1986. 99 p.

BRANDÃO, D. M. S.; CREMA, R. (Org.). Visão holística em Psicologia e Educação. Tradução: A. F. Negrini; D. Bolanho; M. Goldfeder. 2 ed. São Paulo: Summus, 1991. $197 \mathrm{p}$.

BRASIL. Ministério da Educação e Cultura. LEI 5540/68, de 28 de novembro de 1968. Diretrizes e Bases do Ensino Superior no Brasil. Diário Oficial da União, Brasília, DF, seção 1, v. 106, n. 231, p. 10369-72, col. 4, 29/11/1968. Ret. 03/12/68, v. 106, n. 233, p.10433, col. 3.

BRASIL. Ministério da Educação. LEl 9394/96, de 20 de dezembro de 1996. Diretrizes e Bases da Educação Nacional. Diário Oficial da União, Brasília, DF, seção 1, v. 134, n. 248, p. 27833-41, col. 1, 23/12/96.

BRASIL. Ministério da Educação. DECRETO LEI 3860/01, de 9 de julho de 2001. Organização do ensino superior, avaliação de cursos e instituições. Diário Oficial da União, Brasília, DF, seção 1, n. 132, 10 / 07/ 2001.

BYRNE, M. S. More effective practical work. Education in Chemistry, v. 27, n. 1, p. 12-13, 1990.

CARDOSO, J. J. Planejamento na escola: o projeto político-pedagógico. Revista de Administração Educacional, Recife, v. 1, n. 3, p. 27-36, 1999. CATANI, A. M. (Org). Novas perspectivas nas políticas de Educação Superior na América Latina no limiar do século XXI. Campinas, SP: Autores Associados, 1998. 291 p. (Coleção Educação Contemporânea).

CENTRO DE DESENVOLVIMENTO DE EDUCAÇÃO MÉDICA \& NÚCLEO DE PESQUISAS SOBRE ENSINO SUPERIOR DA UNIVERSIDADE DE SÃO PAULO. O ensino médico e a saúde no Brasil. São Paulo: NUPES-CAI / 94, 1994. 32 p. CERVO, A. L.; BERVIAN, P. A. Metodologia científica. 4. ed. São Paulo: Makron Books, 1996. 209 p. 
CHAIMOVICH, H. G. Depoimento. In: SCHREIER, S. (Coord.). 25 anos do Departamento de Bioquímica - Instituto de Química, Universidade de São Paulo. São Paulo: Instituto de Química, 1995, p. 85-88.

CHIZZOTTI, A. Pesquisa em Ciências Humanas e Sociais. 2. ed. São Paulo: Cortez, 1995. (Biblioteca da Educação. Série I. Escola, 16). 164p.

CREMA, R. Introdução à visão holística: breve relato de viagem do velho ao novo paradigma. São Paulo: Summus, 1989. 133 p.

CRONBACH, L. J., MEEHL, P. E. Construct validity in Psychological tests. Psychological Bulletin. New York: APA, 52 (4): 281-301, julho 1955. Apud: GRESSLER, L. A. Pesquisa Educacional. 3. ed. São Paulo: Loyola, 1989. 135 p. (Coleção Realidade Educacional).

CUNHA, M. I. Aportes teóricos e reflexões da prática: a emergente reconfiguração dos currículos universitários. In: MASETTO, M. T. (Org.). Docência na universidade. Campinas, SP: Papirus, 1998. cap. 2, p.27-38. (Coleção Praxis). DELDIME, R.; DEMOULIN, R. Tradução: G. C. BOTELHO. Introdução à Psicopedagogia. São Paulo: EPU-EDUSP, 1977. 267 p.

DEMO, P. Introdução à metodologia científica. 2. Ed. São Paulo: Atlas, 1987. 118p. DOMIN, D. S. A review of laboratory styles. Journal of Chemical Education, v. 76, n. 4, p. $543,1999$.

FAZENDA, I. C. A. A aquisição de uma formação interdisciplinar de professores. In: FAZENDA, I. C. A. (Org). Didática e interdisciplinaridade. Campinas, SP: Papirus, 1998. cap. 1, p. 9-26. (Coleção Práxis).

FEIJOO, A. M. L. C. A pesquisa e a estatística na Psicologia e na Educação. Rio de Janeiro: Bertrand Brasil, 1996. 171p.

FORESTI, M. C. P. P.; PEREIRA, M. L. T. A formação pedagógica construída na área da saúde: excertos de uma prática interdisciplinar na pósgraduação. In: MASETTO, M. (Org.). Docência na universidade. Campinas, SP: Papirus, 1998, cap. 5, p. 69-76. (Coleção Práxis).

GAL, R. História da educação. Tradução: A. Cabral. São Paulo: Martins Fontes, 1989. 115p.

GIL, D.; FURIÓ, C.; VALDÉS, P.; SALINAS, J.; MARTÍNEZ-TORREGROSA, J.; GUISASOLA, J.; GONZÁLEZ, E.; DUMAS-CARRÉ, A.; GOFFARD, M.; 
PESSOA, A. M. ? Tiene sentido seguir distinguiendo entre aprendizage de conceptos, resolución de problemas de lápiz y papel y realización de prácticas de laboratorio? Enseñanza de Las Ciências, v. 17, n. 2, p. 311-320, 1999.

GIORDAN, M. O papel da experimentação no ensino de ciências. Química Nova na Escola, n. 10, p. 43-49,1999.

GRAYSON, D. A holistic approach to preparing disadvantaged students to succeed in tertiary science studies. Part I - Design of the Science Foundation Programme (SFP). International Journal of Science Education, v. 19, n. 1, p. 993-1013, 1997.

GRESSLER, L. A. The effect of research course upon attitudes and critical thinking abilities of graduate students. 1976. 71 p. Tese (Doutoramento) Mississipi State University, Estados Unidos. Apud: GRESSLER, L. A. Pesquisa Educacional. 3. ed. São Paulo: Loyola, 1989. 135 p. (Coleção Realidade Educacional, 2).

Pesquisa Educacional. 3. ed. São Paulo: Loyola, 1989, cap. 1, p. 13-25, cap. 2, p. 27 -42, cap. 4, p. 87 - 96. (Coleção Realidade Educacional, 2).

HODSON, D. In search of a meaningful relationship: an explanation of some issues relating to integration in science and science education. International Journal of Science Education, v. 14, n. 5, p. 541-566, 1992.

. Hacia un enfoque más crítico del trabajo de laboratorio. Enseñanza de las Ciencias, v. 12, n. 3. p. 299-313, 1994.

HOWE, A. C. Development of science concepts within a Vygotskian framework. Science Education, v. 80, n. 1, p. 35-51, 1996.

ISAAC, S.; MICHAEL, W. Handbook in research and evaluation. California: Edits, 1971. Apud: GRESSLER, L. A. Pesquisa Educacional. 3. ed. São Paulo: Loyola, 1989. 135 p. (Coleção Realidade Educacional, 2).

JOHNSTONE, A. H.; LETTON, K. M. Laboratory work. Education in Chemistry, v. 27, n. 1, p. 9-11, 1990.

KENNETH, R. H. Getting over the quantitative-qualitative debate. American Journal of Education, v. 100, n. 2, p. 236-256, 1992.

KENSKI, V. M. A formação do professor-pesquisador: experiências do grupo de pesquisa "Memória, Ensino e Novas Tecnologias (MENT)". In: FAZENDA, 
I. C. A. (Org.). Didática e interdisciplinaridade. Campinas, SP: Papirus, 1998. Cap .7, p. 133-145. (Coleção Práxis).

KIRSCHNER, P.; MEESTER, M.; MIDDELBEEK, E.; HERMANS, H. Agreement between student expectations, experiences and actual objectives of practical in the Nature Sciences at the Open University of The Netherlands. International Journal of Science Education, v. 15, n. 2, p. 175-197, 1993.

KYLE JR, W. C.; LINN, M. C.; BITNER, B. L.; MITCHENER, C. P.; PERRY, $B$. The role of the research in Science teaching: An NSTA theme paper. Science Education, v. 75, n. 4, p. 413-418, 1991.

LAKATOS, E. M.; MARCONI, M. A. Fundamentos de metodologia científica. 2. ed. rev. e ampl. São Paulo: Atlas, 1990. 261p.

LA TAILLE, Y.; KOHL, M. O.; DANTAS, H. Piaget, Vygotsky, Wallon: teorias psicogenéticas em discussão. São Paulo: Summus, 1992. 117p.

LEITE, D.; BRAGA, A. M.; FERNANDES, C.; GENRO, M. E.; FERLA, A. A. avaliação institucional e os desafios da formação do docente na universidade pós-moderna. In: MASETTO, M. (Org.) Docência na universidade. Campinas, SP: Papirus, 1998, cap. 3, p. 39-56. (Coleção Práxis).

LEWIS, J. The use of mini-projects in preparing students for independent openended investigative labwork. Biochemical Education, v. 27, n. 3, p. 137- 144, 1999. LÜDKE, M.; ANDRÉ, M. E. D. A. Pesquisa em Educação: abordagens qualitativas. São Paulo: EPU, 1986. 99p. (Temas básicos de educação e ensino). LYTHCOTT, J.; DUSCHL, R. Qualitative research: From methods to conclusions. Science Education, v. 74, n. 3, p. 445-459, 1990.

MAGER, R. F. Preparing instructional objectives. Palo Alto, Califormia, 1962. Apud: ABREU, M. C.; MASETTO, M. T. O professor universitário em aula: prática e princípios teóricos. 8. ed. São Paulo: MG Ed. Associados, 1990. 130p.

. Goal analysis. Belmont, California, 1972. Apud: ABREU, M. C.; MASETTO, M. T. O professor universitário em aula: prática e princípios teóricos. 8. ed. São Paulo: MG Ed. Associados, 1990. 130p.

MASETTO, M. T. Aula na universidade In: FAZENDA, I. C. A. (Org.). Didática e interdisciplinaridade. Campinas, SP: Papirus, 1998a. cap. 10, p. 179-192. (Coleção Práxis). 
. O professor universitário: um profissional da educação na atividade docente. In: MASETTO, M. T. (Org.). Docência na universidade. Campinas, SP: Papirus, 1998b. cap. 1, p. 9-26. (Coleção Praxis).

MCKENZIE, G. Alternative modes of organizing biochemical laboratory work. Biochemical Education, v. 24, n. 3, p.137-141, 1996.

MINAYO, M. C. S. O desafio do conhecimento: pesquisa qualitativa em Saúde. São Paulo - Rio de Janeiro: ABRASCO-HUCITER, 1992. Apud: MINAYO, M. C. S. Pesquisa social: teoria, método e criatividade. 5. ed. Petrópolis, RJ: Vozes, 1994. cap. 1, p. 9-30. (Coleção Temas Sociais). . Ciência, técnica e arte: o desafio da pesquisa social. In: MINAYO, M. C. S. Pesquisa social: teoria, método e criatividade. 5. ed. Petrópolis, RJ: Vozes, 1994. cap. 1, p. 9-30. (Coleção Temas Sociais).

MORETTO, R.; MANSUR, O. C. Interdisciplinaridade. In: CONGRESSO BRASILEIRO DE EDUCAÇÃO MÉDICA, 34., Salvador, 1996. Anais, p. 97-113. MORIN, E. Articuler les savoir. In: MORIN, E., BONNEFOY, Y. Quels savoirs enseigner dans les lycées. Paris: Centre National de Documentation Pédagogique Ministère de L'Éducation Nationale, de Recherche et de La Technologie, 1998. 78 p. NÉRICE, I. G. Introdução à orientação educacional. 5. ed. São Paulo: Atlas, 1992. 283p.

NIAZ, M. Can we integrate qualitative and quantitative research in Science Education? Science \& Education, v. 6, n. 3, p. 291-300, 1997.

NISKIER, A. LDB: a nova lei da Educação. Rio de Janeiro: Consultor, 1996. 305p. NORATO, D. Y. J.; SILVA, S. H. S. A formação do professor de medicina em foco: avaliação discente das disciplinas Pedagogia Médica e Didática Especial na pós-graduação da FCM / UNICAMP. In: CONGRESSO BRASILEIRO DE EDUCAÇÃO MÉDICA, 34., Salvador, 1996. Anais, p. 7- 16.

PAMULA, F.; WIGMORE, G. J.; WHELDRAKE, J. F. Computer mediated learning in laboratory classes. Biochemical Education, v. 24, n. 3, p. 141-146, 1996.

PERRI DE CARVALHO, A. C. Formação do cirurgião dentista: ensino e profissionalização. São Paulo: NUPES - Documentos de Trabalho 4 / 96, 1996. $32 \mathrm{p}$. 
PERRI DE CARVALHO, A. C.; FERNANDES NETO, A. J.; MADEIRA, M. C. Diretrizes curriculares e projeto pedagógico para curso de Odontologia. São Paulo: NUPES - Documentos de Trabalho $2 / 98,1998.37$ p.

PICH-OTERO, A.; MOLINA-ORTIZ, S.; DELAPLACE, L.; CASTELLANI, O.; HOZBOC, D.; SORGENTINI, D.; LODEIRO, A. Laboratory practical work as a technological process. Biochemical Education, v. 26, n. 4, p. 281-285, 1998.

RICHARDSON, R. J. et al. Pesquisa social: métodos e técnicas. 2. ed. São Paulo: Atlas, 1989. 287p.

ROBERTS, D. A. What counts as quality in qualitative research? Science \& Education, v. 80, n. 3, p. 243-8, 1996.

RUIZ, J. A. Metodologia científica: guia para eficiência nos estudos. 2. ed. São Paulo: Atlas, 1986. 183p.

RYDER, J., LEACH, J. University science students' experiences of investigative project work and their images of Science. International Journal of Science Education, v. 21, n. 9, p. 945-956, 1999.

SANTOS FILHO, J. C.; GAMBOA, S. S. Pesquisa educacional: quantidadequalidade. 2. ed. São Paulo: Cortez, 1997. 111p. (Coleção Questões de Nossa Época, 42).

SANTOS, W. L. P.; SCHNETZLER, R. P. Função social: o que significa ensino de química para formar o cidadão? Química Nova na Escola, n. 4, p. 28-34, 1996.

SCHNETZLER, R. P.; ARAGÃO, R. M. R. Importância, sentido e contribuição de pesquisas para o ensino de química. Química Nova na Escola, n. 1, p. 27-31, 1995.

SCHWARTZ, A. T. Creating a context for Chemistry. Science \& Education, v. 8, n. 6, p. 605-618, 1999.

SEVERINO, A. J. Educação, ideologia e contra-ideologia. São Paulo: EPU, 1986. 106p.

. Metodologia do trabalho científico. 20. ed. rev. e ampl. São Paulo: Cortez, 1996. 272p.

. O conhecimento pedagógico e a interdisciplinaridade: o saber como intencionalização da prática. In: Fazenda, I. C. A. (Org) Didática e 
interdisciplinaridade. Campinas, SP: Papirus, 1998. cap. 3, p. 31-44. (Coleção Práxis).

SILVA, T. M. N. A construção do currículo na sala de aula: o professor como pesquisador. São Paulo: EPU, 1990. 74p.

SILVERMAN, M. P. Self-direct learning: philosophy and implementation.

Science \& Education, v. 5, n. 4, p. 357-380, 1996.

SMITH, C. A.; ATTWELL, R. W.; DAWSON, M. M.; GAFFNEY, J. J.; GHAHAM, I.; WILLCOX, J. Laboratory practical class precision in a first-year undergraduate modular program. Biochemical Education, v. 23, n. 1, p. 69-71, 1995.

TAVARES, C. S. C. Iniciação à visão holística. 4. ed. Rio de Janeiro: Record, 1998. $167 \mathrm{p}$.

THIOLLENT, M. Metodologia da pesquisa-ação. São Paulo: Cortez, 1985. Apud: LÜDKE, M., ANDRÉ, M. E. D. A. Pesquisa em Educação: abordagens qualitativas. São Paulo: EPU, 1986. 99 p.

TOFFLER, A. The third wave. New York: W. Morrow, 1980. 544 p.

TORRES, B. B. Learning by posing questions. Biochemical Education, v. 26, n. 4, p. 294-296, 1998.

$\checkmark$ TSAI, C. Laboratory exercises help me memorise the scientific truths: a study of "Eighth Graders" scientific epistemological views and learning in laboratory activities. Science Education, v. 83, n. 6, p. 654-673, 1999.

VELLA, F. Teaching Biochemistry for the $21^{\text {st }}$ Century. Biochemical Education, v. 17 , n. 1, p. 6-8, 1989.

WATTS, M.; ALSOP, S. The affective dimensions of learning science. International Journal of Science Education, v. 22, n. 12, p. 1219-1220, 2000.

WEIL, P. Holística: uma visão e abordagem do real. São Paulo: Palas Athena, 1990. $122 \mathrm{p}$.

WOOD, E. J. Laboratory practical classes in Biochemistry courses. Biochemical Education, v. 18, n. 1, p. 9-12, 1990.

. Laboratory work in Biochemical Education: purpose and practice. Biochemical Education, v. 24, n. 3, p. 132-137, 1996.

\footnotetext{
* Referências bibliográficas de acordo com NBR 6023:2000 - Informação e documentação Referẻncias - Elaboração. Associação Brasileira de Normas Técnicas, 2000.
} 


\section{UNIVERSIDADE DE SÃO PAULO INSTITUTO DE QUÍMICA}

\section{MODELO DE ANÁLISE DO PAPEL DAS AULAS PRÁTICAS NO ENSINO DE BIOQUÍMICA \\ Vol. 2}

Marina André de Alvarez

Tese de Doutorado

Orientador: Prof. Dr. Bayardo Baptista Torres 


\section{ÍNDICE}

\section{Vol. 2 - APÊNDICES E ANEXOS}

\section{Conteúdo}

APÉNDICES - Resultados da pesquisa de campo - Aplicação dos instrumentos de coleta de dados XXV

Apêndice 1 -FACULDADES INTEGRADAS HEBRAICOBRASILEIRAS RENASCENÇA 212

A. Caracterização do contexto ......................................... 212

$A_{1}$. Instituição

$A_{2}$. Curso analisado e disciplina com conteúdo de Bioquímica

Curso 212

Disciplina 213

$A_{3}$. Laboratório 213

$\mathrm{A}_{4}$. Resultados dos questionários respondidos por alunos e professor

Alunos 214

Professor 216

B. Análise das aulas práticas 217

$\mathrm{B}_{1}$. Dados gerais 217

$B_{2}$. Aulas práticas observadas 217

Apêndice 2 - CENTRO UNIVERSITÁRIO SÃO CAMILO 220

A. Caracterização do contexto 220

$A_{1}$. Instituição 220

$A_{2}$. Curso analisado e disçiplina com conteúdo de Bioquímica

Curso 221

Disciplina 221

$A_{3}$. Laboratório 221 
A4. Resultados dos questionários respondidos por alunos e professores ................................................. 223

Alunos .................................................... 223

Professores .............................................. 224

B. Análise das aulas práticas .......................................... 226

$\mathrm{B}_{1}$. Dados gerais ................................................ 226

$B_{2}$. Aulas práticas observadas ............................. 226

Apêndice 3 - FACULDADES OSWALDO CRUZ ....................................... 230

A. Caracterização do contexto ...................................... 230

$A_{1}$. Instituição ................................................... 230

$A_{2}$. Curso analisado e disciplina com conteúdo de Bioquímica .................................................. 230

Curso ................................................... 230

Disciplina ............................................... 231

$\mathrm{A}_{3}$. Laboratório ................................................ 231

A4. Resultados dos questionários respondidos por alunos e professores ................................................ 233

Alunos ....................................................... 233

Professores ............................................... 234

B. Análise das aulas práticas .......................................... 236

$\mathrm{B}_{1}$. Dados gerais ........................................... 236

$B_{2}$. Aulas práticas observadas .............................. 236

Apêndice 4 - UNIVERSIDADE DE SÃO PAULO - CAMPUS DA CAPITAL -

Departamento de Bioquímica do Instituto de Química . 239 Caracterização do contexto geral do Departamento de Bioquímica do Instituto de Química ................................ 239

A. Instituição - Departamento de Bioquímica do Instituto de Química ....................................................... 239

B. Laboratórios ................................................. 240 
Apêndice 5 - FACULDADE DE SAÚDE PÚBLICA - CURSO DE NUTRIÇÃO

A. Caracterização do contexto particular do curso de Nutrição

$A_{1}$. Instituição

A2. Curso analisado e disciplina com conteúdo de Bioquímica . 242

Curso

Disciplina

Distribuição dos alunos no recinto do laboratório ..

$A_{3}$. Resultados dos questionários respondidos por alunos e professora

Alunos

Professora 244

B. Análise das aulas práticas 245

$\mathrm{B}_{1}$. Dados gerais 245

$\mathrm{B}_{2}$. Aulas práticas observadas 245

Apêndice 6 - FACULDADE DE CIÊNCIAS FARMACÊUTICAS -

CURSO DE FARMÁCIA E BIOQUIIMICA

A. Caracterização do contexto particular do curso de Farmácia e Bioquímica

$A_{1}$. Instituição 249

A2. Curso analisado e disciplina com conteúdo de Bioquímica. 249

Curso 249

Disciplina 249

Distribuição dos alunos no recinto do laboratório .. 250

$A_{3}$. Resultados dos questionários respondidos por alunos e professor 250

Alunos 250

Professor 251

B. Análise das aulas práticas 252 
$B_{1}$. Dados gerais ............................................. 252

$B_{2}$. Aulas práticas observadas ............................. 252

Apêndice 7 - INSTITUTO DE BIOCIÊNCIAS - CURSO DE CIÊNCIAS BIOLÓGICAS. 256

A. Caracterização do contexto particular do curso de Ciências Biológicas ............................................ 256

$A_{1}$. Instituição .................................................. 256

A2. Curso analisado e disciplina com conteúdo de Bioquímica . 256

Curso ..................................................... 256

Disciplina ................................................. 256

Distribuição dos alunos no recinto do laboratório .. 257

$A_{3}$. Resultados dos questionários respondidos por alunos e professores .................................................. 257

Alunos ....................................................... 257

Professores ............................................... 258

B. Análise das aulas práticas ....................................... 260

$B_{1}$. Dados gerais ............................................. 260

$B_{2}$. Aulas práticas observadas .............................. 260

Apêndice 8 - QUESTIONÁRIO DA PESQUISA EXPLORATÓRIA ................. 264

ANEXOS - Currículos dos cursos analisados - Programas das disciplinas analisadas - Protocolos das aulas práticas observadas ......... xxvi FACULDADES INTEGRADAS HEBRAICO-BRASILEIRAS RENASCENÇA ............. 266

Anexo 1 - Grade curricular do curso de Ciências Biológicas .......................................... 266

Anexo 2 - Programa da disciplina de Química de Biomoléculas ....................................... 267

Anexo 3 - Protocolos das aulas práticas observadas .... 268 CENTRO UNIVERSITÁRIO SÃO CAMILO ................................................... 272

Anexo 4 - Grade curricular do curso de Nutrição ........... 272 
Anexo 5 - Programa da disciplina de Bioquímica

Anexo 6 - Protocolos das aulas práticas observadas .. 273 FACULDADES OSWALDO CRUZ

Anexo 7 - Grade curricular do curso de Engenharia

Química

Anexo 8 - Programa da disciplina de Bioquímica Aplicada 277

Anexo 9 - Protocolos das aulas práticas observadas .. 278 UNIVERSIDADE DE SÃO PAULO - CAMPUS DA CAPITAL 280

FACULDADE DE SAÚDE PÚBLICA 280

Anexo 10 - Currículo do curso de Nutrição 280

Anexo 11 - Programa da disciplina de Bioquímica . 281

Anexo 12-Protocolos das aulas práticas observadas .. 282

FACULDADE DE CIÊNCIAS FARMACÊUTICAS 286

Anexo 13 - Currículo do curso de Farmácia e Bioquímica 286

Anexo 14 - Programa da disciplina de Bioquímica Experimental 287

Anexo 15 - Protocolos das aulas práticas observadas 289 INSTITUTO DE BIOCIÊNCIAS 294

Anexo 16 - Grade curricular do curso de Ciências Biológicas 294 Anexo 17 - Programa da disciplina de Bioquímica 295 Anexo 18 - Protocolos das aulas práticas observadas 296 


\section{APÊNDICES}

\section{RESULTADOS DA PESQUISA DE CAMPO APLICAÇÃO DOS INSTRUMENTOS DE COLETA DE DADOS}

Apêndice 1 - FACULDADES INTEGRADAS HEBRAICO-BRASILEIRAS RENASCENÇA

Apêndice 2 - CENTRO UNIVERSITÁRIO SÃO CAMILO

Apêndice 3 - FACULDADES OSWALDO CRUZ

Apêndice 4 - UNIVERSIDADE DE SÃO PAULO - CAMPUS DA CAPITAL DEPARTAMENTO DE BIOQUÍMICA DO INSTITUTO DE QUÍMICA Apêndice 5 - FACULDADE DE SAÚDE PÚBLICA - USP CURSO DE NUTRIÇÃO

Apêndice 6 - FACULDADE DE CIÊNCIAS FARMACÊUTICAS - USP CURSO DE FARMÁCIA E BIOQUIMICA Apêndice 7- INSTITUTO DE BIOCIÊNCIAS - USP CURSO DE CIÊNCIAS BIOLÓGICAS Apêndice 8 - QUESTIONÁRIO DA PESQUISA EXPLORATÓRIA 


\section{APÊNDICE 1}

\section{FACULDADES INTEGRADAS HEBRAICO BRASILEIRAS RENASCENÇA}

\section{A. Caracterização do contexto}

\section{$A_{1}$. Instituição}

Dados gerais

Endereços

e-mail - faculdadebr@renacenca.br site: www.renacenca.br/faculdade

Campus Bom Retiro - R. Prates, 790 - Bom Retiro - São Paulo - SP

CEP-01121-000 telefone-3311-0778

Campus Higienópolis - R. São Vicente de Paulo, 659 - Higienópolis - São Paulo - SP

CEP - 01229-010 telefone - 3824-0788

Natureza / Classificação

Empresa privada / Faculdades

Cursos

Administração, Ciências Biológicas com Enfoque em Ciências Ambientais, Letras (Português - Inglês; Português Hebraico), Matemática, Pedagogia, Secretariado Executivo Bilíngüe, Tecnologia em Informática, Tecnologia em Hotelaria.

Atividades de Pós-Graduação

- a instituição possuía centro de pós-graduação em nível de especialização (lato sensu) e stricto sensu (Mestrado em Educação credenciado pela CAPES e em processo de autorização), por ocasião desta pesquisa;

- os cursos de especialização $(360$ h) eram: Administração Escolar, Ciência da Computação, Hotelaria, Informática na Educação, Metodologia do Ensino Superior, Orientação Educacional, Psicopedagogia;

- não havia participação de alunos de graduação em programas de pós-graduação.

Atividades de pesquisa

- a instituição começou, a partir de 1999, a fazer pesquisa na área de Educação, feita por alunos do Mestrado e, a partir de 2000, pretendia realizar pesquisa na área de Botânica, feita por alunos de graduação de Ciências Biológicas; neste último caso, com bolsa de iniciação científica da própria instituição;

- a instituição promovia semanas dos vários cursos de graduação em suas dependências, com conferências e apresentação de trabalhos de alunos da graduação;

- a instituição não mantinha estrutura para professores e/ou alunos de graduação participarem de congressos, cursos, palestras ou similares fora da instituição.

Prestação de serviço à comunidade (atividades de extensāo)

- a instituição fornecia bolsas para aumento de titulação de seu corpo docente (especialização e mestrado), em cursos do Centro de Pós-Graduação da própria instituição.

Publicações científicas

- a instituição possuía revista que publicava artigos científicos de seus membros, professores e alunos, e profissionais convidados: "Revista Renascença de Ensino e Pesquisa" (ISSN 1518-2339);

- a instituição não mantinha estrutura para professores e alunos de graduação participarem de publicações de outras instituições.

Regime de trabalho do professor de Química de Biomoléculas

- horista -4 h semanais;

- o professor não fazia pesquisa na instituição;

- não havia remuneração do professor para horário de planejamento / preparo de aulas práticas, nem para atendimento de alunos fora das aulas;

- o professor fazia pesquisa no Instituto de Química da USP, estando cursando doutoramento.

Apoios técnico e didático ao professor

- havia 1 técnica de laboratório de nível superior (bióloga);

- não havia pessoal para datilografar material produzido pelo professor, para uso em aulas práticas;

- as fotocópias para reproduzir material para uso em aulas práticas eram pagas pelos alunos;

- havia 2 salas de projeção;

- recursos audio-visuais:

- havia vários projetores de diapositivos e de transparências;

- havia vários vídeos e I projetor multimídia;

- os seguintes aparelhos podiam ser transportados para o laboratório - projetores de diapositivos e de transparências e multimídia;

- havia 2 laboratórios de informática que eram utilizados pelos vários cursos e que poderiam ser usados pela disciplina aqui analisada, para demonstrações do professor e para trabalho dos alunos;

- havia biblioteca com livros sobre Bioquímica e com acesso à Internet.

$\mathrm{A}_{2}$. Curso analisado e disciplina com conteúdo de Bioquímica

Curso

- nome do curso - Ciências Biológicas; 
- $\quad$ ênfase - meio ambiente;

- enfoque - pesquisa em ciência pura e aplicada e docência;

- habilitações - bacharelado e licenciatura;

- atividades profissionais para as quais habilitava - elaboração de projetos de pesquisa, orientação e assessoria de empresa que atue na área ambiental; realização de perícias e assinatura de laudos técnicos nas diversas áreas de conhecimento biológico; ensino de Ciências (ensino fundamental) e de Biologia (ensino médio); ecoturismo;

- período de funcionamento - noturno;

- duração / regime -8 semestres / regime semestral;

- currículo - séries e disciplinas, objetivos do curso - ver Anexo 1;

- não havia convênios da instituição com empresas ou outras instituições para treinamento profissional dos alunos. Alunos de licenciatura faziam estágios em escolas de ensino fundamental e médio.

Disciplina

- nome da disciplina - Química de Biomoléculas;

- carga horária - 4 aulas semanais / total de $80 \mathrm{~h}$;

- posição na grade curricular - disciplina lecionada no $1^{9}$ semestre do curso;

- objetivos e programa da disciplina - ver Anexo 2;

- $\quad$ porcentagem de assuntos da programação que foi desenvolvida em aulas práticas - 50\%;

- 4 assuntos de aulas práticas estavam fora da programação de aulas teóricas;

- divisão / proporção entre tipos de aulas:

* $\quad \mathrm{n}^{\mathrm{Q}}$ de aulas práticas -3 ;

* $\quad \mathrm{n}^{0}$ de aulas teóricas - 14 ;

* $\quad \mathrm{n}^{\mathrm{Q}}$ de outras atividades diferentes de aulas teóricas e práticas -3 ;

- $\mathrm{n}^{2}$ de períodos de discussão - 0 ;

- $\mathrm{n}^{\mathrm{O}}$ de aulas de exercícios - 0 ;

- $\mathrm{n}^{\mathrm{O}}$ de seminários -0 ;

- $\mathrm{n}^{0}$ de avaliações -2 ;

- $\mathrm{n}^{\mathrm{o}}$ de trabalhos bibliográficos - 1;

* proporção aulas práticas : atividades diferentes de aulas teóricas e práticas - 1:1;

* proporção aulas práticas : aulas teóricas - 1: 4,6;

- $\quad$ integração com outras disciplinas - Bioquímica ( $2^{\circ}$ semestre);

- relações de pré-requisitos com outras disciplinas - Biologia Geral I e II, Física e Biofisica, Fisiologia(s); Imunologia e Microbiologia, Biotecnologia, Biologia Celular e Molecular, Metodologia das Ciências;

- titulação do professor e instituição onde a obteve - doutorando em Química - IQ - USP;

- $\quad$ atividades de pesquisa do professor - fazia pesquisa pura na área de Química - IQ - USP;

- atividades docentes do professor na Disciplina de Química de Biomoléculas - dava aulas teóricas e práticas;

- a instituição não fez o perfil dos alunos ingressantes na disciplina analisada.

A. Laboratório

Natureza

- didática.

Condições fisicas

- dimensões da sala - largura - 5m; comprimento - 10m; área $-50 \mathrm{~m}^{2}$;

- bancadas - 2 bancadas altas com tampo de mármore; 4 locais para trabalho por bancada ( 2 de cada lado);

- instalações de água - 1 pia na extremidade da bancada de alunos; não havia local de armazenamento de água destilada no laboratório;

- instalações de gás - 1 bujão pequeno com bico de Bunsen sobre uma das extremidades de uma das bancadas;

- instalações elétricas:

- 10 conjuntos de 2 tomadas de $110 \mathrm{~V}$ em cada bancada; 2 tomadas de 1 I0V em uma das paredes;

- não havia tomadas de $220 \mathrm{~V}$;

- $\quad$ iluminação artificial - 9 conjuntos de 4 lâmpadas fluorescentes no teto;

- iluminação natural / ventilação:

- janelas - basculantes em toda a extensão de uma das paredes laterais, em cima, e porta de vidro no fundo, que ficava aberta durante as aulas práticas;

- não havia ventiladores; não havia ar condicionado;

- sistema de exaustão de ar e vapores:

- não havia capela para uso dos alunos;

- não havia capela para uso do professor e da técnica;

- não havia nenhum tipo de exaustor de vapores e/ou sistema de renovação de ar ou arejamento forçado;

- havia 1 lousa de acrílico em uma das paredes laterais, de frente para as bancadas;

- não havia quadro de avisos e/ou outros afixados nas paredes;

- instalações para uso dos alunos:

- tipo de assento dos alunos - bancos altos, em número suficiente para uso de todos os alunos; 
- local para colocação de material pessoal dos alunos - os alunos deixavam o material pessoal no chão, no fundo da sala;

- $\quad$ local para os alunos fazerem o registro de dados - a própria bancada;

- instalações para uso do professor, da técnica e do pessoal de limpeza:

- $\quad$ professor - usava a bancada da frente, não havendo assento diferenciado para seu uso;

- técnica - não havia local apropriado para seu uso, nem dentro, nem fora do laboratório;

- pessoal da limpeza - possuía local próprio, fora do laboratório.

- sistema de segurança:

- não havia avisos ou regras de segurança ou de primeiros socorros afixados no recinto do laboratório, mas foram entregues normas de segurança por escrito, para cada aluno, no início do curso, e foi assinado ciente pelos alunos;

- havia avisos orais do professor no início e durante as aulas práticas e constavam alertas no protocolo, sobre produtos tóxicos ou de alguma forma perigosos ao serem manuseados;

- $\quad$ o uso de avental pelo professor, pela técnica e pelos alunos era obrigatório;

- foram usados óculos protetores pelo professor e por alguns alunos, quando necessários; os óculos eram de propriedade particular;

- houve uso de pêras, quando necessárias;

- não havia chuveiros e lava-olhos;

- $\quad$ extintores de incêndio - 2, no corredor externo;

- piso - cerâmica lisa;

- falhas de segurança - piso escorregadio, falta de chuveiro e lava-olhos, falta de capela ou outro sistema de exaustão de ar e vapores, falta de sistemas de ventilação forçada, falta dc gás cncanado, pouca disponibilidadc de água;

OBS - o laboratório usado pelas disciplinas de Química de Biomoléculas e de Bioquímica era um laboratório adequado a outras disciplinas que não faziam experimentos na área de Química. O laboratório próprio para as duas disciplinas citadas estava em fase de conclusão;

- não houve nenhum acidente ou incidente com relação à segurança, durante as aulas práticas observadas;

- formas de descarte de materiais - os alunos foram orientados sobre as formas de descarte de materiais; havia preocupação com o prejuízo ecológico que o descarte de materiais poderia causar;

- os alunos levavam a vidraria e deixavam-na sobre a bancada, no fim da aula;

- higiene:

- condições de higiene - boas;

- limpeza de vidraria - o material era recolhido após as aulas práticas, lavado e guardado pela técnica, no dia seguinte;

- $\quad$ latões de lixo - 1 perto da pia;

- local de estoque e colocação de materiais:

- vidraria e drogas - armários no fundo da sala;

- aparelhos e equipamentos - armários no fundo da sala e em uma das extremidades das bancadas; geladeira, estufa e autoclave no chão, junto à uma das paredes laterais, oposta à lousa.

Condiçóes de trabalho dos alunos

- distribuição dos alunos no recinto do laboratório:

- $\quad n^{\circ}$ total de alunos - 10 ;

- densidade populacional nas aulas práticas $-0,2$ alunos $/ \mathrm{m}^{2}$;

- $\quad n^{2}$ de alunos por bancada - 4 a 6 ;

- $\quad \mathrm{n}^{\circ}$ de alunos por grupo - 2 a 3 ;

- adequação do local às necessidades dos experimentos - média;

- acesso a:

- água-pouco;

- gás - pouco;

- eletricidade - bom;

- materiais dos experimentos - bom;

- aparelhos - bom;

- equipamentos - bom;

- lixo-pouco.

- condições de:

- iluminação - boas;

- ventilação - boas;

- distribuição do material - o material era colocado sobre a bancada, antes da aula, pela técnica;

- possibilidades de visualizar e ouvir o professor e a lousa ou recursos audio-visuais - boas;

- facilidade de circulação pelo laboratório durante as aulas - boa.

A. $_{4}$ Resultados dos questionários respondidos por alunos e professor

Alunos (respostas de 10 alunos)

- Expectativas em relação às aulas práticas:

- $\quad$ alguns alunos esperavam que as aulas práticas fossem mais freqüentes do que foram; 
- alguns alunos esperavam que as aulas práticas fizessem entender melhor o conteúdo das aulas teóricas;

- segundo opiniões individuais - um aluno:

* temia ter dificuldade em acompanhar as aulas práticas;

* esperava que as aulas práticas fossem menos complicadas;

* esperava que as aulas práticas deixassem mais claro o campo de estudo da Bioquímica;

- Um aluno não respondeu a questão.

- Opiniões sobre as aulas práticas:

- As aulas práticas mais interessantes foram aquelas em que:

* os resultados foram surpreendentes, segundo alguns alunos;

* entendeu-se a explicação do professor, segundo um aluno;

- Nenhuma aula foi interessante, segundo um aluno e todas foram interessantes, segundo outro aluno;

- Dois alunos não compreenderam a questão sobre qual aula prática foi mais interessante, um apontando aulas de outras disciplinas;

- Um aluno declarou não saber responder que aula foi mais interessante, porque as aulas práticas são muito complicadas.

- As aulas práticas mais proveitosas foram aquelas em que:

* aprenderam a manusear materiais de laboratório, segundo alguns alunos;

* $\quad$ segundo opiniões individuais:

- a explicação foi bem dada;

- houve esclarecimento sobre os conteúdos das aulas teóricas;

- todas as aulas práticas foram proveitosas;

- Um aluno não entendeu a questão sobre qual aula prática foi mais proveitosa e dois citaram aulas de outra disciplina e um aluno não respondeu;

- Um aluno apontou o título da aula que considerou proveitosa, mas não deu explicações.

- Os defeitos das aulas práticas apontados pelos alunos foram:

* seu pequeno número, segundo alguns alunos;

* tempo escasso, os experimentos eram pouco trabalhados, segundo alguns alunos;

* falta de material, segundo alguns alunos;

* segundo opiniões individuais:

- as aulas práticas não tinham defeitos;

- muito aluno para um único professor dar assistência.

- As limitações para o aluno ter bom desempenho em aulas práticas apontadas foram:

* na opinião de poucos alunos, as aulas práticas serem complicadas;

* na opinião de alguns alunos, as aulas práticas serem dificeis de entender; terem pouco tempo para realizar o trabalho, o que causava intranqüilidade nos alunos;

- A maioria dos alunos não viu limitações para seu desempenho em aulas práticas.

- As diferenças entre aulas práticas e teóricas apontadas foram:

* "nas aulas práticas, os alunos vivenciam, observam, têm curiosidade, interesse e ficam na expectativa, enquanto que nas aulas teóricas, eles apenas imaginam, porque são mais abstratas e o conteúdo fica mais no papel do que em suas cabeças"- opinião expressa com essas palavras, por um aluno, e de formas similares, por vários alunos;

* "nas aulas práticas, aprende-se, porque vê-se os resultados", de acordo com vários alunos;

* as aulas práticas foram mais animadas, segundo um aluno, e as teóricas mais cansativas, segundo outro aluno.

- Comentários sobre os relatórios de aulas práticas:

- a maioria dos alunos não opinou sobre o relatório;

- um aluno considerou o relatório importante, sem ter dado explicações;

- um aluno não entendeu sobre o que deveria comentar.

- Considerações sobre os relacionamentos pessoais:

- Entre alunos -

* um aluno considerou ótimo seu relacionamento com os colegas;

* a maior parte dos alunos considerou o relacionamento com os colegas bom e um considerou-o regular;

* alguns apontaram o individualismo como barreira para o relacionamento entre os alunos não ser o melhor possivel;

- Entre professor e alunos -

* alguns consideraram seu relacionamento com o professor ótimo e a maioria o considerou bom, apenas um achou que seu relacionamento com o professor foi regular;

* o professor foi considerado atencioso;

- Entre alunos e a técnica -

* um aluno considerou ótimo seu convívio com a técnica e a maioria, o considerou bom;

* um aluno não entendeu a questão e outro declarou não ter nenhum convívio com a técnica.

- Atitude dos alunos frente ao questionário: 
- os alunos foram solícitos, não colocando nenhum impedimento para responder o questionário, não apresentando nenhum tipo de comportamento negativo em relação a ele;

- em geral, os alunos tiveram dificuldade na compreensão das questões; alguns aproveitaram para elogiar a iniciativa de avaliar aulas práticas.

Professor

Grégoire Jean-François Demets

- Cargo na Instituição - professor de aulas teóricas e práticas.

- Curso de Graduação - Química - bacharelado (IQ - USP).

- Pós-Graduação - doutorando em Química (IQ - USP).

- $\quad$ Atividades de pesquisa - pesquisa pura na área de Química (IQ - USP).

- Opiniões sobre aulas práticas no ensino de Bioquímica:

- Importância - "as aulas práticas são fundamentais no entendimento e na sedimentação dos conceitos teóricos".

- Critério de escolha do número de aulas práticas, de suas posições na programação e de seus assuntos distribuição de forma uniforme ao longo do semestre, para que os assuntos das aulas teóricas fossem abordados aos poucos, na prática.

- Realização das expectativas nas aulas práticas ministradas:

* em parte frustradas, devido à incapacidade dos alunos de entender o protocolo dos experimentos;

* apesar da boa vontade do professor e dos alunos, as aulas práticas não corresponderam às expectativas.

- As limitações das aulas práticas foram:

* poucos equipamentos e falta de materiais, o que reduz o leque de escolha de experimentos e o número de conceitos que se podem abordar;

* a formação dos alunos, que era muito fraca;

* falha de preparação, porque os experimentos ainda não haviam sido suficientemente testados e adaptados às condições das aulas, uma vez que foram criados ou modificados pelo professor, especialmente para o curso em questão;

* não houve limitações de ordem pessoal, ética e/ou moral, impostas pela estrutura institucional e/ou legal, de número de alunos, de espaço e de tempo.

- Consecução dos objetivos:

- Quanto ao conteúdo:

* Objetivos alcançados -

- ilustrar fatos e fenômenos;

- mostrar a importância da Bioquímica em campos específicos do conhecimento.

* Objetivo não alcançado -

- ensinar a compreender e construir conceitos.

* Objetivo que as aulas práticas deveriam ter, mas que não foi colocado no curso -

- aplicar teoria, lei, princípio.

* Objetivo que as aulas práticas não deveriam ter, entre aqueles apresentados no questionário -

- divulgar descobertas recentes da Ciência.

- Quanto à metodologia de ensino:

* Objetivos alcançados -

- ensinar como seguir protocolo;

- ensinar como comunicar resultados oralmente;

- ensinar como testar hipóteses.

* Objetivos não alcançados -

- ensinar como processar dados;

- ensinar como fazer relatório escrito;

- ensinar como propor hipóteses;

- ensinar como validar ensaios;

- ensinar como criticar dados.

* Objetivo que as aulas práticas deveriam ter, mas que não foi colocado no curso -

- ensinar como consultar literatura.

* Objetivos que as aulas práticas não deveriam ter, entre aqueles apresentados no questionário -

- desenvolver autonomia na execução de experimentos;

- ensinar como propor novos experimentos;

- ensinar como escrever protocolo.

- Quanto ao treinamento de habilidades técnicas experimentais:

* Objetivos alcançados -

- treinar manuseio de material de laboratório e de reagentes;

- treinar uso de equipamentos e aparelhos;

- treinar técnicas de pesquisa laboratorial.

* Objetivo não alcançado -

- ensinar como observar. 
* Objetivo que as aulas práticas deveriam ter, mas que não foi colocado no curso -

- treinar manipulação de material biológico.

- Quanto à interação entre os participantes:

* Objetivos alcançados -

- o professor não colocou objetivos neste item.

* Objetivos não alcançados -

- motivar aluno;

- encorajar entusiasmo pela Ciência.

* Objetivos que as aulas práticas não deveriam ter, entre aqueles apresentados no questionário -

- melhorar relações entre professor e aluno;

- melhorar relações entre alunos.

\section{B. Análise das Aulas Práticas}

\section{$\mathrm{B}_{1}$. Dados gerais}

- total de aulas práticas na programação - 3;

- $\quad \mathrm{n}^{\mathrm{O}}$ de aulas práticas observadas -3 ;

- datas - 4/09/2000;23/10/2000; 4/12/2000;

- período - noturno;

- professor - Grégoire Jean-François Demets;

- técnica / tipo de participação na aula - Fabiana Tavares Moreira / atuou no preparo das aulas práticas e auxiliou na parte técnica, durante as aulas.

$\mathrm{B}_{2}$. Aula Práticas observadas

Características gerais

- $\quad$ assuntos (unidades da programação) - ver Anexo 3:

Identificação de metais alcalinos (Matéria, átomos, moléculas; Distribuição eletrônica, periodicidade química); Reações redox (Reações redox e pilhas); Polaridade de solventes, Titulação ácido-base, Determinação do ponto de viragem de um indicador (Equilíbrio químico, água, $\mathrm{pH}$ e tampões, reações de neutralização, indicadores); Síntese $\mathrm{e}$ propriedades de um sabão, Cromatografia em papel (assuntos fora da programação de aulas teóricas); Amido nas plantas, Digestão de amido e do açúcar de cana (Química orgânica); Floculantes e tratamento de água, Cromatografia em coluna (assuntos fora da programação de aulas teóricas); Catálise da decomposição de água oxigenada (Enzimas e cinética enzimática); Complexos metálicos do Ferro (Moléculas de interesse biológico);

- ordem dentro da programação $-6^{\mathrm{a}}, 13^{\mathrm{a}}$ e $19^{\mathrm{a}}$ aulas (ver Anexo 2);

- as aulas práticas não tiveram ligação com qualquer atividade desenvolvida pela instituição, que não seja as da própria disciplina;

- $\quad$ as aulas práticas não foram acompanhadas de artigo científico correlato;

- as aulas práticas, na maioria, foram ministradas após as aulas teóricas correspondentes, apenas uma, antes;

- dinâmica da aula:

- duração - 2:30 h a 4:00 h;

- divisão de tempo da aula -

* planejamento / explicações iniciais - 7,5\% a $18 \%$;

* execução-48\% a $77 \%$;

* análise de resultados / discussão - $12,5 \%$ a $34 \%$;

- condições de orientação dos alunos:

- $\quad \mathrm{n}^{0}$ de professores -1

- $\quad n^{\circ}$ de auxiliares que participaram da orientação - 1;

- $\quad \mathrm{n}^{\circ}$ de alunos - 10; proporção orientador : aluno - 1:5;

- condições dos alunos quanto a conhecimentos necessários para a compreensão da aula - os alunos tinham dificuldade de entender as instruções orais e escritas, tinham pouco conhecimento sobre os assuntos ministrados em aulas teóricas e participavam pouco das discussões;

- possibilidade de uso do laboratório fora do horário de aula - à tarde;

- não havia possibilidade de orientação do professor fora do horário de aula, mas, com o consentimento do professor e havendo material disponivel, os alunos poderiam ser orientados pela técnica;

- possibilidade de os alunos trabalharem em grupo fora da aula: - local - cantina, biblioteca e salas vazias;

Materiais - horário - tarde e noite.

- foram usados equipamentos e vidrarias corriqueiros em laboratório de Química;

- os aparelhos e equipamentos foram colocados nas extremidades das bancadas;

- as drogas e materiais biológicos foram distribuídos no momento do experimento, pelo professor e pela técnica;

- custo do material de consumo - não estimado. 


\section{Preparo e teste}

- o preparo de aulas práticas da disciplina era feito pela técnica, à tarde, antes do período de aula, com o planejamento, orientação e supervisão do professor;

- alguns experimentos foram previamente testados pelo professor.

Normas de segurança e de manipulação de material biológico

- foram dadas normas de segurança orais e por escrito, com ciência por escrito, assinada pelos alunos;

- não houve treinamento específico sobre segurança no laboratório ou sobre manipulação de tecidos, órgãos ou animais.

\section{Conteúdo da aula}

- relações:

- com o resto da programação -

* as aulas práticas acompanhavam o conteúdo das aulas teóricas, em geral, e 4 experimentos estavam fora da programação de aulas teóricas;

* as aulas práticas geralmente foram dadas após as aulas teóricas correspondentes;

- as aulas práticas tinham todos os assuntos relacionados com Bioquímica, alguns com Fisiologia(s) e com Física e Biofísica e um relacionado com Ecologia;

- as aulas práticas não tinham relações com pesquisa da instituição ou de fora dela ou com projeto de extensão da instituição e com publicações científicas, dentro ou fora da instituição;

- a questão do descarte de materiais de forma a não poluir o meio ambiente e a do tratamento de água foram assuntos que se relacionavam com a vida profissional futura dos alunos, com a suas vidas cotidianas e com o contexto social geral dos alunos como cidadãos;

- não houve relações das aulas práticas com a vida universitária dos alunos;

- de acordo com a opinião do professor, algumas aulas práticas poderiam ser substituídas por discussão de artigos científicos com resultados semelhantes, por resolução de problemas e por análise de casos;

- as aulas práticas não partiram de um problema a ser resolvido pelos resultados obtidos; havia perguntas, no protocolo, que serviam como orientação para a discussão dos resultados e que eram os itens do relatório.

Roteiro / Protocolo

Ver Anexo 3:

- os protocolos eram impressos, deixados na fotocopiadora para serem comprados pelos alunos e foram fornecidos com antecedência;

- os protocolos eram produzidos pelo professor;

- no conteúdo dos protocolos:

- não constavam os objetivos das aulas ou dos experimentos, nem eles foram fornecidos oralmente;

- não constavam listas de materiais;

- havia todas as diretrizes para a execução dos experimentos;

- eram fornecidas normas de segurança específicas para cada experimento e estas eram reforçadas oralmente;

- não havia regras de higiene;

- não havia instruções do quê e como observar;

- havia instruções sobre como registrar os dados;

- não havia questões e/ou problemas a serem resolvidos no relatório, usando os dados obtidos;

- havia orientação para a discussão dos dados;

- não constava bibliografia específica sobre a técnica e/ou sobre o assunto das aulas práticas.

Etapas da aula / Estratégia de ensino

- utilização do protocolo (roteiro de aula):

- os protocolos deveriam ser lidos pelos alunos, previamente, antes do início das aulas práticas, por recomendação do professor;

- $\quad$ os alunos tiravam dúvidas sobre o protocolo, com o professor, à medida que executavam os trabalhos;

- o conjunto de dados a ser obtido foi definido previamente;

- tipo de execução:

- demonstração pelo professor, quando havia escassez de material ou perigo na manipulação de drogas;

- a maior parte dos experimentos foi executada pelos alunos, sob a orientação do professor;

- a manipulação de aparelhos foi feita pelos alunos, com o auxílio da técnica e do professor;

- principalmente um ou poucos alunos executavam os experimentos, apesar de os grupos serem pequenos;

- precisão / sensibilidade / higiene:

- houve preocupação com a precisão na obtenção dos dados; não houve preocupação com as sensibilidades dos métodos e técnicas;

- não houve preocupação com higiene;

- habilidades:

- técnicas -

* exigidas pelas aulas - manipulação de vidraria simples de laboratório de Química;

- os alunos não tinham as seguintes habilidades - alguns não sabiam pipetar corretamente;

* treinadas durante as aulas - uso de pêra e de banho-maria;

- mentais - 
* exigidas pelas aulas - compreender instruçð̃es orais e escritas;

- os alunos não tinham as seguintes habilidades - capacidade de compreender instruçס̃es orais e escritas;

* treinadas durante as aulas - seguir protocolo, observar e anotar, analisar e sintetizar;

- forma de orientaçăo dos alunos pela equipe:

- $\quad$ as orientações eram dadas no início das aulas, pelo professor e durante toda a aula, por ele e pela técnica;

- observaçóes sobre as explicações iniciais - o professor reproduzia os dados do protocolo na lousa, dava o embasamento teórico das técnicas, relacionando-as com os assuntos de aulas teóricas;

- forma de registro dos resultados - no caderno, com orientação escrita no protocolo;

- processamento dos dados obtidos:

- os dados dos grupos foram colocados na lousa;

- $\quad$ cada experimento foi tratado como único; cada grupo trabalhou com seus próprios dados;

- houve cobrança dos resultados previamente esperados;

- um experimento planejado para demonstração (Cromatografia em coluna) não foi realizado, porque o preparo não foi adequado; não se repetiu o experimento, nem fez-se comentários sobre ele;

- o tempo disponível para a execução proposta no início da aula foi suficiente;

- comportamento dos participantes:

- alunos -

* estavam sempre interessados, quase sempre envolvidos e comprometidos com o trabalho;

* faziam as atividades, queriam ver os resultados, mas não se arriscavam a responder perguntas feitas pelo professor;

- professor -

* comprometido, com intencionalidade;

* explicava tudo detalhadamente, do manuseio de materiais aos princípios das técnicas;

* falava rápido para dar tempo de dar todo o conteúdo; perguntava pouco aos alunos; entregava as conclusões prontas;

* ficava preocupado com a falta de lembrança dos alunos com relação ao conteúdo das aulas teóricas;

- encerramento das aulas - as aulas encerraram-se após a obtenção dos dados pelos grupos, sua colocação na lousa, com o professor comentando os resultados e dando seus significados e relacionando-os com os assuntos das aulas teóricas, seguindo-se a confecção dos relatórios.

Discussåno dos dados

- a discussão ocorreu no fim da aula, com o professor relacionando os resultados dos alunos, colocados na lousa, com os assuntos das aulas teóricas.

Relatório das Aulas Práticas

- obrigatório; realizado e entregue na próprỉa aula;

- feito por escrito, em grupo;

- feito a partir de diretrizes específicas - respostas de perguntas e resolução de problemas;

- ensinava a:

- fazer tratamento de dados;

- discutir resultados - analisar e relacionar dados;

- fazia parte da avaliação.

Atividades suscitadas pelas Aulas Práticas

- as aulas práticas encerraram-se em si mesmas, não suscitaram trabalhos posteriores.

Avaliação do aprendizado em aulas práticas

- a avaliação das aulas práticas era feita pelo relatório, somente.

Ocorrências não previstas durante as aulas práticas

- não houve qualquer ocorrência a assinalar. 


\section{APÊNDICE 2}

\section{CENTRO UNIVERSITÁRIO SÃO CAMILO}

\section{A. Caracterização do contexto}

\section{$A_{1}$. Instituição}

Dados gerais

Endereços

e-mail-unic@scamilo.br site: www.scamilo.br telefone: 0800-178585

Campus Pompéia - R. Raul Pompéia, 144 - Vila Pompéia - São Paulo - SP

CEP - 05025-010 telefone-3873-2533

Campus Nazaré - Av. Nazaré, 1501 - Ipiranga - São Paulo - SP

CEP-04263-200 telefone - 272-6077

Natureza / Classificação

Empresa privada / Centro Universitário.

Cursos

Administração de Empresas, Administração com Habilitação em Administração Hospitalar, Ciência da Computação, Ciências Biológicas com Enfase em Meio Ambiente, Enfermagem, Farmácia, Fisioterapia, Fonoaudiologia, Letras, Matemática, Nutrição, Pedagogia, Tecnologia em Radiologia Médica, Terapia Ocupacional. Atividades de Pós-Graduação

- a instituição possuía centro de pós-graduação em nível de especialização (lato sensu) e MBA em várias áreas, por ocasião desta pesquisa:

- especialização -

* em Nutrição, a área do curso observado, a instituição possuía os cursos de Nutrição Clínica (460 h) e de Educação Continuada ( 480 h);

* em outras áreas - Audiologia, Bioética e Pastoral da Saúde, Controle de Infecção Hospitalar, Enfermagem Clínica, Enfermagem em Emergência, Enfermagem em Neonatologia, Enfermagem em Terapia Intensiva, Enfermagem Obstétrica, Fonoaudiologia Hospitalar, Gerontologia, Gestão Ambiental, Medicina do Trabalho, Reabilitação Clínica, Reabilitação Respiratória, Saúde Pública;

- MBA - Auditoria de Sistemas de Saúde, Gestão de Marketing em Saúde, Gestão Financeira em Saúde, Gestão Hospitalar;

- não havia participação de alunos de graduação em programas de pós-graduação.

Atividades de pesquisa

- a instituição não realizava pesquisa por ocasião desta observação, apenas alguns alunos participavam de pequenos projetos de iniciação científica com professores da Graduação;

- a instituição promovia semanas dos vários cursos de graduação em suas dependências, com conferências, "workshops" etc;

- a instituição não mantinha estrutura para professores êou alunos de graduação participarem de congressos, cursos, palestras ou similares fora da instituição.

Prestação de serviço à comunidade (atividades de extensão)

- a instituição possuía um Centro de Orientação e Atendimento em Nutrição (COAN), ligado ao curso de Nutrição, e uma Clínica de Fonoaudiologia, ligada ao curso de Fonoaudiologia.

Publicações científicas

- a instituição possuía revista que publicava artigos de divulgação científica "O Mundo da Saúde" (ISSN 0104-7809) e o periódico "Cadernos do Centro Universitário São Camilo" (ISSN - 0104-5865), dedicado a um dos cursos, a cada número, com artigos de professores e alunos do curso em questão;

- a instituição não mantinha estrutura para professores e alunos de graduação participarem de publicações de outras instituições.

Regime de trabalho dos professores de Bioquímica

- horista $-4 \mathrm{~h}$ semanais por turma;

- os professores não faziam pesquisa na instituição;

- não havia remuneração dos professores para horário de planejamento / preparo de aulas práticas, nem para atendimento de alunos fora das aulas;

- os professores, por ocasião da observação realizada para o presente trabalho, não faziam pesquisa laboratorial própria;

- a professora titular coordenava projetos de pesquisa de iniciação científica com alunos voluntários que já haviam cursado Bioquímica.

Apoios técnico e didático aos professores

- havia 1 técnica de laboratório de nível médio;

- não havia pessoal para datilografar material produzido pelos professores, para uso em aulas práticas;

- as fotocópias para reproduzir material para uso em aulas práticas eram pagas pelos alunos; 
- havia 1 sala de projeção;

- recursos audio-visuais:

- havia vários projetores de diapositivos e de transparências;

- havia vários vídeos;

- $\quad$ os aparelhos não eram transportados para o laboratório;

- havia 1 laboratório de informática que era utilizado pelos vários cursos e que poderia ser usado pela disciplina aqui analisada, para demonstrações dos professores;

- havia biblioteca com livros e periódicos sobre Bioquímica e com acesso à Internet.

$\mathrm{A}_{2}$. Curso analisado e disciplina com conteúdo de Bioquímica

Curso

- nome do curso - Nutrição;

- enfoque - ciência aplicada e tecnologia;

- habilitação - bacharelado;

- atividades profissionais para as quais habilitava - nutricionista (técnico de nível universitário) com atuação em equipes médicas e de saúde pública multidisciplinares e em indústria alimentícia, restaurantes, hospitais e instituições esportivas;

- período de funcionamento - matutino;

- duração / regime - 8 semestres / regime semestral;

- currículo - séries e disciplinas, objetivos do curso - ver Anexo 4;

- treinamento profissional dos alunos:

- havia convênios da instituição com empresas e outras instituições para treinamento profissional dos alunos;

Disciplina

- os alunos faziam treinamento profissional no COAN da própria instituição.

- nome da disciplina-Bioquímica;

- carga horária - 4 aulas semanais / total de $80 \mathrm{~h}$;

- posição na grade curricular - disciplina lecionada no $2^{Q}$ semestre do curso;

- objetivos e programa da disciplina - ver Anexo 5;

- $\quad$ porcentagem de assuntos da programação que foi desenvolvida em aulas práticas $-25 \%$;

- 2 assuntos de aulas práticas estavam fora da programação de aulas teóricas;

- divisão / proporção entre tipos de aulas:

* $\quad \mathrm{n}^{\circ}$ de aulas práticas -7 ;

* $\quad \mathrm{n}^{\mathrm{Q}}$ de aulas teóricas -22 ;

* $\quad \mathrm{n}^{\varrho}$ de outras atividades diferentes de aulas teóricas e práticas -9 ;

- $\mathrm{n}^{\mathrm{O}}$ de períodos de discussão - 0;

- $\mathrm{n}^{\mathrm{O}}$ de aulas de exercícios -2 ;

- $\mathrm{n}^{\mathrm{Q}}$ de seminários -4

- $\mathrm{n}^{\mathrm{O}}$ de avaliações -3 ;

- $\mathrm{n}^{2}$ de trabalhos bibliográficos -1 ;

* proporção aulas práticas : atividades diferentes de aulas teóricas e práticas - 1:1,3;

* proporção aulas práticas : aulas teóricas - 1: 3,1;

- $\quad$ integração com outras disciplinas - Fundamentos de Química Orgânica ( $1^{\circ}$ semestre);

- relações de pré-requisitos com outras disciplinas - Biologia I e II, Metodologia da Pesquisa Científica; Fisiologia Humana I e II, Bromatologia, Farmacologia, Microbiologia e Imunologia, disciplinas referentes à Nutrição, Dietética e Alimentos;

- titulações dos professores e instituições onde as obtiveram - os dois professores tinham Mestrado em Ciências dos Alimentos - FCF - USP;

- $\quad$ atividades de pesquisa dos professores- não faziam pesquisa;

- atividades docentes dos professores na Disciplina de Bioquímica - a professora titular dava aulas teóricas e práticas e o professor assistente dava aulas práticas;

- a instituição não fez o perfil dos alunos ingressantes na disciplina analisada.

A3. Laboratório

Natureza

- didática.

Condições fisicas

- dimensões da sala - largura-8,5m; comprimento - 9m; área - 76,5 $\mathrm{m}^{2}$;

- bancadas - 6 bancadas altas com tampo de mármore com 2 locais para trabalho por bancada ( 1 em cada extremidade);

- $\quad$ instalações de água - 6 pias ( 1 em cada bancada de alunos, no meio), 1 na bancada de aparelhos, 1 na capela;

1 bujão de água destilada em prateleira acima da pia da bancada de aparelhos;

- instalações de gás - gás encanado ; 2 bicos de gás por bancada de alunos e 1 bico na capela;

- instalações elétricas:

- conjuntos de 2 tomadas de $110 \mathrm{~V}$ em cada bancada de aluno; 1 tomadas de $110 \mathrm{~V}$ em uma das paredes; 1 tomada de $110 \mathrm{~V}$ na capela; 7 tomadas de $110 \mathrm{~V}$ na bancada de aparelhos; 
- 1 tomada de $220 \mathrm{~V}$ na bancada de aparelhos;

- $\quad$ iluminação artificial - 3 conjuntos de 6 lâmpadas fluorescentes no teto;

- iluminação natural / ventilação:

- janelas - basculantes em toda a extensão de uma das paredes laterais, com persianas;

- não havia ventiladores;

- não havia aparelhos de ar condicionado;

- sistema de exaustão de ar e vapores:

- não havia capela para uso dos alunos;

- havia capela para uso dos professores e da técnica, na sala anexa ao laboratório;

- havia 1 lousa de acrílico em uma das paredes;

- havia cartazes sobre segurança e tabela periódica dos elementos químicos afixados nas paredes;

- instalações para uso dos alunos:

- $\quad$ tipo de assento dos alunos - bancos altos, em número suficiente para uso de todos os alunos;

- local para colocação de material pessoal dos alunos - a própria bancada, em recuo abaixo do tampo;

- local para os alunos fazerem o registro de dados - a própria bancada;

- instalaçð̃es para uso dos professores, da técnica e do pessoal de limpeza:

- professores - usavam a bancada da frente, não havendo assento diferenciado para seu uso;

- técnica - tinha sala própria, fora do laboratório;

- pessoal da limpeza - possuía local próprio, fora do laboratório;

- sistema de segurança:

- havia avisos ou regras de segurança escritos, afixados no recinto do laboratório;

- o uso de avental pelos professores, pela técnica e pelos alunos era obrigatório;

- não foram usados óculos protetores pelos professores e pelos alunos;

- houve uso de pêras e de pipetadores automáticos, quando necessários;

- chuveiros e lava-olhos - 1 junto à porta de entrada;

- $\quad$ extintores de incêndio - 1 , junto à porta de entrada;

- $\quad$ piso-emborrachado liso;

- falhas de segurança - houve pouca orientação sobre segurança por parte dos professores, durante as aulas práticas observadas; houve pouco cuidado com descarte de materiais, não havendo orientação dos professores neste sentido;

* não houve nenhum acidente ou incidente com relação à segurança, durante as aulas práticas observadas;

- formas de descarte de materiais - os alunos não receberam nenhuma orientação sobre descarte de materiais;

- os alunos deixavam o material usado sobre a bancada, no fim da aula, nem sempre de forma ordenada;

- higiene:

- condiçס̃es de higiene-boas;

- limpeza de vidraria - o material era recolhido após as aulas práticas, lavado e guardado pela auxiliar técnica e pelo pessoal da limpeza, após a aula;

- latões de lixo - 1 perto da porta de entrada e 1 na sala anexa;

- local de estoque e colocação de materiais:

- vidraria e drogas - sala anexa ao laboratório;

- aparelhos e equipamentos - bancada de aparelhos do laboratório e sala anexa.

Condiçóes de trabalho dos alunos

- distribuição dos alunos no recinto do laboratório:

- $\quad \mathrm{n}^{\circ}$ total de alunos - 80;

- densidade populacional nas aulas práticas $-1,04$ alunos $/ \mathrm{m}^{2}$;

- $\quad \mathrm{n}^{\circ}$ de alunos por bancada - 10 a 12 ;

- $\quad \mathrm{n}^{\circ}$ de alunos por grupo - 5 a 6 ;

- adequação do local às necessidades dos experimentos - boa;

- acesso a:

- água - bom;

- gás - bom;

- eletricidade - bom;

- materiais dos experimentos - bom;

- aparelhos - médio;

- $\quad$ equipamentos - médio;

- lixo-médio;

- condições de:

- iluminação - boa;

- ventilação - boa;

- distribuição do material - o material era colocado sobre a bancada, antes da aula, pela técnica;

- possibilidades de visualizar e ouvir:

- os professores - médias, as bancadas atrapalhavam a visualização dos professores;

- a lousa ou recursos audio-visuais - médias, porque o espaço entre a parede da lousa e a próxima bancada era pequeno e não permitia que todos os alunos se aproximassem; 
- facilidade de circulação pelo laboratório durante as aulas - médias, porque o local era pequeno para o número de alunos e as filas para distribuição de materiais ou para uso de aparelhos atrapalhavam a movimentação.

$A_{4}$. Resultados dos questionários respondidos por alunos e professores

Alunos (respostas de 12 alunos)

- Expectativas em relação às aulas práticas:

- a maioria dos alunos pensava entender melhor os assuntos das aulas teóricas, tendo visão menos abstrata dos conceitos, "colocando em prática o que se viu na teoria";

- um aluno pretendia conhecer técnicas e/ou aprender a fazer experimentos;

- dois alunos esperavam que houvesse menos alunos do que havia e um esperava que as aulas fossem mais organizadas e que todos pudessem participar diretamente;

- um aluno temia que as aulas práticas fossem perigosas ou muito complicadas.

- Opinióes sobre as aulas práticas:

- As aulas práticas mais interessantes foram aquelas em que:

* havia ligação com os materiais usados no cotidiano da vida das pessoas, com alimentos e não só com soluções químicas, segundo boa parte dos alunos;

* segundo opiniões individuais:

- estudaram-se patologias humanas;

- os resultados não eram previstos ou havia um efeito espetacular;

- os alunos participaram mais diretamente e conseguiram ver os fenômenos acontecerem;

- a aula era mais dinâmica, mais visual;

- havia mais organização;

- Um aluno considerou que todas as aulas práticas eram interessantes, porque explicavan o funcionamento do organismo humano.

- As aulas práticas mais proveitosas foram aquelas em que:

* os assuntos foram aqueles que o aluno gostava, que o interessava pessoalmente ou se referiam à sua vida profissional futura, segundo alguns alunos;

* os alunos já conheciam o assunto por meio das aulas teóricas, já sabiam que resultado iria dar e qual seu significado, segundo dois alunos;

* segundo opiniões individuais:

- foram discutidas patologias humanas;

- havia poucos experimentos e havia tempo para discutir os resultados;

- todas as aulas práticas eram proveitosas, quando houve empenho dos alunos;

- Dois alunos escreveram que todas as aulas práticas, em geral, eram satisfatórias;

- Dois alunos acharam que as aulas práticas foram pouco proveitosas, porque havia muita gente, havendo desorganização e tomando as aulas tumultuadas e cansativas;

- Um aluno declarou não saber qual aula prática teria sido mais proveitosa;

- Os defeitos das aulas práticas apontados foram:

* havia muita gente no laboratório e grande número de alunos por grupo, tomando a densidade populacional alta e provocando desorganização e tumulto, na opinião de boa parte dos alunos;

* os experimentos eram abstratos, longe da vida cotidiana, segundo alguns alunos;

* havia falta de materiais, segundo alguns alunos;

* segundo opiniões individuais:

- dispersão de alguns alunos que atrapalharam;

- grupos de trabalho grandes, não dando para todos participarem;

- falta de tempo;

- falta de didática do professor assistente;

- roteiros mal feitos, perdendo-se tempo durante a aula, para explicá-los;

- não se conseguiu aprender muito;

- não se aprendeu nada.

- As limitações para o aluno ter bom desempenho em aulas práticas foram:

* número grande de alunos, no total e nos grupos, não dando para realizar todas as etapas pessoalmente, não permitindo discutir os experimentos e dividir corretamente as tarefas, segundo alguns alunos;

* pouco material ou aparelhos que não funcionavam direito, muita espera para usar os aparelhos, segundo vários alunos;

* falta de tempo para realizar e completar os experimentos propostos, segundo alguns alunos;

* segundo opiniões individuais:

- falta de espaço;

- sua própria falta de habilidades técnicas;

- falta de capacidade de fazer o relatório;

- falta de entendimento da aula teórica correspondente;

- "o que deveria ser uma aula prática se torna uma aula teórica mal esclarecida".

- As diferenças entre aulas práticas e teóricas apontadas foram:

* na opinião de alguns alunos, as aulas práticas foram mais dinâmicas e tiveram mais participação dos alunos;

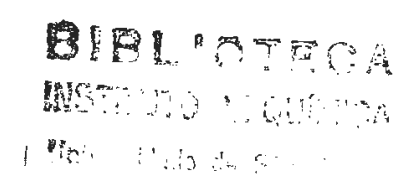


* as aulas teóricas foram mais complexas, abstratas e difíceis, segundo alguns alunos;

* as aulas práticas esclareceram o conteúdo das teóricas, tudo ficava mais fácil, segundo alguns alunos:

* nas aulas teóricas, a professora era mais disponível para esclarecer dúvidas, segundo dois alunos;

* as aulas teóricas prenderam mais a atenção, segundo poucos alunos;

* segundo opiniões individuais:

- as aulas práticas permitiram maior fixação do conteúdo;

- as aulas teóricas foram mais organizadas;

- as aulas práticas foram mais divertidas;

- nas aulas práticas, os professores passaram informações que a professora não havia dado em aulas teóricas, o que foi bom para a futura profíssão;

- "nas aulas teóricas aprendemos, nas práticas, brincamos".

- Comentários sobre os relatórios de aulas práticas:

- "na verdade, o relatório é uma pesquisa bibliográfica, porque não há discussão dos resultados após a aula; esta poderia ser feita sem a aula prática, descontados os procedimentos metodológicos e o relato do material utilizado" - esta frase expressa a opinião de alguns alunos;

- o relatório era importante para a fixação da aprendizagem, segundo dois alunos;

- o relatório foi importante, em sua maior parte, mas havia itens que não eram importantes, segundo dois alunos;

- o relatório foi, às vezes, difícil, segundo alguns alunos;

- segundo opiniões individuais:

* há pouco esclarecimento com relação à confecção dos relatórios;

* com a confecção do relatório, aprende-se mais, porque há necessidade de fazer pesquisa;

* o relatório fez pensar em questões que durante a aula prática não foram levantadas, porque, naquela ocasião, o aluno estava voltado para os procedimentos metodológicos;

* os relatórios eram mal feitos, porque nem todos participavam;

* "o relatório é uma obrigação horrivel, porque tenho que relatar uma coisa que não entendi";

* o relatório serviu para ensinar como redigir trabalho científico.

- Considerações sobre os relacionamentos pessoais:

- Entre alunos -

* metade dos alunos considerou ótimo seu relacionamento com os colegas, assinalando causas, como amizade e troca de informações;

* alguns alunos apontaram dificuldades no relacionamento, devido a serem muitos alunos nos grupos;

* alguns alunos consideraram seu relacionamento com os colegas bom e um terço, regular.

- Entre professores e alunos -

* a maioria considerou bom ou ótimo seu relacionamento com os professores, mas alguns apontaram que eles não conseguiram dar a atenção devida aos alunos, por causa de seu grande número;

* alguns assinalaram que os professores explicavam bem e eram atenciosos;

* o professor assistente foi considerado impaciente, por um aluno.

- Entre alunos e técnica:

* quase nenhum aluno teve contato com a técnica, os poucos que tiveram, consideraram este contato bom;

* alguns alunos declararam que, se a técnica estivesse presente nas aulas práticas, seria bom, ajudaria bastante.

- $\quad$ Atitude dos alunos frente ao questionário:

- os alunos foram solícitos, não colocando nenhum impedimento para responder o questionário, não apresentando nenhum tipo de comportamento negativo em relação a ele;

- alguns pediram para responder, mesmo sem terem sido solicitados;

- alguns queriam responder, porque julgavam que isto serviria para avaliar o curso e poderiam expressar seu descontentamento com algumas situações da escola.

Professores

Renata Basso

- Cargo na Instituição - professora titular de Bioquímica - ministra aulas teóricas e práticas.

- Curso de Graduação - Farmácia e Bioquímica - bacharelado (FCF - USP).

- Pós-Graduação - Mestrado em Ciências dos Alimentos (FCF - USP).

- Atividades de pesquisa - não estava realizando pesquisa no momento em que respondeu este questionário.

Alexsandro Marcelo Silva

- Cargo na Instituição - professor assistente de Bioquímica e titular de outra disciplina - na Disciplina de Bioquímica, ministrava somente aulas práticas.

- Curso de Graduação - Farmácia e Bioquímica - bacharelado (Universidade Federal de Juiz de Fora - MG).

- Pós-Graduação - Mestrado em Ciências dos Alimentos (FCF - USP).

- Atividades de pesquisa - não estava realizando pesquisa no momento em que respondeu este questionário.

- Opiniões sobre aulas práticas no ensino de Bioquímica:

- Importância - 
* segundo a opinião da professora titular - tornam palpável a teoria, tornam possível compreender melhor a teoria;

* $\quad$ segundo a opinião do professor assistente - permitem conhecer os meios de identificar os macronutrientes e realizar testes para quantificar os parâmetros bioquímicos.

- Critérios de escolha do número de aulas práticas, de suas posições na programação e de seus assuntos -

* conteúdos das aulas teóricas, priorizando patologias associadas à nutrição;

* segundo a opinião da professora titular - tempo disponível do professor assistente, que dá aula a cada quinze dias;

* $\quad$ segundo a opinião do professor assistente - disponibilidade de reagentes e demais materiais.

- Realização das expectativas nas aulas práticas ministradas:

* $\quad$ segundo a opinião da professora titular - melhorar o aproveitamento dos alunos;

* segundo a opinião do professor assistente - associar os assuntos das aulas práticas com o dia-a-dia dos alunos e sua futura vida profissional; ensinar como consultar literatura científica.

- As limitações das aulas práticas foram:

* o espaço físico do laboratório não era compatível com o número de alunos;

* o número de alunos era muito grande, não dava para dar atenção a todos, o ideal seria 1 professor para 20 alunos e não 40 ;

* a formação dos alunos era fraca, não possuíam informações suficientes de química geral e orgânica, (embora, no primeiro semestre, os mesmos professores ministraram a disciplina "Fundamentos de Química Orgânica");

* segundo a opinião da professora titular:

- dificuldade de coletar material biológico;

- pouco contato com a técnica, o que dificultou a eliminação de erros no preparo de aulas;

- os alunos não tinham habilidades técnicas tidas como pré-requisitos;

- o tempo disponível foi parcialmente adequado;

- os alunos não tinham treinamento quanto à segurança;

- a quantidade de equipamentos era insuficiente.

- Consecução dos objetivos:

- Quanto ao conteúdo:

* Objetivos alcançados -

- ilustrar fatos e fenômenos;

- segundo a opinião da professora titular:

- mostrar a importância da Bioquímica em campos específicos do conhecimento.

* Objetivos não alcançados -

- segundo a opinião do professor assistente:

- aplicar teoria, lei, princípio;

- ensinar como compreender conceitos;

- mostrar a importância da Bioquímica em campos específicos do conhecimento.

* Objetivos que as aulas práticas deveriam ter, mas que não foram colocados no curso -

- segundo a opinião da professora titular:

- aplicar teoria, lei princípio;

- segundo a opinião do professor assistente:

- ensinar como construir conceitos;

- divulgar descobertas recentes da Ciência.

* Funções que as aulas práticas exerceram, mesmo sem terem sido colocadas como objetivos -

- segundo a opinião da professora titular:

- ensinar como compreender conceitos;

- ensinar como construir conceitos;

- divulgar descobertas recentes da Ciência.

- Quanto à metodologia de ensino:

* Objetivos alcançados -

- segundo a opinião da professora titular:

- ensinar como comunicar resultados oralmente;

- ensinar como consultar literatura.

* Objetivos não alcançados -

- segundo a opinião do professor assistente:

- ensinar como seguir protocolo;

- ensinar como observar e anotar;

- ensinar como processar dados;

- ensinar como fazer relatório escrito;

- desenvolver autonomia na execução de experimentos;

- ensinar como validar ensaios;

- ensinar como criticar dados;

- ensinar como escrever protocolos;

- ensinar como consultar literatura científica. 
* Objetivos que as aulas práticas deveriam ter, mas que não foram colocados no curso -

- ensinar como propor hipóteses;

- ensinar como testar hipóteses;

- ensinar como montar experimentos;

- ensinar como pensar novos experimentos;

- segundo a opinião da professora titular:

- ensinar como seguir protocolo;

- ensinar como observar e anotar;

- ensinar como processar dados;

- desenvolver autonomia na execução dos experimentos;

- ensinar como validar ensaios;

- ensinar como criticar dados;

- ensinar como escrever protocolos;

- segundo a opinião do professor assistente:

- ensinar como comunicar resultados oralmente.

* Funções que as aulas práticas exerceram, mesmo sem terem sido colocadas como objetivos -

- segundo a opinião da professora titular:

- ensinar como fazer relatório escrito.

- Quanto ao treinamento de habilidades técnicas experimentais:

* Objetivos não alcançados -

- segundo a opinião do professor assistente:

- treinar manuseio de material de laboratório e de reagentes;

- treinar uso de equipamentos e aparelhos.

* Objetivos que as aulas práticas deveriam ter, mas que não foram colocados no curso -

- treinar técnicas de pesquisa laboratorial;

- treinar manuseio de material biológico;

- segundo a opinião da professora titular:

- treinar manuseio de material de laboratório e de reagentes;

- treinar uso de equipamentos e aparelhos.

- Quanto à interação entre os participantes:

* Objetivos alcançados -

- segundo a opinião da professora titular:

- melhorar as relaçôes entre professor e alunos.

* Objetivos não alcançados -

- segundo a opinião do professor assistente:

- motivar aluno;

- melhorar relações entre professor e alunos;

- melhorar relações entre alunos.

* Objetivos que as aulas práticas deveriam ter, mas que não foram colocados no curso -

- segundo a opinião da professora titular:

- motivar aluno;

- segundo a opinião do professor assistente:

- encorajar o entusiasmo pela Ciência.

* A professora titular não soube pronunciar-se a respeito dos seguintes objetivos:

- melhorar as relações entre alunos;

- encorajar o entusiasmo pela Ciência.

OBS - não houve concordância entre as opiniōes dos dois professores em boa parte das respostas.

\section{B. Análise das aulas práticas}

$\mathrm{B}_{1}$. Dados gerais

- total de aulas práticas na programação - 7;

- $\mathrm{n}^{\mathrm{o}}$ de aulas práticas observadas -3 ;

- datas - $30 / 08 / 2000 ; 20 / 09 / 2000 ; 18 / 10 / 2000$;

- período - matutino;

- professores - Renata Basso e Alexsandro Marcelo Silva;

- técnica / tipo de participação na aula - Teresa Muriane Brittes / atuou no preparo das aulas práticas somente.

$\mathrm{B}_{2}$. Aulas práticas observadas

Características gerais

- $\quad$ assuntos (unidades da programação) - ver Anexo 6; Identificação de carboidratos e determinação da atividade da amilase salivar, Digestão e absorção de carboidratos (Metabolismo de carboidratos); Determinação de proteinas totais do sangue (Metabolismo de aminoácidos e proteínas); Dosagem de triglicerídeos, colesterol e HDL-colesterol (Metabolismo dos lipídeos); 
- $\quad$ ordem dentro da programação - $10^{\mathrm{a}}, 16^{\mathrm{a}}$ e $23^{\mathrm{a}}$ aulas (ver Anexo 5);

- as aulas práticas não tiveram ligação com qualquer atividade desenvolvida pela instituição que não seja as da própria disciplina;

- as aulas práticas não foram acompanhadas de artigo científico correlato;

- as aulas práticas foram ministradas antes e após as aulas teóricas correspondentes;

- dinâmica da aula:

- duração - 1:25 h a 1:45 h;

- divisão de tempo da aula -

* planejamento / explicações iniciais - 5\% a $12 \%$;

* execução-88\% a $95 \%$;

* análise de resultados / discussão $-0 \%$;

- condições de orientação dos alunos:

- $\mathrm{n}^{\mathrm{Q}}$ de professores - 2 ;

- $\quad n^{2}$ de auxiliares que participaram da orientação - 0 ;

- $\quad n^{2}$ de alunos - 80;

- proporção orientador : aluno - 1:40;

- condições dos alunos quanto a conhecimentos necessários para a compreensão da aula - os alunos já haviam tido contato com os conceitos desenvolvidos na aula e com a maioria dos assuntos;

- possibilidade de uso do laboratório fora do horário de aula - não;

- não havia possibilidade de orientação dos professores fora do horário de aula;

- $\quad$ possibilidade de os alunos trabalharem em grupo fora da aula;

- local - cantina (centro de convivência), biblioteca;

- horário - tarde e noite.

Materiais

- foram usados equipamentos e vidrarias corriqueiros em laboratório de Química;

- os aparelhos e equipamentos estavam colocados sobre a bancada de aparelhos e na sala anexa;

- a vidraria e a maior parte dos reagentes estavam colocadas sobre as bancadas de alunos, no momento dos experimentos;

- os materiais biológicos foram distribuídos no momento do experimento, pelos professores, formando longas filas para recebê-los;

- custo do material de consumo - não estimado.

Preparo e teste

- o preparo de aulas práticas da disciplina era feito pela técnica, antes das aulas práticas, com o planejamento e supervisão do professor assistente;

- os experimentos não foram previamente testados pelos professores, nem pela técnica.

Normas de segurança e de manipulação de material biológico

- não foram fornecidas normas de segurança por escrito, com compromisso escrito e assinado;

- não houve treinamento específico sobre segurança no laboratório ou sobre manipulação de tecidos, órgãos ou animais;

- houve avisos orais dos professores sobre materiais tóxicos ou que constituiam algum perigo ao serem manuseados e sobre os cuidados que deveriam ser tomados na manipulação de material biológico.

Conteúdo da aula

- relações:

- com o resto da programação -

* as aulas práticas acompanharam ou não o conteúdo das aulas teóricas, 2 assuntos estavam fora da programação de aulas teóricas;

- as aulas práticas tinham alguns assuntos relacionados com Fisiologia(s) e com disciplinas de Nutrição;

- as aulas práticas não tinham relações com pesquisa da instituição ou de fora dela ou com projeto de extensão da instituição e com publicações científicas, dentro ou fora da instituição;

- $\quad$ alguns conteúdos relacionavam-se com a vida profissional futura dos alunos e com a suas vidas cotidianas;

- não houve relações das aulas práticas com a vida universitária dos alunos, nem com sua vida como cidadão;

- de acordo com a opinião da professora titular, havia alguns experimentos que poderiam ser substituídos por discussão de casos clínicos;

- as aulas práticas não partiram de um problema a ser resolvido pelos resultados obtidos.

Roteiro / Protocolo

Ver Anexo 6:

- o protocolo da primeira aula observada era impresso, deixado na fotocopiadora para ser comprado pelos alunos e os demais, das duas outras aulas observadas, foram escritos na lousa e copiados pelos alunos;

- no conteúdo dos protocolos:

- constavam apenas os objetivos no protocolo impresso, a saber -

* identificar a presença de glicose e amido em alimentos;

* conhecer as reações de identificação de mono, di e polissacarídeos; 
- nos protocolos colocados na lousa, não foram explicitados por escrito os objetivos das aulas ou dos experimentos, nem eles foram fornecidos oralmente;

- havia lista de materiais no protocolo impresso e não constavam listas de materiais nos protocolos escritos na lousa;

- havia todas as diretrizes para a execução dos experimentos;

- não havia normas de segurança específicas para cada experimento, por escrito, algumas foram comentadas oralmente;

- não havia regras de higiene;

- não havia instruções do quê e como observar;

- havia instruções sobre como registrar os dados;

- não havia questões e/ou problemas a serem resolvidos no relatório, usando os dados obtidos;

- havia orientação para a discussão dos dados no relatório;

- não apresentava bibliografia específica sobre a técnica e/ou sobre o assunto das aulas práticas.

Etapas da aula / Estratégia de ensino

- utilização do protocolo (roteiro de aula):

- não houve leitura prévia dos protocolos;

- os alunos tiravam dúvidas sobre o protocolo, com os professores, à medida que executavam os trabalhos;

- o conjunto de dados a ser obtido foi definido previamente;

- tipo de execução:

- os experimentos foram executados pelos alunos, sob a orientação dos professores;

- a manipulaçăo de aparelhos foi feita principalmente pelos professores e, quando eles eram usados pelos alunos, houve supervisão constante dos professores;

- precisão / sensibilidade / higiene:

- não houve preocupação com a precisão na obtenção dos dados, nem com as sensibilidades dos métodos e técnicas;

- não houve preocupação com higiene;

- habilidades:

- técnicas -

* exigidas pelas aulas - manipulação de vidraria e equipamentos simples de laboratório de Química,

- os alunos possuíam, geralmente, as habilidades exigidas, aqueles que não as possuíam, eram ensinados no momento das aulas;

* treinadas durante as aulas - uso de pêra, de pipetador automático, de banho-maria, de espectrofotômetro, manipulação de componentes do sangue humano;

- mentais -

* exigidas pelas aulas - compreender instruções orais e escritas;

* treinadas durante as aulas - seguir protocolo, observar e anotar, buscar dados na literatura científica, analisar e sintetizar;

- formas de orientação dos alunos pela equipe:

- as orientações eram dadas no início das aulas, pelo professor assistente e durante toda a aula, por ele e pela professora titular;

- observações sobre as explicações iniciais - a professora titular reproduzia os dados do protocolo na lousa, o professor assistente explicava toda a execução dos experimentos, não fornecendo o embasamento teórico das técnicas, nem relacionando-as com os assuntos de aulas teóricas; o professor não solicitava a participação dos alunos nesta fase;

- forma de registro dos resultados - no caderno, com orientação escrita no protocolo impresso e não naqueles colocados na lousa;

- $\quad$ processamento dos dados obtidos:

- os dados dos grupos não foram colocados na lousa;

- cada experimento foi tratado como único; cada grupo trabalhou com seus próprios dados;

- houve cobrança dos resultados previamente esperados;

- nem todos os experimentos deram os resultados esperados;

- quando os resultados esperados não foram obtidos, a professora titular explicava o que deveria ter ocorrido, levantando hipóteses e os alunos lançavam mão de dados teóricos, obtidos por pesquisa bibliográfica, para fazer o relatório; quando não obtinham os resultados esperados;

- quando um grupo não obtinha os resultados esperados, usava os dados de outro grupo, em que os experimentos "deram certo";

- o tempo disponível para a execução dos experimentos, proposto no início da aula foi suficiente, mas, às vezes, corrido;

- comportamento dos participantes:

- alunos -

* estavam sempre interessados, às vezes comprometidos com o trabalho e animados;

* $\quad$ sentiam-se muitas vezes perdidos, nå sabiam para que estavam fazendo cada coisa; 
* não procuravam descobrir, tudo pediam auxílio, alguns queriam que a professora analisasse os resultados para eles;

* conversavam o tempo todo, nunca sobre os experimentos ou sobre a matéria;

- professores -

* comprometidos, com intencionalidade;

* não davam oportunidade aos alunos para entenderem e seguirem o protocolo sozinhos, o professor assistente explicava as técnicas detalhadamente, dava a forma de fazer os cálculos, praticamente fornecendo os resultados que deveriam ser obtidos;

- $\quad$ encerramento das aulas - as aulas encerraram-se após a obtenção dos dados pelos grupos.

Discussão dos dados

- a discussão ocorreu fora da aula, em outro local e momento, somente pelos grupos, sem orientação dos professores;

- a discussão dos relatórios pelo professara titular foi feita em aulas teóricas posteriores, após eles terem sido avaliados.

Relatório das aulas práticas

- obrigatório;

- realizado após as aulas práticas;

- com prazo de quinze dias para a entrega;

- feito por escrito, em grupo;

- feito no padrão normal desse tipo de redação científica: Introdução, Objetivos, Materiais e Métodos, Resultados, Discussão, Conclusões e Referências Bibliográficas;

- ensinava a:

- discutir resultados - analisar e relacionar dados;

- consultar literatura científica;

- fazer redação científica;

- fazia parte da avaliação.

Atividades suscitadas pelas aulas práticas

- as aulas práticas encerraram-se em si mesmas, não suscitaram trabalhos posteriores.

Avaliação do aprendizado em aulas práticas

- pelo relatório;

- não foi pesquisada outra forma de avaliação do conteúdo de aulas práticas e o valor do relatório na avaliação final.

Ocorrências não previstas durante as aulas prátícas

- não houve qualquer ocorrência a assinalar. 
APÊNDICE 3

\title{
FACULDADES OSWALDO CRUZ
}

\section{A. Caracterização do contexto}

\author{
A. Instituicão \\ Dados gerais \\ Endereços \\ e-mail - faculdades@oswaldocruz.br site: www.oswaldocruz.br \\ R. Brigadeiro Galvão, 540 - Barra Funda - São Paulo - SP \\ CEP-01151-000 telefones - 3825-4266 e 3667-2682 \\ Natureza / Classificação \\ Empresa privada / Faculdades e Escolas Superiores. \\ Cursos
}

Administração, Bioquímica Industrial, Ciências com Habilitação em Química, Contabilidade, Economia,

Engenharia Química, Farmácia, Letras, Matemática, Química Industrial, Pedagogia.

Atividades de Pós-Graduação

- a instituição possuía centro de pós-graduação em nível de especialização (lato sensu), por ocasião desta pesquisa;

- os cursos de especialização (360 h) na área de Saúde eram: Farmácia Hospitalar, Microbiologia, Plantas Medicinais e Produtos Naturais, Cosmetologia;

- os cursos de especialização em outras áreas eram: Programa Especial de Formação Pedagógica de Docentes (Licenciatura em Matemática e Química), especialização em Química, em Educação Matemática, em Língua Portuguesa, em Literatura e em Psicopedagogia (lato sensu); Engenharia de Gás Natural, Engenharia de Segurança do Trabalho; Administração Financeira e Controladoria: Gestão Empresarial, Administração em Marketing, Administração com Especialização em Direito Empresarial, Administração em Gerência de Tecnologia de Informação, Administração em Finanças, Administração em Comércio Exterior, Master em Finanças, Administração em Recursos Humanos, Administração Bancária, Gestão de Qualidade;

- não havia participação de alunos de graduação em programas de pós-graduação.

Atividades de pesquisa

- a instituição não fazia pesquisa laboratorial na área de Saúde, por ocasião desta pesquisa;

- a instituição promovia semanas dos vários cursos de graduação em suas dependências, com conferências e apresentação de trabalhos de alunos da graduação;

- a instituição não mantinha estrutura para professores e/ou alunos de graduação participarem de congressos, cursos, palestras ou similares fora da instituição.

Prestação de serviço à comunidade (atividades de extensão)

- a instituição fornecia bolsas de estudo restituíveis e tinha programa de auxílio ao aluno carente;

- Lab Service - laboratório de análises clínica e microbiológicas, ligado aos cursos de Química e Farmácia.

Publicações científicas

- a instituição possuía revista que publicava artigos de divulgação das atividades da institujção: "Revista Acadêmica" (ISSN 1414-7572);

- a instituição não mantinha estrutura para professores e alunos de graduação participarem de publicações de outras instituições.

Regime de trabalho dos professores de Bioquímica Aplicada

- horista $-4 \mathrm{~h}$ semanais por turma (professora de aulas práticas e professora auxiliar de aulas de laboratório) e mensalista (20 h semanais - professor de aulas teóricas);

- os professores não faziam pesquisa na instituição;

- não havia remuneração das professoras para horário de planejamento / preparo de aulas práticas, nem para atendimento a alunos fora das aulas;

- o professor de aulas teóricas fazia pesquisa no Instituto de Química da USP, estando cursando doutoramento no Departamento de Bioquímica.

Apoios téenico e didático aos professores

- havia 1 técnico de laboratório;

- as fotocópias para reproduzir material para uso em aulas práticas eram pagas pelos alunos;

- havia biblioteca com livros e periódicos sobre Bioquímica;

- não foi pedida informação sobre outras formas de apoio técnico-didático, por ocasião desta pesquisa.

A.2. Curso analisado e disciplina com conteúdo de Bioquímica

Curso

- nome do curso - Engenharia com Habilitação em Engenharia Química;

- enfoque - tecnologia;

- habilitação - bacharelado;

- atividades profissionais para as quais habilitava - engenheiro nos setores petroquímico, de celulose e de papel, de álcool, alimentício, de tintas e vernizes, de plásticos, cerâmico, de fertilizantes etc; profissionais que 
podem atuar em estudo de viabilidade técnico-científica de projetos de instalações industriais químicas, de projetos, planejamento e manipulação de indústrias químicas, em coordenação da execução de projetos de montagem industrial na área de química, em consultoria, peritagem, vistoria e elaboração de laudos e pareceres relativos à sua especialidade;

- período de funcionamento - noturno;

- duração / regime -6 anos / regime anual;

- currículo - séries e disciplinas, objetivos do curso - ver Anexo 7;

- havia convênios da instituição com empresas e outras instituições para treinamento profissional dos alunos.

Disciplina

- nome da disciplina - Bioquímica Aplicada (Bioquímica Industrial) - ênfase em Alimentos - foi observado o

$2^{0}$ semestre da programação;

- carga horária - 4 aulas semanais / total de $140 \mathrm{~h}$;

- posição na grade curricular - disciplina lecionada na $6^{a}$ série do curso;

- objetivos e programa da disciplina - ver Anexo 8:

- $\quad$ porcentagem de assuntos da programação ( $2^{\circ}$ semestre) que foi desenvolvida em aulas práticas - $40 \%$;

- 1 assunto de aulas práticas do $2^{\circ}$ semestre era referente ao conteúdo de aulas práticas do $1^{\circ}$ semestre;

- divisão / proporção entre tipos de aulas do $2^{0}$ semestre:

* $\mathrm{n}^{9}$ de aulas práticas- 6 ;

* $\quad \mathrm{n}^{\mathrm{Q}}$ de aulas teóricas -5 ;

* $\quad \mathrm{n}^{9}$ de outras atividades diferentes de aulas teóricas e práticas - 6 -

- $\mathrm{n}^{\mathrm{Q}}$ de períodos de discussão - 1 ;

- $\mathrm{n}^{2}$ de aulas de exercícios -1 ;

- $\mathrm{n}^{\mathrm{Q}}$ de seminários -0 ;

- $\mathrm{n}^{\mathrm{Q}}$ de avaliações -3 ;

- $\mathrm{n}^{\mathrm{Q}}$ de outras atividades - "Semana da Química" - 1;

* proporção aulas práticas : atividades diferentes de aulas teóricas e práticas - 1:1;

* proporção aulas práticas : aulas teóricas - 1:0,8;

- integração com outras disciplinas $-1^{\circ}$ semestre da própria disciplina;

- relações de pré-requisitos com outras disciplinas - Química Orgânica I e II, Físico-Química, Processos Industriais Orgânicos, Metodologia do Trabalho Científico;

- titulações dos professores e instituições onde as obtiveram:

* professor de aulas teóricas - Mestrado - Escola Politécnica - USP, doutorando em Bioquímica do Departamento de Bioquímica - IQ - USP;

* $\quad$ professora de aulas práticas - Especialista em Microbiologia de Alimentos, UNIBAN;

* professora auxiliar de aulas de laboratório - sem pós-graduação;

- atividades de pesquisa dos professores de Bioquímica Aplicada:

* o professor de aulas teóricas fazia pesquisa pura na área de Bioquímica - Departamento de Bioquímica - IQ - USP;

* a professora de aulas práticas e a professora auxiliar de aulas de laboratório não faziam pesquisa, por ocasião da realização desta pesquisa;

- atividades docentes dos professores na Disciplina de Bioquímica Aplicada - um professor dava somente aulas teóricas e uma professora, somente aulas práticas, auxiliada por uma professora auxiliar de aulas de laboratório;

- a instituição fazia o perfil dos alunos ingressantes nas faculdades, mas os alunos observados estavam no fim do curso ( $2^{\underline{o}}$ semestre da $6^{\underline{a}}$ série) e não havia diagnóstico do início do ano.

A . Laboratórios (2)

Natureza

- didática.

Condições físicas

- dimensões de cada sala - largura - 7,5m; comprimento - 15m; área - 112,5 $\mathrm{m}^{2}$; - área total $-225 \mathrm{~m}^{2}$

- bancadas - 4 bancadas altas com tampo de madeira tratada e pintada, em cada laboratório, com 4 locais para trabalho por bancada ( 2 de cada lado);

- instalações de água - 1 pia em uma das extremidades das bancadas de alunos, nos 2 laboratórios; 2 pias na bancada lateral, no laboratório $1 ; 1$ pia na bancada lateral e 1 tanque fundo, no laboratório $2 ; 1$ bujão de água destilada em cada bancada de aluno;

- instalações de gás: - gás encanado - 4 bicos de gás de um lado e 4 de outro, em cada bancada de alunos, nos 2 laboratórios;

- instalações elétricas:

- 8 tomadas de $110 \mathrm{~V}$ em cada bancada de alunos, nos 2 laboratórios; 3 tomadas de $110 \mathrm{~V}$ na parede, 7 tomadas de $110 \mathrm{~V}$ em 3 bancadas laterais, no laboratório $1 ; 2$ tomadas de $110 \mathrm{~V}$ na bancada lateral e 1 tomada de $110 \mathrm{~V}$ na parede, no laboratório 2;

1 tomada de $220 \mathrm{~V}$ em uma bancada de alunos, no laboratório 1; 1 tomada de $220 \mathrm{~V}$ em 3 bancadas laterais, no laboratório 1; 
- iluminação artificial - 30 lâmpadas fluorescentes no teto, nos 2 laboratórios;

- iluminação natural / ventilação:

- janelas - basculantes em toda a extensão das paredes do corredor, em cima, nos 2 laboratórios;

- 2 ventiladores nas paredes da frente e do fundo, nos 2 laboratórios;

- não havia aparelhos de ar condicionado;

- $\quad$ sistema de exaustão de ar e vapores:

- não havia capela para uso dos alunos;

- havia capela para uso das professoras e do técnico na sala anexa ao laboratório 2;

- havia 1 lousa de acrílico em uma das paredes laterais, no laboratório 1, e 1 lousa comum, no laboratório 2;

- havia quadro de segurança e avisos de não fumar afixados nas paredes, no laboratório 1; havia quadro de primeiros socorros, sobre microscopia eletrônica, tabela periódica e aviso de não fumar afixados nas paredes, no laboratório 2;

- instalações para uso dos alunos:

- tipo de assento dos alunos - bancos altos, em número menor que o número de alunos;

- local para colocação de material pessoal dos alunos - prateleiras junto à parede lateral, no laboratório 1;

- local para os alunos fazerem o registro de dados - a própria bancada;

- instalações para uso das professoras e auxiliares:

- professoras - usavam a sala anexa ao laboratório 2;

- não há assento especial para professores nos laboratórios;

- técnico - usava a sala anexa ao laboratório 2 e outros laboratórios;

- pessoal da limpeza - possuía local próprio, fora do laboratório;

- sistema de segurança:

- havia avisos de não fumar e quadros de primeiros socorros afixados no recinto dos laboratórios;

- o uso de avental pelas professoras, pelo técnico e pelos alunos era obrigatório, tendo sido esta obrigatoriedade reforçada no começo do ano e seu respeito influenciava sobre a avaliação. Durante as aulas observadas, fazia grande calor, aumentado pelos muitos bicos de gás acesos e muitos alunos não usavam o avental e sua atenção não era chamada para isto;

- não foram usados óculos protetores pelas professoras e pelos alunos, por não serem necessários;

- $\quad$ havia chuveiros e lava-olhos na sala anexa ao laboratório 2;

- $\quad$ extintores de incêndio - 1, em cada laboratório, na parede;

- piso - granito liso;

- falhas de segurança - piso escorregadio, presença de muitos aparelhos de grande porte no próprio laboratório (estufas, autoclaves, entre outros), pouca ventilação. Foi permitido aos alunos que deixassem material pessoal sobre as bancadas, mesmo tendo: local apropriado para tal, alguns alunos comeram durante a aula, embora não permitido;

- formas de descarte de materiais:

* os alunos levavam a vidraria e deixavam-na sobre a bancada, no fim da aula;

* não foi dada nenhuma instrução quanto ao descarte de materiais e não foi tomado nenhum cuidado especial, mesmo no caso de produtos perigosos;

- higiene:

- condições de higiene - boas;

- limpeza de vidraria - o material era recolhido após as aulas práticas, lavado e guardado pela técnico, no dia seguinte;

- latões de lixo - 1 junto às prateleiras de materiais pessoais dos alunos, 1 junto à parede oposta, 1 junto à pia da bancada lateral, no laboratório $1 ; 1$ numa parede, outro na parede oposta e 1 junto à pia da bancada lateral, no laboratório 2;

- local de estoque e colocação de materiais:

- vidraria e drogas - na sala anexa ao laboratório 2;

- $\quad$ aparelhos e equipamentos - na sala anexa ao laboratório 2 e espalhados pelos 2 laboratórios, nas bancadas e no chão, junto às paredes.

Condições de trabalho dos alunos

- distribuição dos alunos no recinto do laboratório:

- $\quad \mathrm{n}^{\circ}$ total de alunos - 68, distribuídos pelos 2 laboratórios;

- densidade populacional nas aulas práticas - 0,3 alunos $/ \mathrm{m}^{2}$;

- $\quad \mathrm{n}^{\circ}$ de alunos por bancada -6 a 12 ;

- $\quad n^{2}$ de alunos por grupo-3 a 6 ;

- adequação do local às necessidades dos experimentos - o laboratório era adequado às aulas desenvolvidas, embora apresentasse falhas de ventilação, de segurança e ter um número insuficiente de bancos para os alunos;

- acesso a:

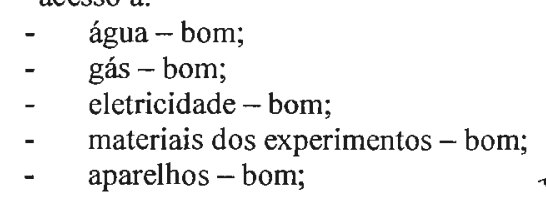


- $\quad$ equipamentos - bom;

- lixo-bom;

- condições de:

- iluminação - boa;

- ventilação - deixava a desejar, havia aquecimento excessivo, mesmo com os ventiladores ligados;

- distribuição do material - o material era colocado sobre a bancada, antes da aula, pelo técnico;

- possibilidades de visualizar e ouvir:

- as professoras - deixavam a desejar, porque os alunos do laboratório 2 deslocavam-se para o laboratório 1 , onde a professora de aulas práticas dava as explicações. Os materiais e as prateleiras sobre as bancadas atrapalhavam a visualização da lousa e das professoras;

- a lousa ou recursos audio-visuais - deixavam a desejar, porque o laboratório era muito atulhado;

- facilidade de circulação pelo laboratório durante as aulas - não havia muita facilidade de circulação, devido ao grande número de aparelhos e equipamentos no chão e muitos alunos no laboratório 1.

$\mathrm{A}_{4}$. Resultados dos questionários respondidos por alunos e professores

Alunos (respostas de 9 alunos)

- Expectativas em relação às aulas práticas:

- boa parte dos alunos pretendia adquirir noções de como seria realizado um processo industrial de produção de alimentos;

- alguns alunos queriam aprender técnicas atualizadas sobre processamento de alimentos;

- um aluno pretendia aumentar o cabedal de informações e ter oportunidade de pesquisar mais sobre determinados assuntos (não citados).

- Opiniðes sobre as aulas práticas:

- As aulas práticas mais interessantes foram aquelas em que:

* trabalhou-se com alimentos que se usam no dia-a-dia, segundo alguns alunos;

* o processo de produção do alimento era totalmente desconhecido, segundo a maior parte dos alunos;

* foram explicadas as funções dos alimentos, de acordo com um aluno.

- As aulas práticas mais proveitosas foram aquelas em que:

* o tempo de aula foi suficiente para que o processo pudesse ser acompanhado em todas as suas etapas, de acordo com vários alunos;

* obteve-se melhor resultado, na opinião de alguns alunos;

* o processo de produção de um alimento consumido diariamente foi explicado, de acordo com vários alunos;

* os produtos obtidos foram testados e analisados com maior detalhe, segundo um aluno;

* "todas - na opinião de um aluno -, porque nos deu oportunidade para conhecermos o básico da indústria de alimentos".

- Os defeitos das aulas práticas apontados pelos alunos foram:

* equipamentos antiquados, segundo alguns alunos;

* processos muito demorados para o tempo disponível, segundo vários alunos;

* falta de tempo para executar com calma todas as etapas; perdendo-se muito tempo no início das aulas, esperando os alunos atrasados chegarem, segundo alguns alunos;

* segundo opiniōes individuais:

- muitos alunos para poucos equipamentos, muitos alunos por grupo;

- o momento da explicação inicial foi pouco explorado;

- houve prejuízo nas explicações durante as aulas, porque eram poucos professores para o número de alunos;

- laboratório inadequado;

- o material para pesquisa bibliográfica era escasso;

- qualificação das professoras deixava a desejar.

- As limitações para o aluno ter bom desempenho em aulas práticas foram:

* menos da metade dos alunos considera que há muitos alunos por experimento e por equipamento;

* segundo opiniões individuais:

- as professoras são pouco qualificadas;

- falta de tempo;

* a maioria dos alunos não vê limitações para seu desempenho em aulas práticas.

- As diferenças entre aulas práticas e teóricas apontadas foram:

* nas aulas práticas, era possível observar as coisas acontecerem, na teoria, era preciso acreditar, de acordo com a opinião de alguns alunos;

* nas aulas teóricas, aprenderam-se os princípios, nas aulas práticas, ele foram aplicados, de acordo com alguns alunos;

* as aulas teóricas eram mais complexas, nem tudo pôde ser visto na prática, segundo alguns alunos;

* năo havia diferenças entre aulas teóricas e práticas, de acordo com um aluno.

- Comentários sobre os relatórios de aulas práticas:

- foram uma maneira de expressar o rendimento obtido na aula prática, de acordo com alguns alunos;

- foram proveitosos, complementaram a aula prática, segundo boa parte dos alunos; 
- $\quad$ as professoras não tiveram critérios claros para a correção dos relatórios, de acordo com alguns alunos;

- $\quad$ segundo opiniões individuais:

* serviram para diagnosticar dificuldades;

* deveriam ser mais sintéticos;

* a revisão da literatura apenas repetiu o conteúdo de aulas teóricas;

* deixaram o conteúdo mais claro e aprofundaram o conhecimento.

- Considerações sobre os relacionamentos pessoais:

- Entre alunos -

* alguns alunos consideraram o relacionamento com os colegas bom, "mantém-se o espírito de colaboração";

* a metade dos alunos considerou ótimo o relacionamento, apontando que trabalharam juntos e que houve divisão eqüitativa das tarefas;

- Entre professora de aulas práticas e alunos -

* alguns consideraram seu relacionamento com a professora bom, outros, muito bom ou ótimo e apenas um, ruim;

* um aluno assinalou que a professora simplifica e explica o conteúdo, enquanto outro considerou que ela fica a desejar no esclarecimento de dúvidas;

* um aluno considerou que o excesso de conteúdo às vezes desgastava o relacionamento entre a professora e os alunos.

- $\quad$ Entre alunos e professora auxiliar de aulas de laboratório -

* boa parte dos alunos considerou o relacionamento com a professora muito bom ou bom;

* um aluno considerou o relacionamento com a professora ótimo e um assinalou que teve pouco contato com ela.

- Atitude dos alunos frente ao questionário:

- a maior parte dos alunos solicitados atendeu com boa vontade o pedido para responder o questionário, poucos foram displicentes ao responder as perguntas;

- um aluno aceitou responder o questionário, mas não o fez.

Professores

Cleber Wanderlei Líria

- Cargo na Instituição - Professor Adjunto IV - professor de aulas teóricas.

- Curso de Graduação -: Engenharia Química - bacharelado (Universidade Federal de Uberlândia - MG).

- Pós-Graduação - Mestrado na Escola Politécnica (USP).

- Atividades de pesquisa - realizava pesquisa pura na área de Bioquímica, em curso de doutorado - IQ (USP).

Érica Helena dos Santos

- Cargo na Instituição - professora de aulas práticas.

- Curso de Graduação - Engenharia Química - bacharelado (FOC).

- Pós-Graduação - lato sensu em Microbiologia de Alimentos (UNIBAN).

- Atividades de pesquisa - não realizava pesquisa quando respondeu a este questionário.

Cristiane Peverari Costa

- Cargo na Instituição - professora auxiliar de aulas de laboratório.

- Curso de Graduação - Nutrição - bacharelado (Universidade São Judas).

- Pós-Graduação - não possuía curso de pós-graduação por ocasião desta pesquisa.

- Atividades de pesquisa - não realizava pesquisa quando respondeu a este questionário.

- Opiniões sobre aulas práticas no ensino de Bioquímica:

- Importância - as aulas práticas são importantes para:

* complementar o conteúdo das aulas teóricas;

* facilitar a fixação de conteúdos teóricos;

* Servir para diferenciar a Bioquímica de outras áreas da Química;

* melhorar o relacionamento entre alunos e desses com a matéria.

- Critérios de escolha do número de aulas práticas, de suas posições na programação e de seus assuntos -

* exigência da instituição de que as aulas práticas perfaçam $50 \%$ do total de aulas;

* acompanhar o assunto das aulas teóricas;

* disponibilidade de materiais, equipamentos e matérias-primas.

- Realização das expectativas nas aulas práticas ministradas -

* cumprimento do cronograma;

* entusiasmo de boa parte dos alunos;

* participação, freqüêencia, acompanhamento e entendimento bons, por parte dos alunos;

* possibilidade de os professores terem liberdade de escolha dos assuntos.

- As limitações das aulas práticas foram:

* a imposição da instituição de que as aulas práticas perfaçam $50 \%$ da programação;

* o número excessivo de alunos, o que impedia que a supervisão dos trabalhos fosse melhor;

* desinteresse de alguns alunos, provocada pela falta de formação adequada no ensino médio;

* não houve tempo para testar os processos antes das aulas práticas, nem para criar novas técnicas; 
* tempo curto das aulas práticas, porque o curso noturno limita o período de aulas em 4 horas, o que foi pouco, para alguns processos.

- Os professores não apontaram limitações de ordem pessoal, ética e/ou moral, de preparação de aulas e de espaço físico.

- Consecução dos objetivos:

- Quanto ao conteúdo:

* Objetivos alcançados -

- ilustrar fatos e fenômenos;

- aplicar teoria, lei, princípio;

- mostrar a importância da Bioquímica em campos específicos do conhecimento.

* Objetivo não alcançado -

- ensinar como compreender conceitos.

* Objetivos que as aulas práticas deveriam ter, mas que não foram colocados no curso -

- ensinar como construir conceitos;

- divulgar descobertas recentes da Ciência.

- Quanto à metodologia de ensino:

* Objetivos alcançados -

- ensinar como seguir protocolo;

- ensinar como fazer relatório escrito;

- ensinar como criticar dados;

- ensinar como consultar literatura científica;

- segundo as opiniões da professora de aulas práticas e da professora auxiliar:

- ensinar como comunicar resultados oralmente;

- ensinar como propor novos experimentos;

- segundo a opinião do professor de aulas teóricas:

- ensinar como processar dados.

* Objetivos não alcançados -

- ensinar como observar e anotar;

- segundo as opiniões da professora de aulas práticas e da professora auxiliar:

- desenvolver autonomia na execução de experimentos;

- ensinar como propor hipóteses;

- ensinar como escrever protocolos;

- segundo a opinião da professora de aulas práticas:

- ensinar como processar dados;

* Objetivos que as aulas práticas deveriam ter, mas que não foram colocados no curso -

- ensinar como testar hipóteses;

- ensinar como montar experimentos;

- ensinar como validar ensaios;

- segundo a opinião da professora auxiliar:

- ensinar como processar dados;

- segundo a opinião do professor de aulas teóricas:

- ensinar como comunicar resultados oralmente;

- desenvolver autonomia na execução de experimentos;

- ensinar como propor hipóteses;

- ensinar como escrever protocolos;

- ensinar como pensar novos experimentos;

- Quanto ao treinamento de habilidades técnicas experimentais:

* Objetivos alcançados -

- treinar manipulação de material biológico;

* Objetivos não alcançados -

- treinar técnicas de pesquisa laboratorial;

- segundo a opinião do professor de aulas teóricas e da professora de aulas práticas: - treinar manuseio de material de laboratório e de reagentes.

* Objetivos que as aulas práticas deveriam ter, mas que não foram colocados no curso:

- treinar uso de equipamentos e aparelhos;

- segundo a opinião da professora auxiliar:

- treinar manuseio de material de laboratório e de reagentes.

- Quanto à interação entre os participantes:

* Objetivos alcançados -

- motivar alunos;

- melhorar relações entre professor e alunos;

- segundo a opinião da professora de aulas práticas e da professora auxiliar de aulas de laboratório: - encorajar entusiasmo pela Ciência.

* Objetivos não alcançados - 
- melhorar relações entre alunos;

- segundo a opinião do professor de aulas teóricas:

- encorajar entusiasmo pela Ciência.

OBS - Os três professores responderam em conjunto o questionário e diferiram em suas respostas mais na parte de consecução dos objetivos, havendo maior coincidência entre as respostas das duas professoras que ministraram as aulas práticas.

\section{B. Análise das Aulas Práticas}

$\mathrm{B}_{1}$. Dados gerais

- total de aulas práticas na programação - 5;

- $\mathrm{n}^{\mathrm{o}}$ de aulas práticas observadas -3 ;

- datas - 18/09/2000;2/10/2000;23/10/2000;

- período - noturno;

- professora de aulas práticas - Érica Helena dos Santos;

- professora auxiliar de aulas de laboratório - Cristiane Peverari Costa;

- técnico / tipo de participação na aula - Euclides Gomes de Lima / atuou no preparo das aulas práticas e repôs material durante as aulas, quando necessário.

$\mathrm{B}_{2}$. Aulas práticas observadas

Características gerais

- $\quad$ assuntos (unidades da programação) - ver Anexo 8;

Doce de Leite e Queijo de Minas tipo Frescal (Processamento de produtos láteos); Polpa de fruta desidratada: farinha de banana (Preservação de alimentos pelo calor);

- $\quad$ ordem dentro da programação - 6 ${ }^{\mathrm{a}}, 8^{\mathrm{a}}$ e $11^{\mathrm{a}}$ aulas (ver Anexo 8);

- as aulas práticas não tiveram ligação com qualquer atividade desenvolvida pela instituição que não seja as da própria disciplina;

- as aulas práticas não foram acompanhadas de artigo científico correlato;

- as aulas práticas foram ministradas após as aulas teóricas correspondentes;

- dinâmica da aula:

- duração - 2:50 h a 3:00 h;

- divisão de tempo da aula -

* planejamento / explicações iniciais $-6 \%$ a $11 \%$.

* execução - $80 \%$ a $88 \%$;

* análise de resultados / discussão - 6\% a 10\%;

- condições de orientação dos alunos:

- $\quad n^{0}$ de professores -2 ;

- $\mathrm{n}^{\mathrm{Q}}$ de auxiliares que participaram da orientação - 0 ;

- $\quad n^{0}$ de alunos -68 ;

- proporção orientador : aluno - 1:34;

- condições dos alunos quanto a conhecimentos necessários para a compreensão da aula - os alunos tinham iniciativa, eficiência e conheciam os princípios básicos que eram usados nos processo industriais desenvolvidos nas aulas práticas;

- não havia possibilidade de uso do laboratório fora do horário de aula, quer porque os laboratórios eram usados para outras aulas, quer pela ausência dos professores para orientação, quer pelo fato de a maioria dos alunos trabalharem durante o dia;

- não havia possibilidade de orientação dos alunos pelos professores fora do horário de aula;

- local para os alunos trabalharem em grupo fora da aula:

- local - centro de convivência e biblioteca;

- horário - não definido.

Materiais

- foram usados equipamentos e vidrarias corriqueiros em laboratório de Química e em cozinha industrial;

- os aparelhos e equipamentos estavam em locais fixos no laboratório (ver item sobre o laboratório);

- as drogas e materiais biológicos foram distribuídos antes das aulas, pelo técnico;

- custo do material de consumo - não estimado.

Preparo e teste

- o preparo de aulas práticas da disciplina era feito pelo técnico, antes do período de aula, com o planejamento e supervisão das professoras;

- os processos não foram previamente testados.

Normas de segurança e de manipulação de material biológico

- foram dadas normas de segurança por escrito no início do curso, sem assinatura de compromisso em seguilas; nesta ocasião, uma aula foi reservada para discussão de normas de segurança;

- antes de cada aula, foram dadas oralmente regras de segurança e higiene, como prender os cabelos compridos, quando há uso de fogo, lavagem adequada das matérias-primas etc. 
Conteúdo da aula

- relações:

- $\quad$ com o resto da programação -

* as aulas práticas geralmente acompanhavam o conteúdo das aulas teóricas correspondentes;

* as aulas práticas foram dadas após as aulas teóricas correspondentes;

as aulas práticas tinham os assuntos relacionados com as disciplinas de Processos Industriais Orgânicos

e Transferência de Calor e Massa;

- as aulas práticas não tinham relações com pesquisa da instituição ou de fora dela ou com projeto de extensão da instituição e com publicações científicas, dentro ou fora da instituição;

- as aulas práticas tiveram relação com a vida profissional futura dos alunos e com seu cotidiano fora da faculdade, mas não se relacionaram com o contexto social geral deles como cidadãos;

- não houve relações das aulas práticas com a vida universitária dos alunos;

- de acordo com a opinião da professora de aulas práticas, as aulas práticas não poderiam ser substituídas por qualquer outra atividade, com os mesmos objetivos;

- as aulas práticas não partiram de um problema a ser resolvido pelos resultados obtidos, nem havia perguntas, no protocolo, que serviam como orientação para a discussão dos resultados e que eram os itens do relatório.

Roteiro / Protocolo

Ver Anexo 9:

- os protocolos eram impressos, deixados na fotocopiadora para serem comprados pelos alunos e foram fornecidos com antecedência;

- no conteúdo dos protocolos:

- não constavam os objetivos das aulas ou dos processos, nem eles foram fornecidos oralmente;

- constavam listas de materiais;

- havia todas as diretrizes para a execução dos processos;

- não havia normas de segurança;

- eram fornecidas normas de higiene específicas para cada processo e estas eram reforçadas oralmente;

- não havia instruções do quê e como observar;

- havia instruções sobre que dados registrar;

- não havia questões e/ou problemas a serem resolvidos no relatório, usando os dados obtidos;

- não havia orientações para a discussão dos dados no protocolo ou como escrever o relatório, elas foram dadas no início do curso;

- não constava bibliografia específica sobre a técnica e/ou sobre o assunto das aulas práticas.

Etapas da aula / Estratégia de ensino

- utilização do protocolo (roteiro de aula):

- não houve leitura prévia dos protocolos no início das aulas práticas;

- os alunos seguiam o protocolo, à medida que executavam os trabalhos;

- o conjunto de dados a ser obtido foi definido previamente;

- tipo de execução:

- houve uma demonstração pela professora auxiliar, quando do uso de um aparelho, devido a só existir um para uso de toda a classe e devido à dificuldade de seu manuseio;

- a maior parte dos processos foi executado pelos alunos, sob a orientação das professoras;

- a manipulação de aparelhos foi feita pelos alunos, com a supervisâo das professoras;

- todos os alunos executavam os processos, com divisão eqüitativa dos trabalhos;

- precisão / sensibilidade / higiene:

- $\quad$ não houve preocupação com a precisão na obtenção dos dados;

- não houve preocupação com as sensibilidades dos métodos e técnicas;

- houve principalmente preocupação com higiene;

- habilidades:

- técnicas -

* exigidas pelas aulas - manipulação de vidraria simples de laboratório de Química e de cozinha industrial,

- os alunos não tinham as seguintes habilidades - alguns não sabiam pipetar corretamente, apesar de cursarem o último ano do curso;

* treinadas durante as aulas - uso de refratômetro e estufa com corrente de ar;

- mentais -

* exigidas pelas aulas - compreender instruções orais e escritas, observar e anotar,

- os alunos tinham as habilidades exigidas;

* treinadas durante as aulas - analisar e sintetizar, consultar literatura científica;

- formas de orientação dos alunos pela equipe:

- as orientações eram dadas no início das aulas, pela professora de aulas práticas e durante toda a aula, por ela e pela professora auxiliar;

- observações sobre as explicações iniciais - a professora reproduzia os dados do protocolo na lousa, dava o embasamento teórico das técnicas, relacionando-as com os assuntos de aulas teóricas, explicava o que e como observar, o que anotar, como tratar e processar os dados; 
- forma de registro dos resultados - no caderno, sem orientação específica, nos dois primeiros protocolo, e com tabela de anotações, no terceiro;

- processamento dos dados obtidos:

- os dados dos grupos não foram colocados na lousa no fím das aulas observadas;

- cada processo foi tratado como único; cada grupo trabalhou com seus próprios dados;

- houve cobrança dos resultados previamente esperados;

- os processos utilizados deram os resultados esperados, com pequenos desvios;

- o tempo disponível para a execução proposta no início das aulas foi suficiente, mas tanto os alunos como as professoras consideraram que seria melhor se houvesse mais tempo;

- comportamento dos participantes:

- alunos -

* boa parte do tempo estavam interessados, alguns faziam os trabalhos por obrigação;

* alguns ficavam preocupados em terminar o relatório anterior;

* em geral, conversavam bastante sobre assuntos fora do das aulas, vendiam objetos, brincavam, namoravam, comiam, inclusive os produtos alimentícios produzidos nos processos desenvolvidos em aula;

* muitos chegavam atrasados, alguns saíam antes de a aula terminar;

professoras -

* comprometidas, com intencionalidade;

* a maior parte do tempo, davam total liberdade aos alunos;

- encerramento das aulas - as aulas encerravam-se após a obtenção dos dados pelos grupos, as observações que demandavam espera eram feitas nas aulas subseqüentes.

Discussão dos dados

- a discussão dos dados era feita pelos grupos, por ocasião da confecção dos relatórios;

- os alunos tiravam dúvidas sobre a interpretação dos resultados e sobre a explicação dos processos, com as professoras, durante as aulas práticas subseqüentes.

Relatório das aulas práticas

- obrigatório:

- realizado após a aula, em outro local;

- com prazo de entrega de quinze dias;

- feito por escrito, em grupo;

- a partir de diretrizes específicas, dadas pelos professores, no início do curso, com o padrão tradicional deste tipo de redação científica, incluindo pesquisa bibliográfica sobre o assunto;

- ensinava a:

- discutir resultados - analisar e relacionar dados;

- fazer pesquisa bibliográfica sobre assuntos correlatos às aulas práticas;

- fazer redação científica;

- fazia parte da avaliação.

Atividades suscitadas pelas aulas práticas

- as aulas práticas suscitaram a execução de um trabalho final do curso, com aplicação do conhecimento básico nelas desenvolvido e incluindo criatividade, iniciativa, inovação técnica ou de uso de materiais.

Avaliação do aprendizado em aulas práticas

- a avaliação das aulas práticas era feita pelo relatório e pelo trabalho final.

Ocorrências não previstas durante as aulas práticas

- não houve qualquer ocorrência a assinalar. 


\title{
APÊNDICE 4
}

\section{UNIVERSIDADE DE SÃO PAULO - CAMPUS DA CAPITAL Departamento de Bioquímica do Instituto de Química}

\section{Caracterização do contexto geral do Departamento de Bioquímica do Instituto de Química}

\author{
A. Instituição-Instituto de Química-Departamento de Bioquímica \\ Dados gerais \\ Endereços \\ site: www.iq.usp.br \\ Av. Lineu Prestes, 748 - Butantã - São Paulo - SP - C..P. - 26077 \\ CEPs - 05508-900/05513-970 telefones - 3091-3257/3091-3839
}

Natureza / Classificação

Instituição pública - Governo do Estado de São Paulo / Universidade.

Disciplinas de graduação oferecidos a outras unidades da universidade

Bioquímica I (Escola de Enfermagem), Bioquímica XI (Escola de Educação Física e Esporte da Faculdade de Medicina), Bioquímica: Estrutura de Biomoléculas e Metabolismo (Faculdade de Medicina Veterinária e Zootecnia), Biologia Molecular do Gene (Faculdade de Medicina Veterinária e Zootecnia), Bioquímica V (Faculdade de Odontologia), Bioquímica: Estrutura de Biomoléculas e Metabolismo (Faculdade de Medicina), Bioquímica e Biologia Molecular do Gene (Faculdade de Medicina), Química de Biomoléculas (Faculdade de Saúde Pública), Bioquímica* (Faculdade de Saúde Pública), Bioquímica: Estrutura de Biomoléculas e Metabolismo (Faculdade de Ciências Farmacêuticas), Bioquímica Experimental* (Faculdade de Ciências Farmacêuticas), Bioquímica e Biologia Molecular do Gene (Faculdade de Ciências Farmacêuticas), Química de Biomoléculas ${ }^{+}$(Instituto de Biociências), Bioquímica* ${ }^{*}$ (Instituto de Biociências), Radicais Livres em Biologia e Medicina - optativa (Faculdade de Medicina), Introdução à Pesquisa Científica em Bioquímica - optativa (Faculdade de Medicina).

* disciplinas observadas nesta pesquisa. $\quad+$ as duas disciplinas foram reunidas numa só, com a denominação de "Bioquímica" no ano desta observação

Atividades de Pós-Graduação

- o Departamento de Bioquímica do Instituto de Química oferecia cursos de extensão universitária e projetos de iniciação científica para estudantes de graduação e cursos em nível de Mestrado e Doutorado, em várias áreas de pesquisa de Bioquímica e em Ensino de Bioquímica, por ocasião desta pesquisa.

Atividades de pesquisa

- os docentes do Departamento de Bioquímica e alunos de graduação e pós-graduação faziam pesquisa laboratorial em várias áreas de Bioquímica e desenvolviam projetos na área de Ensino de Bioquímica, no momento em que foi feita esta pesquisa;

- o Departamento promovia regularmente seminários nas várias áreas de Bioquímica, congressos e similares, em suas dependências;

- o Departamento mantinha estrutura para professores e/ou alunos de graduação e pós-graduação participarem de congressos, cursos, palestras ou similares fora da instituição.

Prestação de serviço à comunidade (atividades de extensão)

- o Departamento de Bioquímica não possuía nenhum centro próprio de atendimento direto à comunidade.

Publicaçzes científicas

- o Departamento de Bioquímica não possuía, por ocasião desta pesquisa, nenhuma publicação científica própria;

- o Departamento de Bioquímica mantinha estrutura para professores e alunos publicarem seus trabalhos em periódicos nacionais e internacionais.

Regime de trabalho dos professores de disciplinas com conteúdo de Bioquímica

- os professores do Departamento de Bioquímica trabalhavam em tempo integral, com regime de dedicação exclusiva;

- os professores com quem foi feita esta pesquisa, todos faziam pesquisa laboratorial e orientação de pesquisa de Bioquímica;

- havia remuneração do professor para horário de planejamento / preparo de aulas práticas e para atendimento de alunos fora das aulas.

Apoios técnico e didático ao professor

- havia I auxiliar técnica de laboratório;

- não havia pessoal para datilografar material produzido pelos professores, para uso em aulas práticas;

- as fotocópias para reproduzir material para uso em aulas práticas eram pagas pelos alunos ou retiradas de sites na internet;

- não havia salas especiais de projeção;

- recursos audio-visuais:

- havia vários projetores de diapositivos e de transparências;

- havia vários vídeos e projetores multimídia;

- todos os aparelhos audio-visuais podiam ser transportados para salas de aula e laboratórios, mediante prévia requisição;

- não havia laboratórios de informática para serem utilizados pelos vários cursos e que poderiam ser usados pelas disciplinas aqui analisadas, para demonstrações dos professores e para trabalho dos alunos; 
- havia biblioteca com livros e periódicos sobre Bioquímica e com acesso à Internet.

B. Laboratórios (2)**

**O Departamento de Bioquímica possuía dois laboratórios didáticos, com saída para o corredor externo e interligados por um corredor interno. As disciplinas observadas utilizaram-se de apenas um deles que é descrito a seguir.

Natureza

- didática.

Condições fisicas

- dimensões da sala - largura - 9m; comprimento-15m; área - $135 \mathrm{~m}^{2}$;

- bancadas - 4 bancadas altas com tampo de mármore ( 1 para uso dos professores, monitores e técnicos e 3 para uso dos alunos), com alguns apoios de borracha e suportes para apoiar vidraria e com 2 locais para trabalho por bancada ( 1 em cada extremidade);

- instalações de água - 1 pia na extremidade de cada uma das bancadas; 1 bujão de água destilada em prateleira acima da pia da bancada de aparelhos;

- instalações de gás - gás encanado - 1 bico em cada uma das 2 capelas;

- instalações elétricas:

- 3 conjuntos de 4 tomadas de $110 \mathrm{~V}$ em cada bancada; 2 conjuntos de 2 tomadas de $110 \mathrm{~V}$ nas paredes, 4 conjuntos de 2 tomadas de $110 \mathrm{~V}$ na bancada lateral;

1 conjunto de 4 tomadas de $220 \mathrm{~V}$ por bancada;

- iluminação artificial - 18 lâmpadas fluorescentes no teto;

- iluminação natural / ventilação:

- janelas - basculantes em toda a extensão de uma das paredes laterais, com persianas;

- não havia ventiladores;

- não havia aparelhos de ar condicionado;

- $\quad$ sistema de exaustão de ar e vapores:

- 1 capela fixa e 1 móvel;

- havia 1 lousa de acrílico em uma das paredes, de frente para as bancadas, e 1 tela de projeção na parede oposta;

- mapa metabólico, quadros sobre precipitação de proteínas e sobre espectrofotômetro e relógio afixados nas paredes;

- instalações para uso dos alunos:

- tipo de assento dos alunos - bancos altos, em número suficiente para uso de todos os alunos;

- local para colocação de material pessoal dos alunos - prateleiras junto à parede do corredor interno que separa os dois laboratórios didáticos;

- local para os alunos fazerem o registro de dados - a própria bancada;

- instalações para uso dos professores, da técnica e dos auxiliares e do pessoal de limpeza:

- professores e monitores - usavam a bancada da frente e as salas anexas aos laboratórios, não havendo assento diferenciado para seu uso;

- auxiliar técnica - utilizava as salas entre os dois laboratórios;

- pessoal da limpeza - possuía local próprio, fora do laboratório;

- sistema de segurança:

- não havia avisos ou regras de segurança ou de primeiros socorros afixados no recinto do laboratório, mas foram entregues normas de segurança por escrito, para cada aluno, no início do curso, e foi assinado ciente pelos alunos;

- havia avisos orais de alguns professores no início e durante as aulas práticas, sobre produtos tóxicos ou perigosos e sobre manipulação de material biológico;

- o uso de avental pelos professores, pela técnica e pelos alunos era obrigatório; eram fornecidos aventais descartáveis para os alunos que esqueciam os aventais;

- foram usados óculos protetores pelos professores e pelos alunos, quando necessários; os óculos eram de propriedade do laboratório;

- houve uso de pêras e pipetadores automáticos, quando necessários;

- havia 1 chuveiros com lava-olhos, junto à porta de entrada, no corredor externo;

- extintores de incêndio - 1 , junto à porta, no chão;

- $\quad$ piso - emborrachado liso;

- falhas de segurança - não foram constatadas;

- não houve nenhum acidente ou incidente com relação à segurança, durante as aulas práticas observadas;

- formas de descarte de materiais - os alunos deixavam o material usado em cubas junto às pias das bancadas. Havia avisos sobre as bancadas, informando a maneira correta de descartar os materiais;

- higiene:

- condições de higiene - boas;

- limpeza de vidraria - o material era recolhido após as aulas práticas, lavado e guardado pelos auxiliares técnicos;

- latões de lixo - 3 latões grandes com tampa, que variavam a posição no laboratório, conforme a aula;

- local de estoque e colocação de materiais: 
- vidraria - armários nas bancadas, armários junto à parede e salas anexas;

- drogas - salas anexas aos laboralórios;

- aparelhos e equipamentos - bancada de aparelhos, junto às janelas e nas salas anexas.

Condições de trabalho dos alunos

(Ver também cursos e disciplinas observados)

- adequação do local às necessidades dos experimentos - boa;

- acesso a:

- água-bom;

- gás - bom;

- eletricidade-bom;

- materiais dos experimentos - bom;

- aparelhos - bom;

- equipamentos - bom;

- lixo-bom

- condições de:

- iluminação - boa;

- ventilação - boa;

- distribuição do material - o material era colocado sobre as bancadas, antes da aula, pela auxiliar técnica e pelos monitores; o material biológico era distribuído na hora da aula, pelos professores e monitores;

- possibilidades de visualizar e ouvir:

- os professores - médias, as bancadas afastavam os alunos do local onde ficavam os professores;

- a lousa ou recursos audio-visuais - médias, alguns alunos, no fundo da sala, não participavam igualmente;

- facilidade de circulação pelo laboratório durante as aulas - boa. 


\title{
APÊNDICE 5
}

\section{FACULDADE DE SAÚdE PÚBLICA - CURSO DE NUTRIÇÃO}

\section{A. Caracterização do contexto particular do Curso de Nutrição}

\author{
$A_{1}$. Instituição \\ Dados gerais \\ Endereços \\ e-mail - svgrad006 ssp@recad.usp.br site: www.fsp.usp.br \\ Av. Dr. Arnaldo, $7 \overline{15}$ - Perdizes - São Paulo - SP \\ CEP - 01246-904 telefone - 3066-7733 \\ Prestação de serviço à comunidade (atividades de extensão)
}

- a instituição possuía o Serviço Especial de Saúde Pública de Araraquara (Saúde da Criança e da Mulher); Serviço Especial de Saúde Geraldo de Paula Souza e o Centro de Educação Permanente.

Publicaçóes científicas

- a instituição possuía a "Revista Brasileira de Crescimento e Desenvolvimento Humano" (ISSN - 0104-1282), a "Revista de Saúde Pública" (ISSN - 0034-8910) e "Saúde e Sociedade" (ISSN - 0104-1290);

- a instituição mantinha estrutura para professores e alunos participarem de publicações de outras instituições.

$\mathrm{A}_{2}$. Curso analisado e disciplina com conteúdo de Bioquímica

Curso

- enfoque - ciência aplicada e tecnologia;

- habilitação - bacharelado;

- atividades profissionais para as quais habilitava - planejamento, organização e gerenciamento de unidade de alimentação e de programação governamentais de nutrição, orientação e atendimento dietético a indivíduos ou coletividades sadias e enfermas, incluindo atendimento a atletas e esportistas, pesquisa nas áreas de alimentação e nutrição, assessoria, consultoria e marcketing na área de nutrição, assessoria e coordenação em restaurantes industriais e comerciais, hospitais, consultórios médicos, centros de saúde, escolas, empresas da área de alimentação;

- $\quad$ período de funcionamento - matutino;

- duração / regime - 10 semestres / regime semestral;

- currículo - séries e disciplinas, objetivos do curso - ver Anexo 10;

- havia convênios da instituição com empresas ou outras instituições para treinamento profissional dos alunos.

Disciplina

- nome da disciplina-Bioquímica;

- carga horária - 4 aulas semanais / total de $120 \mathrm{~h}$;

- posição na grade curricular - disciplina lecionada no $2^{0}$ semestre do curso;

- objetivos e programa da disciplina - ver Anexo 11;

- porcentagem de assuntos da programação que foi desenvolvida em aulas práticas - $15 \%$;

- nenhum assunto estava fora da programação de aulas teóricas;

- divisão / proporção entre tipos de aulas:

* $\quad \mathrm{n}^{\mathrm{o}}$ de aulas práticas -3 ;

* $\quad \mathrm{n}^{\underline{0}}$ de aulas teóricas -22 ;

* $\quad \mathrm{n}^{0}$ de outras atividades diferentes de aulas teóricas e práticas - 24 -

- $\mathrm{n}^{\mathrm{Q}}$ de períodos de discussão -5 ;

- $\mathrm{n}^{\circ}$ de aulas de exercícios -5 ;

- $\mathrm{n}^{\mathrm{o}}$ de seminários - 11;

- $\quad \mathrm{n}^{\mathrm{o}}$ de avaliações -3 ;

- $\mathrm{n}^{\mathrm{O}}$ de trabalhos bibliográficos - 1 ;

* proporção aulas práticas : atividades diferentes de aulas teóricas e práticas $-1: 8$;

* proporção aulas práticas : aulas teóricas - 1: 7,3;

- integração com outras disciplinas - Química de Biomoléculas ( $1^{\circ}$ semestre);

- relações de pré-requisitos com outras disciplinas - Fisiologia e Biofísica, Citologia, Histologia e Embriologia, Microbiologia, Imunologia, Disciplinas referentes à Nutrição, Dietética e Alimentos, Bromatologia;

- titulação da professora e instituição onde a obteve - Doutorado - Departamento de Bioquímica - IQ - USP;

- atividades de pesquisa da professora - fazia pesquisa pura na área de Bioquímica - Departamento de Bioquímica - IQ - USP;

- $\quad$ atividades docentes da professora na Disciplina de Bioquímica - dava aulas teóricas e práticas;

- a instituição não fez o perfíl dos alunos ingressantes na disciplina analisada.

Distribuição dos alunos no recinto do laboratório

- $\quad n^{2}$ total de alunos -42 ;

- densidade populacional nas aulas práticas $-0,3$ alunos $/ \mathrm{m}^{2}$; 
- $\quad \mathrm{n}^{\mathrm{o}}$ de alunos por bancada - 10 a 12 ;

- $\quad n^{2}$ de alunos por grupo - 5 a 6.

$\mathrm{A}_{3}$. Resultados dos questionários respondidos por alunos e professora

Alunos (respostas de 11 alunos)

- Expectativas em relação às aulas práticas:

- alguns alunos esperavam ver nas aulas práticas o que aprenderam nas aulas teóricas e entender melhor seus conteúdos;

- alguns alunos gostariam de complementar e aprofundar os assuntos de aulas teóricas, um assinalou que isto serviria para fixar os conceitos;

- poucos alunos imaginavam que as práticas envolveriam somente assuntos de nutrição;

- segundo opiniões individuais - um aluno:

* esperava treinar o uso de equipamentos e vidrarias;

* esperava que as aulas práticas fossem mais simples.

- Opiniões sobre as aulas práticas:

- As aulas práticas mais interessantes foram aquelas em que:

* o assunto abordava o metabolismo, na opinião de quase todos os alunos;

* os experimentos usavam seres vivos, para alguns alunos;

* pôde-se compreender a teoria, para alguns alunos;

* segundo opiniões individuais:

- ficou claro que o experimento pode não dar certo;

- pôde-se tirar conclusões a partir dos próprios dados;

- aprendeu-se a usar equipamento novo;

- pôde-se observar melhor os resultados;

- havia familiaridade com os materiais usados;

* Dois alunos apontaram a aula mais interessante, mas não explicaram por quê.

- As aulas práticas mais proveitosas foram aquelas em que:

* é possivel entender a matéria de forma mais ampla, de acordo com a opinião de vários alunos;

* de acordo com a opinião de alguns alunos, eram obtidos os resultados esperados, tinha-se uma visão real do assunto;

* pôde-se tirar conclusões a partir dos próprios dados, segundo alguns alunos;

* já se estava familiarizado com os materiais, segundo alguns alunos;

* nem sempre os resultados são os esperados, de acordo com a opinião de um aluno.

- Os defeitos das aulas práticas apontados pelos alunos foram:

* as aulas foram cansativas, com muita coisa para fazer em pouco tempo, o que levava a erros, segundo mais da metade dos alunos;

* as aulas práticas foram longas, segundo alguns alunos;

* o tempo foi escasso, na opinião de boa parte dos alunos;

* houve desorganização, segundo vários alunos;

* segundo opiniões individuais:

- a preparação não foi sempre adequada;

- as aulas tinham muita informação para o tempo disponível;

- havia muitos alunos por equipamento;

- as banquetas do laboratório eram desconfortáveis;

- as explicações iniciais tomaram parte da aula, deveriam ser dadas na aula anterior, na sala de aula;

- havia pouca familiaridade dos alunos com os materiais.

- As limitações para o aluno ter bom desempenho em aulas práticas foram:

* pêras que não funcionavam, de acordo com alguns alunos;

* falta de tempo, para alguns alunos;

* pouca prática no manuseio de materiais, de acordo com alguns alunos;

* deficiência teórica do aluno, segundo alguns alunos;

* Não há limitações para os alunos terem bom desempenho em aulas práticas, de acordo alguns alunos.

- As diferenças entre aulas práticas e teóricas apontadas foram:

* nas aulas teóricas, a aprendizagem foi passiva e nas aulas práticas, ela foi ativa, segundo a maioria dos alunos;

* as aulas práticas foram mais proveitosas, porque nelas deu para entender melhor os fenômenos, segundo alguns alunos;

* as aulas teóricas e as práticas complementaram-se, segundo alguns alunos;

* segundo opiniões individuais:

- "na teoria, não há comprometimento, não precisa prestar atenção, na prática, há mais envolvimento";

- "nas aulas práticas, podemos ver as coisas acontecerem";

- as aulas teóricas foram mais longas e cansativas; 
- em aulas práticas, apareciam mais dúvidas;

- as aulas teóricas foram mais interessantes.

- Comentários sobre os relatórios de aulas práticas:

- proporcionaram discussão e reflexão a respeito do conteúdo das aulas práticas, de acordo com a opinião de alguns alunos;

- permitiram fixar e esclarecer o assunto das aulas práticas, segundo alguns alunos;

- eram trabalhosos, porém, proveitosos, de acordo com alguns alunos;

- $\quad$ segundo opiniões individuais:

- tinham conteúdo adequado, mas deveriam ser desenvolvidos em 2 partes, primeiro a introdução, antes da aula prática, e as outras partes após a aula prática;

- eram bons, porque os conteúdos das pesquisas eram interessantes;

- "são chatos, levam muito tempo":

- ensinavam a fazer redação científica, o que também serve para outras disciplinas;

- Um aluno não fez comentários sobre os relatórios.

- Considerações sobre os relacionamentos pessoais:

- Entre alunos -

* a maioria dos alunos considerou bom seu relacionamento com colegas e um aluno o considerou ótimo;

* alguns alunos assinalaram que o relacionamento foi de cooperação;

* um aluno assinalou que o relacionamento era bom intra-grupos e não inter-grupos.

- Entre professora e alunos -

* a maioria considerou bon seu relacionamento com a professora e um aluno o considerou ótimo;

* alguns alunos salientaram que a professora era prestativa e paciente.

- Entre alunos e monitores -

* a maioria considerou bom o relacionamento com monitores, destacando atitudes de cooperação;

* alguns alunos consideraram os monitores prestativos e pacientes;

* um aluno considerou o relacionamento com monitores ótimo.

- Atitude dos alunos frente ao questionário:

- os alunos foram receptivos e tiveram boa vontade em responder as perguntas, sem fazer nenhum Professora

comentário adicional em relação à tarefa solicitada.

Maria Terêsa Machini de Miranda

- Cargo na Instituição - professora de aulas teóricas e práticas (no ano em que foi feita esta pesquisa) e pesquisadora.

- Curso de Graduação - Química - bacharelado (FCL - USP de Ribeirão Preto).

- Pós-Graduação - Doutoramento em Bioquímica (IQ - USP).

- Atividades de pesquisa - pesquisa pura na área de Bioquímica - Departamento de Bioquímica (IQ - USP).

- Opiniões sobre aulas práticas no ensino de Bioquímica:

- Importância -

* as aulas práticas são fundamentais na transmissão e fixação de conteúdo;

* as aulas práticas desenvolvem habilidades técnicas;

* as aulas práticas dão senso crítico e desenvolvem a capacidade de observação, dão a capacidade de relatar e discutir resultados.

- Critério de escolha do número de aulas práticas, de suas posições na programação e de seus assuntos experimentos que ilustram alguns aspectos do metabolismo animal, distribuídos ao longo do semestre.

- Realização das expectativas nas aulas práticas ministradas: pela primeira vez, os alunos de Nutrição tiveram contato com os materiais de laboratório e fizeram uma redação científica.

- As limitações das aulas práticas foram:

* um único professor para um número grande de alunos;

* ausência da técnica e preparo inadequado das aulas pela auxiliar técnica;

* poucas aulas: houve uma redução de 6 para 3, neste curso, porque o total de aulas foi diminuído em 4 aulas;

* não houve limitações de ordem pessoal, ética e/ou moral, impostas pela estrutura institucional e/ou legal, de formação dos alunos, de espaço.

- Consecução dos objetivos:

- Quanto ao conteúdo:

* Objetivos alcançados -

- ilustrar fenômenos;

- ensinar a compreender conceitos.

- Quanto à metodologia de ensino:

* Objetivos alcançados -

- ensinar como seguir protocolo;

- ensinar como observar e anotar;

- ensinar como processar dados; 
- ensinar como fazer relatório escrito;

- ensinar como comunicar resultados oralmente;

- ensinar como criticar dados;

- ensinar como consultar literatura científica.

- Quanto ao treinamento de habilidades técnicas experimentais:

* Objetivos alcançados -

- treinar manuseio de material de laboratório e de reagentes;

- treinar uso de equipamentos e aparelhos.

- Quanto à interação entre os participantes:

* Objetivos alcançados -

- motivar aluno;

- melhorar as relações entre professor e alunos

- melhorar as relações entre alunos.

* Objetivos não alcançados -

- encorajar entusiasmo pela Ciência.

OBS - A professora preocupou-se em estudar o questionário e respondê-lo com cuidado. Estava interessada nos resultados para avaliar seu desempenho.

\section{B. Análise das Aulas Práticas}

$\mathrm{B}_{1}$. Dados gerais

- total de aulas práticas na programação - 3;

- $\quad \mathrm{n}^{\circ}$ de aulas práticas observadas - 3;

- datas - 4/10/2000;01/11/2000;22/11/2000;

- período-matutino;

- professora - Maria Terêsa Machini de Miranda;

- monitor - Ricardo de Marco - auxiliou nas 3 aulas práticas observadas, na parte técnica;

- técnico do laboratório de pesquisa - Cleber Wanderley Líria - auxiliou em uma das aulas, principalmente na parte técnica;

- auxiliar técnica - atuou no preparo das aulas práticas.

$\mathrm{B}_{2}$. Aulas práticas observadas

Características gerais

- $\quad$ assuntos (unidades da programação) - ver Anexo 12:

Cinética enzimática (Enzimas); Fracionamento celular, verificação da atividade da succinato desidrogenase, inibição da succinato desidrogenase por malonato (Cadeia respiratória); Transaminação (Metabolismo de aminoácidos);

- ordem dentro da programação - $13^{\mathrm{a}}, 22^{\mathrm{a}}$ e $28^{\mathrm{a}}$ aulas (ver Anexo 11 );

- as aulas práticas não tiveram ligação com qualquer atividade desenvolvida pela instituição que não seja as da própria disciplina;

- as aulas práticas não foram acompanhadas de artigo científico correlato;

- as aulas práticas foram ministradas após as aulas teóricas correspondentes;

- dinâmica da aula:

- duração - 2:54 h a 3:20 h;

- divisão de tempo da aula -

* planejamento / explicações iniciais - $14,5 \%$ a $28,5 \%$;

* execução $-65 \%$ a $85,7 \%$;

* análise de resultados / discussão - $0 \%$ a $15 \%$;

- condições de orientação dos alunos:

- $\quad \mathrm{n}^{\mathrm{o}}$ de professores -1 ;

- $\quad \mathrm{n}^{\mathrm{o}}$ de auxiliares que participaram da orientação - 1;

- $\quad \mathrm{n}^{0}$ de alunos -42

- proporção orientador : aluno - 1:21;

- condições dos alunos quanto a conhecimentos necessários para a compreensão da aula - os alunos não dominavam todos os assuntos relativos ao curso do primeiro semestre, Química de Biomoléculas;

- $\quad$ possibilidade de uso do laboratório fora do horário de aula - não;

- havia possibilidade de orientação da professora fora do horário de aula, desde que os alunos a procurassem em sua sala;

- possibilidade de os alunos trabalharem em grupo fora da aula:

- local - não há um local específico para os alunos se reunirem; muitas vezes viam-se alunos fazendo relatórios sentados nas escadas do prédio, antes do início das aulas;

Materiais horário - não especificado.

- foram usados equipamentos e vidrarias corriqueiros em laboratório de Química;

- os aparelhos e equipamentos tinham geralmente locais fixos no laboratório; 
- as vidrarias e os reagentes foram colocados sobre as bancadas antes da aula, pelo monitor e pela auxiliar técnica;

- o material biológico foi distribuído no momento do experimento, pela professora e pelo monitor;

- custo do material de consumo - não estimado;

Preparo e teste

- as aulas práticas foram preparadas pela auxiliar técnica e pelo monitor, antes do período de aula, com planejamento e orientação da professora;

- os experimentos foram previamente testados pela professora e pelo monitor.

Normas de segurança e de manipulaçåo de material biológico

- foram dadas normas de segurança por escrito, com assinatura de ciência;

- não foram dadas instruções orais específicas sobre normas de segurança, durante as aulas observadas;

- não houve treinamento específico sobre segurança no laboratório ou sobre manipulação de tecidos, órgãos ou animais.

Conteúdo da aula

- relações:

- com o resto da programação -

* as aulas práticas acompanhavam o conteúdo das aulas teóricas;

* as aulas práticas geralmente foram dadas após as aulas teóricas correspondentes;

- as aulas práticas tinham todos os assuntos relacionados com Química de Biomoléculas e com Fisiologia;

- as aulas práticas não tinham relações com pesquisa da instituição ou de fora dela ou com projeto de extensão da instituição e com publicações científicas, dentro ou fora da instituição;

- as aulas práticas não se relacionavam com a vida profissional e nem com o cotidiano do aluno, nem com sua vida universitária, nem com sua vida como cidadão;

- não houve relações das aulas práticas com a vida universitária dos alunos;

- de acordo com a opinião da professora, as aulas práticas não poderiam ser substituídas por outro tipo de atividade com os mesmos objetivos;

- as aulas práticas não partiram de um problema a ser resolvido pelos resultados obtidos; havia perguntas, no protocolo, que serviam como orientação para a discussão dos resultados e que eram os itens do relatório;

Roteiro / Protocolo

Ver Anexo 12:

- os protocolos foram produzidos pela professora;

- os protocolos eram impressos, fornecidos graciosamente aos alunos no início das aulas práticas;

- no conteúdo dos protocolos, constavam os objetivos das aulas, a saber:

* Cinética enzimática -

- estudar as influências das concentrações de enzima, de substrato, de pH e de temperatura na velocidade de uma reação enzimática;

- examinar as curvas obtidas;

- obter alguns parâmetros cinéticos $\left(K_{M}\right.$ e $\left.V_{\max }\right)$ e discutir seus valores e importância;

* Fracionamento celular; verificação da atividade da succinato desidrogenase; inibição da succinato desidrogenase por malonato -

- realizar o fracionamento celular a partir do figado de um rato;

- identificar a fração que contém desidrogenase;

- verificar a inibição competitiva da desidrogenase por malonato;

* Transaminação -

- verificar a reação de transaminação em homogenato de figado;

- identificar os produtos de reação por cromatografia em papel;

- constava lista de materiais e de reagentes em apenas 1 de 3 protocolos;

- havia todas as diretrizes para a execução dos experimentos;

- não foram fornecidas normas de segurança específicas para cada experimento, por escrito;

- não havia regras de higiene;

- não havia orientação sobre o quê e como observar;

- havia instruções sobre como registrar os dados;

- havia questões e/ou problemas a serem resolvidos no relatório, usando os dados obtidos;

- havia orientação para a discussão dos dados no relatório; a professora acrescentou oralmente algumas orientações;

- foi fornecida bibliografia específica sobre a técnica e/ou sobre o assunto das aulas práticas; a professora recomendou leituras paralelas em uma das aulas.

Etapas da aula / Estratégia de ensino

- utilização do protocolo (roteiro de aula):

- os protocolos foram lidos por um aluno, em voz alta, no início das aulas, com comentários da professora;

- os alunos tiravam dúvidas sobre o protocolo, com a professora e o monitor, à medida que executavam os trabalhos;

- o conjunto de dados a ser obtido foi definido previamente;

- tipo de execução: 
- a maior parte dos experimentos foi executada pelos alunos, sob a orientação da professora e do monitor;

- a manipulação de aparelhos foi feita pelos alunos, com o auxilio do monitor e da professora;

- as tarefas eram distribuídas eqüitativamente, entre os membros dos grupos; houve alguns alunos que não participaram de nenhuma atividade;

- precisão / sensibilidade / higiene:

- houve preocupação com a precisão na obtenção dos dados;

- não houve preocupação com as sensibilidades dos métodos e técnicas;

- não houve preocupação com higiene;

- habilidades:

- técnicas -

* exigidas pelas aulas - manipulação de vidraria simples de laboratório de Química,

- os alunos não tinham as seguintes habilidades - alguns não dominavam algumas das habilidades exigidas, como pipetar corretamente, e foram treinados durante as aulas;

* treinadas durante as aulas - uso de pêra e pipetador automático, centrífuga, banho-maria e homogeneizador, espectrofotômetro, manipulação de material biológico;

- mentais -

* exigidas pelas aulas - compreender instruções orais e escritas,

- os alunos dominavam as habilidades exigidas;

* treinadas durante as aulas - observar e anotar, buscar dados na literatura científica, analisar e sintetizar;

- forma de orientação dos alunos pela equipe:

- as orientações eram dadas no início das aulas, pela professora e durante toda a aula, por ela e pelo monitor;

- observações sobre as explicações iniciais - a professora reproduzia alguns dados do protocolo na lousa, explicava toda a execução dos experimentos, sem a explicação do embasamento teórico das técnicas e relacionando, às vezes, o conteúdo da aula com a matéria das aulas teóricas. A professora solicitava a participação dos alunos nessa fase, incentivando-os a responder questões e as dúvidas dos colegas;

- forma de registro dos resultados - no caderno, com orientação escrita no protocolo;

- processamento dos dados obtidos:

- cada experimento foi tratado como único; cada grupo trabalhou com seus próprios dados;

- houve cobrança dos resultados previamente esperados;

- em uma das aulas, os resultados não foram os esperados e as possíveis razões do fracasso foram explicadas pela professora;

- o tempo disponível para a execução proposta no início da aula foi suficiente;

- comportamento dos participantes:

- alunos -

* reclamavam da dinâmica das aulas;

* impacientaram-se com o atraso no início de uma aula, quando os ratos demoraram a chegar do biotério;

* eram interessados, comprometidos, envolvidos e animados, em sua maioria;

* havia alunos que conversavam o tempo todo e não faziam nada, nem prestavam atenção e havia alguns que só faziam o necessário;

- professora -

* comprometida, com intencionalidade;

* esforçava-se para reforçar os conceitos que os alunos já deveriam saber antes de entrar no curso;

* preocupada em justificar as falhas no preparo de aulas;

- encerramento das aulas - as aulas encerraram-se após a obtenção dos dados pelos grupos.

Discussão dos dados

- a discussão era feita pelos alunos sozinhos, com seus próprios dados, no final das aulas ou após as mesmas e, posteriormente, pela professora, por ocasião do comentário sobre a correção dos relatórios.

Relatório das aulas práticas

- obrigatório;

- $\quad$ realizado fora das aulas práticas;

- prazo de 15 dias para entrega;

- feito por escrito, em grupo;

- dentro dos padrões normais desse tipo de redação científica, com ênfase no entendimento dos resultados obtidos;

- ensinava a:

- fazer apresentação e tratamento de dados;

- discutir resultados - analisar e relacionar dados;

- fazer redação científica;

- fazia parte da avaliação.

Atividades suscitadas pelas aulas práticas 
- após realizada a aula prática sobre cinética enzimática, foi pedida a confeç̧ão de protocolos a respeito dos efeitos da temperatura e do $\mathrm{pH}$ sobre a atividade enzimática;

- durante a realização do experimento sobre verificação da atividade da succinato desidrogenase, foi pedido o planejamento do controle do experimento;

Avaliação do aprendizado em aulas práticas

- a forma de avaliação das aulas práticas não foi pesquisada.

Ocorrências nåo previstas durante as aulas práticas

- não houve qualquer ocorrência a assinalar. 


\section{APÊNDICE 6}

\section{FACULDADE DE CIÊNCIAS FARMACÊUTICAS - CURSO DE FARMÁCIA E BIOQUÍMICA}

\section{A. Caracterização do contexto particular do Curso de Farmácia e Bioquímica}

$A_{1} \cdot \frac{\text { Instituição }}{\text { Dados gerais }}$

Endereços

e-mail - fcf@ usp.br site: www.fcp.usp.br

Av. Prof. Lineu Prestes, 580 - Cidade Universitária - Butantã - São Paulo - SP

CEP - 05508-900 telefone - 3091-3672

Prestação de serviço à comunidade (atividades de extensão)

- $\quad$ instituição possuía sob sua responsabilidade os seguintes serviços de atendimento à comunidade da USP e de fora dela:

- Biofar - pesquisa e serviços em áreas essenciais relacionadas ao desenvolvimento, produção e avaliação de medicamentos;

- Biotério - animais para pesquisa;

- Confar - laboratório modelo de prestação de serviços técnicos (físico-químico e biológico), controle de qualidade de medicamentos e cosméticos;

- Fitopar - plantas medicinais e fitoterápicos;

- Farmácia Universitária - estágios e atendimento à comunidade, principalmente da USP.

Publicações científicas

- a instituição possuía a "Revista de Farmácia e Bioquímica da USP" (ISSN - 0370-4726);

- a instituição mantinha estrutura para professores e alunos participarem de publicações de outras instituições.

$\mathrm{A}_{2}$. Curso analisado e disciplina com conteúdo de Bioquímica

Curso

- enfoque - ciência aplicada e tecnologia;

- habilitação - bacharelado;

- atividades profissionais para as quais habilitava - farmacêutico em farmácias, drogarias, farmácias de manipulação e hospitais; pesquisador nas áreas relacionadas à biomedicina, farmácia e bioquímica; técnico de nível universitário em indústrias farmacêuticas e das áreas de alimentação e cosmetologia, técnico de nível superior em laboratório de análises clínicas e toxicológicas;

- período de funcionamento do curso observado - diurno integral;

- duração / regime - 10 semestres / regime semestral;

- currículo - séries e disciplinas, objetivos do curso - ver Anexo 13;

- havia convênios da instituição com empresas ou outras instituições para treinamento profissional dos alunos.

Disciplina

- nome da disciplina - Bioquímica Experimental;

- carga horária - 8 aulas semanais / total de $120 \mathrm{~h}$;

- $\quad$ posição na grade curricular - disciplina lecionada no $4^{\circ}$ semestre do curso;

- objetivos e programa da disciplina - ver Anexo 14:

- porcentagem de assuntos da programação que foi desenvolvida em aulas práticas no laboratório $48,2 \%$;

- o curso era prático, não tendo programação de aulas teóricas propriamente ditas, mas apenas teoria sobre técnicas laboratoriais;

- divisão / proporção entre tipos de aulas:

* $\quad \mathrm{n}^{\circ}$ de aulas práticas no laboratório - $1 \mathrm{I}$;

* $\quad \mathrm{n}$ o de aulas teóricas -1 ;

* $\quad \mathrm{n}^{\mathrm{o}}$ de outras atividades diferentes de aulas teóricas e práticas - 31 -

- $\quad \mathrm{n}^{0}$ de períodos de discussão - 9;

- $\quad \mathrm{n}^{\mathrm{O}}$ de aulas de exercícios e aulas de revisão - 4;

- $\mathrm{n}^{\mathrm{O}}$ de seminários - 11;

- $\mathrm{n}^{0}$ de avaliações -3 ;

- $\quad \mathrm{n}^{\mathrm{O}}$ de correções de avaliações - 2;

- participação na Semana de Farmácia - 2;

* proporção aulas práticas : atividades diferentes de aulas teóricas e práticas $-1: 2,8$;

* proporção aulas práticas : aulas teóricas - 11:1;

- integração com outras disciplinas - cursos teóricos - Bioquímica: Estrutura de Biomoléculas e Metabolismo e Bioquímica e Biologia Molecular do Gene;

- relações de pré-requisitos com outras disciplinas - Química Orgânica I e II, Citologia, Histologia e Embriologia, Fisiologia e Biofisica, Microbiologia, Disciplinas referentes a Alimentos e Fermentação, Genética Humana; 
- titulação do professor e instituição onde a obteve - Doutorado - Departamento de Bioquímica - IQ - USP; pós-doutorado (Utrecht - Holanda); livre docência - Departamento de Bioquímica (IQ - USP);

- atividades de pesquisa do professor - fazia pesquisa pura na área de Bioquímica - Departamento de Bioquímica - IQ - USP;

- atividades docentes do professor na Disciplina de Bioquímica Experimental - dava aulas práticas e orientava os seminários da disciplina observada, por ocasião desta pesquisa;

- a instituição não fez o perfil dos alunos ingressantes na disciplina analisada.

Distribuição dos alunos no recinto do laboratório

- $\quad \mathrm{n}^{\mathrm{Q}}$ total de alunos -40 ;

- densidade populacional nas aulas práticas $-0,29$ alunos $/ \mathrm{m}^{2}$;

- $\quad \mathrm{n}^{\mathrm{O}}$ de alunos por bancada - 10 a 12 ;

- $\quad n^{\circ}$ de alunos por grupo - 5 a 6 .

$A_{3}$. Resultados dos questionários respondidos por alunos e professor

Alunos (respostas de 9 alunos)

- Expectativas em relação às aulas práticas:

- metade dos alunos esperava uma integração das aulas práticas com a parte teórica já aprendida;

- $\quad$ segundo opiniões individuais - um aluno:

* esperava que as aulas práticas fossem difíceis, complicadas;

* esperava que as aulas práticas fossem interessantes, bem dadas;

* esperava aprender métodos laboratoriais nas aulas práticas;

* pretendia complementar a teoria;

* esperava ter melhor entendimento do conteúdo de Bioquímica.

- Opiniões sobre as aulas práticas:

- As aulas práticas mais interessantes foram aquelas em que:

* havia semelhança com a teoria, na opinião de alguns alunos;

* segundo opiniões individuais:

- houve maior aproveitamento do conteúdo;

- aprendeu-se a usar equipamento modernos;

- Metade dos alunos indicou alguma aula prática que julgou mais interessante, mas não explicou qual.

- As aulas práticas mais proveitosas foram aquelas em que:

* já se tinha conhecimento da teoria, segundo metade dos alunos;

* houve maior aprofundamento do conteúdo, segundo alguns alunos;

* houve maior envolvimento com o experimento ou empenho em entender, de acordo com a opinião de dois alunos;

- Um aluno disse que a aula mais proveitosa foi aquela de seu interesse pessoal;

- Um aluno apontou a aula mais proveitosa, mas não deu explicações;

- Alguns alunos consideraram todas as aulas proveitosas.

- Os defeitos das aulas práticas apontados pelos alunos foram:

* as discussões poderiam ser de outra maneira, segundo alguns alunos;

* a falta de alguns assuntos, segundo dois alunos;

* falta de didática do professor, de acordo com alguns alunos;

* segundo opiniões individuais:

- o professor estende-se muito, no início;

- o grande número de alunos por bancada;

- a falta de embasamento teórico para alguns experimentos;

- experimentos que não deram certo;

- pouco tempo para assimilar o conteúdo.

- As limitações para o aluno ter bom desempenho em aulas práticas foram:

* a falta de conhecimento dos conteúdos ou dos procedimentos, segundo dois alunos;

* segundo opiniões individuais:

- a falta de entendimento do protocolo;

- medo de tirar dúvidas com o professor

* Não há limitações para os alunos terem bom desempenho em aulas práticas, de acordo com a metade dos alunos.

- As diferenças entre aulas práticas e teóricas apontadas foram:

* as aulas teóricas foram mais abertas a dúvidas, segundo alguns alunos;

* as aulas práticas e as teóricas diferenciam-se na metodologia de ensino, segundo alguns alunos;

* "as aulas práticas mostram, com os dados obtidos no laboratório, como se constrói a teoria", segundo alguns alunos;

* segundo opiniões individuais:

- a teoria foi mais bem dada;

- as aulas práticas exigiram raciocínio para a aplicação dos conhecimentos da teoria;

- em aulas práticas, entendeu-se o que foi visto nas aulas teóricas; 
- Comentários sobre os relatórios de aulas práticas:

- permitem um aprofundamento do conteúdo tcórico, segundo alguns alunos;

- pelo menos alguns relatórios deveriam ser obrigatórios, segundo alguns alunos;

- metade dos alunos comentaram sobre este questionário, considerando-o bom e não deram opinião sobre o relatório de aulas práticas;

- $\quad$ segundo opiniões individuais:

- as partes de resultados e discussão são mais importantes;

- o professor impede maior aproveitamento do relatório, porque intimida os alunos durante sua correção.

- Considerações sobre os relacionamentos pessoais:

- Entre alunos -

* a maioria dos alunos considerou bom seu relacionamento com colegas;

* alguns alunos consideraram o relacionamento com colegas muito bom ou ótimo;

* vários apontam que o relacionamento foi de colaboração.

- Entre professor e alunos -

* alguns alunos consideraram bom seu relacionamento com o professor e outros, que foi regular;

* alguns alunos consideraram o professor hostil e impaciente;

* segundo opiniões individuais:

- o relacionamento com o professor era ruim;

- o relacionamento com o professor poderia ser melhor;

- as atitudes do professor intimidam os alunos e limitam o estudo dos alunos;

- o relacionamento foi razoável, mas o professor foi rígido;

- o professor foi, às vezes, irascível;

- o professor foi prepotente;

- o professor faz raciocinar.

- Entre alunos e monitores -

* a maioria considerou bom o relacionamento com monitores;

* alguns alunos consideraram os monitores atenciosos e disseram que eles ajudaram;

* um aluno considerou o relacionamento com monitores ótimo e outro, muito bom.

- Atitude dos alunos frente ao questionário:

- os alunos foram receptivos e tiveram boa vontade em responder as perguntas, sem fazer nenhum comentário adicional em relação à tarefa solicitada;

Professor

- um aluno não devolveu o questionário respondido, nem em branco.

Pedro Soares de Araújo

- Cargo na Instituição - professor de aulas práticas (no ano em que foi feita esta pesquisa) e pesquisador.

- Curso de Graduação - Medicina - bacharelado (FM - USP).

- Pós-Graduação - Doutoramento em Bioquímica - Livre Docente (IQ - USP); pós-doutoramento - Utrecht Holanda.

- Atividades de pesquisa: pesquisa pura na área de Bioquímica - Departamento de Bioquímica (IQ - USP).

- Opiniões sobre aulas práticas no ensino de Bioquímica:

- Importância -

* as aulas práticas permitem a resolução direta e pessoal de problemas experimentais, consolidando o aprendizado teórico.

- Critérios de escolha do número de aulas práticas, de suas posições na programação e de seus assuntos -

* cobrir, em aulas práticas, no laboratório, tópicos abordados na teoria, que perfaçam, no máximo, 8 horas de trabalho cada um;

* usar seminários para abordar técnicas fora das condições do laboratório de ensino, ministrando-os nos $2 / 3$ finais do curso.

- Realização das expectativas nas aulas práticas ministradas: nenhuma, as expectativas foram frustradas, porque a ausência da técnica aumentou a confusão nas aulas de laboratório.

- As limitações das aulas práticas foram:

* ausência da técnica e preparo inadequado das aulas pela auxiliar técnica;

* não houve limitações de ordem pessoal, ética e/ou moral, impostas pela estrutura institucional e/ou legal, de formação dos alunos, de espaço e de tempo.

- Consecução dos objetivos:

- Quanto ao conteúdo:

* Objetivos alcançados -

- compreender conceitos;

* Objetivos não alcançados -

- aplicar teoria, lei, princípio;

- ensinar a construir conceitos.

- Quanto à metodologia de ensino:

* Objetivos alcançados - 
- ensinar como seguir protocolo;

- ensinar como fazer relatório escrito.

* Objetivos não alcançados-

- ensinar como processar dados;

- ensinar como comunicar resultados oralmente;

- desenvolver autonomia na execução de experimentos;

- ensinar como propor e testar hipóteses;

- ensinar como montar experimentos;

- ensinar como validar ensaios;

- ensinar como criticar dados;

- ensinar como pensar novos experimentos;

- ensinar como consultar literatura científica.

- Quanto ao treinamento de habilidades técnicas experimentais:

* Objetivos alcançados -

- treinar manuseio de material de laboratório e de reagentes;

- treinar manuseio de material biológico;

- treinar uso de equipamentos e aparelhos;

- treinar técnicas de pesquisa laboratorial.

- Quanto à interação entre os participantes:

* Objetivos não alcançados -

- motivar aluno;

- melhorar relações entre professor e alunos;

- encorajar entusiasmo pela Ciência.

OBS - O professor respondeu o questionário com boa vontade, respondeu a todas as solicitações da pesquisa e não fez comentários adicionais em relação a seu conteúdo.

\section{B. Análise das Aulas Práticas}

$\mathrm{B}_{1}$. Dados gerais

- total de aulas práticas na programação-11;

- $\quad \mathrm{n}^{\mathrm{O}}$ de aulas práticas observadas -4 ;

- datas - 28/08/2000; 18/09/2000, 13/11/2000;20/11/2000;

- período - diurno integral - período observado - manhã;

- $\quad$ professor - Pedro Soares de Araújo;

- monitores - Gláucia Noeli Maroso Hajj e Edson José Martha - auxiliaram nas 4 aulas práticas observadas, na parte técnica.

- auxiliar técnica - atuou no preparo das aulas práticas.

$\mathrm{B}_{2}$. Aulas práticas observadas

Características gerais

- $\quad$ assuntos (unidades da programação) - ver Anexo 14:

Separação de aminoácidos por cromatografia em papel, Separação de um aminoácido, um derivado de aminoácido e um peptídeo por cromatografia em camada delgada, Espectro da hemoglobina (Aminoácidos e proteínas); Fracionamento celular, Verificação da atividade da succinato desidrogenase, Inibição da succinato desidrogenase por malonato (Cadeia respiratória); Transaminação (Metabolismo dos aminoácidos);

- ordem dentro da programação - $4^{\underline{a}}, 10^{\underline{a}}, 24^{\underline{a}}$ e $27^{\underline{a}}$ aulas (ver Anexo 14);

- as aulas práticas não tiveram ligação com qualquer atividade desenvolvida pela instituição que não seja as da própria disciplina;

- as aulas práticas, em sua maioria, não foram acompanhadas de artigo científico correlato; uma aula foi acompanhada de caso clínico para análise e acrescida de exercícios sem respostas, os quais podiam ser obtidos via computador;

- as aulas práticas relacionam-se com aulas teóricas correspondentes, ministradas em outro curso, apenas teórico;

- os assuntos de 11 seminários e 2 aulas práticas dos 23 assuntos da programação não se relacionavam diretamente com a programação do curso teórico;

- dinâmica da aula - período de aula observado - manhã:

- duração - 1:25 h a 3:30 h;

- divisão de tempo da aula -

* discussão da aula anterior com o professor / planejamento / explicações iniciais - 7,14\% a 28,57\%;

* execução - $28,57 \%$ a $71,42 \%$;

* análise de resultados / discussão entre alunos - 0\% a 64,28\%;

- condições de orientação dos alunos:

- $\quad \mathrm{n}^{\mathrm{O}}$ de professores -1 ;

- $\quad \mathrm{n}^{\mathrm{o}}$ de auxiliares que participaram da orientação - 0 ; 
- $\quad \mathrm{n}^{0}$ de alunos -40 (Turma 1 );

- proporção orientador : aluno - 1:40;

- condições dos alunos quanto a conhecimentos necessários para a compreensão da aula - os alunos já tinham conhecimento teórico sobre todos os assuntos relativos ao curso;

- possibilidade de uso do laboratório fora do horário de aula - não;

- havia possibilidade de orientação do professor fora do horário de aula, desde que os alunos o procurassem em sua sala;

- possibilidade de os alunos trabalharem em grupo fora da aula:

- local - não há um local específico para os alunos se reunirem; muitas vezes viam-se alunos fazendo relatórios sentados nas escadas do prédio, antes do início das aulas;

- $\quad$ horário - não especificado.

Materiais

- foram usados equipamentos e vidrarias corriqueiros em laboratório de Química;

- os aparelhos e equipamentos tinham geralmente locais fixos no laboratório;

- as vidrarias e os reagentes foram colocados sobre as bancadas antes da aula pelos monitores e professor e pela auxiliar técnica;

- o material biológico foi distribuído no momento do experimento, pelo professor e pelos monitores;

- custo do material de consumo - não estimado.

Preparo e teste

- o preparo de aulas práticas da disciplina era feito pela auxiliar técnica e monitores, antes do período de aula, com o planejamento e supervisão do professor;

- os experimentos foram previamente testados pelo professor e pelos monitores.

Normas de segurança e de manipulação de material biológico

- foram dadas normas de segurança por escrito, com compromisso escrito e assinado;

- foram dadas instruções orais específicas sobre normas de segurança, durante as aulas observadas;

- não houve treinamento específico sobre segurança no laboratório ou sobre manipulação de tecidos, órgãos ou animais.

Conteúdo da aula

- relações:

- com o resto da programação -

* as aulas práticas acompanhavam alguns conteúdos das aulas do curso teórico;

as aulas práticas tinham todos os assuntos relacionados com Bioquímica: Estrutura de Biomoléculas e Metabolismo, Bioquímica e Biologia Molecular do Gene, alguns assuntos relacionavam-se com Citologia e com Fisiologia;

- as aulas práticas não tinham relações com pesquisa da instituição ou de fora dela ou com projeto de extensão da instituição e com publicações científicas, dentro ou fora da instituição;

- as aulas práticas relacionavam-se com a vida profissional e cotidiana do aluno fora da universidade;

- as aulas práticas não se relacionavam com a vida universitária do aluno;

- $\quad$ as aulas práticas não se relacionavam com a vida dos alunos como cidadãos;

- de acordo com a opinião do professor, algumas aulas práticas poderiam ser substituídas por simulação de computador ou por instrução programada;

- as aulas práticas não partiram de un problema a ser resolvido pelos resultados obtidos; havia perguntas, no protocolo, que serviam como orientação para a discussão dos resultados e que eram os itens do relatório.

Roteiro / Protocolo

Ver Anexo 15:

- os protocolos eram produzidos pelo professor;

- os protocolos eram impressos, deixados na fotocopiadora para serem copiados e disponíveis via internet;

- no conteúdo dos protocolos constavam os objetivos das aulas, a saber:

* Separação de aminoácidos por cromatografia em papel -

- demonstrar a separação e identificação de aminoácidos por meio de cromatografia em papel;

- introduzir o conceito de $\mathrm{R}_{\mathrm{f}}$;

* Cromatografia em camada delgada de aminoácidos, derivado de aminoácído e peptídeo / reveladores variados-

- realizar uma cromatografia de camada delgada de dois aminoácidos, um derivado de aminoácido e um peptídeo;

- determinar os valores de $\mathrm{R}_{\mathrm{f}}$ de cada um deles;

- prever o comportamento cromatográfico dos compostos analisados em função de suas polaridades e daquelas dos sistema eluentes empregados;

* Espectros da hemoglobina -

- determinar os espectros da hemoglobina na região visível;

* Fracionamento celular; verificação da atividade da succinato desidrogenase; inibição da succinato desidrogenase por malonato -

- realizar o fracionamento celular a partir do figado de um rato;

- identificar a fração que contém desidrogenase; 
- verificar a inibição competitiva da desidrogenase por malonato;

* Transaminação -

- verificar a reação de transaminação em homogenato de figado;

- identificar os produtos de reação por cromatografia em papel;

- não havia listas de materiais e de reagentes;

- havia todas as diretrizes para a execução dos experimentos;

- constavam normas de segurança específicas para cada experimento;

- não havia regras de higiene;

- não havia orientação sobre o quê e como observar;

- havia instruções sobre como registrar os dados;

- havia instruções e dados para a discussão no relatório;

- havia questões e/ou problemas a serem resolvidos no relatório, usando os dados obtidos;

- não havia instruções de como redigir o relatório;

- foi fornecida uma extensa bibliografia específica sobre a técnica e/ou sobre o assunto de uma das aulas, em um protocolo e uma bibliografía sobre os assuntos teóricos, por escrito, no início do curso, junto com os protocolos e orientações gerais;

- durante as aulas, o professor recomendava a leitura de livros didáticos sobre os assuntos abordados.

Etapas da aula / Estratégia de ensino

- utilização do protocolo (roteiro de aula):

- os protocolos não foram lidos em conjunto, em voz alta ou silenciosamente, no início das aulas;

- os alunos seguiam os protocolos, à medida que executavam os trabalhos;

- o conjunto de dados a ser obtido foi definido previamente;

- tipo de execução:

- os experimentos foram executados pelos alunos, sob a supervisão do professor e dos monitores;

- a manipulação de aparelhos foi feita pelos alunos, com a supervisão dos monitores;

- $\quad$ as tarefas eram distribuídas eqüitativamente, entre os membros dos grupos;

- $\quad$ recisão / sensibilidade / higiene:

- houve preocupação com a precisão na obtenção dos dados;

- o professor chamou a atenção para os erros técnicos mais freqüentes, para a sensibilidade dos métodos e técnicas dos experimentos;

- houve preocupação com a forma correta de descartar os materiais e como evitar desperdícios;

- habilidades:

- técnicas -

* exigidas pelas aulas - manipulação de vidraria simples de laboratório de Química,

- os alunos, com raras exceções tinham as habilidades exigidas;

* treinadas durante as aulas - uso de pêra e pipetador automático, centrífuga, banho-maria e homogeneizador, bomba de vácuo, espectrofotômetro, manipulação de material biológico, técnicas de pesquisa laboratorial;

- mentais -

* exigidas pelas aulas - compreender instruções orais e escritas, observar e anotar,

- os alunos dominavam as habilidades exigidas;

* treinadas durante as aulas - buscar dados na literatura científica, analisar e sintetizar e, em poucas situações, ter capacidade de propor hipóteses;

- forma de orientação dos alunos pela equipe:

- as aulas práticas iniciaram-se com o professor discutindo dados de aulas anteriores;

- observações sobre as explicações iniciais - o professor levava os alunos e entenderem a execução dos experimentos que constavam do protocolo, cobrando o embasamento teórico das técnicas já aprendidas e relacionando os experimentos com o conteúdo de outras disciplinas. Explicava os porquês das técnicas e solicitava sempre a participação dos alunos nessa fase;

- o professor e os monitores orientavam os alunos durante toda a aula prática;

- forma de registro dos resultados - no caderno, com orientação escrita no protocolo;

- processamento dos dados obtidos:

- $\quad$ cada experimento foi tratado como único; cada grupo trabalhou com seus próprios dados;

- houve cobrança dos resultados previamente esperados;

- em uma das aulas, os resultados não foram os esperados e as possíveis razões do fracasso foram explicadas pelo professor;

- o tempo disponível para a execução proposta no início da aula foi suficiente;

- comportamento dos participantes:

- alunos -

* metade dos alunos foi, às vezes, interessada e comprometida;

* os alunos ficavam temerosos, contidos, intimidados, na maior parte do tempo; pareciam apenas executar as ordens, o mínimo necessário;

- $\quad$ professor -

* comprometido, com intencionalidade todo o tempo; 
* personalíssimo, às vezes agressivo;

- encerramento das aulas - a parte experimental das aulas encerrava-se ao serem obtidos os resultados em cada grupo;

- não houve troca ou compartilhamento de resultados entre os grupos.

Discussão dos dados

- a discussão era feita pelos alunos sozinhos, com seus próprios dados, no final das aulas ou após as mesmas e, posteriormente, pelo professor, na aula subseqüente.

Relatório das aulas práticas

- não obrigatório, voluntário;

- realizado fora das aulas práticas;

- com prazo máximo de 15 dias para entrega;

- feito por escrito, em grupo;

- com forma sucinta, discutindo os resultados obtidos, feito de acordo com explicações orais dadas no início do curso;

- ensinava a:

- fazer apresentação e tratamento de dados;

- $\quad$ discutir resultados - analisar e relacionar dados;

- poderia fazer parte da avaliação, se o aluno optasse por entregá-lo: o conjunto de 5 relatórios poderia valer até 0,5 ponto na média final, caso o aluno não atingisse nota final 5,0. (Esse critério foi explicado pelo professor, oralmente, ele é ligeiramente diferente daquele que consta das instruções dadas por escrito aos alunos, no início do curso - ver Anexo 14);

- todos os relatórios entregues eram corrigidos e comentados pelo professor.

Atividades suscitadas pelas aulas práticas

- após realizadas, as aulas práticas não suscitaram nenhum trabalho ou atividade subseqüente.

Avaliação do aprendizado em aulas práticas

- a forma de avaliação das aulas práticas não foi pesquisada;

Ocorrências não previstas durante as aulas práticas

- não houve qualquer ocorrência a assinalar. 


\title{
APÊNDICE 7
}

\section{INSTITUTO DE BIOCIÊNCIAS - CURSO DE CIÊNCIAS BIOLÓGICAS}

\section{A. Caracterização do contexto particular do Curso de Ciências Biológicas}

\author{
A.1. Instituição \\ Dados gerais \\ Endereços \\ e-mail-ccexibio@edu.usp.br_site: www.ib.usp.br
}

R. do Matão, Travessa 14, 321 - Cidade Universitária - Butantã - São Paulo - SP

CEP-05508-900 telefone-3091-7538

Prestação de serviço à comunidade (atividades de extensão)

- Departamento de Biologia - aconselhamento genético; atendimento a parentes e familiares de portadores de doenças genéticas e distrofia muscular progressiva;

- Departamento de Botânica - lâminas para fins didáticos e identificação de plantas;

- Departamento de Ecologia - informações sobre abelhas, monitoramento de comunidades marinhas, recuperação de áreas degradadas, imagens obtidas por satélites;

- Departamento de Fisiologia - informações sobre toxinas presentes em animais e em algas marinhas, marés vermelhas, amostras de plancton;

- Departamento de Zoologia - criação de minhocas, identificação de invertebrados marinhos, preparo de material didático;

- Comissão de Visitas - programa de visitas escolares.

Publicações científicas

- a instituição não possuía revista ou periódico próprios;

- a instituição mantinha estrutura para professores e alunos participarem de publicações de outras instituições.

$\mathrm{A}_{2}$. Curso analisado e disciplina com conteúdo de Bioquímica

Curso

- enfoque - ciência pura, aplicada e docência;

- habilitações - bacharelado e licenciatura;

- atividades profissionais para as quais habilitava - pesquisa pura e aplicada em várias áreas de Biologia (Genética, Biologia Molecular, Microbiologia, Imunologia, Parasitologia, Botânica, Zoologia, Ecologia, Conservação, Oceanografia e Biologia marinha); ensinos fundamental e médio (licenciados); avaliação e planejamento ambientais; assessoria técnico-científica a entidades ligadas ao meio ambiente;

- $\quad$ período de funcionamento - diurno integral; período observado - manhã e uma tarde;

- duração / regime -8 semestres / regime semestral;

- currículo - séries e disciplinas, objetivos do curso - ver Anexo 16;

- não havia convênios da instituição com empresas ou outras instituições para treinamento profissional dos alunos. Alunos de licenciatura faziam estágio em escolas de ensino fundamental e médio.

Disciplina

- nome da disciplina-Bioquímica;

- carga horária - 12 aulas semanais / total de $120 \mathrm{~h}$;

- posição na grade curricular - disciplina lecionada no $2^{\circ}$ semestre do curso;

- objetivos e programa da disciplina - ver Anexo 17:

- $\quad$ porcentagem de assuntos da programação que foi desenvolvida em aulas práticas $-15,78 \%$;

- não havia assuntos fora da programação de aulas teóricas;

- divisão / proporção entre tipos de aulas:

* $\quad \mathrm{n}^{\mathrm{O}}$ de aulas práticas -3 ;

* $\quad \mathrm{n}^{\mathrm{o}}$ de aulas teóricas -30 ;

* $\quad \mathrm{n}^{\mathrm{Q}}$ de outras atividades diferentes de aulas teóricas e práticas - 33 -

- $\quad \mathrm{n}^{\mathrm{O}}$ de períodos de discussão -6 ;

- $\mathrm{n}^{\mathrm{O}}$ de aulas de exercícios - 19;

- $\mathrm{n}^{\mathrm{O}}$ de seminários - 1

- $\mathrm{n}^{\mathrm{O}}$ de avaliações -4

- semana temática - 3;

* proporção aulas práticas : atividades diferentes de aulas teóricas e práticas - 1:11;

* proporção aulas práticas : aulas teóricas - 1: 10;

- integração com outras disciplinas - Biologia Molecular;

- relações de pré-requisitos com outras disciplinas - Biologia Celular, Fisiologia(s), Genética, Microbiologia e Imunologia;

- titulação dos professores e instituições onde as obtiveram:

- Professor - Mestrado - Departamento de Bioquímica - IQ - USP; doutorado Marquetk University - USA;

- Professora-Doutorado - FCM - UNICAMP; 
- $\quad$ atividades de pesquisa dos professores - faziam pesquisa pura na área de Bioquímica - Departamento de Bioquímica - IQ - USP;

- atividades docentes dos professores na Disciplina de Bioquímica - davam aulas práticas e o professor discutia as práticas;

- a instituição não fez o perfil dos alunos ingressantes na disciplina analisada.

Distribuição dos alunos no recinto do laboratório

- $\quad n^{Q}$ total de alunos -60 ;

- densidade populacional nas aulas práticas $-0,4$ alunos $/ \mathrm{m}^{2}$;

- $\quad \mathrm{n}^{\mathrm{O}}$ de alunos por bancada - 10 a 12 ;

- $\quad \mathrm{n}^{\mathrm{O}} \mathrm{de}$ alunos por grupo -4 .

$\mathrm{A}_{3}$. Resultados dos questionários respondidos por alunos e professores

Alunos (respostas de 10 alunos)

- Expectativas em relação às aulas práticas:

- $\quad$ segundo opiniões individuais - um aluno:

* esperava entender melhor os assuntos ensinados na teoria;

* acreditava que as aulas práticas seriam uma demonstração da vida profissional futura;

* pretendia aplicar a teoria e conhecer o dia-a-dia de um laboratório;

* esperava que as aulas práticas fossem mais freqüentes;

* esperava que houvesse mais materiais nas aulas práticas;

* acreditava que aprenderia técnicas básicas de pesquisa laboratorial;

* esperava que as aulas fossem mais interessantes;

* esperava que houvesse um manuseio mais direto dos instrumentos de laboratório;

- Dois alunos não tiveram expectativas em relação às aulas práticas, sendo que um desconhecia que haveria aulas práticas na disciplina de Bioquímica.

- Opiniões sobre as aulas práticas:

- As aulas práticas mais interessantes foram aquelas em que:

* aprenderam técnica importante ou entenderam os processos, segundo alguns alunos;

* fizeram sozinhos, havia mais atividades, para alguns alunos;

* a teorias era mostrada na prática, para alguns alunos;

* o assunto era de seu interesse pessoal, de acordo com poucos alunos;

* segundo opiniões individuais:

- havia explicações mais claras;

- os alunos trabalhavam "sozinhos", refletindo sobre os resultados;

- Um aluno apontou a aula mais interessante, mas não deu explicações.

- As aulas práticas mais proveitosas foram aquelas em que:

* conseguiu-se bastante partícipação, segundo alguns alunos;

* houve mais manuseio de material de laboratório, segundo alguns alunos;

* segundo opiniões individuais:

- foi necessário usar raciocínio;

- pôde-se fazer cálculos com dados reais;

- o assunto interessava particularmente;

- o assunto era de grande importância para a Biologia;

- houve explicações mais claras;

- "conheci métodos e processos que não conhecia";

- Dois alunos afirmaram que todas as aulas práticas foram proveitosas;

- Um aluno indicou o nome da aula mais proveitosa, mas não explicou por quê.

- Os defeitos das aulas práticas apontados pelos alunos foram:

* grupos muito grandes e pouco trabalho para muita gente, segundo metade dos alunos;

* $\quad$ segundo opiniões individuais:

- faltam monitores;

- muito aluno para pouco espaço;

- houve confusão durante a aula;

- havia muita bagunça;

- "falta de entendimento do que deve ser feito, o protocolo é uma receita de bolo, deveria ter uma aula teórica antes sobre o assunto";

- os experimentos foram longos;

- as aulas foram longas;

- as aulas práticas não abrangeram todos os conceitos vistos em aulas teóricas.

- As limitações para o aluno ter bom desempenho em aulas práticas foram:

* os grupos eram grandes, de acordo com boa parte dos alunos;

* havia dificuldade de acompanhar as explicações e fazer experimentos simultaneamente, para alguns alunos;

* segundo opiniões individuais:

- falta de material; 
- receio de que haja substâncias tóxicas;

- não dava para manusear tudo pessoaimente;

- falta de pré-requisitos de Química e Biologia para entender Bioquímica e aproveitar melhor as aulas práticas;

* Um aluno não respondeu a questão.

- As diferenças entre aulas práticas e teóricas apontadas foram:

* as aulas práticas mostraram o que foi aprendido na teoria, permitiram "verificar que a teoria é uma realidade", segundo a maior parte dos alunos;

* as aulas práticas mostraram o dia-a-dia da pesquisa, como a teoria é obtida, segundo alguns alunos;

* segundo opiniões individuais:

- a prática aumentava o interesse e a fixação do conteúdo, porque trabalhava com dados concretos;

- as aulas práticas foram mais estimulantes;

- as aulas práticas complementaram a teoria;

- as aulas práticas permitiam interagir com os materiais de laboratório;

- as aulas teóricas eram mais abstratas;

- as aulas teóricas foram mais abrangentes;

- "na teoria, decoramos, na prática, aprendemos";

- Comentários sobre os relatórios de aulas práticas:

- metade dos alunos entendeu que deveria opinar sobre este questionário e o considerou bom para avaliar a aula prática;

- um aluno comentou que o relatório é uma atividade importante para "refletir objetivamente sobre as atividades, estabelecer relações entre as atividades de laboratório e os conhecimentos teóricos e sintetizar conhecimentos em geral".

- Considerações sobre os relacionamentos pessoais:

- Entre alunos -

* a maioria dos alunos considerou bom seu relacionamento com colegas;

* segundo opiniões individuais:

- ótimo;

- ruim, assinalando rivalidades;

- de cooperação;

- de amizade;

- com pouco relacionamento, isolado

- Entre professores e alunos -

* boa parte dos alunos considerou bom seu relacionamento com os professores;

* alguns alunos assinalaram que era dificil falar com os professores, porque estavam ocupados, enquanto outros declararam que eles esclareceram as dúvidas;

* $\quad$ segundo opiniões individuais:

- o relacionamento era muito bom;

- o relacionamento era ótimo;

- os professores foram atenciosos.

- Entre alunos e monitoras -

* a maioria considerou bom o relacionamento com as monitoras e dois alunos consideraram esse relacionamento ótimo;

* alguns alunos consideraram as monitoras muito ocupadas;

* segundo opiniões individuais:

- as monitoras foram acessíveis;

- as monitoras estavam sempre presentes;

- houve pouco relacionamento com as monitoras;

- as monitoras eram atenciosas;

* Um aluno não respondeu à questâo.

- Atitude dos alunos frente ao questionário:

- os alunos foram receptivos e tiveram boa vontade em responder as perguntas, sem fazer nenhum comentário Professores adicional em relação à tarefa solicitada.

Maurício da Silva Baptista

- Cargo na Instituição - professor de aulas teóricas e práticas (no ano em que foi feita esta pesquisa) e pesquisador.

- Curso de Graduação - Farmácia e Bioquímica - bacharelado (FCF - USP).

- Pós-Graduação - Mestrado em Bioquímica (IQ - USP); Doutoramento - Marquetke University - USA.

- Atividades de pesquisa - pesquisa pura em Bioquímica - Departamento de Bioquímica (IQ - USP).

Alícia Kowaltowski

- Cargo na Instituição - professora de aulas práticas (no ano em que foi feita esta pesquisa) e pesquisadora.

- Curso de Graduação - Medicina - bacharelado (FCM - UNICAMP). 
- Pós-Graduação - Doutoramento em Ciências Biomédicas (FCM - UNICAMP).

- Atividades de pesquisa - pesquisa pura em Bioquímica - Departamento de Bioquímica (IQ - USP).

- Opiniões sobre aulas práticas no ensino de Bioquímica:

- Importância -

* segundo o professor:

- construção e compreensão de conceitos;

* segundo a professora:

- fixação de conceitos;

- introdução a técnicas de laboratório;

- individualização da atenção ao aluno.

- Critérios de escolha do número de aulas práticas, de suas posições na programação e de seus assuntos possibilidade de realização e relevância, adequação à programação.

- Realização das expectativas nas aulas práticas ministradas:

* segundo o professor:

- as expectativas foram realizadas durante o curso (não citou quais);

* segundo a professora:

- o curso teórico superou as expectativas pela qualidade dos alunos e organização, mas o curso prático ficou limitado, devido à mão de obra do laboratório didático.

- As limitações das aulas práticas foram:

* falta da técnica de laboratório para o preparo das aulas;

* pouco material;

* segundo o professor:

- pouco tempo na programação para desenvolver aulas práticas;

* segundo a professora:

- grande número de alunos;

- falta de ar condicionado.

- Os professores não apontaram limitações de ordens pessoal, ética e/ou moral, impostas pela estrutura institucional e/ou legal, de formação dos alunos e de espaço.

- Consecução dos objetivos:

- Quanto ao conteúdo:

* Objetivos alcançados -

- ilustrar fatos;

- ilustrar fenômenos;

- ensinar a compreender conceitos;

- segundo a professora:

- mostrar a importância da Bioquímica em campos específicos do conhecimento.

* Objetivos não alcançados -

- segundo o professor:

- mostrar a importância da Bioquímica em campos específicos do conhecimento.

* Objetivos que as aulas práticas deveriam ter, mas que não foram colocados no curso -

- segundo o professor:

- divulgar descobertas recentes da Ciência.

- Quanto à metodologia de ensino:

* Objetivos alcançados -

- segundo a professora:

- ensinar como seguir protocolo;

- ensinar como processar dados;

- desenvolver autonomia na execução de experimentos; ensinar como criticar dados.

* Objetivos não alcançados -

- segundo o professor:

- ensinar como seguir protocolo;

- ensinar como observar e anotar;

- ensinar como processar dados;

- ensinar como fazer relatório escrito;

- desenvolver autonomia na execução de experimentos;

- ensinar como propor hipótese;

- ensinar como testar hipótese;

- ensinar como criticar dados;

- ensinar a pensar novos experimentos.

* Objetivos que as aulas práticas deveriam ter, mas que não foram colocados no curso -

- segundo o professor:

- ensinar como comunicar resultados oralmente

- ensinar como validar ensaios;

- ensinar como escrever protocolo; 
- ensinar como consultar literatura;

- segundo a professora:

- ensinar como observar e anotar;

- ensinar como fazer relatório escrito;

- ensinar como propor hipótese;

- ensinar como testar hipótese.

- Objetivos que as aulas práticas não deveriam ter, entre aqueles colocados no questionário:

* segundo a professora:

- ensinar como comunicar resultados oralmente;

- ensinar como montar experimentos;

- ensinar como validar ensaios;

- ensinar como escrever protocolos;

- ensinar como pensar novos experimentos;

- ensinar como consultar literatura.

- Quanto ao treinamento de habilidades técnicas experimentais:

* Objetivos alcançados -

- segundo a professora:

- treinar manuseio de material de laboratório e de reagentes;

- treinar uso de equipamentos e aparelhos;

- treinar técnicas de pesquisa laboratorial.

- Objetivos que as aulas práticas não deveriam ter, entre aqueles colocados no questionário:

* segundo a professora:

- treinar manipulação de material biológico;

* segundo o professor:

- treinar manuseio de material de laboratório e de reagentes;

- treinar uso de equipamentos e aparelhos;

- treinar técnicas de pesquisa laboratorial.

- Quanto à interação entre os participantes:

* Objetivos alcançados -

- segundo a professora:

- motivar aluno;

- melhorar relações entre professor e alunos;

- encorajar entusiasmo pela Ciência.

* Objetivos não alcançados -

- segundo o professor:

- motivar aluno;

- melhorar relações entre professor e alunos;

- melhorar relações entre alunos;

- encorajar entusiasmo pela Ciência.

* Objetivos que as aulas práticas deveriam ter, mas que não foram colocados no curso -

- segundo a professora:

- melhorar relações entre alunos.

OBS - Os professores pediram um tempo para responder o questionário e o fizeram de boa vontade. A professora mostrou-se interessada em saber o resultado da pesquisa, para ajudar em sua auto-avaliação. Não houve muita concordância nas opiniões dos dois professores, embora se imagine que tenham feito o planejąmento do curso juntos.

\section{B. Análise das Aulas Práticas}

$\mathrm{B}_{1}$. Dados gerais

- $\quad$ total de aulas práticas na programação - 3 ;

- $\quad \mathrm{n}^{\mathrm{O}}$ de aulas práticas observadas -3 ;

- datas - 22/08/2000;03/10/2000; 17/10/2000;

- período - integral; período observado - manhã;

- $\quad$ professores - Maurício da Silva Baptista e Alícia Kowaltowski;

- monitoras - Adriana Rios Lopes e Renata Bolognesi - auxiliaram nas 3 aulas práticas observadas, na parte técnica;

- auxiliar técnica - atuou no preparo das aulas práticas.

$\mathrm{B}_{2}$. Aulas práticas observadas

Características gerais

- $\quad$ assuntos (unidades da programação) - ver Anexo 17: 
Titulação de aminoácidos (pH, pK e tampão); Determinação da atividade específica (Enzimas); Eletroforese em gcl de poliacrilamida (Aminoácidos e proteínas);

- ordem dentro da programação - $2^{\mathrm{a}}, 20^{\mathrm{a}}$ e $26^{\mathrm{a}}$ aulas (ver Anexo 17);

- as aulas práticas não tiveram ligação com qualquer atividade desenvolvida pela instituição que não seja as da própria disciplina;

- as aulas práticas, em sua maioria, não foram acompanhadas de artigo científico correlato;

- as aulas práticas foram ministradas após as aulas teóricas correspondentes;

- dinâmica da aula - período de aula observado - manhã:

- duração - 3:00 h a 4:00 h;

- divisão de tempo da aula -

* planejamento / explicações iniciais - 10,81\% a 17,39\%;

* execução - 40,54\% a $62,5 \%$;

* análise de resultados / discussão - 20,83\% a 48,64\%;

- condições de orientação dos alunos:

- $\quad \mathrm{n}^{2}$ de professores -2 ;

- $\quad n^{2}$ de auxiliares que participaram da orientação - 0;

- $n^{2}$ de alunos - 60;

- $\quad$ proporção orientador : aluno - 1:30;

- condições dos alunos quanto a conhecimentos necessários para a compreensão da aula - os alunos não dominavam todos os assuntos relativos às aulas teóricas;

- possibilidade de uso do laboratório fora do horário de aula - não;

- havia possibilidade de orientação dos professores fora do horário de aula, desde que os alunos os procurassem em suas salas;

- possibilidade de os alunos trabalharem em grupo fora da aula:

- $\quad$ local - não há um local específico para os alunos se reunirem; muitas vezes viam-se alunos fazendo relatórios sentados nas escadas do prédio, antes do início das aulas;

- horário - não especificado.

Materiais

- foram usados equipamentos e vidrarias corriqueiros em laboratório de Química;

- os aparelhos e equipamentos tinham geralmente locais fixos no laboratório;

- as vidrarias e os reagentes foram colocados sobre as bancadas antes da aula, pelos professores, pelas monitoras e pela auxiliar técnica;

- custo do material de consumo - não estimado.

Preparo e teste

- o preparo de aulas práticas da disciplina era feito pela auxiliar técnica e monitoras, antes do período de aula, com o planejamento e supervisão dos professores;

- os experimentos foram previamente testados pelos professores e pelas monitoras.

Normas de segurança e de manipulação de material biologico

- foram dadas normas de segurança por escrito, com compromisso escrito e assinado;

- não foram dadas instruções orais específicas sobre normas de segurança, durante as aulas observadas;

- não houve treinamento específico sobre segurança no laboratório ou sobre manipulação de tecidos, órgãos ou animais;

Conteúdo da aula

- relações:

- com o resto da programação -

* as aulas práticas acompanhavam o conteúdo das aulas teóricas e houve desenvolvimento de um assunto técnico;

* as aulas práticas foram dadas após as aulas teóricas correspondentes:

- as aulas práticas não tinham os assuntos relacionados diretamente com outras disciplinas do currículo;

- $\quad$ as aulas práticas não tinham relações com pesquisa da instituição ou de fora dela ou com projeto de extensão da instituição e com publicações científicas, dentro ou fora da instituição;

- as aulas práticas não se relacionavam com a vida profissional e cotidiana do aluno, nem com sua vida universitária, nem com sua vida como cidadão;

- as aulas práticas não partiram de um problema a ser resolvido pelos resultados obtidos; não havia perguntas, no protocolo, que serviam como orientação para a discussão dos resultados ou que eram os itens do relatório; havia problemas a serem resolvidos a partir dos dados obtidos.

\section{Roteiro / Protocolo}

Ver Anexo 18:

- os protocolos foram produzidos pelos professores;

- os protocolos eram impressos, comprados com antecedência pelos alunos e estavam disponíveis na fotocopiadora da faculdade;

- no conteúdo dos protocolos - em uma aula não constavam os objetivos, em duas outras, constavam, a saber:

* Titulação de aminoácidos . 
- identificar um aminoácido desconhecido por meio da comparação de valores de pKa obtidos numa curva de titulação, com os valores de pKa de uma tabela de pKs;

* Eletroforese em gel de poliacrilamida -

- determinar a taxa de migração (Mr) e estimar a massa molecular de diferentes preparações de proteína;

- não constavam listas de materiais e de reagentes;

- havia todas as diretrizes para a execução dos experimentos;

- não foram fornecidas normas de segurança específicas para cada experimento, por escrito;

- não havia regras de higiene;

- não havia orientação do quê e como observar;

- havia instruções sobre como registrar os dados;

- não havia instruções para a discussão dos dados;

- havia problemas a serem resolvidos a partir dos dados obtidos;

- não foi fornecida bibliografia específica sobre a técnica e/ou sobre o assunto das aulas, apenas bibliografia geral de Bioquímica.

Etapas da aula / Estratégia de ensino

- utilização do protocolo (roteiro de aula):

- $\quad$ os protocolos foram lidos silenciosamente pelos alunos, no início das aulas;

- os alunos acompanham o protocolo, à medida que executavam os trabalhos;

- o conjunto de dados a ser obtido foi definido previamente;

- tipo de execução:

- os experimentos foram executados pelos alunos, sob a orientação dos professores e das monitoras;

- a manipulação de aparelhos foi feita pelos alunos, com o auxílio das monitoras e dos professores;

- as tarefas não eram distribuídas eqüitativamente, entre os membros dos grupos; havia alunos que faziam os experimentos praticamente sozinhos e os outros olhavam;

- $\quad$ precisão / sensibilidade / higiene:

- $\quad$ houve pouca preocupação com a precisão na obtenção dos dados;

- $\quad$ não houve preocupação com as sensibilidades dos métodos e técnicas;

- $\quad$ não houve preocupação com higiene, nem com o problema de descarte de materiais;

- habilidades:

- técnicas -

* exigidas pelas aulas - manipulação de vidraria e equipamentos simples de laboratório de Química,

- poucos tinham as habilidades exigidas e os demais foram treinados durante as aulas;

* treinadas durante as aulas - uso de pêra e pipetador automático, espectrofotômetro, agitador magnético, banho-maria, unidade de eletroforese;

- mentais -

* exigidas pelas aulas - compreender instruções orais e escritas,

- os alunos dominavam as habilidades exigidas;

* treinadas durante as aulas - observar e anotar, analisar e sintetizar;

- forma de orientação dos alunos pela equipe:

- as orientações eram dadas no início das aulas, fora do laboratório, pelo professor, que explicava as técnicas a serem desenvolvidas, antecipando alguns resultados e conclusões que deveriam ser obtidos.

Nesses momentos, o professor fornecia dados teóricos, não havendo quase participação dos alunos, apenas para esclarecer dúvidas;

- os professores e as monitoras orientavam de perto os trabalhos dos alunos durante todas as aulas práticas, mas permitiam que eles executassem as tarefas sozinhos;

- $\quad$ os rnonitores ficaram mais responsáveis pela execução em si;

- forma de registro dos resultados - no caderno, com orientação escrita no protocolo;

- processamento dos dados obtidos:

- $\quad$ cada experimento foi tratado como único; cada grupo trabalhou com seus próprios dados;

- houve cobrança dos resultados previamente esperados;

- o tempo disponível para a execução proposta no início da aula foi suficiente;

- comportamento dos participantes:

- alunos -

* interessados, a maior parte do tempo;

* quase todos envolvidos;

* alguns animados;

* alguns tomavam a frente e faziam tudo, enquanto outros apenas acompanhavam, mas prestavam atenção;

- professores -

* comprometidos, com intencionalidade;

* contidos, falando baixo; 
* circulavam, só respondiam a dúvidas particulares quando solicitados, não davam avisos durante as aulas;

* não davam espaço para os alunos descobrirem sozinhos a interpretação dos dados, mas permitiam que executassem os procedimentos sozinhos;

- encerramento das aulas - as aulas encerraram-se após a obtenção dos dados pelos grupos.

Discussão dos dados

- a discussão era feita pelo professor, após a aula, no fím da manhã ou à tarde.

Relatório das aulas práticas

- não era feito um relatório escrito; os alunos levavam seus resultados para a discussão e o professor os usava, com pouca participação dos alunos;

- ênfase no entendimento dos resultados obtidos, com apresentação oral, informal dos mesmos;

- ensinava a:

- fazer apresentação e tratamento de dados;

- interpretar resultados - analisar;

- não fazia parte da avaliação diretamente.

Atividades suscitadas pelas aulas práticas

- após realizadas, as aulas práticas não suscitaram nenhum trabalho subseqüente.

Avaliaçăo do aprendizado em aulas práticas

- a forma de avaliação das aulas práticas não foi pesquisada.

Ocorrências não previstas durante as aulas práticas

- não houve qualquer ocorrência a assinalar. 
APÊNDICE 8

\section{QUESTIONÁRIO DA PESQUISA EXPLORATÓRIA}

\section{Prezado Professor}

Este questionário visa a obter dados para uma pesquisa exploratória que está sendo realizada com o objetivo de obter subsídios para o planejamento de um Projeto de Pesquisa de Doutoramento. O mesmo versa sobre A Função das Aulas de Laboratório em cursos de Bioquímica, sendo por mim realizado sob a orientação do Prof. Dr. Bayardo Baptista Torres do Instituto de Química da USP.

Os nomes dos entrevistados e as informações aqui obtidas não serão diretamente relatados no projeto, os dados servirão apenas como ponto de partida para uma reflexão sobre o assunto em foco. A instituição em que leciona não terá acesso a suas respostas.

Desde já agradeço sua colaboração.

Marina André de Alvarez

Doutoranda do Departamento de Bioquímica do Instituto de Química - Universidade de São Paulo

\section{INSTRUÇÕES}

Responda as perguntas na ordem em que foram feitas.

Não é necessário identificar-se.

É importante que não deixe de responder nenhuma questão.

As questões são abertas, suas opiniões podem ser amplamente explanadas.

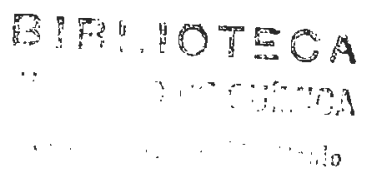


Universidade / Faculdade:

Curso:

\section{Disciplina de Bioquímica}

Duração: __ semestre(s)_ Carga horária semanal:___ horas.

Professor (identificação optativa):

\section{Responda as seguintes questões:}

Há aulas de laboratório em sua programação?

Por que ter aulas práticas?

Como você acha que devam ser as aulas práticas?

As suas aulas práticas estão de acordo com as opiniões que expressou acima? Justifique. 


\title{
ANEXOS \\ CURRÍCULOS DOS CURSOS ANALISADOS \\ PROGRAMAS DAS DISCIPLINAS ANALISADAS \\ PROTOCOLOS DAS AULAS PRÁTICAS OBSERVADAS
}

\author{
FACULDADES INTEGRADAS HEBRAICO-BRASILEIRAS RENASCENÇA \\ Anexo 1 - Grade curricular do curso de Ciências Biológicas \\ Anexo 2 - Programa da disciplina de Química de Biomoléculas \\ Anexo 3 - Protocolos das aulas práticas observadas
}

\section{CENTRO UNIVERSITÁRIO SÃO CAMILO}

Anexo 4 - Grade curricular do curso de Nutrição

Anexo 5 - Programa da disciplina de Bioquímica

Anexo 6 - Protocolos das aulas práticas observadas

\section{FACULDADES OSWALDO CRUZ}

Anexo 7 - Grade curricular do curso de Engenharia Química

Anexo 8 -Programa da disciplina de Bioquímica Aplicada

Anexo 9-Protocolos das aulas práticas observadas

\section{UNIVERSIDADE DE SÃO PAULO - CAMPUS DA CAPITAL \\ FACULDADE DE SAÚDE PÚBLICA}

Anexo 10 - Currículo do curso de Nutrição

Anexo 11 - Programa da disciplina de Bioquímica

Anexo 12 - Protocolos das aulas práticas observadas

\section{FACULDADE DE CIÊNCIAS FARMACÊUTICAS}

Anexo 13 - Currículo do curso de Farmácia e Bioquímica

Anexo 14 - Programa da disciplina de Bioquímica Experimental

Anexo 15 - Protocolos das aulas práticas observadas

\section{INSTITUTO DE BIOCIÊNCIAS}

Anexo 16 - Grade curricular do curso de Ciências Biológicas

Anexo 17 - Programa da disciplina de Bioquímica

Anexo 18 - Protocolos das aulas práticas observadas 


\begin{abstract}
ANEXOS
Os anexos aqui apresentados são transcrições de currículos e/ou grades curriculares e de programas de disciplinas fornecidos pelas instituições ou obtidos de páginas da internet. Foram copiados os protocolos impressos fornecidos aos alunos pelos professores e transcritos os roteiros transmitidos oralmente ou escritos na lousa, durante as explicações iniciais das aulas práticas observadas. Foram feitas correções gramaticais e algumas adaptações gráficas para melhor apresentação, mas mantiveram-se o conteúdo e as mensagens do material original.
\end{abstract}

\title{
FACULDADES INTEGRADAS HEBRAICO BRASILEIRAS RENASCENÇA
}

\section{Anexo 1 - Grade Curricular do Curso de Ciências Biológicas}

Primeiro semestre $-400 \mathrm{~h}$

Biologia Geral $\mathrm{l}-80 \mathrm{~h}$

Química de Biomoléculas $-80 \mathrm{~h}$

Princípios de Sistemática e Biogeografia $-60 \mathrm{~h}$

Estatística $-80 \mathrm{~h}$

Metodologia das Ciências $-60 \mathrm{~h}$

Educação Tísica I - $40 \mathrm{~h}$

Segundo semestre $-400 \mathrm{~h}$

Biologia Geral II $-80 \mathrm{~h}$

Zoologia I $-80 \mathrm{~h}$

Botânica I $-80 \mathrm{~h}$

Física e Biofísica $-80 \mathrm{~h}$

História do Povo e da Cultura dos Judeus I - 40 h

Educação Física II $-40 \mathrm{~h}$

Terceiro semestre $-400 \mathrm{~h}$

Bioquímica $-80 \mathrm{~h}$

Zoologia II $-80 \mathrm{~h}$

Botânica II $-80 \mathrm{~h}$

Ecologia Geral - $80 \mathrm{~h}$

História do Povo e da Cultura dos Judeus II - 40 h

Educação Física III - $40 \mathrm{~h}$

Quarto semestre $-360 \mathrm{~h}$

Fisiologia Humana e Comparativa I $-80 \mathrm{~h}$

Geologia e Paleontologia - $80 \mathrm{~h}$

Biologia Celular e Molecular - $80 \mathrm{~h}$

Didática $-80 \mathrm{~h}$

Educação Física IV - $40 \mathrm{~h}$

Quinto semestre $-400 \mathrm{~h}$

Fisiologia Humana e Comparativa II $-80 \mathrm{~h}$

Imunologia e Microbiologia - $40 \mathrm{~h}$

Botânica III - $80 \mathrm{~h}$

Prática de Ensino - 80 h

Estrutura e Funcionamento do Ensino Fundamental - $80 \mathrm{~h}$

Educação Física V - $40 \mathrm{~h}$

Sexto semestre $-360 \mathrm{~h}$

Ecossistemas $-80 \mathrm{~h}$

Ecologia Vegetal $-80 \mathrm{~h}$

Ecologia Animal - $80 \mathrm{~h}$

Psicologia da Educação - $80 \mathrm{~h}$

Educação Física VI - $40 \mathrm{~h}$

Sétimo semestre $-470 \mathrm{~h}$

Processos Evolutivos $-60 \mathrm{~h}$

Ecologia Humana - $80 \mathrm{~h}$

Conservação da Natureza - $60 \mathrm{~h}$

Estrutura e Funcionamento do Ensino Médio - $80 \mathrm{~h}$

Estágio Supervisionado - $150 \mathrm{~h}$

Educação Física VII - 40 h

Oitavo semestre $-390 \mathrm{~h}$

Recursos Naturais $-60 \mathrm{~h}$

Biotecnologia $-80 \mathrm{~h}$ 
Estágio Supervisionado II - $150 \mathrm{~h}$

Educação e Legislação Ambiental - $60 \mathrm{~h}$

Educação Física VIII - $40 \mathrm{~h}$

\section{Anexo 2 - Programa da Disciplina de Química de Biomoléculas}

\section{Ementa}

A disciplina de Química de Biomoléculas tem por objetivos os tópicos mais importantes da Química com um conteúdo voltado para a Bioquímica. Isso engloba noções básicas de Química, como atomística, eletroquimica, cinética, química orgânica básica e tópicos específicos voltados para a química de organismos vivos, como estrutura, função e caracterização dos principais grupos de biomoléculas. Além disso, são apresentados os fundamentos dos mecanismos enzimáticos, familiarizando os alunos com termos específicos de Bioquímica.

\section{$\underline{\text { Metas }}$}

- Homogeneizar o nível de conhecimento dos alunos em Química Elementar.

- Preparar os alunos para a disciplina de Bioquímica, apresentando-lhes tópicos fundamentais da química das biomoléculas.

\section{Estratégias}

As estratégias empregadas são as de resolução interativa de exercícios, a título de exemplo, o emprego de métodos audiovisuais e a realização de aulas práticas que facilitem a compreensão da aplicą̧ão e da real utilidadc dos temas abordados em sala de aula.

\section{$\underline{\text { Avaliação }}$}

Os métodos de avaliação englobam provas escritas, relatórios de aulas de laboratório e uma monografia de final de curso. Nas provas escritas, são solicitados os conhecimentos teóricos da disciplina, assim como a resolução de problemas reais aplicados à química, com que se deparam os biólogos. Nas aulas de laboratório, são realizados experimentos que têm por objetivo colocar o aluno em contato com o que é dado em classe. Das aulas práticas, é solicitado um relatório de atividades que consiste em um questionário que pode ser respondido com base na teoria, no roteiro dos experimentos e nas conclusões deles esperadas. O trabalho de final de curso consiste no desenvolvimento de um tema escolhido em forma de monografia. Esse trabalho é realizado em duplas. Os temas abordam técnicas modernas de identificação, caracterização e separação de biomoléculas. Os objetivos desse tipo de trabalho são de educar o aluno no sentido de fazer uma boa pesquisa bibliográfica, colocá-lo em contato com o que há de mais moderno em Bioquímica, além de ensiná-lo a escrever trabaihos técnicos. Com base nesses instrumentos, teremos uma nota de laboratório, que é a média dos 3 relatórios dirigidos, uma de teoria, média de 3 provas, e uma da monografia. Com essas 3 notas é feita uma média final.

Bibliografia

Russel, J.B. Química geral. 2a ed. São Paulo: Makron Books, 1994.

Mahan, B. Química , um curso universitário. $4^{\mathfrak{a}}$ ed. São Paulo: Edgard Blücher, 1995.

Lee, J.D. Química inorgânica não tão concisa. $5^{\mathrm{a}}$ ed. São Paulo: Edgard Blücher, 1996.

Atkins, P.W. Physical chemistry. 5무 ed. New York: Oxford Press, 1994.

Solomons, T.W. Quimica orgânica. São Paulo: LTC, 1996.

Marzzocco A. e Torres, B.B. Bioquimica básica. Rio de Janeiro: Guanabara Koogan, 1990.

Feltre, R. Química Geral. 2ª ed. São Paulo: Ed. Moderna, 1982.

Lehninger, A.L. Bioquimica. Barcelona: Omega Ed., 1973.

Voet, D. e Voet, J.G. Biochemistry. New York: John Willey and Sons, 1990.

Conteúdo programático

Matéria, Átomos, Moléculas

Distribuição eletrônica, Periodicidade química, Estruturas de Lewiss

Ligações químicas: iônicas, covalentes e metálicas

Reações: aspectos cinéticos e termodinâmicos

Equilíbrios químicos

Água, pH e tampões

Reações de neutralização, Indicadores

$1^{\mathrm{a}}$ Aula prática

1 a prova

Reações redox e pilhas

Química orgânica: introdução, hidrocarbonetos - estrutura, propriedades e nomenclatura

Química orgânica: funções contendo Oxigênio

Química orgânica: funções contendo Nitrogênio

Reações orgânicas comuns em Biologia

$2^{\mathbf{a}}$ Aula Prática

$2^{\mathrm{a}}$ prova 
Aminoácidos, proteínas: estrutura, ligações peptídicas e pontes de Hidrogênio

Enzimas: cinética enzimática, controle alostérico e enzimas michaelianas

Moléculas de interesse biológico: DNA, carboidratos, ácidos graxos, micelas

Técnicas de caracterização, separação e purificação de proteínas

$3^{3}$ Aula Prática

$3^{3}$ prova

Exame Final

Anexo 3 - Protocolos das Aulas Práticas observadas (transcritos dos protocolos impressos fomecidos aos alunos pelo professor)

Aula Prática I ( $1^{\text {a }}$ Aula Prática da programação)

Identificação de eletrólitos

Informação

Compostos contendo ligações iônicas dissociam-se em água, dando origem a soluções iônicas.

$$
\text { Ex: } \mathrm{H}_{2} \mathrm{SO}_{4}+\mathrm{H}_{2} \mathrm{O} \rightarrow 2 \mathrm{H}^{+}(\mathrm{aq})+\mathrm{SO}_{4}{ }^{2-}(\mathrm{aq})
$$

Procedimento

a. Em um béquer contendo $50 \mathrm{~mL}$ de $\mathrm{H}_{2} \mathrm{O}$, dissolva uma ponta de espátula dos seguintes compostos:

- sacarose

- cloreto de sódio

- $\quad$ etanol $(2 \mathrm{~mL})$

b. Com o dispositivo suportando uma lâmpada e uma pilha, mergulhe rapidamente os dois eletrodos nas soluções obtidas. Observe a lâmpada. Limpe os eletrodos.

Identificação de metais alcalinos por emissão atomica

Informaçōes

A estrutura dos metais alcalinos $\left([\ldots] s^{\prime}\right)$ facilita a formação de cátions monovalentes, com a perda do elétron de valência e a obtenção de uma configuração de gás nobre. As interações eletrostáticas do núcleo do átomo com esse último elétron variam de acordo com o tamanho e a distância na qual ele se encontra. Esse fenômeno representa a energia, a "força" com a qual o elétron de valência está ligado ao seu núcleo. Quando aquecemos, em uma chama, um sal de metal alcalino, geramos, a partir de seus íons, alguns átomos de metal. Estes absorvem energia da chama e devolvem-na em forma de luz, por um mecanismo chamado de "emissão atômica". A energia da luz radiante é dada por $E=h v$, em que $\underline{h}$ é a constante de Planck e $\underline{v}$ é a sua freqüência. Assim sendo, numa visão extremamente simplificada, é possível relacionar o valor da energia radiante com a energia de ligação dos elétrons ao núcleo, envolvidas na emissão atômica.

\section{Procedimento}

a. Mergulhe o fio de $\mathrm{NiCr}$, com auxilio de um pregador de roupas, nos sais a serem estudados, um de Sódio, um de Potássio, um de Cálcio (alcalino-terroso) e um de Lítio.

b. Passe cada sal na chama de um bico de Bunsen e observe a coloração da chama. Entre cada sal, devemos lavar o fio com $\mathrm{H}_{2} \mathrm{O}$ destilada. Deixe o Sódio por último.

Reações redox

Procedimento

Em três tubos de ensaio, misture os reagentes de acordo com as equações abaixo, agite devagar e observe. (A reação b é demonstrativa e será realizada pelo professor)

a. $\mathrm{Fe}+2 \mathrm{HCl} \rightarrow \mathrm{FeCl}_{2}+\mathrm{H}_{2}$

b. $\mathrm{Cu}+2 \mathrm{AgNO}_{3} \rightarrow \mathrm{Cu}\left(\mathrm{NO}_{3}\right)_{2}+2 \mathrm{Ag}$

c. $2 \mathrm{Fe}+3 \mathrm{CuSO}_{4} \rightarrow \mathrm{Fe}_{2}\left(\mathrm{SO}_{4}\right)_{3}+3 \mathrm{Cu}$

d. $\mathrm{Cr}_{2} \mathrm{O}_{7}{ }^{2-}+\mathrm{C}_{2} \mathrm{O}_{4}{ }^{2-}+14 \mathrm{H}^{+} \rightarrow 2 \mathrm{Cr}^{3+}+7 \mathrm{H}_{2} \mathrm{O}+2 \mathrm{CO}_{2}$

Polaridade de solventes

$\mathrm{OBS}$ - O descarte desses produtos não pode ser feito na pia.

Procedimento

a. Existem três buretas contendo diferentes solventes no laboratório. São eles a água, o etanol e o tolueno. Ao lado das buretas, há uma régua de plástico e uma flanela.

b. Esfregue a régua na flanela, a fim de carregá-la eletrostaticamente. Uma vez carregada, abra devagar a torneira da bureta e aproxime a lateral da régua do filete de solvente. Observe.

Titulação ácido-base

Procedimento

a. Com a ajuda de uma pipeta, transfira $20 \mathrm{~mL}$ de uma solução de $\mathrm{NaOH}$ de concentração desconhecida para um erlenmeyer grande.

b. Adicione ao $\mathrm{NaOH}$, algumas gotas de fenolftaleína.

c. Numa bureta de $50 \mathrm{~mL}$ bem presa ao seu suporte e com a torneira devidamente FECHADA, coloque

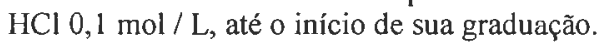


d. Abra devagar a torneira da bureta (aguardar instruções), de forma que o ácido goteje na base. Ao mesmo tempo, agite suavemente o erlenmeyer, de forma a homogeneizar a solução. Faça-o até a viragem do indicador.

e. Feche a torneira e anote o volume de ácido gasto para neutralizar toda a base, de acordo com a equação:

$$
\mathrm{HCl}+\mathrm{NaOH} \rightarrow \mathrm{H}_{2} \mathrm{O}+\mathrm{Na}^{+}+\mathrm{Cl}^{-}
$$

Determinação do ponto de viragem de un indicador colorido natural Procedimento

a. Repita o procedimento descrito anteriormente, substituindo, desta vez, as gotas de fenolftaleína por gotas de suco de repolho roxo.

b. Anote o volume de ácido necessário para a viragem desse indicador.

Questionário dirigido

1. Quais compostos são iônicos? Quando e por que a lâmpada acende?

2. Quais as cores observadas no experimento de emissão atômica?

$\mathrm{Na}:$
$\mathrm{Li}$ :
$\mathrm{Ca}$ :

3. Classifique-os em ordem crescente de emissão de energia

4. O que ocorreu nas reações redox? Identifique o oxidante e o redutor das reações.

5. Qual a concentração de $\mathrm{NaOH}$ na titulação?

6. O ponto de viragem do suco de repolho está em $\mathrm{pH}$ acima ou abaixo do ponto de viragem da fenolftaleína? Justifique.

Visite:

http://www.ufpa.br/quimicanalitica/titrimetriaacidobase.htm

http://www.geocities.com/ esabio/agua/agua.htm

Aula Prática II ( $2^{a}$ Aula prática da programação)

Sintese e propriedades de um sabão

Informação

Sabões são moléculas anfifilicas que têm a propriedade de alterar a tensão superficial da água.

Procedimento

a. Em um béquer, o professor fará uma reação de saponificação de ácidos graxos com $\mathrm{NaOH}$.

b. Após o preparo de sabão, encha um béquer com água e, sobre a superficie do líquido, deite um pouco de pó de giz finamente dividido, de maneira que flutue.

c. A seguir, com um conta-gotas, adicione um pouco de sabão e faça-o escorrer pela lateral do béquer.

Amido nas plantas

Observe o pó de giz.

\section{Procedimento}

a. Apanhe uma tira de folha de chuchu previamente cortada e mergulhe-a em etanol quente (no banhomaria), até que ela fique marrom.

b. Em seguida, em uma placa de Petri, deite-a sobre tintura de iodo-iodetado. Aguarde uns minutos e observe.

Crontatografia em papel

Procedimento

a. Tome uma tira de papel cromatográfico e nele faça uma marca com caneta esferográfica preta ou azul, conforme instruções na aula.

b. No fundo da proveta, onde ocorrerá a eluição da amostra, coloque $1 \mathrm{~mL}$ de eluente (etanol / água $50 \%$ ).

c. Deixe o solvente chegar ao topo do papel. Observe.

Digestão do amido e do açúcar de cana

\section{Procedimento}

a. Dissolva, em um béquer de $50 \mathrm{~mL}$, uma colher de chá de açúcar de cana em $20 \mathrm{~mL}$ de $\mathrm{H}_{2} \mathrm{O}$ destilada.

b. Faça o mesmo com um pouco de amido de milho.

c. Deixe os béqueres no banho-maria.

d. De cada um dos béqueres, tome 2 vezes $2 \mathrm{~mL}$ de amostra em tubos de ensaio. Estes serão chamados de tubos de controle.

e. A seguir, chame o professor para que ele adicione, aos béqueres, $\mathrm{HCl}$ concentrado (perigoso).

f. Espere por duas horas e tome novamente duas alíquotas de $2 \mathrm{~mL}$ de cada béquer, em quatro outros tubos que serão chamados de acúcares digeridos 1 e 2 e amidos digeridos 1 e 2.

g. Peça ao professor que neutralize o $\mathrm{pH}$ desses tubos com $\mathrm{NaOH}$ concentrado (perigoso).

h. A seguir, tome um tubo dc controle de açúcar e um de amido e adicione aos dois uma gota de solução de iodo (a mesma usada acima). Observe. 
i. Tome os dois outros tubos de controle e pingue umas gotas de reagente de Tollens (cuidado, é tóxico e mancha a pele por semanas!!, além de ser caríssimo). Aguarde 5 minutos e observe.

j. Faça os mesmos testes agora com os tubos digeridos. Anote suas observações abaixo:

\author{
Tubo com: \\ Açúcar de cana \\ Amido de milho \\ Açúcar de cana digerido \\ Amido digerido
}

Iodo-iodetado

Reagente de Tollens

\title{
Questionário dirizido
}

1. Explique (não descreva) com suas palavras o que aconteceu com o pó de giz em contato com o sabão.

2. Sabendo-se que as folhas de chuchu foram parcialmente protegidas da luz, o que pode ser associado à Fotossíntese, de acordo com o resultado do experimento?

3. O que aconteceu com a marca de tinta na cromatografia? Por quê?

4. Sabendo-se que o reagente de Tollens é específico para aldeídos típicos de "sacarídeos redutores" e que o iodoiodetado reage com o amido, que é um polissacarídeo, o que o quarto experimento nos mostrou? Expliquem, pois vocês têm base para isso.

Aula Prática III ( $3^{\mathrm{a}}$ Aula prática da programação)

Floculantes e tratamento de água

Procedimento

a. Em duas provetas grandes, coloque água suja.

b. Em uma delas, adicione 10 gotas de $\mathrm{FeCl}_{3}$. Deixe em repouso por mais de uma hora e observe.

Catálise da decomposiçâao de $\mathrm{H}_{2} \mathrm{O}_{2}$

Procedimento

a. Com o auxílio do aparato para coleta de gases, coloque, em um tubo de ensaio, $5 \mathrm{~mL}$ de água oxigenada 20 volumes.

b. Tampe o sistema por 2 minutos, coletando o gás em uma proveta.

c. Meça quanto gás foi liberado na graduação da proveta.

d. Repita o procedimento, desta vez pingando uma gota de $\mathrm{FeCl}_{3}$ e tampando o sistema rapidamente.

Compare os volumes.

Cromatografia em coluna

(Demonstração que não pode ser realizada, porque a coluna preparada não ficou perfeita.)

Complexos metálicos de Ferro

Informaçães

Os íons $\mathrm{Fe}^{2+}$ e $\mathrm{Fe}^{3+}$, como a maioria dos íons metálicos com orbitais eletrônicos do tipo d ou f, possuem a característica de formarem moléculas complexas com algumas moléculas geralmente orgânicas. A molécula que se forma é chamada.de complexo metálico e as moléculas orgânicas que se ligam em volta do íon metálico são chamadas de ligantes. Aquele tipo de molécula é muito comum em sistemas biológicos, uma vez que, como na hemoglobina, os sítios ativos de muitas enzimas, que contêm metais $(\mathrm{Zn}, \mathrm{Cr}, \mathrm{Fe}, \mathrm{Co}, \mathrm{Cu}$ etc) são, na verdade, complexos desses metais e o esqueleto protéico é um ligante. Os metais geralmente têm 4 ou 6 pontos de coordenação, que é por onde se ligam os ligantes, por ligações de coordenação. No caso do $\mathrm{Fe}$, são 6. Isso significa que ele pode ligar-se com até 6 ligantes. Os ligantes, por sua vez, têm pontos de coordenação específicos, geralmente ligam-se ao Fe pelos Nitrogênios ou pelos Oxigênios. Esses ligantes costumam ter "atração", afinidade preferencial por metais de certo tipo e de certo estado de oxidação.

Procedimento

a. Tome 4 tubos de ensaio e encha-os até a metade, com água destilada.

b. Nos quatro tubos, adicione uma gota de $\mathrm{FeCl}_{3}$.

c. Ao primeiro, adicione algumas gotas de solução de tiocianato de sódio (NaSCN). Agite e observe.

d. No segundo, adicione gotas de solução de bipiridina (um ligante orgânico). Agite e observe.

e. No terceiro, coloque uma ponta de espátula de ácido ascórbico (vitamina C), um redutor forte. Agite e espere 5 minutos. No mesmo tubo, adicione agora tiocianato de sódio. Observe.

f. No quarto tubo, coloque uma ponta de espátula de ácido ascórbico. Agite e espere 5 minutos. No mesmo tubo, adicione agora bipiridina. Observe.

g. Em outros dois tubos, coloque um pouco de água de torneira. Adicione a um deles tiocianato e ao outro,

Azul da Prússia bipiridina. Observe (guarde esses dois últimos tubos)

Procedimento

a. Em um tubo de ensaio com água destilada, pingue gotas de solução de ferrocianeto de potássio $\left(\left[\mathrm{Fe}(\mathrm{CN})_{6}\right] \mathrm{K}_{4}\right.$ - trata-se de $\mathrm{Fe}^{2+} !$ !)

b. A seguir, adicione uma gota de $\mathrm{FeCl}_{3}$. Observe.

Albumina, uma proteina com poder complexante

Procedimento

a. Em um béquer, tome água de torneira ( $50 \mathrm{~mL}$ mais ou menos). Adicione ao béquer uma clara de ovo.

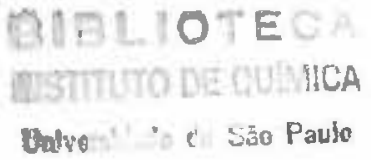


b. Deixe em banho-maria até que coagule a albumina.

c. Separe um pouco da água que ficou no béquer e pingue tiocianato de sódio. Compare o resultado com os tubos que você guardou em outro experimento.

d. Agora, tome um pouco de clara coagulada e pingue tiocianato sobre ela, em um vidro de relógio.

Questionário dirigido

1. Quais foram as velocidades médias de decomposição da $\mathrm{H}_{2} \mathrm{O}_{2}$, com e sem catalisador, em $\mathrm{mL}$ de $\mathrm{O}_{2} / \mathrm{s}$ ?

2. Sabendo-se que o ligante cianeto $\left(\mathrm{CN}^{-}\right)$pode ligar-se pelos dois lados (ou pelo Carbono ou pelo Nitrogênio) e que o Nitrogênio se liga preferencialmente a íons $\mathrm{Fe}^{2+}$ e que o outro lado do ligante tem afinidade com íons $\mathrm{Fe}^{3+}$, proponha uma estrutura para o azul da Prússia. Lembre-se que geralmente o que é muito grande é insolúvel em água.

3. A cromatografia líquida poderia ser utilizada industrialmente para separar e isolar compostos? Explique. 


\section{CENTRO UNIVERSITÁRIO SÃO CAMILO}

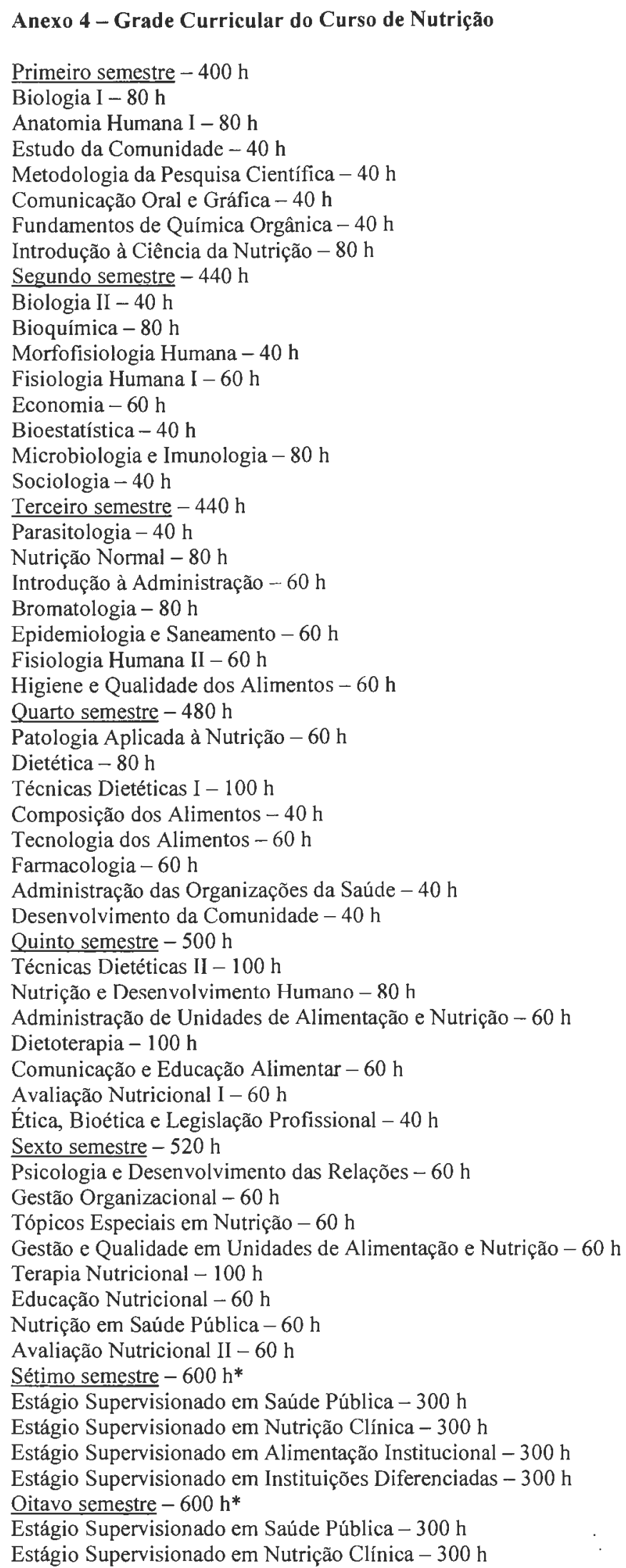


Estágio Supervisionado em Alimentação Institucional - $300 \mathrm{~h}$

Estágio Supervisionado em Instituições Diferenciadas - $300 \mathrm{~h}$

* O aluno deverá cumprir 2 áreas de estágio por semestre

\section{Anexo 5-Programa da Disciplina de Bioquímica}

\section{Conteúdo Programático}

Membranas - composição e estrutura

Introdução ao Metabolismo - conceito de catabolismo e anabolismo, conceito de reação de óxido-redução, coenzimas como transportadores de elétrons

Digestão e absorção de carboidratos - amido, sacarose, lactose

Glicólise - via de degradação da glicose para obtenção de energia

Fermentação - utilização da glicose na ausência de oxigênio; fermentação lática e alcoólica; organismos que utilizam essa via

Glicogenólise - degradação do Glicogênio

$1^{\text {a }}$ Aula prática: $\mathrm{pH}$ e sistema tampão

Ciclo de Krebs - ciclo do ácido cítrico

$2^{3}$ Aula Prática: Identificação de carboidratos

Cadeia respiratória e fosforilação oxidativa - formação de ATP; terceira fase da respiração celular

$3^{\text {a }}$ Aula Prática: Determinação da atividade da amilase salivar

Digestão, absorção e transporte de lipídeos

$\beta$ - oxidação - via de degradação dos ácidos graxos para obtenção de energia

Digestão e absorção de proteínas

Degradação de aminoácidos

Discussão dos exercícios

$4^{\underline{a}}$ Aula Prática: Determinação de proteínas totais no sangue

$1^{\underline{a}}$ prova bimestral

Entrega da cópia do artigo de seminário

Gliconeogênese - síntese de glicose

$5^{\text {a }}$ Aula Prática: Dosagem de glicose no sangue

Glicogênese - síntese de glicogênio

Síntese de aminoácidos

Síntese de ácidos graxos e triglicerídeos

$6^{\mathrm{a}}$ Aula Prática: Dosagem de triglicerídeos no sangue

Metabolismo do colesterol e das lipoproteínas

Bioquímica do exercício físico

$7^{\mathrm{a}}$ Aula prática: Dosagem de colesterol e HDL - colesterol no sangue

Inter-relação e regulação metabólicas

Controle hormonal

Discussão dos exercícios

$2^{\mathrm{a}}$ prova bimestral

$8^{\mathrm{a}}$ Aula prática: Determinação de uréia e de ácido úrico

Apresentação dos seminários

Prova substitutiva

\section{Anexo 6 - Protocolos das Aulas Práticas observadas}

Aula Prática I ( $2^{\underline{a}}$ e $3^{\text {a }}$ Aulas Práticas da programação)

Identificação de carboidratos - Identificação de açúcares em alimentos (transcrito do protocolo impresso entregue aos alunos pelos professores)

Objetivos

- Identificar a presença de glicose e amido em alimentos.

- Conhecer as reações de identificação de mono, di e polissacarídeos.

Informaçð̄es

A glicose reage especificamente com a orto-toluidina, em meio acético, formando a correspondente base de Schiff, de cor azul clara. A molécula helicoidal do amido, amilose, reage com o iodo, ficando com a cor azul arroxeado.

Materiais

por grupo:

- $2 \mathrm{~mL}$ de suco de laranja

- $\quad 2 \mathrm{~mL}$ de mel diluído (1:10)

- 1 clara de ovo

- 1 gema de ovo 
1 rodela de batata

- 1 porção de arroz

- 1 porção de feijão

- 1 fatia de pão de glúten

- $\quad 2 \mathrm{~mL}$ de solução padrão de glicose

- $2 \mathrm{~mL}$ de solução padrão de amido

- $\quad 25 \mathrm{~mL}$ de solução de orto-toluidina

- $\quad 25 \mathrm{~mL}$ de água destilada

- $5 \mathrm{~mL}$ de solução de lugol diluído

- $\quad 25 \mathrm{~mL}$ de água destilada

- 5 pipetas de $1 \mathrm{~mL}$

- 2 pipetas de $5 \mathrm{~mL}$

- 1 pipeta Pasteur

- 7 tubos de ensaio

- 2 estantes para tubos de ensaio

- $\quad$ fita crepe para marcação de tubos

para a classe:

- banho-maria fervente

- espectrofotômetro

A. Identificação de glicose em suco de laranja e solução de mel

Procedimento

a. Monte quatro tubos de acordo com a tabela abaixo:

$\begin{array}{clcc}\text { Tubos } & \text { Amostra (0,1 mL) } & \begin{array}{c}\text { Reativo de } \\ \text { orto- } \\ \text { toluidina } \\ (\mathbf{m} \mathbf{L})\end{array} & \begin{array}{c}\text { Água } \\ \text { destilada } \\ (\mathbf{m L} \mathbf{L})\end{array} \\ 1 & \text { água destilada (branco) } & 5,0 & 5,0 \\ 2 & \text { padrão de glicose } & 5,0 & 5,0 \\ 3 & \text { suco de laranja puro } & 5,0 & 5,0 \\ 4 & \text { mel diluído } & 5,0 & 5,0\end{array}$

b. Coloque os tubos em banho-maria fervente por 10 minutos; esfrie os tubos.

c. Use o tubo 1 para zerar o espectrofotômetro em $630 \mathrm{~nm}$.

d. Meça a absorbância dos tubos 2, 3 e 4 em $630 \mathrm{~nm}$.

e. Calcule a concentração de glicose nos tubos 3 e 4 , fazendo a seguinte regra de três:

solução conhecida de glicose $1 \%$

Abs do tubo 2

$\mathrm{X}$ (concentração de glicose do tubo 3 ou 4)

Abs do tubo 3 ou 4

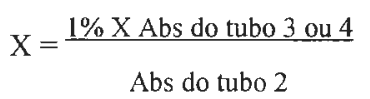

B. Identificação de amido em alimento

Procedimento

a. Pingue 3 gotas de lugol diluído no tubo contendo amido $1 \%$. Observe sua coloração e tome-a como padrão para determinar a presença de amido nos materiais que serão analisados.

b. Pingue 3 gotas de lugol em 1 tubo de ensaio contendo $2 \mathrm{~mL}$ de suco de laranja e em 1 tubo de ensaio contendo $2 \mathrm{~mL}$ de mel diluído (1:10). Verifique, pela coloração, se esses materiais contêm amido.

c. Pingue lugol sobre a batata, o arroz, o feijão, o pão de glúten, a clara e a gema de ovo. Verifique a presença de amido nesses alimentos.

Determinação da atividade da amilase salivar (transcrito dos dados passados oralmente aos alunos e escritos na lousa, pelo professor assistente)

Informações

A saliva é incubada com o substrato (amido), em condições ótimas de temperatura, $\mathrm{pH}$ e concentração de cloretos. A atividade amilásica é medida pelo tempo mínimo necessário à digestão total do amido, o que se revela pela reação negativa com iodo (ponto acrômico).

Procedimento

a. Diluir com água destilada, a $100 \mathrm{~mL}$, exatamente $1 \mathrm{~mL}$ de saliva não filtrada, em frasco volumẻtrico. b. Preparar uma série de 10 tubos de hemólise, contendo $2 \mathrm{~mL}$ de lugol diluído.

c. Transferir, para um tubo de ensaio, $5 \mathrm{~mL}$ de uma solução de amido, $2 \mathrm{~mL}$ da solução de cloreto de sódio e $2 \mathrm{~mL}$ de solução tampão. Manter a mistura em banho-maria a $38^{\circ} \mathrm{C}$, durante 5 minutos.

d. Juntar $1 \mathrm{~mL}$ de saliva diluída, agitar, marcar o tempo e tornar a mergulhar o tubo no banho.

e. De minuto a minuto, com o auxílio de um conta-gotas, pingar duas gotas da mistura em um dos tubos contendo lugol, até que não se produza cor alguma (ponto acrômico). 
Aula Prática II (4a Aula Prática da programação)

Proteinas totais do sangue (transcrito dos dados passados oralmente aos alunos e escritos na lousa, pelo professor assistente)

\section{Procedimento}

a. Monte três tubos de ensaio de acordo com a tabela a seguir.

b. Deixe os tubos no banho-maria a $37^{\circ} \mathrm{C}$, por 15 minutos.

c. Faça as medidas de absorbância das soluções no espectrofotômetro, com o comprimento de onda de $540 \mathrm{~nm}$.

$\begin{array}{ccccc}\text { Tubos } & \text { Soluções } & \text { Branco } & \text { Padrão } & \text { Amostra (soro) } \\ 1 & \text { Reativo (biureto) } & 3,5 \mathrm{~mL} & 3,5 \mathrm{~mL} & 3,5 \mathrm{~mL} \\ 2 & \text { Padrão } & - & 50 \mu \mathrm{L} & - \\ 3 & \text { Água } & 50 \mu \mathrm{L} & - & 50 \mu \mathrm{L}\end{array}$

Dosagem de Albumina (transcrito dos dados passados oralmente aos alunos e escritos na lousa, pelo professor assistente)

\section{Procedimento}

a. Monte três tubos de ensaio de acordo com a tabela abaixo.

b. Deixe os tubos à temperatura ambiente, por 20 minutos.

c. Faça as medidas de absorbância das soluções no espectrofotômetro, com o comprimento de onda de $625 \mathrm{~nm}$.

$\begin{array}{ccccc}\text { Tubos } & \text { Soluções } & \text { Branco } & \text { Padrão } & \text { Amostra (soro) } \\ 1 & \text { Reativo (UBC) } & 3,5 \mathrm{~mL} & 3,5 \mathrm{~mL} & 3,5 \mathrm{~mL} \\ 2 & \text { Padrão } & - & 10 \mu \mathrm{L} & - \\ 3 & \text { Água } & 10 \mu \mathrm{L} & - & 10 \mu \mathrm{L} \\ & \text { Concentração padrão de Albumina }-2,86 \mathrm{~g} / 100 \mathrm{~mL} & \end{array}$

Aula Prática III ( $6^{\mathrm{a}}$ e $7^{\mathrm{a}}$ Aulas Práticas da programação)

Dosagem de triglicerídeos no sangue (transcrito dos dados passados oralmente aos alunos e escritos na lousa, pelo professor assistente)

Procedimento

Deve ser realizado por três grupos

a. Monte três tubos de ensaio de acordo com a tabela a seguir

b. Deixe os tubos no banho-maria a $37^{\circ} \mathrm{C}$, por 15 minutos.

c. Faça as medidas de absorbância das soluções no espectrofotômetro, com o comprimento de onda de $505 \mathrm{~nm}$.

$\begin{array}{ccccc}\text { Tubos } & \text { Soluções } & \text { Branco } & \text { Padrão } & \text { Amostra (soro) } \\ 1 & \text { Padrão } & - & 50 \mu \mathrm{L} & - \\ 2 & \text { Amostra } & - & - & 50 \mu \mathrm{L} \\ 3 & \text { Reativo } & 5 \mathrm{~mL} & 5 \mathrm{~mL} & 5 \mathrm{~mL}\end{array}$

Dosagem de Colesterol no sangue (transcrito dos dados passados oralmente aos alunos e escritos na lousa, pelo professor assistente)

Procedimento

a. Monte quatro tubos de ensaio de acordo com a tabela abaixo.

b. Deixe os tubos à $37^{\circ} \mathrm{C}$, por 10 minutos.

c. Faça as medidas de absorbância das soluções no espectrofotômetro, com o comprimento de onda de $505 \mathrm{~nm}$.

$\begin{array}{ccccc}\text { Tubos } & \text { Soluções } & \text { Branco } & \text { Padrão } & \text { Amostra (soro) } \\ 1 & \text { Reativo } & 5 \mathrm{~mL} & 5 \mathrm{~mL} & 5 \mathrm{~mL} \\ 2 & \text { Padrão } & - & 50 \mu \mathrm{L} & - \\ 3 & \text { Amostra } & - & - & 50 \mu \mathrm{L} \\ 4 & \text { Água destilada } & 50 \mathrm{~mL} & - & -\end{array}$

Dosagem de HDL - Colesterol no sangue (transcrito dos dados passados oralmente aos alunos e escritos na lousa. pelo professor assistente)

Procedimento

a. Misturar $500 \mu \mathrm{L}$ da amostra com $50 \mu \mathrm{L}$ do reativo.

b. Colocar no gelo, por 15 minutos.

c. Centrifugar a $3000 \mathrm{rpm}$, por 15 minutos.

d. Separar o sobrenadante. 
e. Montar os tubos de acordo com a tabela abaixo:

$\begin{array}{ccc}\text { Tubos } & \text { Soluções } & \text { Branco } \\ 1 & \text { Sobrenadante } & - \\ 2 & \text { Padrão } & - \\ 3 & \text { Reativo } & 4 \mathrm{~mL}\end{array}$

Padrão

Amostra (soro)

Reativo

$40 \mu \mathrm{L}$

$4 \mathrm{~mL}$

$200 \mu \mathrm{L}$

$4 \mathrm{~mL}$ 


\section{FACULDADES OSWALDO CRUZ}

\section{Anexo 7 - Grade Curricular do Curso de Engenharia Química}

Primeira série $-700 \mathrm{~h}$ anuais

Cálculo Diferencial, Integral e Vetorial I - $140 \mathrm{~h}$

Geometria Analítica e Álgebra Linear - $70 \mathrm{~h}$

Física Geral e Experimental I $-175 \mathrm{~h}$

Desenho Técnico Aplicado - $70 \mathrm{~h}$

Micro-informática Básica $-70 \mathrm{~h}$

Química Geral e Inorgânica - 175 h

Segunda série $-700 \mathrm{~h}$ anuais

Cálculo Diferencial, Integral e Vetorial II $-140 \mathrm{~h}$

Cálculo Numérico - $70 \mathrm{~h}$

Física Geral e Experimental II - 140 h

Mecânica Geral - $70 \mathrm{~h}$

Resistência dos Materiais - $70 \mathrm{~h}$

Química Orgânica I - 70 h

Físico-Química I - $140 \mathrm{~h}$

Terceira série $-700 \mathrm{~h}$ anuais

Química Orgânica II $-140 \mathrm{~h}$

Eletrotécnica Geral - $70 \mathrm{~h}$

Balanço Material e Energético I - 70 h

Química Analítica - $140 \mathrm{~h}$

Fenômenos de Transporte $\mathrm{I}-140 \mathrm{~h}$

Físico-Química II - $140 \mathrm{~h}$

Quarta série - $630 \mathrm{~h}$ anuais

Análise Instrumental - $70 \mathrm{~h}$

Instrumentação Industrial - $70 \mathrm{~h}$

Operações Unitárias da Indústria Química I - $70 \mathrm{~h}$

Balanço Material e Energético Il - 140 h

Fenômenos de Transporte II - $70 \mathrm{~h}$

Corrosão e Proteção dos Materiais - $70 \mathrm{~h}$

Termodinâmica Química Aplicada - 140 h

Quinta série $-630 \mathrm{~h}$ anuais

Operações Unitárias da Indústria Química II $-140 \mathrm{~h}$

Materiais de Construção da Indústria Química - $70 \mathrm{~h}$

Cinética Química e Cálculo de Reatores - $140 \mathrm{~h}$

Processos Industriais Orgânicos $-140 \mathrm{~h}$

Engenharia Ambiental e Recursos Naturais - $70 \mathrm{~h}$

Análise e Simulação de Processos Químicos $-70 \mathrm{~h}$

Sexta série $-700 \mathrm{~h}$ anuais

Estatística Aplicada - 70 h

Metodologia do Trabalho Científico $-70 \mathrm{~h}$

Processos Industriais Inorgânicos -140 h

Bioquímica Aplicada (Bioquímica Industrial) $-140 \mathrm{~h}$

Planejamento e Projetos da Indústria Química - 140 h

Legislação Industrial $-70 \mathrm{~h}$

Economia e Organização Industrial $-70 \mathrm{~h}$

\section{Anexo 8-Programa da Disciplina de Bioquímica Aplicada}

Conteúdo Programático $-2^{\circ}$ semestre do curso (semestre observado na pesquisa)

Processamento de produtos láticos

$1^{\mathrm{a}}$ Aula Prática: Presunto cozido 1

$2^{\mathrm{a}}$ Aula Prática: Presunto cozido 2

$3^{\underline{a}}$ Aula Prática: Doce-de-leite

Preservação de alimentos pelo frio - refrigeração

$3^{\mathrm{a}}$ Prova oficial

4 Aula Prática: Queijo Frescal

Semana da Química

Preservação de alimentos pelo frio - congelamento

$5^{a}$ Aula Prática: Polpa de fruta desidratada 
Preservação de alimento pelo calor - Pasteurização e esterilização

Discussão de trabalhos científicos

$4^{\mathrm{a}}$ Prova oficial

Aditivos utilizados em alimentos

Revisão de notas de laboratório

Revisão de prova

Anexo 9 - Protocolos das Aulas Práticas observadas (transcritos dos protocolos impressos fornecidos aos alunos pelas professoras)

\section{Aula Prática I ( $3^{\mathrm{a}}$ Aula Prática da programação) \\ Doce-de-leite}

Higienização

- Higienização das mãos: lavagem com detergente e etanol $70 \%$.

- Higienização dos frascos: lavar os recipientes e tampas e colocá-los em água fervente por 5 minutos.

Material

$2 \mathrm{~L}$ de leite pasteurizado.

Procedimento

a. Determinar a acidez do leite: titulação com soda Dornic (solução de NaOH 1/9 N). Sabe-se que a acidez do leite em ${ }^{\circ}$ Domic é igual ao volume de soda Dornic gasto na titulação multiplicado por 10; portanto, $0,1 \mathrm{~g}$ de ácido lático por litro de leite corresponde a $1^{\circ}$ Dornic.

b. Aquecer o leite até a temperatura de $70-80^{\circ} \mathrm{C}$.

c. Neutralizar o leite com bicarbonato de sódio para 12 a $13^{\circ} \mathrm{D}$. Sabe-se que:

massa de $\mathrm{NaHCO}_{3}(\mathrm{~g})=\Delta^{\circ} \mathrm{D} \times \mathrm{V} \times 0,0934$

Onde: $\Delta{ }^{\circ} \mathrm{D}=$ variação de acidez em ${ }^{\circ}$ Dornic e $\mathrm{V}=$ volume do leite a ser neutralizado

d. Adicionar os ingredientes: $10 \%$ de leite em pó (200 g) e 45\% de sacarose ( $900 \mathrm{~g})$, em relação à massa de leite.

e. Proceder a concentração inicial: cozinhar até 55 a $58^{\circ}$ Brix, sob agitação. Os testes devem ser feitos periodicamente, com a amostra resfriada.

f. Adicionar $5 \%$ de glicose (hidrolisado de amido) em relação à massa de leite.

g. Proceder a cocção final: cozimento até $72^{\circ} \mathrm{Brix}$, sob agitação.

h. Proceder o envasamento: colocar o doce-de-leite ainda quente nos frascos previamente higienizados.

i. Proceder a exaustão: após o envase, as embalagens devem ficar em banho-maria, na temperatura de $90^{\circ} \mathrm{C}$ no centro do frasco, por 5 minutos. $\mathrm{O}$ fechamento deve ser imediatamente após isso; dessa forma, expulsa-se grande quantidade de ar do frasco.

j. Proceder a pasteurização: imergir os frascos fechados em banho-maria fervente, por 20 minutos.

1. Resfriar com cuidado em água corrente até a temperatura de $40^{\circ} \mathrm{C}$, identificar os frascos e armazenar por 15 dias.

m. Teste após 15 dias:

- Vácuo;

- Organolépticos: cor, odor, sabor e textura.

Aula Prática II (4 Aula Prática da programação)

Queijo tipo "Minas Frescal"

Higienização

Higienização das mãos: lavagem com detergente e etanol $70 \%$.

Material

$5 \mathrm{~L}$ de leite pasteurizado.

Procedimento

a. Fazer o tratamento térmico: aquecimento do leite até $72{ }^{\circ} \mathrm{C}$ e resfriamento rápido até $39^{\circ} \mathrm{C}$.

b. Adicionar os ingredientes:

- $\quad 0,5 \%$ em volume de solução de $\mathrm{CaCl}_{2} 5 \%$;

- $\quad 0,04 \%$ em volume de coalho líquido (suspensão contendo renina);

- $\quad 2,5 \%$ em volume de fermento lático

c. Proceder a coagulação em estufa a $39^{\circ} \mathrm{C}$, por 1 hora.

d. Separar amostras de $10 \mathrm{~mL}$ em tubos de ensaio acondicionados em banho-maria termostatizado a $39^{\circ} \mathrm{C}$.

e. Determinar a acidez do leite pelo método da titulação com soda Dornic para os tempos de 0 min., 30 $\min ., 60 \mathrm{~min}$. e $120 \mathrm{~min}$.

f. Fazer o corte: utilizar a lira e obter cubos de 1,0 a $1,5 \mathrm{~cm}$.

g. Proceder o dessoramento.

h. Enformar: adicionar a massa dessorada em formas perfuradas e comprimir a fim de continuar o dessoramento. 
i. Fazer a salga seca: adiciona $1 \%$ de $\mathrm{NaCl}$ (em relação à massa do coalho) na superficie do queijo (adicionar uma parcela dessa massa em cada viragem que deve ser feita a cada meia hora).

j. Fazer a salga úmida: adicionar salmoura $5 \%$ na superfície do queijo.

1. Armazenar por 24 horas.

m. Fazer, após esse tempo, os testes organolépticos: cor, sabor, odor e textura.

Aula Prática III ( $5^{\text {a }}$ Aula Prática da programação)

Polpa de fruta desidratada - Farinha de banana

Informaçōes

a. A desidratação é útil quando há excesso de produção.

b. A farinha de banana é usada para alimentos em pó, como preparados para sucos.

c. Fatores que afetam o dessecamento: temperatura, tempo, umidade do ar, velocidade do vento.

Higienização

- Higienização das mãos: lavagem com detergente e etanol $70 \%$.

- Higienização da matéria-prima: lavar por imersão, antes de descascar a banana e aspirar.

Procedimento

a. Selecionar a banana que não deve ser muito madura, para não ficar muito doce; descascar.

b. Cortar a banana em 4, longitudinalmente ( 6 grupos de trabalho) e em rodelas de $1 \mathrm{~cm}$ ( 5 grupos de trabalho).

c. Separar um pedaço e pesar o restante.

d. Fazer o tratamento químico: imergir a banana em solução de bissulfito de sódio $0,4 \%$, por 5 min. e pesar na peneira.

e. Fazer a secagem em estufa com ventilação forçada à temperatura de $\sim 70{ }^{\circ} \mathrm{C}$. Corrente de ar na estufa: $2 \mathrm{~m} / \mathrm{s}$.

f. Pesar a cada 20 min. ( 6 a 8 pesagens).

g Proceder a pesagem final com 24 horas de secagem. Anotar os resultados das pesagens na tabela abaixo:

\begin{tabular}{|c|c|c|c|c|c|c|c|c|c|}
\hline \multirow{7}{*}{ Tiras } & grupo & $0 \mathrm{~min}$. & $\begin{array}{c}20 \\
\text { min. }\end{array}$ & $\begin{array}{c}40 \\
\text { min. }\end{array}$ & $\begin{array}{c}60 \\
\text { min. }\end{array}$ & $\begin{array}{c}80 \\
\text { min. }\end{array}$ & $\begin{array}{l}100 \\
\text { min. }\end{array}$ & $\begin{array}{r}120 \\
\text { min. }\end{array}$ & $24 \mathrm{~h}$ \\
\hline & 1 & & & & & & & & \\
\hline & 2 & & & & & & & & \\
\hline & 3 & & & & & & & & \\
\hline & 4 & & & & & & & & \\
\hline & 5 & & & & & & & & \\
\hline & 6 & & & & & & & & \\
\hline \multirow{5}{*}{ Rodelas } & 7 & & & & & & & & \\
\hline & 8 & & & & & & & & \\
\hline & 9 & & & & & & & & \\
\hline & 10 & & & & & & & & \\
\hline & 11 & & & & & & & & \\
\hline
\end{tabular}

h. Proceder os teste organolépticos: cor, sabor, odor e textura.

i. Calcular o rendimento.

j. Comparar os tipos de corte.

1. Fazer os gráficos: massa de banana $\mathrm{X}$ tempo e velocidade de evaporação $\mathrm{X}$ tempo

velocidade de evaporação $=\frac{\text { massa de água evaporada }}{\text { minuto }}$

velocidade de evaporação $=\underline{\text { massa de água inicial }- \text { massa de água final }}$

20 minutos 


\section{UNIVERSIDADE DE SÃO PAULO - CAMPUS DA CAPITAL}

\section{FACULDADE DE SAÚdE PÚBLICA}

\section{Anexo 10 - Currículo do Curso de Nutrição}

Fundamentos Bromatológicos da Dietética - 75 h

Estudo Experimental dos Alimentos - $105 \mathrm{~h}$

Nutrição Normal $-90 \mathrm{~h}$

Dietética - $105 \mathrm{~h}$

Dietoterapia - $120 \mathrm{~h}$

Fisiopatologia da Nutrição - $120 \mathrm{~h}$

Administração de Unidades de Aliméntação e Nutrição - $90 \mathrm{~h}$

Higiene e Controle de Alimentos $-75 \mathrm{~h}$

Avaliação do Consumo Alimentar $-75 \mathrm{~h}$

Nutrição em Saúde Pública $-60 \mathrm{~h}$

Técnica Dietética - $105 \mathrm{~h}$

Substâncias Tóxicas em Alimentos $-30 \mathrm{~h}$

Antropologia Social - $30 \mathrm{~h}$

Sociologia Aplicada à Nutrição - $30 \mathrm{~h}$

Desenvolvimento de Comunidades $-45 \mathrm{~h}$

Gerenciamento Institucional $-120 \mathrm{~h}$

Epidemiologia $-45 \mathrm{~h}$

Bioestatística Aplicada à Saúde Pública - 75 h

Orientação Bibliográfica $-30 \mathrm{~h}$

Informática $-15 \mathrm{~h}$

Fundamentos do Saneamento do Meio - $30 \mathrm{~h}$

Saúde Materna, da Criança e do Adolescente - 75 h

Educação Nutricional - $105 \mathrm{~h}$

Disciplinas ministradas no Instituto de Ciências Biomédicas

Farmacologia $-45 \mathrm{~h}$

Fisiologia e Biofisica - $135 \mathrm{~h}$

Anatomia Humana - $105 \mathrm{~h}$

Citologia, Histologia e Embriologia - 75 h

Parasitologia Aplicada à Nutrição - $60 \mathrm{~h}$

Microbiologia $-60 \mathrm{~h}$

Imunologia Básica e Aplicada à Nutrição - 60 h

Microbiologia de Alimentos $-60 \mathrm{~h}$

Disciplinas ministradas na Faculdade de Ciências Farmacêuticas

Bromatologia Básica $-90 \mathrm{~h}$

Tecnologia de Alimentos $-60 \mathrm{~h}$

Disciplinas ministradas no Instituto de Química

Química de Biomoléculas $-60 \mathrm{~h}$

Bioquímica - $120 \mathrm{~h}$

Disciplina ministrada na Faculdade de Medicina

Patologia Geral - $30 \mathrm{~h}$

Ciclo Básico

Anatomia

Biologia

Fisiologia e outras

Ciclo Profissionalizante

Nutrição Normal

Bromatologia

Técnica Dietética

Dietética

Higiene e Controle de Alimentos

Administração de Unidades de Alimentação e Nutrição

Educação Nutricional

Estudo Experimental dos Alimentos

Dietoterapia

Nutrição em Saúde Pública e outras

Estágios - realizados no $5^{\circ}$ ano, em hospitais, indústrias, centros de saúde, cozinhas experimentais e outros, nas seguintes áreas, com 255 h cada:

Nutrição Clínica 
Administração de Unidades de Alimentação e Nutrição

Nutrição de Grupos Populacionais

Experimentação com Alimentos e "Marketing"

\section{Anexo 11 - Programa da Disciplina de Bioquímica}

Objetivo

Proporcionar uma visão global do metabolismo celular e da biologia molecular, por meio de aulas teóricas e práticas. Portanto, o curso consistirá de aulas expositivas, de discussão, de exercícios e de laboratório. Seminários, versando sobre assuntos relacionados ao que está sendo estudado, serão ministrados por grupos de alunos, de modo a ilustrar e enriquecer o conteúdo das aulas.

\section{Avaliação}

Serão realizadas duas provas de mesmo peso e uma outra substitutiva. As provas versarão sobre conteúdos estudados durante os períodos de aulas que as precederem. A substitutiva poderá substituir qualquer uma delas, mas versará sobre todo o conteúdo do curso. Cada um dos 11 grupos estabelecidos terá uma nota média de seminários, os quais serão avaliados em termos de conteúdo, clareza de apresentação e capacidade de organização do grupo. Os grupos terão também uma nota de laboratório, correspondente a relatórios entregues, referentes aos experimentos realizados durante o curso. O cálculo da média deve ser feito com base na seguinte distribuição: provas $=70 \%$; seminários $=20 \%$; relatórios $=10 \%$.

Serão aprovados os alunos que atingirem média 5,0 . Terão direito a uma prova de recuperação os alunos que atingirem média 3,5 .

\section{Conteúdo programático}

\section{Biologia Molecular}

Introdução - material genético

Replicação, reparo, rearranjo gênico

RNA, sintese de RNA

Código genético, síntese protéica

Controle da expressão gênica

Técnica do DNA recombinante

Seminários 1,2,3, discussão e exercícios

\section{Metabolismo Celular}

Enzimas - tipos, propriedades e cinética

Enzimas - estrutura, mecanismos de ação e inibição

Introdução ao metabolismo

Seminários 4 e 5 , discussão e exercícios

$1^{\mathrm{a}}$ Aula prática: Enzimas

Degradação de Carboidratos

Prova 1

Ciclo de Krebs, discussão e exercícios

Cadeia respiratória e fosforilação oxidativa

Síntese de carboidratos

Degradação de lipídeos

Síntese de lipídeos, seminário 6

$2^{\underline{a}}$ Aula Prática: Cadeia respiratória

Degradação de proteínas, peptídeos e aminoácidos

Síntese de aminoácidos, discussão e exercícios

Degradação e síntese de outros compostos nitrogenados, seminário 7

Hormônios, seminário 8

$3^{\underline{a}}$ Aula Prática: Transaminases

Integração e regulação metabólicas

Contração muscular, seminário 9

Seminários 10 e 11, discussão e exercícios

Prova 2

Aula de discussão geral

Prova substitutiva

Anexo 12 - Protocolos das Aulas Práticas observadas (transcritos dos protocolos impressos fomecidos aos alunos pela professora) 


\section{Cinética enzimática}

Informaç̃es

A enzima escolhida para esse estudo é a Invertase de levedura, que catalisa a hidrólise da sacarose para produzir glicose e frutose.

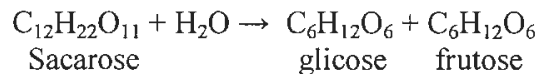

A determinação da velocidade de reação (ou da atividade enzimática) pode ser feita por meio da dosagem dos açúcares redutores formados (glicose e frutose). A dosagem baseia-se na reação entre o ácido 3,5 dinitro-salicílico (DNS) e os açúcares redutores. Esses monossacarídeos reduzem o DNS, fornecendo um produto de cor característica, cuja formação pode ser acompanhada a $540 \mathrm{~nm}$.

Nesses experimentos, as velocidades da reação serão expressas em $\mu$ moles de sacarose hidrolisada por minuto. Conhecendo-se, por colorimetria, a quantidade ( $\mu$ moles) de açúcares redutores formada, por um cálculo estequiométrico simples, pode-se determinar a quantidade correspondente ( $\mu$ moles) de sacarose hidrolisada.

Em altas concentrações de substrato, a velocidade de uma reação enzimática é diretamente proporcional à concentração da enzima. Nessas condições, [S] pode ser considerado constante e, então, a velocidade é igual à constante multiplicada pela concentração de enzima.

A velocidade da reação enzimática também é diretamente proporcional à concentração de substrato (desde que haja uma quantidade suficientemente grande de enzima), depende do $\mathrm{pH}$ (há um ótimo para cada enzima) e da temperatura (existem faixas de maior e menor atividade; acima de $60^{\circ} \mathrm{C}$ pode ocorrer inativação irreversível).

\section{Objetivos}

Estudar as influências das concentrações de enzima e do substrato, do $\mathrm{pH}$ e da temperatura na velocidade de uma reação enzimática; examinar as curvas obtidas; obter alguns parâmetros cinéticos $\left(\mathrm{K}_{\mathrm{M}} \mathrm{e} \mathrm{V}_{\max }\right) \mathrm{e}$ discutir seus valores e importância.

\section{Materiais}

por grupo:

- tubos de ensaio grandes

- béquer

- pipetas

- pêra

- pedaços de papel celofane

para a classe:

- espectrofotômetro

- banhos-marias $\left(37^{\circ} \mathrm{C}\right.$ e fervente $)$

- cronômetro

reagentes:

- $\quad$ solução padrão redutora (glicose $5,5 \mathrm{mM}$ e frutose $5,5 \mathrm{mM}$ )

- $\quad$ solução tampão acetato $0,2 \mathrm{M}, \mathrm{pH} 4,77$

- $\quad$ solução de DNS

- $\quad$ solução de sacarose $5 \%$ em tampão

- $\quad$ solução de Invertase $0,24 \mu \mathrm{M}$ e $0,48 \mu \mathrm{M}$

A. Curva padrão

A finalidade da curva padrão é relacionar valores de absorbância, a $540 \mathrm{~nm}$, com número de $\mu$ moles de sacarose hidrolisada.

Procedimento

a. Para construir a curva padrão, utilizar 6 tubos de ensaio $(180 \times 20 \mathrm{~mm})$, conforme indicado abaixo, contendo volumes crescentes de solução padrão redutora (glicose $5,5 \mathrm{mM}+$ frutose $5,5 \mathrm{mM}$ ). Adicionar tampão de modo que cada tubo contenha $2,0 \mathrm{~mL}$ totais. Como não ocorrerá hidrólise de sacarose nos tubos de 1 a 5, pode-se acrescentar logo em seguida ao tampão, 2,0 mL de DNS.

$\begin{array}{cccccc}\text { Tubos } & \begin{array}{c}\text { Solução } \\ \text { padrão } \\ \text { redutora } \\ \text { (mL) }\end{array} & \begin{array}{c}\text { Solução } \\ \text { tampão } \mathbf{~ p H} \\ \mathbf{4 , 7 7}(\mathbf{m L})\end{array} & \begin{array}{c}\text { Reagente - } \\ \text { DNS (mL) }\end{array} & \begin{array}{c}\text { Abs } \\ \mathbf{5 4 0} \mathbf{~ n m}\end{array} & \begin{array}{c}\text { Sacarose } \\ \text { hidrolisada } \\ \boldsymbol{\mu M}\end{array} \\ \text { Branco } & - & 2,0 & 2,0 & 0,000 & 0,00 \\ 1 & 0,2 & 1,8 & 2,0 & & \\ 2 & 0,4 & 1,6 & 2,0 & & \\ 3 & 0,6 & 1,4 & 2,0 & & \\ \mathbf{4} & 0,8 & 1,2 & 2,0 & & \\ 5 & 1,0 & 1,0 & 2,0 & & \end{array}$


b. Após a adição de DNS, colocar os tubos em banho-maria fervente, por 10 minutos. Findo o tempo, esfriar em água corrente e adicionar $16 \mathrm{~mL}$ de água destilada. Homogeneizar e ler as absorbâncias a $540 \mathrm{~nm}$, contra o branco.

c. Construir um gráfico Abs x $\mu$ moles de sacarose hidrolisada (curva padrão).

B. Efeito da Concentração da enzima

Procedimento

a. Numerar sete tubos de ensaio $(180 \times 20 \mathrm{~mm})$ e colocá-los no gelo. Adicionar os reagentes segundo o protocolo abaixo.

\begin{tabular}{|c|c|c|c|c|c|c|}
\hline Tubos & $\begin{array}{c}\text { Sacarose } \\
5 \% \text { em } \\
\text { tampão }\end{array}$ & $\begin{array}{c}\text { Solução } \\
\text { tampão pH } \\
4,77(\mathrm{~mL})\end{array}$ & $\begin{array}{c}\text { Solução de } \\
\text { enzima } 0,24 \\
\mu \mathrm{M}(\mathrm{mL})\end{array}$ & $\begin{array}{c}\text { Concentração } \\
\text { de Enzima } \\
(\mu \mathbf{M})\end{array}$ & $\underset{540 \mathrm{~nm}}{\mathrm{Abs}}$ & $\begin{array}{c}\text { Sacarose } \\
\text { hidrolisada } / \\
\text { minuto } \\
(\mu \mathrm{M} / \mathrm{min})\end{array}$ \\
\hline Branco & 1,0 & 1,0 & - & 0,00 & 0,000 & 0,00 \\
\hline 1 & 1,0 & 0,9 & 0,1 & & & \\
\hline 2 & 1,0 & 0,7 & 0,3 & & & \\
\hline 3 & 1,0 & 0,5 & 0,5 & & & \\
\hline 4 & 1,0 & 0,3 & 0,7 & & & \\
\hline 5 & 1,0 & 0,1 & 0,9 & & & \\
\hline 6 & 1,0 & - & 1,0 & & & \\
\hline
\end{tabular}

b. Após a adição da enzima, agitar suavemente. Retirar os tubos do gelo e colocá-los simultaneamente em banho-maria a $37{ }^{\circ} \mathrm{C}$, por 5 ou 7 minutos. Transcorrido este tempo, os tubos devem voltar imediatamente para o gelo. Assume-se que nesse instante a reação pára. Ainda no gelo, adicionar a cada tubo $2 \mathrm{~mL}$ de DNS. Transferir os tubos para banho-maria fervente e esperar 10 minutos. Findo este tempo, esfriar em água corrente e adicionar $16 \mathrm{~mL}$ de água destilada em cada tubo. Agitar com inversão da posição vertical ( 3 vezes). Ler as absorbâncias a $540 \mathrm{~nm}$.

c. Fazer um gráfico, colocando a concentração da enzima em $\mu \mathrm{M}$ nas abcissas e a velocidade de hidrólise, expressa em $\mu$ moles de sacarose hidrolisada por minuto, nas ordenadas.

C. Efeito da concentração do substrato

Procedimento

a. Numerar 7 tubos de ensaio $(180 \times 20 \mathrm{~mm})$ e colocá-los no gelo para adicionar os reagentes, segundo o protocolo abaixo:

\begin{tabular}{|c|c|c|c|c|c|c|}
\hline Tubos & $\begin{array}{l}\text { Sacarose } \\
5 \% \text { em } \\
\text { tampão }\end{array}$ & $\begin{array}{c}\text { Solução } \\
\text { tampão pH } \\
\mathbf{4 , 7 7 ( m L )}\end{array}$ & $\begin{array}{c}\text { Solução de } \\
\text { enzima } 0,48 \\
\mu \mathrm{M}(\mathrm{mL})\end{array}$ & $\begin{array}{c}\text { Concentração } \\
\text { de Enzima } \\
(\mu \mathrm{M})\end{array}$ & $\begin{array}{c}\text { Abs } \\
540 \mathrm{~nm}\end{array}$ & $\begin{array}{c}\text { Sacarose } \\
\text { hidrolisada } / \\
\text { minuto } \\
(\mu \mathbf{M} / \mathrm{min})\end{array}$ \\
\hline Branco & - & 1,5 & 0,5 & 0,00 & 0,000 & 0,00 \\
\hline 1 & 0,05 & 1,45 & 0,5 & & & \\
\hline 2 & 0,1 & 1,4 & 0,5 & & & \\
\hline 3 & 0,3 & 1,2 & 0,5 & & & \\
\hline 4 & 0,5 & 1,0 & 0,5 & & & \\
\hline 5 & 0,7 & 0,8 & 0,5 & & & \\
\hline 6 & 1,0 & 0,5 & 0,5 & & & \\
\hline
\end{tabular}

b. Proceder exatamente como no experimento anterior.

c. Fazer um gráfico de velocidade ( $\mu \mathrm{M}$ de sacarose hidrolisada / min) X concentração inicial do substrato ( $\mathrm{mM}$ de sacarose). Estimar os valores de $\mathrm{V}_{\text {max }}$ e $\mathrm{K}_{\mathrm{M}}$.

d. Fazer o gráfico de Lineweaver-Burk e calcular os valores exatos de $V_{\max }$ e $\mathrm{K}_{\mathrm{M}}$. Comparar com o valor de $\mathrm{K}_{\mathrm{M}}$ encontrado na literatura.

Resultados e Discussão

1. Determinar as curvas obtidas e responder as questões propostas acima.

2. Elaborar protocolos para estudar os efeitos da temperatura e do $\mathrm{pH}$ sobre a atividade enzimática.

Bibliografia:

Boyer, ed. The Enzymes, vol. 5, cap. 10, 1971.

Villela, Bacila e Tastaldi. Técnicas e experimentos de Bioquímica, cap. 4, p. 222 a 232, 1973.

Asare-Brown,E. e Bullock, C. Simple Practical Investigations Using Invertase. Biochm. Educ., v. 16, n. 2, p.98$100,1988$.

Aula Prática II ( $2^{\underline{a}}$ Aula Prática da programação)

Cadeia respiratória - Fracionamento celular; verificação da atividade da succinato desidrogenase; inibição da succinato desidrogenase por malonato

Objetivos

Realizar o fracionamento celular a partir do figado de um rato, identificar a fração que contém a succinato desidrogenase e verificar a sua inibição competitiva pelo malonato. 


\section{A. Fracionamento celular}

Procedimento

a. Sacrificar um rato por concussão cerebral. Remover o figado, mergulhá-lo em $20 \mathrm{~mL}$ de uma solução de sacarose $0,25 \mathrm{M}$ (previamente resfriada a $0{ }^{\circ} \mathrm{C}$ ), picando-o bem com tesoura. Decantar e descartar o sobrenadante. Adicionar outros $20 \mathrm{ml}$ da solução de sacarose, misturar, tornar a decantar e descartar o sobrenadante.

b. Adicionar novamente $20 \mathrm{~mL}$ de sacarose $0,25 \mathrm{M}$, homogeneizar o fígado e centrifugar a $800 \mathrm{x} \mathrm{g}$

(4 000 rpm), por 10 minutos. Você obterá o precipitado 1.

c. Separar o sobrenadante 1 e centrifugá-lo novamente a 10000 x g $(10000 \mathrm{rpm})$, por 30 minutos. Novamente você obterá o precipitado 2 e o sobrenadante 2.

d. Recolher o sobrebadante 2 com uma pipeta Pasteur, em tubo de ensaio, e conservá-lo no gelo. Essa será a fração celular 1 .

e. Ressuspender o precipitado 2 obtido, em $2 \mathrm{~mL}$ de sacarose $0,25 \mathrm{M}$ gelada. Essa será a fração celular 2.

$B$. Verificação da atividade da succinato desidrogenase

Informações

$\mathrm{O}$ azul de metileno pode apresentar-se na forma oxidada (azul) ou na forma reduzida (incolor). A redução desse corante pode ser obtida a partir da oxidação do succinato, catalisada pela succinato desidrogenase.

Procedimento

a. Seguir o protocolo 1 para verificar a oxidação do succinato. As frações devem ser incubadas a $37^{\circ} \mathrm{C}$, por 10 minutos.

b. Antes de iniciar o experimento, o grupo deve:

- escrever a reação que está sendo analisada;

- discutir as funções de succinato, sacarose, azul de metileno e óleo mineral;

- planejar o controle do experimento.

C. Inibição da succinato desidrogenase por malonato

Informações

Sabendo em que fração celular encontra-se a atividade da succinato desidrogenase, é possível observar a inibição competitiva da enzima por malonato, um processo historicamente importante na elucidação das etapas do ciclo de Krebs. A redução do MTT via succinato desidrogenase será utilizada. O MTT é amarelo quando oxidado e violeta quando reduzido, não sendo reoxidado pelo $\mathrm{O}_{2}$ do ar.

Procedimento

a. Siga o protocolo 2 .

b. Deixe os tubos 10 minutos à temperatura ambiente e compare suas cores. Se a reação estiver lenta (isso dependerá da sua preparação mitocondrial), aqueça os tubos a $37^{\circ} \mathrm{C}$, por 5 minutos, e compare-os novamente.

c. Não esqueça: a inibição é competitiva, existe o fator cinético e você deverá fazer as comparações atentamente, a curtos intervalos de tempo.

Protocolo 1

\begin{tabular}{lccccc}
\multicolumn{1}{c}{ Tubos } & $\mathbf{1}$ & $\mathbf{2}$ & $\mathbf{3}$ & $\mathbf{4}$ & $\mathbf{5}$ \\
Tampão A & $0,3 \mathrm{~mL}$ & $0,3 \mathrm{~mL}$ & $0,3 \mathrm{~mL}$ & $0,3 \mathrm{~mL}$ & $0,3 \mathrm{~mL}$ \\
Sacarose 0,7 M & $1,0 \mathrm{~mL}$ & $1,0 \mathrm{~mL}$ & $1,0 \mathrm{~mL}$ & $1,0 \mathrm{~mL}$ & $1,0 \mathrm{~mL}$ \\
Succinato 0,5 M & - & - & $0,2 \mathrm{~mL}$ & $0,2 \mathrm{~mL}$ & $0,2 \mathrm{~mL}$ \\
Azul de metileno & $0,1 \mathrm{~mL}$ & $0,1 \mathrm{~mL}$ & $0,1 \mathrm{~mL}$ & $0,1 \mathrm{~mL}$ & $0,1 \mathrm{~mL}$ \\
Água destilada & $1,5 \mathrm{~mL}$ & $1,5 \mathrm{~mL}$ & $1,3 \mathrm{~mL}$ & $1,3 \mathrm{~mL}$ & $1,4 \mathrm{~mL}$ \\
Fração celular & $0,1(1)$ & $0,1(2)$ & $0,1(1)$ & $0,1(2)$ & - \\
Nujol & $0,5 \mathrm{~cm}$ & $0,5 \mathrm{~cm}$ & $0,5 \mathrm{~cm}$ & $0,5 \mathrm{~cm}$ & $0,5 \mathrm{~cm}$
\end{tabular}

\section{Protocolo 2}

\begin{tabular}{lccccccc}
\multicolumn{1}{c}{ Tubos } & $\mathbf{1}$ & $\mathbf{2}$ & $\mathbf{3}$ & $\mathbf{4}$ & $\mathbf{5}$ & $\mathbf{6}$ & $\mathbf{7}$ \\
Tampão A & $0,2 \mathrm{~mL}$ & $0,2 \mathrm{~mL}$ & $0,2 \mathrm{~mL}$ & $0,2 \mathrm{~mL}$ & $0,2 \mathrm{~mL}$ & $0,2 \mathrm{~mL}$ & $0,2 \mathrm{~mL}$ \\
Malonato & - & - & - & $0,1 \mathrm{~mL}$ & $0,1 \mathrm{~mL}$ & $0,1 \mathrm{~mL}$ & $0,1 \mathrm{~mL}$ \\
Succinato $0,5 \mathrm{M}$ & - & $0,1 \mathrm{~mL}$ & $0,2 \mathrm{~mL}$ & - & $0,1 \mathrm{~mL}$ & $0,2 \mathrm{~mL}$ & $0,4 \mathrm{~mL}$ \\
MTT & $25 \mu \mathrm{L}$ & $25 \mu \mathrm{L}$ & $25 \mu \mathrm{L}$ & $25 \mu \mathrm{L}$ & $25 \mu \mathrm{L}$ & $25 \mu \mathrm{L}$ & $25 \mu \mathrm{L}$ \\
Água destilada & $0,6 \mathrm{~mL}$ & $0,5 \mathrm{~mL}$ & $0,4 \mathrm{~mL}$ & $0,5 \mathrm{~mL}$ & $0,4 \mathrm{~mL}$ & $0,3 \mathrm{~mL}$ & $0,1 \mathrm{~mL}$ \\
Fração celular & $0,2 \mathrm{~mL}$ & $0,2 \mathrm{~mL}$ & $0,2 \mathrm{~mL}$ & $0,2 \mathrm{~mL}$ & $0,2 \mathrm{~mL}$ & $0,2 \mathrm{~mL}$ & $0,2 \mathrm{~mL}$
\end{tabular}

\section{Resultados e discussão}

1. Escreva a reação catalisada pela succinato desidrogenase.

2. Por que o malonato inibe competitivamente essa enzima?

3. Explique o porquê de uma das duas frações celulares obtidas ser tão rica nessa enzima. 


\section{Aula Prática III ( $3^{\text {a }}$ Aula Prática da programação)}

Transaminação

Informações

A transaminação consiste na transferência reversível do grupo $\alpha$-amino de um $\alpha$-aminoácido a um $\alpha$ cetoácido, sem que os grupos $-\mathrm{NH}_{2}$ ou $-\mathrm{NH}_{3}^{+}$fiquem livres no meio aquoso. $\mathrm{O} \alpha$-aminoácido perde o grupo $\alpha$-amino e se converte no $\alpha$-aminoácido respectivo.

As transaminases encontram-se na maioria dos tecidos animais. A maioria dos $\alpha$-aminoácidos que fazem parte das proteínas participam em transaminações enzimáticas.

Objetivo

Verificar a reação de transaminação em homogenato de figado. Para tanto, uma alíquota de um homogenato de figado será incubada com um $\alpha$-aminoácido e um $\alpha$-cetoácido. A identificação dos produtos da reação será feita por cromatografia em papel.

\section{A. Preparação enzimática}

Procedimento

a. O figado de rato é picado e lavado 2 vezes com $20 \mathrm{~mL}$ de tampão fosfato $0,05 \mathrm{M}, \mathrm{pH} 7,4$ e, em seguida, é homogeneizado com $10 \mathrm{~mL}$ desse tampão fosfato.

b. Esse homogenato é centrifugado a $800 \times \mathrm{g}$, por 15 minutos, para eliminar células não destruídas e núcleos. O sobrenadante é decantado em um tubo de ensaio mantido em gelo: essa fração consiste na preparação enzimática (notar que não é necessária a enzima pura para que esta catalise a reação de transaminação).

\section{B. Reação de transaminação}

Procedimento

a. O sistema completo de reação é composto por um $\alpha$-aminoácido, um $\alpha$-cetoácido, a preparação enzimática, arsenito de sódio [ $\mathrm{NaAs})_{2}$ ] e tampão. O arsenito é empregado com a finalidade de evitar a oxidação posterior dos $\alpha$-cetoácidos pelo sistema enzimático presente no hepatócito.

b. Mistura de reação:

\begin{tabular}{lc}
\multicolumn{1}{c}{ Reagentes } & Volumes \\
$\alpha$-cetoglutarato 0,2 M, pH 7,4 & $0,1 \mathrm{~mL}$ \\
Alanina 0,2 M, pH 7,4 & $0,1 \mathrm{~mL}$ \\
Preparação enzimática & $0,2 \mathrm{~mL}$ \\
Tampão fosfato 0,05 M, pH 7,4 & $0,2 \mathrm{~mL}$ \\
Arsenito de sódio 0,2 M & $0,2 \mathrm{~mL}$
\end{tabular}

c. Incubar a $37{ }^{\circ} \mathrm{C}$, por 30 minutos. Em seguida, colocar em banho-maria fervente, por 3 minutos. Centrifugar por 10 minutos, em centrífuga Eppendorf.

d. Decantar o sobrenadante transferido para um segundo tubo Eppendorf e fazer a cromatografia com os padrões adequados.

Cromatografia em papel

Procedimento

a. Em um retângulo de papel de filtro Whatman $n^{\circ} 1(14 \times 20 \mathrm{~cm})$, traçar, com lápis, uma linha a $2,5 \mathrm{~cm}$ do lado maior e marcar pontos com $2,5 \mathrm{~cm}$ de distância entre si.

b. Colocar padrões de alanina, glutamato, piruvato e $\alpha$-cetoglutarato, mistura de reação, branco (mistura de apenas alanina e $\alpha$-cetoglutarato) e 2,4 dinitrofenilhidrazina. Sobre os pontos onde foram aplicados o $\alpha$ cetoglutarato, piruvato e mistura de reação, adicionar uma aplicação capilar de 2,4-dinitrofenilhidrazina. c. O solvente utilizado para a cronmatografia será n-butanol / etanol $/ \mathrm{NH}_{4} \mathrm{OH}(0,5 \mathrm{~N})(70: 20: 30, \mathrm{v} / \mathrm{v} / \mathrm{v})$. d. Após o solvente chegar a $1 \mathrm{~cm}$ da extremidade do papel, interromper a cromatografia, marcar a frente do solvente, secar o papel, marcar as manchas amarelas dos produtos de reação da 2,4-dinitrofenilhidrazina e os $\alpha$-cetoácidos e revelar o cromatograma com ninhidrina. Marque imediatamente as manchas reveladas.

Resultados $e$ discussão

1. Interprete os resultados obtidos na cromatografia.

2. Qual é o significado da palavra transaminar?

3. Por que as transaminases são tão importantes?

4. O que aconteceria com seus resultados, caso não tivesse utilizado o arsenito de sódio? 


\section{FACULDADE DE CIÊNCIAS FARMACÊUTICAS}

\section{Anexo 13 - Currículo do Curso de Farmácia e Bioquímica}

\section{Ciclo Básico}

Matemática para Biociências

Química Geral e Inorgânica Básicas

Introdução às Ciências Farmacêuticas

Primeiros Socorros

Introdução às Medidas Físicas para Farmácia

Noções de Estatística

Química Orgânica I

Físico-Química

Química Inorgânica

Física para Ciências Farmacêuticas I

Química Orgânica II

Química Orgânica Experimental

Química Analítica Qualitativa

Anatomia Humana I

Citologia, Histologia e Embriologia I

Fisiologia e Biofisica I

Bioquímica: Estrutura de Biomoléculas e Metabolismo

Bioquímica Experimental

Anatomia Humana II

Citologia, Histologia e Embriologia II

Fisiologia e Biofisica II

Química Analítica Quantitativa

Microbiologia Básica

Imunologia Básica

Parasitologia

Bromatologia - tópicos gerais

Química Analítica Instrumental

Bioquímica e Biologia Molecular do Gene

Patologia - processos gerais

Farmacodinâmica

Química Farmacêutica

Compostos Heterocíclicos

Biofarmacognosia (Farmacobotânica e Farmacognosia)

Farmacotécnica

Ciclo Profissional

Modalidade Alimentos

Toxicologia I

Física Industrial

Tecnologia de Soros e Vacinas (optativa)

Saúde Pública Aplicada às Ciências Farmacêuticas

Metodologia e Aplicações de Radioisótopos

Física para Ciências Farmacêuticas II

Deontologia e Legislação Farmacêuticas

Organização Farmacêutica (Economia e Administração de Empresas Farmacêuticas)

Análise Microbiológica de Alimentos

Tecnologia de Fermentações para Alimentos

Análise de Alimentos

Química e Bioquímica de Alimentos

Genética Humana

Enzimologia Industrial

Fiscalização de Alimentos

Tecnologia de Alimentos

Controle de Qualidade de Alimentos

Nutrição Humana

Supervisão de Produção

Pescado como Alimento (optativa)

Modalidade Análise Clínicas e Toxicológicas

Metodologia e Aplicações de Radioisótopos 
Toxicologia I

Saúde Pública Aplicada às Ciências Farmacêuticas

Imunologia Clínica

Deontologia e Legislação Farmacêuticas

Bioquímica Clínica

Organização Farmacêutica (Economia e Administração de Empresas Farmacêuticas)

Hematologia Clínica

Citologia Clínica

Toxicologia II

Genética Humana

Microbiologia Clínica

Garantia de Qualidade em Análises Clínicas

Parasitologia e Micologia Clínicas

Administração de Laboratório de Análises Clínicas (optativa)

Farmacotécnica

Modalidade Fármaco e Medicamento

Física Industrial

Toxicologia I

Física para Ciências Farmacêuticas II

Saúde Pública Aplicada às Ciências Farmacêuticas

Farmacotécnica

Metodologia e Aplicações de Radioisótopos

Deontologia e Legislação Farmacêuticas

Organização Farmacêutica (Economia e Administração de Empresas Farmacêuticas)

Tecnologia das Fermentações

Farmacoterapia

Cosmetologia

Farmacotécnica Industrial

Genética Humana

Enzimologia Industrial

Supervisão de Produção

Tecnologia Químico-Farmacêutica

Controle Físico-Químico de Qualidade de Medicamentos e Cosméticos

Controle Biológico de Qualidade de Medicamentos e Cosméticos

Farmácia Hospitalar (optativa)

Tecnologia de Soros e Vacinas (optativa)

\section{Anexo 14-Programa da Disciplina de Bioquímica Experimental}

Introducão

Este curso prático, oferecido aos alunos de Farmácia e Bioquímica, tem como objetivos:

- Complementar a formação de bioquímica básica, relativa à estrutura de biomoléculas e ao metabolismo celular.

- Colocar os alunos em contato com diversas técnicas de laboratório empregadas nessa área e introduzir os princípios teóricos nas quais elas se baseiam.

Com vistas a atingir tais objetivos:

- foram selecionados experimentos que utilizam tais técnicas e demonstram experimentaímente o que está sendo estudado no curso teórico complementar. Tais experimentos e seus princípios básicos deverão ser discutidos com os alunos, previamente e posteriormente à sua realização. Esses foram divididos em dois blocos: o primeiro bloco referese à estrutura e propriedade de aminoácidos, peptídeos, proteínas, enzimas e membranas e o segundo bloco, algumas etapas importantes do metabolismo celular,

- foram elaboradas aulas de discussão e de exercícios para esclarecer, ampliar e consolidar os conhecimentos adquiridos durante a realização dos experimentos propostos;

- foram propostos seminários a serem dados pelos alunos, sobre temas de grande importância prática em Bioquímica.

\section{Estrutura das aulas}

O curso consistirá de aulas de discussão, de laboratório e de revisão / exercícios.

O total de alunos será dividido em duas turmas, A e B. Durante todo o semestre, cada turma terá um único professor e monitoria de dois estudantes de Pós-Graduação.

Cada uma das aulas será antecedida de uma discussão geral sobre o experimento a ser realizado, sobre a(s) técnica(s) empregada(s) e sobre os princípios teóricos nas quais elas se baseiam. Essa discussão será coordenada pelo professor responsável pela turma. Em seguida, os alunos elaborarão um protocolo a ser utilizado 
para a realização do experimento (isso não aconteceu nas aulas observadas), que será discutido antes de ser posto em prática. Finalmente, o experimento será realizado por grupo de 4 alunos e os resultados obtidos serão discutidos. Durante essas duas últimas etapas, a turma contará com a assistência do docente responsável e dos monitores.

Aulas de revisão / exercícios antecederão às provas dadas no semestre.

Os seminários terão um caráter monográfico e deverão ser apresentados por grupos de 4 a 5 alunos, tendo duração de $\sim 50$ minutos.

\section{Avaliação}

Testes esporádicos de avaliação individual deverão ser aplicados pelos professores, durante as aulas de discussão, tanto nas que antecedem os experimentos, quanto naquelas que os sucedem. Tais testes versarão sobre a matéria dada até então ou sobre o tópico em estudo, na ocasião.

Os seminários apresentados serão avaliados em seu conteúdo, clareza de apresentação e organização.

Serão realizadas duas provas durante o semestre, sobre os conteúdos estudados durante os períodos que as precederam. Uma prova substitutiva, versando sobre a matéria dada no semestre também será aplicada no final do curso: essa deverá substituir uma das provas anteriores, ficando a critério do aluno a escolha de fazê-la ou não.

O cálculo da média deve ser feito com base na seguinte distribuição: provas $=50 \%$; seminários $=25 \%$; testes $=25 \%$.

Serão aprovados os alunos que atingirem média superior a 5,0.

Por considerar importante que saber relatar e discutir um experimento e seus resultados é tão importante quanto planejá-lo e executá-lo, os professores e monitores deste curso colocam-se à disposição dos alunos para corrigir e discutir um mínimo de 3 e um máximo de 5 relatórios de cada um dos grupos de trabalho, entregues ao longo do curso (após 15 dias da realização do expcrimento). Além de aprimorar-se nessa atividade, os alunos que decidirem pela confeç̧ão / entrega dos relatórios poderão ser beneficiados, em caso de não conseguirem atingir nota 5,0, exigida para aprovação. A média final atingida poderá sofrer um acréscimo de até $25 \%$ de seu valor.

Ex: média final atingida 4,5; nota de relatório - 10,0

Nota final: $4,5+1,13(25 \%$ de 4,5$)=5,63$

Aulas de laboratório

A participação nas aulas práticas é obrigatória. É também obrigatório o uso do avental e, sempre que necessário, de luvas e óculos de segurança próprios.

Bibliografia

Voet, D. e Voet, J.G. Biochemistry. $2^{\mathbb{a}}$ ed. Wiley \& Sons.

Lehninger, A.L., Nelson, D.L. e Cox, M.M. Principles in Biochemistry. $2^{\mathrm{a}}$ ed. Worth Publishers.

Stryer, L.B. Biochemistry. $4^{\mathrm{a}}$ ed. W. H. Freeman and Company.

Marzzocco, A. e Torres, B.B. Bioquímica básica. $2^{\mathrm{a}}$ ed. Rio de Janeiro: Ed. Guanabara, 1999.

\section{Conteúdo programático}

\section{Temas dos seminários}

(para sua preparação, sugerimos consulta adicional à literatura mais especializada, sugerida pelos professores ou encontrada na Biblioteca do Conjunto das Químicas)

1. Separação e dosagem de aminoácidos

2. Separação e dosagem de proteínas

3. Separação e dosagem de açúcares

4. Preparação e isolamento de peptídeos

5. Vitaminas: papel biológico e dosagem

6. Determinação da estrutura primária de uma proteína

7. Métodos de investigação estrutural e propriedades de membranas biológicas

8. Caracterização química de uma biomolécula

9. Investigação da conformação de uma biomolécula em solução

10. O emprego das enzimas em diferentes áreas da Bioquímica

11. Hormônios: importância bioquímica e métodos de dosagem

Programação

Introdução / Discussão

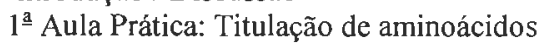

Discussão

$2^{\underline{a}}$ Aula Prática: Separação de aminoácidos por cromatografia em papel; separação entre um aminoácido, um derivado de aminoácido e um peptídeo, por cromatografia em camada delgada

Discussão

$3^{\mathbf{a}}$ Aula Prática: Separação de proteínas por eletroforese em fita de acetato de celulose

Discussão

$4^{\mathrm{a}}$ Aula Prática: Dosagem de proteínas pelo método do biureto; fracionamento de proteínas do soro sangüineo Discussão

5ª Aula Prática: Espectro de hemoglobina 


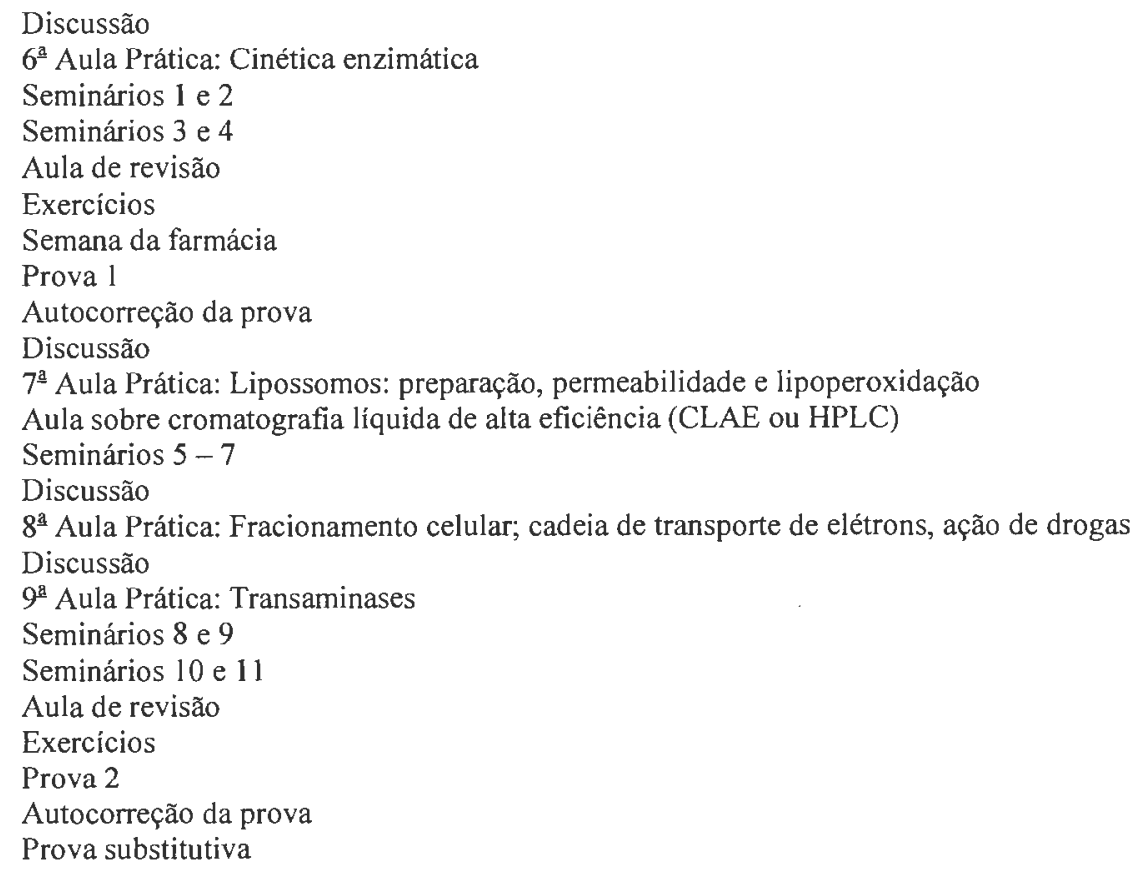

Anexo 15 - Protocolos das Aulas Práticas observadas (transcritos dos protocolos impressos fomecidos aos alunos pelo professor)

Aula Prática I ( $2^{\underline{a}}$ Aula Prática da programação)

Separação de aminoácidos por cromatografía em papel

Informações

A cromatografia em papel é uma técnica muito usada em Bioquímica, para a separação e identificação de componentes de determinadas misturas de biomoléculas.

A separação baseia-se na migração diferencial dos compostos da mistura, num sistema formado por duas fases, a estacionária (que é a celulose do papel) e a móvel (que é o solvente ou mistura de solventes que percorre o papel por capilaridade e arrasta as substâncias nele depositadas). Nesse sistema, o principal fenômeno responsável é a partição, isto é, a relação entre a quantidade de substância que permanece na fase estacionária, quando o solvente percorre o papei por capilaridade, e a quantidade de substância que migra com o solvente. De maneira geral, se a fase móvel empregada for menos polar que a celulose do papel (a fase estacionária), pode-se prever que substâncias pouco polares migrarão mais do que as mais polares. É justamente essa diferença de comportamento que permite uma separação eficiente.

A identificação baseia-se na comparação entre as migrações de substâncias conhecidas (padrões ou referências) que são analisadas isolada ou juntamente e as dos componentes da mistura-problema. Para efeito prático, a migração é medida por um parâmetro chamado $R_{f}$ (razão de fluxo), que nada mais é do que a relação entre a distância (d) migrada pela substância e a distância ( $L_{f}$ ou linha de frente) percorrida pelo solvente, ou seja, $R_{f}=d / L_{f}$. Os $R_{f} s$ são sempre $<l$ ou $=1$. O reconhecimento da presença dos padrões e dos componentes da mistura-problema no processo de análise dá-se, geralmente, por meio de reações químicas que produzem, com as substâncias analisadas, produtos coloridos. Esse reconhecimento possibilita a determinação das posições das substâncias no papel. Substâncias que, num mesmo sistema cromatográfico, possuem o mesmo $R_{\mathrm{f}}$ e dão a mesma reação de coloração são muito provavelmente idênticas.

Objetivos

Neste experimento, será analisada cromatograficamente uma mistura composta de aminoácidos. Os padrões são aminoácidos conhecidos, que são aplicados separadamente no papel, onde sua posição é revelada pela reação com ninhidrina.

O objetivo é introduzir o conceito de $\mathrm{R}_{\mathrm{f}}$ e demonstrar a separação e identificação de aminoácidos por meio da cromatografia em papel.

Materiais

reagentes e solventes:

- $\quad$ solução de ninhidrina $(0,1 \%$ em acetona)

- mistura desconhecida de aminoácidos

- aminoácido conhecido

- soluções-padrões de aminoácidos

- $\quad$ mistura de n-butanol:ácido acético:água $(4: 1: 1, \mathrm{v} / \mathrm{v} / \mathrm{v})$ 
por grupo:

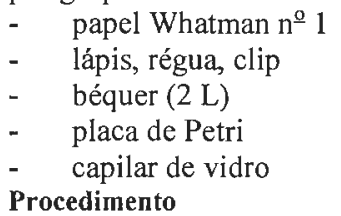

Procedimento

a. Tomar uma folha $(21 \times 16 \mathrm{~cm})$ de papel Whatman $\mathrm{n}^{\circ} 1$ e fazer um traço, a lápis, ao longo do comprimento maior e a $2 \mathrm{~cm}$ da borda. Evitar tocar com os dedos o papel, durante toda a operação.

b. Marcar 5 pontos sobre o traço, que distem $3 \mathrm{~cm}$ um do outro e numerá-los a lápis, de 1 a 5 . As amostras devem ser aplicadas nos pontos numerados, com o auxílio de um capilar de vidro, de forma que a mancha sobre o papel tenha o menor diâmetro possível. Nos pontos de 1 a 4 , aplicar os padrões e no 5 , a amostra a ser analisada.

c. Enrolar o papel de modo a transformá-lo num cilindro e prender as extremidades superiores com a ajuda de um clip. Colocar $25 \mathrm{~mL}$ do solvente de Patridge (n-butanol:ácido acético:água 4:1:1, v/v/v) em uma placa de Petri e mergulhar o cilindro de papel em seu interior, de modo que esse fique perfeitamente vertical. Evitar que o papel toque a parede da placa.

d. Cobrir o sistema com um béquer de 2 litros e deixar o solvente migrar uns $10 \mathrm{~cm}$.

e. Retirar o papel e marcar imediatamente a linha de frente do solvente, usando lápis. Secar o papel na capela, com o exaustor ligado, mergulhar em solução $0,1 \%$ de ninhidrina em acetona e levar à estufa $(80-100$ ${ }^{\circ} \mathrm{C}$ ), durante $3-4$ minutos.

\section{Cuidado especial}

- Não utilize luvas para a preparação do papel, aplicação de amostras e revelação.

- Não fale, assopre ou espirre sobre o papel.

Resultados e discussão

1. Traçar os centros imaginários de cada mancha. Determinar a distância migrada (d), medindo a distância entre a intersecção das duas linhas, centro hipotético da mancha e origem (ponto de aplicação).

2. Calcular os valores de $\mathrm{R}_{\mathrm{f}}$ de cada componente da mistura e dos padrões empregados.

3. Identificar os aminoácidos desconhecidos, comparando as distâncias de migração dos padrões e dos aminoácidos desconhecidos e comparando os $\mathrm{R}_{\mathrm{f}} \mathrm{s}$ dos desconhecidos com os valores listados na tabela abaixo:

$\begin{array}{cccc}\text { Aminoácido } & \mathbf{R}_{\boldsymbol{f}} & \text { Aminoácido } & \mathbf{R}_{\mathbf{f}} \\ \text { Cys } & 0,08 & \text { Ala } & 0,38 \\ \text { Lys } & 0, \mathrm{I} 4 & \text { Pro } & 0,43 \\ \text { His } & 0,20 & \text { Tyr } & 0,45 \\ \text { Arg } & 0,20 & \text { Trp } & 0,50 \\ \text { Asp } & 0,20 & \text { Met } & 0,55 \\ \text { Gly } & 0,26 & \text { Val } & 0,60 \\ \text { Ser } & 0,27 & \text { Phe } & 0,68 \\ \text { Glu } & 0,35 & \text { Ile } & 0,72 \\ \text { Thr } & 0,35 & \text { Leu } & 0,73\end{array}$

4. Indicar se houve discrepância de resultados entre os dois métodos. Em caso positivo, sugerir uma explicação para esse fato.

5. Escrever as fórmulas estruturais dos aminoácidos identificados e a sua reação com ninhidrina. Sugerir uma explicação para o seu comportamento cromatográfico (maior ou menor migração em relação aos padrões), com base na polaridade de sua cadeia lateral.

Separação entre um aminoácido, um derivado de aminoácido e um peptídeo, por cromatografia em camada delgada Informaçסes

A separação de uma mistura por cromatografia, em uma camada delgada de sílica, baseia-se nos seguintes fenômenos: adsorção e partição. Nesse caso, a fase estacionária é uma camada fina de sílicagel, fixada a uma placa de vidro, plástico ou alumínio. Essas fases estacionárias podem ser adquiridas no comércio ou preparadas em laboratório. Em ambos os casos, a espessura da camada é determinada.

A cromatografia em camada delgada é uma técnica útil para a análise e separação de aminoácidos, peptídeos e derivados de ambos ou ainda para a determinação da pureza desses compostos. Na etapa de separação, empregam-se fases estacionárias de composiçôes variáveis: clorofórmio / metanol / ácido acético; clorofórmio / metanol; clorofórmio / ácido acético; acetona / ácido acético; butanol / ácido acético / água; propano / hidróxido de amônia; clorofórmio / acetona, em diferentes proporções. A revelação dos compostos separados pode ser feita com diferentes reagentes. Alguns deles, tais como a ninhidrina, fluorescamina e o clorox (este último consiste em sprays alternados de hipoclorito de sódio, etanol, iodeto de potássio e o-toluidina) reagem especificamente com os grupamentos $\alpha$-amino dos aminoácidos. Outros são específicos para determinados grupos químicos presentes nas cadeias laterais dos aminoácidos: iodoplatinato de sódio (específico para grupos $\mathrm{SH}$ ) e o reativo de Sakaguchi (sprays alternados de $\alpha$-naftol e hipoclorito de sódio), específico para arginina. 


\section{Objetivos}

Realizar uma cromatografia em camada delgada de dois aminoácidos, um derivado de aminoácido e um peptídeo; determinar os valores de $\mathrm{R}_{\mathrm{f}}$ de cada um deles e prever o comportamento cromatográfico desses compostos em função de suas polaridades e daquelas dos sistema eluentes empregados.

\section{Materiais}

por grupo:

- placas de sílica-gel de $0,25 \mathrm{~mm}$ de espessura

- lápis

- borrifador

- $\quad$ cuba de vidro com tampa

- papel de filtro

- capilar de vidro

para a classe:

- bomba de vácuo

reagentes e solventes:

- $\quad$ solução de aminoácidos (Asp e Phe)

- $\quad$ solução de derivado de aminoácido (Boc-Asp(Obzl)-OH) em MeOH

- $\quad$ solução de peptídeo (Aspartame: Asp-Phe-oMe) em $\mathrm{H}_{2} \mathrm{O} / \mathrm{MeOH}(4: 1, \mathrm{v} / \mathrm{v}$ )

- ácido acético

- clorofórmio

- metanol

- solução de ácido clorídrico $1 \mathrm{~N}$

- $\quad$ solução de ninhidrina em etanol $2 \%$

\section{Procedimento}

a. Preparar a placa de sílica para aplicação da amostra, fazendo um risco com lápis, bem apontado, a 2,5 $\mathrm{cm}$ da borda de sílica. Essa será a linha de origem para aplicação das amostras.

b. Com o auxílio de um capilar, em quatro pontos distintos, aplique as suas soluções, contendo os compostos a serem identificados.

c. Prepare $50 \mathrm{~mL}$ da fase móvel clorofórmio / metanol / ácido acético / água (70:20:10:10, v/v/v/v) e coloque-a dentro da cuba de vidro contendo um pedaço de papel de filtro no fundo. Feche-a imediatamente e aguarde 15 minutos.

d. Segurando pela parte superior, coloque a placa de vidro contendo as amostras em contato com o solvente. Feche a cuba.

e. Permita que a eluição ocorra até que a fase móvel atinja $2 \mathrm{~cm}$ abaixo da borda superior da camada de sílica.

f. Retire a placa, seque-a na capela, por 15 minutos.

g. Em seguida, proceda a revelação com ninhidrina, de acordo com as instruções do professor ou monitores (grupos 1-5: solução de $\mathrm{HCl}$ seguida de solução de ninhdrina; grupos 6-10: solução de ninhidrina).

\section{Cuidado especial}

- $\quad$ Use luvas durante as etapas de aplicação das amostras e revelação.

- Não toque na camada delgada em nenhuma das etapas.

- Não assopre, fale ou espirre sobre a camada delgada.

\section{Resultados e discussão}

1. Quais os $\mathrm{R}_{\mathrm{f}} \mathrm{s}$ encontrados para cada um dos compostos revelados?

2. Esses valores seriam modificados no caso de ter sido usada a fase móvel composta por butanol / ácido acético / água $(4: 1: 1, \mathrm{v} / \mathrm{v} / \mathrm{v})$ ? Por quê?

3. Por que um dos compostos não foi revelado após borrifamento com solução de ninhidrina?

4. Liste outros reagentes empregados na revelação de aminoácidos e peptideos empregados. Indique com que grupos específicos eles reagem, que colorações são obtidas e, se possível, que reações químicas ocorrem.

Aula Prática 11 ( $5^{\text {a }}$ Aula Prática da programação)

Informações

Os fundamentos da espectrofotometria já foram apresentados no protocolo da $4^{\underline{a}}$ Aula Prática.

Objetivo

Determinar os espectros da hemoglobina na região do visível.

Materiais

reagentes:

- hemolisado de sangue de rato ou cameiro

- ditionito de sódio em cristais

- ferricianeto de potássio $3 \mathrm{mM}$

- óleo mineral

Procedimento

a. Ajuste a concentração de hemoglobina no hemolisado, para obter uma leitura de 0,7 Abs a $540 \mathrm{~nm}$. 
b. Faça o espectro da oxihemoglobina na região do visível, entre 670 a $450 \mathrm{~nm}$, fazendo leituras de 5 em 5 nanômetros.

c. Prepare a desoxihemoglobina pela adição de alguns cristais de ditionito de sódio ao hemolisado diluído.

d. Misture rapidamente, sem fazer bolhas, transfira para a cubeta do espectrofotômetro e cubra a solução com um filme de óleo. Faça o espectro.

e. Prepare metahemoglobina pela adição de 1 a 2 gotas da solução de ferricianeto de potássio a $5 \mathrm{~mL}$ de hemolisado diluído. Faça o espectro.

f. Plote os dados obtidos em papel milimetrado e discuta os resultados.

Discussão

1. A que se deve a absorção de luz pela hemoglobina, na região do visível?

2. Seria possível fazer um espectro de absorção para a albumina? Em que faixa de comprimentos de onda você esperaria encontrar picos de absorção? A que aminoácidos seriam devidos?

3. Como se comparam os espectros de absorção de proteínas e de ácidos nucléicos na região do ultravioleta? Espectros podem ser usados para identificar substâncias?

Caso Clínico

Um bebê com 26 semanas foi levado a uma clínica pediátrica por apresentar letargia crescente e cianose. A criança nasceu bem de saúde e era amamentada pela mãe. Como não apresentava um padrão normal de crescimento, o médico da família havia recomendado, anteriormente, que fosse dada ao bebê uma suplementação alimentar com mamadeira. Quando a criança deu entrada na clínica, o leite da mãe já havia virtualmente secado.

Uma amostra de sangue foi coletada durante o exame inicial. O médico residente agitou uma alíquota do sangue que estava em contato com o ar da sala, por vários minutos, mas não notou mudança de cor. $O$ restante da amostra foi enviado ao laboratório clínico para outros exames e o teste para metahemoglobinemia deu positivo. O bebê foi tratado com ascorbato e azul de metileno, por via endovenosa. Em dois dias, a criança foi dispensada e a mãe instruída para preparar a mamadeira com água destilada.

O que se pode concluir desse problema clínico?

Informação - As metahemoglobinemias podem ser adquiridas ou hereditárias. As adquiridas advêm de contaminação por agentes tóxicos do ambiente e as hereditárias, por alterações na estrutura primária da hemoglobina ou das enzimas que mantêm o Ferro na forma $\mathrm{Fe}^{2+}$.

Aula Prática III ( $8^{\text {a }}$ Aula Prática da programação)

Fracionamento celular, verificação da atividade da succinato desidrogenase; inibição da succinato desidrogenase por malonato

Ver Aula Prática II - Anexo 12

Determinação do ponto de ação de drogas na cadeia de transporte de elétrons

Objetivos

Verificar o funcionamento da cadeia de transporte de elétrons e determinar o ponto de ação de algumas drogas na mesma.

Informaçōes

A determinação do ponto de ação de drogas na cadeia de transporte de elétrons deve ser feita com o uso de aceptores e doadores artificiais de elétrons: a escolha daqueles a serem utilizados deve ser feita, consultando as tabelas que se seguem.

Os aceptores e doadores são fornecidos na forma oxidada, com exceção do reagente p-fenilenodiamina.

\begin{tabular}{|c|c|}
\hline PAR REDOX & $\mathbf{E}_{0}^{\prime}$ \\
\hline $\mathrm{NADH} / \mathrm{NAD}^{+}$ & $-0,32$ \\
\hline Succinato / Fumarato & $-0,30$ \\
\hline $\mathrm{FADH}_{2} / \mathrm{FAD}$ & 0,00 \\
\hline Azul de metileno red / ox & 0,10 \\
\hline Cit b $\left(\mathrm{Fe}^{2+}\right) /$ Cit b $\left(\mathrm{Fe}^{3+}\right)$ & 0,06 \\
\hline Cit $c_{1}\left(\mathrm{Fe}^{2+}\right) / \mathrm{Cit}_{1}\left(\mathrm{Fe}^{3+}\right)$ & 0,22 \\
\hline Cit $\mathrm{c}\left(\mathrm{Fe}^{2+}\right) / \mathrm{Cit} \mathrm{c}\left(\mathrm{Fe}^{3+}\right)$ & 0,25 \\
\hline Cit a-a $\left(\mathrm{Fe}^{2+}\right) /$ Cit a-a $\mathrm{a}_{3}\left(\mathrm{Fe}^{3+}\right)$ & 0,40 \\
\hline $\mathrm{H}_{2} \mathrm{O} / 1 / 2 \mathrm{O}_{2}$ & 0,82 \\
\hline
\end{tabular}

ACEPTORES E DOADORES ARTIFICIAIS E'

Piocianina red / ox $\quad-0,34$

2,6-diclorofenolindofenol (DCPI) red / ox $\quad-0,20$

Benzilviológeno red / ox $\quad-0,36$

Ferricianeto $\mathrm{Fe}(\mathrm{CN})_{6}{ }^{4-} / \mathrm{Fe}(\mathrm{CN})_{6}{ }^{3-} \quad 0,36$

p-fenilenodiamino (p-FDA) red / ox $\quad 0,77$ 
COR DOS ACEPTORES E DOADORES ARTIFICIAIS

Piocianina

2,6-diclorofenolindofenol (DCPI)

Benzilviológeno

Ferricianeto

p-fenilenodiamino (p-FDA)

\begin{tabular}{|c|c|c|}
\hline & & VOLUME \\
\hline REDUZIDO & OXIDADO & UTILIZADO \\
\hline incolor & azul & 0,1 \\
\hline incolor & azul & 0,3 \\
\hline incolor & violeta & 0,3 \\
\hline incolor & amarelo & 0,2 \\
\hline incolor & violeta & 0,5 \\
\hline
\end{tabular}

Procedimento

a. Fazer um esquema da cadeia de transporte de elétrons da mitocôndria, localizando a posição dos aceptores e doadores de elétrons (tabela acima), de acordo com seu potencial redox.

b. Usar o protocolo 3 a seguir.

c. Incubar os tubos a $37^{\circ} \mathrm{C}$, por 10 minutos e discutir o resultado com os colegas, identificando as drogas A e B.

Resultados e discussão

1. Discutir a escolha dos aceptores e doadores artificiais de elétrons.

2. Discutir as evidências experimentais obtidas, que permitem determinar o ponto de ação das drogas A e B.

3. Por que o uso de aceptores e doadores artificiais de elétrons foi importante no estabelecimento da seqüência de transportadores da cadeia e a determinação do ponto de ação de certas drogas?

\section{$\underline{\text { Protocolo } 3}$}

Tubos

Tampão A

Sacarose $0,7 \mathrm{M}$

Succinato $0,5 \mathrm{M}$

Droga A ou B

Ferricianeto

DCPI

p-FDA

Água destilada

Fração celular

Nujol

$\begin{array}{ccccccccc}\mathbf{1} & \mathbf{2} & \mathbf{3} & \mathbf{4} & \mathbf{5} & \mathbf{6} & \mathbf{7} & \mathbf{8} & \mathbf{9} \\ \mathbf{( \mathbf { m } \mathbf { L } )} & (\mathbf{m} \mathbf{L}) & (\mathbf{m L}) & (\mathbf{m L}) & (\mathbf{m L}) & (\mathbf{m L}) & (\mathbf{m L}) & (\mathbf{m L}) & (\mathbf{m L}) \\ 0,4 & 0,4 & 0,4 & 0,4 & 0,4 & 0,4 & 0,4 & 0,4 & 0,4 \\ 1,0 & 1,0 & 1,0 & 1,0 & 1,0 & 1,0 & 1,0 & 1,0 & 1,0 \\ - & - & - & 0,2 & 0,2 & - & 0,2 & 0,2 & - \\ - & - & - & - & - & - & 0,1 & 0,1 & 0,1 \\ 0,2 & - & - & 0,2 & - & - & 0,2 & - & - \\ - & 0,3 & - & - & 0,3 & - & - & 0,3 & - \\ - & - & 0,5 & - & - & 0,5 & - & - & 0,5 \\ 1,3 & 1,2 & 1,0 & 1,0 & 0,9 & 0,9 & 0,9 & 0,8 & 0,8 \\ - & - & - & 0,2 & 0,2 & 0,2 & 0,2 & 0,1 & 0,1 \\ 0,5 \mathrm{~cm} & 0,5 \mathrm{~cm} & 0,5 \mathrm{~cm} & 0,5 \mathrm{~cm} & 0,5 \mathrm{~cm} & 0,5 \mathrm{~cm} & 0,5 \mathrm{~cm} & 0,5 \mathrm{~cm} & 0,5 \mathrm{~cm}\end{array}$

$\underline{\text { Aula Prática IV ( }} 9^{\mathrm{a}}$ Aula Prática da programação)

Transaminação

Ver Aula Prática III - Anexo 12 


\section{INSTITUTO DE BIOCIÊNCIAS}

\section{Anexo 16 - Grade Curricular do Curso de Ciências Biológicas}

\section{Bacharelado}

Primeiro semestre $-450 \mathrm{~h}$

Geologia Geral - 60 h

Genética - $120 \mathrm{~h}$

Fauna, Flora e Ambiente - $60 \mathrm{~h}$

Princípios de Sistemática e Biogeografia - $60 \mathrm{~h}$

Matemática - $30 \mathrm{~h}$

Noções de Estatística - 60 h

Química de Biomoléculas - 60 h*

Segundo semestre - $540 \mathrm{~h}$

Ecologia - $60 \mathrm{~h}$

Biologia Celular - $120 \mathrm{~h}$

Morfologia e Taxonomia de Criptógamas - $120 \mathrm{~h}$

Invertebrados I - $120 \mathrm{~h}$

Bioquímica $-120 \mathrm{~h}$ *

Terceiro semestre $-540 \mathrm{~h}$

Microbiologia - $60 \mathrm{~h}$

Biologia Molecular - $120 \mathrm{~h}$

Morfologia e Anatomia de Plantas Vasculares - $120 \mathrm{~h}$

Invertebrados II $-120 \mathrm{~h}$

Física e Biofísica - $120 \mathrm{~h}$

Quarto semestre $-420 \mathrm{~h}$

Biologia Tecidual $-60 \mathrm{~h}$

Processos Evolutivos $-60 \mathrm{~h}$

Taxonomia de Fanerógamas - $60 \mathrm{~h}$

Vertebrados - $120 \mathrm{~h}$

Fisiologia Humana e Comparativa I - $120 \mathrm{~h}$

Quinto semestre $-420 \mathrm{~h}$

Saúde Coletiva - $60 \mathrm{~h}$

Fisiologia Vegetal - $120 \mathrm{~h}$

Ecologia Animal - $60 \mathrm{~h}$

Paleontologia Geral - $60 \mathrm{~h}$

Fisiologia Humana e Comparativa II - $120 \mathrm{~h}$

Sexto semestre $-630 \mathrm{~h}$

História e Fílosofia das Ciências - 60 h

Imunologia - $60 \mathrm{~h}$

Recursos Econômicos Vegetais - $60 \mathrm{~h}$

Ecologia Vegetal - $240 \mathrm{~h}$

Ecologia Humana - $60 \mathrm{~h}$

Fisiologia Humana e Comparativa III $-120 \mathrm{~h}$

Prática Esportiva - $30 \mathrm{~h}$

\section{Licenciatura}

Sexto semestre $-60 \mathrm{~h}$

Introdução aos Estudos da Educação - 60 h

Sétimo semestre $-360 \mathrm{~h}$

Didática - $60 \mathrm{~h}$

Prática de Ensino em Ciências Biológicas - $120 \mathrm{~h}$

Psicologia da Educação - 60 h

Instrumentação para o Ensino de Ciências - $60 \mathrm{~h}$

Coleta e Manutenção de Material Biológico - 60 h

Oitavo semestre $-300 \mathrm{~h}$

Estrutura e Funcionamento dos Ensinos Fundamental e Médio - 60 h

Prática de Ensino em Ciências Biológicas II - 120 h

Ensino de Educação Ambiental - $60 \mathrm{~h}$

Projeto de Ensino de Biologia - $60 \mathrm{~h}$

* No ano em que esta pesquisa foi feita, as disciplinas de "Química de Biomoléculas" e "Bioquímica" foram unidas em uma única disciplina, com a denominação de "Bioquímica", ministrada no segundo semestre do curso, com 180 h semanais. 
Anexo 17 - Programa da Disciplina de Bioquímica

Bibliografia

Marzzocco, A. e Torres, B.B. Bioquímica básica. $2^{\underline{a}}$ ed. Rio de Janeiro: Ed. Guanabara, 1999.

Lehninger, A.L., Nelson, D.L. e Cox, M.M. Princípios de Bioquímica. São Paulo: Ed. Sarvier, 1995.

Stryer, L. Bioquímica. 3모 ed. Rio de Janeiro: Ed. Guanabara Koogan, 1992.

Stryer, L. Biochemistry. $4^{\mathrm{a}}$ ed. W.H.Freeman and Company, 1995.

Voet, D. e Voet, J.G. Biochenistry. John Willey and Sons, 1995.

Horton, H.R., Moran, L.A., Ochs, R.S., Rawn, J.D. e Scrimgeour, K.G. Principles of Biochemistry.

Prentice Hall, 1993.

Zubay, G.L., Parson, W.W. e Vance, D.E. Principles of Biochemistry. WCB Publishers, 1995.

Rityter, P. Biochemistry - A Foundation. Brooks / Cole Publishing Company, 1996.

Conteúdo programático

Apresentação do curso

$\mathrm{PH}, \mathrm{pKa}$, tampão

$1^{\text {a }}$ Aula Prática: Titulação

Discussão da aula prática

Discussão sobre $\mathrm{pH}, \mathrm{pKa}$, tampão

Aminoácidos, proteína e ligação entre grupos $\mathrm{R}$

Exercícios a, b, c

Vírus e clonagem de aminoácidos e proteínas

Cromatografias

Programa Pharmacia

Outras técnicas laboratoriais (além de cromatografia)

Bioenergética

Enzimas - introdução

Enzimas - problemas

Semana temática

Enzimas - exercício sobre maltase em intestino de inseto

$2^{\mathrm{a}}$ Aula Prática: Atividade específica

Discussão da aula prática

Revisão

$1^{\text {a }}$ Prova

Introdução ao metabolismo

Seminário - introdução à pesquisa

Correção da prova

$3^{\mathrm{a}}$ Aula Prática: Eletroforese

Exercício - cálculo de peso molecular

Glicólise e Neoglicogênese

Glicólise e Neoglicogênese - problemas

Oxidação de triacilgliceróis

Ciclo de Krebs

Ciclo de Krebs - problemas

Cadeia de transporte de elétrons

Fosforilação oxidativa

Fosforilação oxidativa - problemas

Exercício sobre ponto de ação de drogas na cadeia respiratória e fosforilação oxidativa

Revisão

$2^{\underline{a}}$ Prova

Via das pentoses

Fotossíntese

Glicogênio

Correção da prova

Glicogênio - problemas

Síntese de ácidos graxos e triacilgliceróis

Metabolismo de aminoácidos

Metabolismo de aminoácidos - problemas

Problemas sobre metabolismo

Revisão

$3^{\text {a }}$ Prova

Correção da prova 
Anexo 18 - Protocolos das Aulas Práticas observadas (transcritos dos protocolos impressos fornecidos aos alunos pelos professores)

Aula prática I ( I $^{\mathrm{a}}$ Aula Prática da programação)

Titulação de aminoácidos

Objetivo

Identificar um aminoácido desconhecido, por meio da comparação dos valores de pKa obtidos numa curva de titulação, com os valores de pKa da Tabela I.

Procedimento

a. Tomar $40 \mathrm{~mL}$ de uma solução $0,025 \mathrm{M}$ do aminoácido em um béquer e titular com $\mathrm{KOH} 0,1 \mathrm{M}$, medindo o pH para cada adição de 10 gotas, até atingir $\mathrm{pH}=11$.

b. Repetir o procedimento, nas mesmas condições, utilizando $\mathrm{HCl}$ 0,1 $\mathrm{M}$ no lugar de $\mathrm{KOH}$, até atingir o $\mathrm{pH} 1,8$.

c. Fazer o gráfico da titulação do aminoácido com base, colocando, em abcissas, os volumes (em gotas) de $\mathrm{KOH}$ adicionados e, em ordenadas, o $\mathrm{pH}$ registrado.

d. Fazer um gráfico semelhante com os valores obtidos na titulação com $\mathrm{HCl}$.

e. Assinalar, nos gráficos, os valores dos pKs. Comparar esses valores com os da tabela I e identificar o aminoácido.

Tabela 1 - Valores de pKa de alguns aminoácidos

$\begin{array}{lccc}\quad \text { Aminoácido } & \mathbf{P K a}_{\mathbf{1}} & \mathbf{P K a}_{\mathbf{2}} & \mathbf{P K a _ { 3 }} \\ \text { Arginina } & 1,8 & 9,0 & 12,5 \\ \text { Aspartato } & 2,0 & 9,9 & 3,9 \\ \text { Glicina } & 2,3 & 9,8 & - \\ \text { Glutamato } & 2,1 & 9,5 & 4,1 \\ \text { Histidina } & 1,8 & 9,3 & 6,0 \\ \text { Prolina } & 1,9 & 10,6 & -\end{array}$

Aula prática II ( $2^{\mathrm{a}}$ Aula Prática da programação)

Determinação da atividade específica

Informações

A atividade de uma enzima constitui-se na determinação da velocidade da reação catalisada, isto é, na determinação da quantidade de produto formado em um intervalo de tempo, em condições determinadas. A quantificação da formação do produto geralmente, depende de uma reação secundária à de catálise propriamente dita. Na maioria dos casos, essas reações produzem cor, tornando possível a quantificação do produto.

A atividade enzimática é medida em unidade (U), sendo que $1 \mathrm{U}$ corresponde à quantidade de enzima necessária para a formação de $1 \mu \mathrm{mol}$ de produto, por minuto. Uma vez que a velocidade de formação de produto depende da concentração da enzima, faz-se necessário estabelecer a relação da atividade enzimática com a quantidade de proteína. Essa relação é a atividade específica. A determinação da atividade específica é um dado importante para uma série de estudos bioquímicos.

Nesta aula, serão realizadas a quantificação de proteína e a determinação da atividade de uma enzima. Com esses dados, será possível a determinação da atividade específica.

A dosagem da concentração de proteína será realizada por fotometria, utilizando-se do método do biureto. Íons $\mathrm{Cu}^{2+}$, em meio alcalino, têm a propriedade de formar ligações com o Nitrogênio das ligações peptídicas. Dessa reação (reação de biureto) resulta uma coloração púrpura intensa. Esse fato pode ser explorado para se determinar, colorimetricamente, a quantidade de proteína de uma solução. O método do biureto é mais apropriado para proteínas cujas soluções são incolores, ou seja, para proteínas nãoconjugadas (simples). A cor desenvolvida numa reação de íons de $\mathrm{Cu}^{2+}$, em meio alcalino, com essas proteínas, deve-se exclusivamente às ligações peptídicas e à sua extensão para uma dada massa protéica, qualquer que seja a natureza da proteína não-conjugada em solução. O produto da reação absorve luz intensamente no comprimento de onda $(\lambda)$ de $540 \mathrm{~nm}$.

Podemos utilizar uma solução de proteína de concentração conhecida para construir uma curva de absorbância em função da concentração da substância em questão. Com essa curva, denominada curva padrão, podemos medir a quantidade de proteína em uma amostra de concentração desconhecida, pela simples medida de suas absorbâncias, desde que, nas mesmas condições utilizadas para a construção da curva padrão.

A enzima escolhida para este estudo foi a Invertase de levedura, que catalisa a hidrólise da sacarose para produzir glicose e frutose:

$$
\underset{\text { Sacarose }}{\mathrm{C}_{12} \mathrm{H}_{22} \mathrm{O}_{11}}+\mathrm{H}_{2} \mathrm{O} \rightarrow \underset{6}{\mathrm{C}_{6} \mathrm{H}_{12} \mathrm{O}_{6}}+\underset{\text { glicose }}{\mathrm{C}_{6} \mathrm{H}_{12} \mathrm{O}_{6}}
$$


A determinação da velocidade da reação (ou da atividade da enzima) pode ser feita por meio da dosagem dos açúcares redutores formados (frutose e glicose). A dosagem baseia-se na reação entre o ácido 3,5-dinitro-salicílico (DNS) e os açúcares redutores. Esses monossacarídeos reduzem o DNS, fornecendo um produto de cor característica, cuja formação pode ser acompanhada a $550 \mathrm{~nm}$.

Nestes experimentos, as velocidades de reação serão expressas em $\mu$ moles de sacarose hidrolisada por minuto. Conhecendo-se, por calorimetria, a quantidade de $\mu$ moles de açúcares redutores formados, por um

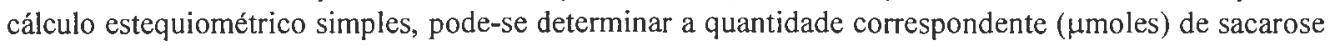
hidrolisada.

A. Determinação da concentração de proteína

Procedimento

a. Preparar os tubos como descrito na tabela 1, utilizando uma solução de $8 \mathrm{mg} / \mathrm{mL}$ de albumina (proteína padrão) e a solução de proteína desconhecida.

b. A um dos tubos (branco) não deverá ser adicionada a solução de proteína. A ordem de adição dos componentes da reação deve ser: primeiro, a solução desconhecida de proteína, depois, água e, por último, o reagente biureto.

c. Após a adição do reagente, agitar e incubar os tubos por 15 minutos, a $37^{\circ} \mathrm{C}$. Transferir o conteúdo dos tubos para cubetas do espectrofotômetro e ler as absorbâncias a $540 \mathrm{~nm}$.

d. Utilizando a curva padrão e o valor medido da absorção, a $540 \mathrm{~nm}$, da amostra desconhecida, calcular a concentração de proteína nessa amostra.

Tabela 1: Curva padrão para determinação de concentração de proteínas

$\begin{array}{cccccc}\text { Tubos } & \begin{array}{c}\text { Padrão de } \\ \text { albumina } \\ (\mathbf{8 m g} / \mathbf{m L})\end{array} & \begin{array}{c}\text { Proteína } \\ \text { desconhecida }\end{array} & \begin{array}{c}\text { Água } \\ \text { destilada } \\ \text { (mL) }\end{array} & \begin{array}{c}\text { Reagente de } \\ \text { biureto } \\ \text { (mL) }\end{array} & \begin{array}{c}\text { Absorbância } \\ (\mathbf{5 4 0} \mathbf{n m})\end{array} \\ \text { Branco } & - & - & 1,5 & 2,5 & 0,00 \\ \mathbf{1} & 0,1 & - & 1,4 & 2,5 & 0,080 \\ \mathbf{2} & 0,2 & - & 1,3 & 2,5 & 0,160 \\ \mathbf{3} & 0,4 & - & 1,1 & 2,5 & 0,310 \\ \mathbf{4} & 0,7 & - & 0,8 & 2,5 & 0,500 \\ \mathbf{5} & 1,0 & - & 0,5 & 2,5 & 0,680 \\ \mathbf{6} & - & 1,0 & 0,5 & 2,5 & \end{array}$

B. Determinação da atividade enzimática

Procedimento

a. Para estudos de velocidade, o tempo de reação deve ser medido com a maior exatidão possível. Para isso, o grupo deverá organizar-se de maneira a não permitir que a reação se inicie em tempos diferentes, em cada tubo. Para tal, é importante manter os tubos em gelo durante a adição dos reagentes. Esses devem ser adicionados na ordem em que aparecem nos protocolos, com a enzima sendo adicionada por último.

b. Levam-se, então, os tubos, todos juntos, ao banho a $37^{\circ} \mathrm{C}$, para reagir. Transcorrido o tempo determinado, os tubos devem voltar para o gelo e deve-se adicionar DNS. Nesse ponto, a reação é interrompida. Após o ensaio de todos os tubos, estes devem ser fervidos, como descrito para a curva padrão de determinação de extremidades redutoras.

$\mathrm{B}_{1}$. Curva padrão para determinação de extremidades redutoras - a finalidade dessa curva padrão é relacionar valores de absorbância a $550 \mathrm{~nm}$ com $\mu$ moles de sacarose hidrolisada.

a. Utilizar seis tubos para construir a curva padrão, conforme indicado a seguir (Tabela 2), contendo volumes crescentes de solução padrão redutora (glicose $6 \mathrm{mM}+$ frutose $6 \mathrm{mM}$ ).

Tabela 2: Construção de curva padrão para sacarose hidrolisada

\begin{tabular}{|c|c|c|c|c|c|}
\hline Tubos & $\begin{array}{c}\text { Solução - } \\
\text { Padrão } \\
\text { redutora } \\
\text { (8mg / mL) }\end{array}$ & $\begin{array}{c}\text { Solução } \\
\text { tampão } \\
(\mathrm{mL})\end{array}$ & $\begin{array}{c}\text { Reagente } \\
\text { DNS } \\
\text { (mL) }\end{array}$ & $\begin{array}{l}\text { Absorbância } \\
(550 \mathrm{~nm})\end{array}$ & $\begin{array}{c}\text { Sacarose } \\
\text { hidrolisada } \\
\text { ( } \mu \text { Moles) }\end{array}$ \\
\hline Branco & - & 2,0 & 2,0 & 0,000 & 0,00 \\
\hline 1 & 0,2 & 1,8 & 2,0 & & 1,2 \\
\hline 2 & 0,4 & 1,6 & 2,0 & & 2,4 \\
\hline 3 & 0,6 & 1,4 & 2,0 & & 3,6 \\
\hline 4 & 0,8 & 1,2 & 2,0 & & 4,8 \\
\hline 5 & 1,0 & 1,0 & 2,0 & & 6,0 \\
\hline
\end{tabular}

b. Após a adição de DNS, colocar os tubos em banho-maria fervente, por 10 minutos. Findo esse tempo, esfriá-los em água corrente e adicionar $8 \mathrm{~mL}$ de água destilada. Homogeneizar e ler as absorbâncias a 550 nm contra o branco. 
c. Construir um gráfico $\mathrm{Abs}_{550} \times \mu$ Moles de sacarose hidrolisada (curva padrão).

$\mathrm{B}_{2}$. Ensaio enzimático

a. Numerar os tubos de ensaio e adicionar os reagentes, segundo o protocolo abaixo (os tubos devem estar no gelo)

Tabela 3: Determinação da velocidade de consumo de sacarose

$\begin{array}{cccccc}\text { Tubos } & \begin{array}{c}\text { Sacarose 5\% } \\ \text { em tampão }\end{array} & \begin{array}{c}\text { Tampão pH } \\ \mathbf{4 , 7}(\mathbf{m L})\end{array} & \begin{array}{c}\text { Solução de } \\ \text { enzima }(\mathbf{m L})\end{array} & \begin{array}{c}\text { Tempo } \\ (\mathbf{m i n})\end{array} & \begin{array}{c}\text { Absorbância } \\ \mathbf{5 5 0} \mathbf{~ n m}\end{array} \\ \mathbf{1} & 1,0 & 0,9 & 0,1 & 0 & \\ \mathbf{2} & 1,0 & 0,9 & 0,1 & 5 & \\ \mathbf{3} & 1,0 & 0,9 & 0,1 & 10 & \\ \mathbf{4} & 1,0 & 0,9 & 0,1 & 15 & \\ \mathbf{5} & 1,0 & 0,9 & 0,1 & 20 & \end{array}$

b. Após a adição da enzima, agitar suavemente. Retirar os tubos de uma temperatura de $0^{\circ} \mathrm{C}$ e colocálos simultaneamente em banho-maria, a $37^{\circ} \mathrm{C}$, pelo tempo indicado na Tabela 3 .

c. Transcorrido o tempo específico de cada tubo, esses devem retornar imediatamente para o gelo. Assume-se que, nesse instante, a reação é interrompida. Ainda no gelo, adicionar, a cada tubo, $2 \mathrm{~mL}$ de DNS. Na presença de DNS, devido à alcalinidade do reagente, a enzima (nesse valor elevado de $\mathrm{pH}$ ) deixa de funcionar.

d. Transferir os tubos para banho-maria fervente e esperar 10 minutos. Findo esse tempo, esfriar em água corrente e adicionar $8 \mathrm{~mL}$ de água destilada em cada tubo. Agitar com inversão da pósição na vertical ( 3 vezes). Ler as absorbâncias a $550 \mathrm{~nm}$.

e. Fazer o gráfico, colocando o tempo nas abcissas e, nas ordenadas, a absorbância. Calcular a velocidade de catálise ( $\mu$ moles / $\mathrm{min}$ ), a quantidade de unidades de sacarose e a atividade específica.

Aula prática III ( $3^{\mathfrak{a}}$ Aula prática da programação)

Eletroforese em gel de poliacrilamida

Informaçð̃es

A acrilamida é um monômero que na presença de radicais livres, os quais são gerados por persulfato de amônio e estabilizados por TEMED ( $\mathrm{N}, \mathrm{N}, \mathrm{N}^{\prime}, \mathrm{N}^{\prime}$ - tetrametilenediamine), gera uma reação em cadeia, na qual os monômeros de acrilamida são polimerizados em cadeias longas. Quando é incluído também um agente bifuncional, N.N'-metilenebisacrilamida, na reação de polimerização, as cadeias tornam-se ligadas entre si, formando um gel, cuja porosidade é determinada pelo comprimento das cadeias e pelo grau de interligação entre essas.

O sistema de eletroforese que será utilizado será um sistema denominado descontínuo. São utilizados dois tipos de gel, um denominado gel de empilhamento e outro, gel de corrida. A função do primeiro é de concentrar amostras com grande volume, resultando em uma melhor definição e resolução dos resultados. As moléculas são, então, completamente separadas no gel de corrida.

Objetivo

Determinar a taxa de migração (Mr) e estimar a massa molecular de diferentes preparações de proteína.

Materiais

soluções utilizadas para o gel de corrida (12\%): volume total $-10 \mathrm{~mL}$

- água destilada $-3,35 \mathrm{~mL}$

- $\quad 1,5 \mathrm{M}$ tris-HCL $\mathrm{pH} 8,8-2,5 \mathrm{~mL}$

- $\quad 10 \% \mathrm{SDS}-100 \mu \mathrm{L}$

- acrilamida / bis-acrilamida $-4,0 \mathrm{~mL}$

- $10 \%$ persulfato de amônio - $50 \mu \mathrm{L}$

- $\quad$ TEMED - $5 \mu \mathrm{L}$

[ sulfato de amônio $(100 \mathrm{mg} / \mathrm{mL})$ ]

soluções utilizadas para o gel de empilhamento: volume total $-10 \mathrm{~mL}$

- água destilada $-6,1 \mathrm{~mL}$

- $\quad 0,5 \mathrm{M}$ Tris-HCl pH $6,8-2,5 \mathrm{~mL}$

- $\quad 10 \%$ SDS $-100 \mu \mathrm{L}$

- acrilamida / bis-acrilamida $-1,3 \mathrm{~mL}$

- $\quad 10 \%$ persulfato de amônio - $50 \mu \mathrm{L}$

- TEMED - $10 \mu \mathrm{L}$

tampão de corrida - Diluir 5 vezes essa solução antes do uso:

- Tris $-15 \mathrm{~g} / \mathrm{L}$

- Glicina $-72 \mathrm{~g} / \mathrm{L}$

- $\quad$ SDS $-5 \mathrm{~g} / \mathrm{L}$

amostras

- $\quad 5 \mu \mathrm{L}$ de mistura de proteínas de peso molecular conhecido previamente corada (marcador de peso molecular)

- $\quad 20 \mu \mathrm{L}$ de uma proteína (caseína fluoresceína) de massa molecular desconhecida 
Procedimento

a. Serão montados géis de poliacrilamida de concentração 12\% para separação de proteínas de diferentes pesos moleculares.

b. Aplicar as amostras.

c. Estabelecer uma corrente de $200 \mathrm{~V}$, por 45 minutos, visualizando a separação das diferentes proteínas, tanto do marcador de peso molecular, quanto da proteína de peso molecular desconhecido.

d. Fazer a curva, distância percorrida x log P.M., com os valores da tabela e usar essa curva padrão para determinar o logaritmo do P. M. desconhecido. Em seguida, determinar o antilog para determinar o peso molecular desconhecido.

\section{Padrões de peso molecular}

\begin{tabular}{|c|c|c|c|c|c|}
\hline Proteína & $\begin{array}{l}\text { Peso } \\
\text { molecular }\end{array}$ & Proteína & $\begin{array}{l}\text { Peso } \\
\text { molecular }\end{array}$ & Proteína & $\begin{array}{l}\text { Peso } \\
\text { molecular }\end{array}$ \\
\hline Fosforilase B & 97400 & Ovoalbumina & 45000 & $\begin{array}{l}\text { Inibidor de } \\
\text { tripsina de soja }\end{array}$ & 21500 \\
\hline Albumina bovina & 66200 & $\begin{array}{l}\text { Anidrase } \\
\text { carbônica }\end{array}$ & 31000 & Lisozima & 14400 \\
\hline
\end{tabular}

